
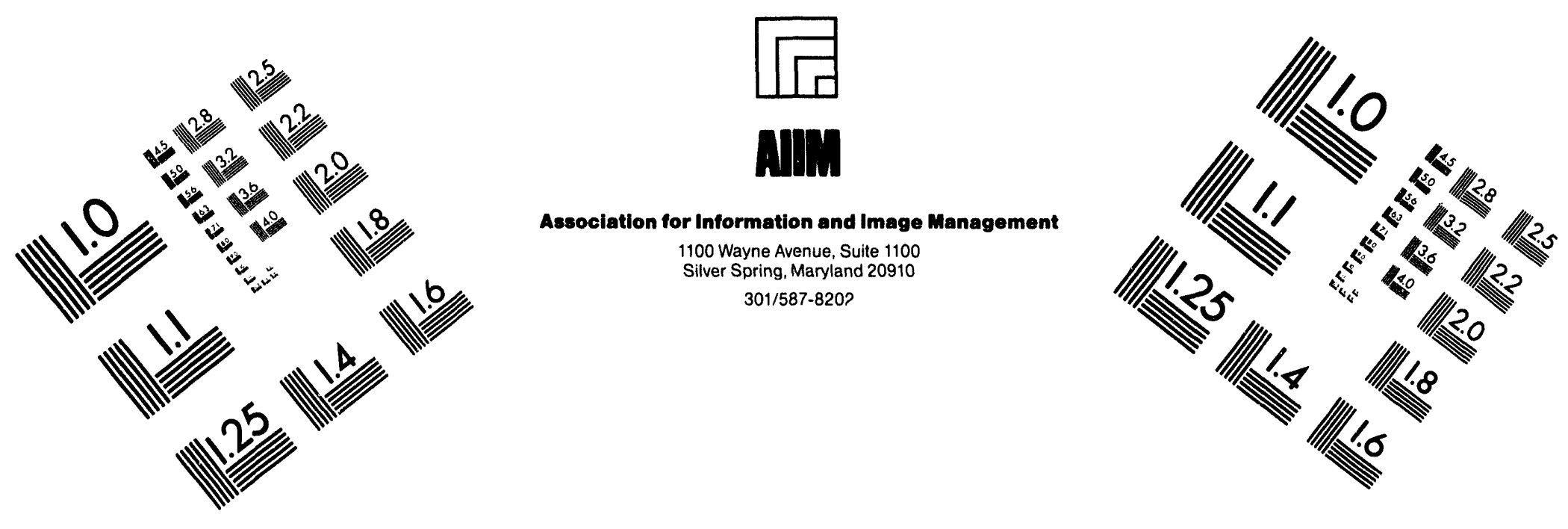

\title{
Centimeter
}

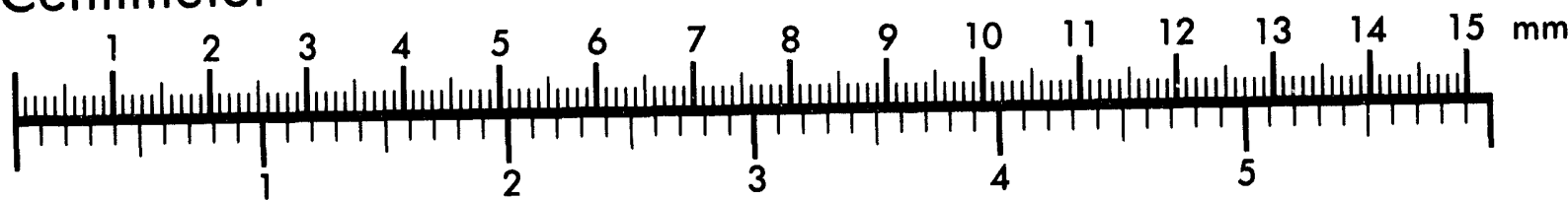

Inches
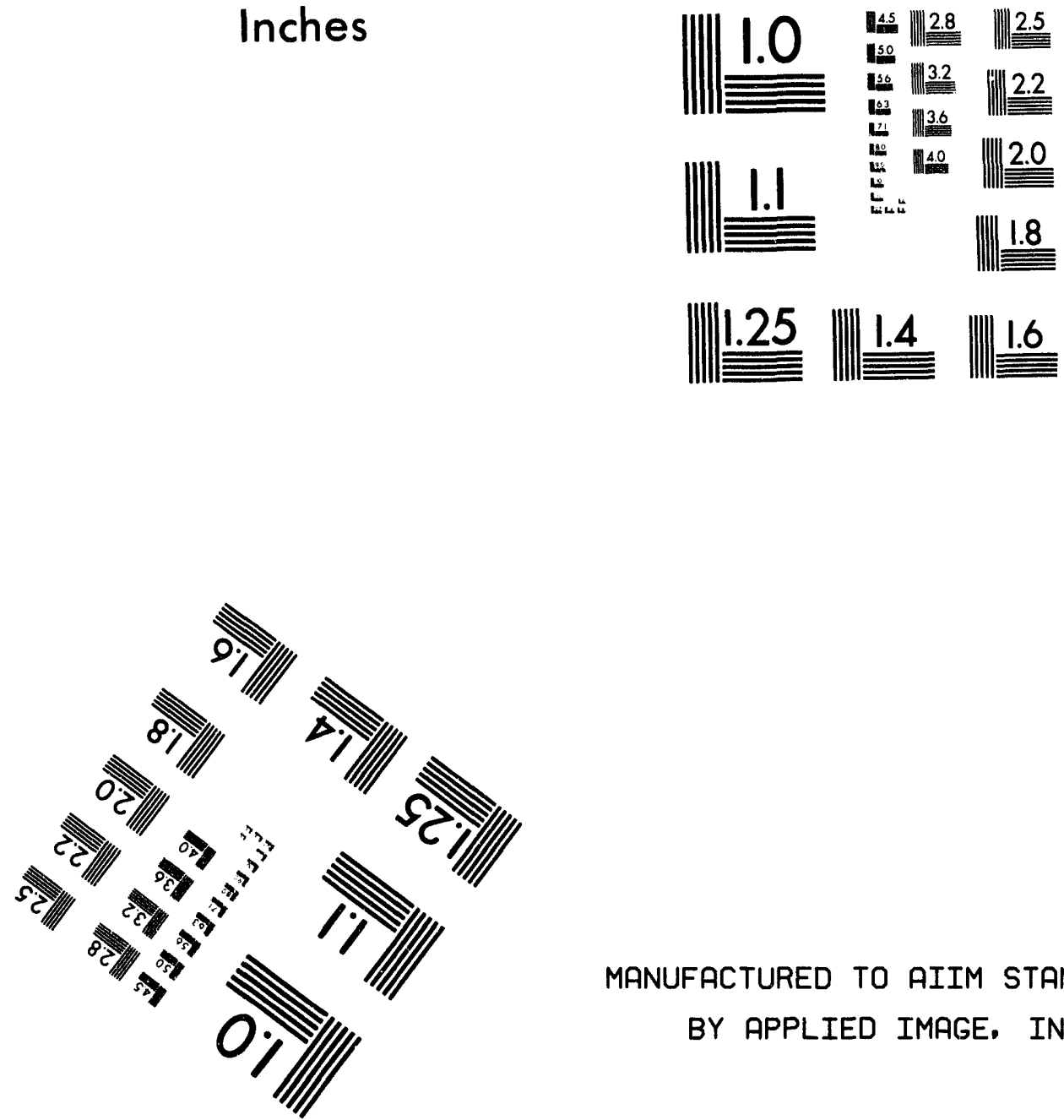

MANUFACTURED TO AIIM STANDARDS

BY APPLIED IMAGE. INC.

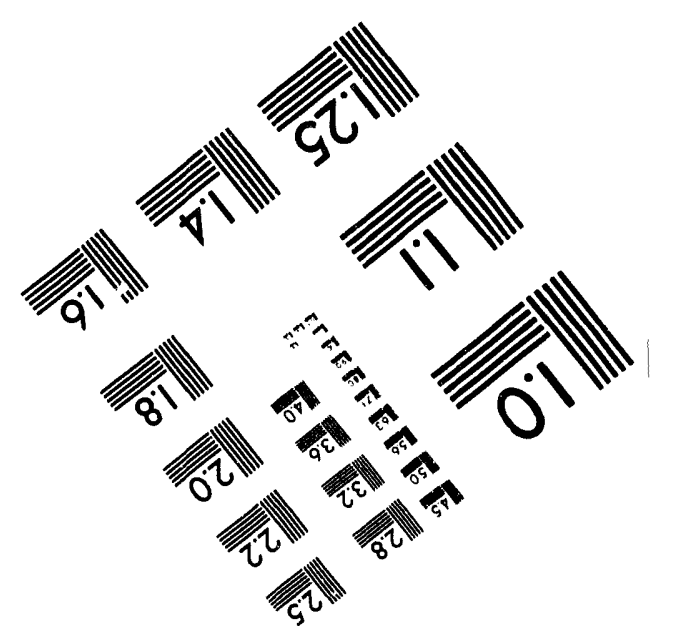



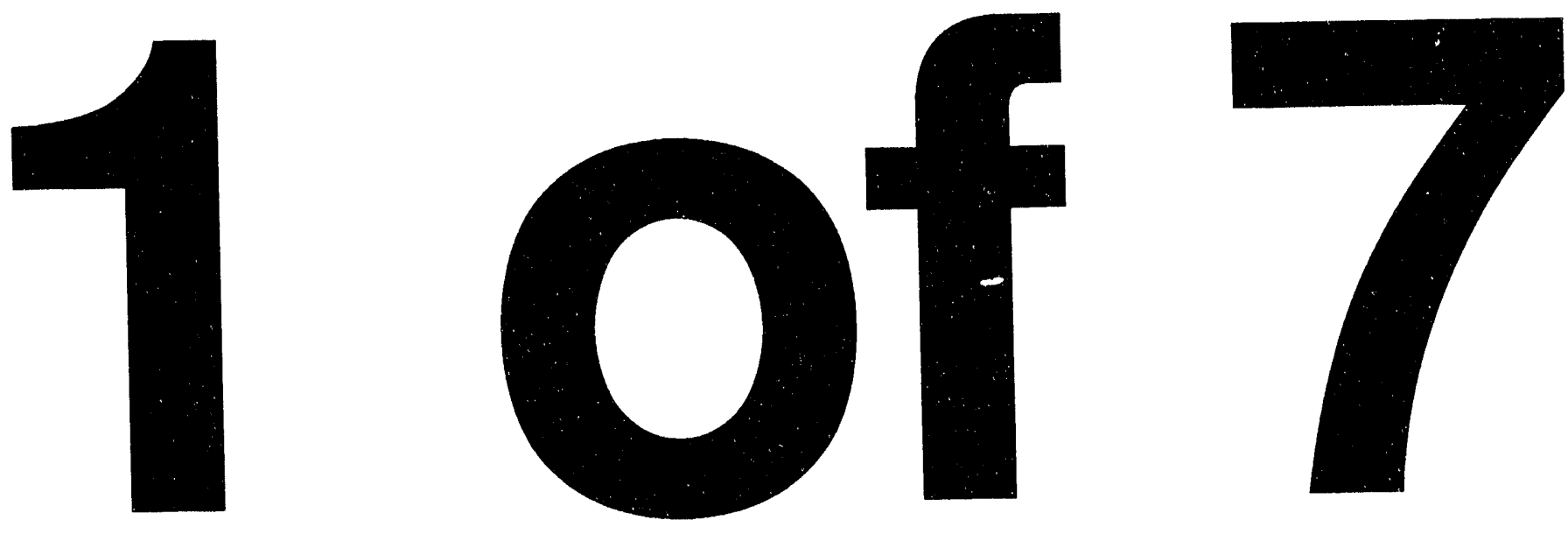
DOE/RL-94-40

Revision 0

UC- 630,721

\section{Corrective Action Management Unit Application for the Environmental Restoration Disposal Facility}

Date Published June 1994

\section{$\therefore$ Engineering drawings for this project are identified as CAPE- 3081 inquiries may be directed to:}

Office of Scientific and Technical Information P. O. Box 62

Oak Ridge, TN 37831

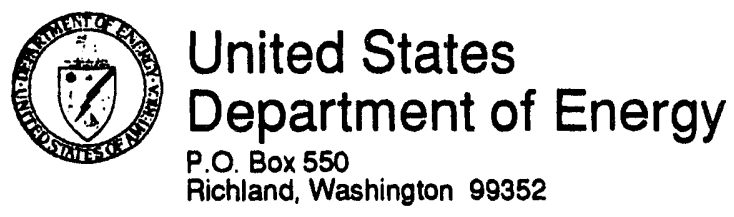

Approved for Public Release 
TRADEMARK DISCLAIMER

Reference herein to any specific commercial product, process, or service by trade name, trademark, manufacturer, or otherwise, does not necessarily constitute or imply its endorsement, recommendation, or favoring by the United States Government or any agency thereof or its contractors or subcontractors.

This report has been reproduced from the best available copy. Available in paper copy and microfiche.

Available to the U.S. Department of Energy

and its contractors from

Office of Scientific and Technical Information

P.O. Box 62

Oak Ridge, TN 37831

(615) $576-8401$

Available to the public from the U.S. Department of Commerce

National Tochnical Information Service

5285 Port Royal Road

Springfield, VA 22161

(703) 487.4650

Printed in the Uniled Stales ol Amorice

DISCLM-5.CHP (8.91) 
DOE/RL-94-40, Rev. 0 $06 / 94$

\section{EXECUTIVE SUMMARY}

The Hanford Facility, located in southeastern Washington State (Figure E-1), has been operated by the Federal Government since 1943. Its primary mission has been plutonium production for military use, as well as nuclear energy research and development. These activities resulted in release of waste to the environment that caused contamination of soil and groundwater with hazardous/dangerous waste constituents and radioactive constituents (DOE-RL 1994d). The mission of the Hanford Facility currently is focusing on waste management and environmental restoration and remediation activities.

In 1989, the Hanford Federal Facility Agreement and Consent Order (Tri-Party Agreement) was signed by the U.S. Environmental Protection Agency (EPA), Region 10, Washington State Department of Ecology (Ecology), and the U.S. Department of Energy (DOE). The Tri-Party Agreement has been amended over the course of activities, with the Fourth Amendment made in January of 1994 (Ecology et a1. 1994). Cleanup of contaminated areas was the principal component of this agreement. The Tri-Party Agreement includes an Action Plan that designates how cleanup is to progress. The Tri-Party Agreement designated remediation sites as either Resource Conservation and Recovery Act (RCRA) of 1976 past-practice or Comprehensive Environmental Response, Compensation, and Liability Act (CERCLA) of 1980 past-practice sites. Ecology is the lead regulatory agency for RCRA past-practice sites while the EPA is the lead regulatory agency for CERCLA past-practice sites.

In accordance with the Tri-Party Agreement, cleanup of remediation sites is being initiated at both RCRA and CERCLA past-practice sites. As designated in the Tri-Party Agreement and presented in Figure E-2, remediation of sites will follow the RCRA facility assessment (RFA) - RCRA facility investigation (RFI) - corrective measures study (CMS) or CERCLA prel iminary assessment (PA) - remedial investigation (RI) - feasibility study (FS) processes normally observed for RCRA remediation activities and CERCLA remediation activities, respectively. As shown in Figure E-2, both RCRA and CERCLA remedial actions use a decision process that evaluates remediation options, including treatment alternatives. Based on this evaluation, remedial options are developed for each remediation site. The remediation sites are integrated into the Hanford Facility Dangerous Waste Permit via a permit modification for RCRA pastpractice units, or are articulated in a record of decision (ROD) for CERCLA past-practice units). It must be noted that RCRA treatment, storage, and/or disposal units (TSD) do occur in association with RCRA past-practice remediation sites. Many of these TSD units are to undergo closure, and documentation associated with cleanup of RCRA past-practice units and the closure plans for TSD units are included within the same document.

As shown in Figure E-2, although the processes for determining the remedial action at both CERCLA and RCRA sites are similar, the methods are different for implementing these actions. In the case of the RCRA pastpractice remediation sites, RFI/CMS documentation--which includes the proposed remediation strategy--is submitted for approval. The proposed remediation strategy is incorporated in the Hanford Facility Permit by the regulatory agency via permit modification. 
For CERCLA past-practice sites, a proposed plan is submitted that is used by the regulatory agency to prepare a ROD. The ROD for the first CERCLA past-practice unit, 100-BC, is scheduled for issuance in 1994 or 1995 . It is anticipated that for this site--and perhaps all--RCRA and CERCLA past-practice remediation sites, the permit modification/ROD likely will include removal of the waste from its close proximity to the Columbia River and isolation of the waste in a central location. A waste management facility was foreseen as necessary to meet this probable need for waste isolation, and thus the Environmental Restoration Disposal Facility (ERDF) was initiated.

The ERDF will be located southeast of the existing 200 West Area and

\subsection{THE ENVIRONMENTAL RESTORATION DISPOSAL FACILITY AND ITS RELATIONSHIP TO CERCLA, RCRA, AND THE RCRA CORRECTIVE ACTION MANAGEMENT UNIT}

The ERDF is to accept both CERCLA (EPA-reguiated) and RCRA (Ecology-regulated) remediation waste. The ERDF is considered part of the overal1 remediation strategy on the Hanford Site, and as such, determination of ERDF viability has followed both RCRA and CERCLA decision making processes. Typically, determination of the viability of a unit, such as the ERDF, would occur as part of ROD or permit modification for each remediation site before construction of the ERDF. However, because construction of the ERDF may take a significant amount of time, it is necessary to begin design and construction of the ERDF before final RODs/permit modifications for the remediation sites. This will allow movement of waste to occur quickly once the final remediation strategy for the RCRA and CERCLA past-practice units is determined. Construction of the ERDF is a unique situation relative to Hanford Facility cleanup, requiring a Hanford Facility specific process be developed for implementing the ERDF that would satisfy both RCRA and CERCLA requirements. While the ERDF will play a significant role in the remediation process, initiation of the ERDF does not preclude the evaluation of remedial alternatives at each remediation site.

To facilitate this, the January 1994 amendment to the Tri-Party Agreement recognizes the necessity for the ERDF, and the Tri-Party Agreement states: "Ecology, EPA, and DOE agree to proceed with the steps necessary to design, approve, construct, and operate such a ...facility." The Tri-Party Agreement requires the DOE-RL to prepare a comprehensive 'package' for the EPA and Ecology to consider in evaluating the ERDF. The package is to address the criteria listed in 40 CFR 264.552 (c) for corrective action management unit (CAMU) designation and a CERCLA ROD. This CAMU application is submitted as part of the Tri-Party Agreement-required information package, and is discussed in more detail in Section 3.0.

The Tri-Party Agreement cites the following assumptions and decisions that are implicit in the ERDF milestones: (1) the definitive design of the 52 ERDF will be submitted to Ecology and the EPA for approval 3 months after 
approval of the ERDF; (2) a double-flexible, membrane liner and leachate collection system will be used for initial design; and (3) risk assessment parameters will be used and will assume that the point of assessment will be the intersection of the groundwater and the vertical line drawn from the edge of the ERDF, that the time assessment for radionuclides is 10,000 years, and that the compliance standard will be $10^{-5}$ for the first 100 years, and $10^{-4}$ thereafter. Note that each individual ROD/permit modification wi11 specify how waste from that remediation site can be treated and will reference, as appropriate, placement of waste in the ERDF.

The Tri-Party Agreement requires [by referencing 40 CFR $264.552(c)$ ] that information pertinent to a RCRA CAMU be provided for regulatory review. The CAMU regulations, finalized in February of 1993 , essentially provide a new option for onsite land-based management of remediation waste that previously was not available to facilities with RCRA past-practice units. Before the CAMU regulations, if the RFI/CMS process determined that onsite land disposal (e.g., landfilling) of waste was the desired remediation alternative, the landfill would be regulated under the same laws pertinent to active manufacturing facilities that dispose of "as generated" waste. Specifically, RCRA required that landfills be designed to meet very specific minimum technology requirements (MTRs), including double liners, and that most waste undergo specific treatment as mandated by the land disposal regulations (LDRs). However, these strict requirements were a disincentive to many facilities to manage remediation waste. The CAMU regulations were promulgated to promote remediation of sites requiring cleanup under RCRA by allowing the regulatory agencies more flexibility with regard to management of remediation waste, without compromising human health and the environment.

The CAMU is an area within a facility that is designated by the Regional Administrator (or Director) under 40 CFR 264, Subpart S [WAC 173-303-646 (4), (5) and (6)] for the purpose of implementing corrective action requirements under 40 CFR 264.101 and RCRA Section 3008(h) [WAC 173-303-646(2)]. A CAMU will only be used for the management of remediation waste pursuant to implementing such corrective action requirements at the facility; as such, no "as generated," or operational waste can be placed in a CAMU. While the CAMU is a "land based" unit, it is not considered a "disposal facility" into which remediation waste is placed. A disposal facility, as defined in 40 CFR 260.10, is "a facility or part of a facility at which hazardous waste is intentionally placed into or on any land or water and at which waste will remain after closure. The term disposal facility does not include a CAMU into which remediation waste are placed." Hence, placement of remediation waste into a CAMU is not land disposal, and RCRA regulations (LDRs and MTRs) applicable to land disposal units, such as landfills, are not mandatorily applicable. However, Ecology regulations indicate that LDRs and MTRs could be imposed for a CAMU if required to protect human health and the environment.

The CAMU regulations allow "RCRA-regulated" units, defined in 40 CFR $264.90(a)(2)$ as being only landfills, surface impoundments, waste piles, and land treatment units that received hazardous waste after July 26, 1982, to be present with in the boundaries of the CAMU. Although not specifically addressed within the CAMU regulations and preamble ( 58 FR 29), it is apparent that other types of units that are regulated under RCRA (but are 
1 not, by definition, "RCRA-regulated"), such as tanks, could be present within 2 the CAMU area, but cannot be designated a CAMU and must be regulated under 3 other RCRA regulations (i.e., tank storage regulations or temporary unit 4 requirements). In the case of the ERDF, the entire 4.14 square kilometer 5 ( 1.6 square mile) area is included in the CAMU because the CAMU is defined as 6 an area wherein remediation waste is managed. Only one unit within this area, 7 the ERDF trench, will be land based and technically can be included as part of 8 the CAMU. Other support units regulated under RCRA, including tanks, will be 9 within the area of the CAMU and will retain separate regulatory identity, 10 although these regulated units support CAMU activities.

For an area to be designated a CAMU, seven decision criteria must be

met, and the Tri-Party Agreement requires the comprehensive 'package' for the ERDF to discuss the following same criteria.

"1. The CAMU shall facilitate the implementation of reliable, effective, protective, and cost-effective remedies.

2. Waste management activities associated with the CAMUs shall not create unacceptable risks to humans or to the environment resulting from exposure to hazardous waste or hazardous constituents.

3. The CAMU shall include uncontaminated areas of the facility, only if including such areas for the purpose of managing remediation waste is more protective than management of such waste at contaminated areas of the facility.

4. Areas within the CAMU, where waste remain in place after closure of the CAMU, shall be managed and contained so as to minimize future releases, to the extent practicable.

5. The CAMU shall expedite the timing of remedial activity implementation, when appropriate and practicable.

6. When appropriate, the CAMU shall enable the use of treatment technologies (including innovative technologies) to enhance the long-term effectiveness of remedial actions by reducing the toxicity, mobility, or volume of waste that will remain in place after closure of the CAMU.

7. The CAMU shall, to the extent practicable, minimize the land area of the facility upon which waste will remain place after closure of the CAMU."

Specifically how the ERDF meets each of these criteria is addressed in detai1 in Chapter 15.0. 
DOE/RL-94-40, Rev. 0 06/94

3

\subsection{USE OF THE CORRECTIVE ACTION MANAGEMENT UNIT AT THE ENVIRONMENTAL RESTORATION DISPOSAL FACILITY AND RCRA/CERCLA RELATIONSHIPS}

The Tri-Party Agreement states that information necessary for issuance of an EPA CERCLA ROD be included in the package. This ROD would be unique to the ERDF, and separate from those for each CERCLA past-practice remediation site. As such, the individual remediation site RODs will be specific to each site, and may separately evaluate treatment options. Information necessary to issue the ERDF ROD includes a document that uses the RI/FS process to evaluate the ERDF design and to determine viability of the ERDF for long-term management of remediation waste. A proposed plan also is necessary.

Also, CERCLA requires that a demonstration must be made before issuance of the ERDF ROD, and that the substantive standards of other applicable or relevant and appropriate requirements (ARARs) have been met, including those substantive requirements of RCRA. That is, it must be demonstrated that the 'fundamenta 1' requirements of the ARARs are met (i.e., design requirements), but the typical documentation associated with each of these regulations that may be required to be submitted to other agencies for approval are not necessary. Once it has been demonstrated that substantive requirements of ARARs have been met to the satisfaction of the EPA, the ROD can be issued. The submittal of information pertineit to the RCRA CAMU, if approved, would satisfy this ARAR (demonstration).

It is important to note that the ROD would allow for design, approval, construction, and operation of the ERDF only for management of CERCLA remediation waste. For management of RCRA past-practice waste, a Class 3 permit modification of the Hanford Facility Permit (which currently is in draft form) is required. The CAMU documentation submitted within the information package is intended to have a dual purpose: (1) documentation serves to demonstrate that the CAMU meets substantive requirements of RCRA as an ARAR under CERCLA so that the CERCLA ROD process can proceed and (2) it serves as the CAMU application that contains necessary information that must be submitted to Ecology for designation of the CAMU and subsequent inclusion in a permit modification so that RCRA past-practice waste can be managed within the ERDF. Figure E-2 shows the relationship of the CERCLA/RCRA interface relative to the ERDF and the Hanford Facility remediation process as a whole.

The Tri-Party Agreement includes a major milestone (M-70-00) that the ERDF will be operational and available to receive remediation waste in September of 1996. It is anticipated that the ERDF ROD will be made (assuming requisite information is submitted) during September of 1994 . Three months after issuance of the ERDF ROD by the EPA, the definitive design of the ERDF will be submitted to Ecology and the EPA for approval (in accordance with the Tri-Party Agreement). Additional information pertaining to design and operation of the ERDF will be submitted for regulatory approval before operation and will be submitted following a schedule (presumed to be included) in the ERDF ROD or permit modification. Information that must be submitted for regulatory approval before acceptance of waste at the ERDF includes: 
- Definitive design information, including design information for the ERDF trench and supporting units, such as designs for waste water storage units

- Operational information, including the ERDF operations plan and information necessary to support safe operation, including building emergency plans, and other procedures to prevent hazards (i.e., air monitoring plans)

- Waste management information, including final waste acceptance criteria, waste tracking information, and other waste management information.

The ROD wi11 designate the ERDF as a CERCLA unit that may manage CERCLA past-practice waste once constructed and all requisite information is submitted and approved. Because RCRA is an ARAR under CERCLA, the substantive requirements of RCRA (i.e., CAMU unit design requirements) will be met. Parallel to the construction of the ERDF, the CAMU application--that also was submitted, in part, within the ERDF 'information package'--will undergo regulatory review by Ecology. When Ecology has determined that the ERDF meets all of the CAMU designation criteria, a Ciass 3 permit modification may be obtained and the ERDF may then accept RCRA past-practice remediation waste.

During operation as a CERCLA unit, the ERDF will be regulated by the EPA and operated under U.S. Department of Energy, Richland Operations Office requirements. When the Class 3 permit modification is in place, Ecology will regulate the ERDF, assuming that Ecology has received authorization over the CAMU program via acquisition of Hazardous and Solid Waste Amendments of 1984 (HSWA) authority. It must be noted that the ERDF may operate for management of CERCLA remediation waste without obtaining permits (i.e., RCRA, Clean Air Act of 1977 , etc.), although substantive requirements of these regulations must be met. However, all required permits/documents must be 'in place' before acceptance of RCRA waste, including those for support units (i.e., tanks) within the boundary of the ERDF.

\subsection{OVERVIEW OF ENVIRONMENTAL RESTORATION DISPOSAL FACILITY SETTING}

The ERDF will be located southeast of the existing 200 West Area and will extend east near the US Ecology, Inc. site (Figure E-1). The ERDF will cover a 4.14 square kilometer ( 1.6 square mile) area. A single trench and multiple support units will be present within the ERDF boundary. The CAMU will incorporate the entire 4.14 square kilometer ( 1.6 square mile) area and will include the trench; although the support units will occur within the CAMU area, the support units cannot be included as part of the CAMU and will maintain separate regulatory identity. The nearest public roadway, Washington State Highway 240 , is approximately 1.5 kilometers $(0.9$ mile) from the ERDF. Transport of remediation waste to the ERDF may occur either by tractor/trailer or railcar, with railcar transport the most likely option.

Approximately 150,000 people live within Benton and Franklin Counties, which encompass the Hanford Facility. The closest major population center is 
1 Richland, Washington, which has an estimated population of 32,315

2 (U.S. Department of Commerce 1991). Richland is located over 28 kilometers

3 (17 miles) from the ERDF. The ERDF also will be over 13 kilometers ( 8 miles)

4 from the Columbia River at its closest point, while the majority of the

5 remediation sites from which waste is being removed are immediately adjacent

6 to the Columbia River.

7
Only remediation waste will be managed within the ERDF, and this waste will be generated during cleanup of CERCLA and RCRA past-practice remediation sites. Approximately 21.4 million cubic meters (28 million cubic yards) will be managed within the ERDF trench. Remediation waste to be managed includes low leve1, hazardous/dangerous, and 'mixed' (hazardous/dangerous plus low leve1) remediation waste. The vast majority of the waste (approximately 98 percent) that contains radioactive constituents will be able to be contact handled (<200 millirem per hour surface dose rate) and will be transported in bulk within reusable containers for dumping and spreading in the ERDF trench. However, some remediation waste may require remote handling ( $>200$ millirem per hour surface dose rate) and wiil be placed in the ERDF in single-use containers. Waste acceptance criteria have been developed based on safety considerations pertaining to waste management, liner compatibility requirements, and risk assessment information. The risk values were calculated keeping in mind the Tri-Party Agreement allowable risk at the ERDF boundary within the first 100 years being $10^{-5}$, with $10^{-4}$ the allowable risk thereafter, to 10,000 years. Table E-1 presents the waste acceptance criteria for the ERDF. These criteria ensure that waste placed within the ERDF will not migrate beyond the requisite health-based standards within the 10,000 year period required for evaluation within the Tri-Party Agreement. In addition to the waste acceptance criteria, waste tracking, waste confirmation, and monitoring systems will be developed to ensure that information necessary to manage remediation waste appropriately is generated and available.

The Hanford Facility is located within a structural depression known as the Pasco Basin. The Hanford Facility is underlain by the Columbia River Basalts that are capped by suprabasalt sediments. These sediments are up to approximate 7230 meters $(750$ feet) thick on the Hanford Facility, and are principally composed of the Ringold and overlying Hanford formations. The water table below the ERDF occurs within the suprabasalt sediments, and is approximately 75 to 90 meters (250 to $300 \mathrm{feet}$ ) below ground surface at the ERDF site. Groundwater flow within the water table below the ERDF is to the east, with ultimate discharge to the Columbia River (WHC 1991b). The RI/FS (DOE-RL 1994d) indicates that it takes over 500 years for water to flow through the vadose zone to the water table.

Groundwater below the ERDF will be monitored by a network of 12 groundwater monitoring wells. These wells, screened within the uppermost water-bearing interval, will monitor groundwater semiannually and will monitor for a suite of analytes representative of waste anticipated for placement within the ERDF. As part of this network, five groundwater monitoring wells upgradient from the ERDF will monitor groundwater quality that contains preexisting contamination including carbon tetrachloride, nitrate, tritium, iodine-129, and uranium. Upgradient groundwater monitoring is required to ensure that knowledge of preexisting contamination is obtained and understood 
so that any releases from the ERDF can be distinguished from preexisting contamination. Further, the groundwater monitoring program will incorporate information obtained from leachate detection/collection programs so that immediate understanding of potential contaminant migration to the vadose zone can be detected. Figure E-3 presents the groundwater monitoring network proposed for the ERDF. This network will detect releases from the ERDF trench as well as support units. Although support units are regulated separately from the ERDF, this network provides monitoring of potential releases associated with units that do not require groundwater monitoring under RCRA (i.e., tank) and thus, is more protective than that required by RCRA regulations.

The Hanford Facility is a large, relatively undisturbed area of shrub-steppe habitat that contains numerous plant and animal species adapted to the region's semiarid environment. Major plant species include sagebrush, bitterbrush, Sandberg's bluegrass, cheatgrass, and rabbitbrush. The DOE-RL recognizes that contiguous blocks of mature shrub-steppe habitat are important for many plant and animal species. Habitat value will be assessed before start of construction, an losses will be mitigated based on the ecological value of the habitat disturbed. Bird species documented as species of concern near the ERDF include the long-billed curlew, sage sparrow, grasshopper sparrow, loggerhead shrike, and Swainson's hawk. Mammals present in the ERDF area include the Great Basin pocket mouse, badger, coyote, mule deer, and black-tailed jackrabbit. A more complete discussion of biota present at the ERDF is presented in Chapter 2.0 and the RI/FS (DOE-RL 1994d).

The climate at the Hanford Facility is semiarid. The Cascade Mountain Range, located to the west, affects the climate of ERDF by causing a rain shadow effect and serves as a source of cold air drainage (PNL 1989). Average annual precipitation on the Hanford Facility is approximately 160 centimeters ( 6.3 inches). The prevailing wind direction is either west-northwest or northwest. The highest monthly wind average that occurs during the month of June averages 14.5 to 16.1 kilometers (9 to 10 miles) per hour. However, gusts of up to 129 kilometers ( 80 miles) per hour may occur (PNL 1989). Monthly rates of pan evaporation average between 8.1 to 25.4 centimeters (3.2 to 10 inches). Data obtained from groundwater recharge monitoring programs on the Hanford Facility indicate that evaporation and transpiration range from 14.3 centimeters ( 5.6 inches) to 19.9 centimeters ( 7.9 inches) for bare and vegetative surfaces, respectively. These data show natural conditions on the Hanford Facility indicating that little--if any-precipitation has the opportunity to move through the vadose zone to groundwater in this area. Further, it is not expected that the construction and operation of the ERDF will have an overall impact on the ambient air quality of the region, although some local site impacts could be expected from fugitive dust emissions during construction (DOE-RL 1994d; WHC 1994C).

\subsection{THE DESIGN, OPERATION AND CLOSURE OF THE ENVIRONMENTAL RESTORATION DISPOSAL FACILITY}

The ERDF will be a 4.14 square kilometer ( 1.6 square mile) area that includes a waste management trench and support units, such as waste water 
1 treatment and a decontamination building. Figure E-4 presents a conceptual

2 model for the ERDF trench and support units. Although the ERDF support units

3 will be located physically within the CAMU, these support units will maintain

4 their separate regulatory identify as required in 40 CFR 264.552 and

5 WAC 173-303-646. The design, permitting, and operational details of the

6 support units will be provided in a separate document, but some information is

7 included within the application because the operation of these support units

8 support the CAMU decision criteria, which must be met to show that CAMU

9 decision criteria relative to the ERDF have been met. The ERDF trench will be

10 the only land-based unit within the ERDF that can be included in the CAMU, and

11 the only unit detailed within this application. The following are support

12 units for the ERDF trench, for which separate RCRA or other permits will be

13 sought, as applicable:

- Rail and tractor trailer container handling facilities, including:

- Loaded rail and tractor trailer transfer/unloading area

- Empty contaminated container transfer area

- Empty decontaminated container transfer area

- Decontamination building, including:

- Conveyor system

- Water recycling system

- Mobile decontamination unit

- Waste water treatment building

- Subsidence control plant.

The current conceptual design for the ERDF trench is a trench with an average finished depth of 21.3 meters ( $70 \mathrm{feet}$ ), constructed almost entirely below grade. The total trench length will be approximately 305 meters ( 1,000 feet) wide and approximately 2,740 meters (9,000 feet) long. The trench will be comprised of individual cells that are approximately 23,225 square meters (approximately 250,000 square feet) in area. The entire trench will not be constructed at once; instead, trench construction will progress in stages as waste placement capacity is required. Figure E-5 presents a conceptual drawing of the ERDF showing the location of the trench relative to the support units. The trench will be equipped with a double liner system with a leachate collection/leak detection system above each liner, and a surface water run-on/run-off control system. Detailed operating procedures for the ERDF, including procedures associated with trench filling/management, will be developed before acceptance of waste at the ERDF. However, operation of the ERDF will proceed in a manner that safeguards human health and the environment, and will include dust suppression activities. The ERDF design currently is conceptual, and definitive design of the ERDF will be completed for regulatory agency approval approximately 3 months after issuance of the ROD for the ERDF.

As indicated previously, a double-liner system will be installed within the ERDF trench, and will include a geomembrane primary liner and a composite geomembrane/low-permeability soil secondary liner. A 0.9-meter-(3-foot-) 
DOE/RL-94-40, Rev. 0

$06 / 94$

operations layer will be emplaced on the primary liner system to prevent mechanical and frost damage to the liner system during waste emplacement.

Support units will be used to facilitate remediation waste placement within the ERDF trench. Figure E-6 presents a generalized flow diagram showing how waste will be managed in the ERDF support units and the ERDF trench. Remediation waste will be placed into reusable containers at the remediation sites and transferred to the ERDF via rail (or possibly tractor trailer). Remediation waste entering the ERDF will be transferred to an incoming loaded container siding/off-loading area. Waste containers will be transferred from the railcars or tractor trailers to dedicated ERDF transport vehicles, which will be transported to and emptied into the ERDF trench at the trailer tipping area. Single-use containers will be placed directly within the ERDF trench. Bulk remediation waste will be spread within the trench using dozers or other equipment. As necessary, waste will undergo subsidence cuntrol (i.e., infilling with cement). Dust control operations, including dust suppressants and possibly water sprays, will be conducted to prevent wind dispersal of remediation waste and minimize dust generated from gravel

roadways. Also, an interim cover will be placed in the trench to prevent wind dispersal of waste and to provide a clean working surface for the ERDF equipment. Further, a final interim cover consisting of a low-permeability material, such as asphalt or a geomembrane layer, will be placed annually atop filled cells to further prevent liquid infiltration before emplacement of the final rover. Reusable containers will be transferred to the empty contaminated container transfer area adjacent to the decontamination building. Containers will be transported through the decontamination building via a conveyor system. Rinsate water from the decontamination process will be collected, diverted to a water treatment (recycling) system, and will be reused within the decontamination building. Once washed, the containers will be passed through a drying room and to the radiation survey room, where the external portion of the containers will be decontaminated before return to the remediation sites for refilling.

All water used at or collected from the ERDF will be managed to control its release. Potentially contaminated surface water run-on/run-off will be collected and routed through the waste water treatment system if appropriate. Waters used for decontamination will be treated before reuse. The conceptual design report (DOE-RL 1994a) details the intended waste water system.

Operation of the waste water system will ensure that water associated with the ERDF is managed in a manner that safeguards human health and the environment.

A number of procedures will be in place at the ERDF to prevent hazards (Chapter 6.0). For example, security procedures such as a surveillance systems and barriers will be in place during operations, and a comprehensive inspection schedule for the ERDF trench will be enacted. Communication equipment and safety measures taken to prevent hazards associated with unloading operations, etc. Will be in place. The Hanford Facility Contingency Plan (DOE-RL 1993h) will apply to the ERDF. Additionally, a building emergency plan (Chapter 7.0 and Appendix 7A) will be in place before acceptance of waste at the ERDF. A11 personnel working at the ERDF will undergo extensive training (Chapter 8.0 and Appendix 8A) to ensure that 
1 operations associated with the ERDF are conducted appropriately and activities

2 are conducted in a manner to safeguard human health and the environment.

3

Closure of the ERDF trench also is addressed in the application. The preliminary design for the ERDF trench final cover is a multi-layer system consisting of soil and geosynthetic material(s). Each layer performs a different function that, when combined, results in the minimization of 1iquid (water) infiltration into the waste, while also minimizing the need for long-term maintenance. The main layers of the final cover will include (from ground surface downward): a 0.9-meter- (3-foot-) thick surface soil layer with vegetative cover; a 30 -centimeter- (12-inch-) thick sandy soil drainage layer to collect precipitation, which then flows laterally to a perimeter drainage system; and a low-permeability geomembrane or low-permeability soil layer to prevent moisture from reaching the final interim cover above the remediation waste. The hydraulic conductivity of the cover will be $10^{-7}$ centimeters per second ( $3 \times 10^{-4}$ feet per day) or less. The final cover will require minimal maintenance, and will minimize the potential for water erosion by limiting surface slopes of the cover, employing a 1-meter- (3-foot-) thick soil layer, and providing a drainage system for run-on/run-off control.

Once closure of the ERDF trench has occurred, a postclosure plan will take effect. Although the postclosure period is not specified for a CAMU, it is anticipated that postclosure care will continue for a minimum of 30 years, where on reassessment of the postclosure plan will take place, based on data collected during this time. The postclosure plan includes inspections that will be conducted routinely throughout the postclosure period. The following will be inspected: the integrity of the cover; security control devices; erosion effects/damage; cover inspection for settlement, subsidence, and displacement; vegetative cover conditions; animal activity; cover drainage system functioning; leachate collection/detection and removal systems; groundwater monitoring well condition; benchmark integrity; and inspection training and frequency.

\subsection{CORRECTIVE ACTION MANAGEMENT UNIT DECISION CRITERIA AND THE ENVIRONMENTAL RESTORATION DISPOSAL FACILITY}

As discussed previously, to demonstrate viability of the ERDF as a CAMU, seven specific criteria must be met. Information sufficient to demonstrate that the CAMU criteria will be met is summarized in this Executive Summary and is detailed in Chapters 1.0 through 15.0 of the CAMU application.

CAMU Criterion No. 1: The CAMU shall facilitate the implementation of reliable, effective, protective, and cost-effective remedies. The information presented within the application indicate that the ERDF will significantly fulfill this requirement. The ERDF site environmental conditions and overall setting support this criterion because the ERDF will be located in an area that is significantly more distant from the Columbia River than any of the remediation sites. Further, because the distance to groundwater is over 90 meters (290 feet) and the rainfall is very low (16 centimeters, or 6.3 inches per year), the potential for groundwater--and, hence contaminant-migration due to site conditions alone is minimized. This conclusion is 
1 supported by groundwater modeling under the ERDF RI/FS activity. Via

2 modeling, the RI/FS (DOE-RL 1994d) shows that contaminant transport within the 3 vadose and saturated zones is minimal to nonexistent up to 500 years in the 4 future, assuming an ERDF trench/design very similar to that presented within 5 the CAMU application. Also, dust suppression actions during the operational 6 phase will mitigate contaminant migration in the air pathway during the 7 operational, closure, and postclosure periods.

The ERDF will not involve impoundment of any body of water, and all water uses/discharges will be strictly controlled and monitored. This is in contrast to the current situation at the remediation sites, where waste is present in soil and groundwater immediately adjacent to the Columbia River and where contaminant discharges to the river are occurring (i.e., 100-N Springs). Therefore, the ERDF will afford protection of human health and the environment that is not provided if waste were to remain in their current remediation site locations proximal to the Columbia River.

Through its period of operation, the ERDF also will meet Criteria No. 1 standards through the use of specific design and operation/management strategies. The proposed trench design (double liner, leachate collection) offers significant protection to human health and the environment during the operational period because underlying clean soil will not come in contact with overlying waste material. Further, collection of any leachate will divert potentially contaminated water from migrating downward, again providing protection to the local, underlying environment. Although the liner system is not intended to function intact for the entire 10,000 year period required for evaluation under the Tri-Party Agreement, use of the systems offers near-term (through the 30-year postclosure period) protection, and will provide valuable data regarding leachate generation that may be used to further evaluate effectiveness of overlying caps/barriers. Interim caps will offer protection in the near term from dust dispersion.

The ERDF will require that waste accepted into the ERDF trench meet certain standards (waste acceptance criteria) to ensure that constituents will not migrate from and can be managed safety in the ERDF. Treatment, if necessary, will be decided on an individual remediation site-specific basis because the potential suite of treatment options is broad, and should not be limited or mandated by the ERDF.

The closure and postclosure design for the ERDF will offer significant protection against downward infiltration of surface waters, thus minimizing potential contaminant migration from ERDF waste. Although the RI/FS (DOE-RL 1994d) models a somewhat different final barrier design than that presented within this application, overall, both barriers have equal low permeability. The effectiveness of the final barrier (final cover) presented in this application is well documented and offers the significant long-term protection and effectiveness.

Relative to qualitative risk reduction, both near- and long-term risk will be mitigated by ERDF design and operation, reducing the possibility for contaminant transport in the air, surface water, soil, and groundwater pathways. Contaminant transport modeling indicates that the ERDF trench 
1 design and final barrier design exhibit 'high long-term performance'. The

2 RI/FS (DOE-RL 1994d) also states that the design has relatively higher cost

3 than other designs and is "redundant" in terms of protection. However,

4 preliminary screening of various trench configurations and the use of a single

5 versus multiple sites indicated that the ERDF trench design will be

6 significantly more cost-effective than other trench designs and

7 configurations.

The determination that the ERDF is protective of human health and the environment and is a reliable, effective, protective, and cost-effective remedy is supported because the ERDF will:

- Isolate hazardous/dangerous waste and radioactive waste and constituents to a single, manageable area

- Remove hazardous/dangerous materials from the environment that are currently in locations significantly close (and therefore, presented a greater potential threat) to the Columbia River and hence, environmental receptors

- Contain hazardous/dangerous and radioactive material within a unit designed to offer both long-term and short-term protectiveness of the environment through engineering controls

- Use waste acceptance criteria that restrict placement to only remediation waste that safely can be managed within the ERDF, confirming that only those materials that can be managed appropriately will be placed in the ERDF

- Provide operational activities, including those to be used during waste transport and emplacement, that are sufficiently rigorous to ensure that workers are protected from exposure

- Use Hanford Facility contingency plans as well as unit-specific emergency plans to ensure that sufficient mechanisms are in place to protect human health and the environment if a release occurs

- Be located in an area underlain by geologic materials that offer significant isolation from the water table; the permeability of underlying vadose zone materials and deeper aquifers is such that contaminant migration within the water-bearing interval to the Columbia River would be much slower than if material were left at existing locations closer to the river

- Demonstrate effectiveness of the ERDF through documented effectiveness of design, as well as preliminary modeling results as the ERDF is intended to isolate hazardous/dangerous and radioactive material from humans and the environment; design (double-liner/leachate collection/detection system) ensures near-term isolation, while the final barrier design ensure long-term isolation 
D0E/RL-94-40, Rev. 0

$06 / 94$

- Provide a design that is much more cost-effective than transporting waste offsite or constructing numerous waste management units at individual remediation sites.

CAMU Criterion No. 2: Waste management activities associated with the CAMUs shall not create unacceptable risks to humans or to the environment resulting from exposure to hazardous waste or hazardous constituents. Significant operational constraints and controls will be in place to meet the standards of this CAMU criterion. These constraints and controls, which also are required under DOE-RL internal standards and orders, will ensure that operations will protect worker safety and human health and the environment. As discussed previously, an operations plan will be developed before commencement of ERDF operation. This plan wil1 describe waste management activities within the ERDF to ensure proper management (i.e., management of potentially incompatible waste from different remediation sites). While the plan is required by DOE Order 5820.2A for radioactive waste, the plan will serves a dual purpose by demonstrating that operation of the ERDF will proceed in a manner to meet the standards of this second criterion.

Because the ERDF will include an ERDF-specific emergency and training plan and will employ procedures to prevent hazards (Chapters 6.0 through 8.0), protection of human health and the environment resulting from exposure to hazardous/dangerous waste will be minimized because personnel will be trained appropriately and emergency situations will be handled appropriately, or avoided altogether. Dust suppression at the ERDF will mitigate potential airborne contaminant transport. Also, management of waste within a single location (rather than at multiple remediation sites) will decrease the potential for unintentional releases because the risk for such releases to occur declines with fewer numbers of waste management units.

The ERDF-specific measures will be in place to prevent uncontrolled release of hazardous/dangerous constituents and radioactivity to the environment during trench operations, including decontamination of reusable waste containers and use of dust suppressants. Further, use of equipment such as high-efficiency particulate air (HEPA) filters in various areas of the ERDF will protect human health and the environment by decreasing the potential for inhalation of dust particles.

In summary, the ERDF operations will ensure that waste management activities within the ERDF will not create unacceptable risks to human health and the environment because the ERDF will:

- Offer design (i.e., double liner) that mitigates the potential for contaminant migration into soil and groundwater during the operation phase

- Use an operations plan that ensures the ERDF will be managed in a safe manner

- Have mitigation measures to minimize the potential for contaminant transport in air throughout the ERDF and supporting operations, including dust, suppression, use of HEPA filters, etc. 
- Ensure that ERDF personnel are trained appropriately and that procedures are in place to ensure that hazards will not arise

- Use in-place methods and plans that will be followed in the event that an emergency response is warranted, to remedy the situation before human health and the environment are endangered.

CAMU Criterion No, 3: The CAMU shall include uncontaminated areas of the facility, only if including such areas for the purpose of managing remediation waste is more protective than management of such waste at contaminated areas of the facility. While ERDF soils are relatively uncontaminated with respect to the remediation site soils, the ERDF offers distinct advantages over waste management at the remediation sites. One of the most compelling supporting elements for the ERDF is that placement of material in this location will remove the waste from immediate proximity to the Columbia River, which is a potential receptor pathway. In fact, the remediation sites have been designated for remediation based on their potential for imminent threat to human health and the environment. Also, as discussed under Criterion No. 1, use of a single site rather than multiple sites offers less opportunity for hazards to arise because there is only one site at which such situation could arise. Environmental conditions at the ERDF (i.e., depth to groundwater, precipitation infiltration rates) also support ERDF protectiveness.

Numerous options were evaluated before selection of the current ERDF location. For example, offsite transport of waste was eliminated because there are few facilities prepared to accept Hanford Facility remediation waste because it is 'mixed' and requires more specific handling than hazardous/dangerous or low-level waste. Also, no offsite facilities with sufficient capacity to manage the requisite volume are available within the designated timeframe needed for remediation waste management. Also, transport of the remediation waste offsite likely would meet public opposition relative to transport along public highways.

The Future Site Uses Working Group (the Group), as part of its mission to identify and develop future uses for the Hanford Facility, proposed that the 200 Areas Plateau be reserved for waste management (Eastern Washington University 1992). The ERDF is located within this selected area. Further, the Group recommended that waste management activities on the 200 Areas Plateau be concentrated within a limited area (i.e., the central portion of the plateau, which again is where the ERDF is located).

Additional locations within the 200 Areas were evaluated for construction of the ERDF. These locations included the current ERDF site, as well as an area immediately northwest of the 200 West Area and a site located to the north of the 200 West Area. The current ERDF location was selected above these two sites because it will be sited and operated in an area that minimizes overall habitat destruction, offered better protection of human health and the environment, and was more favorable, relative to regulatory, construction, and operating criteria.

A7though the ERDF site does not contain soil contamination when compared to the remediation sites or other areas on the Hanford Facility, preexisting 
1 groundwater contamination is present below the ERDF (refer to Chapter 5.0). 2 Although the source of this contamination is upgradient of the ERDF, the ERDF 3 is not unequivocally a 'pristine' location.

The ERDF meets standards of Criterion No. 3 because the ERDF will:

- Be located in land areas below which preexisting groundwater contamination has been documented

- Be located within an area of the Hanford Facility identified by the Hanford Future Site Uses Working Group as the recommended waste management area, and will be in an area with environmental conditions that offer protectiveness

- Offer a significantly greater level of human health arid environmental protection than available from waste management locations situated along the Columbia River

- Be a single facility in a specified location, as opposed to multiple remediation waste placement locations that enhances long-term control, management, and reliability.

CAMU Criterion No. 4: Areas within the CAMU, where waste remain in place after closure of the CAMU, shall be managed and contained so as to minimize future releases, to the extent practicable. The ERDF trench design and final barrier design will offer significant protection relative to both near- and long-term future releases. The double-liner trench design system, with leachate collection/detection systems, will ensure that downward contaminant migration during the operational period and near term is prevented, particularly because any leachate generated will be collected and managed appropriately rather than released to the underlying environment. Interim covers will offer dust control, but also will decrease infiltration of precipitation through the waste before emplacement of the final barrier, thus decreasing the potential for contaminant release during this period.

The final cover design has a 'proven track record' in industry, and will have a permeability less than $10^{-7}$ centimeters per second $\left(3 \times 10^{-4}\right.$ feet per day). The barrier will have a drainage system to divert infiltrated rainwater from the barrier, and the uppermost layer above the drainage layer will consist of soil with sufficient thickness to afford frost protection and grain size distribution to enhance moisture retention in the shallow root zone of the vegetative cover. Thus, potential for downward contaminant migration in the postclosure period and thereafter will be minimized in the long term. The postclosure program will include inspections and maintenance plans/procedures to ensure that the final barrier integrity is maintained. Groundwater monitoring will be conducted through the operational period and the postclosure period so that any releases from the ERDF wil1 be detected and remedied as appropriate.

Contaminant transport modeling performed for the RI/FS (DOE-RL 1994d) indicate that, based upon known maximum concentrations, less than 10 contaminants will reach the water table within the 10,000-year Tri-Party 
1 Agreement evaluation period, and these only in de minimus values. Additional

2 modeling currently is being performed under the RI/FS that may modify or alter

3 these results to indicate that even fewer constituents may enter the water

4 table during the designated timeframe.

The ERDF provides long-turm protectiveness via release minimization through appropriate design/management because it will:

- Provide the controls to ensure long-term reliability of design, including monitoring of leachate generation over a 30-year period that will demonstrate the cap design effectiveness

- Incorporate the design elements that ensure long-term waste management effectiveness (e.g., double liner and leachate collection) and monitoring of potential release of contaminants to groundwater

- Effectively protect human health and the environment, as shown by contaminant transport modeling results.

CAnU Criterion No. 5: The CANU shall expedite the timing of remedial activity implementation, when appropriate and practicable. The ERDF

facilitates rapid remediation on the Hanford Facility, as required under the

Tri-Party Agreement. Offsite management of the remediation waste will not facilitate timely, effective, or cost-effective remediation activities, as discussed under CAMU Criterion No. 3. In addition, the Tri-Party Agreement states that delay of the ERDF would result in subsequent Hanford Facility remediation delays and thus endorses construction of the ERDF.

Because a facility capable of receiving large quantities of remediation waste is needed on the Hanford Facility, delays in the acquisition of this facility would not facilitate timely remediation. By having the ERDF ready to receive waste when cleanup of the first remediation site begins, the ERDF will facilitate the timing of site remediation by providing a timely waste management option. The criticality of initiating the ERDF in a timely fashion was emphasized with in the Tri-Party Agreement: "Delay in construction of the (ERDF) would impact cleanup of waste sites." "Therefore, use of the ERDF is in accordance with Tri-Party goals and milestones.

The ERDF will help Hanford Facility remediation in a timely manner because it wi11:

- Facilitate the Tri-Party Agreement mandates that require cleanup schedules that could not be met without the ERDF

- Make available a waste management facility that could not be constructed at each remediation site in a timely fashion because construction of remediation site-specific waste management units would be initiated after each RI/FS, and could therefore take years to construct.

CAmU Decision Criteria No. 6: The CAMU shall enable the use, when appropriate, of treatment technologies (including innovative technologies) to 
DOE/RL-94-40, Rev. 0 06/94

enhance the long-term effectiveness of remedial actions by reducing the toxicity, mobility, or volume of waste that will remain in place after closure of the CAMU. The CAMU regulations indicate a definite 'bias' toward treatment of waste, and the use of innovative technologies is preferred. However, the regulations also indicate that while treatment is a preference, it is not a mandate; under certain situations, treatment at a CAMU is not required. The ERDF will not mandate treatment before emplacement because of its role in the overal1 site remediation process, as discussed in the following.

Following the typical RI/FS or RFI/CMS process, construction of a unit such as the ERDF normally would occur after full characterization of all remediation site(s) has occurred. However, construction of the ERDF is to occur before full characterization at each remediation site. More significantiy, the remediation process at each CERCLA and RCRA past-practice remediation site requires that treatment options be evaluated on a site-bysite basis. Therefore, although the ERDF does not require specific treatment and instead imposes waste acceptance criteria, this does not mean that treatment of waste will not occur. Waste treatment options will be evaluated on a remediation site-specific basis, thus allowing for specific, 'tailored' treatment to be performed, as applicable, at each site.

If the ERDF imposed specific waste treatment options, this could conceivably limit treatment that would be performed at each remediation site. This constraint is contrary to the intent of the CAMU regulations that promote the use of innovative technologies that are best developed on a remediation site-specific basis. Also, the preamble to the final CAMU rule (58 FR 29) states that "this criterion does not preclude remedial actions that do not include treatment," and the waste acceptance criteria for the ERDF will provide waste characterization guidance that must be met by each remediation site before acceptance of waste at the ERDF.

It is anticipated that the bulk of the waste to be emplaced at the ERDF will be high-volume, low concentration (e.g., toxicity). The CAMU preamble (58 FR 29) states that "Given the example, therefore, of a situation involving large volumes of low concentration contaminated soils or other waste, the Regional Administrator would have the discretion to evaluate containment-based remedial approaches." By leaving treatment determination to the remediation site, high-volume, low-concentration waste would undergo appropriate treatment, as appiicable, while higher concentration waste could undergo a different treatment. If the ERDF were to mandate a treatment, the flexibility necessary to determine appropriate treatment options for the spectrum of waste anticipated potentialiy would be lost.

The RI/FS (DOE-RL 1994d) modeling does not take into account any treatment of waste. Instead, maximum known waste concentrations were usad in the calculations. Current modeling results show that very few contaminants will exceed allowable constituent concentrations at the ERDF trench boundary in 10,000 years, and it takes over 500 years for the first contaminants to even travel through the vadose zone to the water table. Modeling currently is being refined that could show even longer travel times within the vadose zone and groundwater. The ERDF waste acceptance criteria wi11 require that waste 
1 concentration be below that which would result in breach of the allowable groundwater concentrations at the ERDF boundary.

The CAMU requirements relative to the use, when appropriate, of waste treatment wi11 be met by the ERDF because the ERDF wi11:

- Be an implementation component of a broad-scale restoration. program that includes treatment evaluation on a remediation site-specific basis

- Allow for consideration of remediation waste treatment on an individual remediation site basis enables the use of tailored, innovative technologies (where applicable) to be developed, which actually could be hindered if more general treatment requirements were mandated at the ERDF

- Accept very large quantities of low concentration/toxicity remediation waste, and the preamble to EPA's final CAMU rule (58 FR 29) states that this is a specific example of an instance in which containmentbased remedial approaches only may be used

- Be more than sufficient to minimize contaminant migration for the remediation waste to be accepted for placement in the ERDF without the additional cost of waste treatment at the ERDF, based on modeling results

- Not accept waste that does not meet the waste acceptance criteria.

CAMU criterion No. 7: The CAMU shall, to the extent practicable, minimize the land area of the facility upon which waste will remain in place after closure of the CAMU. The ERDF will consolidate material from around the Hanford Facility, thereby maximizing the area that will be available for future use, and minimizing the 1 and area on which waste would remain until closure. Based on available data, remediation waste within the 100, 200, and 300 Areas covers as much as approximately 28.5 square kilometers (11 square miles). The ERDF trench covers approximately 1.24 square kilometers ( 0.48 square miles), which represents a reduction in areal extent of up to 95 percent.

The CAMU minimizes the land area of the Hanford Facility on which waste will remain after closure because it will:

- Consolidate remediation waste, thus minimizing the land area of the Hanford Facility on which waste will remain after closure

- Facilitate subsequent reuse of remediation sites

- Minimize the land area used for waste management. 


\subsection{SUMMARY}

3 Information contained within the application demonstrates that the ERDF 4 will meet all CAMU decision criteria before operation. Therefore, designation 5 of the ERDF as a CAMU under RCRA is appropriate, given that existing data gaps 6 will be filled before acceptance of RCRA past-practice remediation waste at 7 the ERDF. 
DOE/RL-94-40, Rev. 0

06/94

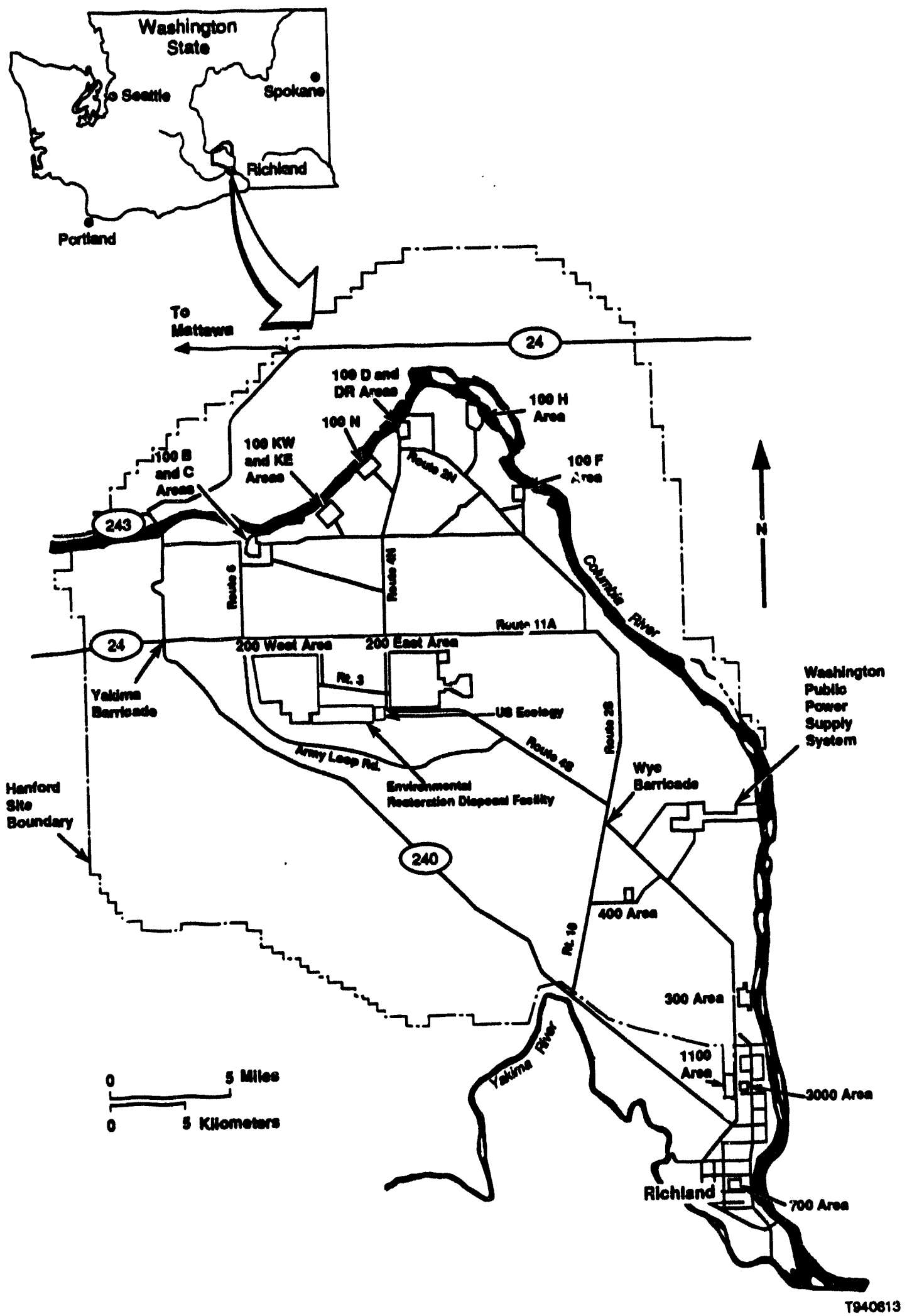

Figure E-1. Hanford Facility. 


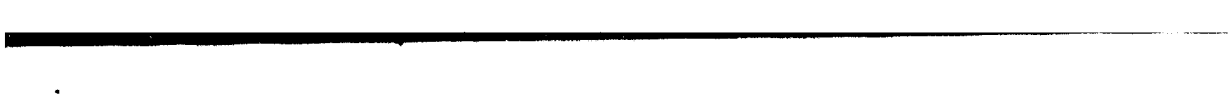

.

•

.

. 

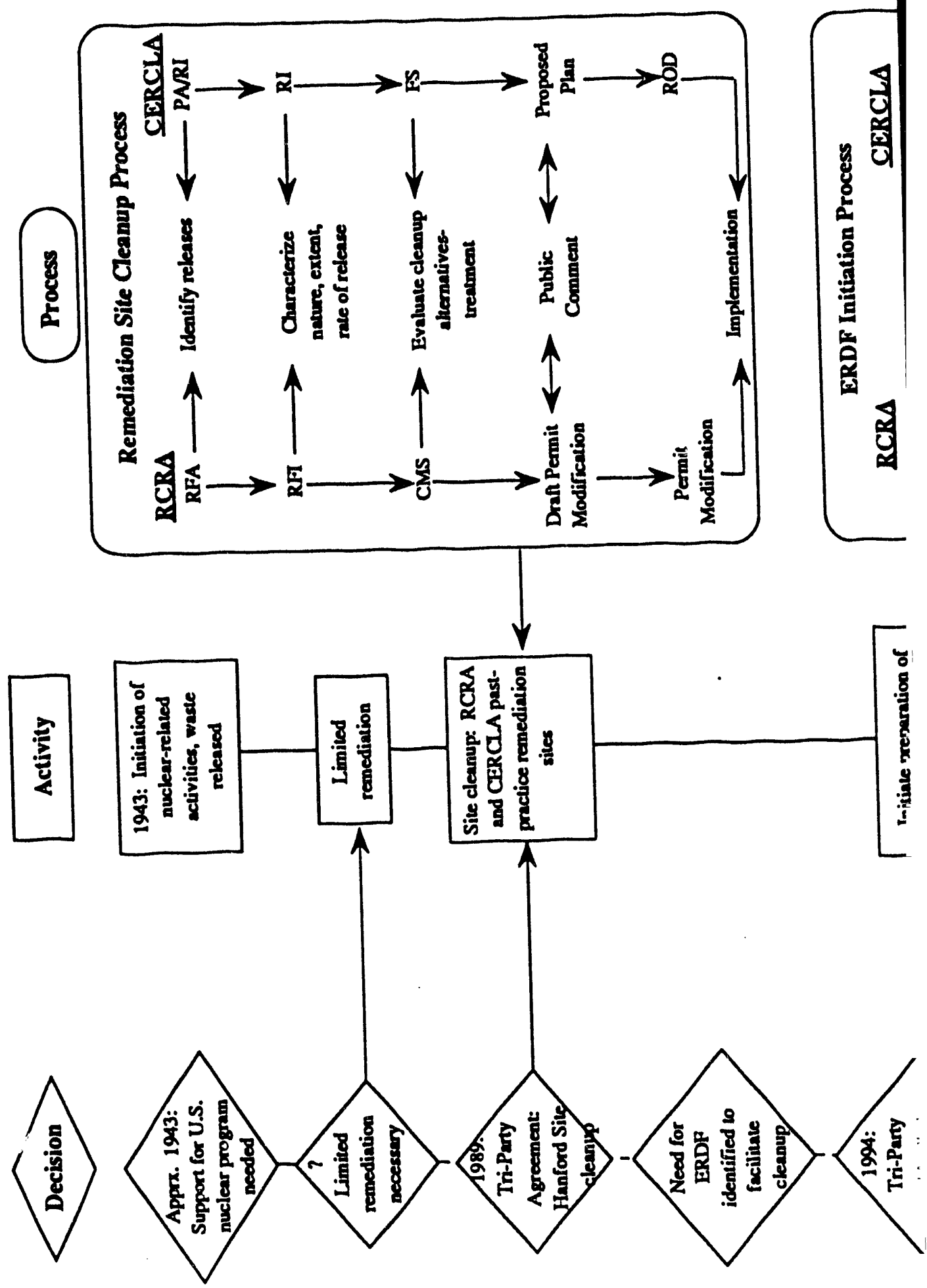


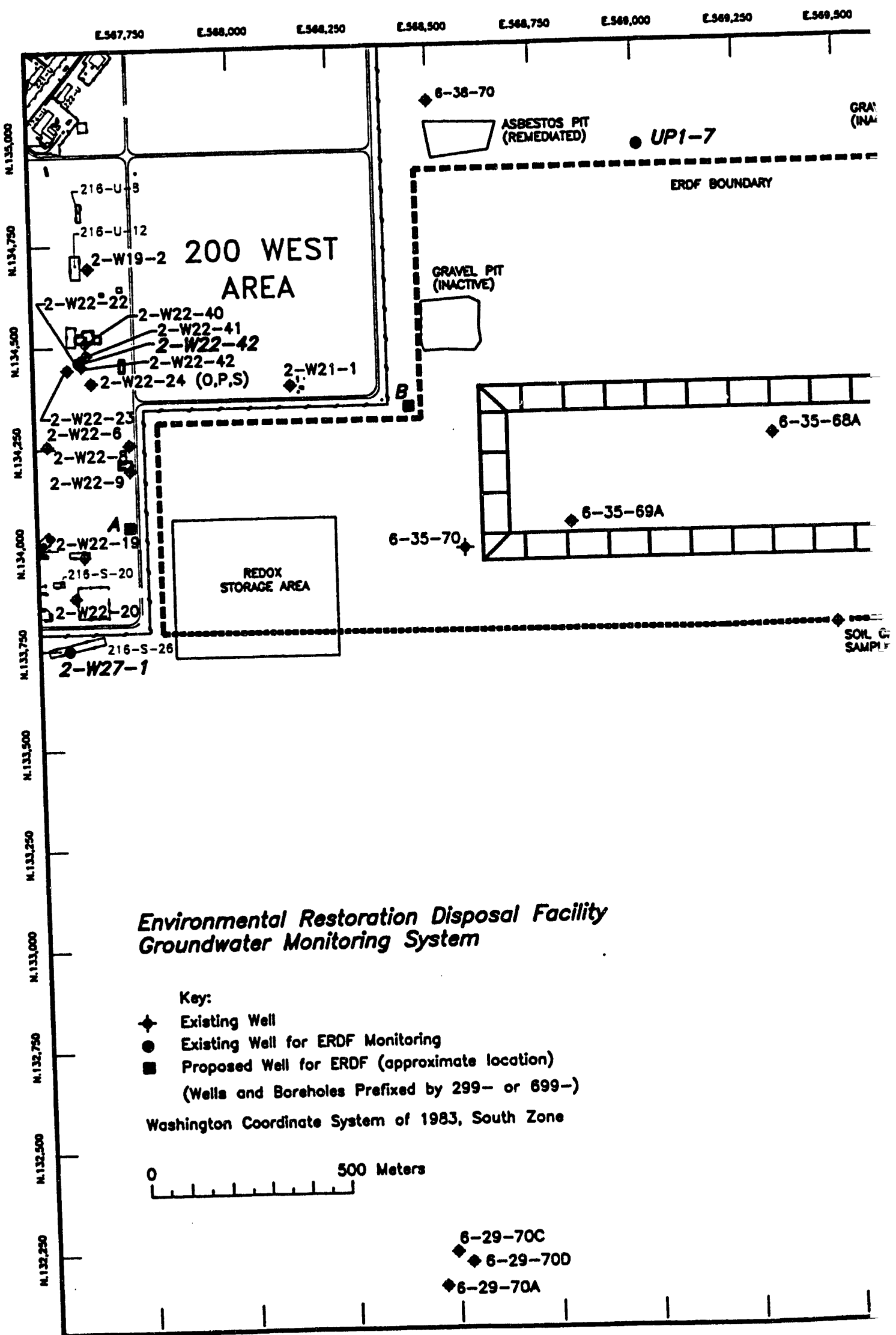




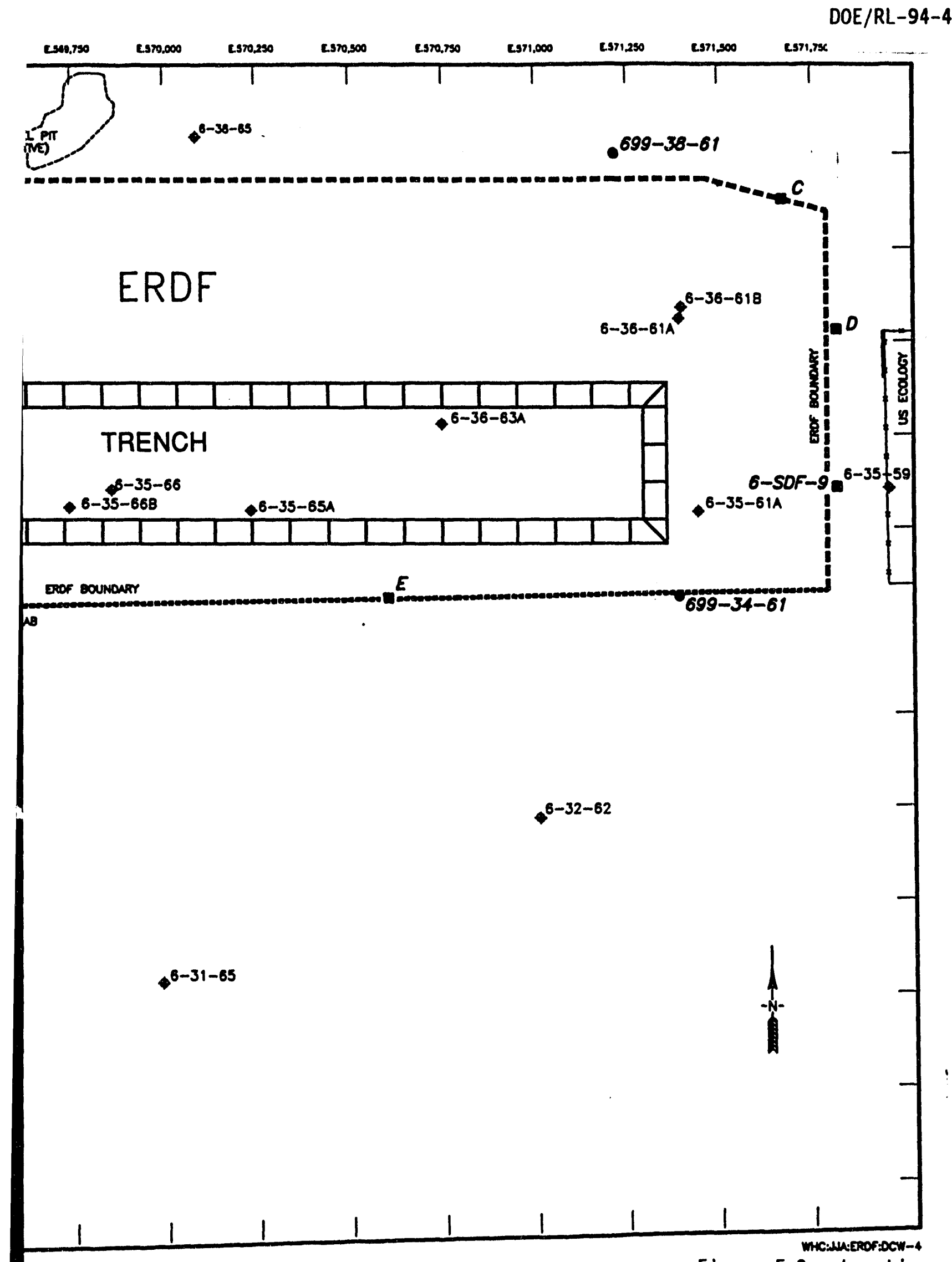

Figure E-3. Location of Environmental Restoration Disposal Facility Monitoring Wells. 


$$
\text { DOE/RL-94-40, Rev. } 0
$$

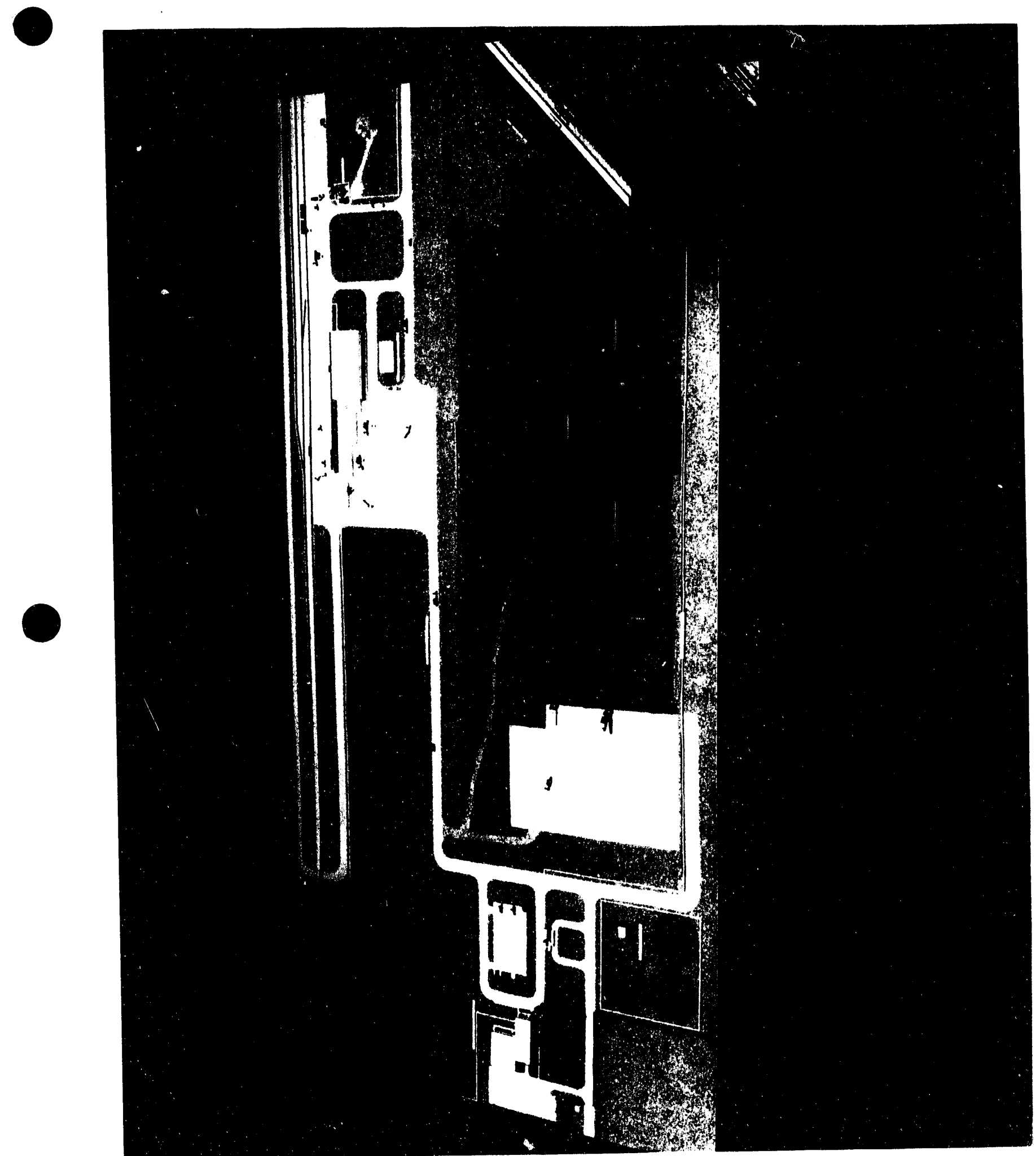

Figure E-4. Conceptual Model of the Environmental Restoration Disposal Facility. 


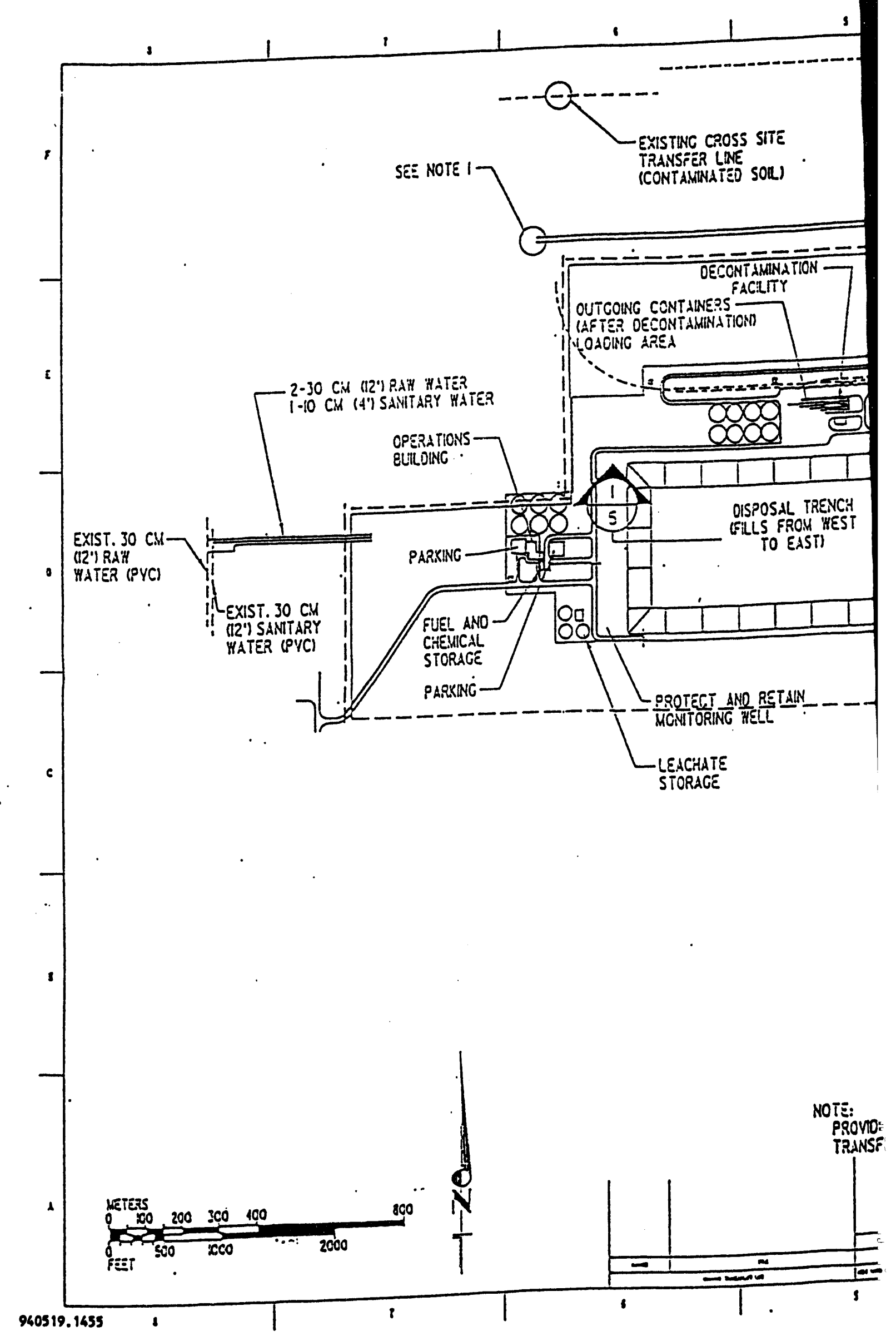




\section{$51-3$}

- deW $\partial 7 ! S$ Kq!Llorej lesods!0

uo!fenozsay Lequawuod!nu\} 's-3 aגn6!J

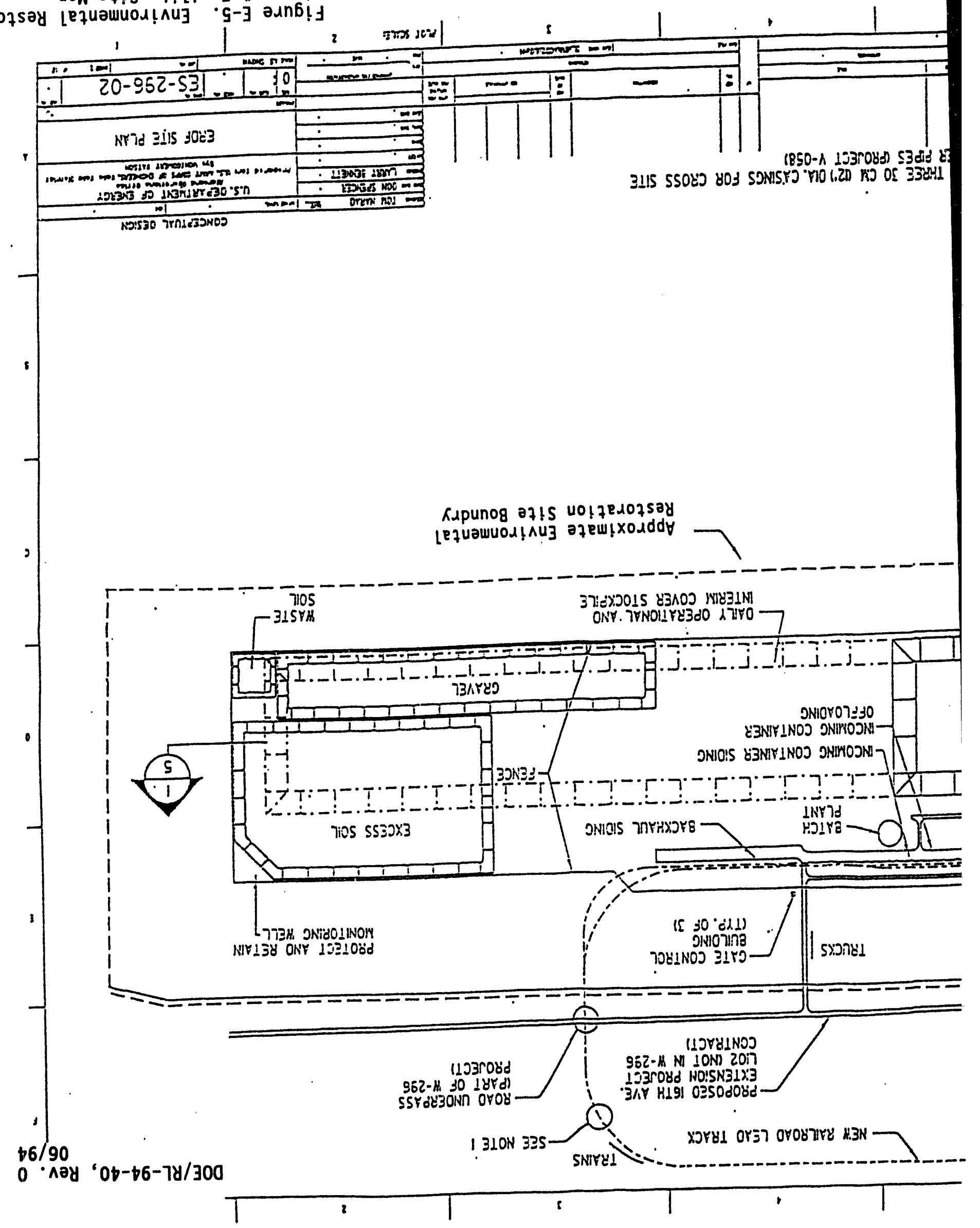




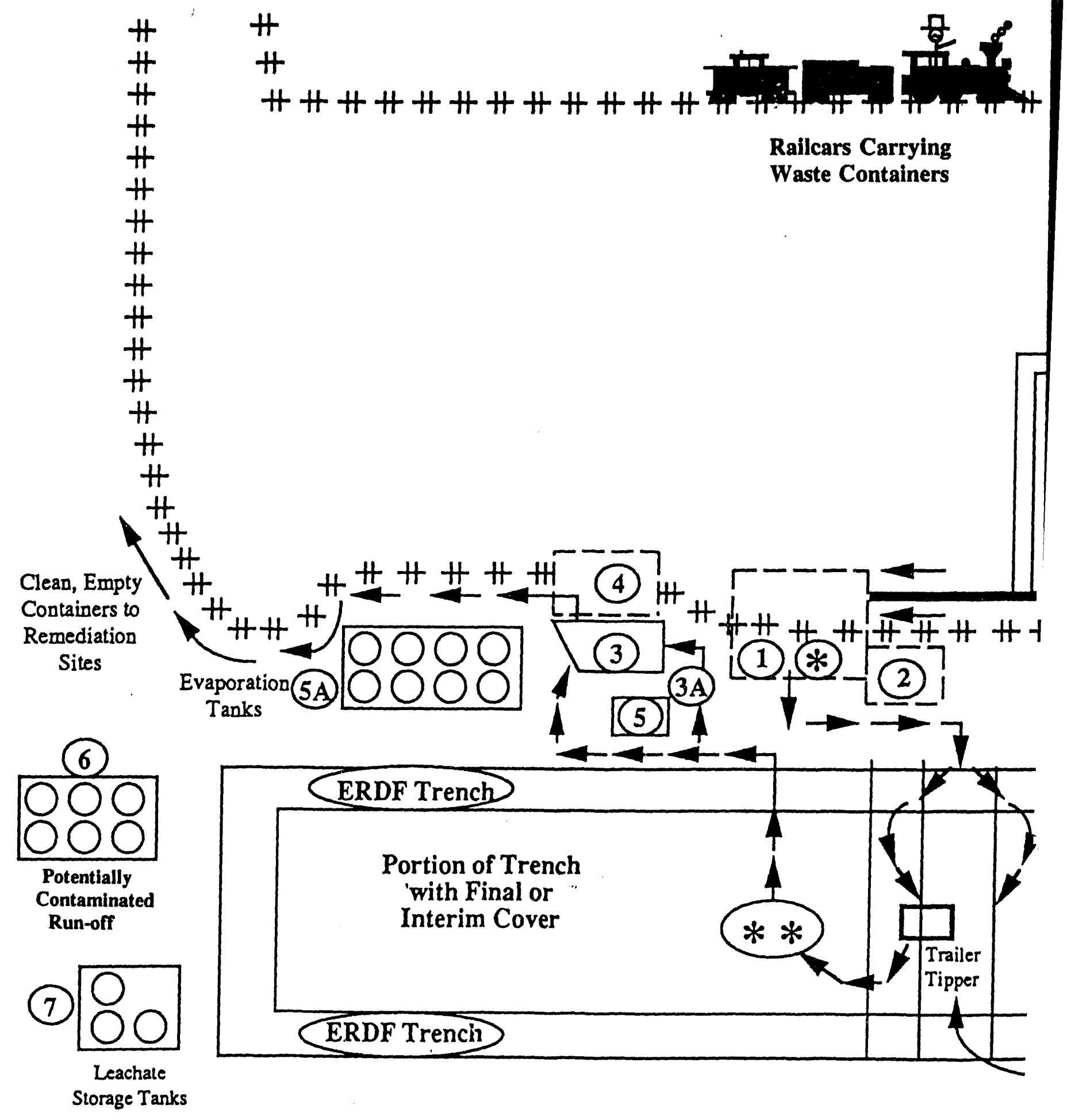




$$
\text { DOE/RL-94-40, Rev. } 0
$$

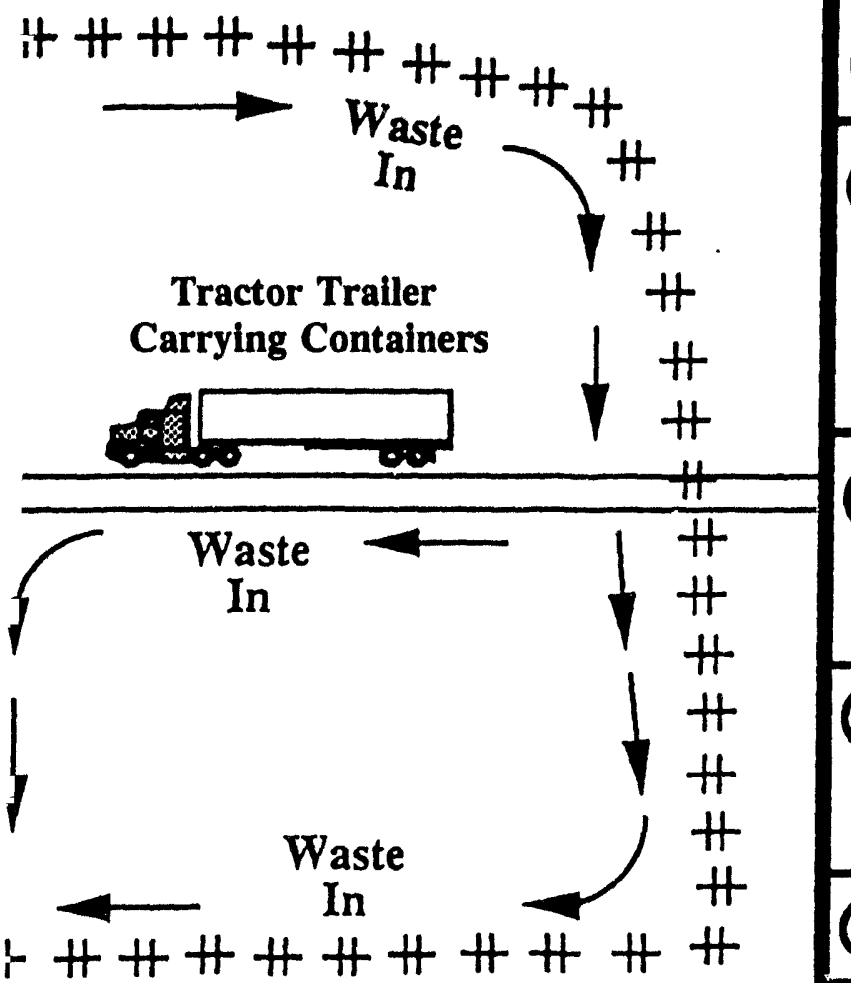

(1) Loaded Rall and Tractor Traller Transfer/Unloadine Area

Design - Precipitation collected and segregated

Permits - Generator accumulation storage

* Container contents confirmed; if suspect stored at 2

2) Temporary Container Storage Area at Unloadine Area (if required)

Design - Precipitation collected and segregated

Permits - Generator accumulation storage or RCRA hazardous waste operating permit

Containers either - Go back to remediation site or continue to

ERDF trench trailer tipper or bottom of trench face

**) Visual Inspection of Empty Container

A lot of residue - Container scraped or sent to outdoor wash

pad (3A)

Not much residue - Container to Decontamination Building 3

(3) Decontamination Building

Design - The floor and sumps must meet RCRA tank MTRs

Permits - Generator accumulation storage or RCRA hazardous waste operating permit

3A Outdoor Container Wash Pad must meet RCRA tank MTRs

4) Empty Decontamination Container Transfer Area

Design - No requirements for collecting precipitation

Permits - None required

5) Waste Water Treatment Building

Receives waste water for leachate storage tanks (7)

Potentially contaminated run-off tanks (6)

Decontamination Building blowdown (3)

Design - RCRA hazardous waste tank MTRs

Permits - Generator accumulation storage or RCRA

Single-Use Containers

Go to Bottom of

Working Face
Excavated but

Unlined Trench

Precipitation

Evaporates or Infiltrates

operating permit

Evaporation tanks

6) Potentially Contaminated Run-off Storage Tanks

Design - Six tanks that meet RCRA hazardous waste tank MTRs

Permits - Generator accumulation storage or RCRA hazardous waste operating permit

Trench Working Face

Leachate Storage Tanks

Design - Three tanks that meet RCRA hazardous waste tank MTRs

Permits - Generator accumulation storage or RCRA

hazardous waste operating permit

Figure E-6. Environmental Restoration

Disposal Facility Generalized

Operational Flow Diagram. 
Table E-1. Environmental Restoration Disposal Facility Waste Acceptance Criteria Maximum Allowable Constituent Concentration in Remediation Waste. (sheet 1 of 5)

\begin{tabular}{|c|c|}
\hline Constituent & $\begin{array}{c}\text { Maximum Waste Acceptance Level } \\
\mathrm{mg} / \mathrm{kg} \text { (nonradionuclides) } \\
\mathrm{pCi} / \mathrm{g} \text { (radionuclides) }\end{array}$ \\
\hline \multicolumn{2}{|l|}{ VOLATILE OREANIC CONPOUNDS } \\
\hline \multicolumn{2}{|l|}{ 1,1,1-Trichloroethane } \\
\hline \multicolumn{2}{|l|}{ 1.1.2.2-Tetrachloroethane } \\
\hline \multicolumn{2}{|l|}{ 1,2-Dichloroethene } \\
\hline \multicolumn{2}{|l|}{ 2-Butanone } \\
\hline \multicolumn{2}{|l|}{ 2-Hexanone } \\
\hline \multicolumn{2}{|l|}{ 4-Methy 1-2-pentanone } \\
\hline \multicolumn{2}{|l|}{ Acetone } \\
\hline \multicolumn{2}{|l|}{ Benzene } \\
\hline \multicolumn{2}{|l|}{ Carbon disulfide } \\
\hline \multicolumn{2}{|l|}{ Carbon tetrachloride } \\
\hline \multicolumn{2}{|l|}{ Chloroform } \\
\hline \multicolumn{2}{|l|}{ Ethylbenzene } \\
\hline \multicolumn{2}{|l|}{ Methylene chloride } \\
\hline \multicolumn{2}{|l|}{ Tetrachloride } \\
\hline \multicolumn{2}{|l|}{ Toluene } \\
\hline \multicolumn{2}{|l|}{ Trichlorethene } \\
\hline \multicolumn{2}{|l|}{ Total xylenes } \\
\hline \multicolumn{2}{|l|}{ Vinyl chloride } \\
\hline \multicolumn{2}{|l|}{ SEMIVOLATILE ORGANIC COMPOUNDS } \\
\hline \multicolumn{2}{|l|}{ 1,3-Dichlorobenzene } \\
\hline \multicolumn{2}{|l|}{ 1,4-Dichlorobenzene } \\
\hline \multicolumn{2}{|l|}{ 4-Chloro-3-methylphenol } \\
\hline \multicolumn{2}{|l|}{ 4-Methylphenol } \\
\hline Acenaphthene & \\
\hline
\end{tabular}


Table E-1. Environmental Restoration Disposal Facility Waste Acceptance Criteria Maximum Allowable Constituent Concentration in Remediation Waste. (sheet 2 of 5)

\begin{tabular}{|l|l|}
\hline \multicolumn{1}{|c|}{ Constituent } & $\begin{array}{c}\text { Maximum Waste Acceptance Level } \\
\text { mg/kg (nonradionuclides) } \\
\text { pCi/g (radionuclides) }\end{array}$ \\
\hline Anthracene & \\
\hline Benzo(a)pyrene & \\
\hline Benzo(b)fluoranthene & \\
\hline Benzo(g,h, 1 )perylene & \\
\hline Benzo(k)fluoranthene & \\
\hline Benzoic acid & \\
\hline Bis(2-ethyl)phthalate & \\
\hline Butylbenzylphthalate & \\
\hline Carbazole & \\
\hline 4-Chloroaniline & \\
\hline 2-Chlorophenol & \\
\hline Chrysene & \\
\hline Di-n-butyl-phthalate & \\
\hline Di-n-octyl-phthalate & \\
\hline Dibenzo(a, h)anthracene & \\
\hline Dibenzofuran & \\
\hline Diethylphthalate & \\
\hline Fluoranthene & \\
\hline Fluorene & \\
\hline Ideno(1,2,3-cd)pyrene & \\
\hline 2-Methylnaphthalene & \\
\hline 4-Methylphenol & \\
\hline Naphthalene & \\
\hline 2-Nitrophenol & \\
\hline N-nitrosodiphenylamine & \\
\hline
\end{tabular}


Table E-1. Environmental Restoration Disposal Factlity Waste Acceptance Criterta Maximum Allowable Constituent Concentration in Remediation Waste. (sheet 3 of 5)

\begin{tabular}{|l|l|}
\hline \multicolumn{1}{|c|}{ Constituent } & $\begin{array}{c}\text { Maximum Waste Acceptance Leve1 } \\
\mathbf{m g} / \mathbf{k g} \text { (nonradionuclides) } \\
\text { pC1/g (radionuclides) }\end{array}$ \\
\hline Pentachlorophenol & \\
\hline Phenanthrene & \\
\hline Phenol & \\
\hline Pyrene & \\
\hline PESTICIDES/PCBs & \\
\hline $4,4-D D D$ & \\
\hline $4,4-D D E$ & \\
\hline PCB Aroclor*-1248 & \\
\hline PCB Aroclor*-1254 & \\
\hline PCB Aroclor*-1260 & \\
\hline Beta-BHC & \\
\hline Gamma-Chlordane & \\
\hline Dieldrin & \\
\hline Methoxychlor & \\
\hline METALS & \\
\hline Aluminum & \\
\hline Antimony & \\
\hline Arsenic & \\
\hline Barium & \\
\hline Beryllium & \\
\hline Cadmium & \\
\hline Calcium & \\
\hline Cobalt & \\
\hline Copper & \\
\hline Chromium & \\
\hline
\end{tabular}


Table E-1. Environmental Restoration Disposal Facility Waste Acceptance Criteria Maximum Allowable Constituent Concentration in Remediation Waste. (sheet 4 of 5)

\begin{tabular}{|l|l|}
\hline \multicolumn{1}{|c|}{ Constituent } & $\begin{array}{c}\text { Maximum Waste Acceptance Level } \\
\text { mg/kg (nonradionucl Ides) } \\
\text { pCi/g (radionuclides) }\end{array}$ \\
\hline Iron & \\
\hline Lead & \\
\hline Magnesium & \\
\hline Manganese & \\
\hline Mercury & \\
\hline Nickel & \\
\hline Potassium & \\
\hline Selenium & \\
\hline Silver & \\
\hline Sodium & \\
\hline Thallium & \\
\hline Vanadium & \\
\hline Zinc & \\
\hline MisCELLANEOUS IMORGaNICS & \\
\hline Ammonia & \\
\hline Chloride & \\
\hline Chromium VI & \\
\hline Fluoride & \\
\hline Nitrate & \\
\hline Nitrite & \\
\hline Phosphate & \\
\hline Sulfate & \\
\hline RaDionuCLIDES & \\
\hline Americium-241 & \\
\hline Beryllium-7 & \\
\hline
\end{tabular}


Table E-1. Environmental Restoration Disposal Facility Waste Acceptance Criteria Maximum Allowable Constituent Concentration in Remediation Waste. (sheet 5 of 5)

\begin{tabular}{|l|l|}
\hline \multicolumn{1}{|c|}{ Constituent } & $\begin{array}{c}\text { Maximum Waste Acceptance Level } \\
\text { mg/kg (nonradionuci ides) } \\
\text { pCi/g (radionuclides) }\end{array}$ \\
\hline Carbon-14 & \\
\hline Cesium-134 & \\
\hline Cesium-137 & \\
\hline Chromium-51 & \\
\hline Cobalt-58 & \\
\hline Cobalt-60 & \\
\hline Europium-152 & \\
\hline Europium-154 & \\
\hline Europium-155 & \\
\hline Plutonium-238 & \\
\hline Plutonium-239 & \\
\hline Plutonium-240 & \\
\hline Potassium-40 & \\
\hline Radium-226 & \\
\hline Sodium-22 & \\
\hline Strontium-90 & \\
\hline Technetium-99 & \\
\hline Thorium-228+D & \\
\hline Uranium (total) (as U-238) & \\
\hline
\end{tabular}

*Aroclor is a trademark of Monsanto Company. $\mathrm{mg} / \mathrm{kg}=\mathrm{milligram} / \mathrm{kilogram}$

$\mathrm{pCi} / \mathrm{g}=$ picocurie/gram

Source: U.S. Army Corps of Engineers 1994 
DOE/RL-94-40, Rev. 0

06/94

\section{FOREMORD}

The Hanford Facility is owned by the U.S. Government and operated by the U.S. Department of Energy, Richland Operations Office. Hazardous/dangerous waste and mixed waste (containing both radioactive and hazardous/dangerous components) are produced and managed on the Hanford Facility. The hazardous/dangerous waste is regulated in accordance with the Resource Conservation and Recovery Act of 1976 and the State of Washington Hazardous Waste Management Act of 1976 (as administered through the Washington State Department of Ecology Dangerous Waste Regulations, Washington Administrative Code 173-303). The radioactive component of mixed waste is interpreted by the U.S. Department of Energy to be regulated under the Atomic Energy Act of 1954; the nonradioactive dangerous component of mixed waste is interpreted to be regulated under the Resource Conservation and Recovery Act (40 Code of Federal Regulations 264-270) and the State of Washington Hazardous Waste Management Act.

For purposes of the Resource Conservation and Recovery Act and the Washington State Department of Ecology Dangerous Waste Regulations, the Hanford Facility is considered to be a single facility. The single dangerous waste permit identification number issued to the Hanford Facility by the U.S. Environmental Protection Agency and the Washington State Department of Ecology is U.S. Environmental Protection Agency/State Identification Number WA7890008967. This identification number encompasses over 60 treatment, storage, and/or disposal units within the Hanford Site, hereinafter referred to as the Hanford Facility when cited in the context of the Resource Conservation and Recovery Act and the Washington State Department of Ecology Dangerous Waste Regulations. Under the Comprehensive Environmental Response, Compensation, and Liability Act of 1980, the term "facility" is used when referring to the area of contamination. For the purposes of this document, the term facility refers to the entire Hanford Facility, as defined by the single dangerous waste permit number.

Designation of the Environmental Restoration Disposal Facility as a Corrective Action Management Unit under the Resource Conservation and Recovery Act is required before the acceptance of Resource Conservation and Recovery Act past-practice remediation waste for management in the Environmental Restoration Disposal Facility. The Corrective Action Management Unit, as defined in 40 Code of Federal Regulations 264.552 and Washington Administrative Code $173-303-646$, is an area used for the management of remediation waste. The Corrective Action Management Unit is not a treatment, storage, and/or disposal unit under Washington Administrative Code 173-303 and 40 Code of Federal Regulations 264 or 265. However, this Corrective Action Management Unit application has been prepared in the Part B permit application documentation format used for the Hanford Facility Dangerous Waste Permit Application to present information in a format familiar to the U.S. Environmental Protection Agency and the Washington State Department of Ecology.

Once the Hanford Facility Dangerous Waste Permit is issued, the following process will be used to incorporate the Environmental Restoration 
DOE/RL-94-40, Rev. 0

$06 / 94$

1 Disposal Facility as a Corrective Action Management Unit that will accept

2 Resource Conservation and Recovery Act remediation waste. As final

3 Environmental Restoration Disposal Facility-specific documents are developed

4 (and approved by the appropriate agency) that demonstrate that the

5 Environmental Restoration Disposal Facility meets Corrective Action Management

6 Unit standards (as stated in 40 Code of Federal Regulations 264.552 and

7 Washington Administrative Code 173-303-646), additional Environmental

8 Restoration Disposal Facility-specific permit conditions will be incorpcrated

9 into the Hanford Facility Dangerous Waste Permit through the permit

10 modification process. The Environmental Restoration Disposal Facility may be

11 incorporated as a Corrective Action Management Unit at that time as a $\mathrm{Class} 3$

12 permit modification. The Environmental Restoration Disposal Facility also may

13 be designated a Corrective Action Management Unit by way of an

14 U.S. Environmental Protection Agency or Washington State Department of Ecology 15 Order, if the Hanford Facility is still under interim status.

This Corrective Artion Management Unit for the Environmental Restoration 


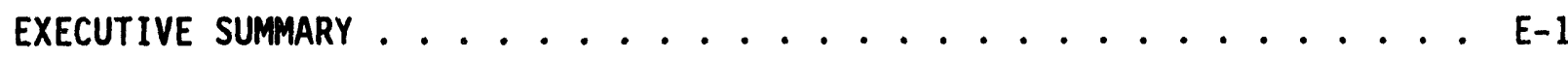

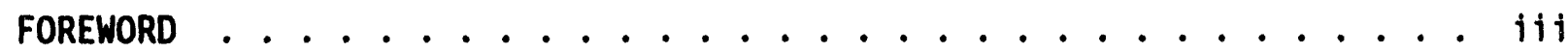

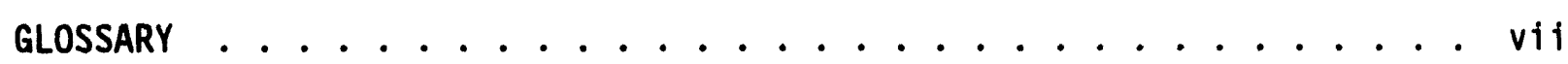

1.0 INTRODUCTION ........................ . . . .

2.0 FACILITY DESCRIPTION ................ . . . . .

3.0 WASTE CHARACTERISTICS ................. . . . . .

4.0 PROCESS INFORMATION ................. . . . . .

5.0 GROUNDWATER MONITORING $\ldots \ldots \ldots \ldots \ldots$ 5- . . . . . . . .

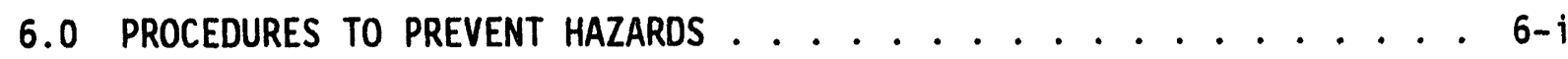

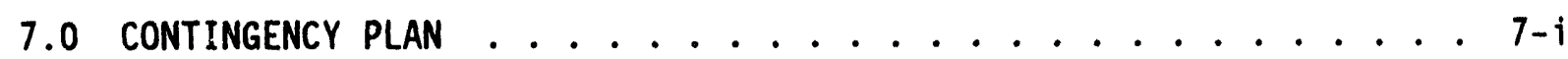

8.0 PERSTYNEL TRAINING ................ . . . . .

9.0 EXPOSURE INFORMATION REPORT ...............

10.0 WASTE Minimization $\ldots \ldots \ldots \ldots \ldots$. . . . . . . . . .

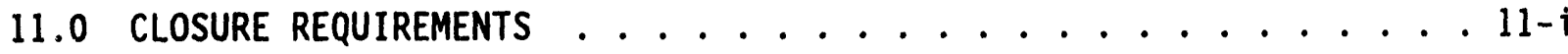

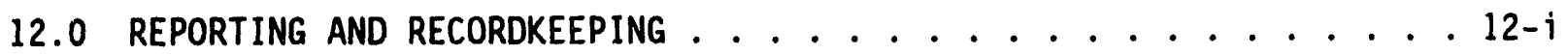

13.0 OTHER RELEVANT LAWS . . . . . . . . . . . . 13-i

14.0 Certification . . . . . . . . . . . . . 14-i

15.0 DECISION CRITERIA FOR CORRECTIVE ACTION MANAGEMENT UNIT $\ldots \ldots$. $15-i$

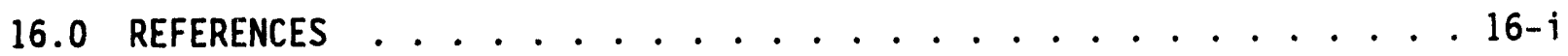

\section{APPENDICES}

IA CHANGE NUMBER M-70-93-01 OF THE HANFORD FEDERAL FACILITY AGREEMENT AND CONSENT ORDER (JANUARY 1994)

2A ENGINEERING DRAWINGS 
APPENDICES (cont)

2B ECOLOGICAL SURVEY OF THE ENVIRONMENTAL RESTORATION DISPOSAL FACILITY SITE

5A MONITORING WELL LOG AND CONSTRUCTION INFORMATION

5B MONITORING EFFICIENCY MODEL INFORMATION: USER'S MANUAL

5C GROUNDWATER SAMPLING AND ANALYSIS PLAN FOR THE ENVIRONMENTAL RESTORATION DISPOSAL FACILITY

TA BUILDING EMERGENCY PLAN FOR THE ENVIRONMENTAL RESTORATION DISPOSAL FACILITY

8A TRAINING PLAN FOR THE ENVIRONMENTAL RESTORATION DISPOSAL FACILITY 
DOE/RL-94-40, Rev. 0

06/94

AAQS

ARAR

ALR

ANOVA

ASTM

BACT

BED

BFCCAA

CAMU

CDR

CERCLA

CFC

CFR

CMS

CQA

DBE

$D \& D$

DOE

DOE-RL

DOT

Ecology

EPA

ER

ERDF

FEMA

FS

GWAS

HCRL

HDPE

HEHF

HEPA

HLAN

HLW

HSWA

HVAC

\section{GLOSSARY}

ambient air quality standards

applicable or relevant and appropriate

requirements

action leakage rate

analysis of variance

American Society for Testing and Materials

best available control technology

Building Emergency Director

Benton-Frankl in Counties Clean Air Authority

corrective action management unit

conceptual design report

Comprehensive Environmental Response, Compensation, and Liability Act of 1980

chlorofluorocarbons

Code of Federal Regulations

corrective measure study

construction quality assurance

design-basis earthquake

decontamination and decommissioning

U.S. Department of Energy

U.S. Department of Energy, Richland Operations Office

U.S. Department of Transportation

Washington State Department of Ecology

U.S. Environmental Protection Agency

environmental restoration

Environmental Restoration Disposal Facility

Federal Emergency Management Agency

feasibility study

generator and waste acceptance services

Hanford Cultural Resources Laboratory

high-density polyethylene

Hanford Environmental Health Foundation

high-efficiency particulate air

Hanford Local Area Network

high-level waste

Hazardous and Solid Waste Amendments (to RCRA) of 1984

heating, ventilation, and air conditioning 
11

$$
12
$$

\section{GLOSSARY (cont)}

1 and disposal restrictions

Low-Level Burial Grounds

low-level waste

monitoring efficiency mode 1

Model Toxics Control Act of 1990

minimum technology requirements

not applicable

National Environmental Policy Act of 1969

National Emission Standards for Hazarious

Air Pollutants

NTU

OGWMN

$P A$

PCB

PCM

PNL

PQL

PSD

PSP\&L

RCRA

RFA

RFI

RI

RI/FS

ROD

RPA

SWDD

SWITS

SWM

TEGD

Tri-Party Agreement

TRU

TSCA

TSD

TSP

TU

UCL

US Ecology

UTL nephelometric turbidity unit

operational groundwater monitoring network

preliminary assessment (CERCLA)

polychlorinated biphenyls

process control module

Pacific Northwest Laboratory practical quantification limit

Prevention of Significant Deterioration

Puget Sound Power \& Light Company

Resource Conservation and Recovery Act of 1976

RCRA facility assessment

RCRA facility investigation

remedial investigation

remedial investigation/feasibility study

record of decision

radiological performance assessment

Solid Waste Disposal Division

solid waste information tracking system

solid waste management

Technical Enforcement Guidance Document Hanford Federal Facility Agreement and Consent Order

transuranic

Toxic Substances Control Act of 1976

treatment, storage, and/or disposal

total suspended particles

temporary unit

upper confidence limit

US Ecology, Inc.

upper tolerance limit 


$\begin{array}{ll}1 & \\ 2 & \\ 3 & \\ 4 & \text { VOC } \\ 5 & \\ 6 & \text { WAC } \\ 7 & \text { Westinghouse Hanford } \\ 8 & \text { WHC } \\ 9 & \\ 10 & { }^{\circ} \mathrm{C} \\ 11 & { }^{\circ} \\ 12 & \mathrm{ams} 1 \\ 13 & \mathrm{~cm} \\ 14 & \text { in } \\ 15 & \mathrm{ky} \\ 16 & \mathrm{~m}^{3} \\ 17 & \mathrm{mi1} \\ 18 & \mathrm{pH} \\ 19 & \\ 20 & \mathrm{seC} \\ 21 & \mu \mathrm{g} \\ 22 & \end{array}$

\section{GLOSSARY (cont)}

volatile organic compounds

Washington Administrative Code

West inghouse Hanford Company

Westinghouse Hanford Company

degree Celsius

degree Fahrenheit

above mean sea level

centimeter

inches

kilovolt

cubic meters

one-thousandth of an inch

negative logarithm of the hydrogen-ion

concentration

second

micrograms 
DOE/RL-94-40, Rev. 0

06/94

1
2
3
4
5

This page intentionally left blank 
DOE/RL-94-40, Rev. 0

$06 / 94$

1

2

4

5

6

7

\section{DEFINITIONS}

Buried Naste - Contaminated wood articles (railroad ties, dimensional lumber, plywood), contaminated consumables (cardboard, rags, paper, plastic), and biological waste generated during remediation.

Constituent or Dangerous Maste Constituent - A chemically distinct component of a dangerous waste stream or mixture (WAC 173-303-040).

Contact-Handled Haste - Waste containing radiologic constituents that do not exceed 200 millitrem per hour at contact.

Container - Any portable device in which a material is stored, transported, treated, disposed of, or otherwise handled (WAC 173-303-040 and 40 CFR 260.10).

Contaminated Soil - Soil, ranging in size from boulders to fine silt, dry to moist, that could contain dangerous and/or radioactive constituents.

Ded Waste - Waste generated as a result of decommissioning and decontamination activities.

Dangerous Waste - Those solid wastes designated in WAC 173-303-070 through 173-303-103 as dangerous or extremely hazardous waste. As used, the words "dangerous waste" refer to the full universe of wastes regulated by WAC 173-303-040.

Decommissioning - Actions taken to reduce the potential health and safety impacts of U.S. Department of Energy-contaminated sites, including activities to stabilize, reduce, remove, or demolish the facilities (DOE Order 5820.2A, Attachment 2).

Decontamination - The removal of radioactive contamination from facilities, equipment, or soils by washing, heating, chemical or electrochemical action, mechanical cleaning or other techniques (DOE Order 5820.2A, Attachment 2).

Geocomposite - A manufactured material using geotextiles, geogrids, geonets, and/or geomembranes in laminated or composite form.

Geomembrane - An essentially impermeable geosynthetic composed of one or more synthetic sheets.

Geonet - A geosynthetic consisting of integrally connected parallel sets of ribs overlying similar sets at various angles for planar drainage of liquids and gases. 
DOE/RL-94-40, Rev. 0

$06 / 94$

Geosynthetics - The generic term for all synthetic materials used in geotechnical engineering applications; the term includes geotextiles, geogrids, geonets, geomembranes, geosynthetic clay liners, and geocomposites.

Geotextile - A permeable geosynthetic comprised solely of textiles. Current manufacturing techniques produce nonwoven fabrics, knitted (nontubular) fabrics, and woven fabrics.

Hanford Facility - The Hanford Facility is a single RCRA facility identified by the EPA/State Identification Number WA7890008967 that consists of over 60 TSD units conducting dangerous waste management activities. The Hanford Facility consists of all contiguous land, and structures, other appurtenances, and improvements on the land, used for recycling, reusing, reclaiming, transferring, storing, treating, or disposing of dangerous waste, which, for the purposes of the RCRA, are owned by the U.S. Government and operated by the DOE-RL (excluding lands north and east of the Columbia River, river islands, lands owned or used by the Bonneville Power Administration, lands leased or under lease obligation to the Washington Public Power Supply System, and lands owned by or leased to the state of Washington).

Hazardous Waste - Those solid wastes designated by 40 CFR 261, and regulated as hazardous waste by the EPA (WAC 173-303-040).

High-Density Polyethylene (HDPE) - A polymer prepared by low pressure polymerization of ethylene as the principal monomer and having the characteristics of ASTM D-1348 Type III and IV polyethylene. Such polymer resins have density greater than or equal to 0.941 grams per cubic centimeter as noted in ASTM-1248.

High-Level Waste (HLW) - HLW is defined by the DOE Order 5820.2A as "... the highly radioactive waste material that results from the reprocessing of spent nuclear fuels, including liquid waste produced directly in reprocessing, and any solid waste derived from the liquid that contains a combination of transuranic waste and fission products in concentrations as to require permanent isolation." The primary source of HLW is reprocessing of spent uranium and plutonium fuel and irradiated targets.

Hydraulic Conductivity - The rate of discharge of water under laminar flow conditions through a unit cross-sectional area of a porous medium under a unit hydraulic gradient and standard temperature conditions $\left(68^{\circ} \mathrm{F}, 20^{\circ} \mathrm{C}\right)$.

Incompatible Waste - (1) A hazardous/dangerous waste that is unsuitable for placement in a particular device or facility because the waste might cause corrosion or decay of containment material (e.g., container inner liners or tank walls) or (2) co-mingling with another waste or material under uncontrolled conditions because the co-mingling might produce heat 
or pressure, fire or explosion, violent reaction, toxic dusts, mists, fumes, gases or mists, or flammable fumes or gases (WAC 173-303-040 and 40 CFR 260.10).

Leachate - Liquid that has percolated through or drained from solid waste or other person-emplaced materials and contains soluble, partially soluble, or miscible components removed from such waste.

Low-Level Waste (L4K) - Waste that contains radioactivity and is not classified as high-level waste, transuranic waste, or spent nuclear fuel, or byproduct material as defined by DOE Order 5820.2A. Test specimens of fissionable material irradiated for research and development only, and not for the production of power or plutonium, may be classified as LLW provided the concentration of transuranic waste is less than 100 nanocuries per gram (DOE Order 5820.2A, Attachment 2).

Mixed Haste - Waste containing both radioactive and hazardous/dangerous components as defined by the Atomic Energy Act of 1954 and the Resource Conservation and Recovery Act of 1976 (DOE Order 5820.2A, Attachment 2).

Performance Assessment - A systematic analysis of the potential risks posed by waste management systems to the public and environment, and a comparison of those risks to established performance objectives (DOE Order 5820.2A, Attachment 2).

Permeability - (1) The capacity of a porous medium to conduct or transmit fluid or (2) the amount of liquid moving through a barrier in a unit time, unit area, and unit gradient not normalized for, but directly related to thickness. Refer to hydraulic conductivity.

Permittivity - For a geotextile, the volumetric flow rate of water per unit cross-section area, per unit head, under laminar flow conditions, in the perpendicular direction through the fabric.

Radioactive Waste - Solid, liquid, or gaseous material that contains radionuclides regulated under the Atomic Energy Act of 1954, as amended, and of negligible economic value considering costs of recovery (DOE Order 5820.2A, Attachment 2).

Reactive Waste - A dangerous waste that exhibits the characteristic of reactivity described in WAC 173-303-090(7) (40 CFR 261.23).

Remote-Handled Waste - Waste containing radiologic constituents that exceed 200 millirem per hour at contact.

Reverse 0smosis - A treatment process for 1iquid waste that uses a special, semipermeable membrane that, under pressure, permits pure water to pass 
through the membrane while acting as a barrier to impurities. Reverse osmosis is often used in conjunction with other treatment steps such as coagulation, filtration, and $\mathrm{pH}$ adjustment.

Spent Nuclear Fuel - Fuel that has been withdrawn from a nuclear reactor following irradiation, but that has not been reprocessed to remove its constituent elements (DOE Order 5820.2A, Attachment 2).

Iransuranic (TRU) Waste - Without regard to source or form, waste that is contaminated with alpha-emitting transuranium radionuclides with an atomic number $>92$ and with half-lives greater than 20 years and concentrations greater than 100 nanocuries per gram at the time of assay (DOE Order 5820.2A, Attachment 2).

Ireatment - Any method, technique, or process, including neutralization, designed to change the physical, chemical, or biological character or composition of any hazardous waste so as to neutralize such waste, or so as to recover energy or material resources for the waste, or so as to render such waste nonhazardous, or less hazardous; safer to transport, store, or dispose of; or amenable for recover, amenable for storage, or reduced in volume (WAC 173-303-040, 40 CFR 260.10, and DOE Order 5820.2A, Attachment 2). 


$$
\text { DOE/RL-94-40, Rev. } 0
$$

06/94

3 4 5 6 7

\section{Contents}

1.0 INTRODUCTION . . . . . . . . . . . . . . . 1-1

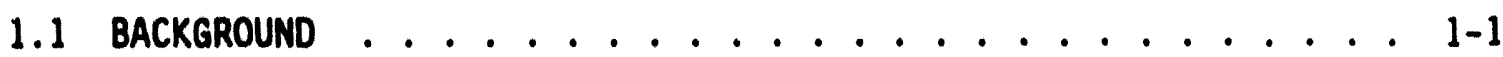

1.2 THE ENVIRONMENTAL RESTORATION DISPOSAL FACILITY AND ITS

RELATIONSHIP TO CERCLA, RCRA, AND THE RCRA CORRECTIVE

ACTION MANAGEMENT UNIT ................ 1-3

1.3 USE OF THE CORRECTIVE ACTION MANAGEMENT UNIT AT THE ENVIRONMENTAL RESTORATION DISPOSAL FACILITY AND

RCRA/CERCLA RELATIONSHIPS . . . . . . . . . . . 1-6

1.4 THE ENVIRONMENTAL RESTORATION DISPOSAL FACILITY

CORRECTIVE ACTION MANAGEMENT UNIT . . . . . . . . . . . 1-8

1.5 THE ENVIRONMENTAL RESTORATION DISPOSAL FACILITY

CORRECTIVE ACTION MANAGEMENT UNIT APPLICATION CONTENTS . . . 1-9

1.5.1 Facility Description and General Provistons..... 1-10

1.5.2 Waste Characteristics .............. 1-10

1.5.3 Process Information ................1-10

1.5.4 Groundwater Monitoring .............. . 1-10

1.5.5 Procedures to Prevent Hazards ........... . 1-10

1.5.6 Contingency Plan .............. . 1-10

1.5.7 Personnel Training ............. . . 1-10

1.5.8 Exposure Information Report ............. 1-11

1.5.9 Waste Minimization ................ 1-11

1.5.10 Closure and Postclosure . . . . . . . . . . . . . 1-11

1.5.11 Reporting and Recordkeeping ............ . 1-11

1.5.12 Other Relevant Laws .. . . . . . . . . . . . . . . 1-11

1.5.13 Certification . . . . . . . . . . . . . . . 1-11

1.5.14 Corrective Action Management Unit Criteria . . . . . 1-11

1.5.15 References ................ 1-11

1.6 CROSS-REFERENCE TABLE . . . . . . . . . . . . . . 1-12

\section{APPENDIX}

1A CHANGE NUMBER M-70-93-01 OF THE HANFORD FEDERAL FACILITY

AGREEMENT AND CONSENT ORDER (JANUARY 1994) .......... APP IA-i 
1

$$
2
$$

3

4 1-1. Hanford Facility ........................ F1-1

5 1-2. History and Regulatory Process for the Environmental

6

7

8

9

10

11

12

13

\section{FIGURES}

\section{TABLES}

1-1. Chapter 1.0 Cross-Reference Table ............... . T1-1 
DOE/RL-94-40, Rev. 0

06/94

\subsection{INTRODUCTION}

This chapter briefly describes the Corrective Action Management Unit (CAMU) Application for the Environmental Restoration Disposal Facility (ERDF). Table 1-1 provides a cross-reference comparing state and federal regulations for the CAMU with state and federal regulations for other hazardous waste management units. The term "RCRA and WAC" may be used in this document when discussing these federal and state regulations.

\subsection{BACKEROUND}

The Hanford Site covers approximately 560 square miles $(1,450$ square kilometers) of semiarid 1 and that is owned by the U.S. Government and managed by the U.S. Department of Energy, Richland Operations Office (DOE-RL). The Hanford Site is located northwest of the city of Richland, Washington (Figure 2-1). The city of Richland adjoins the southeastern most portion of the Hanford Site boundary and is the nearest population center. In early 1943, the U.S. Army Corps of Engineers selected the Hanford Site as the location for reactor, chemical separation, and related activities for the production and purification of special nuclear materials and other nuclear activities. These activities resulted in release of waste to the environment that caused contamination of soil and groundwater with hazardous/dangerous waste constituents and radioactive constituents (DOE-RL 1994d). The mission of the Hanford Site is currently focusing on waste management and environmental restoration and remediation activities.

The Hanford Site is divided into numerically designated areas (Drawing H-6-958 in Appendix 2A). The reactors are located along the Columbia River in the 100 Areas. The reactor fuel reprocessing units are in the 200 Areas, which are on a plateau approximately 7 miles (11 kilometers) from the Columbia River. The 300 Area, located adjacent to and north of Richland, contains the reactor fuel manufacturing $\mathrm{plants}$ and the research and development

laboratories. The 400 Area, 5 miles ( 8 kilometers) northwest of the 300 Area, contains the Fast flux Test facility designed for testing liquid metal reactor systems. The 600 Area covers all locations not specifically given an area designation. Adjacent to and north of Richland, the 1100 Area contains offices associated with administration, maintenance, transportation, and materials procurement and distribution. The 3000 Area, between the 1100 Area and 300 Area, contains engineering offices and administrative offices.

Administrative offices also are located in the $700 \mathrm{Area}$, which is in downtown Richl and.

The Hanford Site is discussed in this application as the Hanford Facility.

The Hanford Facility is a single RCRA facility identified by the EPA/State Identification Number WA7890008967 that consists of over 60 treatment, storage, and/or disposal (TSD) units conducting dangerous waste management activities. The Hanford Facility consists of all contiguous 1 and, and structures, other appurtenances, and improvements on the land, used for 
1 recycling, reusing, reclaiming, transferring, storing, treating, or disposing

2 of dangerous waste, which, for the purposes of the RCRA, are owned by the

3 U.S. Government and operated by the DOE-RL (excluding lands north and east of

4 the Columbia River, river islands, lands owned or used by the Bonneville Power

5 Administration, lands leased or under lease obligation to the Washington

6 Public Power Supply System, and lands owned by or leased to the state of

7 Washington).

In 1989, the Hanford Federal Facility Agreement and Consent Order (Tri-Party Agreement) was signed by the U.S. Environmental Protection Agency (EPA), Washington State Department of Ecology (Ecology), and the U.S. Department of Energy (DOE). Cleanup of contaminated areas was the principal component of this agreement. The Tri-Party Agreement includes an Action Plan that designates how site cleanup is to progress. The Tri-Party Agreement designated remediation sites as either Resource Conservation and Recovery Act (RCRA) of 1976 past-practice or Comprehensive Environmental Response, Compensation, and Liability Act (CERCLA) of 1980 past-practice sites. Ecology is the lead regulatory agency for RCRA past-practice sites while the EPA is the lead regulatory agency for CERCLA past-practice sites. The Tri-Party Agreement has been amended over the course of activities, with the Fourth Amendment made in January of 1994 (Ecology et a1. 1994).

In accordance with the Tri-Party Agreement, cleanup of remediation sites is being initiated at both RCRA and CERCLA past-practice areas. As designated in the Tri-Party Agreement and presented in Figure 1-2, remediation of sites will follow the RCRA facility assessment (RFA) - RCRA facility investigation (RFI) - corrective measures study (CMS) or CERCLA preliminary assessment (PA) - remedial investigation (RI) - feasibility study (FS) processes normally observed for RCRA remediation activities and CERCLA remediation activities, respectively. As shown in Figure 1-2, both RCRA and CERCLA remedial actions use a decision process that evaluates remediation options, including treatment alternatives. Based on this evaluation, remedial options are developed for each remediation site, and are integrated into the Hanford Facility Dangerous Waste Permit via a permit modification for RCRA past-practice units, or are articulated in a record of decision (ROD) for CERCLA past-practice units. It must be noted that RCRA TSD units occur in association with RCRA pastpractice remediation sites. All of these TSD units are to undergo RCRA closure, and documentation associated with cleanup of RCRA past-practice units and the closure plans for TSD units are included within the same document.

As shown in Figure 1-2, although the processes for determining the remedial action at both CERCLA and RCRA facilities are similar, the methods for implementing these actions are different. In the case of the Hanford Facility RCRA past-practice remediation sites, RFI/CMS documentation--which includes the proposed remediation strategy--is submitted for approval. The remediation strategy then is incorporated in the Hanford Facility Permit by the regulatory agency via permit modification.

For CERCLA past-practice sites, a proposed plan is submitted to the regulatory agency, which is used by the regulatory agency to prepare a ROD. The ROD for the first CERCLA past-practice unit, 100-BC, is scheduled for issuance in 1994 or 1995. It is anticipated that for this--and perhaps all-- 
1 RCRA and CERCLA past-practice remediation sites, the ROD/permit modification 2 will likely include removal of the waste from its close proximity to the 3 Columbia River and isolation of the waste in a central location. A waste 4 management facility was foreseen as necessary to meet this probable need for 5 waste isolation and, thus, planning of the ERDF was initiated.

The ERDF will be located southeast of the existing 200 West Area and extends east to near the US Ecology, Inc. site. The ERDF will encompass 4.14 square kilometers ( 1.6 square miles), and include a waste management trench and associated support units.

\subsection{THE ENVIRONMENTAL RESTORATION DISPOSAL FACILITY AND ITS RELATIONSHIP TO CERCLA, RCRA, AND THE RCRA CORRECTIVE ACTION MANAGEMENT UNIT}

The ERDF will accept both CERCLA (EPA-regulated) and RCRA (Ecology-regulated) remediation waste. The ERDF is considered part of the overali remediation strategy on the Hanford Facility, and as such, determination of ERDF viability has followed both RCRA and CERCLA decision processes. Typically, determination of the viability of a unit, such as the ERDF, would occur as part of the ROD or permit modification for each remediation site before construction. However, because construction of the ERDF could take a significant amount of time, it is necessary to begin design and construction of the ERDF before final RODs/permit modifications for the remediation sites. This will allow movement of waste to occur quickly once the final remediation strategy for the RCRA and CERCLA past-practice units is determined. Construction of the ERDF is a unique situation relative to Hanford Facility cleanup, requiring a Hanford Facility-specific process be developed for implementing the ERDF that would satisfy both RCRA and CERCLA requirements. While the ERDF will play a significant role in the remediation process, initiation of ERDF does not preclude the evaluation of remedial alternatives at each remediation site.

To facilitate initiation of the ERDF, the January 1994 amendment to the Tri-Party Agreement (Appendix 1A) recognizes the necessity for the ERDF, and the Tri-Party Agreement states: "Ecology, EPA, and DOE agree to proceed with the steps necessary to design, approve, construct, and operate such a ...facility." The Tri-Party Agreement requires the DOE-RL to prepare a comprehensive 'package' for EPA and Ecology to consider in evaluating the ERDF. The package is to address the "criteria 1 isted in 40 CFR 264.552(c) for Corrective Action Management Unit (CAMU) designation and a CERCLA Record of Decision (ROD)" (Ecology et a7. 1994). This CAMU application for the ERDF is being submitted as part of the Tri-Party Agreement-required information package, and is discussed in more detail in Section 1.3.

The Tri-Party Agreement cites several assumptions and decisions that are implicit in Change Number M-70-93-01, which include: (1) the definitive design of the ERDF will be submitted to Ecology and the EPA for approval 3 months after approval of the ERDF; (2) a double flexible, membrane liner and leachate collection system will be used for initial design; and (3) the ERDF will use risk assessment parameters that will assume the following: the point of assessment is the intersection of the groundwater and the vertical line 
1 drawn from the edge of the ERDF; the assessment period for radionuclides is 210,000 years; and the compliance standard will be $10^{-5}$ for the first

3100 years, and $10^{-4}$ thereafter. Note that ROD/permit modification for each

4 individual remediation site will specify how remediation of waste can be

5 treated and will reference, as appropriate, placement of waste in the ERDF.

The Tri-Party Agreement requires [by referencing 40 CFR 264.552 (c)] that information pertinent to a RCRA CAMU be provided for regulatory review. The CAMU regulations, finalized in February of 1993 , essentially provide a new option for onsite land-based management of remediation waste that was previously not available to facilities with RCRA past-practice units. Before the CAMU regulations, if the RFI/CMS process determined that onsite 1 and disposal (e.g., landfilling) of waste was the desired remediation alternative, the landfill would be regulated under the same laws applicable to active manufacturing facilities that dispose of "as generated" waste. Specifically, RCRA requires that landfills be designed to meet very specific minimum technology requirements (MTRs), including double liners, and that most waste undergo specific treatment as mandated by the 1 and disposal restrictions (LDRs). However, these strict requirements were a disincentive to many facilities to manage remediation waste. The CAMU regulations were promulgated to promote remediation of sites requiring cleanup under RCRA more flexibility with regard to management of remediation waste, without compromising human health and the environment.

The CAMU is an area within a facility that is designated by the Regional Administrator (or Director) under 40 CFR 264, Subpart $S$ [WAC 173-303-646(4), (5) and (6)] for the purpose of implementing corrective action requirements under 40 CFR 264.101 and RCRA Section 3008(h) [WAC 173-303-646(2)].

As described in the preamble to the final CAMU rule, a CAMU will be used only for the management of remediation waste pursuant to implementing such corrective action requirements at the facility, as such, no "as generated, "or operational waste can be placed in a CAMU. While the CAMU is a 'land-based' unit, it is not considered a 'disposal facility' into which remediation waste is placed. A disposal facility, as defined in 40 CFR 260.10, is "a facility or part of a facility at which hazardous waste is intentionally placed into or on any 1 and or water and at which waste will remain after closure. The term disposal facility does not include a CAMU into which remediation waste is placed." Hence, placement of remediation waste into a CAMU is not land disposal, and RCRA regulations (LDRs and MTRs) applicable to land disposal units, such as landfills, are not mandatorily applicable. However, Ecology regulations indicate that LDRs and MTRs could be imposed for a CAMU if required to protect human health and the environment.

The CAMU regulations allow "RCRA-regulated" units, defined in 40 CFR 264.90 (a)(2) as being only landfills, surface impoundments, waste piles, and land treatment units that received hazardous waste after July 26, 1982, to be present within the boundaries of the CAMU. Although not specifically addressed within the CAMU regulations and preamble, it is apparent that other types of units that are regulated under RCRA (but are not, by definition, "RCRA-regulated"), such as tanks, may be present within the CAMU area, but cannot be designated a CAMU, and must be regulated under other RCRA regulations (i.e., tank storage regulations or temporary unit 
DOE/RL-94-40, Rev. 0

$06 / 94$

requirements). In the case of the ERDF, the entire 4.14 square kilometers (1.6 square mile) area is included in the CAMU because the CAMU is defined as an area wherein remediation waste is managed. Only one unit within this area, the ERDF trench, will be land-based and technically can be included as part of the CAMU. Other units regulated under RCRA, including tanks, will be within the area of the CAMU and will retain separate regulatory identity, although the units support CAMU activities.

For an area to be designated a CAMU, seven decision criteria must be met, and the Tri-Party Agreement requires the comprehensive 'package' for the ERDF to discuss the following same criteria.

"1. The CAMU shall facilitate the implementation of reliable, effective, protective, and cost-effective remedies.

2. Waste management activities associated with the CAMUs shall not create unacceptable risks to humans or to the environment resulting from exposure to hazardous waste or hazardous constituents.

3. The CAMU shall include uncontaminated areas of the facility, only if including such areas for the purpose of managing remediation waste is more protective than management of such waste at contaminated areas of the facility.

4. Areas within the CAMU, where waste remain in place after closure of the CAMU, shall be managed and contained so as to minimize future releases, to the extent practicable.

5. The CAMU shall expedite the timing of remedial activity implementation, when appropriate and practicable.

6. When appropriate, the CAMU shall enable the use of treatment technologies (including innovative technologies) to enhance the long-term effectiveness of remedial actions by reducing the toxicity, mobility, or volume of waste that will remain in place after closure of the CAMU.

7. The CAMU shall, to the extent practicable, minimize the land area of the facility upon which waste will remain place after closure of the CAMU."

Specifically how the ERDF meets each of these criteria is addressed in detail in Chapter 15.0.

In addition to the CAMU regulations, the ERDF will be subject to the DOE Order requirements, including those for DOE Order 5820.2A. These orders require the following for the ERDF:

- Preparation of a radiological performance assessment (RPA)

- Establishment of an auditable program by the generating units 
D0E/RL-94-40, Rev. 0

$06 / 94$

30

- Implementation of a waste certification program by the generating units

- Audits of low-level waste (LLW) certification programs

- Site-specific closure plans for new and existing operating LLW disposal sites

- An environmental monitoring program that conforms with DOE Order 5484.1

- Waste tracking (manifest)

- Exposure assessments (i.e., releases to atmosphere and via inadvertent intrusion)

- Protection of groundwater resources consistent with federal, state, and local requirements

- Hazards assessment document and safety analysis report preparation.

While DOE Orders are not applicable or relevant and appropriate requirements (ARARs), these Orders will be implemented at the ERDF and will ensure that human health and the environment are protected. Applicable DOE Order requirements are discussed within forthcoming chapters of this application (as applicable and by topic) to demonstrate DOE-RL's commitment to protectiveness via implementation of a spectrum of requirements mandated by DOE Orders, as well as RCRA and WAC regulations.

\subsection{USE OF THE CORRECTIVE ACTION MANAGEMENT UNIT AT THE ENVIRONMENTAL RESTORATION DISPOSAL FACILITY AND RCRA/CERCLA RELATIONSHIPS}

The Tri-Party Agreement states that information necessary for issuance of an EPA CERCLA ROD be included in an information 'package' (refer to

Section 1.2). This ROD would be unique to the ERDF, and separate from those for each CERCLA past-practice remediation site. As such, the individual remediation site RODs will be specific to each site, and may separately evaluate treatment options. Information necessary to issue the ERDF ROD includes a document that uses the RI/FS process to evaluate the ERDF unit conceptual and definitive design and to determine viability of the ERDF for long-term management of remediation waste. A proposed plan is also necessary.

Also, CERCLA requires that a demonstration must be made before issuance of the ERDF ROD, and that the substantive standards of other ARARs have been met, including those substantive requirements of RCRA. That is, it must be demonstrated that the 'fundamental' requirements of the ARARs are met (i.e., unit design requirements), but the typical documentation associated with each of these regulations (that may be required to be submitted and approved) are not explicitly necessary. Once it has been demonstrated that substantive requirements of ARARs have been met to the satisfaction of the EPA, the ROD 
DOE/RL-94-40, Rev. 0

$06 / 94$

1 can be issued. The submittal of information pertinent to the RCRA CAMU, if 2 approved, would satisfy this ARAR (demonstration).

It is important to note that the ROD would allow for design, approval, construction, and operation of the ERDF only for management of CERCLA remediation waste. For management of RCRA past-practice remediation waste, a Class 3 permit modification of the Hanford Facility Permit would be required. The CAMU documentation submitted within the information package, therefore, has a dual purpose: (1) to demonstrate that the CAMU meets substantive requirements of RCRA as an ARAR under CERCLA so that the CERCLA ROD process can proceed and (2) the CAMU application contains necessary information that must be submitted to Ecology for designation of the CAMU and subsequent inclusion in a permit modification so that RCRA past-practice waste can be managed within the ERDF. Figure 1-2 shows the relationship of the CERCLA/RCRA interface relative to the ERDF and the Hanford Facility remediation process as a whole.

The Tri-Party Agreement includes a major milestone that the ERDF will be operational and available to receive remediation waste in September of 1996. It is anticipated that the ERDF ROD will be issued (assuming requisite information is submitted) during September of 1994. Three months after issuance of the ERDF ROr by the EPA, the definitive design of the ERDF will be submitted to Ecology and the EPA for approval (in accordance with the Tri-Party Agreement). Additional information pertaining to design and operation of the ERDF will be submitted for regulatory approval before operation and will be submitted following a schedule (presumed to be included) in the ERDF ROD or permit modification. Information that must be submitted for regulatory approval before acceptance of waste at the ERDF includes the following:

- Definitive design information, including design information for the ERDF trench and supporting units, such as designs for waste water storage units

- Operational information, including the ERDF operations plan and information necessary to support safe operation, including building emergency $\mathrm{plans}$, and other procedures to prevent hazards (i.e., air monitoring plans)

- Waste management information, including final waste acceptance criteria, waste tracking information, and other waste management information.

The ROD will designate the ERDF as a CERCLA unit that may manage CERCLA past-practice waste once constructed and all requisite information is submitted and approved. Because RCRA is an ARAR under CERCLA, the substantive requirements of RCRA (i.e., CAMU unit design requirements) will be met.

Parallel to the construction of the ERDF, the CAMU application--which also was submitted, in part, with in the ERDF 'information package'--will undergo regulatory review by Ecology. When Ecology has determined that the ERDF meets all of the CAMU designation criteria, a Class 3 permit modification will be obtained and the ERDF may accept RCRA past-practice remediation waste. 
During operation as a CERCLA unit, the ERDF will be regulated by the EPA and operated by the DOE-RL. When the Class 3 permit modification is in place, Ecology will regulate the ERDF, assuming that Ecology has received authorization over the CAMU program via acquisition of the Hazardous and Solid Waste Amendments of 1984. It must be noted that the ERDF may operate for management of CERCLA remediation waste without obtaining permits (i.e., RCRA, Clean Air Act of 1977, etc.), although substantive requirements of these regulations must be met. However, all required permits/documents must be 'in place' before acceptance of RCRA waste, including those for support units (i.e., tanks) within the boundary of the ERDF.

\subsection{THE ENVIRONMENTAL RESTORATION DISPOSAL FACILITY CORRECTIVE ACTION MANAGEMENT UNIT}

The ERDF will be an integral and necessary part of overall remediation on the Hanford Facility. Only remediation waste will be accepted, which will consist mainly of contaminated solls, construction debris, and onsite decontamination and decommissioning waste. In accordance with 40 CFR 260.10, "remediation waste may originate only from within the facility..."; therefore, no waste from off the Hanford Facility will be accepted at the ERDF.

The ERDF will be a 4.14 square kilometer ( 1.6 square mile) area that includes a waste management trench and support units, such as a waste water treatment building and a decontamination building. The ERDF trench will be approximately 21.3 meters deep, 305 meters wide, and 2,740 meters long (70 feet deep, 1,000 feet wide and 9,000 feet long). The trench currently is designed with a double-liner system, a leachate collection system, and an interim and final closure cover that meet the applicable requirements of RCRA.

Although the ERDF support units will be physically located within the proposed CAMU, the support units will maintain their separate regulatory identity as required in 40 CFR 264.552 and WAC 173-303-646. The design, permitting, and operational details of the support units will be provided in separate documents; some information is included within this application because the operation of these support units supports the CAMU decision criteria that must be met. The ERDF trench will be the only land-based unit within the ERDF that can be included in the CAMU, and the only unit detailed within this application. The following are support units for the ERDF trench, for which separate RCRA or other permits will be sought, as applicable:

- Rail and tractor trailer container handling facilities, including: - Loaded rail and tractor trailer transfer/unloading area

- Empty contaminated container transfer area

- Empty decontaminated container transfer area

- Decontamination building, including:

- Conveyor system

- Water recycling system

- Mobile decontamination unit 
2

- Waste water treatment building

- Subsidence control plant.

The final CAMU regulations also included provisions for another type of unit that may be used during the RCRA corrective action process: the temporary unit (TU). As defined in 40 CFR 264.552 and WAC-303-173-646(c)(7), TUs are temporary tanks and container storage areas used for the treatment or storage of remediation waste during implementation of RCRA corrective action activities. The TUs may operate for a period of 1 year, with a 1 year extension. Because the ERDF support units (that are tanks) are anticipated to operate for well over 2 years, operation of these units as TUs cannot be sought.

\subsection{THE ENVIRONMENTAL RESTORATION DISPOSAL FACILITY CORRECTIVE ACTION MANAGEMENT UNIT APPLICATION CONTENTS}

This application consists of the following 16 chapters, the contents of which are summarized in Sections 1.5.1 through 1.5.15:

- Introduction (Chapter 1.0)

- Facility Description and General Provisions (Chapter 2.0)

- Waste Characteristics (Chapter 3.0)

- Process Information (Chapter 4.0)

- Groundwater Monitoring (Chapter 5.0)

- Procedures to Prevent Hazards (Chapter 6.0)

- Contingency Plan (Chapter 7.0)

- Personnel Training (Chapter 8.0)

- Exposure Information Report (Chapter 9.0)

- Waste Minimization (Chapter 10.0)

- Closure and Postclosure (Chapter 11.0)

- Reporting and Recordkeeping (Chapter 12.0)

- Other Relevant Laws (Chapter 13.0)

- Certification (Chapter 14.0)

- The CAMU Criteria (Chapter 15.0)

- References (Chapter 16.0).

The outline for this application is based on the Washington State Part $B$ permit application documentation, but only those portions that apply to the CAMU are discussed in detail. Also, as inferred in 40 CFR 264.552 and stated in the preamble to the CAMU Rule, and proposed Subpart $S$ regulations, a CAMU can include only land-based units; support units, such as railways and waste water treatment units cannot be included in the CAMU. However, because operation of these support units supports operation of the ERDF in accordance with requirements set forth in 40 CFR 264.552, these support units also are discussed in summary within this application. 


\subsubsection{Facility Description and General Provisions (Chapter 2.0)}

This chapter provides a general description of the ERDF, including a brief discussion of the ERDF environmental setting and conditions.

\subsubsection{Waste Characteristics (Chapter 3.0)}

This chapter describes the chemical and physical characteristics of the waste to be managed at the ERDF, including ERDF waste acceptance criteria.

\subsubsection{Process Information (Chapter 4.0)}

This chapter provides avallable information concerning the ERDF trench and support units, with an emphasis on the proposed trench design.

\subsubsection{Groundwater Monitoring (Chapter 5.0)}

This chapter describes the hydrogeologic characteristics of the ERDF area and the proposed ERDF groundwater monitoring program.

\subsubsection{Procedures to Prevent Hazards (Chapter 6.0)}

Although not explicitly required under CAMU regulations, this chapter is included to address 40 CFR 270.42 (c) requirements, and to discuss hazard prevention and emergency preparedness equipment, structures, and procedures.

\subsubsection{Contingency P1an (Chapter 7.0)}

Although not explicitly required under CAMU regulations, this chapter is included to address 40 CFR 270.42 (c) requirements, and to provide information on contingency planning to ensure that the ERDF has measures in place to lessen the potential impact on public health and the environment in the event of an emergency.

\subsubsection{Personnel Training (Chapter 8.0)}

Although not explicitly required under CAMU regulations, this chapter is provided to address 40 CFR 270.42 (c) requirements, and outlines the training program used for ERDF employees whose primary duties are associated with hazardous/dangerous waste management. 


\subsubsection{Exposure Information Report (Chapter 9.0)}

This chapter is not required under CAMU regulations. The ERDF does not store, treat, or dispose of dangerous waste in a surface impoundment or landfil1. Justification is included in this chapter.

\subsubsection{Waste Minimization (Chapter 10.0)}

This chapter is not required under CAMU regulations. The ERDF support units will have a waste minimization program in place.

\subsubsection{Closure and Postclosure (Chapter 11.0)}

This chapter describes the generalized closure and postclosure activities for the ERDF trench.

\subsubsection{Reporting and Recordkeeping (Chapter 12.0)}

This chapter summarizes commitments for reporting and recordkeeping that are applicable to the ERDF.

\subsubsection{Other Relevant Laws (Chapter 13.0)}

This chapter discusses federal and state laws that affect the construction and operation of the ERDF, other than the RCRA, as amended.

\subsubsection{Certification (Chapter 14.0)}

This chapter is not required under CAMU regulations. This chapter discusses certification requirements as these requirements pertain to the ERDF.

\subsubsection{Corrective Action Management Unit Criteria (Chapter 15.0)}

This chapter contains the justification demonstrating that the ERDF unit meets all criteria for consideration as a CAMU.

\subsubsection{References (Chapter 16.0)}

References used throughout this application documentation are 1isted in this chapter. All references 1 isted here, which generally are not avallable from other sources, will be made available for review, upon request, to any regulatory agency or public commentor. References can be obtained by contacting the following: 
Administrative Records Specialist

Publ tc Access Room H6-08

Westinghouse Hanford Company

P. O. Box 1970

Richland, Washington 99352.

\subsection{CROSS-REFERENCE TABLE}

Table 1-1 presents a comparison of the informational requirements/CAMU decision criteria under 40 CFR 264.552 and WAC 303-173-646 CAMU regulations, with comparable requirements for TSD units under RCRA regulations

40 CFR Parts 260-270 and WAC 173-303. This table shows similarities and

differences between both the federal and state requirements for both CAMUs and TSO units. The table also provides the location within this application where the CAMU-required information is discussed. A regulatory checklist that can be used to locate information that must be provided in Washington State Part $B$ permit application documentation, al so was used to prepare this table (Ecology 1987). The location of this information in the Ecology checklist is found (within brackets [ ]) in column I of Table 1-1. 
DOE/RL-94-40, Rev. O

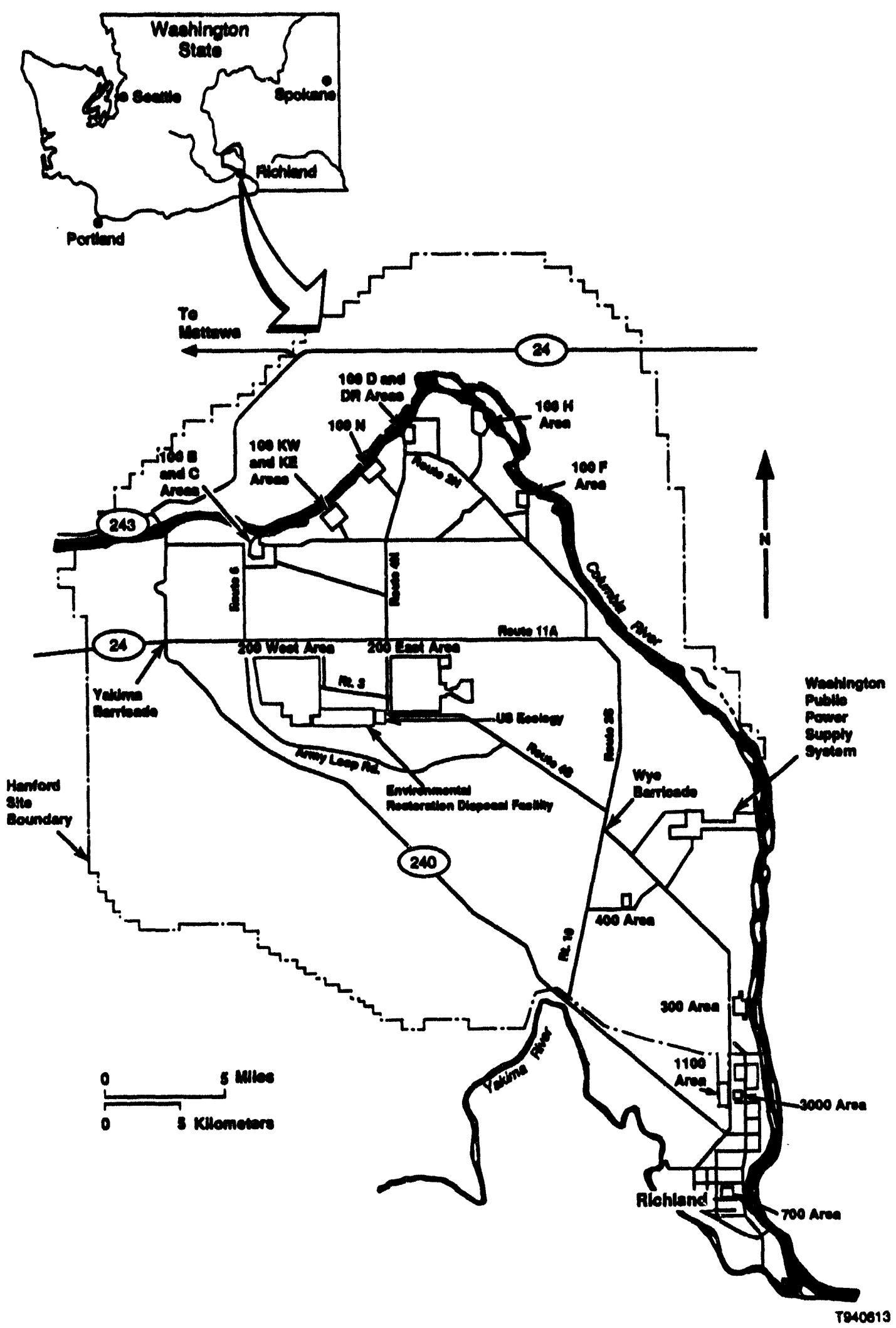

Figure 1-1. Hanford Facility. 

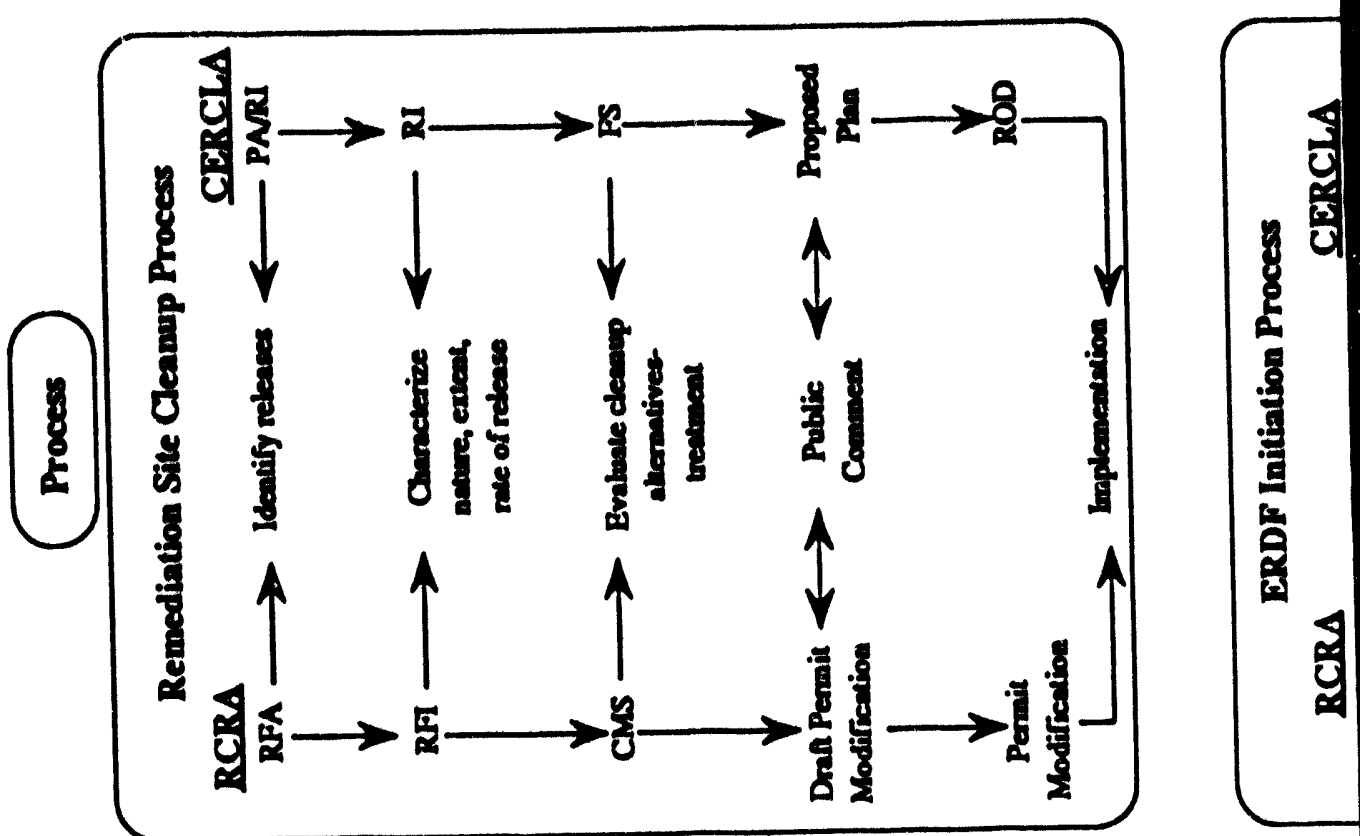

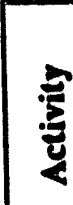
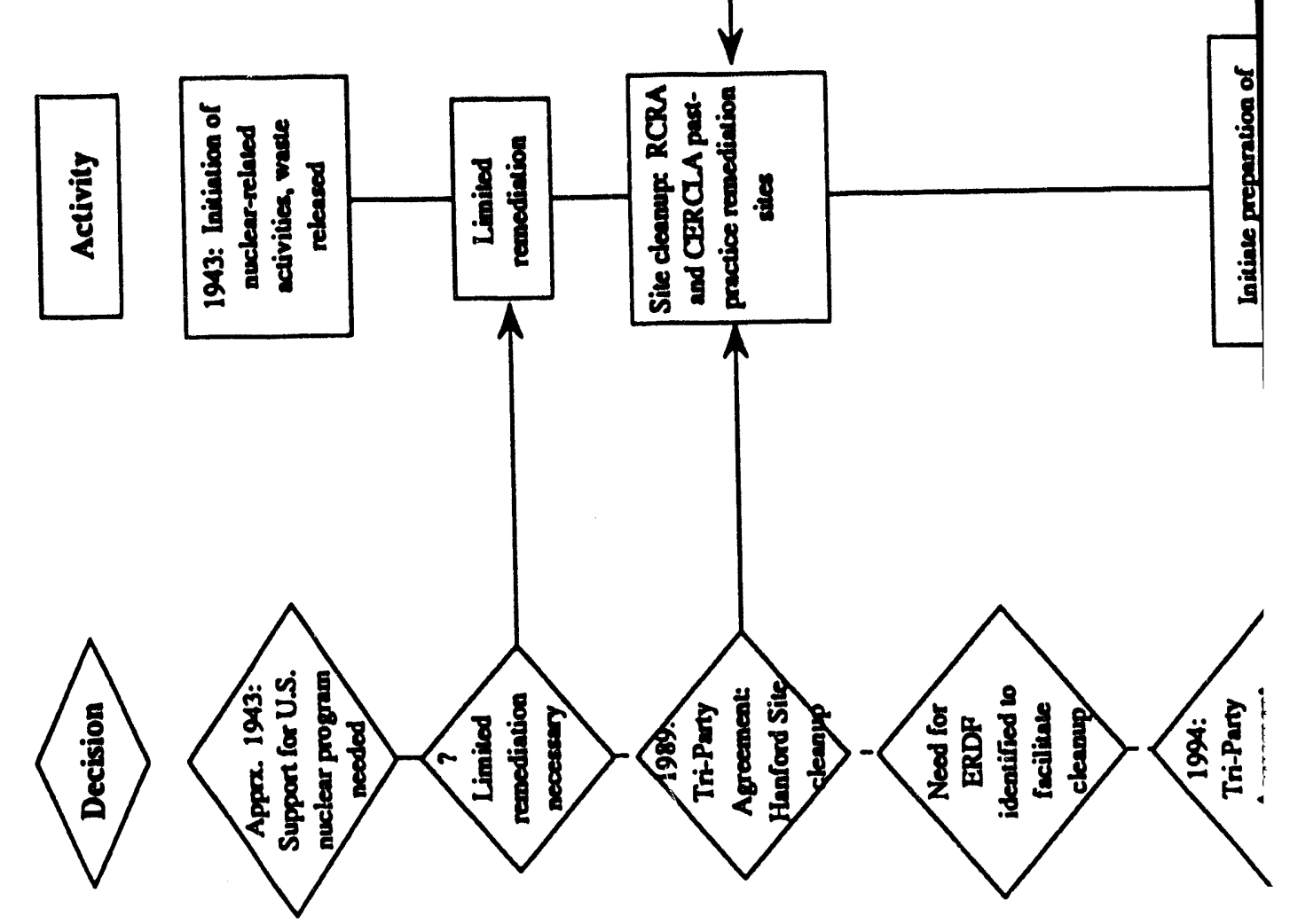

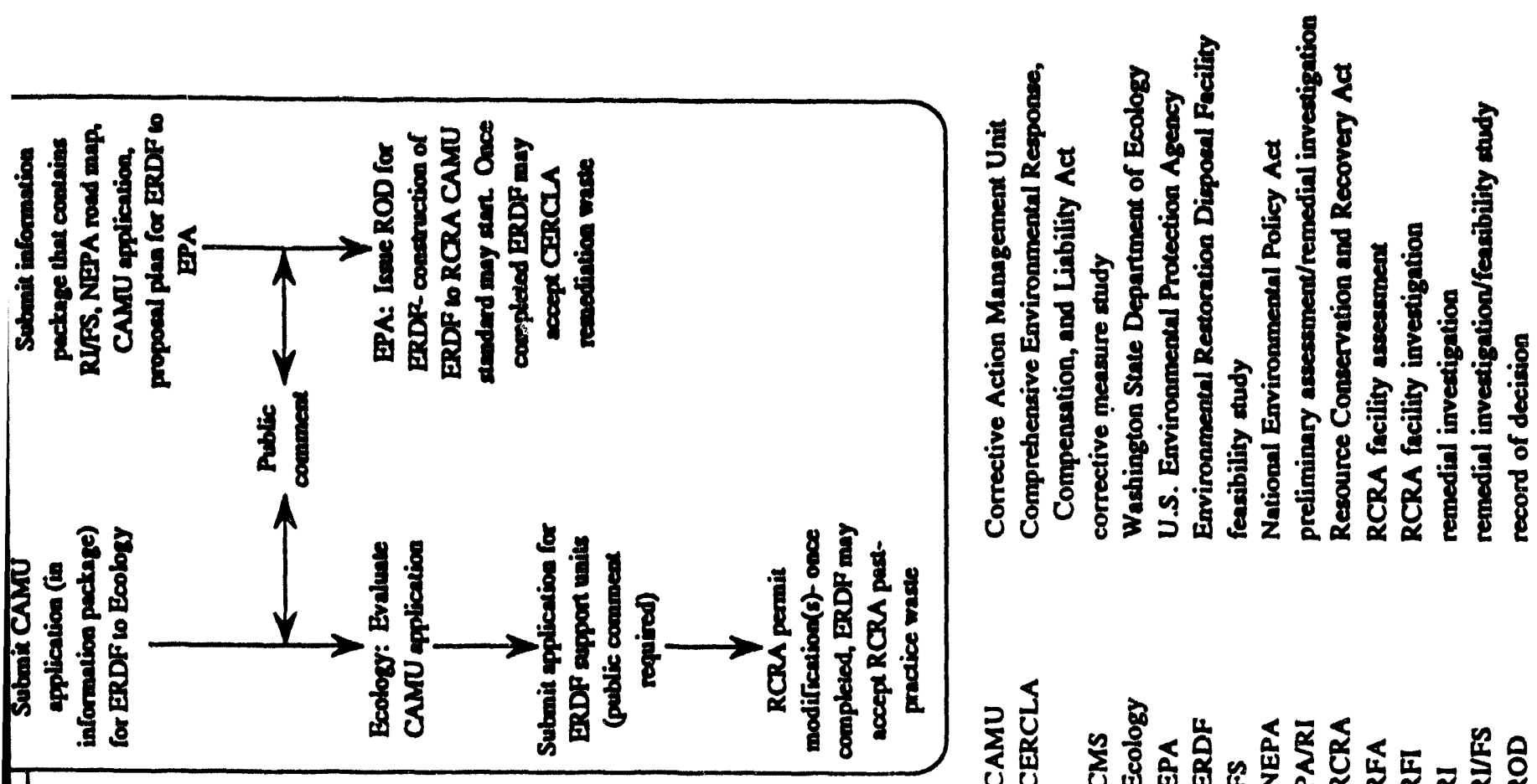

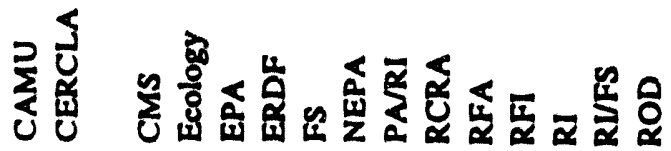

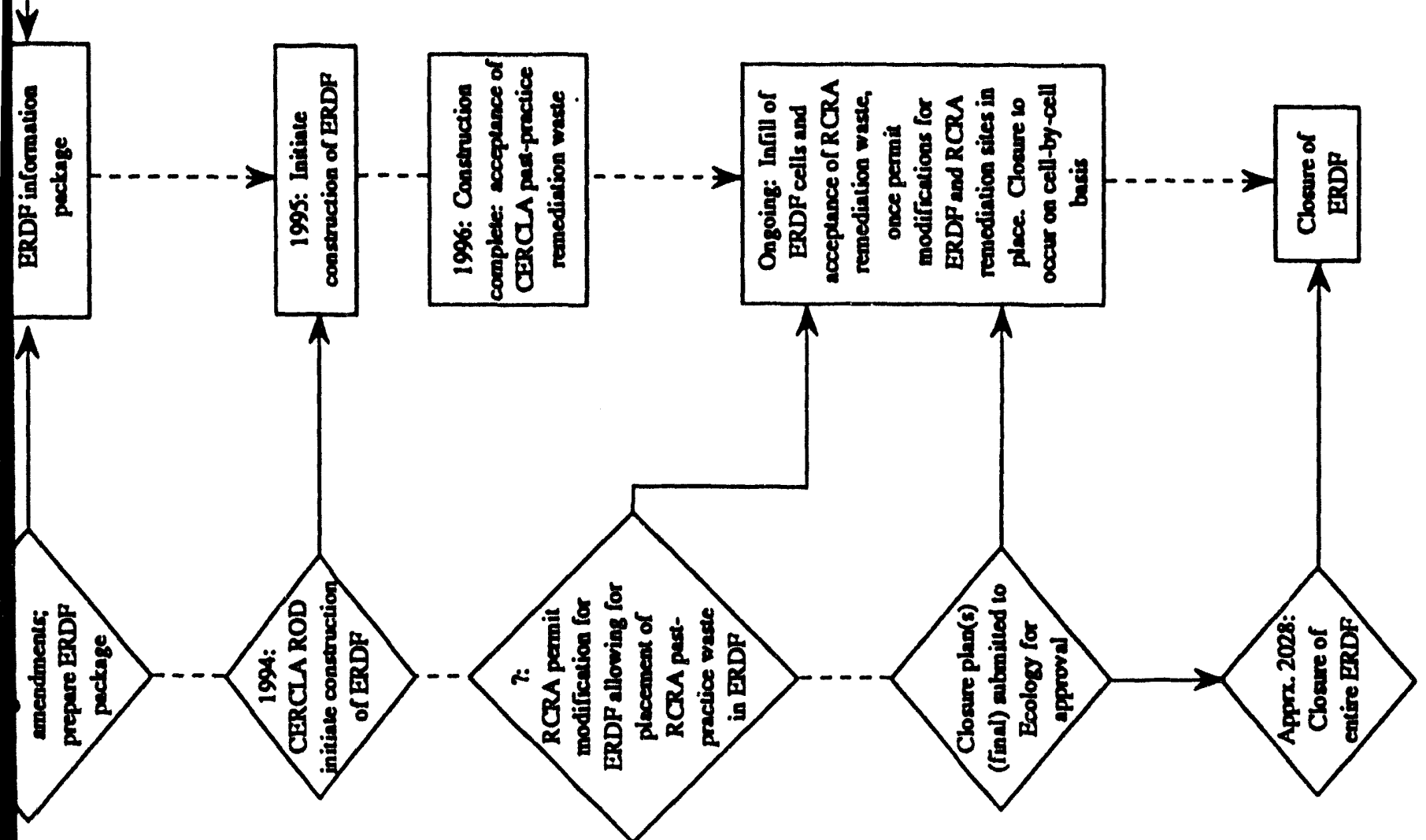

Figure 1-2. History and Regulatory Process for the Environmental Restoration Disposal Facility. 
Table 1-1. Chapter 1.0 Cross-Reference Table.

([ ] - Denotes location of information in Ecology Part B checkl ist)

(sheet 1 of 9 )

\begin{tabular}{|c|c|c|c|}
\hline ERDF outl ine chepter* & $\begin{array}{l}\text { Specifically required } \\
\text { by cave requlation? }\end{array}$ & $\begin{array}{l}\text { Washington State } \\
\text { CNN Regulations } \\
173-303 \\
\end{array}$ & $\begin{array}{l}\text { Federal } \\
\text { CAMus regulations } \\
40 \text { CFR }\end{array}$ \\
\hline 1.0 Introduction [A] & \multicolumn{2}{|c|}{$\cdots$} & \\
\hline 2.0 Facility Description [8] & & & \\
\hline $\begin{array}{l}2.1 \text { General Description [B-1] } \\
\text { WAC } 173-303-806(4)(a)(i) \\
\text { WAC } 173-303-806(4)(a)(x) \\
\text { WAC } 173-303-806(4)(a)(x v i i i) \\
\text { WAC } 173-303-145 \\
\text { WAC } 173-303-283 \\
40 \text { CFR } 270.14(b)(1)\end{array}$ & $\begin{array}{l}\text { No--information is } \\
\text { provided in support of } \\
\text { CAN criteria }\end{array}$ & $\begin{array}{l}646(5)(a)(i),(i i i) \text {, and } \\
\text { (vii) }\end{array}$ & $\begin{array}{l}264.552(c)(1),(3), \text { and }(7) \\
\text { CAMU Criteria } 1,3 \text { and } 7\end{array}$ \\
\hline $\begin{array}{l}2.2 \text { Topographic Map [B-2] } \\
\text { WAC } 173-303-806(4)(a)(x v i i i) \\
\text { WAC } 173-303-806(4)(a)(x x)(C) \\
\text { WAC } 173-303-806(4)(a)(x x)(0) \\
\text { WAC } 173-303-645(6) \\
\text { WAC } 173-303-645(8) \\
40 \text { CFR } 270.14(b)(19)\end{array}$ & Yes & $\begin{array}{l}646(5)(a)(i),(i i i) \text {, and } \\
(v i i) \\
646(5)(b)(i)\end{array}$ & $\begin{array}{l}264.552(c)(1),(3) \text {, and }(7) \\
264.552(e)(1) \\
\text { CAM Criteria 1, 3, and } 7\end{array}$ \\
\hline $\begin{array}{l}2.3 \text { Location Information [B-3] } \\
\text { WAC } 173-303-806(4)(a)(x i) \& \\
\text { (a)(xvi }(x)(B), \&(a)(x v i)(K) \text {, } \\
\text { WAC } 173-303-806(4)(a)(x) \\
\text { WAC } 173-303-282(6)(A)(i) \\
\text { WAC } 173-303-282(6)(c)(1)(A)(1) \& \\
\text { (11) } \\
40 \text { CFR } 270.14(b)(11) \\
40 \text { CFR 264.18(a) \& (b) } \\
40 \text { CFR 264, Appendix VI }\end{array}$ & $\begin{array}{l}\text { Mo--information is } \\
\text { provided in support of } \\
\text { CAMU criteria }\end{array}$ & $\begin{array}{l}646(5)(a)(i),(i i i) \text {, and } \\
\text { (vii) }\end{array}$ & $\begin{array}{l}264.552(c)(1),(3) \text {, and }(7) \\
\text { CAMU Criteria } 1,3 \text {, and } 7\end{array}$ \\
\hline $\begin{array}{l}2.4 \text { Traffic Information }[B-4] \\
\text { WAC } 173-303-806(4)(a)(x) \\
40 \text { CFR } 270.14(b)(10) \\
\end{array}$ & $\begin{array}{l}\text { No- - information is } \\
\text { provided in support of } \\
\text { CAm criteria }\end{array}$ & $646(5)(a)(i)$ and $(i i)$ & $\begin{array}{l}264.552(c)(1) \text { and }(2) \\
\text { CAMU Criteria } 1 \text { and } 2\end{array}$ \\
\hline $\begin{array}{l}2.5 \text { Performance Standards [B-5] } \\
\text { WAC } 173-303-283\end{array}$ & Refer to Chapter 15.0 & 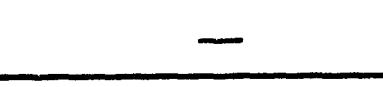 & 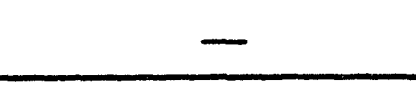 \\
\hline $\begin{array}{l}2.6 \text { Spill and Discharges [B-7] } \\
\text { WAC } 173-303-640(a)(b) ; \\
\text { WAC } 173-303-440(1)(a) ; \\
\text { WAC } 173-303-145\end{array}$ & Refer to Chapter 7.0 & - & $\longrightarrow$ \\
\hline $\begin{array}{l}2.7 \text { Waste Tracking System [B-8] } \\
\text { WAC } 173-303-370\end{array}$ & $\begin{array}{l}\text { Refer to Chapters } 3.0 \\
\text { and } 12.0\end{array}$ & - & - \\
\hline $\begin{array}{l}2.8 \text { Envirommental Setting [B-1] } \\
\text { WAC } 173-303-806(4)(a)(i) \\
\text { WAC } 173-303-806(4)(a)(x) \\
\text { WAC } 173-303-806(4)(a)(x v i i i) \\
\text { WAC } 173-303-145 \\
\text { WAC } 173-303-283 \\
40 \text { CFR } 270.14(b)(1)\end{array}$ & $\begin{array}{l}\text { No--information is } \\
\text { provided in support of } \\
\text { CAMU criteria }\end{array}$ & $646(5)(a)(i)$ & $\begin{array}{l}264.552(c)(1) \\
\text { CAMU Criterion } 1\end{array}$ \\
\hline
\end{tabular}


Table 1-1. Chapter 1.0 Cross-Reference Table.

([ ] - Denotes location of information in Ecology Part B checki ist)

(sheet 2 of 9 )

\begin{tabular}{|c|c|c|c|}
\hline Exof outl ine chapter* & $\begin{array}{l}\text { Specifically required } \\
\text { by cany requlation? }\end{array}$ & $\begin{array}{c}\text { Woshington State } \\
\text { CAN Regulationst* } \\
173-303 \\
\end{array}$ & $\begin{array}{l}\text { Federal } \\
\text { CAMU regulations } \\
40 \text { CFR } \\
\end{array}$ \\
\hline $\begin{array}{l}\text { 2.9 Introduction to ERDF Waste } \\
\text { [B-TI } \\
\text { WAC } 173-303-806(4)(a)(i) \\
\text { WAC } 173-303-806(4)(a)(x) \\
\text { WAC } 173-303-806(4)(a)(x \text { xi i i) } \\
\text { WAC } 173-303-145 \\
\text { WAC } 173-303-283 \\
40 \text { CFR } 270.14(b)(1)\end{array}$ & $\begin{array}{l}\text { Mo--information is } \\
\text { provided in support of } \\
\text { Carv criterie }\end{array}$ & $646(5)(a)(i)-(v i i)$ & $\begin{array}{l}264.552(c)(1)-(7) \\
\text { CAMU Criteria } 1-7\end{array}$ \\
\hline \multicolumn{4}{|c|}{ 3.0 ERDF CAMU Haste Characteristics [C] } \\
\hline $\begin{array}{l}3.1 \text { Sumnary Description of } \\
\text { Remediation Waste to be Managed } \\
\text { at the ERDF [C-1] } \\
\text { WAC } 173-303-806(4)(a)(i i i) \\
\text { WAC } 173-303-300(1)-(5) \\
40 \text { CFR } 270.14(b)(1) \& \text { (2) } \\
40 \text { CFR } 264.13(a)\end{array}$ & Yes & $646(5)(a)(i),(i i)$, and (vi) & $\begin{array}{l}264.552(c)(1),(2) \text { and( } 6) \\
\text { CAMU Criteria 1, 2, and } 6\end{array}$ \\
\hline $\begin{array}{l}3.2 \text { Waste Analysis Plan [C-2] } \\
\text { WAC } 173-303-806(4)(a) ; \\
\text { WAC } 173-303-300(5) \\
\text { WaC } 173-303-110(2) \&(3) \\
\text { WAC } 173-303-395(1) \& \text { (2) } \\
40 \text { CFR } 270.14(b)(3) \\
40 \text { CFR } 264.13(b) \& \text { (c) } \\
40 \text { CFR } 268.7\end{array}$ & $\begin{array}{l}\text { No--informetion is } \\
\text { provided in support of } \\
\text { CAM criteria }\end{array}$ & $\begin{array}{l}646(5)(a)(i),(i i),(i v) \text {, } \\
\text { and }(v i)\end{array}$ & $\begin{array}{l}264.552(c)(1),(2),(4) \\
\text { and( } 6) \\
\text { CAMU Criteria 1, 2, 4, and } 6\end{array}$ \\
\hline $\begin{array}{l}3.3 \text { Waste Acceptance Criteria } \\
\text { for the ERDF } \\
\text { WAC } 173-303-806(4) \text { (a) } \\
\text { WAC } 173-303-300(5) \\
\text { WAC } 173-303-110(2) \text { \& (3) } \\
\text { WAC } 173-303-395(1) \text { \& (2) } \\
40 \text { CFR } 270.14(b)(3) \\
40 \text { CFR } 264.13(b) \text { \& (c) } \\
40 \text { CFR } 268.7\end{array}$ & $\begin{array}{l}\text { No--information is } \\
\text { provided in support of } \\
\text { CAMU criteria }\end{array}$ & $\begin{array}{l}646(5)(a)(i),(i i),(i v) \text {, } \\
\text { and }(v i)\end{array}$ & $\begin{array}{l}264.552(c)(1),(2),(4) \\
\text { and }(6) \\
\text { CANU Criteria 1, 2, 4, and } 6\end{array}$ \\
\hline $\begin{array}{l}3.4 \text { Land Disposal Restrictions } \\
\text { in Relation to the ERDF [C-3] } \\
\text { WAC } 173-303-300(1)(5) \\
\text { WAC } 173-303-806(3)(a)(i i i) \\
40 \text { CFR } 264.13 \\
40 \text { CFR } 270.14(b) \\
\end{array}$ & $\begin{array}{l}\text { Mo--information is } \\
\text { provided in support of } \\
\text { CAMU criteria }\end{array}$ & $646(4)(b)$ & $264.552(a)(1)$ \\
\hline 4.0 Process Information $[D]$ & & & \\
\hline $\begin{array}{l}4.1 \text { Containers }[D-1] \\
\text { WAC } 173-303-680 \\
40 \text { CFR } 264.170-40 \text { CFR } 264.178\end{array}$ & No & N/A under 646 & N/A under 264.552 \\
\hline $\begin{array}{l}4.2 \text { Tank Systems [D-2] } \\
\text { WAC } 173-303-640 \\
40 \text { CFR } 264.190 \\
40 \text { CFR } 264.191 \\
\end{array}$ & No & N/A under 646 & N/A under 264.552 \\
\hline
\end{tabular}


Table 1-1. Chapter 1.0 Cross-Reference Table. ([ ] - Denotes location of information in Ecology Part B checklist) (sheet 3 of 9 )

\begin{tabular}{|c|c|c|c|}
\hline ERDF outl ine chapter" & $\begin{array}{l}\text { specifically required } \\
\text { by cavil regulation? }\end{array}$ & $\begin{array}{c}\text { Washington State } \\
\text { CANU Regulations** } \\
173-303 \\
\end{array}$ & $\begin{array}{l}\text { Federal } \\
\text { CAms regulations } \\
40 \text { CFR } \\
\end{array}$ \\
\hline $\begin{array}{l}4.3 \text { Waste Piles [D-3] } \\
\text { WAC 173-303-660 } \\
40 \text { CFR } 264.191 \\
40 \text { CFR } 264.250-40 \text { CFR } 264.259 \\
\end{array}$ & Mo & N/A under 646 & N/A under 264.552 \\
\hline $\begin{array}{l}4.4 \text { Surface Impoundments }[D-4] \\
\text { WAC 173-303-650 } \\
40 \text { CFR } 264.220-231 \\
\end{array}$ & No & $N / A$ under 646 & N/A under 40 CFR 264.552 \\
\hline $\begin{array}{l}4.5 \text { Incinerators }[D-5] \\
\text { WAC } 173-303-670 \\
40 \text { CFR } 264.340-351 \\
\end{array}$ & No & N/A under 646 & N/A under 264.552 \\
\hline $\begin{array}{l}4.6 \text { Landfills }[D-6] \\
\text { HAC } 173-303-665 \\
40 \text { CFR } 264.300-264.317 \\
\end{array}$ & No & N/A under 646 & N/A under 264.552 \\
\hline $\begin{array}{l}4.7 \text { Land Treatment }[0-7] \\
\text { WAC 173-303-655 } \\
40 \text { CFR } 264.270-264.283 \\
\end{array}$ & No & N/A under 646 & N/A under 264.552 \\
\hline $\begin{array}{l}4.8 \text { Miscellaneous Units } D-81 \\
\text { WAC } 173-303-680 \\
40 \text { CFR } 264.600-264.603\end{array}$ & No & N/A under 646 & N/A under 264.552 \\
\hline $\begin{array}{l}4.9 \text { Drip Pads } \\
40 \text { CFR } 264.510-264.574 \\
\end{array}$ & No & N/A under 646 & N/A under 264.552 \\
\hline $\begin{array}{l}4.10 \text { Air Emissions Standards for } \\
\text { Process Vents } \\
40 \text { CFR } 264.1030-264.1037 \\
\end{array}$ & No & N/A under 646 & N/A under 264.552 \\
\hline $\begin{array}{l}4.11 \text { Air Emissions Standards for } \\
\text { Equipment Leaks } \\
40 \text { CFR 264.1050-264.1057 }\end{array}$ & No & N/A under 646 & N/A under 264.552 \\
\hline $\begin{array}{l}4.12 \text { ERDF Trench } \\
\text { WAC } 173-303-806(4)(h) \text {; } \\
\text { WAC } 173-303-665(2) \\
\text { WAC } 173-303-810(13) \\
\end{array}$ & Yes & $\begin{array}{l}646(5)(a)(i)-(v i i) \\
646(5)(b)(i i)\end{array}$ & $\begin{array}{l}264.552(c)(1)-(7) \\
264.552(e)(2) \\
\text { Criteria } 1-7\end{array}$ \\
\hline 4.13 Other CAMUs & $\begin{array}{l}\text { No--information is } \\
\text { provided in support of } \\
\text { CANU criteria }\end{array}$ & N/A & N/A \\
\hline $\begin{array}{l}4.14 \text { Description of ERDF Support } \\
\text { Facilities }\end{array}$ & $\begin{array}{l}\text { No--information is } \\
\text { provided in support of } \\
\text { CAMU criteria }\end{array}$ & $646(5)(a)(i)$ and $(i i)$ & $\begin{array}{l}264.552(c)(1) \text { and (2) } \\
\text { CAMU Criteria } 1 \text { and } 2\end{array}$ \\
\hline 4.15 ERDF Operations & Yes & $\begin{array}{l}646(5)(a)(i),(i i),(i v), \\
(v) \text {, and (vi) } \\
646(5)(b)(i i)\end{array}$ & $\begin{array}{l}264.552(c)(1),(2),(4), \\
(5) \text {, and }(6) \\
264.552(e)(2) \\
\text { CAMU Criteria 1, 2, 4, } 5 \text {, } \\
\text { and } 6\end{array}$ \\
\hline
\end{tabular}


Table 1-1. Chapter 1.0 Cross-Reference Table.

([ ] - Denotes location of information in Ecology Part $B$ check 1 ist)

\begin{tabular}{|c|c|c|c|}
\hline ERDF outline chapter* & $\begin{array}{l}\text { Specifically required } \\
\text { by cam regulation? }\end{array}$ & $\begin{array}{c}\text { Washington State } \\
\text { CANu Regulations } \\
173-303 \\
\end{array}$ & $\begin{array}{l}\text { Fedaral } \\
\text { CAMu regulations } \\
40 \text { CFR } \\
\end{array}$ \\
\hline \multicolumn{4}{|l|}{ 5.0 Groundwater Monitoring [E] } \\
\hline $\begin{array}{l}5.1 \text { Exemption from Grounduater } \\
\text { Monitoring Requirements [E-1] } \\
\text { WAC 173-303-645 } \\
40 \text { CFR } 264.90(b) \text { (1) }\end{array}$ & No & $N / A$ & N/A \\
\hline $\begin{array}{l}5.2 \text { Interim Status Period } \\
\text { Groundwater Monitoring Date [E-2] } \\
\text { WAC 173-303-645 } \\
40 \text { CFR } 264.90-40 \text { CFR } 264.94 \\
\end{array}$ & No & $N / A$ & N/A \\
\hline $\begin{array}{l}5.3 \text { Environmental Setting and } \\
\text { Aquifer Identification [E-3] } \\
\text { WAC } 173-303-645 \\
\text { HAC } 173-303-806(4)(a)(x x)(8) \\
40 \text { CFR } 270.14(c)(2)\end{array}$ & $\begin{array}{l}\text { No--information is } \\
\text { provided in support of } \\
\text { CAMU criteria }\end{array}$ & $\begin{array}{l}646(5)(a)(i),(i i),(i v), \\
\text { (vi), and (vii) }\end{array}$ & $\begin{array}{l}264.552(e)(1),(2),(4), \\
(6),(7) \\
\text { Camu Criteria 1, 2, 4, 6, 7 }\end{array}$ \\
\hline $\begin{array}{l}5.4 \text { Groundwater Qual ity } \\
\text { [Not in checkl ist] } \\
\text { WAC } 173-303-645 \\
\text { WAC } 173-303-806(4)(\text { a) }(x x)(D) \\
\text { WAC } 173-303-9905 \\
\text { WAC } 173-303-070 \\
40 \text { CFR } 270.14(\text { C)(2), (4) \& (7) } \\
261 \text {, Appendix VIII }\end{array}$ & $\begin{array}{l}\text { Mo--information is } \\
\text { provided in support of } \\
\text { CAN criteria }\end{array}$ & $\begin{array}{l}646(5)(a)(i), \text { (ii), (iv), } \\
\text { (vi), and (vii) }\end{array}$ & $\begin{array}{l}264.552(e)(1),(2),(4), \\
(6),(7) \\
\text { CAMU Criteria 1,2,4,6,7 }\end{array}$ \\
\hline $\begin{array}{l}5.5 \text { Groundwater Monitoring } \\
\text { Program } \\
\text { [Not in checklist] } \\
40 \text { CFR } 264.90-101\end{array}$ & Yes & $\begin{array}{l}646(5)(a)(i) \text { and }(i i) \\
646(5)(b)(i i j)\end{array}$ & $\begin{array}{l}264.552(c)(1) \&(2) \\
264.552(e)(3) \\
\text { CAM Criteria } 1 \text { and } 2\end{array}$ \\
\hline \multicolumn{4}{|c|}{ 6.0 Procedures to Prevent Hazards [F] } \\
\hline $\begin{array}{l}6.1 \text { security }[f-1] \\
\text { WAC } 173-303-806(4)(a)(\text { iv) } \\
\text { WAC } 173-303-310 \\
40 \text { CFR } 270.14(b)(4) \\
40 \text { CFR } 264.14 \\
\end{array}$ & $\begin{array}{l}\text { No--information is } \\
\text { provided in support of } \\
\text { CAMU criteris }\end{array}$ & $646(5)(a)(i)$ and $(i i)$ & $\begin{array}{l}264.552(c)(1) \&(2) \\
\text { CAMU Criteria } 1 \& 22\end{array}$ \\
\hline $\begin{array}{l}6.2 \text { Inspection schedule [F-2] } \\
\text { WAC } 173-303-806(4)(a)(v) \\
\text { WAC } 173-303-320 \\
\text { WAC } 173-303-665(4)(b) \\
40 \text { CFR } 264.15 \\
40 \text { CFR } 270.14(b)(5) \\
40 \text { CFR } 264.303(b) \\
\end{array}$ & $\begin{array}{l}\text { No-- information is } \\
\text { provided in support of } \\
\text { CAMU criteria }\end{array}$ & $646(5)(a)(i)$ and (ii) & $\begin{array}{l}264.552(c)(1) \&(2) \\
\text { CAMU Criteria } 1 \text { \& } 2\end{array}$ \\
\hline $\begin{array}{l}\text { 6.3 Waiver or Documentation of } \\
\text { Preparedness and Prevention } \\
\text { Requirements [F-3] } \\
\text { WAC } 173-303-806(4)(a)(v i) \\
\text { WAC } 173-303-340(1)(a)-(d) \\
40 \text { CFR } 270.14(b) \\
40 \text { CFR } 264.30-35\end{array}$ & $\begin{array}{l}\text { No--information is } \\
\text { provided in support of } \\
\text { CAMU criteria }\end{array}$ & $646(5)(a)(i)$ and $(i i)$ & $\begin{array}{l}264.552(c)(1) \&(2) \\
\text { CAMU Criteria } 1 \& 2\end{array}$ \\
\hline
\end{tabular}


Table 1-1. Chapter 1.0 Cross-Reference Table.

([ ] - Denotes location of information in Ecology Part B checklist)

(sheet 5 of 9)

\begin{tabular}{|c|c|c|c|}
\hline ERDF outline chepter" & $\begin{array}{l}\text { specifically required } \\
\text { by caly requlation? }\end{array}$ & $\begin{array}{c}\text { Washington State } \\
\text { CAMU Regulationst* } \\
173-303\end{array}$ & $\begin{array}{l}\text { Federal } \\
\text { CAmu regulations } \\
40 \text { CFR }\end{array}$ \\
\hline $\begin{array}{l}6.4 \text { Preventive Procedures, } \\
\text { structures and Equipment [f-4] } \\
\text { Wac } 173-303-806(4) \text { (a) (vifi) } \\
\text { (A)-(E) } \\
40 \text { CFR } 270.14(b) \text { (8) }\end{array}$ & $\begin{array}{l}\text { No--information is } \\
\text { provided in support of } \\
\text { CANU criteria }\end{array}$ & $646(5)(a)(i)$ and $(i i)$ & $\begin{array}{l}264.552(c)(1) \\
\text { CAMU Criteria } 1: 22\end{array}$ \\
\hline $\begin{array}{l}\text { 6.5 Provention of Reaction of } \\
\text { Igni table, Reactive and } \\
\text { Incompatible Haste [f-5] } \\
\text { WAC 173-303-806(4)(a)(iv) } \\
\text { WAC } 173-303-395(1)(a)-(c) \\
40 \text { CFR } 270.14(b)(9) \\
40 \text { CFR 264.17(a) }- \text { (b) } \\
40 \text { CFR 264.176-177 } \\
40 \text { CFR 264.198-199 } \\
40 \text { CFR 264.229-230 } \\
40 \text { CFR 264.281-282 } \\
40 \text { CFR 264.312-313 }\end{array}$ & $\begin{array}{l}\text { No--information is } \\
\text { provided in support of } \\
\text { CAW criteria }\end{array}$ & $646(5)(a)(i)$ and (ii) & $\begin{array}{l}264.552(c)(1) \&(2) \\
\text { CAMW Criteria } 1 \& 2\end{array}$ \\
\hline $\begin{array}{l}7.0 \text { Contingency Plan } \\
\text { WAC } 173-303-806(4)(a) \\
\text { WAC } 173-303-350(2)(3)(4)(5) \\
\text { WAC } 173-303-340(4) \\
\text { WAC } 173-303-360(1)(2) \\
40 \text { CFR } 270.14(b)(7) \\
40 \text { CFR } 264.50-40 \text { CFR } 264.56 \\
40 \text { CFR } 264.37\end{array}$ & $\begin{array}{l}\text { No--information is } \\
\text { provided in support of } \\
\text { CAMU criteria } \\
\text { (Refer to Appendix 7A) }\end{array}$ & $646(5)(a)(i)$ and (ii) & $\begin{array}{c}264.552(c)(1) \&(2) \\
\text { CANW Critería } 1 \text { \& } 2\end{array}$ \\
\hline $\begin{array}{l}8.0 \text { Personnel Training [H] } \\
\text { HAC 173-303-806(4)(a)(vii) } \\
\text { HAC 173-303-330(1)-(3) } \\
40 \text { CFR } 270.14(b)(12) \\
40 \text { CFR } 264.16 \\
40 \text { CFR } 264.16(a)(1) \\
40 \text { CFR } 264.16(d)(1)-(4) \\
40 \text { CFR } 264.16(e) \\
\end{array}$ & $\begin{array}{l}\text { No-- information is } \\
\text { provided in support of } \\
\text { CAM criteria } \\
\text { (Refer to Appendix 8A) }\end{array}$ & $646(5)(a)(i)$ and $(i i)$ & $\begin{array}{l}264.552(c)(1) \&(2) \\
\text { CAMU Criteria } 1 \& 2\end{array}$ \\
\hline $\begin{array}{l}9.0 \text { Exposure Information Report } \\
\text { [Not in checklist] } \\
40 \text { CFR } 270.10(j)\end{array}$ & Refer to Chapter 15 & $646(5)(a)(i)$ and $(i i)$ & $\begin{array}{l}264.552(c)(1) \&(2) \\
\text { CAMU Criteria } 1 \& 2\end{array}$ \\
\hline $\begin{array}{l}10.0 \text { Waste Minimization } \\
\text { cMot in check(ist) } \\
40 \text { CFR } 264.73(b)(9)\end{array}$ & No & N/A under 646 & N/A under 264.552 \\
\hline
\end{tabular}


Table 1-1. Chapter 1.0 Cross-Reference Table. ([ ] - Denotes location of information in Ecology Part $B$ checklist) (sheet 6 of 9)

\begin{tabular}{|c|c|c|c|}
\hline ERDF out line chepter" & $\begin{array}{l}\text { Specifically required } \\
\text { by cand requlation? }\end{array}$ & $\begin{array}{c}\text { Washington State } \\
\text { CAMU Regulat fons* } \\
173-303\end{array}$ & $\begin{array}{l}\text { Federal } \\
\text { CAMU regulations } \\
40 \mathrm{CFR} \\
\end{array}$ \\
\hline \multicolumn{4}{|l|}{11.0 Closure and Postclosure [I] } \\
\hline $\begin{array}{l}11.1 \text { Closure for Containers, } \\
\text { Tank Systems, Waste Pilles, } \\
\text { surface Impoundients, Land } \\
\text { Treatment, Landfills, and } \\
\text { Miscellaneous Units } \\
\text { [I-1d(1)-1-1d(6)] } \\
\text { WAC } 173-303-630(10) \\
\text { WAC } 173-303-640(8) \\
\text { WAC } 173-303-650(6) \\
\text { WAC } 173-303-655(8) \\
\text { WAC } 173-303-660(9) \\
\text { WAC } 173-303-665(6) \\
\text { WAC } 173-303-670(8) \\
40 \text { CFR } 264.178 \\
40 \text { CFR } 264.197 \\
40 \text { CFR } 264.228 \\
40 \text { CFR } 264.258 \\
40 \text { CFR } 264.280 \\
40 \text { CFR } 264.310 \\
40 \text { CFR } 264.351 \\
40 \text { CFR } 264.575\end{array}$ & No & N/A under 646 & N/A under 264.552 \\
\hline $\begin{array}{l}11.2 \text { Postclosure/Contingency } \\
\text { Postclosure for Tank Systems, } \\
\text { Waste Piles, Surface } \\
\text { Impoundments, Incinerators, Land } \\
\text { Treatment, LandfIlls and } \\
\text { Miscellaneous Units [I-2] } \\
\text { WAC } 173-303-610(8)(a) \text { and (b) } \\
\text { WAC } 173-303-640(8) \text { (b) } \\
\text { WAC } 173-303-650(6) \\
\text { WAC } 173-303-655(8) \\
\text { HAC } 173-303-660(9) \\
\text { WAC } 173-303-665(6) \\
\text { WAC } 173-303-670(8) \\
\text { WAC } 173-303-680(4) \\
40 \text { CFR } 264.228 \\
40 \text { CFR } 264.258 \\
40 \text { CFR } 264.603 \\
40 \text { CFR } 264.280 \\
40 \text { CFR } 264.310 \\
40 \text { CFR } 264.351 \\
40 \text { CFR } 264.525\end{array}$ & No & N/A under 646 & N/A under 264.552 \\
\hline $\begin{array}{l}11.3 \text { Notices Required for } \\
\text { Disposel focilities }[1-3] \\
\text { WAC } 173-303-610(6) \\
\text { WAC } 173-303-610(11) \\
\text { WAC } 173-303-610(7) \\
\text { WAC } 173-303-610(10) \\
40 \text { CFR } 264.119\end{array}$ & No & N/A under 646 & N/A under 264.552 \\
\hline
\end{tabular}


Table 1-1. Chapter 1.0 Cross-Reference Table.

([ ] - Denotes location of information in Ecology Part B checklist)

(sheet 7 of 9)

\begin{tabular}{|c|c|c|c|}
\hline EROF outline chepter" & $\begin{array}{l}\text { Specifically required } \\
\text { by canu requlation? }\end{array}$ & $\begin{array}{c}\text { Washington State } \\
\text { CANW Regulat lons** } \\
173-303 \\
\end{array}$ & $\begin{array}{c}\text { Federal } \\
\text { CAMu regulations } \\
40 \text { CFR } \\
\end{array}$ \\
\hline $\begin{array}{l}11.4 \text { Certification of Completion } \\
\text { of Postclosure Care } \\
\text { [Not in checkl ist] } \\
\text { WAC } 173-303-610(11) \\
40 \text { CFR 264.120 }\end{array}$ & No & N/A under 646 & N/A under 264.552 \\
\hline $\begin{array}{l}11.5 \text { Closure cost Est imate } \\
{[1-4]} \\
\text { WAC } 173-303-620(3) \text { and }(1)(c) \\
\text { WAC } 173-303-806(4)(a)(x V) \\
40 \text { CFR } 264.142 \\
40 \text { CFR } 270.14(b)(15) \\
\end{array}$ & No & N/A under 646 & N/A under 264.552 \\
\hline $\begin{array}{l}11.6 \text { Financial Assurance } \\
\text { Mechanism for Closure [I-5] } \\
\text { HAC } 173-303-620 \text { (4) } \\
\text { WAC } 173-303-806(4)(a)(x v) \\
40 \text { CFR } 264.143 \\
40 \text { CFR } 264.146\end{array}$ & No & N/A under 646 & N/A under 264.552 \\
\hline $\begin{array}{l}11.7 \text { Postclosure Cost Estimate } \\
{[1-6]} \\
\text { WAC } 173-303-806(4)(a) \text { (xvi) } \\
\text { WAC } 173-303-620(5) \\
40 \text { CFR } 264.144 \\
40 \text { CFR } 270.14(b)(16)\end{array}$ & No & N/A under 646 & $N / A$ under 264.552 \\
\hline $\begin{array}{l}11.8 \text { Financial Assurance } \\
\text { Mechanism for Postclosure Care } \\
{[1-7]} \\
\text { WAC } 173-303-806(a)(x v i) \\
\text { WAC } 173-303-620(6) \\
40 \text { CFR } 264.145 \\
40 \text { CFR } 264.146 \\
\end{array}$ & No & N/A under 646 & N/A under 264.552 \\
\hline $\begin{array}{l}11.9 \text { Liability Requirements } \\
{[1-8]} \\
\text { WAC } 173-303-806(a) \text { (xvii) } \\
\text { WAC } 173-303-620(8) \\
40 \text { CFR } 264.147\end{array}$ & No & N/A under 646 & N/A under 264.552 \\
\hline
\end{tabular}


Table 1-1. Chapter 1.0 Cross-Reference Table.

([ ] - Denotes location of information in Ecology Part B checklist) (sheet 8 of 9)

\begin{tabular}{|c|c|c|c|}
\hline ERDF out line chapter" & $\begin{array}{l}\text { specifically required } \\
\text { by Cavil requlation? }\end{array}$ & $\begin{array}{c}\text { Washington State } \\
\text { CANW Regulations } \\
173-303 \\
\end{array}$ & $\begin{array}{c}\text { Federal } \\
\text { CAMU regulations } \\
40 \text { CFR } \\
\end{array}$ \\
\hline $\begin{array}{l}11.10 \text { Cloaure Plan for ERDF CAMU } \\
\text { Trench } \\
\text { CNOt in checklist] } \\
\text { WAC } 173-303-806(4)(a)(x i 1 i) \\
\text { WAC } 173-303-610 \\
\text { HAC } 173-303-610 \\
\text { WAC } 173-303-610 \\
\text { WAC } 173-303-665(6) \\
\text { WAC } 173-303-806(4)(c)(\text { iv) } \\
\text { WAC } 173-303-665(8)(a)(v i i i) \\
\text { WAC } 173-303-665(6)(a) \\
\text { WAC } 173-303-610(3)(a)(v i i) \\
\text { WAC } 173-303-610(4) \\
\text { WAC } 173-303-610(4)(a) \\
40 \text { CFR } 270.14(b) 13 \\
40 \text { CFR } 264.112(a)(1) \text { \& (a) } \\
40 \text { CFR } 264.112(b)(1)-(6) \\
40 \text { CFR } 264.114 \\
40 \text { CFR } 264.310 \\
40 \text { CFR } 270.21(a) \\
40 \text { CFR } 270.20(f) \\
40 \text { CFR } 264.310(a) \\
40 \text { CFR } 264.310(a)(1)-(5) \\
40 \text { CFR } 264.112(b)(6) \\
40 \text { CFR } 264.112(b)(2) \\
40 \text { CFR } 264.113(a) \&(b)\end{array}$ & Yos & $\begin{array}{l}646(5)(a)(i), \text { (ii), and (iv) } \\
646(5)(b)(i v) \\
646(5)(c)\end{array}$ & $\begin{array}{l}264.552(c)(1),(2) \text {, and }(4) \\
264(a)(2),(3)(i i) \text {, and }(4) \\
\text { CAMU Criteria } 1,2 \text {, and } 4\end{array}$ \\
\hline $\begin{array}{l}11.11 \text { Postclosure Plan [I-2] } \\
\text { HAC } 173-303-610(8)(a) \\
\text { WAC } 173-303-665(6) \\
\text { WAC } 173-303-806(4)(\mathrm{d})(\mathrm{vil}) \\
\text { HAC } 173-303-806(4)(\mathrm{e})(\mathrm{ix}) \\
\text { WAC } 173-303-866(4)(\mathrm{h})(\mathrm{v}) \\
40 \text { CFR } 264.118 \\
40 \text { CFR } 264.119 \\
40 \text { CFR } 264.197(\mathrm{~b}) \\
40 \text { CFR } 264.197(\mathrm{c})(2) \\
40 \text { CFR } 264.310(\mathrm{~b}) \\
40 \text { CFR } 270.14(\mathrm{~b})(13) \\
40 \text { CFR } 270.17(\mathrm{f}) \\
40 \text { CFR } 270.18(\mathrm{~h}) \\
40 \text { CFR } 270.20(\mathrm{f}) \\
40 \text { CFR } 270.20(\mathrm{~g}) \\
40 \text { CFR } 270.21(\mathrm{e}) \\
40 \text { CFR } 270.23(\mathrm{a})(3) \\
\end{array}$ & Yes & $\begin{array}{l}646(5)(a)(i),(i i) \text {, and (iv) } \\
646(5)(b)(i i i)(B) \\
646(5)(b)(i v)\end{array}$ & $\begin{array}{l}264.552(c)(1)-(7) \\
264.552(e)(4)(i v) \\
\text { CAMU Criteria } 1-7\end{array}$ \\
\hline $\begin{array}{l}11.12 \text { closure and Postclosure } \\
\text { Documentation }[1-3] \\
\text { HAC } 173-303-610(7) \\
\text { HAC } 173-303-610(9) \\
\text { WAC } 173-303-610(10) \\
\text { WAC } 173-303-610(11) \\
\text { 40 CFR } 270.14(b)(14) \\
\text { 40 CFR } 264.119\end{array}$ & No & N/A under 646 & N/A under 264.552 \\
\hline
\end{tabular}


Table 1-1. Chapter 1.0 Cross-Reference Table. ([ ] - Denotes location of information in Ecology Part B checklist) (sheet 9 of 9 )

\begin{tabular}{|c|c|c|c|}
\hline EROF outline chepter* & $\begin{array}{l}\text { spocifically requi red } \\
\text { by carn reoulation? }\end{array}$ & $\begin{array}{c}\text { Waehington State } \\
\text { CANN Regulations"*t } \\
173-303 \\
\end{array}$ & $\begin{array}{c}\text { Federal } \\
\text { CAm regulations } \\
40 \text { CFR } \\
\end{array}$ \\
\hline \multicolumn{4}{|c|}{ 12.0 Reporting and Recordkeeping [Not in checkl ist] } \\
\hline $\begin{array}{l}12.1 \text { Notification of Dangerous } \\
\text { Weste Activities }\end{array}$ & No & $N / A$ & N/A \\
\hline $\begin{array}{l}12.2 \text { Treatment, Storage, and } \\
\text { Oisposeal Requirements }\end{array}$ & No & $N / A$ & N/A \\
\hline $\begin{array}{l}12.3 \text { Immediate Reporting } \\
40 \text { CFR } 264.56 . \text { (d) }\end{array}$ & $\begin{array}{l}\text { No-- information is } \\
\text { provided in support of } \\
\text { CAm criteria }\end{array}$ & $646(5)(a)(i i)$ & $\begin{array}{l}264.552(c)(2) \\
\text { CAMU Criteria } 1 \text { and } 2\end{array}$ \\
\hline $\begin{array}{l}12.4 \text { Envirommental Restoration } \\
\text { Disposal Facility Reporting and } \\
\text { Recordkeeping Requirements }\end{array}$ & $\begin{array}{l}\text { No- - information is } \\
\text { provided in support of } \\
\text { Cany criteria }\end{array}$ & $646(5)(a)(i)$ and $(i i)$ & $\begin{array}{l}264.552(c)(1) \text { and (2) } \\
\text { CAMU Criterio } 1 \text { and } 2\end{array}$ \\
\hline $\begin{array}{l}13.0 \text { Other Relevant Laws [J] } \\
\text { WAC } 173-303-806(4)(a)(x i x) \\
40 \text { CFR } 270.14(b)(20) \\
\end{array}$ & No & N/A & $N / A$ \\
\hline $\begin{array}{l}14.0 \text { Certification [K] } \\
\text { WAC } 173-303-810(13) \\
40 \text { CFR } 270.11(\mathrm{a})\end{array}$ & No & $N / A$ & N/A \\
\hline $\begin{array}{l}\text { 15.0 CAm Evaluation Criteria } \\
\text { [Not in checklist] }\end{array}$ & Yes & $646(5)(a)$ & $\begin{array}{l}264.552(\mathrm{c}) \\
\text { CAMu Criteria } 1-7\end{array}$ \\
\hline
\end{tabular}

* The sections of this application are based on the Ecology Part B Checklist. The referenced regulations, both state (WAC 173-303) and federal (40 CFR 260-270), provide the specific requirements that typically are incorporated in these sections.

** Assumes that Washington State has received HSWA authority. 


\section{CONTENTS}

2.0 FACILITY DESCRIPTION . . . . . . . . . . . . . 2-1

2.1 DESCRIPTION OF THE ENVIRONMENTAL RESTORATION DISPOSAL FACILITY ................. 2-1

2.2 TOPOGRAPHIC MAP ................ 2-2

2.3 LOCATION INFORMATION ................. 2-2

2.3.1 Seismicity of Area ............... . 2-2

2.3.2 Floodplain Information ............ 2-3

2.3.3 Shoreline Standard . . . . . . . . . . . . 2-4

2.3.4 Sole Source Aquifer Criteria . . . . . . . . . . 2-4

2.4 TRAFFIC INFORMATION: TRANSPORTATION FACILITIES TO

SERVICE THE ENVIRONMENTAL RESTORATION DISPOSAL FACILITY . . . 2-4

2.4.1 Hanford Facility Roadways . . . . . . . . . . . . . . 2-4

2.4.2 Traffic Control Signs, Signals, and Procedures . . . 2-5

2.4.3 Traffic Pattern Maps . . . . . . . . . . . . . 2-5

2.4.4 Railcar Transportation Summary . . . . . . . . 2-5

2.5 PERFORMANCE STANDARDS .............. 2-6

2.6 SPILLS AND DISCHARGES ............... 2-6

2.7 WASTE TRACKING SYSTEM ............... 2- . . 6

2.8 ENVIRONMENTAL SETTING . . . . . . . . . . . 2-6

2.8.1 Local Land Use Information ..... . . . . . . . 2-6

2.8.2 Population of Hanford Area and Region ........ . 2-7

2.8.3 Ecological Setting ........... 2- . . . .

2.8.3.1 Flora and Fauna of the Hanford Area . . . . 2-7

2.8.3.2 Baseline Ecology Study . . . . . . . . . . 2-8

2.8.3.3 Introduction to Hanford Facility Geology

and Hydrology ............. 2- 2-9

2.8.4 Meteorologic Data... . . . . . . . . . 2-9

2.8.4.1 Local Climate, Rainfal1, Ambient

Temperature, and Air Quality ...... 2-9

2.8.4.2 Air ................2-11

2.9 INTRODUCTION TO ENVIRONMENTAL RESTORATION DISPOSAL

FACILITY WASTE ............... . . 2-12

2.10 IRREVERSIBLE AND IRRETRIEVABLE COMMITMENTS OF RESOURCES . . . 2-13 


\section{APPENDICES}

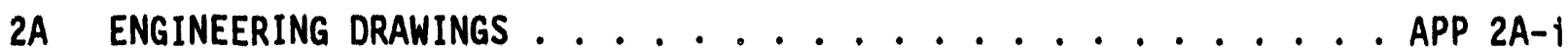

2B ECOLOGICAL SURVEY OF THE ENVIRONMENTAL RESTORATION DISPOSAL

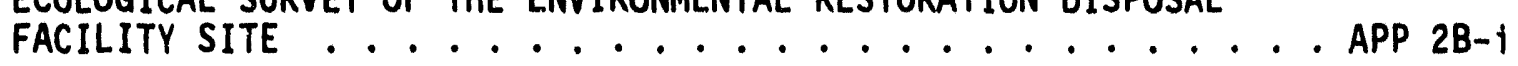

\section{FIGURES}

2-1. Location of the Environmental Restoration Disposal Facility-200 Areas Plateau .................. F2-1

2-2. Conceptual Model of the Environmental Restoration Disposal Facility ................... F2-2

2-3. Environmental Restoration Disposal Facility site Map ...... F2-3

2-4. Columbia River Floodplain (probable maximum flood) . . . . . F2-4

2-5. Yakima River Floodplain ............. F2-5

2-6. Cold Creek Floodplain (probable maximum flood) . . . . . . . F2-6

2-7. Transportation Network - Hanford Facility . . . . . . . F2-7

2-8. Estimated Traffic Volume ................. F2-8

2-9. Monthly Average Precipitation - Hanford Facility (1912-1980) . F2-9

2-10. Total Monthly Evapotranspiration Data ........... F2-10

\section{TABLES}

2-1. Chapter 2.0 Cross-Reference Table . . . . . . . . . T2-1

2-2. Plants and Animals of Concern Potentially Inhabiting the Environmental Restoration Disposal Facility ......... T2-2 
DOE/RL-94-40, Rev. 0

06/94

\subsection{FACILITY DESCRIPTION}

This chapter briefiy describes the ERDF location and operational information including the following:

- General description

- Topography

- Location information

- Traffic information

- Performance standards

- Spills and discharges

- Waste tracking system

- Environmental setting

- Introduction to ERDF waste.

Table 2-1 is regulatory cross-reference table.

\subsection{DESCRIPTION OF THE ENVIRONMENTAL RESTORATION DISPOSAL FACILITY}

The proposed site for the ERDF is between the 200 West and 200 East Areas (Figure 2-1). A conceptual model and site plan of the ERDF are provided in Figures 2-2 and 2-3, respectively.

A general overview of the Hanford Facility (Drawing H-6-958) is provided in Appendix $2 A$ and 111 ustrates the following:

- Legal boundary of the Hanford Facility

- Contours [at 6.1 meters (20 foot) intervals] sufficient to show surface water flow

- Fire control services

- Access roads, internal roads, railroads, perimeter gates, and barricades

- Longitudes and latitudes.

The ERDF will be located southeast of the existing 200 West Area, and extends east to near the US Ecology, Inc. site (Figures 2-1). Construction of the ERDF. will disturb 4.14 square kilometers (1.6 square miles). The proposed location for the ERDF includes approximately 364 hectares (900 acres) of the 405 hectares (1,000 acres) previously leased to Washington State. These 364 hectares (900 acres) are shown on Drawing H-6-10606 (Appendix 2A). The remaining 41 hectares (100 acres) currently are subleased to US Ecology, Inc.

Based on the engineering design presented in Chapter 4.0, the ERDF will include a single large trench and support units (Appendix 2A, Drawing H-6-10606). The trench will be approximately 305 meters (1,000 feet) wide 
1 across the floor, 21 meters (70 feet) deep, and w111 be approximately

2 2,740 meters (9,000 feet) long. The trench will have an east-west

3 orientation. The trench floor w111 be subdivided into approximately 30 cells

4 measuring 150 meters by 150 meters (500 feet by 500 feet). As increased waste capacity becomes necessary, cells will be excavated incrementally within the trench footprint. The exact volume and rate of remediation waste generation 7 has not been determined. As a result, the length of time that the ERDF will remain in operation cannot be specified, but is expected to be at least through the year 2018. The actual schedule of operation for the ERDF Wf11 be in accordance with the most recent version of the Tri-Party Agreement.

Although waste volume estimates are preliminary, it is estimated that up to 21.4 milition cubic meters (28 million cubic yards) of material would be placed in the ERDF over the 1 ife of the ERDF. Data obtained during the initial operation of the ERDF and from the CERCLA RODs for the renediation sites will provide additional information regarding future 1 and requirements for waste management activities at the ERDF. As indicated previously, the total size of the ERDF is expected to be 4.14 square kilometers ( 1.6 square miles), including the space for the associated support units.

The initial increment of the ERDF will include construction of the ERDF trench and support units for management of waste derived by environmental restoration activities. Preliminary proposals for the ERDF indicate that 10 cells will be excavated initially within the trench footprint (DOE-RL 1994a).

\subsection{TOPOGRAPHIC MAP}

A topographic map, including the surrounding 305 meters $(1,000$ feet $)$ is provided in Appendix $2 A$ (Drawing H-6-10606). There are no existing or planned injection or withdrawal wells in the vicinity of the ERDF. There are no barriers planned for flood control at the ERDF. Berms will be constructed around the trenches to avert run-on/run-off from precipitation.

A more precise and detailed topographic map will be provided with the definitive design.

\subsection{LOCATION INFORMATION}

This section describes the location of the ERDF in relation to seismic, floodplain, and shoreline considerations.

\subsubsection{Seismicity of Area}

The ERDF will be located in Benton County, Washington, and will not be within one of the political jurisdictions identified in Appendix VI of 40 CFR 264 or in WAC 173-303-806(4)(a)(xi). The ERDF wil1 be in Zone 2B as identified in the Uniform Building Code (ICBO 1991). The ERDF (including the ERDF trench) will be constructed in accordance with the regulations of 


$$
\text { DOE/RL-94-40, Rev. } 0
$$

1 Section 2312 of the Uniform Building Code for earthquake Zone 2B. The design 2 of the ERDF for seismic considerations will be in accordance with the Hanford 3 Plant Standards, Standard Design Criteria - 4.1 (KEH 1993). This plant

4 standard provides seismic load criteria specific for the Hanford Factlity and 5 is more restrictive than the Uniform Butlding Code (ICBO 1991). According to 6 the International Committee of Building Officials, seismic areas are

7 identifted as zones on a scale of 0 to 4 , with zero being no seismic load and

8 four being the greatest seismic load. The ERDF that will be located in 9 Zone 2B would be considered a medium seismic load zone.

No active faults, or evidence of a fault that has had displacement during Holocene times, have been found on the Hanford Factlity (DOE 1988, WHC 1991b). The youngest faults recognized on the Hanford Factlity occur on Gable Mountain, over 8 kilometers ( 5 miles) north of the ERDF. The nearest known fault to the ERDF is the Yakima Ridge fault at a distance of 3 kilometers (1.86 miles) (DOE 1988). Therefore, no further demonstration of compliance with the seismic standard is requitred (WHC 1994a).

\subsubsection{Floodplain Information}

Three sources of potential flooding of the ERDF were considered:

(1) the Columbia River, (2) the Yakima River, and (3) storm-induced run-off in ephemeral streams draining the Hanford Facility. No perennial streams occur in the central part of the Hanford Facility where the ERDF will be located.

The Federal Emergency Management Agency (FEMA) has not prepared floodplain maps for the Columbla River through the Hanford Facility. The flow of the Columbia River is largely controlled by several upstream dams that reduce major flood flows. Based on a U.S. Army Corps of Engineers study of the flooding potential of the Columbia River that considered historical data and water storage capacity of the dams on the Columbia River (COE 1969), the DOE (ERDA 1976) has estimated the probable maximum flood (Figure 2-4). The estimated probable maximum flood would have a larger floodplain ihan either the 100- or 500-year floods. The ERDF will be above the elevation of the Columbia River probable maximum flood and, consequently, not within the 100or 500-year floodplain.

The 100-year floodplain for the Yakima River, as determined by the Federal Emergency Management Agency (FEMA 1980), is shown in Figure 2-5. The ERDF will not be within this floodplain.

The only other potential source of flooding of the ERDF would be run-off from a large precipitation event in the Cold Creek watershed. This event could cause in flooding of the ephemeral Cold Creek. Skaggs and Walters (1981) have estimated the probable maximum flood using conservative values of precipitation, infiltration, surface roughness, and topographic features. The resulting Cold Creek flood area would not affect the ERDF (Figure 2-6). 
DOE/RL-94-40, Rev. 0

$06 / 94$

\subsubsection{Shoreline Standard}

The ERDF will not be located within regulated 'shorelines of the state' or 'wetlands' as defined in the Shoreline Mariagement Act of 1971. The ERDF will be located on the Hanford Facility, which is owned by the U.S. Government and operated by the DOE-RL. The Hanford Facility is not classified as natural, conservancy, rural, or residential.

\subsubsection{Sole Source Aquifer Criteria}

The ERDF will not be located over a 'sole source' aquifer as defined in Section 1424(e) of the Safe Drinking Water Act of 1974. Refer to Chapter 5.0 for details of the hydrologic system on the Hanford Facility.

\subsection{TRAFFIC INFORMATION: TRANSPORTATION FACILITIES TO SERVICE THE ENVIRONMENTAL RESTORATION DISPOSAL FACILITY}

The regional public highway network traversing the Hanford Facility (Washington State Highways 24 and 240), nonrestrictive access roadways (Route 10 and portions of Route $4 S$ located south of the Wye Barricade), and the restricted access roadways are shown in Figure 2-7.

A description of transportation systems, including roadways and railways, is provided in the following section. In addition, ERDF site-specific transportation issues, including traffic volumes, are discussed.

\subsubsection{Hanford Facility Roadways}

Roadways on the Hanford Facility east of the Yakima Barricade and north of the Wye Barricade, and within the 300 and 400 Areas, are restricted to authorized personnel only. Other U.S. Department of Energy roadways are subject to such restrictions or closure as the U.S. Department of Energy might require. The nearest public roadway to the ERDF site, Washington State Highway 240 , is approximately $1.5 \mathrm{kilometers}(0.9 \mathrm{mile})$ from the ERDF. Estimated traffic volume at the ERDF will be approximately 50 vehicles per day. This estimate, however, could be modified at a later date. Traffic counts for the major roadways on the Hanford Facility have been completed for 1993. This information is provided in Figure 2-8. The majority of the traffic is passenger vehicles used for commuting and conducting company business. Approximately 10 percent of the traffic volume is trucks, and these are mainly delivery, construction, and maintenance vehicles.

Drawing $\mathrm{H}-6-958$ in Appendix $2 \mathrm{~A}$ and Figure 2-7 shows the major roads throughout the Hanford Facility. These roads are classified as either primary or secondary routes. The primary routes include Routes $4 S, 10,2 N, 3,6$, and $11 \mathrm{~A}$, as well as various avenues within each area. The primary routes are constructed of bituminous asphalt [usualiy 5.08 centimeters ( 2 inches) thick, but the thickness of the asphalt layer will vary with each road] with an underlying aggregate base constructed in accordance with U.S. Department of 
1 Transportation requirements. The secondary routes are constructed of layers

2 of an oil and rock mixture with an underlying aggregate base. The aggregate

3 base consists of various types and sizes of rock found onsite. Currentiy, no

4 load-bearing capacities of these roads are available; however, loads as large

5 as 9.8 kilograms per square centimeter (140 pounds per square inch) have been

6 transported without observable damage to road surfaces. All roads meet the

7 requirements for the American Association of State Highway and Transportation

8 Officials HS-20-44 load rating (AASHTO 1983). An HS-20-44 loading represents

9 a two-axle tractor (front axle loading of 3,633 kilograms (8,000 pounds) and

10 rear axle loading of 14,525 kilograms $(32,000$ pounds)) plus a single-axle

11 trailer with a 70,547 kilograms (32,000 pound) axle loading. Vehicles

12 (tractors or trailers) transporting remediation waste on the haul roads to the 13 ERDF will not be allowed to exceed the HS-20-44 requirements.

\subsubsection{Traffic Control Signs, Signals, and Procedures}

Standard traffic control signs are used throughout the Hanford Facility (e.g., octagonal stop signs, triangular yield signs). Speed limits are posted throughout the Hanford Facility, and the maximum posted speed is 88 kilometers per hour ( 55 miles per hour) on major thoroughfares. The maximum speed 1 imit at the ERDF will be determined during definitive design and will be established based on safety, operations, and dust minimization.

\subsubsection{Traffic Pattern Maps}

Traffic pattern maps specific to the ERDF will be provided before initiation of waste management operations at the ERDF. Figure 2-8 provides general traffic volume information for major roadways on the Hanford Facility.

Based on the conceptual design report (DOE-RL 1994a) for the ERDF, it is estimated that up to 65 containers per shift will arrive at the ERDF via tractor/trailer. The containers will be transferred by pneumatic, wheeled container handlers to an ERDF-dedicated tractor trailer that will transport the containers to the trench tipping face. The ERDF-dedicated tractor will back into the trailer tipper and disconnect from the trailer, where the trailer tipper will lift and empty the trailer and container. The ERDFdedicated tractor will reconnect to the trailer and transport the empty containers to the decontamination building. The containers will be removed from the ERDF-dedicated trailers and the exterior of the container will be decontaminated by a water/detergent wash. The empty, decontaminated container will be stored until loaded onto a railcar or tractor/trailer for return to the remediation site.

\subsubsection{Railcar Transportation Summary}

Railcar transportation is expected to be the most predominant form of transportation to the ERDF. A11 railroad track, track bed, and related equipment will be maintained to the requirements of the Federal Railroad 52 Association track safety standards for Class III track, as detailed in 
49 CFR 213. Class III track is sufficient for loads and train speeds occurring on the Hanford Facility. It is expected that up to 150 containers per shift will arrive on rail. All containers arriving by rail will be off-loaded in the raithead area near the north end of the trench.

The procedures for washing and decontamination are the same as discussed in Section 2.4.3, except that containers are not loaded onto a tractor/trailer (DOE-RL 1994a).

\subsection{PERFORMANCE STANDARDS}

Discussion of performance standards is not directly applicable under 40 CFR 264.552 and WAC 173-303-646. However, Chapter 15.0 discusses relevant CAMU regulations that impose similar standards.

\subsection{SPILLS AND DISCHARGES}

Discussion of spills and discharges is not applicable under 40 CFR 264.552 and WAC 173-303-646. However, Chapter 7.0 addresses spills and discharges at the ERDF. In addition, a discussion of preexisting groundwater contamination below the ERDF emanating from sources near the ERDF is presented in Chapter 5.0, Section 5.4.

\subsection{WASTE TRACKING SYSTEM}

The waste tracking system to be used at the ERDF is discussed in Chapters 3.0, 12.0, and 15.0. The waste tracking system used for the ERDF will consist of a unique electronic system developed specifically for the ERDF. The system will serve as an effective inventory control and will be sufficient to ensure that waste handling at the ERDF is protective of human health and the environment.

\subsection{ENVIRONMENTAL SETTING}

A brief discussion of the environmental setting is provided in this section. This information is required to support CAMU criteria (40 CFR 264.552 and WAC 173-303-646), and applicability of this information relative to the ERDF is discussed in Chapter 15.0. A detailed discussion of Hanford Facility and ERDF geology and hydrology is presented in Chapter 5.0.

\subsubsection{Local Land Use Information}

Land use in the areas surrounding the Hanford Facility includes urban and industrial development, irrigated and dry-land farming, and grazing.

Industries in the Tri-Cities (Richland, Kennewick, and Pasco) are mainly those related to agriculture and energy production. Wheat, corn, alfalfa, hay, barley, and grapes are the major crops in Benton and Franklin counties (DOE-RL 1994d). 
DOE/RL-94-40, Rev. 0

$06 / 94$

1

2

4

5

\subsubsection{Population of Hanford Area and Region}

Estimates by the U.S. Bureau of the Census for 1990 (U.S. Department of Commerce 1991) placed the population totals for Benton and Frankl in counties at 112,560 and 37,473 , respectively. When compared to the 1980 census data in which Benton County had 109,444 residents and Frankl in County's population totaled 35,025, the 1990 Census figures reflect the current growth occurring in these two counties. Within each county, the 1990 estimates distribute the Tri-Cities population as follows: Richland, 32,315; Kennewick, 42,159; and Pasco, 20,337. The combined populations of Benton City, Prosser, and West Richland totaled 10,244 in 1990. The unincorporated population of Benton County was 27,842. In Frankl in County, incorporated areas other than Pasco had a total population of 2,424 . The unincorporated population of Franklin County was 14,712 .

\subsubsection{Ecological Setting}

The Hanford Facility is a large, relatively undisturbed area of shrubsteppe habitat that contains numerous $p l$ ant and animal species adapted to the region's semiarid environment. The Hanford Facility consists of mostly undeveloped 1and with widely spaced clusters of industrial buildings located along the western shoreline of the Columbia River and at several interior locations. The industrial buildings are interconnected by roads, railroads, and electrical transmission lines. The major buildings and activities occupy approximately 6 percent of the total available land area, and impact on the surrounding ecosystems is minimal. Most of the Hanford Facility has not experienced tillage or livestock grazing since the early 1940s. The Columbia River flows through the Hanford Facility, and although the river flow is not directly impeded by artificial dams within the Hanford Facility, the historical daily and seasonal water fluctuations have been changed by dams upstream and downstream of the Hanford Facility. The Columbia River and other water bodies on the Hanford Facility provide habitat for aquatic and riparian organisms. The Columbia River also is accessible for public recreational use and for commercial navigation.

2.8.3.1 Flora and Fauna of the Hanford Area, including Endangered Species. The Hanford Facility has been classified primarily as a shrub-steppe grassland (Daubenmire 1970) and is composed of several plant communities. The Washington State Department of Fish and Wildlife has designated the shrubsteppe community a Priority Habitat within the state. This designation represents a proactive measure to help prevent species from becoming threatened or endangered. Priority Habitats support unique or a wide diversity of wildife and must be protected to prevent further species' losses.

Major plant species include big sagebrush (Artemisia tridentata), bitterbrush (Purshia tridentata), Sandberg's bluegrass (Poa sandbergi i), cheatgrass (Bromus tectorum), and rabbitbrush (Chrysothamnus spp.). The ERDF is located within the sagebrush/cheatgrass-Sandberg's bluegrass plant community type (WHC 1992j). According to the Washington State Natural 
1 Heritage Program of 1990, 12 plant species considered to be endangered, 2 threatened, or sensitive, are known to survive on or near the Hanford

3 Facility, seven of which are upland species (WHC 1992a). The upland species 4 are northern wormwood (Artemisia campestris ssp. borealis var. wormskioldii), 5 Columbia milkvetch (Astragalus columbianus), Hoover's desert parsley (Lomatium 6 tuberosum), Pipers daisy (Erigeron piperianus), gray cryptantha (Cryptantha

7 leucophea), Palouse milkvetch (Astragalus arrectus), and coyote tobacco 8 (Nicotiana attenuata). According to an ERDF site-specific ecological report 9 (WHC 1993a, Appendix 2B), the stalked-pod milkvetch (Astragalus sclerocarpus) 10 was the oniy plant species observed at the ERDF that is on a state or federal 11 list as a species of concern. This species is a state-monitored species that is fairly common throughout the 200 Areas Plateau.

The DOE-RL recognizes that contiguous blocks of mature shrub-steppe habitat are important for many plant and animal species, and this habitat is rapidly shrinking elsewhere in Eastern Washington. Habitat value will be assessed before start of construction and losses will be mitigated based on the ecological value of the habitat disturbed. However, rather than implementing mitigation measures on a project-by-project basis, the DOE-RL is developing a plan in cooperation with the Washington State Department of Fish and Wildi ife and the U.S. Fish and Wildlife Service to manage wildlife habitats on a Hanford Facility-wide basis.

According to an ecological survey conducted between April 1993 and June 1993 (WHC 1993a), several species of wildlife, including birds, mammals, and reptiles, have been observed or are known to inhabit the ERDF area. Bird species present (WHC 1992i) and documented as species of concern by state and federal governments include the long-billed curlew (Numenius americanus), sage sparrow (Amphispiza belli), grasshopper sparrow (Ammodramus savannarum), loggerhead shrike (Lanius ludovicianus), and Swainson's hawk (Buteo swainsoni $i$ ). According to the ERDF ecological survey, mammals known to inhabit this area, based on observation, include the Great Basin pocket mouse (Perognathus parvus), badger (Taxidea taxus), coyote (Canis latrans), mule deer (Odocoileus hemionus), and black-tailed jackrabbit (Lepus californicus). other mammals known to inhabit the 200 Areas Plateau include the striped skunk (Mephitis mephitis), long-tailed weasel (Mustela frenata), bobcat (Lynx rufus), and various rodents. Reptiles observed during the ERDF ecological survey were the gopher snake (Pituophis catenifer), racer (Coluber constrictor), and sideblotched lizard (Uta stansburiana). Other reptiles inhabiting the 200 Areas include sagebrush lizard (Sceloporus graciosus), short horned lizard (Phrynosoma douglassii), Great Basin spadefoot toad (Scaphiopus intermantanus), and the Western rattlesnake (Crotalus viridis).

A list of plants and animals of concern that potentially inhabit the ERDF area is presented in Table 2-2. This 1 ist was developed as a result of the site survey conducted between Aprit and June 1993 (Appendix 2B).

2.8.3.2 Baseline Ecology Study. An environmental baseline determination will be made to establish the preoperational conditions at the ERDF site in accordance with DOE. Order 5400.1 . The primary objectives of the preoperational survey include: (1) determining current levels of radionuclides in environmental media attributable to previous and ongoing 
1 operations of other waste management units in the area; (2) providing data

2 that will determine environmental conditions to measure impacts; (3) providing

3 data that could augment the routine monitoring and surveillance program;

4 (4) characterizing pertinent environmental and ecological parameters; and

5 (5) identifying potential pathways for human exposure and environmental

6 impacts.

7

To accomplish these objectives, air monitoring networks in the ERDF will be established. In addition, biota and soil samples to determine baseline conditions at the ERDF will be collected randomily throughout the ERDF. The proposed environmental baseline study is further discussed in the site characterization plan (WHC 1994C).

2.8.3.3 Introduction to Hanford Facility Geology and Hydrology. The Hanford Facility is located within a structural depression known as the Pasco Basin. The Hanford Facility is underlain by the Columbia River Basalts that are capped by suprabasalt sediments. These sediments are up to 229 meters (750 feet) thick and are comprised principally of the Ringold and overlying Hanford formations. The water table occurs within the suprabasalt sediments and is from 0.305 to 107 meters ( 1 to 350 feet) belowground surface.

The water table is approximately 91.5 meters (300 feet) belowground surface below the ERDF. Groundwater flow within the water table below the ERDF is to the east, toward the Columbia River. Detailed discussion of the geology and hydrology for the ERDF is presented in Chapter 5.0.

\subsubsection{Meteorologic Data}

The climate at the Hanford Facility is semiarid. The Cascade Mountain Range located to the west influences the climate of the site by causing a rain shadow effect and by serving as a source of cold air drainage (PNL 1989).

Meteorological observations are made from the Hanford Meteorology Station located approximately 3.2 kilometers $(2$ miles) north of the northern boundary of the ERDF site. Data also are collected at various stations throughout the Hanford Facility. The following climatological summary information is from data collected from 1946 to 1980 (WHC 1994C).

\subsubsection{Local Climate, Rainfall, Ambient Temperature, and Air Quality.} Annual precipitation at the Hanford Meteorology Station averages 16 centimeters ( 6.3 inches). The monthly average precipitation amounts for the period 1912 through 1980 are shown in Figure 2-9. Approximately 44 percent of all precipitation falls from November through January, much of it as snow (WHC 1994C; DOE-RL 1994a). Rainfall intensities of 1.27 centimeters ( 0.5 inch) per hour persisting for 1 hour are expected only once every 10 years, while intensities of 2.54 centimeters ( 1 inch) per hour persisting for 1 hour are expected only once every 500 years (PNL 1989). The greatest 12 hour rainfa11 recorded was 4.78 centimeters ( 1.88 inches) between October 1 and 2, 1957 (WHC 1994C). Winter monthly average snowfall ranges from 0.76 centimeter ( 0.3 inch) in March, to 13.46 centimeters ( 5.3 inches) in January. The record snowfall of 142 centimeters ( 56 inches) occurred in the winter of $1992 / 1993$. 
DOE/RL-94-40, Rev. 0

The average relative humidity at the Hanford Facility is 54 percent with the highest during the winter months, averaging approximate $7 y$ 75 percent, and is lowest during the summer months, averaging approximately 35 percent (PNL 1989). Because of the low humidity, the diurnal temperature range is substantial. During summer months, when the average relative humidity is 30 to $\mathbf{4 0}$ percent, the diurnal temperature range is greatest, on the order of $15^{\circ} \mathrm{C}\left(27^{\circ} \mathrm{F}\right)$. In winter, with relative humidity ranging from 60 to 80 percent, the diurnal temperature range is reduced to approximately $8^{\circ} \mathrm{C}\left(14^{\circ} \mathrm{F}\right)$ (DOE-RL 1994d).

Average temperatures on the Hanford Facility range from $2^{\circ} \mathrm{C}\left(35.6^{\circ} \mathrm{F}\right)$ in early January to $35^{\circ} \mathrm{C}\left(95^{\circ} \mathrm{F}\right)$ in late July (PNL 1989), with an average annual temperature of $11.7^{\circ} \mathrm{C}\left(53.06^{\circ} \mathrm{F}\right)$. The highest maximum temperature recorded was $46.1^{\circ} \mathrm{C}\left(115^{\circ} \mathrm{F}\right)$ in July 1939 and the lowest minimum temperature was $-32.8^{\circ} \mathrm{C}$ $\left(-27^{\circ} \mathrm{F}\right)$ in December 1919 (PNL 1989).

The prevailing wind direction is either west-northwest or northwest, while secondary maxima occur for southwesterly winds (WHC 1994c; DOE-RL 1994a). The wind rose for the Hanford Facility is shown on Drawing H-6-10606 (Appendix 2A). The highest monthly average wind speeds occur in June, averaging 14.5 to 16.0 kilometers (9 to 10 miles) per hour, while the lowest monthly average wind speed occurs during November and December, averaging 9.7 to 11.3 kilometers ( 6 to $7 \mathrm{miles}$ ) per hour (PNL 1989). The strongest wind gusts observed, with speeds of up to 128.7 kilometers ( 80 miles) per hour, generally are southwesterly. Mountain ridges and river valleys locally infiuence wind direction, particularly along the Columbia River where predominant wind directions parallel the river (DOE-RL 1994d).

Tornados are infrequent and generally small in the northwestern portion of the United States. The Hanford Meteorology Station and the National Severe Storms Forecast Center database 1 ist 22 separate tornado occurrences within 161 kilometers (100 miles) of the Hanford Facility from 1916 through August 1982. Two additional tornados have been reported since August 1982 (PNL 1989).

Monthly rates of pan evaporation at the Washington State University Irrigated Agriculture Research and Extension Center, located approximately 20 miles southwest of the ERDF, average from 8.1 to 25.4 centimeters $(3.2$ to 10 inches). Total pan evaporation over the period April through October averaged approximately 126.6 centimeters (49.9 inches). This seasonal component represents approximately 80 percent of the total annual pan evaporation. Free surface evaporation is expected to equal approximately 70 percent of the pan evaporation for the Hanford Facility vicinity, or about 111 centimeters ( 43 inches). Free water surface evaporation closely represents the potential evaporation from adequately watered surfaces, such as vegetation and soil, and the evaporation from a surface body of water.

Data obtained from a groundwater recharge monitoring program initiated in the late 1970 s at the 300 Area buried waste test facility indicated that evaporation and transpiration were approximately 14.3 centimeters ( 5.6 inches) for a bare surface and 19.9 centimeters (7.9 inches) for a vegetated surface. The total monthly evapotranspiration data near the 300 Area are shown in 
DOE/RL-94-40, Rev. 0

$06 / 94$

1 Figure 2-9. Precipitation was approximately 18 centimeters ( 7.1 inches), 2 while drainage was about 4 centimeters ( 1.6 inches) from the bare surface and

31 centimeter ( 0.4 inch) from the vegetated surface. The excess of

4 evapotranspiration and drainage over precipitation was compensated for by a

5 reduction in soll molsture (DOE-RL 1994d).

6

Atmospheric dispersion is a function of wind speed, duration and direction of wind, atmospheric stability, and mixing depth. Dispersion conditions generaliy are good if winds are moderate to strong, the atmosphere is of neutral or unstable stratification, and there is a deep mixing layer. Good dispersion conditions associated with neutral and unstable stratification exist approximately 57 percent of the time during summer. Less favorable dispersion conditions might occur when the wind speed is light and the mixing layer is shallow. These conditions are most common during the winter when moderately to extremely stable stratification exists approximately 66 percent of the time. Less favorable conditions also occur periodically for surface and low-level releases in all seasons from about sunset to about an hour after sunrise as a result of ground-based temperature inversions and shallow mixing layers. Occasionally, there are extended periods of poor dispersion conditions that are associated with stagnant air in stationary high-pressure systems that occur primarily during the winter months (DOE-RL 1994d).

2.8.4.2 Air. The Hanford Facility is located within an airshed that meets all federal and state ambient air quality standards (AAQS), and thus has been declared an "attainment area". Therefore, the requirements of the Prevention of Significant Deterioration (PSD) regulations apply to emissions of pollutants traditionally released from fossil fueled power plants or other large industrial sources, and includes pollutants such as carbon monoxide, nitrogen oxides, sulfur oxides, particulate matter, ozone, lead, asbestos, mercury, etc., commoniy referred to as the "criteria pollutants." The PSD regulations are intended to protect the regional air quality while allowing a margin for future industrial growth. As such, the regulations require approval before construction, and best available control technology (BACT) for any large new source of air emissions or any source modifications involving significant increases in criteria pollutant emissions. The Hanford Facility is considered a major PSD source because of onsite pollutant emissions from various coal and oil fired steam generating plants. Chapter 13.0 discusses regulations relevant to the ERDF other"than RCRA, including those pertaining to air quality.

Other federal and state clean air regulations apply to the Hanford Facility as with any industry, and address a 1 ist of over 700 air pol lutants. The regulations require approval by one or more clean air agencies before any construction or modification begins that would supply any significant increase in emissions. The regulations include controls for sources of volatile organic compounds (VOCs), carcinogens, radionuclides, odors, dust, smoke, and chloroflourocarbons (CFCs) or other ozone depleting substances.

At present, enforcement of air quality regulations and standards are under the jurisdiction of both the federal and state programs, as well as the Benton-Frankl in Count ies Clean Air Authority (BFCCAA). The BFCCAA regularly monitors the air quality in and around the Hanford Facility and 
1

2

Benton-Franklin County area for total suspended particulates (TSP), ozone, and other pollutants. A current concern of the local area outside of the Hanford Facility is TSP. The levels of TSP fluctuate seasonally, with the highest levels occurring from July to October, apparently associated with agricultural activities. The lowest levels occur from November to February. The TSP concentrations have exceeded acceptable levels on several occasions, bringing clean air authorities to formally consider designating the affected area as a nonattainment area for TSP.

It is not expected that the construction and operation of the ERDF will have an overall impact on the amblent air quality of the region. Some local impacts will be expected from fugitive oust emissions and possibly an impact in the level of carbon monoxide and oxides of nitrogen and sulfur due to the use of heavy diesel-fueled construction equipment. The majority of fugitive dust emissions would be generated during the early stages of initial construction and during future cell expansions. Emissions would result from windblown dust from exposed soil areas and from earthmoving equipment. Reasonable efforts to mitigate the impact from construction-related dust will be made by spraying construction roads with water or graveling or paving as necessary (DOE-RL 1994a). The minor increases in the localized levels of carbon monoxide and oxides of nitrogen and sulfur are not expected to offer any offsite impacts. Applicable federal, state, and local clean air regulations are addressed regarding the expected emissions to air in Chapter 13.0.

\subsection{INTRODUCTION TO ENVIRONMENTAL RESTORATION DISPOSAL FACILITY WASTE}

The following is a brief description of the waste that will be accepted for management in the ERDF. Chapter 3.0 addresses the waste characterization and waste analysis $\mathrm{plan}$, and provides additional available information pertaining to waste and waste characteristics.

Waste to be managed in the ERDF includes remediation waste from cleanup of past-practice waste sites governed by CERCLA and RCRA. Operations on the Hanford Facility have resulted in approximately 1,000 waste sites that must be investigated, and, if necessary, cleaned up. Up to 21.4 milliton cubic meters (28 milifion cubic yards) of remediation waste are expecter to be deposited in the ERDF. This waste volume is anticipated to consist 0 approximately 85 percent hazardous/dangerous, radioactive, and mixed waste overburden and soil that will be delivered to the top working face of the ERDF for bulk emplacement. In addition, a small amount of remediation waste might consist of Toxic Substances Control Act (TSCA) of 1976-regulated radioactive polychlorinated bipheny1 (PCB), TSCA-regulated nonradioactive PCB waste, and asbestos materials. Approximately 13 percent of the waste is anticipated to be in the form of metals, buried waste, and decontamination and decommissioning (D\&D) materials that will be delivered to the toe of the working face of the ERDF trench for emplacement. This material will be managed, as necessary, to prevent settling and subsidence of material placed over the waste. The remaining 2 percent of the waste delivered to ERDF is anticipated to require special handling, and will be delivered to the trench floor for emplacement. This waste requiring special handling is described 
1 further in Chapter 3.0. Where possible and practical, nonradioactive

2 nonhazardous waste will be characterized and managed at another location

3 separate from the ERDF.

4

5

\section{6}

7

8

9

10

11

12

13

14

15

16

\subsection{IRREVERSIBLE AND IRRETRIEVABLE COMMITMENTS OF RESOURCES}

Resources committed to the construction and operation of the ERDF will include the land dedicated to the ERDF and support units; energy required for operations; materials and funds involved in the construction of the support units, trench, and liner; the soils and rock materials required for construction of the barrier; and the natural resources present on the ERDF site and rail extension route. 
DOE/RL-94-40, Rev. 0

06/94

1
2
3
4
5

This page intentionally left blank. 
DOE/RL-94-40, Rev. 0

06/94

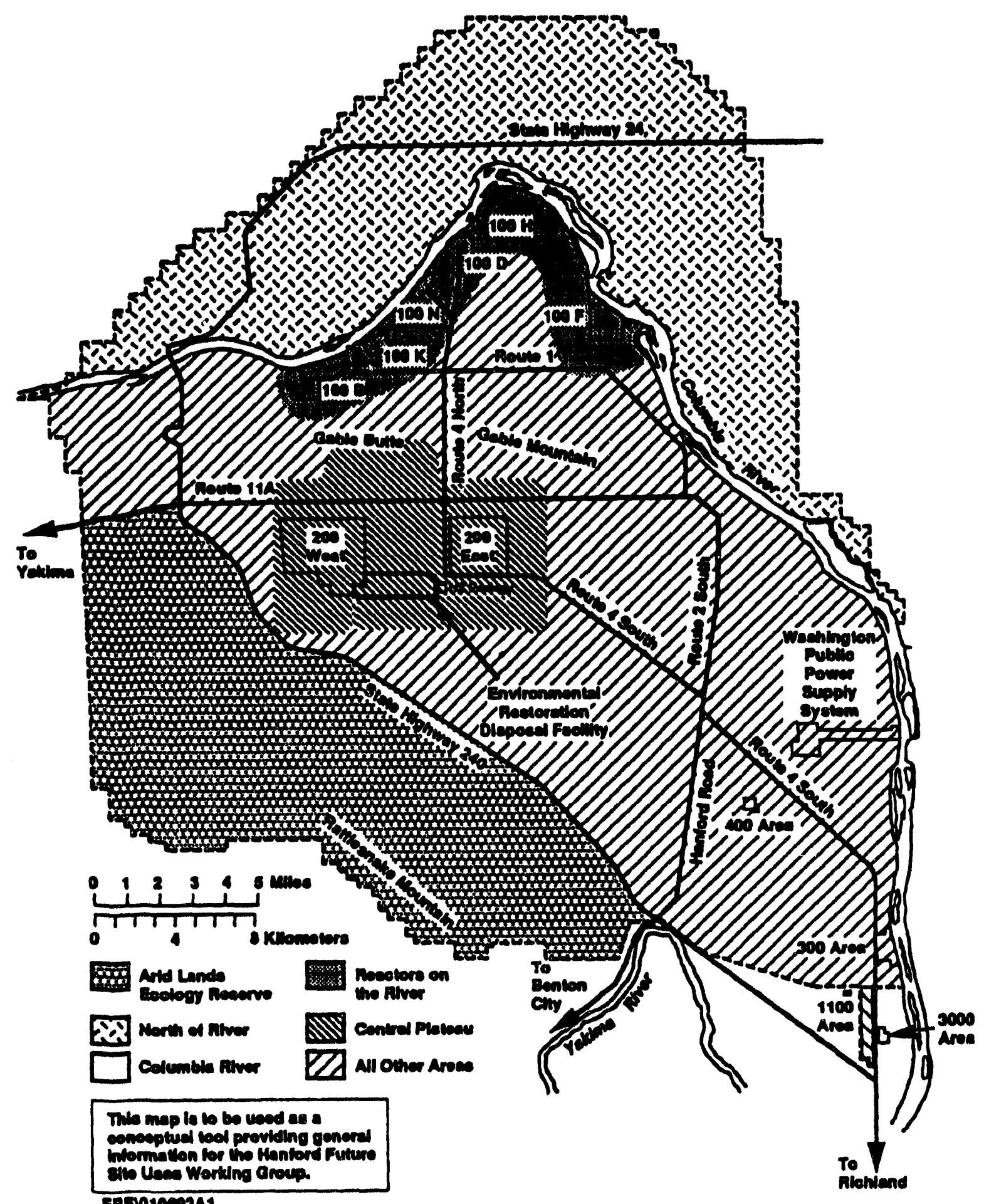

Figure 2-1. Location of the Environmental Restoration Disposal Facility-200 Areas Plateau. 
- $\quad$

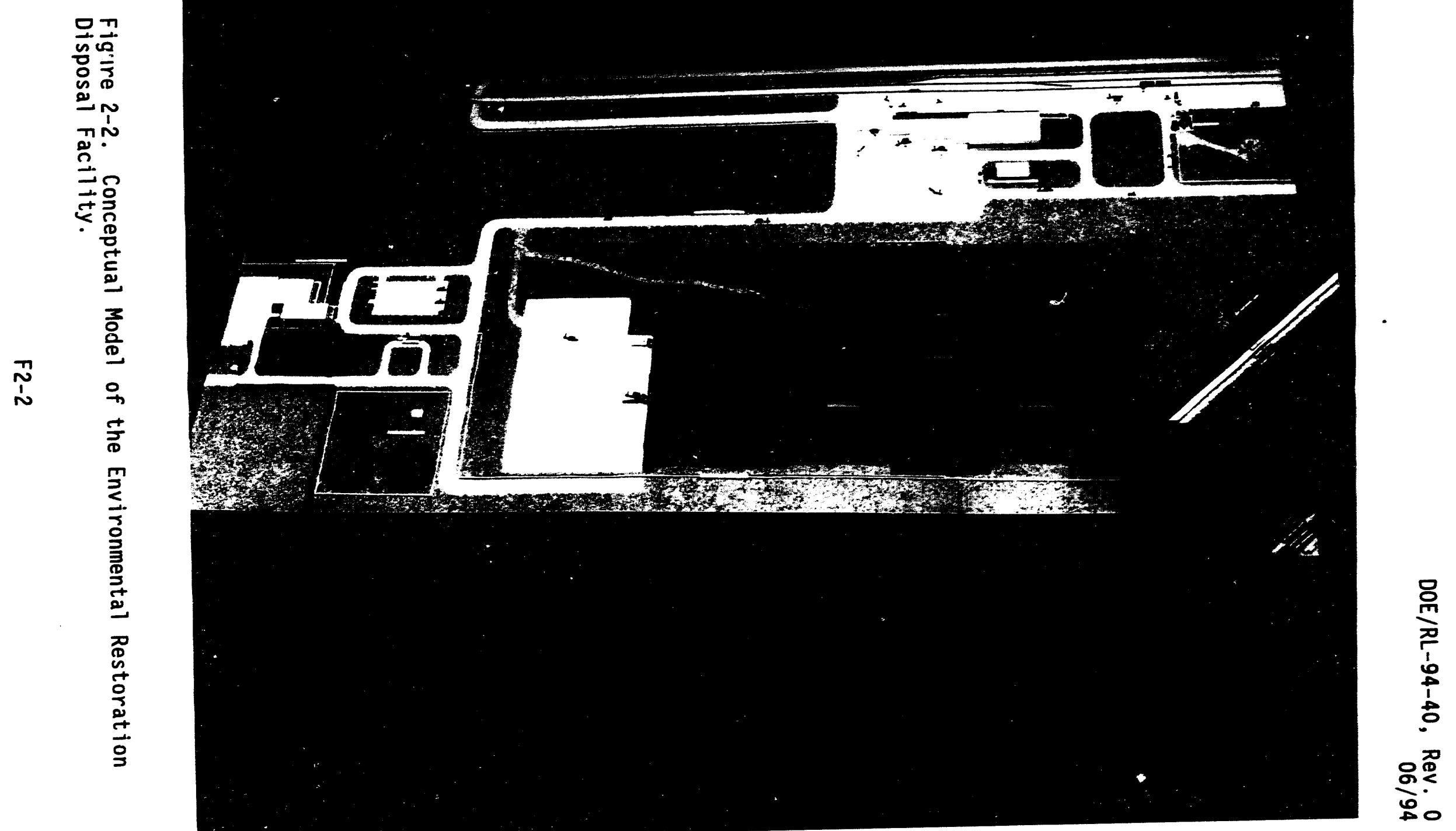




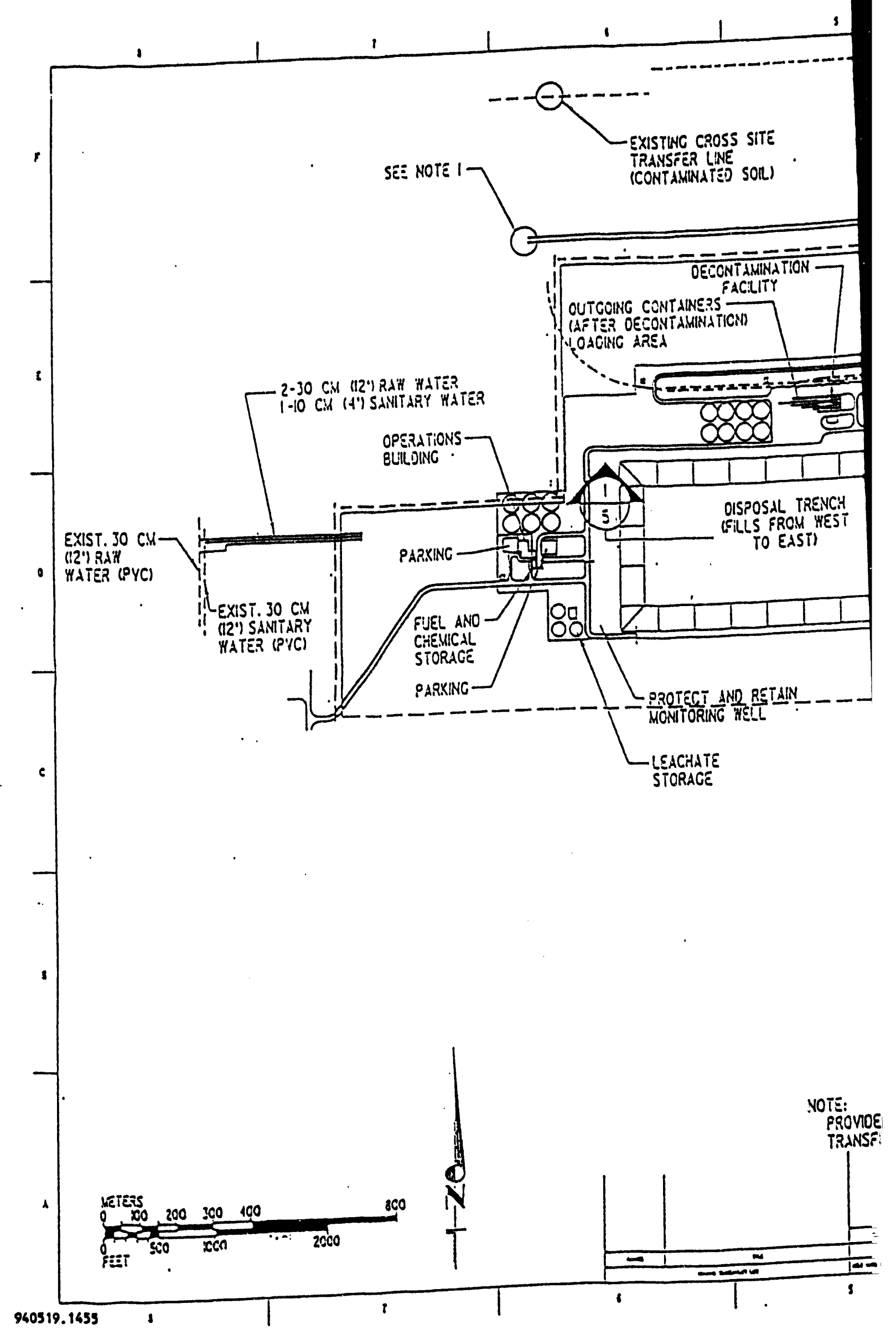



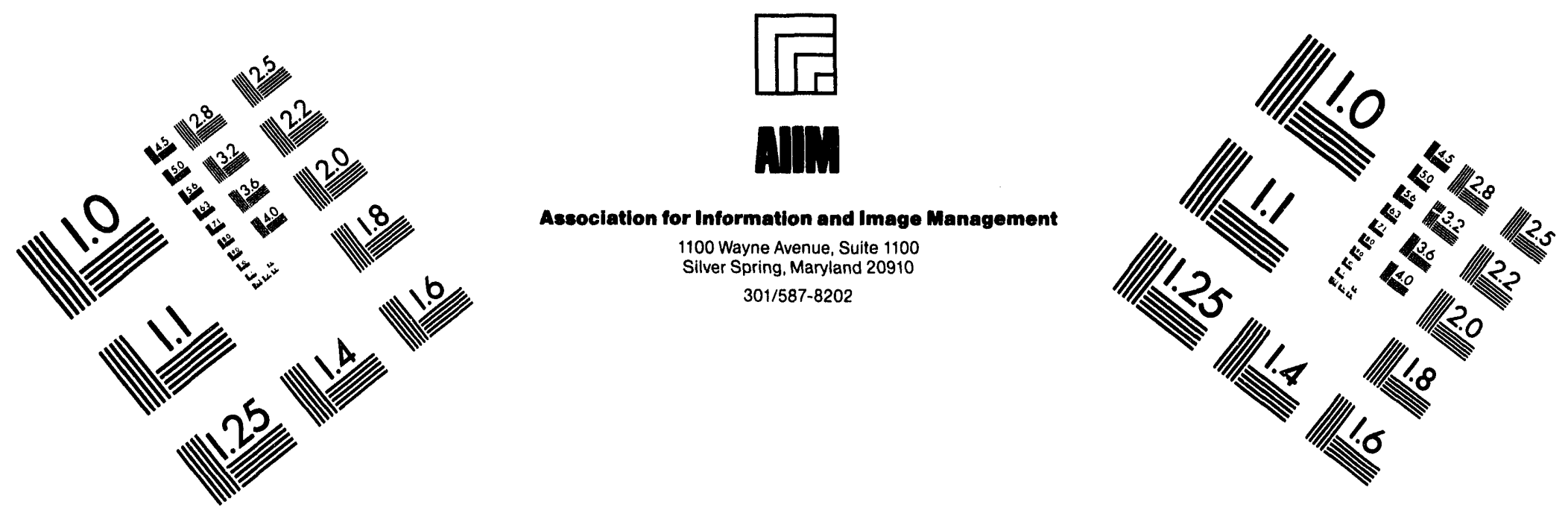

\section{Centimeter}

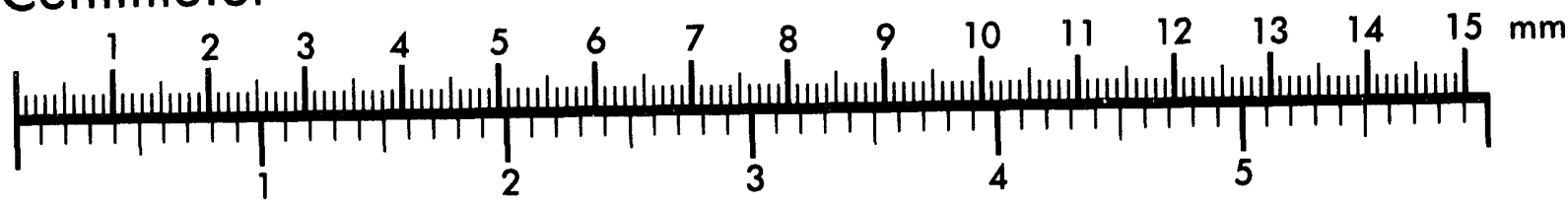
Inches
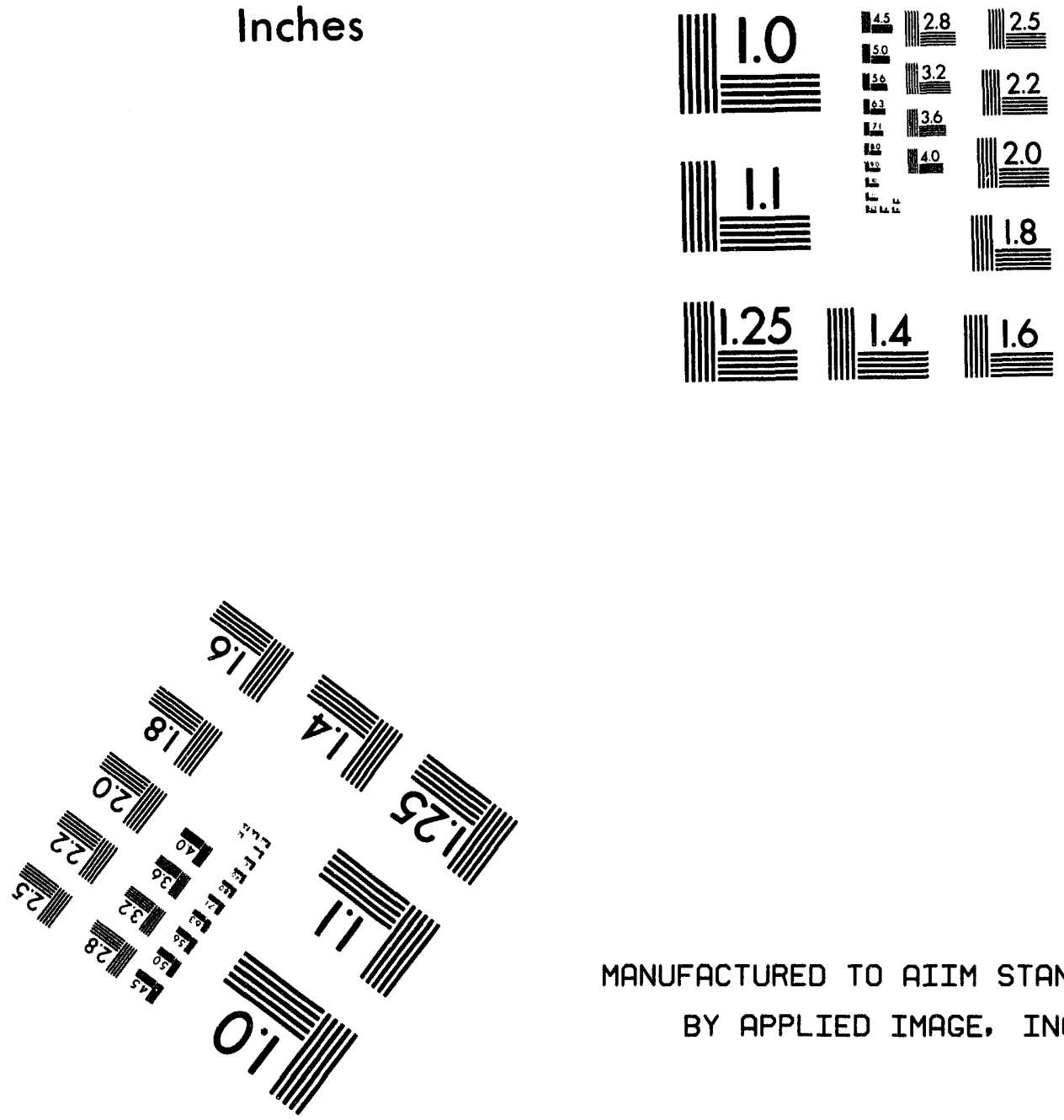

MANUFACTURED TO AIIM STANDARDS

BY APPLIED IMAGE, INC.

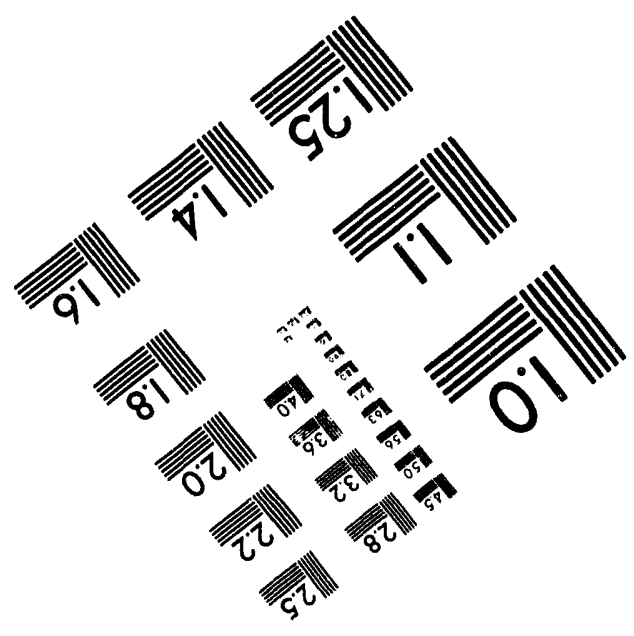



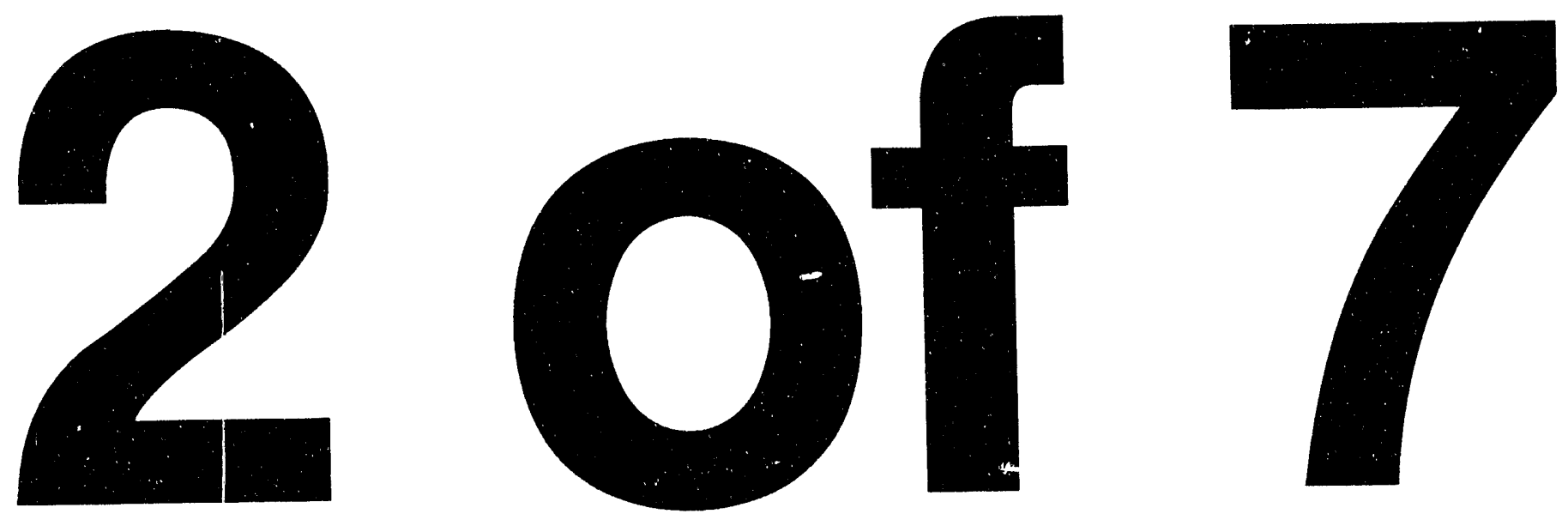


$1,1,1=1$

NEH RALLOAOAO LEAO TRACR

SEE NOTE i

DOE/RL-94-40, Rev. 0

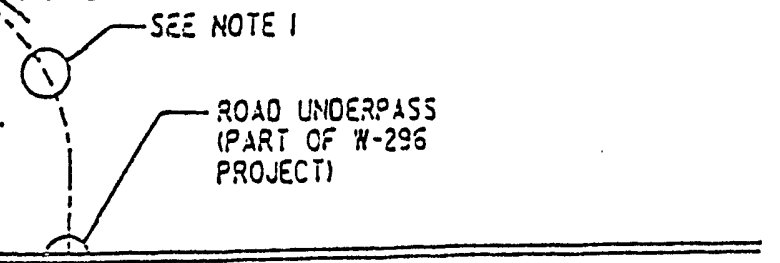

PROPOSED I6TH AVE. I TOAO UNOERRP ASS

ExTENSTON PROJECT TOO 2 NOT IN Y-2CS CONTRACTI

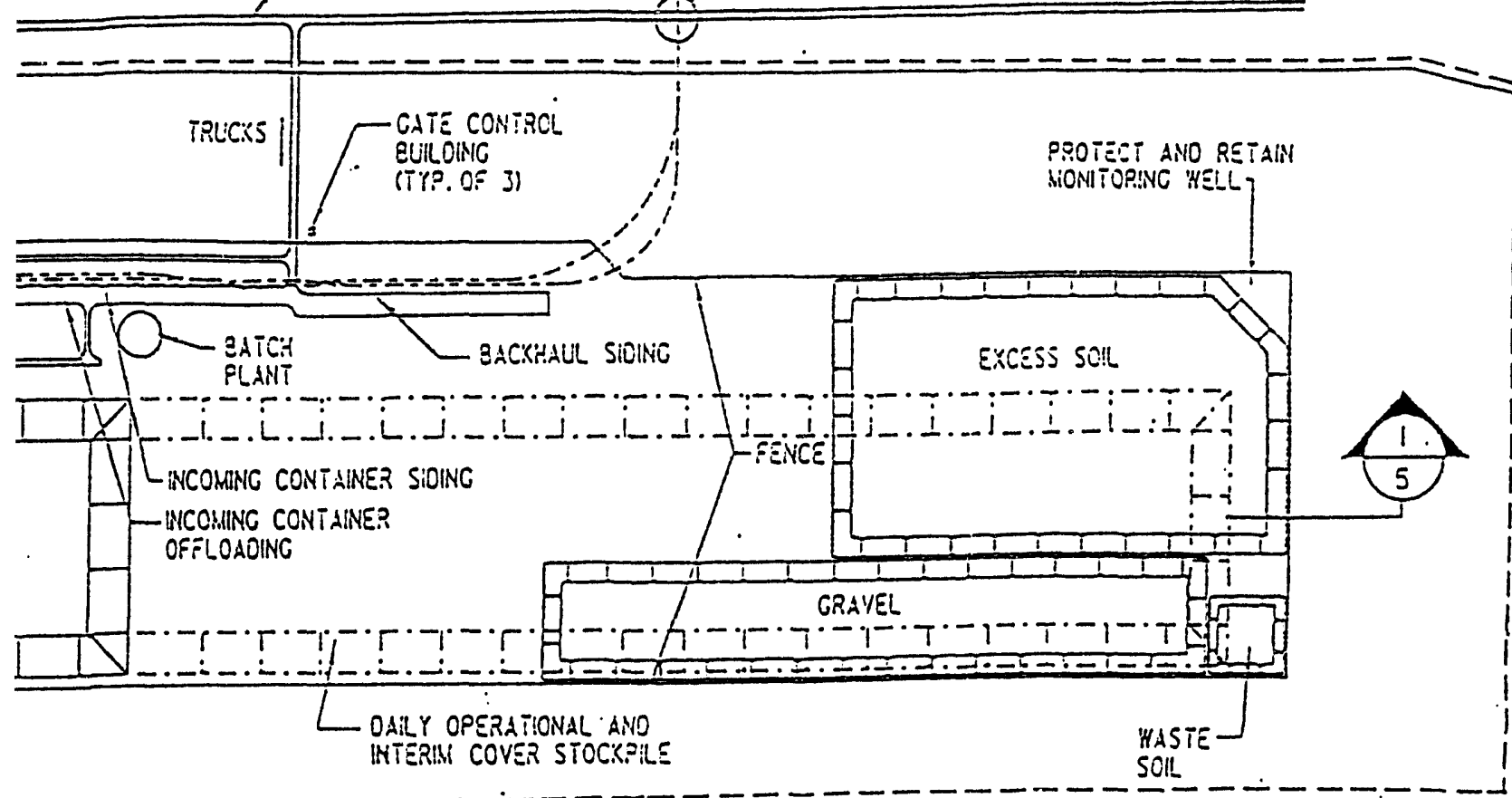

\section{Approximate Environmental \\ Restoration Site Boundry}

THRE jO C.M M2'I OLA. CASINCS FOR CROSS SITE P BPES (FROLECT Y-O5B)
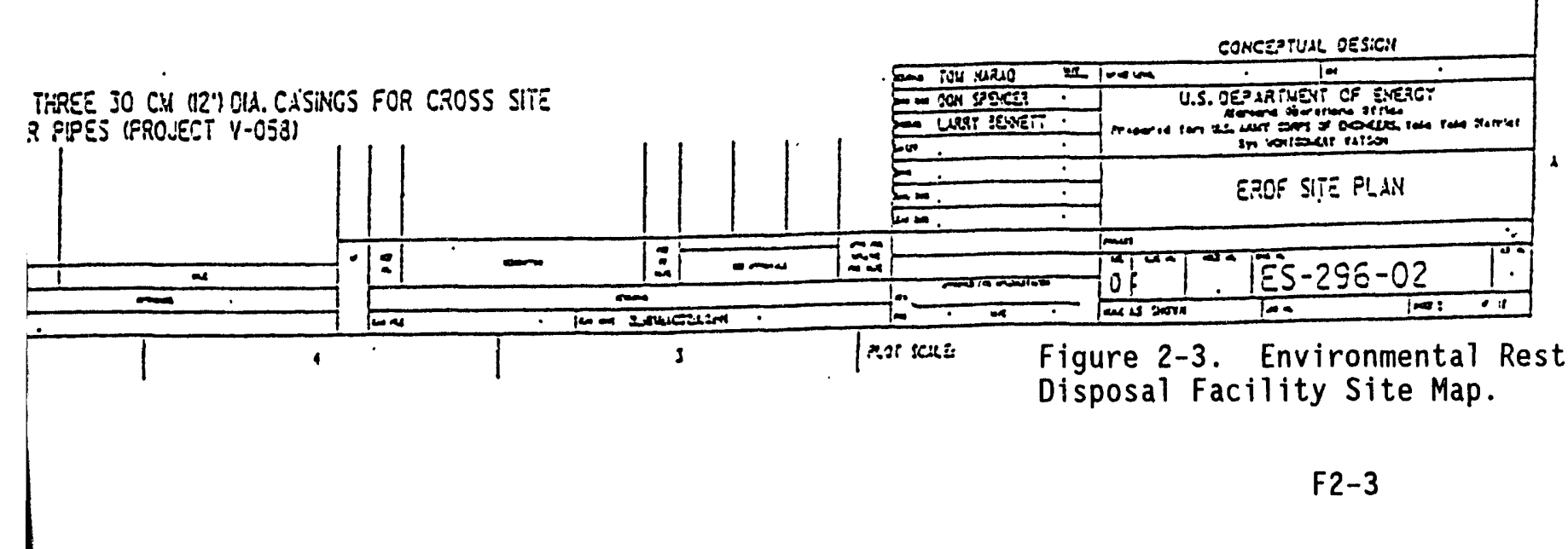

| 1928 scis:

Figure 2-3. Environmental Restoration Disposal Facility Site Map. 
DOE/RL-94-40, Rev. 0

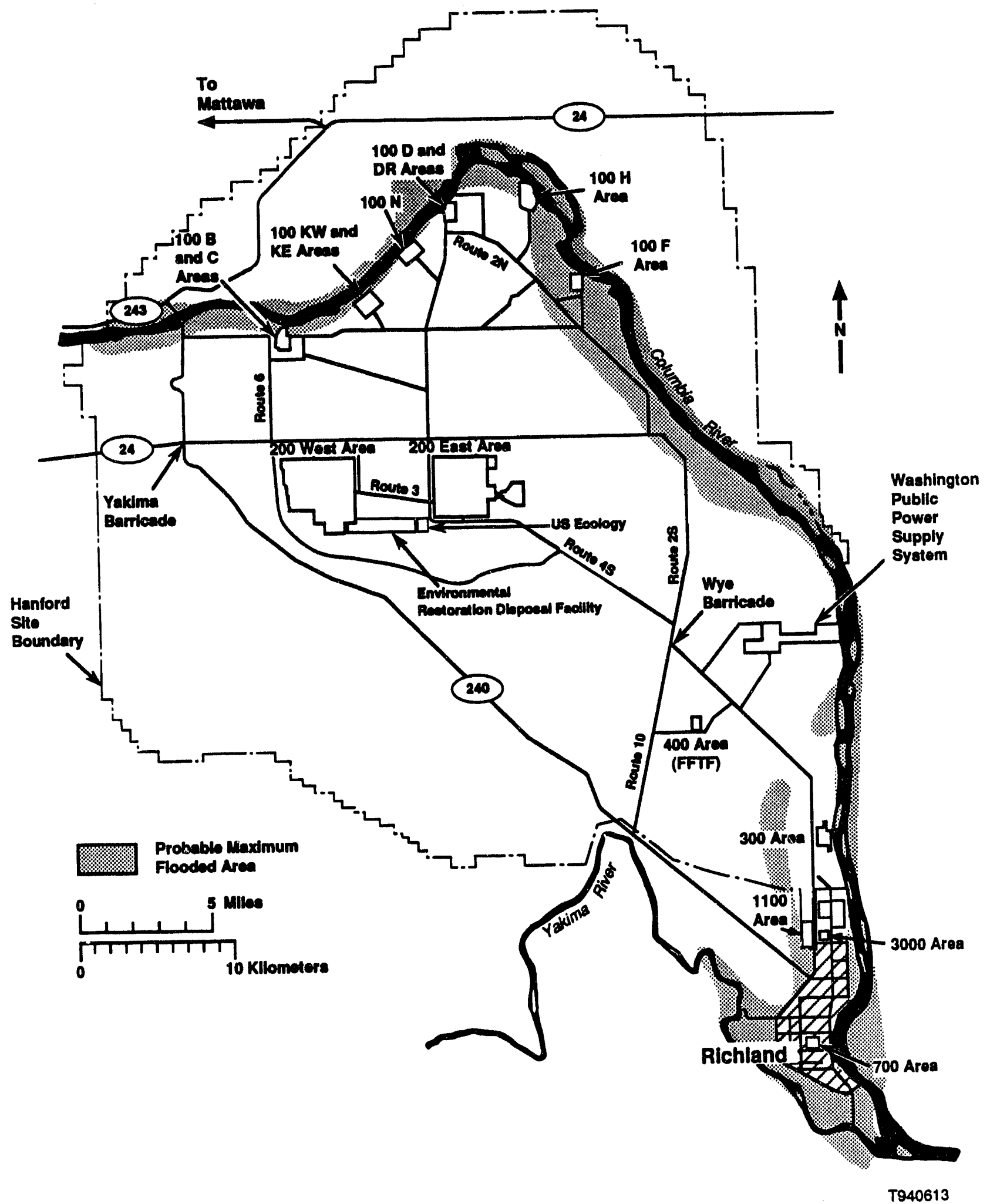

Figure 2-4. Columbia River Floodplain (probable maximum flood). 


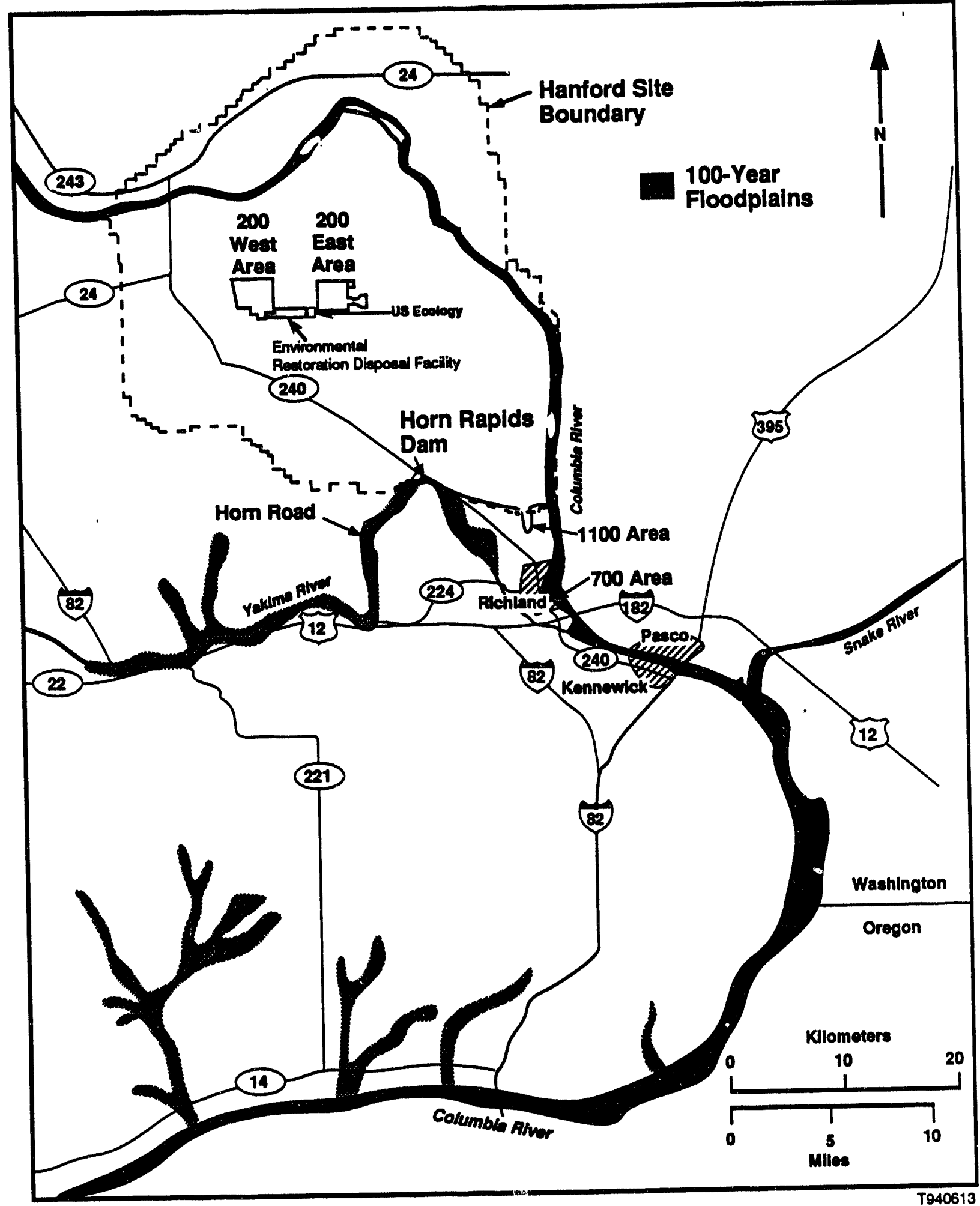

Figure 2-5. Yakima River Floodplain. 


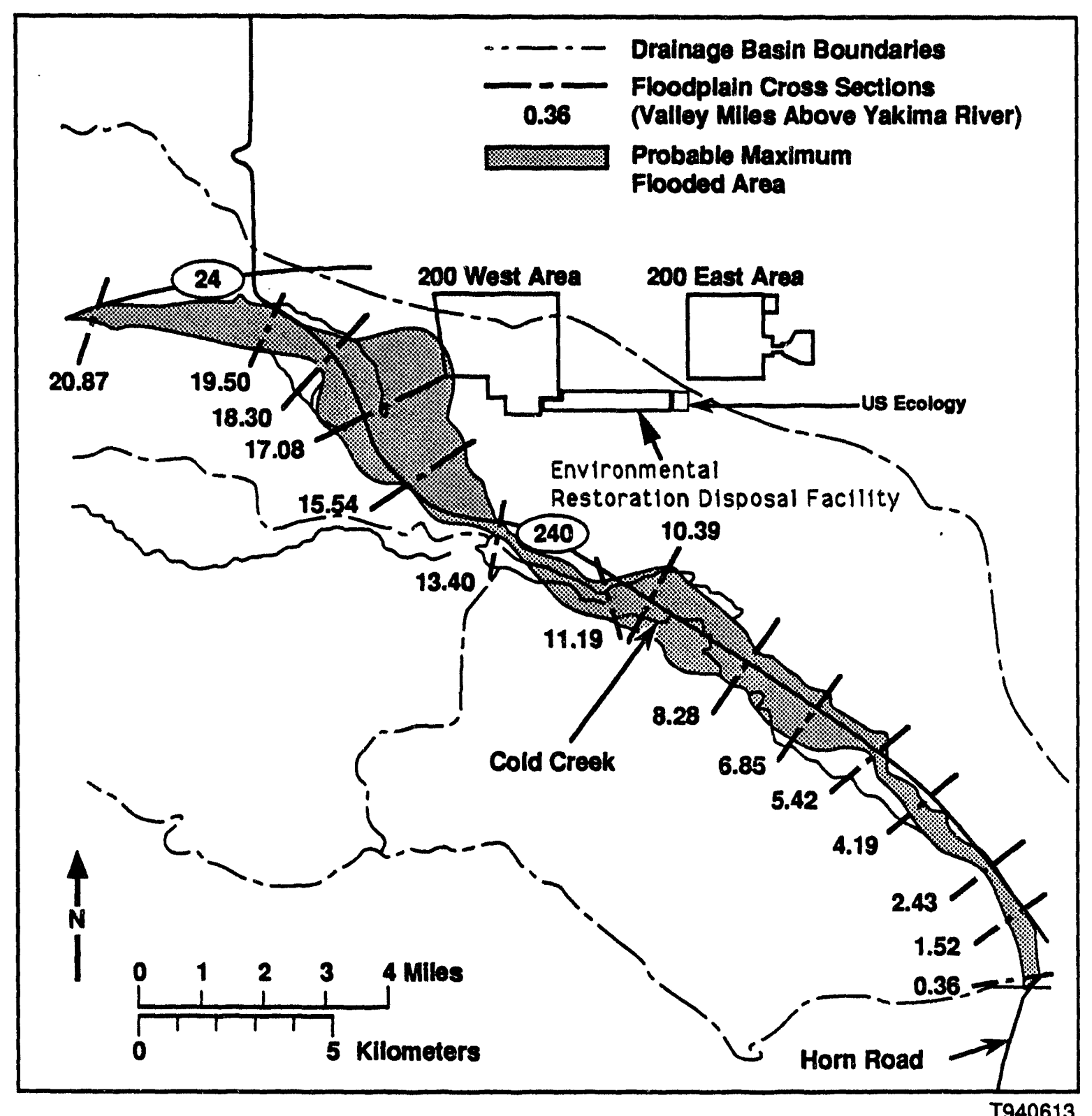

Figure 2-6. Cold Creek Floodplain (probable maximum flood). 
DOE/RL-94-40, Rev. 0

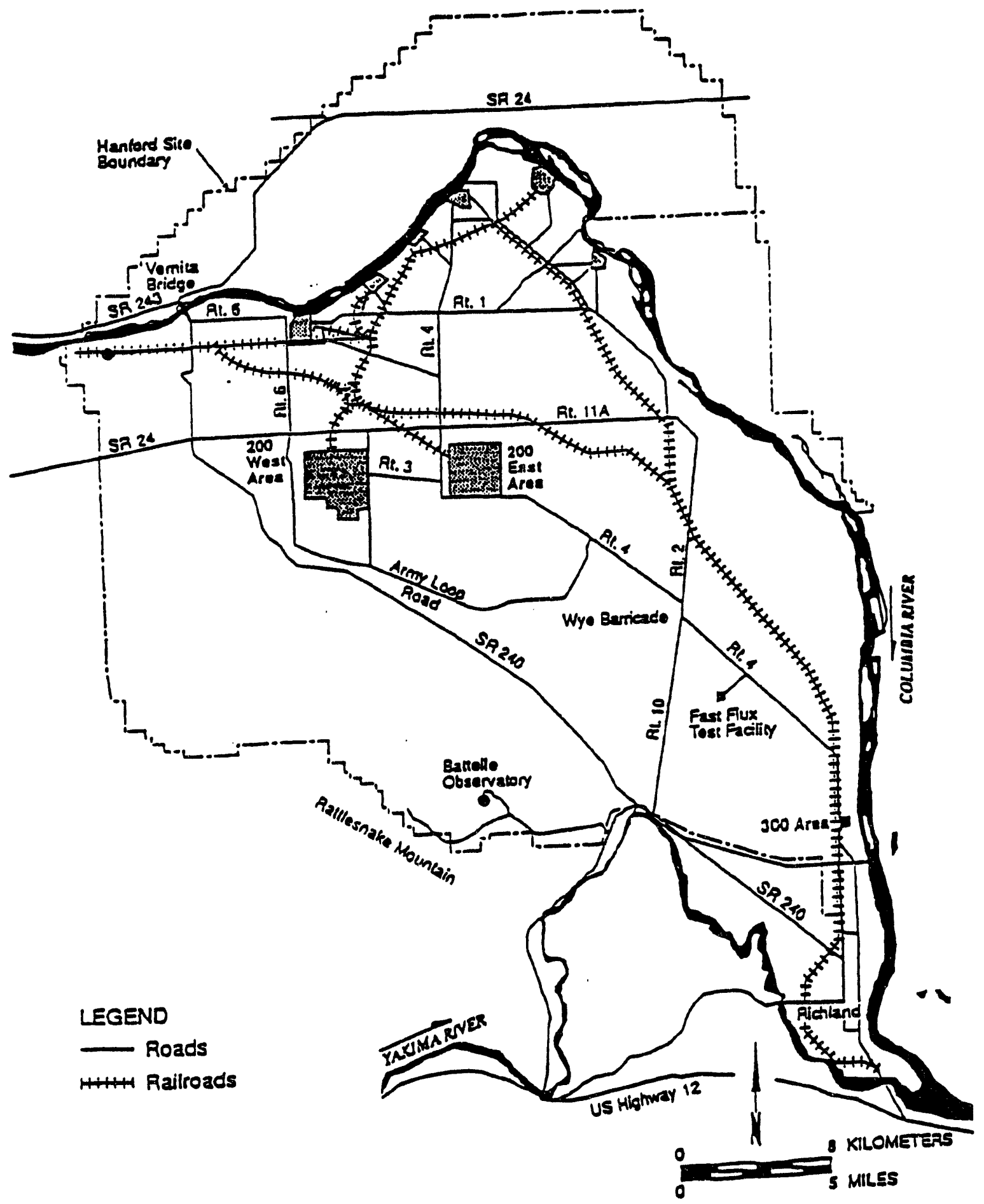

Figure 2-7. Transportation Network - Hanford Facility. 
DOE/RL-94-40, Rev. 0

06/94

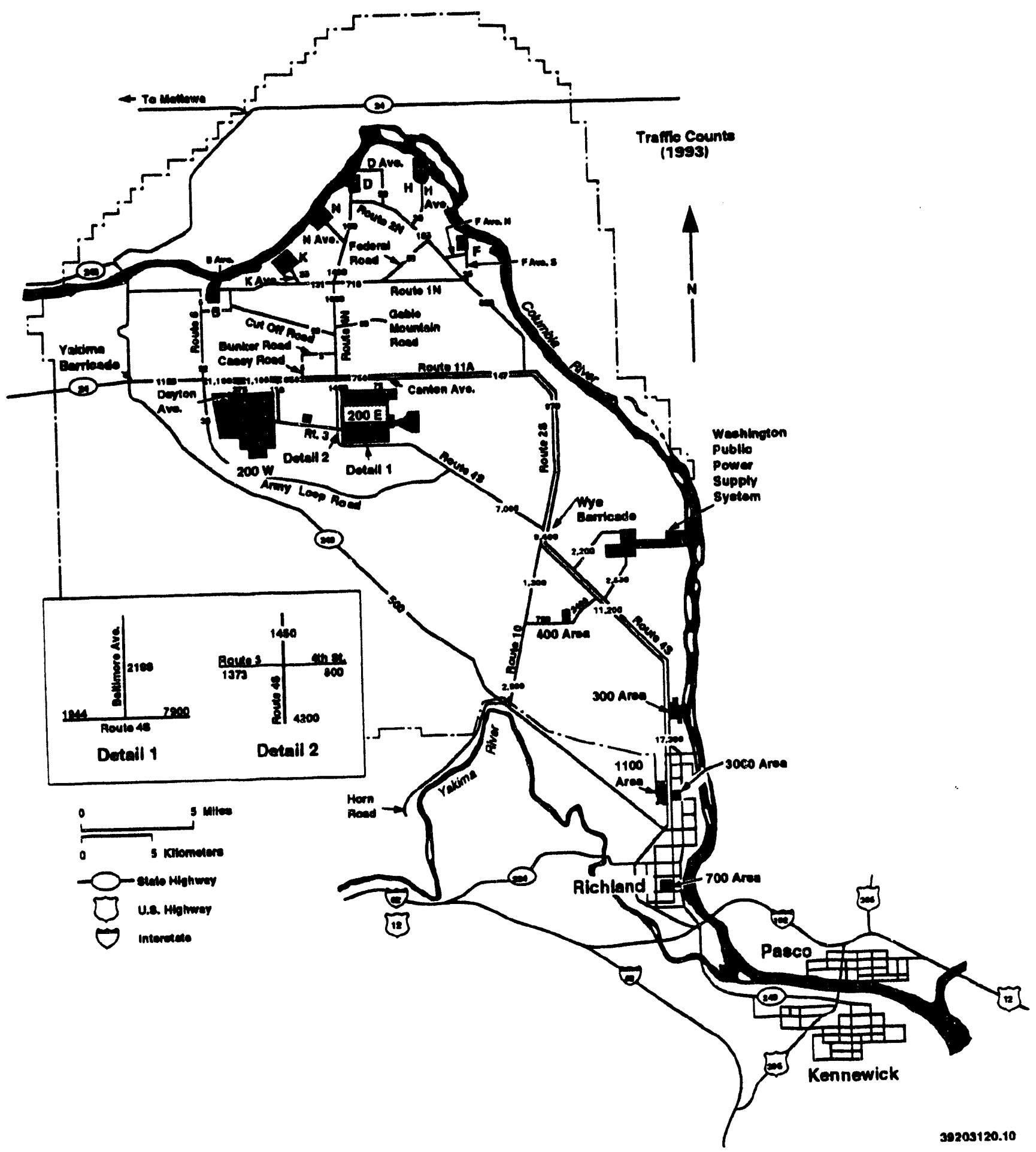

Figure 2-8. Estimated Traffic Volume (vehicles per day). 
DOE/RL-94-40, Rev. 0

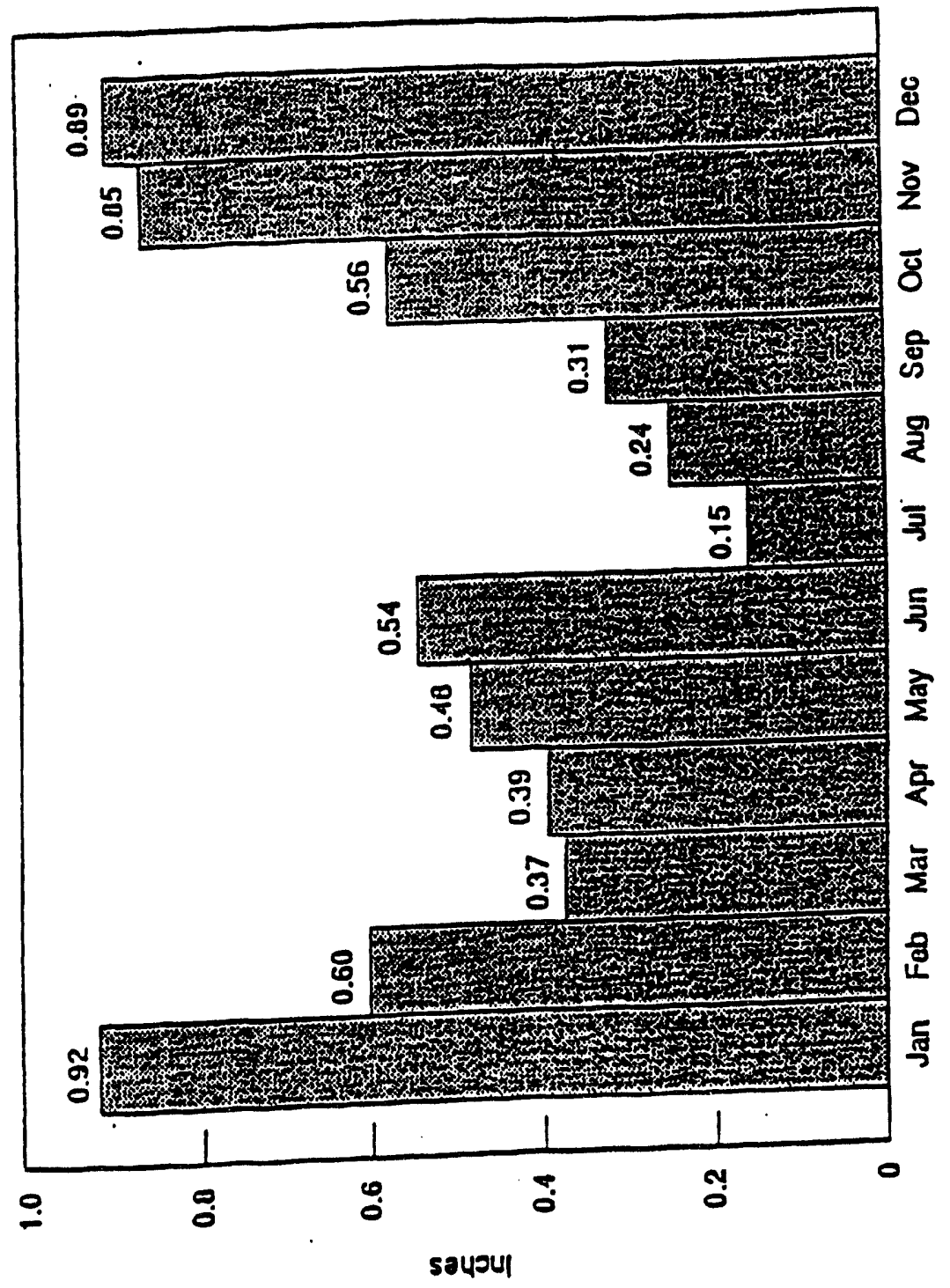

Figure 2-9. Monthly Average Precipitation - Hanford Facility (1912-1980) (Source: DOE-RL 1994d). 
DOE/RL-94-40, Rev. 0

06/94

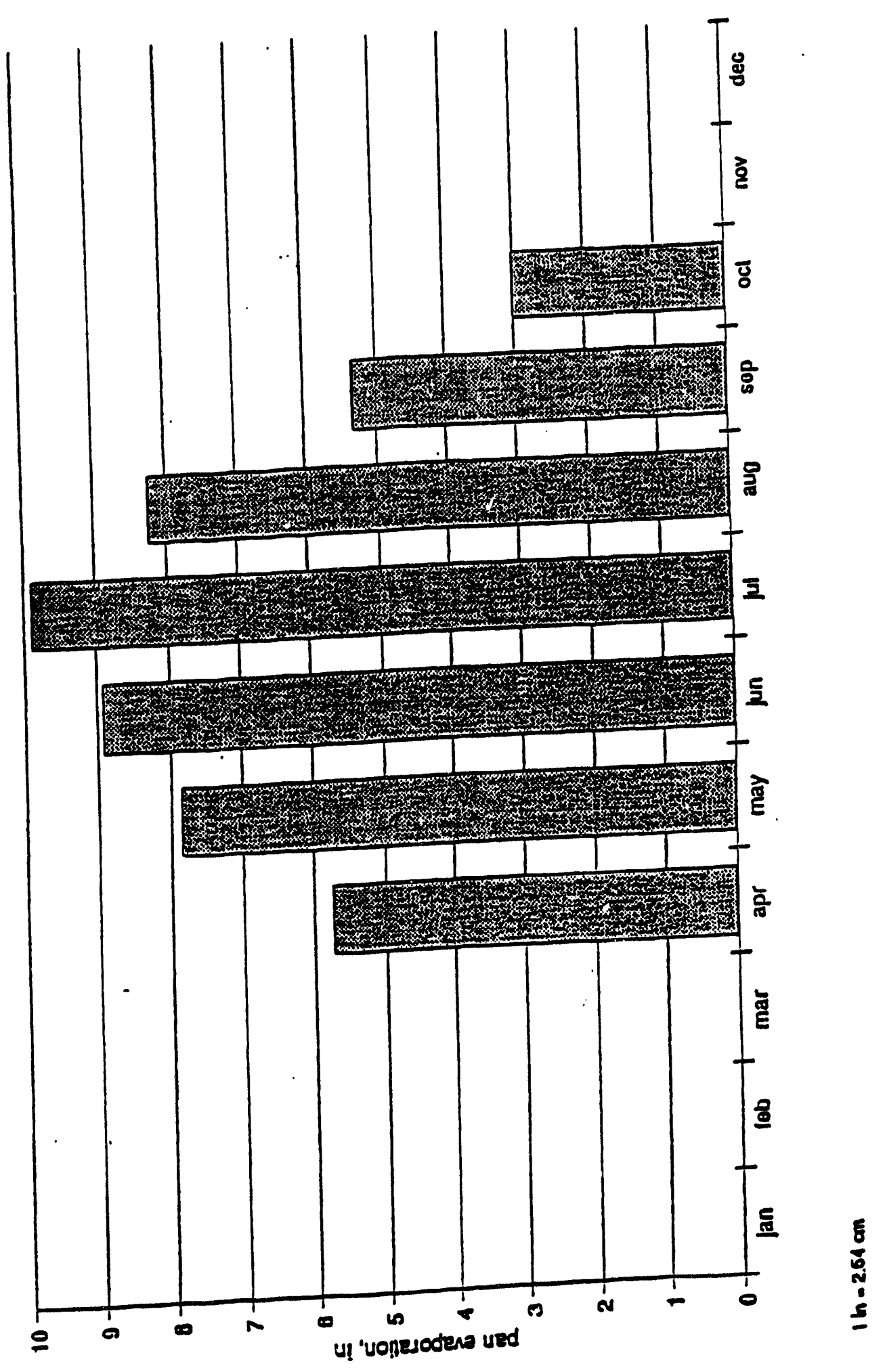

Figure 2-10. Total Monthly Evapotranspiration Data (Source: DOE-RL 1994d). 
Table 2-1. Chapter 2.0 Cross-Reference Table.

([ ] - Denotes location of information in Ecology Part B checklist) (sheet 1 of 2)

\begin{tabular}{|c|c|c|c|}
\hline ERDF outline chapter * & $\begin{array}{l}\text { Specifically required by } \\
\text { CAMU regulation? }\end{array}$ & $\begin{array}{c}\text { Washington State } \\
\text { CAMU Regulations " " } \\
173-303\end{array}$ & $\begin{array}{l}\text { Foderal } \\
\text { CAMU rogulations } \\
40 \text { CFR }\end{array}$ \\
\hline 2.0 Faolltey Desoription [B] & & & \\
\hline $\begin{array}{l}2.1 \text { Conaral Desoription }[B-1] \\
\text { WAC } 173-303-806(4)(a)(i) \\
\text { WAC } 173-303-806(4)(a)(x) \\
\text { WAC } 173-303-308(4)(a)(x v i i) \\
\text { WAC } 173-303-145 \\
\text { WAC } 173-303-283 \\
40 \text { CFR } 270.14(b)(1)\end{array}$ & $\begin{array}{l}\text { No-information is provided } \\
\text { in support of CAMU criteria }\end{array}$ & $646(5)(8)(i)$, (iii), and (vii) & $\begin{array}{l}264.552(c)(1),(3) \text {, and }(7) \\
\text { CAMU Criteria } 1,3 \text { and } 7\end{array}$ \\
\hline $\begin{array}{l}2.2 \text { Topographio Map }[8-2] \\
\text { WAC } 173-303-806(4)(a)(x v i i l) \\
\text { WAC } 173-303-806(4)(a)(x x)(C) \\
\text { WAC } 173-303-806(4)(a)(x x)(D) \\
\text { WAC } 173-303-645(6) \\
\text { WAC } 173-303-645(8) \\
\text { 40 CFR } 270.14(b)(19)\end{array}$ & Yos & $\begin{array}{l}646(5)(a)(i),(i i i) \text {, and (vii) } \\
646(5)(b)(i)\end{array}$ & $\begin{array}{l}264.552(c)(1),(3) \text {, and }(7) \\
264.552(e)(1) \\
\text { CAMU Criteria } 1,3 \text {, and } 7\end{array}$ \\
\hline 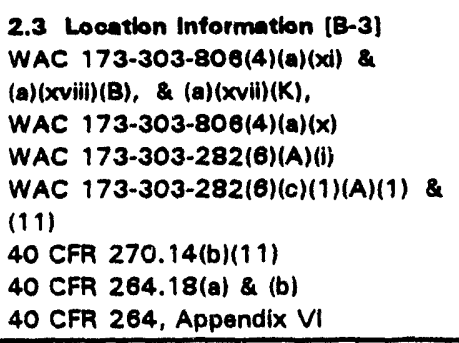 & $\begin{array}{l}\text { No-information is provided } \\
\text { in support of CAMU criteria }\end{array}$ & 648(5)(a)(i), (iii), and (vii) & $\begin{array}{l}284.552(c)(1),(3) \text {, and }(7) \\
\text { CAMU Criteria } 1,3 \text {, and } 7\end{array}$ \\
\hline $\begin{array}{l}2.4 \text { Traffle Information }(B-4) \\
\text { WAC } 173-303-808(4)(a)(x) \\
40 \text { CFR } 270.14(b)(10)\end{array}$ & $\begin{array}{l}\text { No-information is provided } \\
\text { in support of CAMU criteria }\end{array}$ & $646(5)(a)(i)$ and (ii) & $\begin{array}{l}264.552(\mathrm{c})(1) \text { and }(2) \\
\text { CAMU Criteria } 1 \text { and } 2\end{array}$ \\
\hline $\begin{array}{l}\text { 2.5 Porformance Standarde (B-5) } \\
\text { WAC 173-303-283 }\end{array}$ & Rofer to Chapter 15.0 & - & - \\
\hline $\begin{array}{l}\text { 2.6 Spill and Dboharges [B-7] } \\
\text { WAC 173-303-640(a)(b); } \\
\text { WAC 173-303-440(1)(a); } \\
\text { WAC } 173-303-145\end{array}$ & Refer to Chapter 7.0 & - & - \\
\hline $\begin{array}{l}2.7 \text { Waste Traoking syatom [B-8] } \\
\text { WAC 173-303-370 }\end{array}$ & $\begin{array}{l}\text { Rofer to Chapters } 3.0 \text { and } \\
12.0\end{array}$ & - & - \\
\hline $\begin{array}{l}2.8 \text { Environmontal 8etting }[8-1] \\
\text { WAC } 173-303-806(4)(a)(i) \\
\text { WAC } 173-303-806(4)(a)(x) \\
\text { WAC } 173-303-806(4)(a)(x v i i i) \\
\text { WAC } 173-303-145 \\
\text { WAC } 173-303-283 \\
40 \text { CFR } 270.14(b)(1)\end{array}$ & $\begin{array}{l}\text { No-information is provided } \\
\text { in support of CAMU criteria }\end{array}$ & $648(5)(a)(i)$ & $\begin{array}{l}264.552(c)(1) \\
\text { CAMU Criterion } 1\end{array}$ \\
\hline
\end{tabular}


Table 2-1. Chapter 2.0 Cross-Reference Table.

([ ] - Denotes location of information in Ecology Part B check 1 ist) (sheet 2 of 2)

\begin{tabular}{|c|c|c|c|}
\hline ERDF outline chapter" & $\begin{array}{l}\text { Specifically required by } \\
\text { CAMU rogulation? }\end{array}$ & $\begin{array}{c}\text { Washington State } \\
\text { CAMU Regulations * " } \\
173-303\end{array}$ & $\begin{array}{l}\text { Federal } \\
\text { CAMU regulations } \\
40 \text { CFR }\end{array}$ \\
\hline $\begin{array}{l}2.8 \text { Introduotion to ERDF Weate (B-1] } \\
\text { WAC } 173-303-800(4)(a)(1) \\
\text { WAC } 173-303-808(4)(a)(x) \\
\text { WAC } 173-303-808(4)(a)(x v i i) \\
\text { WAC } 173-303-145 \\
\text { WAC } 173-303-283 \\
40 \text { CFR } 270.14(b)(1)\end{array}$ & $\begin{array}{l}\text { No-information is provided } \\
\text { in support of CAMU criteria }\end{array}$ & $646(6)(a)(1)-(v i i)$ & $\begin{array}{l}264.552(c)(1)-(7) \\
\text { CAMU Criteria } 1-7\end{array}$ \\
\hline
\end{tabular}

- The sections of this application are based on the Ecology Part B Checkliat. The referenced regulations, both state (WAC 173-303) and federal (40 CFR 260-270), provide the specific requirements that typically are incorporated in these sections.

* Assumes that Washington State has received HSWA authority. 
Table 2-2. Plants and Animals of Concern Potentially Inhabiting the Environmental Restoration Disposal Facility.

\begin{tabular}{|c|c|c|}
\hline Common name & Federal status & State status \\
\hline \multicolumn{3}{|c|}{ Plants } \\
\hline Northern wornmood & FC & SE \\
\hline Columbia milkvetch & FC & ST \\
\hline Hoover's desert parsley & FC & ST \\
\hline Pipers daisy & & SS \\
\hline Gray cryptantha & & SS \\
\hline Palouse milkvetch & & SS \\
\hline Coyote tobacco & & SS \\
\hline \multicolumn{3}{|c|}{ Animals } \\
\hline Peregrine falcon & $\mathrm{FE}$ & SE \\
\hline Ferruginous hawk & $\mathrm{FC}_{2}$ & ST \\
\hline Swainson's hawk & & SC \\
\hline Burrowing ow1 & & SC \\
\hline Sage thrasher & & SC \\
\hline Sage sparrow & & SC \\
\hline Golden eagle & $\mathrm{FC}_{2}$ & SC \\
\hline Loggerhead shrike & & SC \\
\hline Striped whipsnake & & SC \\
\hline Merriam's shrew & & SC \\
\hline
\end{tabular}

$\mathrm{FE}=$ Federal Endangered

$F C_{2}=$ Federal Candidate, Level 2

$\mathrm{SE}^{2}=$ State Endangered

$S C=$ State Candidate

SS = State Sensitive

ST = State Threatened. 


\section{CONTENTS}

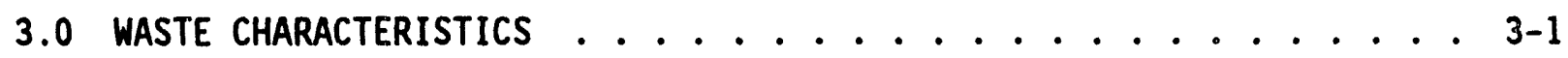

3.1 SUMMARY DESCRIPTION OF REMEDIATION WASTE TO BE MANAGED

AT THE ENVIRONMENTAL RESTORATION DISPOSAL FACILITY . . . . . . 3-1

3.1.1 Sample Waste Descriptions Summary of Waste

Generated at Remediation Sites ........ 3-2

3.1.1.1 Waste Generation Activities in the 100 Areas . . . . . . . . . 3-3

3.1.1.2 Waste Generation Activities in the 200 Areas .......... 3-3

3.1.1.3 Waste Generation Activities at the 300 Area .......... 3-3

3.1.2 Hazardous/Dangerous Waste and Mixed Waste

Components ................ 3-3

3.1.3 Containerized Waste . . . . . . . . 3-5

3.1.4 Waste in Tank Systems .............. 3-5

3.1.5 Waste in Piles ............... 3-6

3.1.6 landfilled Waste ... . . . . . . . . . . . 3-6

3.1.7 Waste to be Incinerated and Waste in

Performanc? Tests ............. . 3-6

3.1.8 Waste to be Land Treated ............. 3-6

3.2 WASTE ANALYSIS PLAN ............... . . . . . . 6

3.2.1 Responsibilities and Authorities . . . . . . . . 3-6

3.2.2 Waste Management Analysis ....... . . . . . 3-8

3.2.3 Waste Shipment and Inspection ........... 3-8

3.2.3.1 Waste Transfer Documentation ........ 3-8

3.2.3.2 Waste Tracking System . . . . . . . . . 3-9

3.2.3.3 Waste Inspections . . . . . . . . . 3-10

3.2.4 Generating Unit Oversight and Certification .... 3-10

3.2.5 Parameters and Rationale ............ 3-11

3.2.6 Test Methods ............... 3-12

3.2.7 Sampling Methods ................ 3-12

3.2.8 Frequency of Analysis . . . . . . . . . . . . 3-12

3.2.9 Additional Requirements for Waste Generated

Offsite............ 3-12

3.2.10 Additional Requirements for Ignitable,

Reactive, or Incompatible Waste ....... . 3-12

3.2.11 Summary of Waste Analys is to be Performed at

Remediation Sites............... 3-13

3.3 WASTE ACCEPTANCE CRITERIA FOR THE ENVIRONMENTAL

RESTORATION DISPOSAL FACILITY . . . . . . . . . . . 3-14

3.3.1 Acceptable/Unacceptable Waste and Waste

Constituent Levels............. 3-14

3.3.2 Waste Generation and Treatment at the

Environmental Restoration Disposal Facility . . . . 3-16 


\section{CONTENTS (cont)}

\subsubsection{Remediation-Related Waste Generated} at the Environmental Restoration Disposal Facility .......... . 3-16

3.3.2.2 Treatment to be Performed at the Environmental Restoration Disposal Facility............. 3-17

\section{TABLES}

3-1. Chapter 3.0 Cross-Reference Table . . . . . . . . . . . . T3-1

3-2. Estimated Maximum Concentration of Radionuclides in 100 Areas Remediation Waste. . . . . . . . . . . . . T3-2

3-3. Estimated Maximum Concentrations of Organic Constituents in 100 Areas Remediation Waste . . . . . . . . . . . . . T3-3

3-4. Estimated Maximum Concentrations of Inorganic and General Chemistry Constituents in 100 Areas Remediation Waste ........... . . T3-4

3-5. Estimated Maximum Concentrations of Radionuclides in 300 Area Remediation Waste ... . . . . . . . . . . T3-5

3-6. Estimated Maximum Concentration of Organic Constituents in 300 Area Remediation Waste . . . . . . . . T3-6

3-7. Estimated Maximum Concentrations of Inorganic and General Chemistry Constituents in 300 Area Remediation Waste ............ . . T3-7

3-8. Estimated Maximum Concentrations and Background Screening for Inorganic and General Chemistry Constituents in 100 and 300 Areas Soils . . . . . . . . . . . . . . . T3-8

3-9. Environmental Restoration Disposal Facility Waste Acceptance Criteria Maximum Allowable Constituent Concentration in Remediation Waste. .............. . . T3-9 


\subsection{WASTE CHARACTERISTICS}

To satisfy CAMU decision criteria, the ERDF must meet the design, construction, and operation standards provided in 40 CFR 264.552 and WAC 173-303-646. These criteria specify that the ERDF must not create unacceptable risks to humans and the environment from exposure to hazardous/dangerous waste, that the waste placed at the ERDF must be managed to minimize releases, and that releases from the ERDF must be detected and characterized. Table $3-1$ is a regulatory cross-reference table.

\subsection{SUMMARY DESCRIPTION OF REMEDIATION WASTE TO BE MANAGED AT THE ENVIRONHENTAL RESTORATION DISPOSAL FACILITY}

Remediation waste from cleanup of past-practice sites regulated under CERCLA and RCRA will be managed at the ERDF. Operations on the Hanford Facility have resulted in approximately 1,000 waste sites that must be investigated, and, if necessary, cleaned up.

Remediation waste generated at CERCLA and RCRA past-practice units that might be managed at the ERDF include the following general waste types:

- Nonradioactive hazardous/dangerous waste

- LLW--Waste that contains radioactivity and is not classified as highlevel waste, transuranic waste, or spent nuclear fuel or 11 le(2) byproduct material as defined by this order. Test specimen of fissionable material irradiated for research and development only, and not for the production of power or plutonium, may be classified as low-level waste, provided the concentration of transuranic is less than $100 \mathrm{nCi} / \mathrm{g}$ (DOE Order 5820.2A). LLW can be divided into the following subgroups:

- Contact-handled, having a surface dose rate of $<200$ millirem per hour

- Remote-handled, having a surface dose rate >200 millirem per hour

- Mixed waste (i.e., containing both hazardous/dangerous and radioactive constituents)

- TSCA regulated waste (i.e., containing asbestos material or containing PCBs in excess of 50 parts per million)

- TSCA mixed waste (i.e., containing TSCA hazardous/dangerous and radioactive constituents).

In addition to these general waste types, nonradioactive, nonhazardous/ dangerous waste, and non-TSCA regulated waste may be among the waste removed from the remediation sites. As practical, this waste may be segregated and managed at a separate location. Where it is impractical to segregate this 
waste from other radioactive, hazardous/dangerous, or TSCA regulated waste, this waste will be managed at the ERDF.

As discussed further in Section 3.3.1, high-level waste (HLW), spent nuclear fuel, and transuranic (TRU) radioactive waste will not be managed at the ERDF (DOE-RL 1994d). Management of TSCA regulated waste at the ERDF, and compliance with TSCA requirements, is discussed further in Chapter 13.0.

\subsubsection{Sample Waste Descriptions Summary of Waste Generated at Remediation Sites}

The ERDF will receive waste resulting from remediation of CERCLA and RCRA past-practice units. Additionaliy, remediation waste generated at other Hanford Facility locations may be managed in the ERDF provided this waste meets ERDF waste acceptance criteria. Remediation waste includes solid waste from landfills and D\&D debris. Hazardous/dangerous and TSCA-regulated constituents, including metals and organic solvents, are found in some of the waste. These constituents cause some of thc remediation waste to be listed as hazardous/dangerous waste, TSCA regulated, and/or mixed waste.

A more detailed discussion of the remediation waste that is expected to be present is provided in the RI/FS document, which is included as part of the Tri-Party Agreement-required ERDF information package (DOE-RL 1994d).

Tables 3-2, 3-3, and 3-4 provide summaries of estimated maximum concentrations of radionuclides, organic and inorganic compounds, and general chemistry constituents of 100 Areas remediation waste. Tables 3-5, 3-6, and 3-7 contain summaries of the estimated maximum concentrations of radionuclides, organic and inorganic compounds, and general chemistry constituents for 300 Area remediation waste that may be managed at the ERDF. Table 3-8 provides a summary of the estimated maximum inorganic and general chemistry constituents in 100 and 300 Areas remediation waste soils in comparison to background soil levels. Summary tables also reference the remediation site where the maximum concentration was encountered.

The estimated maximum waste constituent concentrations presented in Tables 3-2 through 3-8 are provided to summarize known remediation waste characteristics, and are not intended to provide a conclusive list of maximum chemical concentrations that may be encountered during remediation activities. The data were based on limited field investigations conducted for selected past-practice units, where sampling and analysis generally consisted of one shallow borehole at high priority waste units (i.e., those believed to have higher levels of contamination). In addition, data from one waste unit were considered representative for analogous waste units at other remediation sites and, therefore, no additional sampling was conducted at the analogous waste units. The limited field investigations did not address chemical characteristics of the burial grounds (DOE-RL 1994d). The estimated constituent levels presented in Tables 3-2 through 3-8, therefore, were based on sampling that was conservatively biased towards detecting higher contaminant levels. The actual constituent levels that will be encountered in a large proportion of remediation waste to be managed at the ERDF are expected to be lower. Additional past-practice site waste characterization information 
D0E/RL-94-40, Rev. 0

$06 / 94$

1 may be found in the Source Inventory Development Engineering Study for the 2 Environmental Restoration Disposal Facility (DOE-RL 1994e).

4

5

3.1.1.1 Waste Generation Activities in the 100 Areas. Between 1943 and 1962 , nine water-cooled, graphite-moderated plutonium production reactors were built along the shore of the Columbia River, upstream from the now abandoned town of Hanford. Eight of these reactors ( $B, C, D, D R, F, H, K E$, and $K W$ ) have been retired from service and are under evaluation for decommissioning. The ninth reactor, $N$, recently was shutdown, and will be retired. In some of the reactor areas, after the reactor was retired from plutonium production service, the ancillary facilities were used as laboratories for special services or for storage/treatment purposes. Remediation waste in the 100 Areas includes reactor effluent retention basins; reactor effluent pipelines; reactor effluent outfall structures; cribs, french drains, and trenches; solid waste disposal units, and contamination from unplanned releases.

\subsubsection{Waste Generation Activities in the 200 Areas. Historically, the} 200 Areas were used for fuel reprocessing, plutonium recovery, and waste management and disposal. Because of significant human health and environmental risks associated with the excavation of the majority of contaminated past-practice sites in the 200 Areas, in situ disposal methods probably will be used for most sites. Only those sites with lower environmental risks will be excavated and managed at the ERDF. These lower risk sites include migration sites, resulting from unplanned releases of radioactive materials and/or from wind-blown dispersion of radioactive materials, and an extensive network of pipelines and ancillary equipment.

\subsubsection{Waste Generation Activities at the 300 Area. Activities in the} 300 Area historically have been related primarily to the fabrication of nuclear fuel elements. In addition, many technical support, service support, and research and development activities related to fuel fabrication were carried out. Currentiy, research and development activities in the 300 Area focus on peaceful uses of plutonium, 1 iquid metal technology, gas-cooled reactor development, life science research, and Tri-Party Agreement support. The newer buildings in the area house primarily laboratory and large test areas. Remediation waste in the 300 Area primarily includes contamination from unplanned releases, process sewer piping, process ponds and trenches, and burial grounds.

\subsubsection{Hazardous/Dangerous Waste and Mixed Waste Components}

Up to 21.4 million cubic meters ( 28 million cubic yards) of remediation waste are expected to be deposited in the ERDF trench. This waste volume is anticipated to be comprised of approximately 85 percent contaminated soil containing hazardous/dangerous, contact-handled LLW, and contact-handled LLW mixed waste constituents. Remediation waste is to be delivered to the top working face of the ERDF for bulk placement. Approximately 13 percent of the remediation waste is anticipated to be in the form of metals, buried waste, and D\&D materials delivered to the toe of the working face of the ERDF trench for management. This material will be stabilized, as necessary, to prevent 
settling and subsidence of cover material placed over the waste. The remaining 2 percent of the waste delivered to the ERDF is anticipated to be remote-handled LLW and mixed waste requiring special handling. This waste is to be delivered in single-use containers to the trench floor for management (DOE-RL 1994a, 1994d). Where possible and practical, nonradioactive and nonhazardous/dangerous remediation waste may be characterized and managed at a separate location.

The following general waste categories that are eligible for management at the ERDF are anticipated to be generated by remediation activities in the 100,200 , and 300 Areas (DOE-RL 1994d; WHC 1993c).

- Contaminated Soil. Soil, ranging in size from boulders to fine silt, dry to moist, that could contain hazardous/dangerous, TSCA regulated, and/or radioactive constituents. Large volumes of contaminated soils are expected to be excavated during remediation of CERCLA and RCRA past-practice remediation sites. This waste type is anticipated to comprise the majority of the remediation waste to be managed at the ERDF.

Physical properties of vadose zone so:1 samples collected during limited field investigations at $100-B C-1$ and $100-D R-1$ indicated a dry, slightly gravelly sand with an average specific gravity of 2.78 , a moisture content ranging from 3.15 percent to 4.05 percent,
a hydraulic conductivity ranging from $1.4 \times 10^{-3}$ to $4.9 \times 10^{-3}$ centimeters per second (29.7 to 104 gallons per day per square foot), and a porosity ranging from 35.2 percent to 43.2 percent. Physical properties of soil samples collected during limited field investigations at $300-F F-1$ are described as gravel, some sand with trace fines with average overall specific gravity of 2.74 , an average dry density of 1.94 grams per cubic centimeter (121 pounds per cubic foot), a moisture content of 8.1 percent, and an average porosity of 29.1 percent.

As a final step in determining waste acceptance criteria (Section 3.3), concentrations of constituents detected in soil were compared to background values to identify contaminants of potential concern. Maximum detected soil concentrations were compared to Hanford Facility soil background concentrations calculated using a 95/95 upper tolerance 1 imit (UTL) for each parameter (DOE-RL 1993). The $95 / 95$ UTL is the 95 percent upper confidence 1 imit (UCL) on the 95 th percentile. These values are based on a lognormal distribution. Only nonradioactive inorganic constituents were evaluated by background screening. The soil background screening results in comparison to 100 Areas and 300 Area soil maximum constituent levels are presented in Table 3-8 (DOE-RL 1994d).

- Metals. Metallic debris, mixed with nominal amounts of contaminated or uncontaminated soil, also might be generated within the bounds of recognized remediation waste sites. Typically, this past-practice waste material is tube and pipe, structural shapes, metallic plate, discarded equipment, and shielding metals. Pipes are expected to 
DOE/RL-94-40, Rev. 0

$06 / 94$

42

43

44

45

46

47

48

49

50 51

range in size from 1.3 to 64.1 centimeters ( 0.5 to 25 inches) in diameter.

- Buried Waste. Contaminated wood articles (railroad ties, dimensional lumber, plywood), contaminated consumables (cardboard, rags, paper, plastic), and biological waste also might be generated.

- Decommissioning and Decontamination Waste. Contaminated materials, including such items as concrete, rebar, timber, roofing, electrical debris, insulation, and heating, ventilation, and air conditioning (HVAC) debris resulting from D\&D activities associated with remediation of past-practice units, also might be generated.

While only limited waste characterization information for these remediation waste materials is available at this time, Tables 3-2 through 3-7 (DOE-RL 1994d) provide a summary of the estimated maximum levels of radionuclide, organic, inorganic, and general chemistry constituents in remediation waste that might be managed in the ERD'. As explained in Section 3.1.1, these estimated maximum levels were based on sampling that was conservatively biased towards detecting higher contaminant levels, and the actual constituent levels that will be encountered in a large proportion of remediation waste are expected to be lower.

\subsubsection{Containerized Waste}

A portion of the remediation waste will be placed in the ERDF trench in single-use containers. Waste to be packaged in single-use containers includes, but is not 1 imited to, all remote-handled waste; Category 3 radioactive waste, as defined in the Hanford Site Solid Waste Acceptance Criteria (WHC 1993e); and any other waste determined to require containerization to protect the ERDF operators (e.g., waste containing friable asbestos). As a subsidence control measure, the single-use containers may be grout filled to eliminate void spaces before placement in the ERDF trench, in compliance with the ERDF waste acceptance criteria.

Approximately 2 percent of the waste containers arriving at the ERDF are expccted to be placed directly in the ERDF trench. Tractor/trailers will deliver the containers to the floor of the trench where the containers will be offloaded by crane.

\subsubsection{Waste in Tank Systems}

Support units for the ERDF involve the storage of waste in tank systems subject to WAC 173-303-640 or 40 CFR 264 Subpart $J$ requirements. However, as discussed in Chapter 1.0 , these support units will maintain regulatory identity separate from the CAMU, and will be discussed in a separate document. Therefore, this section is not applicable to this application. 


\subsubsection{Waste in Piles}

Operation of the ERDF does not involve the placement of waste in piles subject to WAC 173-303-660 or 40 CFR 264 Subpart L requirements. Therefore, this section is not aoplicable.

\subsubsection{Landfilled Waste}

In accordance with the definitions provided in 40 CFR 260.10 and the requirements specified in WAC 173-303-646, a CAMU is not considered a landfill unit. Therefore, the requirements of this section are not applicable to the ERDF.

\subsubsection{Waste to be Incinerated and Waste in Performance Tests}

Operation of the ERDF does not involve incineration of waste or the use of waste in performance tests subject to WAi 173-303-670 or 40 CFR 264 Subpart 0 requirements. Therefore, this section is not applicable.

\subsubsection{Waste to be Land Treated}

Operation of the ERDF does not involve the 1 and treatment of waste subject to WAC 173-303-806(4)(g)(ii)(D) or 173-303-655 or 40 CFR 264 Subpart $M$ requirements. Therefore, this section is not applicable.

\subsection{WASTE ANALYSIS PLAN}

The purpose of this waste analysis plan is to provide a description of procedures to be used to characterize remediation waste containing hazardous/dangerous, radioactive, and/or TSCA regulated constituents destined for the ERDF. Adequate characterization of remediation waste is necessary to ensure proper handling and management of the waste by both the generating unit and the ERDF operators. Characterization of remediation waste involves qualitatively describing the waste based on physical features, and quantifying the waste components to the level necessary to ensure safe and effective management at the ERDF. Remediation waste characterization, which is the responsibility of the remediation sites, will be based on a combination of sampling and analysis and process knowledge.

The approach for characterizing hazardous/dangerous, TSCA, LLW, and mixed waste is described in the following sections.

\subsubsection{Responsibilities and Authorities}

This section discusses the responsibilities and authorities of the various parties that will be involved in the management of remediation waste 
DOE/RL-94-40, Rev. 0

$06 / 94$

suitable for placement in the ERDF. Only those activities related to the ERDF waste management are included.

Generating units wishing to place remediation waste in the ERDF will be responsible for the following:

- Designating waste as remediation waste and complying with the ERDF waste acceptance criteria

- Developing an auditable waste certification program that includes development of an acceptable waste analysis plan

- Conducting all sampling and analysis required to designate waste as remediation waste suitable for management at the ERDF

- Providing all required information and documentation for remediation waste

- Providing assistance to the ERDF operators in resolving any discrepancies involving remediation waste arriving at the ERDF.

The ERDF operations organization will be responsible for the following:

- Conducting waste certification assessments to ensure remediation waste generating unit compliance with the ERDF waste acceptance criteria

- Performing periodic waste confirmations (conducting limited sampling and analysis to confirm generating unit characterization and designation of remediation waste)

- Conducting inspections of remediation waste received at the ERDF (described in further detail in Section 3.2.3.3), and conducting routine inspections of ERDF components (refer to Chapter 6.0, Section 6.2 for details)

- Operating and maintaining the ERDF waste tracking system

- Recordkeeping (management of all remediation waste documentation received and accepted at the ERDF).

The generating unit and a waste acceptance services organization will be responsible for the following activities that will affect ERDF operations:

- Maintaining and dispensing the ERDF waste acceptance criteria to all remediation waste generating units wishing to ship waste to the ERDF

- Establishing waste characterization requirements (to be developed with remediation site operators to correlate with the observational approach that may be used to characterize remediation waste at the remediation sites, refer to Section 3.2.11) 
- Providing assistance to remediation waste generating unit to designate waste as remediation waste suitable for management at the ERDF

- Providing engineering support for any special packaging, void space filling, treatment, etc. that may be required at the remediation sites.

Details of the minimum sampling and analysis that will be required to demonstra.e compliance with the ERDF waste acceptance criteria and the preapproval process will be provided before placement of waste at the ERDF.

\subsubsection{Waste Management Analys is}

While no remediation waste analysis is proposed to be performed at the ERDF, waste analysis will be performed at the remediation sites. Waste analysis can consist of laboratory or field measurements, process knowledge, or a combination of both. Periodic waste certification assessments and confirmations are performed (refer to Section 3.2.4) to ensure that the remediation waste generating unit complies with the waste acceptance criteria established for the ERDF.

The overall waste analysis process will involve development of a waste certification program by the remediation waste generating unit, with fundamental waste characterization requirements and waste certification assessments and confirmations. These programs will work in concert with the ERDF dedicated waste tracking system and visual and radiological spot-check inspections (refer to Section 3.2.3) to ensure that acceptable remediation waste leaving the remediation sites is the same waste arriving at the ERDF. For these reasons, redundant waste analysis at the ERDF is not deemed necessary. All remediation waste acceptance and/or preapproval will occur at the remediation site before shipment to the ERDF.

The preapproval process and waste tracking protocols will be provided before placement of waste at the ERDF.

\subsubsection{Waste Shipment and Inspection}

Only Hanford Facility remediation waste will be accepted at the ERDF. This section describes the procedures that will be used to track the onsite movement of waste and to inspect waste shipments arriving at the ERDF from the remediation sites.

3.2.3.1 Waste Transfer Documentation. Onsite waste transfer documentation for waste shipped on Hanford Facility roadways will be kept as good management practice for the ERDF operations. The transfer documents will become part of the operating record for the ERDF. This documentation must accompany any onsite hazardous/dangerous, TSCA regulated, or low-level mixed waste that is transported on roadways through or within the 600 Area, unless the roadway is closed to general public access at the time of shipment. The Hanford Patrol or protective force personnel will be involved in any decisions to close 
1 roadways on the Hanford Facility. Information to be included on the onsite 2 waste transfer document inciudes:

- Generating unit name, location, and telephone number

- ERDF name, location, and telephone number

- Description of waste

- Number and type of containers

- Total quantity of waste

- Unit volume/weight

- Hazardous/Dangerous waste number(s)

- Any special handling instructions.

Waste transported by rail is exempt from this documentation requirement.

Information in this section was taken directly from the draft Hanford Facility Dangerous Waste Permit. The requirement to comply with onsite waste tracking documentation is under negotiation. This section will be revised, as necessary, to reflect the outcome of those negotiations.

3.2.3.2 Waste Tracking System. The ERDF will be equipped with a dedicated electronic waste tracking system to record information on the waste contents of each container, note the departure/arrival time of containers shipped to the ERDF, and record the location of waste placement within the ERDF trench. The remediation waste characterization and tracking information collected at the ERDF will be integrated into the onsite solid waste information tracking system (SWITS) database.

A process control module (PCM) and operator terminal at the container offloading area will collect data associated with all incoming containers. An automatic bar code reader, or a similar device, will scan the container and record arrival time. Container weight also will be entered automatically into the electronic data system. Operators at the ERDF will be able to manually enter data, such as the results of visual inspections or radiologic monitoring information. The PCM at the container offloading area will transmit information to the ERDF host computers where the data will be compared to database information received from the remediation sites where waste container loading occurs. This PCM also will be used to record the waste deposit location, which will be either the area where bulk waste was placed, or the area where single-use containers were placed into the ERDF trench.

In a similar manner, a PCM and operator terminal at the empty container outgoing area will collect data associated with the empty containers including automatic and manual inspections and radiological surveys. This area will have the capability for automatic and/or manual scanning and data entry. At the host computer, appropriate data will be inputted to update the SWITS database.

Additional detail concerning the proposed waste tracking system and recordkeeping procedures will be provided before waste placement at the ERDF. The unique waste tracking system to be developed for the ERDF is intended to serve as an effective inventory control system. The ERDF waste tracking 
1 system will be sufficient to ensure that waste handling is protective of human

2 health and the environment and reflects best management practices.

\begin{abstract}
3.2.3.3 Waste Inspections. On receipt at the ERDF, the accompanying documentation will be reviewed and waste containers will be visually inspected to note whether the containers match the description on the accompanying documentation. A subset of the containers also may be radiologically inspected. The radiological inspection may include wipe sampling the outside of the containers for evidence of gross contamination, surveying the exterior of the containers to monitor surface dose rate, and surveying bulk-disposed waste to ensure worker safety.
\end{abstract}

Because of the nature, volume, and frequency of waste shipments to the ERDF, it is not practical to perform both visual and radiological inspections of every incoming container. Additional detail regarding inspection procedures and the proposed frequency of inspection will be provided before waste placement at the ERDF.

While approval to ship waste to the ERDF will be required before shipment, there is a very small possibility that waste arriving at the ERDF might not match the description on its accompanying documentation. Remediation waste with any discrepancies noted during review of accompanying documentation or noted as a result of any inspections performed will be: (1) corrected by the ERDF operations jersonnel in conjunction with the remediation site waste generating unit before acceptance of the waste; (2) held for correction by the remediation waste generating unit before acceptance of the remediation waste; or (3) returned to the remediation site for correction. Discrepant containers wil1 be managed temporarily in an area of the incoming container storage pad. The location of this area will be selected so as to minimize disruption to ongoing ERDF operations. Containers will not be stored at the ERDF for periods exceeding 90 days. In the unlikely event that discrepancies have not been resolved within 90 days, the waste container may be transported back to the remediation waste generating unit for resolution.

Section 3.3 provides available detail regarding the ERDF waste acceptance criteria.

\title{
3.2.4 Generating Unit Oversight and Certification
}

Radionuclide management within the Hanford Facility is addressed by DOE Orders. The DOE Order 5820.2A "Radioactive Waste Management" requires implementation and assessment of waste generating unit certification programs for the management of low-levei waste. Requirements of DOE Order $5820.2 A$ and other Orders, while separate and distinct from CERCLA, and RCRA and WAC requirements, compliment these other regulations. To demonstrate the spectrum of precautions to be taken at the ERDF to ensure protectiveness of human health and the environment, compliance with DOE Order 5820.2A waste certification and assessment requirements is discussed in the following paragraphs. 
DOE/RL-94-40, Rev. 0

$06 / 94$

Periodic waste certification assessments and confirmations to ensure that the remediation waste generating unit complies with the waste acceptance criteria established for the ERDF will be performed. These certifications and confirmations are a key component of the process to designate remediation waste as suitable for management at the ERDF. Because no additional waste analysis will be performed on remediation waste at the ERDF, the certification and confirmation process (in concert with the ERDF dedicated waste tracking system) will be the means to ensure that only characterized remediation waste that meet the ERDF waste acceptance criteria is sent to the ERDF.

The waste certification assessment will consist of an initial assessment and scheduled followup assessment of remediation waste generating units using the ERDF. This assessment is essentially a programmatic review of the remediation waste generating unit's waste certification program, including a review of the waste analysis plan, packaging, and documentation procedures.

Waste confirmation requires chemical and physical analysis, or confirmation through other means, of the accuracy of generating unit remediation waste determinations. Confirmations performed are intended to confirm that remediation waste sent to the ERDF meets the established waste acceptance criteria.

Additional details on the waste certification assessments and confirmations that will be performed will be provided before placement of waste at the ERDF.

\subsubsection{Parameters and Rationale}

Waste characterization will be performed at the remediation sites and not at the ERDF. Characterization of remediation waste to ensure the waste meets the ERDF waste acceptance criteria will be the responsibility of the remediation site generating units. A dedicated waste tracking system will monitor the movement of waste from the remediation sites to its placement in the ERDF trench. Evaluation of waste at the ERDF will consist of document confirmation and visual inspection, and periodic spot-checks including exterior of containers and bulk waste radiological surveying (refer to Section 3.2 .3 .3 ).

However, remediation waste resulting from ERDF management of remediation site waste will be characterized, as appropriate, before placement in the ERDF. This remediation waste may include waste managed in the waste water treatment building, such as waste water treatment system sludge (refer to Chapter 4.0 for more information). Additional details on parameters and rationale, waste certification assessments, and confirmations that will be performed will be provided before placement of this remediation waste at the ERDF. 


\subsubsection{Test Methods}

Waste characterization will be performed at the remediation sites and not at the ERDF. Characterization of remediation waste to ensure the waste meets the ERDF waste acceptance criteria will be the responsibility of the remediation site yenerating units.

Remediation waste created as a result of ERDF management of remediation site waste will be characterized, as appropriate, before placement in the ERDF. Sampling and analys is procedures for the waste water treatment system sludge and effiuent and the ERDF storm water run-off will be provided, as necessary, before operation of the ERDF.

\subsubsection{Sampling Methods}

Waste characterization will be performed at the remediation sites and not at the ERDF. Characterization of remediation waste to ensure the waste meets the ERDF waste acceptance criteria will be the responsibility of the remediation site generating units.

Remediation waste resulting from ERDF management of remediation site waste will be characterized, as appropriate, before placement in the ERDF (Section 3.2.5). Sampling and analys is procedures for the waste water treatment system sludge and effluent and the ERDF storm water run-off will be provided, as necessary, before operation of the ERDF.

\subsubsection{Frequency of Analysis}

Waste characterization will be performed at the remediation sites and not at the ERDF.

Remediation waste resulting from ERDF management of remediation site waste will be characterized, as appropriate, before placement in the ERDF (Section 3.2.5). Sampling and analys is procedures for the waste water treatment system sludge and effluent and the ERDF storm water run-off will be provided, as necessary, before operation of the ERDF.

\subsubsection{Additional Requirements for Waste Generated Offsite}

Only remediation waste generated on the Hanford Facility will be accepted at the ERDF. No waste will arrive from offsite sources for management at the ERDF. Therefore, the requirements of this section are not applicable.

\subsubsection{Additional Requirements for Ignitable, Reactive, or Incompatible Waste}

Remediation waste to ba generated at the remediation sites is expected to consist of contaminated soils, demolition debris, scrap metal, paper, plastics, cardboard, wood, glass, and electrical debris (as described in 
1 Section 3.1.2). All waste will be required to meet the waste acceptance 2 criteria established for the ERDF, which is discussed in Section 3.3. These 3 criteria prohibit the placement of reactive and ignitable waste in the ERDF 4 trench, limit the level of liquid organic constituents in the waste, and 5 prohibit the placement of free liquids in the ERDF.

Procedures that will be followed to ensure that bulk incompatible waste will not be placed into the adjacent parts of the ERDF trench will be provided before management of remediation waste at the ERDF.

\subsubsection{Summary of Waste Analysis to be Performed at Remediation Sites}

Remediation activities are expected to produce hazarjous/dangerous, TSCA regulated, LLW, and mixed waste. The CERCLA RODs for the CERCLA past-practice units and the RCRA remediation plans for the RCRA past-practira units will specify the waste characterization approach to be performed ro ensure that remediation waste meets the ERDF waste acceptance criteria.

Waste characterization requirements will be developed in concert with remediation site operators. Details of the minimum sampling and analysis that will be required to demonstrate compliance with the ERDF waste acceptance criteria and the preapproval process will be provided before placement of remediation waste at the ERDF.

Observational Approach Concept--Sampling and analysis may be conducted at the remediation site using the observational approach method that streamlines site characterization. Hazardous/dangerous waste site characterization and remediation is dominated by uncertainty. In an attempt to overcome this uncertainty, site characterization may consist of excessive sampling at the expense of effective and prompt remedial action. The observational approach offers a way of dealing with the inherent uncertainty of hazardous/dangerous waste site conditions. The approach proposes to address uncertainty of data and data analyses in the site remediation decision process by defining expected conditions and reasonable deviations to those conditions with contingencies provided in the final environmental restoration decision. Three basic tenets of the observational approach ai:: (1) characterization should be undertaken for a specific purpose, such as the selection of a remedy or identification of sites needing remedial action; (2) more data do not necessarily lead to less uncertainty; and (3) convergence on a response action as early as possible is the goal of site remediation.

To accomplish this goal, the observational approach proposed to be used at the remediation site includes a limited analytical program to ensure proper management of remediation waste, while streamlining the remediation process. This approach will use a combination of field screening methods and onsite analyses.

Additional details of the observational approach and how this approach will serve to characterize remediation waste, or an alternative method, will be provided before placement of remediation waste at the ERDF. 
DOE/RL-94-40, Rev. 0 $06 / 94$

\subsection{WASTE ACCEPTANCE CRITERIA FOR THE ENVIRONMENTAL RESTORATION DISPOSAL FACILITY}

This section provides a summary of the waste acceptance criteria for remediation waste to be placed in the ERDF trench. This summary is based on waste acceptance criteria that is being developed for the ERDF.

\subsubsection{Acceptable/Unacceptable Waste and Waste Constituent Levels}

Because the ERDF will be constructed before completion of RI/FSs or RFI/CMSs for remediation sites, waste acceptance criteria have been developed based on contaminant transport and liner compatibility as a function of unit design, as well as human health risks. Waste acceptance criteria are based on the following four integral factors.

- The integrity of the ERDF trench liner system must be protected from potentially damaging chemicals, as well as levels of chemical constituents in leachate that might be produced by waste placed in the trench.

- The integrity of the ERDF trench 1 iner system must be protected from degradation through exposure to radioactive components.

- Human health risks must be considered for those chemical and radioactive constituents that might potentially pass through the trench liner system into the environment.

- Operational constraints impose limits on the levels of radioactivity and chemical hazards that affect worker safety.

The ERDF waste acceptance criteria are composed of two elements. The first element is prohibitions and limitations on the management of certain general remediation waste types, based on regulatory, operational, or DOE order requirements. The second element is bounding limits on the levels of particular constituents that may be present in remediation waste to protect both human health and the integrity of the ERDF trench system.

General remediation waste type prohibitions and limitations are described as follows.

- Corrosive waste will be neutralized or rendered noncorrosive. The waste matrix will not have a pH of less than 2 or greater than 12.5 .

- No free liquids will be placed in the ERDF trench. All liquids will be solidified, absorbed, or otherwise bound in the waste matrix by inert materials. Small amounts of residual liquid may be allowed if the waste generating unit demonstrates that the liquid will not promote the migration of radionuclides. 
- Void space in single-use containers will not exceed 10 percent of the total internal volume of the waste package. [Void space will include any opening within the waste matrix that exceeds 5 centimeters ( 2 inches) in diameter.] Bulk placed waste will be 1 imited to 10 percent by volume degradable material, because degradation may result in void space formation. Limiting void space is important to minimize potential subsidence of the ERDF trench cover material.

- No transuranic (TRU) waste, spent nuclear fuel, or high-level waste (HLW) will be placed in the ERDF trench.

- No waste capable of generating toxic gases, explosive gases, vapors, fumes, or liquids will be placed in the ERDF trench (DOE Order 5820.2A, Chapter III, Section 3.i[5][d]).

- Single-use containers accepted at the ERDF will not contain incompatible waste placed in the same container.

- No pyrophoric waste will be placed in the ERDF trench unless the waste has been processed to stabilize the pyrophoric materials, or the pyrophoric materials comprise $\leq 1$ percent by weight of the waste mixture and generally are dispersed in the waste.

- No waste containing organic peroxides or other chemicals that are capable of reacting with atmospheric oxygen to form shock sensitive organic peroxides will be placed in the ERDF trench. Trace amounts of these compounds in remediation waste that do not pose a risk of expiosion may be managed at the ERDF.

- No infectious waste will be placed in the ERDF trench.

- No explosives or compressed gases will be placed in the ERDF trench.

- No ignitable waste will be placed in the ERDF trench.

- No reactive waste will be placed in the ERDF trench.

- TSCA-regulated asbestos containing material placed in the ERDF trench will comply with the applicable requirements of 40 CFR 61.140 through 61.157 .

- TSCA-regulated PCB waste placed in the ERDF will meet the requirements of 40 CFR 761.75. Compliance with TSCA PCB regulations is discussed further in Chapter 13.0 .

- Ion exchange resins must be thoroughly drained before the resins can be placed in the ERDF trench to minimize the generation of excessive heat or corrosive-reactive products.

- No reactive alkali metal constituents that are capable of generating explosive gases and corrosives will be placed in the ERDF trench. 
Table 3-9 provides a 1 ist of the maximum levels of particular constituents that may be present in remediation waste placed in the ERDF trench. Waste that does not meet these waste acceptance criteria will not be shipped from the remediation site to the ERDF.

Justifications for waste type limitations and prohibitions will be provided when the waste acceptance criteria are finalized. Table 3-9 also will be updated.

\subsubsection{Waste Generation and Treatment at the Environmental Restoration Disposal Facility}

This section describes the waste that will be generated and treated at the ERDF as a result of managing remediation waste.

\subsubsection{Remediation-Related Waste Generated at the Environmental Restoration}

Disposal Facility. Waste associated with remediation activities that potentially will be generated at the ERDF includes container and vehicle decontamination waste, leachate removed from the ERDF trench, potentially contaminated surface water run-off, solids collected from treatment of waste water (treatment described in Section 3.3.3.2), spent high-efficiency particulate air (HEPA) filters taken from the operations buildings and from heavy equipment vehicles operating at the ERDF that are contaminated with remediation waste, remediation waste contaminated spent personnel protective equipment, and other equipment contaminated by remediation waste that is not saivageabie.

This waste generated as a result of managing remediation waste, will be considered remediation waste and also will be placed in the ERDF trench, provided the waste meets the ERDF waste acceptance criteria. As discussed in the final CAMU rule (58 FR 29), waste that is generated pursuant to implementing corrective actions for a facility can be managed within a CAMU. Management of the ERDF generated waste (DOE-RL 1994a) is described as follows:

- Naste Naters. Decontamination waste water will be treated as described in Section 3.3.3.2, and the treated waste waters might be recycled for specific uses at the ERDF in place of raw process water. Some remediation debris placed in the ERDF will require subsidence control to prevent settling of material placed over the debris; the treated waste water may be used as makeup water in subsidence control. Alternatively, the treated waste water may be used for dust control within the ERDF trench. Treated waste water also might be used as decontamination wash water (first decontamination rinse) in lieu of raw process water at the ERDF decontamination building.

- Nonwaste Waters. Nonliquid waste, including waste water treatment solids, spent HEPA filters, and all other spent remediation waste contaminated materials will be placed directly in the ERDF trench. Subsidence control relevant to these materials may be performed, as necessary, to prevent future settling and subsidence. 
DOE/RL-94-40, Rev. 0

$06 / 94$

1 Process knowledge and/or sampling and analysis will be used, as

2 necessary, to characterize remediation waste generated at the ERDF to ensure 3 compliance with the ERDF waste acceptance criterta before placement of the

4 waste in the trench.

5

6

Sampling and analysis procedures for the waste water treatinent system sludge and effluent and the ERDF storm water run-off wil1 be provided before operation of the ERDF. Waste identification, quantification, and tracking information for waste generated at the ERDF will be provided before placement of the waste in the trench.

\subsubsection{Treatment to be Performed at the Environmental Restoration Disposal} Facility. In accordance with the design of the ERDF, no effluents generated as a result of remediation waste management at the ERDF wi11 be discharged as liquids to the environment. Leachate from the ERDF trench and decontamination wash water from those portions of the ERDF where remediation waste is handled will be sent to a waste water treatment plant. (Leachate management is discussed further in Chapter 4.0, Section 4.12.6.8.) Storm water run-off generated in areas of the ERDF where remediation waste is handled will be sampled and treated as necessary.

The waste water treatment plant may use a reverse osmosis process. The resulting residue from the waste water treatment process (containing no free liquids) will be placed in the ERDF trench. The treated waste water may be sent to evaporation tanks, used as makeup water in the ERDF subsidence control grout batch plant, used for dust control within the ERDF trench, and/or used in place of raw water at the container decontamination building.

Sampling and analysis procedures for the waste water treatment system sludge and effluent and the ERDF storm water run-off will be provided before operation of the ERDF.

\subsection{LAND DISPOSAL RESTRICTIONS IN RELATION TO THE ENVIRONMENTAL RESTORATION DISPOSAL FACILITY}

This section discusses the applicability of LDRs with respect to the ERDF. The LDRs are a set of RCRA and WAC requirements that regulate and 1 imit hazardous/dangerous waste sent to land disposal units. The LDRs prohibit the land disposal of hazardous/dangerous waste unless the waste meets specified treatment standards, is otherwise considered treated, or is exempted from the LDR regulations ( 58 FR 98).

\subsubsection{Land Disposal Restrictions and the Corrective Action Management Unit Regulation}

As discussed in the final CAMU rule (58 FR 29), the definition of a CAMU has been structured so that any waste managed within a CAMU that is generated as part of corrective action at a facility (i.e., remediation waste) is not subject to RCRA LDRs (55 FR 145; EPA 1992b; 58 FR 29). Consequently, waste generated from corrective action can be placed within the CAMU without 
1 necessarily requiring pretreatment to the technology-based levels established 2 under the RCRA LDR program, so long as a11 CAMU criteria can be demonstrated.

Hazardous/dangerous remediation waste can be placed into a CAMU without automatically triggering the application of LDRs or any other unit-specific requirements applying to hazardous/dangerous waste land disposal units. Remediation waste generated at a particular facility but outside a CAMU can be consolidated into the CAMU, and remediation waste can be moved between two or more CAMUs at that same facility without automatically triggering LDRs. Remediation waste al so can be excavated from a CAMU, treated in a separate onsite unit (that can be located inside or outside the CAMU at the facility), and redeposited into a CAMU without triggering LDRs.

\subsubsection{Applicability of Land Disposal Restrictions to the Environmental Restoration Disposal Facility}

In accordance with 40 CFR 260.10, 40 CFR 268.2, and WAC 173-303-646(4), a CAMU is specifically exempted from the definition of a land disposal facility and deposition of remediation waste into the CAMU is exempted from the definition of land disposal. Therefore, the placement of waste into the ERDF trench on the Hanford Facility will not automatically trigger LDR

requirements. No treatment of remediation waste delivered from CERCLA and RCRA past-practice units is proposed to be performed at the ERDF. However, remediation waste treatment will be considered and determined, as applicable, for each remediation site during the RI/RFI and FS/CMS process, as discussed in Chapters 1.0 and 15.0 . 
Table 3-1. Chapter 3.0 Cross-Reference Table. ([ ] - Denotes location of information in Ecology Part B check 1 ist)

\begin{tabular}{|c|c|c|c|}
\hline EROF out l ine chapter & $\begin{array}{l}\text { Spacifically requiled } \\
\text { by cam requlation? }\end{array}$ & $\begin{array}{l}\text { Washington State } \\
\text { CAMU Regulationst* } \\
173-303\end{array}$ & $\begin{array}{l}\text { Federal } \\
\text { CAMU regulations } \\
40 \text { CFR } \\
\end{array}$ \\
\hline 3.0 ERDF CAm Waste Characteris & [C] & & \\
\hline $\begin{array}{l}3.1 \text { Summary Description of } \\
\text { Remediation Waste to be Managed } \\
\text { at the ERDF [C-1] } \\
\text { WAC } 173-303-806(4)(a)(i i i) \\
\text { WAC } 173-303-300(1)-(5) \\
40 \text { CFR } 270.14(b)(1) \text { \& (2) } \\
40 \text { CFR } 264.13(a)\end{array}$ & Yes & $646(5)(a)(i),(i i)$, and (vi) & $\begin{array}{l}264.552(c)(1),(2) \text { and( } 6) \\
\text { CAMU Criteria } 1,2 \text {, and } 6\end{array}$ \\
\hline $\begin{array}{l}3.2 \text { Waste Analysis Plan [C-2] } \\
\text { WAC } 173-303-806(4)(a) ; \\
\text { WAC } 173-303-300(5) \\
\text { WAC } 173-303-110(2) \&(3) \\
\text { WAC } 173-303-395(1) \&(2) \\
40 \text { CFR } 270.14(b)(3) \\
40 \text { CFR } 264.13(b) \& \text { (c) } \\
40 \text { CFR } 268.7\end{array}$ & $\begin{array}{l}\text { No-- information is } \\
\text { provided in support of } \\
\text { CAMU criteria }\end{array}$ & $\begin{array}{l}646(5)(a)(i),(i i),(i v) \text {, } \\
\text { and }(v i)\end{array}$ & $\begin{array}{l}264.552(c)(1),(2),(4) \\
\text { and(6) } \\
\text { CAMU Criteria 1, 2, 4, and } 6\end{array}$ \\
\hline $\begin{array}{l}3.3 \text { Waste Acceptance Criteria } \\
\text { for the ERDF } \\
\text { WAC } 173-303-806(4)(a) \\
\text { WAC } 173-303-300(5) \\
\text { WAC } 173-303-110(2) \text { \& (3) } \\
\text { WAC } 173-303-395(1) \text { \& (2) } \\
40 \text { CFR } 270.14(b)(3) \\
40 \text { CFR } 264.13(b) \& \text { (c) } \\
40 \text { CFR } 268.7\end{array}$ & $\begin{array}{l}\text { No--information is } \\
\text { provided in support of } \\
\text { CAMU criteria }\end{array}$ & $\begin{array}{l}646(5)(a)(i),(i i),(i v) \text {, } \\
\text { and (vi) }\end{array}$ & $\begin{array}{l}264.552(c)(1),(2),(4) \\
\text { and }(6) \\
\text { CAMU Criteria } 1,2,4 \text {, and } 6\end{array}$ \\
\hline $\begin{array}{l}3.4 \text { Land Disposal Restrictions } \\
\text { in Relation to the ERDF [C-3] } \\
\text { WAC } 173-303-300(1)(5) \\
\text { WAC } 173-303-806(3)(a)(\text { iii) } \\
40 \text { CFR } 264.13 \\
40 \text { CFR } 270.14(b)\end{array}$ & $\begin{array}{l}\text { No-- information is } \\
\text { provided in support of } \\
\text { CAMU criteria }\end{array}$ & $646(4)(b)$ & $264.552(a)(1)$ \\
\hline
\end{tabular}

* The sections of this application are based on the Ecology Part B Checklist. The referenced regulations, both state (WAC 173-303) and federal (40 CFR 260-270), provide the specific requirements that typically are incorporated in these sections.

** Assumes that Washington State has received HSWA authority. 
Table 3-2. Estimated Maximum Concentration of Radionuclides in 100 Areas Remediation Waste.

(sheet 1 of 2)

\begin{tabular}{|c|c|c|}
\hline Radionuclide & $\begin{array}{c}\text { Maximum } \\
\text { concentration } \\
(\mathrm{pCi} \mathrm{g})\end{array}$ & Waste unit \\
\hline Americium-241 & 34 & 116-C-5 Retention basin \\
\hline Barium-140 & 400 & 116-D-1A Storage bas in trench \#1 \\
\hline Bery11ium-7 & 90 & 116-D-1A Storage basin trench \#1 \\
\hline Carbon-14 & 640 & 116-C-5 Retention basin \\
\hline Cerium-141 & 3 & 116-0-1A Storage basin trench \#1 \\
\hline Cerium-144 & 0.5 & 116-D-1A Storage basin trench \#1 \\
\hline Cesium-134 & 56 & 116-D-1A Storage basin trench \#1 \\
\hline Cesium-137 & 110,000 & 116-K-2 Miscell aneous trench \\
\hline Cobalt-58 & 14.1 & $\begin{array}{l}\text { 116-DR-1 Liquid waste disposal trench } \\
\# 1\end{array}$ \\
\hline Cobalt-60 & 11,000 & 116-K-2 Miscellaneous trench \\
\hline Europium-152 & 29,000 & 116-K-2 Miscellaneous trench \\
\hline Europium-154 & 9,200 & 116-C-5 Retention basin \\
\hline Europium-155 & 9,600 & 116-C-5 Retention basin \\
\hline Gross alpha & 78 & 116-K-2 Miscellaneous trench \\
\hline Gross beta & 3,700 & 116-C-5 Retention basin \\
\hline Iron-59 & 1 & 116-D-1A Storage basin trench \#1 \\
\hline Manganese-54 & 0.07 & 116-D-1A Storage basin trench \#1 \\
\hline Nickel-63 & 62,000 & Process effluent pipeline (BC1) \\
\hline Plutonium-238 & 140 & 116-C-5 Retention basin \\
\hline Plutonium-239 & 2,800 & 116-0-1A Storage basin trench \#1 \\
\hline Potassium-40 & 33 & 116-H-7 Retention basin \\
\hline Radium-226 & 42.8 & 116-D-1A Storage basin trench \#1 \\
\hline Ruthen ium-103 & 1 & 116-D-1A Storage basin trench \#1 \\
\hline Ruthen ium-106 & 0.8 & 116-D-1A Storage basin trench \#1 \\
\hline Sodium-22 & 9.9 & $\begin{array}{l}116-D R-1 \text { Liquid waste disposal } \\
\text { trench \#1 }\end{array}$ \\
\hline
\end{tabular}


Table 3-2. Estimated Maximum Concentration of Radionuclides in 100 Areas Remediation Waste.

(sheet 2 of 2)

\begin{tabular}{|c|c|c|}
\hline Radionuclide & $\begin{array}{c}\text { Maximum } \\
\text { concentration } \\
(\mathrm{pC} 1 / \mathrm{g})\end{array}$ & Waste unit \\
\hline Stront fum-90 & 2,000 & 116-C-5 Retention bas in \\
\hline Technetium-99 & 1.1 & $\begin{array}{l}\text { 116-OR-2 Liquid waste disposal } \\
\text { trench } \# 2\end{array}$ \\
\hline Thortum-228 & 8.6 & $\mathrm{H}-2$ Sept ic tank \\
\hline Thorium-232 & 1.4 & 116-KW-3B Retention basin \\
\hline Thorium-234 & 1 & 116-D-1A Storage basin trench \#1 \\
\hline Tritium & 29,000 & $116-B-5$ \\
\hline Uranium-233/234 & 17 & 116-KW-3B Retention basin \\
\hline Uranium-235 & 1.7 & 116-KW-3B Retention basin \\
\hline Uranium-238 & 17 & 116-KW-3B Retention basin \\
\hline Zinc -65 & 0.3 & 116-D-1A Storage basin trench \#1 \\
\hline Zirconium-95 & 0.56 & 116-H-7 Retention basin \\
\hline
\end{tabular}

$\mathrm{pCi} / \mathrm{g}=\mathrm{picocuries/gram}$

Source: DOE-RL 1994d 
Table 3-3. Estimated Maximum Concentrations of Organic Constituents in 100 Areas Remediation Waste.

(sheet 1 of 3 )

\begin{tabular}{|c|c|c|}
\hline Parameter & $\begin{array}{c}\text { Maximum } \\
\text { concentration } \\
(\mu \mathrm{g} / \mathrm{kg})\end{array}$ & Waste unit \\
\hline \multicolumn{3}{|l|}{ VOLATTLE CONSTITUENTS } \\
\hline $1,1,1$-Trichloroethane & 6 & 100-D Pond \\
\hline $1,1,2,2$-Tetrachloroethane & 3 & 100-D Pond \\
\hline 2-Butanone & 390 & 100-0 Pond \\
\hline 2-Hexanone & 9 & 100-0 Pond \\
\hline 4-Methy1-2-pentanone & 11 & 116-B-2 Storage bas in trench \\
\hline Acetone & 2,800 & $\begin{array}{l}\text { UN-100-N-17 Diesel o11 } \\
\text { supply line leak }\end{array}$ \\
\hline Benzene & 190 & $\begin{array}{l}\text { UN-100-N-17 Diesel oil } \\
\text { supply line leak }\end{array}$ \\
\hline Carbon disulfide & 200 & 116-B-5 Crib \\
\hline Carbon tetrachloride & 8 & $116-N-1$ \\
\hline Chloroform & 4 & $\begin{array}{l}\text { 130-D-1 Gasoline storage } \\
\text { tank }\end{array}$ \\
\hline Ethylbenzene & 330 & $\begin{array}{l}\text { UN-100-N-17 Diesel oil } \\
\text { supply line leak }\end{array}$ \\
\hline Methylene chloride & 110 & 100-D Pond \\
\hline Tetrachloroethene & 4 & 116-K-2 Effluent trench \\
\hline Toluene & 77 & 116-B-5 Crib \\
\hline Trichloroethene & 6 & $\begin{array}{l}116-D R-9 C \text { Process effluent } \\
\text { retention basin }\end{array}$ \\
\hline Xylenes (Total) & 1,100 & $\begin{array}{l}\text { 130-D-1 Gasoline storage } \\
\text { tank }\end{array}$ \\
\hline \multicolumn{3}{|l|}{ SEMIVOLATILE CONSTITUENTS } \\
\hline 1,3-Dichlorobenzene & 48 & $\begin{array}{l}\text { 116-DR-1 Liquid waste } \\
\text { disposal trench \#1 }\end{array}$ \\
\hline 1,4-Dichlorobenzene & 51 & $\begin{array}{l}116-\mathrm{N}-2 \text { Chemical waste } \\
\text { storage tank }\end{array}$ \\
\hline 2-Methylnaphthalene & 13,000 & UN-100-N-17 \\
\hline
\end{tabular}


Table 3-3. Estimated Maximum Concentrations of Organic Constituents in 100 Areas Remediation Waste.

(sheet 2 of 3 )

\begin{tabular}{|c|c|c|}
\hline Parameter & $\begin{array}{c}\text { Maximum } \\
\text { concentration } \\
(\mu \mathrm{g} / \mathrm{kg})\end{array}$ & Waste unit \\
\hline 4-Chloro-3-methylphenol & 38 & $\begin{array}{l}\text { 116-DR-1 Liquid waste } \\
\text { disposal trench } \# 1\end{array}$ \\
\hline Acenaphthene & 210 & $\begin{array}{l}\text { 116-H-1 Liquid waste } \\
\text { disposal trench }\end{array}$ \\
\hline Anthracene & 6,300 & UN-100-N-17 \\
\hline Benzo (a) anthracene & 1,800 & $\begin{array}{l}\text { 1607-H-4 Septic tank } \\
\text { discharge pipe }\end{array}$ \\
\hline Benzo(a)pyrene & 940 & $\begin{array}{l}\text { 1607-H-4 Septic tank } \\
\text { discharge pipe }\end{array}$ \\
\hline Benzo(b) fluoranthene & 2,400 & $\begin{array}{l}\text { 1607-H-4 Septic tan's } \\
\text { discharge pipe }\end{array}$ \\
\hline Benzo $(g, h, i)$ perylene & 460 & $\begin{array}{l}\text { 1607-H-4 Septic tank } \\
\text { discharge pipe }\end{array}$ \\
\hline Benzo(k)fluoranthene & 760 & $\begin{array}{l}\text { 116-H-1 Liquid waste } \\
\text { disposal trench }\end{array}$ \\
\hline Bis(2-ethylhexy1)phthalate & 5,500 & $\begin{array}{l}\text { 130-D-1 Gasoline storage } \\
\text { tank }\end{array}$ \\
\hline Butylbenzylphthalate & 2,600 & $\begin{array}{l}\text { 130-D-1 Gasoline storage } \\
\text { tank }\end{array}$ \\
\hline Carbazole & 54 & $\begin{array}{l}\text { 116-D-1B Fuel storage basin, } \\
\text { trench \#2 }\end{array}$ \\
\hline Chrysene & 920 & $\begin{array}{l}\text { 116-H-1 Liquid waste } \\
\text { disposal trench }\end{array}$ \\
\hline Di-n-butylphthalate & 1,100 & $120-D-1$ \\
\hline Dibenzofuran & 130 & $\begin{array}{l}\text { 116-H-1 Liquid waste } \\
\text { disposal trench }\end{array}$ \\
\hline Diethylphthalate & 1,000 & 100-D Pond \\
\hline Fluoranthene & 2,900 & $\begin{array}{l}\text { 1607-H-4 Septic tank } \\
\text { discharge pipe }\end{array}$ \\
\hline Fluorene & 1,700 & $U N-100-N-17$ \\
\hline Indeno $(1,2,3-c d)$ pyrene & 520 & $\begin{array}{l}\text { 116-H-1 Liquid waste } \\
\text { disposal trench }\end{array}$ \\
\hline
\end{tabular}


Table 3-3. Estimated Maximum Concentrations of Organic Constituents in 100 Areas Remediation Waste.

(sheet 3 of 3 )

\begin{tabular}{|c|c|c|}
\hline Parameter & $\begin{array}{c}\text { Maximum } \\
\text { concentration } \\
(\mu \mathrm{g} / \mathrm{kg})\end{array}$ & Waste unit \\
\hline Naphthalene & 4,100 & UN-100-N-17 \\
\hline $\mathrm{N}$-Nitrosodiphenylamine & 110 & 116-B-2 Storage bas in trench \\
\hline Pentachlorophenol & 920 & 116-C-5 Retention basin \\
\hline Phenanthrene & 2,500 & $U N-100-N-17$ \\
\hline Phenol & 240 & 100-0 Pond \\
\hline Pyrene & 2,700 & $\begin{array}{l}\text { 1607-H-4 Septic tank } \\
\text { discharge pipe }\end{array}$ \\
\hline \multicolumn{3}{|l|}{ PESTICIDES/AROCLORS } \\
\hline $4,4^{\prime}-000$ & 110 & $\begin{array}{l}\text { 1607-H-4 Septic tank } \\
\text { discharge pipe }\end{array}$ \\
\hline $4,4^{\prime}-\mathrm{DDE}$ & 170 & 199-D Pond \\
\hline Aroclor*-1254 & 6,400 & $190-B$ \\
\hline Aroclor*-1260 & 2,300 & 100-D Pond \\
\hline Beta-BHC (Beta-HCH) & 7.8 & $\begin{array}{l}116-0-1 A \text { Fuel storage bas in } \\
\text { trench } \# 1\end{array}$ \\
\hline Gamma-chlordane & 18 & $\begin{array}{l}\text { 1607-H-4 Septic tank } \\
\text { discharge pipe }\end{array}$ \\
\hline Dieldrin & 21 & $\begin{array}{l}116-D-1 A \text { Fuel storage basin, } \\
\text { trench \#1 }\end{array}$ \\
\hline Methoxychlor & 83 & 100-D-Pond \\
\hline
\end{tabular}

*Aroclor is a trademark of Monsanto Company. $\mu \mathrm{g} / \mathrm{kg}=\mathrm{microgram} / \mathrm{kilogram}$

Source: DOE-RL 1994d 
Table 3-4. Estimated Maximum Concentrations of Inorganic and General Chemistry Constituents in 100 Areas Remediation Waste.

(sheet 1 of 2)

\begin{tabular}{|c|c|c|}
\hline Parameter & $\begin{array}{c}\text { Maximum } \\
\text { concentration } \\
(\mathrm{mg} / \mathrm{kg}) \\
\end{array}$ & Waste unit \\
\hline \multicolumn{3}{|c|}{ INORGANIC CONSTITUENTS } \\
\hline Aluminum & 78,400 & 100-D Pond - Liquid waste disposal \\
\hline Antimony & 18.6 & H-2 Septic tank \\
\hline Arsenic & 62.2 & 100-D Pond - Liquid waste disposal \\
\hline Barium & 4260 & H-2 Sept ic tank \\
\hline Beryllium & 4.7 & 116-H-9 Crib \\
\hline Cadmium & 28.5 & H-2 Septic tank \\
\hline Calcium & 79,000 & $116-\mathrm{H}-9 \mathrm{Crib}$ \\
\hline Cobalt & 90.4 & 116-KW-3B Retention basin \\
\hline Copper & 627 & $\mathrm{H}-2$ Septic tank \\
\hline Chromium & 2,510 & H-2 Septic tank \\
\hline Iron & 184,000 & $116-H-.9$ Crib \\
\hline Lead & 564 & 116-C-5 Retention basin \\
\hline Magnesium & 50,000 & $116-\mathrm{H}-9 \mathrm{Crib}$ \\
\hline Manganese & 3,050 & 116-H-9 Crib. \\
\hline Mercury & 37 & H-2 Septic tank \\
\hline Nickel & 132 & $116-H-9$ Crib \\
\hline Potassium & 13,000 & 116-H-9 Crib \\
\hline Selenium & 11.1 & 100-D Pond - Liquid waste disposal \\
\hline Silver & 119 & H-2 Septic tank \\
\hline Sodium & 2,010 & $116-\mathrm{H}-9$ Crib \\
\hline Thallium & 5.4 & $\mathrm{H}-2$ Septic tank \\
\hline Vanadium & 389 & $116-\mathrm{H}-9$ Crib \\
\hline Zinc & 6,160 & H-2 Septic tank \\
\hline
\end{tabular}


Table 3-4. Estimated Maximum Concentrations of Inorganic and General Chemistry Constituents in 100 Areas Remediation Waste. (sheet 2 of 2)

\begin{tabular}{|l|c|l|}
\hline \multicolumn{1}{|c|}{ Parameter } & $\begin{array}{c}\text { Maximum } \\
\text { concentration } \\
\text { (mg/kg) }\end{array}$ & \multicolumn{1}{|c|}{ Waste unit } \\
\hline GENERAL CHEMISTRY CONSTITUENTS & \\
\hline Chloride & 13.1 & $116-C-5$ Retention basin \\
\hline Chromium IV & 5.03 & $116-C-5$ Retention bas in \\
\hline Fluoride & 4.4 & $116-$ B-3 Pluto crib \\
\hline Nitrate & 122.3 & $116-$ B-5 Crib \\
\hline Nitrate/nitrite & 37 & $116-C-5$ Retention basin \\
\hline Nitrite & 1.2 & H-2 Septic tank \\
\hline Phosphate & 15 & $116-$ KW-3B Retention basin \\
\hline Sulfate & 7.115 & H-2 Septic tank \\
\hline
\end{tabular}

$\mathrm{mg} / \mathrm{kg}=\mathrm{milligram} / \mathrm{kilogram}$

Source: DOE-RL 1994d 
DOE/RL-94-40, Rev. 0

Table 3-5. Estimated Maximum Concentrations of Radionuclides in 300 Area Remediation Waste.

\begin{tabular}{|l|c|l|}
\hline \multicolumn{1}{|c|}{ Radionuclide } & $\begin{array}{c}\text { Maximum } \\
\text { concentration } \\
\text { (pCi/g) }\end{array}$ & \\
\hline Cerium-134 & 0.45 & Containers \\
\hline Cerium-141 & 0.28 & $316-1$ South (old) pond \\
\hline Cesium-137 & 50 & Contai ers \\
\hline Chromium-51 & 3.5 & $618-5$ Burial ground \#5 \\
\hline Cobalt-60 & 81 & $316-1$ South (old) pond \\
\hline Gross alpha & 4,450 & $316-53904$ Process waste trenches \\
\hline Gross beta & 12,210 & $316-53904$ Process waste trenches \\
\hline Potassium-40 & 19.5 & 307 T-1 Trench \\
\hline Radium-226 & 2.1 & $316-2$ North (new) pond \\
\hline Strontium-90 & 18 & $316-53904$ Process waste trenches \\
\hline Thorium-228 & 17 & $316-53904$ Process waste trenches \\
\hline Thorium-232 & 3.5 & $316-2$ North (new) pond \\
\hline Total uranium & 20,000 & $316-5$ 3904 Process waste trenches \\
\hline Uranium-234 & 2,100 & $618-4$ Burial ground \#4 \\
\hline Uranium-235 & 640 & $316-5$ 3904 Process waste trenches \\
\hline Uranium-238 & 9,100 & $316-5$ 3904 Process waste trenches \\
\hline Zinc-65 & 0.32 & $316-2$ North (new) pond \\
\hline
\end{tabular}

$\mathrm{pC} \mathbf{i} / \mathrm{g}=$ picocuries/gram

Source: DOE-RL 1994d 
Table 3-6. Estimated Maximum Concentration of Organic Constituents in 300 Area Remediation Waste.

(sheet 1 of 3 )

\begin{tabular}{|c|c|c|}
\hline Parameter & $\begin{array}{c}\text { Maximum } \\
\text { concentration } \\
(\mu \mathrm{g} / \mathrm{kg})\end{array}$ & Waste unit \\
\hline \multicolumn{3}{|l|}{ VOLATILE CONSTITUENTS } \\
\hline 1,2-Dichloroethene (tota1) & 1,000 & $\begin{array}{l}316-5 W 3904 \text { Process waste } \\
\text { trenches }\end{array}$ \\
\hline Acetone & 700 & 316-2 North (new) pond \\
\hline Carbon disulfide & 100 & $\begin{array}{l}316-5 W 3904 \text { Process waste } \\
\text { trenches }\end{array}$ \\
\hline Chloroform & 80 & $\begin{array}{l}316-5 \mathrm{~W} 3904 \text { Process waste } \\
\text { trenches }\end{array}$ \\
\hline Methylene chloride & 4,500 & 316-2 North (new) pond \\
\hline Tetrachloroethene & 1,100 & $\begin{array}{l}316-5 \mathrm{~W} 3904 \text { Process waste } \\
\text { trenches }\end{array}$ \\
\hline Toluene & 150 & 316-2 North (new) pond \\
\hline Trichloroethene & 390 & 618-4 Burial ground \#4 \\
\hline Vinyl chloride & 24 & $\begin{array}{l}316-5 W 3904 \text { Process waste } \\
\text { trenches }\end{array}$ \\
\hline \multicolumn{3}{|l|}{ SEMIVOLATILE CONSTITUENTS } \\
\hline 2-Methylnaphthalene & 8,700 & $\begin{array}{l}316-5 E 3904 \text { Process waste } \\
\text { trenches }\end{array}$ \\
\hline 4-Chloroaniline & 6,300 & C-Sanitary trench \\
\hline 4-Methylphenol & 1,000 & C-Sanitary trench \\
\hline Acenaphthene & 850 & $\begin{array}{l}316-5 W 3904 \text { Process waste } \\
\text { trenches }\end{array}$ \\
\hline Anthracene & 1,200 & $\begin{array}{l}316-5 \mathrm{~W} 3904 \text { Process waste } \\
\text { trenches }\end{array}$ \\
\hline Benzo(a) anthracene & 1,400 & $\begin{array}{l}316-5 E 3904 \text { Process waste } \\
\text { trenches }\end{array}$ \\
\hline Benzo(a)pyrene & 27,000 & $\begin{array}{l}\text { 316-5E } 3904 \text { Process waste } \\
\text { trenches }\end{array}$ \\
\hline Benzo(b)fluoranthene & 1,700 & $\begin{array}{l}316-5 E 3904 \text { Process waste } \\
\text { trenches }\end{array}$ \\
\hline
\end{tabular}


Table 3-6. Estimated Maximum Concentration of Organic Constituents in 300 Area Remediation Waste.

(sheet 2 of 3 )

\begin{tabular}{|c|c|c|}
\hline Parameter & $\begin{array}{c}\text { Maximum } \\
\text { concentration } \\
(\mu \mathrm{g} / \mathrm{kg})\end{array}$ & Waste unit \\
\hline Benzo $(g, h, i)$ perylene & 3,700 & $\begin{array}{l}316-5 E 3904 \text { Process waste } \\
\text { trenches }\end{array}$ \\
\hline Benzo(k)fluoranthene & 180 & $\begin{array}{l}316-5 \mathrm{~W} 3904 \text { Process waste } \\
\text { trenches }\end{array}$ \\
\hline Benzo $(g, h, i)$ perylene & 3,700 & $\begin{array}{l}316-5 E ~ 3904 \text { Process waste } \\
\text { trenches }\end{array}$ \\
\hline Benzo(k) fluoranthene & 180 & $\begin{array}{l}316-5 W 3904 \text { Process waste } \\
\text { trenches }\end{array}$ \\
\hline Benzoic acid & 1,300 & $\begin{array}{l}316-5 E ~ 3904 \text { Process waste } \\
\text { trenches }\end{array}$ \\
\hline Bis(2-ethylhexyl)phthal ate & 33,000 & C-Sanitary trench \\
\hline Butylbenzylphthalate & 230 & C-Sanitary trench \\
\hline Chrysene & 43,000 & $\begin{array}{l}316-5 E 3904 \text { Process waste } \\
\text { trenches }\end{array}$ \\
\hline Di-n-butylphthalate & 5,500 & $\begin{array}{l}\text { 316-5E } 3904 \text { Process waste } \\
\text { trenches }\end{array}$ \\
\hline Dibenzo $(a, h)$ anthracene & 1,700 & $\begin{array}{l}316-5 E 3904 \text { Process waste } \\
\text { trenches }\end{array}$ \\
\hline Dibenzofuran & 500 & $\begin{array}{l}316-5 W 3904 \text { Process waste } \\
\text { trenches }\end{array}$ \\
\hline Diethylphthalate & 810 & $\begin{array}{l}316-5 E 3904 \text { Process waste } \\
\text { trenches }\end{array}$ \\
\hline Fluoranthene & 2,800 & $\begin{array}{l}316-5 W 3904 \text { Process waste } \\
\text { trenches }\end{array}$ \\
\hline Fluorene & 850 & $\begin{array}{l}316-5 W 3904 \text { Process waste } \\
\text { trenches }\end{array}$ \\
\hline Indeno $(1,2,3-c d)$ pyrene & 1,600 & $\begin{array}{l}316-5 E 3904 \text { Process waste } \\
\text { trenches }\end{array}$ \\
\hline $\mathrm{N}$-Nitrosodiphenylamine & 1,800 & $\begin{array}{l}316-5 E 3904 \text { Process waste } \\
\text { trenches }\end{array}$ \\
\hline Naphthalene & 190 & $316-5 \mathrm{~W}$ \\
\hline
\end{tabular}


Table 3-6. Estimated Maximum Concentration of Organic Constituents in 300 Area Remediation Waste.

(sheet 3 of 3 )

\begin{tabular}{|l|c|l|}
\hline \multicolumn{1}{|c|}{ Parameter } & \multicolumn{1}{|c|}{$\begin{array}{c}\text { Maximum } \\
\text { concentration } \\
(\mu \mathrm{g} / \mathrm{kg})\end{array}$} & \multicolumn{1}{|c|}{ Waste unit } \\
\hline Pentachlorophenol & 1,500 & $\begin{array}{l}316-5 \mathrm{E} \text { 3904 Process waste } \\
\text { trenches }\end{array}$ \\
\hline Phenanthrene & 3,900 & $\begin{array}{l}316-5 \mathrm{~W} 3904 \text { Process waste } \\
\text { trenches }\end{array}$ \\
\hline Pyrene & 12,000 & $\begin{array}{l}316-5 \mathrm{E} \text { 3904 Process waste } \\
\text { trenches }\end{array}$ \\
\hline PESTICIOES/AROCLORS* & 81 & C-Sanitary trench \\
\hline 4,4'-DDE & 10,000 & $316-2$ North process pond \\
\hline Aroclor*-1248 & 19,500 & Process trenches \\
\hline PCBs & &
\end{tabular}

*Aroclor is a trademark of Monsanto Company. $\mu \mathrm{g} / \mathrm{kg}=$ microgram $/ \mathrm{kilogram}$ PCBS = polychlorinated biphenyls Source: DOE-RL 1994d 
Table 3-7. Estimated Maximum Concentrations of Inorganic and General Chemistry Constituents in 300 Area Remediation Waste.

(sheet 1 of 2)

\begin{tabular}{|c|c|c|}
\hline Parameter & $\begin{array}{c}\text { Maximum } \\
\text { concentration } \\
(\mathrm{mg} / \mathrm{kg}) \\
\end{array}$ & Waste unit \\
\hline \multicolumn{3}{|c|}{ INORGANIC CONSTITUENTS } \\
\hline Aluminum & 58,600 & 618-4 Burial ground \#4 \\
\hline Antimony & 15.4 & 316-1 South (old) pond \\
\hline Arsenic & 23.3 & 316-1 South (01d) pond \\
\hline Barium & 3,130 & 618-5 Burial ground \#5 \\
\hline Beryllium & 3.3 & 316-2 North (new) pond \\
\hline Cadmium & 23 & 300 Area sanitary sewer system \\
\hline Calcium & 95,300 & 316-1 South (old) pond \\
\hline Cobalt & 18 & 316-2 North (new) pond \\
\hline Copper & 95,300 & 316-1 South (old) pond \\
\hline Chromium & 960 & 618-4 Burial ground \#4 \\
\hline Iron & 2,740 & Process trenches (previous samples) \\
\hline Lead & 747 & $618-4$ Burial ground \#4 \\
\hline Magnesium & 25,500 & 316-1 South (old) pond \\
\hline Manganese & 2,480 & 316-5 3904 Process waste trenches \\
\hline Mercury & 9.3 & 316-1 South (01d) pond \\
\hline Nickel & 1,750 & 316-1 South (01d) pond \\
\hline Potassium & 4,860 & $307 \mathrm{~T}$ \\
\hline Selenium & 7.7 & 300 Area sanitary sewer system \\
\hline Silver & 362 & 316-1 South (o1d) pond \\
\hline Sodium & 2,610 & $618-4$ Burial ground \#4 \\
\hline Strontium & 31 & Process trenches (previous samples) \\
\hline Thallium & 0.8 & 300 Area sanitary sewer system \\
\hline Vanadium & 239 & 316-1 South (old) pond \\
\hline Zinc & 3830 & 300 Area sanitary sewer system \\
\hline
\end{tabular}


Table 3-7. Estimated Maximum Concentrations of Inorganic and General Chemistry Constituents in 300 Area Remediation Waste.

(sheet 2 of 2)

\begin{tabular}{|l|c|l|}
\hline \multicolumn{1}{|c|}{ Parameter } & $\begin{array}{c}\text { Maximum } \\
\text { concentration } \\
\text { (mg/kg) }\end{array}$ & \multicolumn{1}{|c|}{ Waste unit } \\
\hline GENERAL CHEMISTRY CONSTITUENTS & \\
\hline Ammonia & 138 & Containers \\
\hline Chloride & 194 & $316-5$ 3904 Process waste trenches \\
\hline Fluoride & 40 & $316-2$ North (new) pond \\
\hline Nitrate & 125 & $316-2$ North (new) pond \\
\hline Nitrite & 2.9 & 300 Area sanitary sewer system \\
\hline Phosphate & 14 & 300 Area sanitary sewer system \\
\hline Sulfate & 2,636 & $618-5$ Burial ground \#5 \\
\hline $\begin{array}{l}\text { Total organic } \\
\text { halogen }\end{array}$ & 7.2 & Process trenches \\
\hline $\begin{array}{l}\text { Total organic } \\
\text { carbon }\end{array}$ & 43.7 & Process trenches \\
\hline \begin{tabular}{l} 
Coliform (MPH) \\
\hline
\end{tabular} & 110 & Process trenches \\
\hline
\end{tabular}

$\mathrm{mg} / \mathrm{kg}=\mathrm{milligram} / \mathrm{kilogram}$

Source: DOE-RL 1994d 


\begin{tabular}{|c|c|c|}
\hline JN & $2 \cdot L$ & ИәБо \\
\hline $02 \varepsilon^{\prime} I$ & SII'L & 27eflns \\
\hline $9 I$ & $\overline{\mathrm{GI}}$ & 27eydsoyd \\
\hline $966 \mathrm{I}$ & $L \varepsilon$ & $278 d q ! U+27 ! 17 ! N$ \\
\hline JN & $6 \cdot 2$ & $27 ! 17 ! N$ \\
\hline 66 I & S2I & 27e17! N \\
\hline $2 I$ & 06 & ap!don LI \\
\hline$\varepsilon 9 L$ & $66 I$ & 2p!10143 \\
\hline $2 \cdot 82$ & $\overline{8 \varepsilon I}$ & e!coumy \\
\hline $6 L$ & $09 I^{\prime} 9$ & su!z \\
\hline III & $68 \varepsilon$ & unfpeuen \\
\hline JN & $6 \cdot 9$ & un! LIEYL \\
\hline JN & IE & un! 1740175 \\
\hline $062 I$ & $0\left[9^{\prime} 2\right.$ & wn!pos \\
\hline$L \cdot 2$ & $29 \varepsilon$ & $12 \wedge L ! S$ \\
\hline JN & II & un!uश LOS \\
\hline $02 I^{\prime} \varepsilon$ & $000^{6} \varepsilon I$ & un! ssezod \\
\hline$\varepsilon \cdot g 2$ & $O S L^{\prime} I$ & LYXJ!N \\
\hline $92 \cdot I$ & $\angle \varepsilon$ & 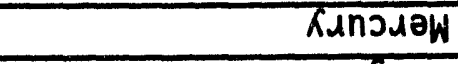 \\
\hline 219 & $050^{\prime} \varepsilon$ & әsәuебuew \\
\hline $09 L^{\prime} 8$ & $000^{\circ} 09$ & un!səubew \\
\hline$S L^{\circ}+I$ & $\angle D L$ & peo7 \\
\hline $09 I^{\prime} 6 \varepsilon$ & $000^{6}+8 I$ & UOdI \\
\hline $2 \cdot 82$ & $00 \varepsilon^{\prime} s 6$ & 12dd03 \\
\hline $9 \cdot 6 I$ & 06 & 718905 \\
\hline JN & $80^{\circ} \mathrm{g}$ & In-4n!̣uod4J \\
\hline $6 \cdot \angle 2$ & $0\left[g^{\prime} Z\right.$ & unf wou4J \\
\hline $026^{\prime} \varepsilon 2$ & $00 \varepsilon^{\prime} \mathrm{g} 6$ & un! [e] \\
\hline JN & 9.82 & ur tupes \\
\hline$\angle L^{\prime} I$ & $L^{\circ} b$ & 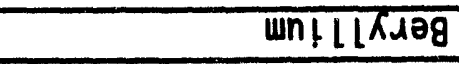 \\
\hline$I L I$ & $092^{\prime} \mathrm{b}$ & un!leg \\
\hline 26.8 & $2 \cdot 29$ & ग!UOSAY \\
\hline JN & $9^{\circ} 8 I$ & Kuow! ?Uy \\
\hline $009^{\prime} \mathrm{SI}$ & $00 t^{\prime} 8 L$ & unu!̣n L \\
\hline 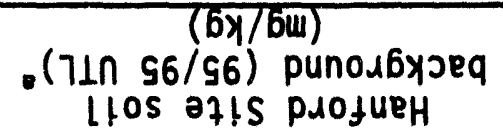 & 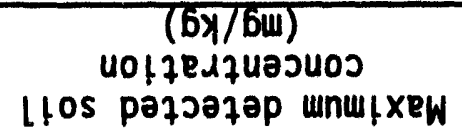 & dә7әше 1 ed \\
\hline
\end{tabular}

\section{(2 to [ 7ә045)}

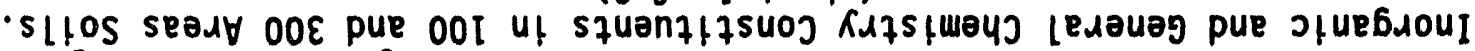

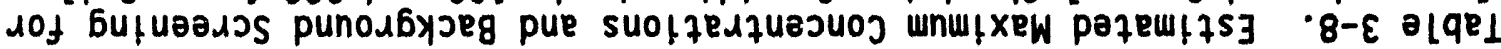


Table 3-8. Estimated Maximum Concentrations and Background Screening for Inorganic and General Chemistry Constituents in 100 and 300 Areas Soils. (sheet 2 of 2)

\begin{tabular}{|l|c|c|}
\hline Parameter & $\begin{array}{c}\text { Maximum detected soil } \\
\text { concentration } \\
(\mathrm{mg} / \mathrm{kg})\end{array}$ & $\begin{array}{c}\text { Hanford Site soil } \\
\text { background } \\
(95 / 95 \text { UTL) } \\
(\mathrm{mg} / \mathrm{kg})\end{array}$ \\
\hline Total organic carbon & 43.7 & $\mathrm{NC}$ \\
\hline Coliform (MPH) & 110 & $\mathrm{NC}$ \\
\hline
\end{tabular}

- 95/95 upper tolerance limit (UTL) is the 95 percent upper confidence limit (UCL) on the 95th percentile. Values from Table 6-9b in Hanford Site Background Part 1, Soil Background for Nonradioactive Analytes (DOE-RL 1993e).

b The background concentration for nitrate is used.

$\mathrm{mg} / \mathrm{kg}=\mathrm{milligram} / \mathrm{kilog} r \mathrm{~m}$

NC = not calculated

Source: DOE-RL 1994d 
Table 3-9. Environmental Restoration Disposal Facility Waste Acceptance Criteria Maximum Allowable Constituent Concentration in Remediation Waste. (sheet 1 of 5 )

\begin{tabular}{|c|c|}
\hline Constituent & $\begin{array}{c}\text { Maximum waste acceptance level } \\
\mathrm{mg} / \mathrm{kg} \text { (nonradionuclides) } \\
\mathrm{pCi} / \mathrm{g} \text { (radionuclides) }\end{array}$ \\
\hline \multicolumn{2}{|l|}{ VOLATILE ORGANIC COMPOUNDS } \\
\hline \multicolumn{2}{|l|}{$1,1,1$-Trichloroethane } \\
\hline \multicolumn{2}{|l|}{ 1.1.2.2-Tetrachloroethane } \\
\hline \multicolumn{2}{|l|}{ 1,2-Dichloroethene } \\
\hline \multicolumn{2}{|l|}{ 2-Butanone } \\
\hline \multicolumn{2}{|l|}{ 2-Hexanone } \\
\hline \multicolumn{2}{|l|}{ 4-Methy1-2-pentanone } \\
\hline \multicolumn{2}{|l|}{ Acetone } \\
\hline \multicolumn{2}{|l|}{ Benzene } \\
\hline \multicolumn{2}{|l|}{ Carbon disulfide } \\
\hline \multicolumn{2}{|l|}{ Carbon tetrachloride } \\
\hline \multicolumn{2}{|l|}{ Chloroform } \\
\hline \multicolumn{2}{|l|}{ Ethylbenzene } \\
\hline \multicolumn{2}{|l|}{ Methylene chloride } \\
\hline \multicolumn{2}{|l|}{ Tetrachloride } \\
\hline \multicolumn{2}{|l|}{ Toluene } \\
\hline \multicolumn{2}{|l|}{ Trichlorethene } \\
\hline \multicolumn{2}{|l|}{ Total xylenes } \\
\hline \multicolumn{2}{|l|}{ Vinyl chloride } \\
\hline \multicolumn{2}{|l|}{ SEMIVOLATILE ORGANIC COMPOUNDS } \\
\hline \multicolumn{2}{|l|}{ 1,3-Dichlorobenzene } \\
\hline \multicolumn{2}{|l|}{ 1,4-Dichlorobenzene } \\
\hline \multicolumn{2}{|l|}{ 4-Chloro-3-methylphenol } \\
\hline \multicolumn{2}{|l|}{ 4-Methylphenol } \\
\hline Acenaphthene & \\
\hline
\end{tabular}


Table 3-9. Environmental Restoration Disposal Facility Waste Acceptance Criteria Maximum Allowable Constituent Concentration in Remediation Waste. (sheet 2 of 5 )

\begin{tabular}{|l|l|}
\hline \multicolumn{1}{|c|}{ Constituent } & $\begin{array}{c}\text { Maximum waste acceptance level } \\
\text { mg/kg (nonradionuclides) } \\
\text { pC1/g (radionuclides) }\end{array}$ \\
\hline Anthracene & \\
\hline Benzo(a)pyrene & \\
\hline Benzo(b)fluoranthene & \\
\hline Benzo(g,h, 1 )perylene & \\
\hline Benzo(k)fluoranthene & \\
\hline Benzolc acid & \\
\hline Bis(2-ethyl)phthalate & \\
\hline Butylbenzylphthalate & \\
\hline Carbazole & \\
\hline 4-Chloroaniline & \\
\hline 2-Chlorophenol & \\
\hline Chrysene & \\
\hline Di-n-butyl-phthalate & \\
\hline Di-n-octyl-phthalate & \\
\hline Dibenzo(a,h)anthracene & \\
\hline Dibenzofuran & \\
\hline Diethylphthalate & \\
\hline Fluoranthene & \\
\hline Fluorene & \\
\hline Ideno(l,2,3-cd)pyrene & \\
\hline 2-Methylnaphthalene & \\
\hline 4-Methylphenol & \\
\hline Naphthalene & \\
\hline 2-Nitrophenol & \\
\hline N-nitrosodiphenylamine & \\
\hline
\end{tabular}


Table 3-9. Environmental Restoration D1sposal Facllity Waste Acceptance Criterla Maximum Allowable Constituent Concentration in Remediation Waste. (sheet 3 of 5 )

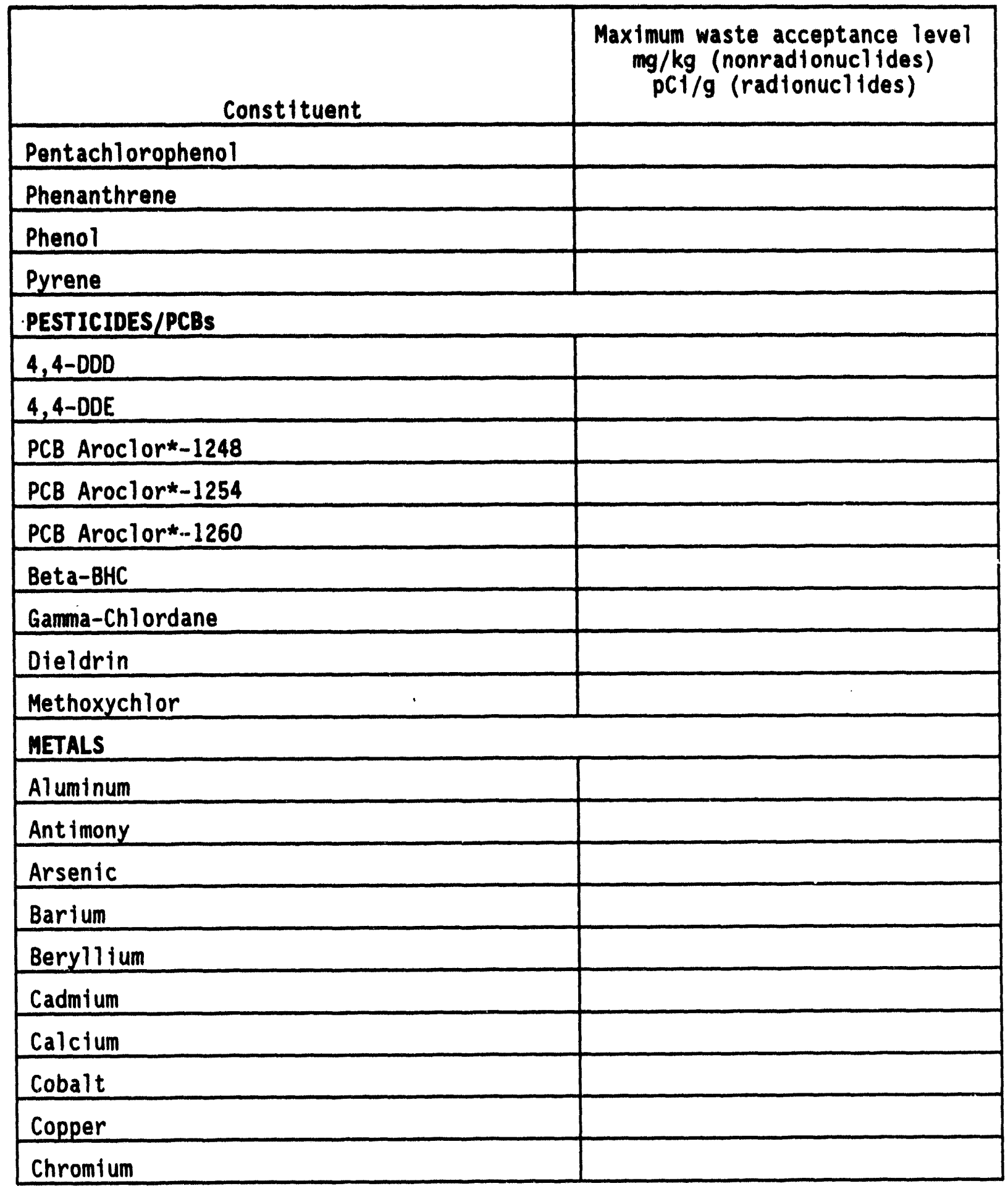


Table 3-9. Environmental Restoration Disposal Facility Waste Acceptance Criteria Maximum Al lowable Constituent Concentration in Remediation Waste. (sheet 4 of 5 )

\begin{tabular}{|c|c|}
\hline Constituent & $\begin{array}{c}\text { Maximum waste acceptance level } \\
\mathrm{mg} / \mathrm{kg} \text { (nonradionuclides) } \\
\mathrm{pCl} / \mathrm{g} \text { (radionuclides) }\end{array}$ \\
\hline \multicolumn{2}{|l|}{ Iron } \\
\hline \multicolumn{2}{|l|}{ Lead } \\
\hline \multicolumn{2}{|l|}{ Magnesium } \\
\hline \multicolumn{2}{|l|}{ Manganese } \\
\hline \multicolumn{2}{|l|}{ Mercury } \\
\hline \multicolumn{2}{|l|}{ Nickel } \\
\hline \multicolumn{2}{|l|}{ Potassium } \\
\hline \multicolumn{2}{|l|}{ Selentum } \\
\hline \multicolumn{2}{|l|}{ Silver } \\
\hline \multicolumn{2}{|l|}{ Sodium } \\
\hline \multicolumn{2}{|l|}{ Thallium } \\
\hline \multicolumn{2}{|l|}{ Vanadium } \\
\hline \multicolumn{2}{|l|}{ Zinc } \\
\hline \multicolumn{2}{|l|}{ MISCELLANEOUS IMOREANICS } \\
\hline \multicolumn{2}{|l|}{ Ammonia } \\
\hline \multicolumn{2}{|l|}{ Chloride } \\
\hline \multicolumn{2}{|l|}{ Chromium VI } \\
\hline \multicolumn{2}{|l|}{ Fluoride } \\
\hline \multicolumn{2}{|l|}{ Nitrate } \\
\hline \multicolumn{2}{|l|}{ Nitrite } \\
\hline \multicolumn{2}{|l|}{ Phosphate } \\
\hline \multicolumn{2}{|l|}{ Sulfate } \\
\hline \multicolumn{2}{|l|}{ RADIONUCLIOES } \\
\hline Americium-241 & \\
\hline Bery 11 ium-7 & \\
\hline
\end{tabular}


Table 3-9. Environmental Restoration Disposal Facility Waste Acceptance Criteria Maximum Allowable Constituent Concentration in Remediation Waste. (sheet 5 of 5 )

\begin{tabular}{|l|l|}
\hline \multicolumn{1}{|c|}{ Constituent } & $\begin{array}{c}\text { Maximum waste acceptance level } \\
\mathrm{mg} / \mathrm{kg} \text { (nonradionuclides) } \\
\mathrm{pC} / \mathrm{g} \text { (radionuclides) }\end{array}$ \\
\hline Carbon-14 & \\
\hline Cesium-134 & \\
\hline Cesium-137 & \\
\hline Chromium-51 & \\
\hline Cobalt-58 & \\
\hline Cobalt-60 & \\
\hline Europium-152 & \\
\hline Europium-154 & \\
\hline Europium-155 & \\
\hline Plutonium-238 & \\
\hline Plutonium-239 & \\
\hline Plutonium-240 & \\
\hline Potassium-40 & \\
\hline Radium-226 & \\
\hline Sodium-22 & \\
\hline Strontium-90 & \\
\hline Technetium-99 & \\
\hline Thorium-228+D & \\
\hline Uranium (total) (as U-238) & \\
\hline
\end{tabular}

*Aroclor is a trademark of Monsanto Company.

$\mathrm{mg} / \mathrm{kg}=\mathrm{milligram} / \mathrm{kilogram}$

$\mathrm{pC} \mathbf{j} / \mathrm{g}=$ picocurie $/$ gram

PCBS = polychlorinated biphenyls

Source: U.S. Army Corps of Engineers 1994 
4.0 PROCESS INFORMATION .................. 4-1

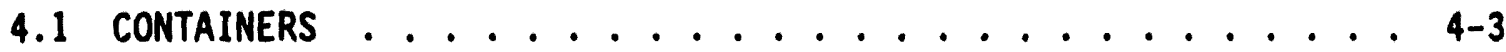

4.2 TANK SYSTEMS ...................... 4-3

4.3 WASTE PILES .................. . . . . . .

4.4 SURFACE IMPOUNDMENTS . . . . . . . . . . . 4-4

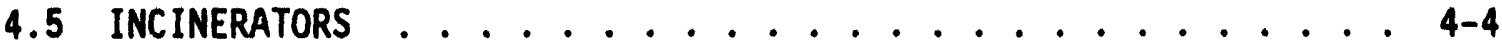

4.6 LANDFILLS . . . . . . . . . . . . . . . 4-4

4.7 LAND TREATMENT . . . . . . . . . . . . . . 4-4

4.8 MISCELLANEOUS UNITS . . . . . . . . . . . . . . 4-4

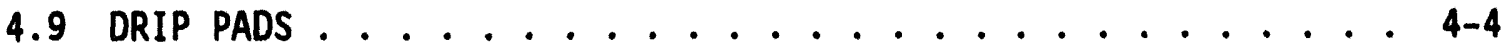

4.10 AIR EMISSIONS STANDARDS FOR PROCESS VENTS . . . . . 4-5

4.11 AIR EMISSIONS STANDARDS FOR EQUIPMENT LEAKS . . . . . . 4-5

4.12 ENVIRONMENTAL RESTORATION DISPOSAL FACILITY TRENCH . . . . 4-5

4.12.1 List of Waste. ............ 4-6

4.12.2 Liner System Exemption Requests .......... 4-7

4.12.3 Liner System, General Items . . . . . . . . . 4-7

4.12.3.1 Liner System Description . . . . . 4-7

4.12.3.2 Location of Seasonal High Water Table

in Relation to Base of Liner...... 4-9

4.12.3.3 Loads on Liner System . . . . . . . . 4-9

4.12.3.4 Extent of Liner System ........ 4-11

4.12.3.5 Liner System Exposure Prevention . . . 4-12

4.12.4 Liner System, Foundation .......... 4-12

4.12.4.1 Foundation Description ........ 4-12

4.12.4.2 Subsurface Exploration Data ....... 4-13

4.12.4.3 Laboratory Testing Data . . . . . . . . 4-15

4.12.4.4 Engineering Analysis ........ 4-16

4.12.5 Liner System, Liners ............. 4-19

4.12.5.1 Synthetic Liners ........ 4-19

4.12.5.2 Synthetic Liner Compatibility Data . . . 4-22

4.12.5.3 Synthetic Liner Strength . . . . . . 4-22

4.12.5.4 Synthetic Liner Bedding . . . . . . . 4-25

4.12.5.5 Soll Liners . . . . . . . . 4-25

4.12.6 Liner System, Leachate Collection/Detection ..... 4-28

4.12.6.1 System Operation and Design. . . . 4-29

4.12.6.2 Equivalent Capability of Synthetic

Drainage Material ......... 4-33 
4.12.6.3 Grading and Drainage ......... . 4-34

4.12.6.4 Maximum Leachate Head . . . . . . . . . . 4-34

4.12.6.5 System Compatibility of Materials and

Waste ............... . 4-34

4.12.6.6 System Strength and Stability of

System Drainage Layers . . . . . . . 4-35

4.12.6.7 Prevention of Clogging ........ 4-35

4.12.6.8 Management of Leachate. . . . . . . . . 4-36

4.12.7 Liner System, Construction, and Maintenance .... . 4-36

4.12.7.1 Material Specifications. . . . . . . . 4-36

4.12.7.2 Construction Specifications. . . . . . 4-37

4.12.7.3 Construction Quality Control Program. . . 4-37

4.12.7.4 Leachate Collection/Detection System

Maintenance. . . . . . . . 4-37

4.12.7.5 Liner Repairs During Operations . . . . . 4-37

4.12.8 Run-on and Run-off Control Systems . . . . . . . 4-38

4.12.8.1 Run-on Control System . . . . . . . . 4-38

4.12.8.2 Run-off Control System ........ 4-39

4.12.8.3 Management of Collection and

Holding Units .......... . 4-39

4.12.8.4 Construction of Run-on/Run-off Control . 4-40

4.12.8.5 Maintenance of Run-on/Run-off Control . . 4-40

4.12.9 Control of Wind Dispersal .............4-41

4.12.8.1 Dust Suppressants .. . . . . . . . . . . . 4-41

4.12.9.2 Interim Cover and Final Interim

Designs .. . . . . . . . . . . 4-41

4.12.9.3 Other Dust Control Measures... . . . 4-42

4.12.10 Liquids in the Environmental Restoration

Disposal Facility Trench ........... 4-42

4.12.11 Containerized Waste as Applied to Environmental

Restoration Disposal Facility Remediation Waste. . 4-43

4.12.12 Special Waste Management Plan for Units

Containing Waste F020, F021, F022, F023,

F026, and F027 ............... 4-43

4.12.13 Prevention of Reaction of Ignitable,

Reactive, and Incompatible Waste in the

Environmental Restoration Disposal Facility . . . . 4-43

4.13 ADDITION OF CORRECTIVE ACTION MANAGEMENT UNITS . . . . . . . 4-44

4.14 DESCRIPTION OF ENVIRONMENTAL RESTORATION DISPOSAL

FACILITY SUPPORT UNITS ................ . . 4-44

4.14.1 Rail and Tractor Trailer Container

Handling Areas . . . . . . . . . . 4-45

4.14.1.1 Loaded Rail Car and Tractor Trailer

Transfer/Unloading Area ...... . 4-45

4.14.1.2 Trailer Tipping Area ........ 4-46 


\section{CONTENTS (cont)}

\subsubsection{Empty Contaminated Container \\ Transfer Area. . 4-47 \\ 4.14.1.4 Empty Decontaminated Container \\ Transfer Area . . . . . . . . . . 4-47 \\ 4.14.2 Decontamination Building ............4-47 \\ 4.14.2.1 Conveyor System . . . . . . . . . . 44-49 \\ 4.14.2.2 Water Recycling System . . . . . . . . 4-49 \\ 4.14.3 Mobile Decontamination Unit ............4-50 \\ 4.14.4 Waste Water Treatment Building ... . . . . . . 4-50 \\ 4.14.5 Subsidence Control P1ant ............. 4-51}

4.15 ENVIRONMENTAL RESTORATION DISPOSAL FACILITY OPERATIONS . . . . 4-51

4.15.1 Waste Transport to the Environmental

Restoration Disposal Facility . . . . . . . 4-52

4.15.2 Loaded Rail and Tractor Trailer Container

Transfer/Unloading Area . . . . . . . . . . 4-52

4.15.3 Transport of Waste Within the Environmental

4.15.4 Restoration Disposal Facility .......... 4-52

4.15.5 Subsidence Control Operations ........... 4-53

4.15.6 Daily Dust Suppressant ........ . . . . . 4-54

4.15.7 Interim Cover Placement ............ . 4-54

4.15.8 Final Interim Cover Placement . . . . . . . . . . 4-54

4.15.9 Dust Control Operations ............. . 4-54

4.15.10 Decontamination Operations ........... 4-55

4.15.11 Equipment Maintenance ............ . 4-56

\section{FIGURES}

4-1. Environmental Restoration Disposal Facility Site Map . . . . . . F4-1

4-2. Environmental Restoration Disposal Facility Trench

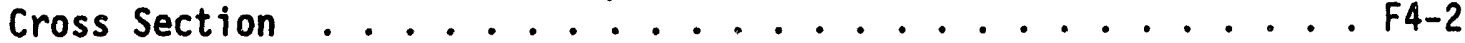

4-3. Environmental Restoration Disposal Facility Trench

Liner System Detail . . . . . . . . . . . . . F4-3

4-4. Plan View of the Environmental Restoration Disposal

Facility Trench Leachate Collection Cells . . . . . . . . . . F4-4

4-5. Environmental Restoration Disposal Facility Trench

Temporary Liner Terminator Detail . . . . . . . . . . F4-5

4-6. Environmental Restoration Disposal Facility Generalized

Operational Flow Diagram ............... F4-6 


\section{TABLES}

4-1. Chapter 4.0 Cross-Reference Table . . . . . . . . . . . . . . . . T4-1

5 4-2. Data Requirements and Test Methods for Foundation Materials: . . . T4-2

6 


\subsection{PROCESS INFORMATION}

This chapter describes the conceptual design and operation of the ERDF trench, with general discussion of the ERDF support units. The ERDF will manage remediation waste from remediation sites on the Hanford Facility. As described in Chapter 3.0 , the remediation waste may contain both a hazardous/dangerous waste component and a radioactive waste component. Under 40 CFR 264.552(a) and WAC 173-303-646(4), placement of remediation waste into or within a CAMU does not constitute land disposal of hazardous/dangerous waste, nor does it constitute creation of a unit automatically subject to the RCRA and WAC MTRs.

For the purposes of this application, the CAMU will include the entire 4.14 square kilometer ( 1.6 square mile) area of the ERDF. However, the conceptual design for the ERDF indicates that the ERDF trench will be the only portion of the CAMU in which remediation waste is left in place after closure. Also, the preamble to the final CAMU rule, the TU rule, and proposed subpart $S$ regulations all imply that the CAMU regulations apply specifically to 1 andbased units, and the ERDF trench will be the only such unit in the ERDF.

Also, although the ERDF support units such as the waste water treatment buildings and the decontamination building, described in Section 4.14, physically will be located within the proposed CAMU, these buildings will maintain their separate regulatory identity as required in 40 CFR 264.552 and WAC 173-303-646. (The design, operation, and permitting (if required) of these support units will meet all RCRA Subtitle $C$ and WAC 173-303 requirements, as applicable, and the detailed information addressing the requirements will be provided in a separate document.) Therefore, this CAMU application details the design and operation of the ERDF trench only. However, because the activities at the support units will be directiy related to operation of the ERDF trench, a brief description of the design and operation of these support units has been included in Sections 4.14 and 4.15 to show that waste management activities at the support units will not create unacceptable risks to human health and the environment.

The current conceptual design for the ERDF trench calls for a trench with an average finished depth of 21.3 meters (70 feet) that is constructed almost entirely below grade. Because the remediation waste placed in the trench will be generated over a relatively long period, the entire trench will not be constructed at one time. Instead, the construction of the trench and the installation of the liner system will be conducted in stages as additional waste placement capacity is required. Up to 21.4 million cubic meters ( 28 million cubic yards) of remediation waste will be placed in the ERDF trench. The final dimensions of the floor of the trench are expected to be 305 meters (1,000 feet) wide and approximately 2,740 meters ( 9,000 feet) long. The side slopes of the trench will be 3 horizontal to 1 vertical resulting in an overall trench width of 433 meters (1,420 feet) and a length of up to 2,871 meters $(9,420$ feet). The long axis of the trench will be oriented east-west. The trench will be equipped with a double liner system with a leachate collection/leak detection system above each liner and a 
1 run-on/run-off control system. In addition, a final cover will be installed 2 on the trench as part of closure as described in Chapter 11.0.

Sections 4.12 and 4.15 describe information that has been or will be obtained to show that the design and operation of the ERDF will meet the CAMU decision criteria in 40 CFR 264.552 and WAC 173-303-646. Because there is no guidance that specifies the format for presenting the process and design information for a CAMU, this chapter has been formatted 1ike a RCRA Part B permit application documentation to assist reviewers familiar with this format in locating specific types of information. Table 4-1 presents a cross-reference of how Chapter 4.0 contents relate to the CAMU regulations and RCRA and WAC TSD requirements. The ERDF trench and ERDF support units will meet the applicable requirements of TSCA (40 CFR 761) for any remediation waste with PCB concentrations of 50 parts per million and above removed from the remediation sites (refer to Chapter 13.0 for additional detail). The substantive requirements of the TSCA regulations are met by the information provided in this chapter.

It is the intent of this chapter to demonstrate that the proposed design and operation of the ERDF will address the CAMU decision criteria through the use of conservative unit design criteria, and following the design mandated by the Tri-Party Agreement. In addition, this chapter presents standards for the design and operation of the ERDF that the regulatory agency may specify when designating the CAMU. The remediation waste placed in the ERDF trench will be managed and contained so as to minimize future releases to the extent practical through the use of a double liner system; a leachate collection, detection, and monitoring system; and a run-on/run-off control system.

Because specific guidance for the design of CAMUs is not available, the proposed ERDF trench design has drawn on the technical requirements for the design of hazardous/dangerous waste land disposal units (40 CFR Subpart F), because these requirements represent a we11-documented, conservative approach to unit design. The information in this chapter presents a conceptual approach to the design and construction of the ERDF trench because the definitive design, which is in progress, is not complete. It should be recognized that the information/details provided in this application present a clear design/operational requirements baseline, which demonstrates conformance with the CAMU designation criteria. Additional details will refine or enhance the performance of these design/operational requirements. Definitive design activities will include the collection and analysis of field and laboratory data, preparation of design drawings and reports, preparation of construction specifications, and preparation of a construction quality assurance (CQA) plan. The definitive design of the ERDF will be submitted to the EPA and Ecology after regulatory approval of the ERDF, as specified in the Tri-Party Agreement.

Unacceptable risks to humans and the environment due to remediation waste management activities associated with the ERDF will be avoided by developing and implementing detailed operating procedures to ensure the safe transport, handling, and placement of remediation waste. In addition, procedures will be developed to control dust, and to maintain and decontaminate equipment. Section 4.15 presents a conceptual discussion of the operations associated 
1 with remediation waste management at the ERDF. Detailed procedures concerning 2 how these operations will take place will be developed before the start of 3 ERDF operations.

Although the initial construction of the ERDF trench will include the use of conservative design features, research and studies are being and will be conducted to determine if alternate ERDF designs also wi11 meet the CAMU designation requirements. A request to modify the trench design may occur in the future if an alternative design is developed and adequate data are collected to show the new design meets the CAMU designation criteria and provides an equivalent or greater level of protection. The request would be submitted to the appropriate regulatory agency(s) for review and approval before change in construction of the ERDF.

The information presented in this chapter is based on information from the following sources: the Conceptual Design Report for the Environmental Restoration Disposal Facility (DOE-RL 1994a) and the Low-Level Burial Grounds Part B Permit Application (DOE-RL 1989). The following EPA publications regarding design, construction, and closure of hazardous waste 1 and disposal units also were used to generate this chapter: Guide to Technical Resources for the Design of Land Disposal Facilities (EPA 1988); Requirements for Hazardous Wast? Landfill Design, Construction and Closure (EPA 1989b); Quality Assurance and Quality Control For Waste Containment Facilities (EPA 1993); and Construction Quality Assurance for Hazardous Waste Disposal Facilities (EPA 1986a).

\subsection{CONTAINERS}

The focus of this application is the ERDF trench, which will manage hazardous/dangerous waste. Support units will be discussed in a separate document. Current ERDF conceptual design does not include the use of greaterthan-90-day container storage.

\subsection{TANK SYSTEMS}

The nonland-based ERDF support units, described in Section 4.14, that are physically located within the proposed CAMU will maintain their separate regulatory identity. Information regarding applicable design, operation, and permitting (if required) for these support units will be submitted to the appropriate regulatory authorities in a separate document $(s)$.

\subsection{WASTE PILES}

The focus of this application is the ERDF trench, which will manage hazardous/dangerous waste. Support units will be discussed in a separate document. Current ERDF conceptual design does not include the use of waste piles. 


\subsection{SURFACE IMPOUNDMENTS}

The focus of this application is the ERDF trench, which will manage hazardous/dangerous waste. Support units will be discussed in a separate document. Current ERDF conceptual design does not include the use of surface impoundments.

\subsection{INCINERATORS}

The focus of this application is the ERDF trench, which will manage hazardous/dangerous waste. Support units will be discussed in a separate document. Current ERDF conceptual design does not include the use of incinerators.

\subsection{LANDFILLS}

Under the 40 CFR 264.552 and WAC 173-303-646, specifically under the regulations defining the expanded CAMU concept [40 CFR 264.552(a)(1) and (2) and WAC 173-303-646(4)(b) and (c) ], a CAMU is not considered a land disposal unit, landfill, or a unit automatically subject to the MTRs. Therefore, the specific requirements for the design and operation of hazardous/dangerous waste landfills do not apply to the ERDF trench. However, hazardous/dangerous waste will be managed at the ERDF.

\subsection{LAND TREATMENT}

The focus of this application is the ERDF trench, which will manage hazardous/dangerous waste. Support units will be discussed in a separate document. Current ERDF conceptual design does not include the use of 1 and treatment.

\subsection{MISCELLANEOUS UNITS}

The nonland-based ERDF support units, described in Section 4.14, that are physically located with in the proposed CAMU will maintain their separate regulatory identity. Information regarding applicable design, operation, and permitting (if required) for these units will be submitted to the appropriate regulatory authorities in a separate document $(s)$.

\subsection{DRIP PADS}

The focus of this application is the ERDF trench, which will manage hazardous/dangerous waste. Support units will be discussed in a separate document. Current ERDF conceptual design does not include the use of drip pads. 


\subsection{AIR EMISSIONS STANDARDS FOR PROCESS VENTS}

The requirements for air emissions standards for process vents do not apply to the design or operation of the ERDF trench. This is because the ERDF trench or support units will not operate process vents associated with distillation, fractionation, thin-film evaporation, solvent extraction, or air or steam stripping operations that manage hazardous waste with organic constituents.

\subsection{AIR EMISSIONS STANDARDS FOR EQUIPMENT LEAKS}

The requirements for air emissions standards for equipment leaks as specified in 40 CFR 264, Subpart BB, do not apply to the design or operation of the ERDF trench because the ERDF trench and support units will not have equipment operating that contains or contacts hazardous waste with organic concentrations at or above 10 percent by weight. (This does not, however, exclude the ERDF from applicable Clean Air Act of 1977 requirements before acceptance of RCRA past-practice waste, as discussed in Chapter 13.0.)

\subsection{ENVIRONMENTAL RESTORATION DISPOSAL FACILITY TRENCH}

The ERDF will manage remediation waste from remediation site activities that may contain both a hazardous/dangerous waste component and a radioactive waste component. The ERDF trench design information presented in this section is intended to provide sufficient information to enable the appropriate regulatory authority to demonstrate that the ERDF meets CAMU decision criteria in 40 CFR 264.552 and WAC 173-303-646.

The ERDF trench will have an average finished depth of 21.3 meters (70 feet) that is constructed almost entirely below grade. The floor of the trench is expected to be 305 meters (1,000 feet) wide and approximately 2,740 meters $(9,000$ feet) long. The side slopes of the trench will be 3 horizontal to 1 vertical resulting in an overall trench width of 433 meters $(1,420$ feet) and a length of up to 2,871 meters $(9,420$ feet). The long axis of the trench will be oriented east-west. General plan and cross-sectional views of the ERDF trench are shown in Figures 4-1 and 4-2. Because the remediation waste placed in the trench will be generated over a relatively long time, the entire trench will not be constructed at one time. Instead, the construction of the trench and the installation of the liner system will be conducted in stages as additional waste placement capacity is required. Up to 21.4 million cubic meters ( 28 million cubic yards) of remediation waste will be placed in the ERDF trench.

The remediation waste placed in the ERDF trench will be managed and contained so as to minimize future releases to the extent practical through the use of a double-liner system, a leachate collection, detection, and monitoring system, and a run-on/run-off control system. Because specific guidance for the design of CAMUs is not available, the proposed ERDF trench design has drawn upon the technical requirements for the design of 
1 hazardous/dangerous waste land disposal units because these requirements 2 represent a well-documented, conservative approach to unit design.

As described in this section, the initial construction of the ERDF trench will include the use of a double-iined trench, as mandated by the Tri-Party Agreement, which includes many conservative design features. However, research and studies are being and will be conducted to determine if alternate, less costly designs, that al so will meet the CAMU designation requirements can be used for the ERDF trench. A request to modify the trench design may occur in the future if an alternative design is developed and adequate data are collected to show the new design meets the CAMU designation criteria and provides an equivalent or greater level of protection. The request would be submitted to the appropriate regulatory agency(s) for review and approval before any change in construction.

The conceptual design for the ERDF trench is based on EPA guidance for the design, construction, and closure of hazardous/dangerous waste disposal units. A conceptual design is presented because the definitive design, which is in progress, for the ERDF trench is not complete. It should be recognized that the information/detalls provided in this application present a clear design/operational requirements baseline that demonstrates conformance with the CAMU designation criteria. Additional detalls will refine or enhance the performance of these design/operational requirements. The definitive design will be prepared in accordance with the most current technical documents (Section 4.0).

The definitive design activities will include the collection and analysis of field and 1aboratory data, preparation of design drawings and reports, and preparation of construction specifications. The definitive design will be submitted to the EPA and Ecology after regulatory approval of the ERDF, as mandated in the Tri-Party Agreement.

A CQA plan will be developed for the ERDF trench as part of the definitive design. The CQA plan will be submitted to the appropriate regulatory authorities for review and approval before construction of the ERDF trench.

\subsubsection{List of Waste}

The ERDF trench will manage remediation waste from several remediation sites on the Hanford Facility. Remediation waste, as defined in 40 CFR 260.10 and WAC 173-303-040, includes all solid and hazardous/dangerous waste and all media (including groundwater, surface water, solls, and sediments) and debris, that contain hazardous/dangerous waste or that exhibit a hazardous/dangerous waste characteristic, which are managed for the purpose of implementing corrective action requirements unde" 40 CFR 264.101 and WAC 173-303-646(2) or (3) and RCRA Section $3008(h)$. The remediation waste placed in the ERDF trench may contain both a hazardous/dangerous waste component and a radioactive waste component. A description of the remediation waste that will be managed in the ERDF trench is provided in Chapter 3.0 . 
The final total volume of remediation waste to be placed in the ERDF 2 trench cannot be determined precisely because the total volume of remediation 3 waste that will be generated is not yet known. However, the proposed ERDF 4 trench has been designed to accept up to 21.4 million cubic meters (28 million 5 cubic yards) of remediation waste. A majority of the remediation waste that 6 will be placed in the ERDF trench will be contaminated soll that will be 7 placed in bulk form. The trench also will receive waste in single-use 8 containers and waste debris that may require subsidence control measures to 9 eliminate void space before covering.

\subsubsection{Liner System Exemption Requests}

Although the conceptual design of the ERDF trench includes the use of a double-1iner system, under 40 CFR 264.552 and WAC 173-303-646 and specifically under the regulations defining the expanded CAMU concept [40 CFR 264.552(a)(1) and (2) and WAC 173-303-646(4)(b) and (c)], a CAMU is not considered $a$ land disposal unit, or considered a unit subject to the MTRs. Therefore, the requests for ilner system exemptions are not applicable to the ERDF trench.

\subsubsection{Liner System, General Items}

This section provides a general description of the proposed 1 iner system that will be used to minimize the release of hazardous/dangerous waste, hazardous/dangerous constituents, leachate, or hazardous/dangerous waste decomposition products to the ground or surface waters from the ERDF trench. As discussed previousiy, this design is based on current conceptual engineering studies and this application will be expanded with actual design data, definitive design drawings, design calculations, construction specifications, and supporting documentation as this information becomes available.

4.12.3.1 Liner System Description. The ERDF trench will be equipped with a double-liner system and an associated leachate collection/leak detection system. As shown in Figure 4-3, the proposed 1 iner system major components, from bottom up, will consist of the following:

- A low-permeability soil layer

- A secondary liner consisting of a high-density polyethylene (HDPE) geomembrane

- A leak detection/secondary leachate collection layer

- A primary liner consisting of a HDPE geomembrane

- A primary leachate collection layer

- An operations layer. 
4.12.3.1.1 Secondary Liner System. The secondary liner system for the ERDF trench will consist of a composite of the low-permeabllity soll layer and a secondary HDPE geomembrane layer. The low-permeability soll layer will be a 0.9-meter- (3-foot-) thick layer of a silty fine sand soll amended by mixing with bentonite. The soll layer will be constructed so that is has a hydraulic conductivity of $1 \times 10^{-7}$ centimeters per second $\left(3 \times 10^{-4}\right.$ feet per day) or less. The low-permeabllity soll layer will be placed on the foundation materials (native solls) beneath the trench. The upper surface of the low-permeability soll layer will be rolled with a smooth steel drum roller before placement of the secondary HDPE geomembrane.

The synthetic portion of the composite secondary 1 iner system will consist of a $60 \mathrm{mil}$ ( 1.5 millimeter, 0.06 inch) HDPE geomembrane.

The geomembrane will be placed directly on the compacted low-permeability soll layer and will be textured to provide high-friction interface with adjacent components to prevent slipping.

The leak detection/secondary leachate collection system will be located immediately above the HDPE geomembrane of the secondary liner. The function of the leak detection/secondary leachate collection system is to allow for the detection and collection of any liquids that might migrate through the primary liner. The design of the system creates a preferential flow path that directs any fluids passing through the primary liner system to a sump (leachate collection systems and sumps are described in more detall in Section 4.12.6).

The materials of construction for the leak detection/secondary leachate collection system will differ depending on the location within the trench. On the floor of the trench, the leak detection/secondary leachate collection system will consist of a $0.3-$ meter- (1-foot-) thick gravel drainage layer between two geotextlle cushions. The bottom geotextile cushion will be placed directly above the secondary HDPE geomembrane, and the top cushion will be placed above the drainage layer. On the side slopes of the trench, the leak detection/secondary leachate collection system will consist of an HDPE geonet with a nonwoven geotextile thermally bonded to each side. This geocomposite will be connected hydraulically to the gravel drainage layer to form the entire leak detection/secondary leachate collection system.

The physical and chemical characteristics of the materials used to construct the secondary liner system are described in Sections 4.12.5, 4.12.6, and 4.12 .7 .

4.12.3.1.2 Primary Liner System. The primary liner will consist of an HDPE geomembrane that will be placed over the secondary leachate collection
layer. This HDPE geomembrane will have a thickness of 60 mil (1.5 millimeter, 0.06 inch) and will be textured to provide a high-friction interface with adjacent components to prevent slipping.

The primary leachate collection system will be located immediately above the primary HOPE geomembrane, and below the operations layer on which waste is placed. The function of the primary leachate collection layer is to prevent leachate from standing on the primary liner by creating a preferential flow path for all potentially contaminated fluids to flow to the primary sump 
1 (leachate collection systems and sumps are described in more detail in 2 Section 4.12.6).

3

The primary leachate collection system will be simflar to the leak detection/secondary leachate collection system described previousiy. On the trench floor, the primary system will consist of a 0.3 -meter- (1-foot-) thick gravel drainage layer underlain by a geotextile cushion. This cushion is used to prevent puncture of the underlying primary geomembrane. The gravel drainage layer will be overlain by a geotextile filter/separator that prevents overlying fine materials (from trench operations layers) from infiltrating into the drainage layer. On the side slopes of the trench, the primary leachate collection system will consist of an HDPE geonet with a nonwoven geotextile thermally bonded to each side (the same configuration as the secondary leachate collection system on the side slopes). This geocomposite will be connected hydraulically to the gravel drainage layer to form the entire primary leachate collection system.

Pipes may be included in the gravel drainage layer if a higher flow capacity is required. If needed, these pipes will collect fluid entering the drainage layer and transport the fluid to the primary sump. The size, position, and need for this piping will be determined during the definitive design process.

The physical and chemical characteristics of the materials used to construct the primary liner system are described in Sections 4.12.5, 4.12.6 and 4.12.7.

4.12.3.1.3 Operations Layer. The primary liner system will be overlain by a 0.9-meter- (3-foot-) thick operations layer. It is expected that the material used for the operations layer will be predominantly granular in nature. The operations layer will be placed as construction of the primary liner progresses and will completely cover the primary liner. The operations layer will be placed on top of the geotextile separator on the floor of the trench and on top of the primary geocomposite drainage layer on the side slopes. The purpose of the operations layer is to prevent mechanical damage to the liner system due to the movement of hauling and placing equipment, and to protect the low-permeability soll layer from frost damage. The physical characteristics and the source of the soll material to be used in the operations layer will be determined during definitive design of the ERDF trench.

4.12.3.2 Location of Seasonal High Water Table in Relation to Base of Liner. The conceptual design of the ERDF trench indicates that the excavation depth may have to be as deep as 26 meters $(85 \mathrm{feet}$ ) below grade to provide an average finished depth of 21 meters (70 feet) for the liner and sumps. As indicated in Chapter 5.0, Section 5.3, the seasonal high water table is located approximately 76 meters (250 feet) below the surface at the proposed ERDF trench location. Water table depths are discussed in more detail in Chapter 5.0, Section 5.3, of this application.

4.12.3.3 Loads on Liner System. The trench liner system will experience several types of stresses during the construction, operation, and postclosure 


$$
\text { DOE/RL-94-40, Rev. } 0
$$

periods. The types of stresses are discussed in the following sections, along with the types of calculations that will be used to evaluate the stresses. In general, standard techniques for analyzing liner systems will be used (e.g., EPA 1987b).

\subsection{Stresses From Installation or Construction Operations.}

During installation of the 1 iner, tension stresses can develop if the coeffictent of friction of the liner materlals is lower than the slope angle. The amount of tension will depend on the material density, slope length, slope angle, coefficient of friction, load transfer from overlying components, and material thickness. During the definitive design, these factors will be taken into account and the interface friction angles within the geosynthetic layers will be specified sufficlently higher that the slope angle plus an appropriate factor of safety. Both sides of the geomembranes will be textured (roughened) to provide a high-friction interface with adjacent components to resist slipping and reduce tension. Therefore, tension exerted on the geosynthetic layers will not be of concern.

Equipment used during placement of the gravel leak detection/leachate collection layers and the soll operations layer will transfer load to the underlying liner components. The magnitude and areal extent of the load will depend on equipment weight and ground contact area, lift thickness, and mechanical properties of the gravel and soll materials. Standard analytical techniques (e.g., for pressures under footings) will be used to calculate loads on the iiner. Dynamic loads from construction vehicles traveling on the access ramp also will be determined. These loads will be used to determine the required interface friction angles.

4.12.3.3.2 Stresses Resulting from Operating Equipment. Both construction and operating equipment will move on the upper surface of the operations layer. The maximum stresses on the liner will depend on which equipment is heavier. Stresses exerted by both the construction and operating equipment will be evaluated during definitive design. The actual operating loads will be calculated using the same methods as for construction loads.

4.12.3.3.3 Stresses from the Maximum Quantity of Naste, Cover, and Proposed Postclosure Land Use. After the ERDF trench is full, the trench liner system will experience static load from the weight of the overlying waste and cover materials. The static load is expected to be higher on the floor of the trench than on the side slopes because the waste is thicker over the floor. The static load per square meter (square foot) of liner will be calculated during definitive design. The exact liner materials specified in the definitive design will be capable of supporting the static load without failure. Adequate preparation of the trench foundation and adequate compaction of the low-permeability soil layer also will help ensure that the liner components can support the static load. It is anticipated that there will be no postclosure land uses that would significantly increase the static load on the liner system.

Dynamic stresses on the liner system would result primarily from ground accelerations during seismic events. To determine whether a potential problem exists, the yield acceleration for the liner system will be calculated using a

940612.1900 
1 stability method that can model the trench geometry and 1 iner strength

2 (e.g., the Sarma method). The results $w 111$ be compared to the Hanford Design

3 Base Earthquake (DBE), and the liner material selection $w i l l$ be altered if

4 required.

4.12.3.3.4 Stresses Resulting from Settlement, Subsidence, or Uplift. Uplift is not considered to be a concern at the ERDF trench because the foundation materials are expected to be sufficiently strong to resist any side slope movement and resulting bottom heave.

10

Regional subsidence, e.g., from groundwater or petroleum extraction, is not expected at the ERDF because these resources et ther have not been identifled (petroleum) or are not used extensively (groundwater). Even if present, regional subsidence probably would not cause significant stresses in the 1 iner system because the deformations would occur over such a large area that strains at any point in the liner would be small. Fluctuations in the groundwater level due to changes in groundwater recharge are al so not expected to be a concern because these changes will occur very slowly and the groundwater table is at least 73 meters (240 feet) below ground surface.

Stresses on the 1 iner system due to total and differential settlement of the foundation materials are not considered to be significant. This is because the foundation material is expected to exhibit a relatively high density, that will prevent excessive settlement. In addition, the foundation materiais at the base of the trench previously will have been loaded with the material excavated from the trench. The load caused by the remediation waste, liner system and final cover is expected within the same range as the load caused by the excavated material so that excessive settlement will not occur.

Settlement of the waste material within the trench could, over time, produce downdrag forces on the side slopes and consequently cause tension in some liner system components. The magnitude of tension is expected to be small due to the compaction of waste during placement and the use of textured geomembranes on the side slopes. A detailed evaluation of waste settlement is presented in the Engineering Study - Load/Deformation Characteristics of Potential Waste Solls for the Environmental Restoration Disposal Facility (DOE-RL 1994C).

4.12.3.3.5 Internal and External Pressure Gradients. Pressure gradients across the 1 iner system from either water or gas are expected to be negligible for several reasons. First, the foundation materials and surrounding native soils are expected to be relatively permeable and free draining. This will prevent gas-pressure buildup and water buildup below the liner. Secondly, the trench will be located substantially above the seasonal high water table (refer to Chapter 5.0). This also will prevent bulldup of water pressure below the liner. Finally, the trench design, particularly the leachate collection and removal system and the final cover (refer to Sections 4.12.6 and Chapter 11.0, Section 11.10.5.2) will prevent pooling of liquids on top of the liner system.

4.12.3.4 Extent of Liner System. As shown in Figure 4-2, the double-1iner system will cover all soils underlying the ERDF trench. The liner system will 
extend up the side slopes of the trench to the ground surface; therefore, coverage of underlying soil is complete.

\subsubsection{Liner System Exposure Prevention. As described in} Section 4.12.3.1.2 and shown in Figure 4-3, a 0.9-meter- (3-foot-) thick operations layer will overlie the primary iiner system throughout the entire ERDF trench. The operations layer will be placed as construction of the primary liner system progresses. Placement of the operations layer over the entire liner system will be conducted in accordance with plans that will ensure that no area of the liner system will be exposed to wind or sunlight for extended periods. The 0.9 meter ( 3 foot) thickness of the operations layer will be sufficient to protect the liner system from any erosional forces, and will protect the low-permeability soil layer from frost damage.

It is possible that the time between construction of the entire liner system and placement of the waste material could be a year or more. During this time, the thickness of the operations layer could be reduced by erosional forces such as wind and precipitation. Based on past experiences on the Hanford Farility, wind erosion during storms can be expected to erode the operations iayer material. If the operations layer material chosen for the ERDF trench is fine-grained and susceptible to wind erosion, dust suppressant will be applied as needed to prevent wind erosion. Precipitation that falls on the operations layer might cause gullying on the side slopes. This type of erosion will be easily detected during visual inspections and will be repaired by placing and compacting additional material as soon as the damage is observed. Visual inspection procedures for the trench are described in Chapter 6.0, Section 6.2.

\subsubsection{Liner System, Foundation}

The following sections provide a description of the properties of the ERDF trench liner system foundation materials.

4.12.4.1 Foundation Description. The foundation for the ERDF trench liner system will consist of native soils. The average finished depth of the trench with liner system will be approximately 21.3 meters ( 70 feet) below the ground surface. To accommodate construction of the liner and sumps, the base of the excavation may extend up to 26 meters ( 85 feet) below the ground surface. Based on the data that have been collected for site characterization, the soils between the surface and depths ranging from 41 to 97 meters (135 to 319 feet) are predominantly fine to medium sand. Subsurface stratigraphic cross-sections and grain-size curves have been prepared for the ERDF site in the Engineering Study for the Trench and Engineered Barrier Configuration for the Environmental Restoration Disposal Facility (DOE-RL 1993d). The grainsize curves presented in this study indicate that from the surface to a depth of 50 feet, the grain sizes generally range from silts (approximately 0.04 millimeter) to coarse sands (up to 5 millimeters). A detailed investigation and assessment of the character of the subsurface materials at the ERDF currentiy is being performed. 
1 4.12.4.2 Subsurface Exploration Data. As indicated previously, subsurface 2 site characterization of the ERDF is currently in progress. Much of the data 3 on the geologic, geotechnical, and hydrogeologic characteristics of the 4 subsurface material beneath the site were obtained during previous and/or 5 ongoing characterization investigations. These data are preliminary and will 6 be evaluated and incorporated into the definitive design of the ERDF trench. 7 This section presents a description of the currently existing subsurface test 8 data, and the data that will be collected for the design of the ERDF trench.

4.12.4.2.1 Test Pit Data. Test pit data are not required for the definitive design of the trench and no test pits are planned as part of the ERDF site investigations.

4.12.4.2.2 Borehole Data. Five borings have been drilled to groundwater within the proposed boundaries of the ERDF. A limited number of additional borings currently are being drilled to depths of 15.25 meters (50 feet) within the ERDF boundaries. Soil samples have been collected from each boring and subjected to. a standard set of engineering laboratory tests to obtain data for use during the definitive design. These tests, described in Section 4.12.4.3, include the following:

- Natural moisture content using ASTM D-2216 (ASTM 1993)

- Triaxial strength testing using ASTM D-4767 (ASTM 1993)

- Grain-size analysis using ASTM D-422 (ASTM 1993)

- Bulk density using standard laboratory techniques

- Calcium carbonate content using [ASTM D-4373 (ASTM 1993)]

- Conventional soil sampling and in situ density testing using the standard penetration test [ASTM 1586 (ASTM 1993)] using both the standard $[3.81$ centimeters ( 1.5 inch)] and large [ 6.35 centimeters (2.5 inch)] inside-diameter split tube samplers.

The data collected to date have not been included in this document because it is preliminary and is not available in a format suitable for publication. The site characterization data will be compiled and submitted to the appropriate regulatory authorities at the completion of the ERDF site characterization activities.

In addition to the current site characterization activities, the character of the geologic material encountered during the actual excavation of the trench will be observed and recorded. The observed character of the foundation material encountered during the excavation will be compared to the site characterization data to determine when unanticipated foundation materials are encountered. If any unanticipated foundation materials are encountered, samples of the materials will be collected and analyzed as appropriate. 
4.12.4.2.3 Borehole Geophysics. Because the depth of the base of the ERDF trench is less than 30.5 meters ( $100 \mathrm{feet}$ ), conventional subsurface investigation techniques (refer to Section 4.12.4.2.2) are feasible, and are expected to provide adequate results for engineering design purposes. Should the depth of the planned excavations increase as a result of the definitive design, collection of geophysical data might be of greater use to engineering evaluations and will be reconsidered:"

4.12.4.2.4 In Situ Hydrologic Test Data. The native geologic materials at the foundation level of the ERDF trench are unsaturated because the materials are located substantially above the seasonal high water table and consist of relatively permeable and free draining materiai. The test method used to obtain in situ hydraulic conductivity data for the native materials at the foundation level is titled Hydraulic Conductivity, Diffusivity, and Sorptivity of Unsaturated Soils (American Society of Agronomy 1986). The preliminary results indicate a hydraulic conductivity of $5 \times 10^{-4}$ centimeters per second ( 10.6 gallions per day per square feet) at a depth of approximately 21.3 meters (70 feet).

Laboratory permeability tests are not planned for the native soil material samples collected from the trench foundation zone.

4.12.4.2.5 Summary of Geologic Data. This section will be expanded as necessary to include more detail when the current subsurface site characterization studies are completed. The following general geologic information is included to provide a context for the trench design considerations.

The ERDF site is underlain by 159 to 177 meters ( 521 to 580 feet) of suprabasalt sediments that rest on top of a basalt (rock) unit. Because the base of the excavation of the trench will extend to a maximum of 26 meters ( 85 feet), the following discussion 1 imits its presentation of general geological data to depths extending to approximately 41 meters (135 feet) (refer to Chapter 5.0 for additional details on site geology).

The Hanford formation is the uppermost geologic unit in the vicinity of the ERDF. The Hanford formation is lateraliy extensive throughout the ERDF and ranges in thickness from 41 to 97 meters (135 to 319 feet) in the vicinity of the unit. As proposed in the conceptual design, the ERDF trench will be constructed entirely within the Hanford formation.

The Hanford formation is divided into the following three facies: (1) sand dominated, (2) gravel dominated, and, (3) silty. The sand-dominated facies are the principal facies under the ERDF site. These facies consist of fine- to coarse-grained sand and granule gravel displaying plane lamination and bedding and, less commonly, plane bedding and channel-fill sequences in outcrop. The laminated sand facies were deposited adjacent to main flood channelways during the waning stages of flooding.

The gravel-dominated facies generally consist of coarse-grained basaltic sand and granule-to-boulder size gravel. These facies are present in a 
1 relatively thin layer near the surface in the northern portion of the ERDF 2 site, but pinches out rapidly to the south.

The silty facies consist of thinly-bedded, plane-laminated and ripple cross-laminated silt and fine-grained sand that commonly display normally graded rhythmites. The silty facies were deposited under slackwater conditions and in back-flooded areas.

Longitudinal sand dunes mantle the Hanford formation in the proposed ERDF area. The height of these dunes is approximately 1.5 to 3 meters (5 to 10 feet). These dunes trend northeast-southwest, and were deposited after the Pleistocene Epoch.

The uppermost aquifer system beneath the proposed trench is located between 73 and 104 meters (240 and 340 feet) below the ground surface.

The aquifer system, that exists in an unconfined hydraulic condition, consists of fluvial gravels of the Ringold Formation.

4.12.4.3 Laboratory Testing Data. The following sections describe the tests that have been or currently are being conducted on the foundation material samples collected from the boreholes.

4.12.4.3.1 Grain size Analysis. The percentage of silt and clay size material and the overall particle size distribution affects the engineering characteristics of the foundation soil. Samples currently are undergoing sieve analyses to separate coarse fractions and to determine the percentage of fines in the material. One of several settling methods (hydrometer, decantation, or pipette) will be used to analyze the distribution of the fine-grained portion of the material [ASTM D-1140 and ASTM D-422 (ASTM 1993)]. Grain sizes will be classified according to the Unified Soil Classification System.

4.12.4.3.2 Calcium Carbonate Analysis. Significant amounts of calcium carbonate can increase the mass strength of the foundation material by cementing the soil particles together. Conversely, dissolution of calcium carbonate in a cemented soil could weaken the material. At the ERDF, calcium carbonate is expected to have a negligible to slightly beneficial effect because of increased, but local, cementation. Areas of potential strength or weakness due to the presence of calcium carbonate will be evaluated during the field investigations described in Section 4.12.4.2.2. The potential for dissolution under the trench is considered almost nonexistent because surface infiltration will be stopped by the overlying liner system. Calcium carbonate content using ASTM D-4373 (ASTM 1993) currently is being determined on samples collected from boreholes; however, no additional special investigations have been conducted and none are planned.

4.12.4.3.3 Natural Moisture Content. Samples currently are being analyzed for natural moisture content using ASTM D-2216 (ASTM 1993).

The results of these analyses will be used to determine whether the moisture content in the natural soils underlying the trench will present stability or operational problems during trench excavation, construction, and waste placement activities. 
4.12.4.3.4 Hydraulic Conductivity Test Data. Laboratory permeability tests are not $\mathrm{planned}$ for the native soil material samples collected from the trench foundation zone. These materials are unsaturated and are relatively permeable and free draining.

4.12.4.3.5 Mineralogy and Geochemical Test Data. Mineralogy and geochemical tests are expected to be of 1 imited value for the design of the ERDF trench. Therefore, these tests are not planned at this time. If engineering design requires mineralogy or geochemical test data, the appropriate test will be conducted on samples collected from the boreholes. If needed, potential tests could include the following:

- Petrography and mineralogy

- X-Ray diffraction analyses

- X-Ray fluorescence analyses

- Cation exchange capacity

- Total carbon/inorganic carbon analyses.

4.12.4.3.6 Triaxial Strength Test Data. The strength of the soil materials that form the foundation of the ERDF trench is important in determining the stability of the trench slopes. The samples of the silty fine sand collected during site characterization are undergoing triaxial strength tests [ASTM 4767 (ASTM 1993)]. The data will be used to conduct slope stability analyses during definitive design of the ERDF trench.

4.12.4.3.7 Geotechnical Data to be Collected During Site Investigations. Table 4-2 summarizes the proposed data requirements and the methods that have been, or currently are being, used to obtain the information necessary to complete the foundation evaluation. These data requirements could be revised as the final design of the trench is prepared.

4.12.4.4 Engineering Analysis. The foundation will be required to support the liner system and overlying waste and cover materials without excessive settlement, compression, or uplift that could damage the liner. This section describes the design approach required to satisfy these criteria.

4.12.4.4.1 Engineering Design Data. No in situ density, strength, or deformability test data are available from existing site investigations. A full suite of engineering data will be collected during field and laboratory investigations (Sections 4.12.4.2 and 4.12.4.3). The data will be used during the definitive design of the ERDF trench. The proposed suite of field and laboratory investigations are presented in Table 4-2.

4.12.4.4.2 Settlement Potential. Because the native soils are granular and relatively free-draining, consolidation is not expected. Therefore, it is likely that foundation deformation essentially will be elastic and will occur during waste placement and cover construction. The foundation soil appears to be relatively dense, and the side slopes will be relatively flat. In addition, the foundation materials at the base of the trench will have previousiy been loaded with the material excavated from the trench. As a result, problems with differential settlement between the floor and the side 
1 slopes are not expected and no further testing related to settlement will be 2 conducted.

4.12.4.4.3 Bearing Capacity. Bearing failure of the foundation soils is not expected to be a problem because the total load from the maximum quantity of waste, cover material, and future land uses is not expected to be higher than the load from the original material excavated from the trench. In addition, the strength of the foundation material is expected to exceed the strength of the low-permeability soil layer that will be placed directly above the foundation material. As indicated in Section 4.12.5.5.4, the strength of the low-permeability soil layer will be determined for the loads expected on the trench liner system. Bearing capacity of the foundation will be analyzed only if the results of the triaxial strength tests of the foundation materials is lower than expected. If necessary, standard bearing capacity analyses will be performed on the foundation materials to confirm that the foundation will not fail.

4.12.4.4.4 Stability of Trench Slopes. As part of the definitive design, slope stability analyses that evaluate circular and noncircular failure surfaces will be performec to confirm that safety factors are adequate for the proposed trench side slope design ( 3 horizontal to 1 vertical). Based on the preliminary data concerning the subsurface soils at the ERDF, it is expected that the proposed slopes w111 be stable.

Both circular and noncircular analyses will provide yield accelerations that will be adjusted for allowable displacements and damping to estimate corresponding ground surface accelerations. Seismic data from the Hanford Facility will be used to determine the probability of exceeding these accelerations and, hence, the risk of earthquake damage.

Recent studies indicate that regional seismicity is low and that the probability of exceeding even the relatively low acceleration of 0.05 the acceleration of gravity $[0.5$ meter per second per second ( 1.6 feet per second per second) is only 0.002 per year (WHC 1994a; Youngs et al. 1985). Hence, the risk of damage is considered to be small and it is not believed that any measures will need to be incorporated in the final design solely to withstand seismic events.

With respect to the stability of liner components on the side slopes of the trench, the low-permeability soil layer will be placed directly on the native soil subgrade. The low-permeability soil layer is expected to have significant cohesion and a moderate friction angle, thus it should be adequately stable on the proposed side slopes. The geosynthetics will be placed on top of the low-permeability soil layer and, in general, will need to support their own weight, as well as the weight of overlying materials. Based on past experience on the Hanford Facility, this weight most likely will be within acceptable limits of the typical strengths of these materials (DOE-RL 1989). Required interface shear strengths will be calculated as part of the definitive design of the trench and will be used in the geosynthetic selection process. The materials will be chosen so that the interface friction angles are sufficiently higher than the slope angle with an appropriate factor of safety. 
The present conceptual design includes a 0.9-meter-(3-foot-) thick operations layer covering the entire trench, including the side slopes. The operations layer should be easy to place and maintain, based on the relatively flat slope ( 3 horizontal to 1 vertical), and the anticipated internal friction angle of this material, and the friction angle with the underlying geocomposite layer.

4.12.4.4.5 Potential for Excess Hydrostatic or Gas Pressure. Before placement of waste in the ERDF trench, excess hydrostatic pressure in the foundation materials under the liner system could result in uplift and damage. Problems due to hydrostatic pressure are not expected for the following reasons.

- Infiltration of precipitation is very low on the Hanford Facility, therefore, the upper 77 meters (250 feet) of unconsolidated material (in the 200 Areas Plateau) normally is unsaturated.

- Properly designed anchor trenches will be constructed at the top of the ERDF trench to prevent water from infiltrating under the geomembranes at the top of the excavation.

- The native soils forming the foundation are relatively permeable and the water table is located at a considerable depth beneath the trench (Section 4.12.3.2). Therefore, any infiltration of surface water at the edge of the trench is expected to travel predominantly downward, rather than collecting under the excavation itself.

4.12.4.4.6 Seismic Conditions. Potential hazards from seismic events include faulting, slope failure, and liquefaction. Disruption by faulting is not considered a significant risk because no major faults have been identified in the vicinity of the ERDF. The only fault on the Hanford Facility that has shown evidence of movement within the past 13,000 years is the fault at Gable Mountain, which is approximately 8 kilometers ( 5 miles) north of the ERDF (WHC 1994a). The potential for slope failure due to seismic events will be determined as discussed in Section 4.12.4.4.4. Liquefaction occurs in 1oose, poorly graded granular materials that are saturated and subjected to shaking from seismic events. Saturated soils are susceptible because of high dynamic pore pressures that temporarily lower the effective stresses. During this process, the soit particles are rearranged into a more dense configuration, with a resulting decrease in volume. The foundation materials at the ERDF are not considered susceptible to 7 iquefaction because the materials are relatively well-graded, unsaturated, and relatively dense. This will be confirmed by field testing as described previously (refer to Table 4-2).

4.12.4.4.7 Subsidence Potential. Subsidence of undisturbed foundation materials is generally the result of fluid extraction (water or petroleum) or mining. Neither petroleum nor economic minerals are believed to be present in the sediments (i.e., those sediments whose deformation could cause subsidence at the ground surface) beneath the ERDF. Potential groundwater resources exist below the trench, but it is not likely that these resources will be used in the future. Fluctuations in the groundwater level due to changes in groundwater recharge also are not expected to be a concern because these 
1 changes will occur very slowly and the groundwater table is very deep.

2 In addition, even if these sediments beneath the ERDF were to consolidate

3 because of fluid withdrawal, the depth at which the consolidation could occur

4 most Tikely would produce a broad, gently sloping area of subsidence. This

5 form of subsidence of the foundation materials would not cause significant

6 strains in the trench liner system. Consequently, the potential for

7 subsidence-related fallures is expected to be negligible.

8

4.12.4.4.8 Sinkhole Potential. Wells completed in the area of the proposed ERDF trench have not identified any soluble materials in the foundation soils or underlying sediments. Additionally, basaltic rock, which underlies the trench at depths of approximately 159 to 177 meters (521 to 580 feet), is not amenable to sinkhole formation. Therefore, the potential for sinkholes is considered negligible.

\subsubsection{Liner System, Liners}

The following sections contain information concerning the synthetic liners in the proposed system.

4.12.5.1 Synthetic Liners. The conceptual liner system described in Section 4.12.3 and shown in Figure 4-3 includes several layers of geosynthetic materials such as geotextiles, geonets, and geomembranes. These components will be selected during the definitive design process on the basis of performance requirements related to the trench geometry, waste compatibility, and material properties of soil components of the liner system. Because these factors have not been defined to date, the following discussion emphisizes the selection criteria for geosynthetics, as opposed to specific details on a selected geosynthetic. Detailed material specifications, including dimensional, chemical, strength, hydraulic, and other pertinent properties will be established during the definitive design process.

4.12.5.1.1 Geotextiles. The primary use of geotextile fabrics at the ERDF trench will be as components of the primary leachate collection and drainage system and the leak detection/secondary leachate collection system.

In the primary leachate collection and drainage system, a geotextile layer will be placed directly on top of the drainage layer to prevent fine material from the operations layer from infiltrating and clogging the primary leachate collection and drainage system. On the floor of the trench, where a gravel layer will be used as the primary drainage layer, this separation will be accomplished by placing a single layer of the geotextile filter/separator directly on top of the gravel drainage layer to prevent infiltration of fine particulates (Figure 4-3). This geotextile layer also will provide support so that the poorly graded, cohesionless gravel drainage layer is not pushed aside or worked into the bottom of the operations layer. A second geotextile layer will be placed at the base of the gravel drainage layer of the primary leachate collection system. This geotextile will act as a cushion to prevent the gravel from puncturing the underlying primary HDPE geomembrane. 
21

On the side slopes of the trench, where a geonet will be used as the primary drainage layer, the geotextiles will be thermally bonded to each side of an HDPE geonet drainage layer to form a geocomposite (Figure 4-3). The geotextiles of the geocomposites will act as a filter to prevent fine materials from the operations layer from clogging the geonet. In addition, the geotextiles form a cushion to protect the primary geomembrane and provide a high strength interface as the geotextile interlocks with the asperities on the textured geomembrane.

For the leak detection/secondary leachate collection system, geotextile layers again will be placed immediately above and below the drainage layer. On the floor of the trench where a gravel layer will be used to provide the secondary drainage layer, the geotextiles will provide puncture protection for the adjacent geomembranes. On the side slopes of the trench where a geonet will be used as the secondary drainage layer, the geotextiles again will be thermally bonded to each side of the geonet to form a geocomposite. The geotextiles will act as a filter (in the event of a leak in the geomembrane), as a cushion layer to protect both the underlying secondary geomembrane and the overlying primary geomembrane, and as a high strength interface component of the drainage layers.

The following factors will be considered in selecting the geotextile.

- The apparent opening size will be appropriate for separating the operations and gravel drainage layers. The apparent opening size will be determined by the manufacturer using standard analytical methods such as ASTM D-4751 (ASTM 1993).

- The cross-plane hydraulic conductivity (permittivity) will be sufficient to allow water to move freely from the soil backfill and operations layer into the drainage layers. Permittivity is determined by the manufacturer and will be confirmed by evaluating the manufacturer's test data.

- The strength (puncture resistance) and thickness of the geotextile will be determined by the manufacturer using standard analytical methods such as ASTM D-4833 (ASTM 1993) and ASTM D-5199 (ASTM 1993) for thickness.

- The geotextile material will be chemically compatible with the soil environment and any leachate from the waste. Compatibility will be determined by either evaluating manufacturer's test data, or by obtaining the results of compatibility tests previously conducted on the Hanford Facility. Results of EPA 9090 tests previously conducted on the Hanford Facility are ayailable in the following documents: 9090 Test Results (WHC 1991a); and Liquid Effluent Retention Facility, 9090 Testing (WHC 1990).

Based on present design concepts and typical properties of commercially available geotextiles, performance requirements related to other factors (i.e., strength, endurance, weathering, etc.) are expected to be easily satisfied. Manufacturer's test data will be evaluated to confirm that the 
DOE/RL-94-40, Rev. 0

$06 / 94$

1 reported results are accurate. If a required property is not evaluated by the 2 manufacturer, standard test methods (such as ASTM) will be used to determine 3 the parameter.

If possible, protective, and cost effective, the same geotextile will be used above and below the gravel drainage layers (in the primary and secondary leachate collection systems) to simplify testing, procurement, and installation.

4.12.5.1.2 Geonet. A geonet will be used to provide both the primary and secondary drainage layers on the side slopes of the trench. The geonet drainage layers w111 be located above both the primary and secondary geomembrane liners on the side slopes of the trench (Figure 4-3). An HDPE geonet with a nonwoven geotextile thermally bonded to both sides will form a geocomposite. The geonet layers will provide flow paths for leachate collected on the side slopes of the trench. The geonets will be connected hydraulically to the gravel drainage layers in the secondary and primary leachate collection systems, so that leachate will flow from the geonet drainage layer to the gravel drainage layer, through the gravel to the primary and secondary sumps. Geonets typically have high in-plane and cross-plane transmissivities, that are particularly important for the leak detection/secondary leachate collection and removal system where rapid detection of leachate is desirable and the expected volume is relatively smal1.

In the conceptual design, HDPE was chosen as the candidate geonet material. The HDPE is expected to be more chemically resistant to leachate than most other materials. The following considerations will be included for the final selection of the geonet material during definitive design.

- The transmissivity of the geonet will be sufficient to accommodate expected flow volumes. To ensure this, the geonet will not compress excessively under the weight of the overlying waste, fill, and cover. The transmissivity of the geonet under different loads will be established by the manufacturer using standard methods such as ASTM D-4716 (ASTM 1993). The transmissivity determined by the manufacturer will be used as part of the definitive design of the liner system.

- The geonet material will be chemically compatible with the soil environment and any leachate from the waste. The HDPE has been selected as the candidate geonet material because it is the most chemically compatible material available and because the ERDF waste acceptance criteria will be based on chemical compatibility with HDPE.

4.12.5.1.3 Geomembrane Liners. A geomembrane liner will be installed under both the primary leachate collection system and the leak detection/secondary leachate collection system (Figure 4-3). The geomembranes will act as barriers to the percolation of leachate out of the ERDF trench. Note that the secondary geomembrane will be placed over a low-permeability soil layer to form a composite liner. 
In the conceptual design, HDPE was chosen as the candidate geomembrane material because HDPE has relatively high strength and is more chemically resistant to most substances than other liner materials and, because the ERDF waste acceptance criterla will be based on chemical compatibility with HDPE. The primary consideration for geomembrane membrane liner selection is compatibility with the leachate because the strength and other properties should be adequate if the HDPE does not deteriorate from leachate attack. As described in the following section, data regarding the geomembrane iner/leachate compatibility will be determined either by reviewing manufacturers test data or by obtaining the results of compatibility tests previously conducted on the Hanford Factlity.

\subsubsection{Synthetic Liner Compatibility Data. The conceptual design of the} ERDF trench indicates that HDPE is the material of choice for the geomembrane and geonet components of the 1 iner system. As described in Chapter 3.0, Section 3.3, one of the factors in determining the waste acceptance criteria for the ERDF will be protection of the integrity of the trench 1 iner system from potentially damaging types and concentrations of chemical constituents in both the waste and leachate generated from the waste. As a result, waste with constituents or properties at levels that are considered incompatible with the HDPE liner materials will not be accepted for placement in the ERDF.

At present, it is anticipated that the compatibility of the HDPE 1 iner material with the waste constituents and properties, and with the leachate that will be generated by the waste, will be determined using manufacturer's literature, the results of manufacturer's testing, or by obtaining the results of compatibility tests previously conducted on the Hanford Facility. Results of EPA 9090 test previously conducted on the Hanford Facility are available (WHC 1991a, WHC 1990a).

The DOE-RL may determine, at some point in the future, that waste types for which there is no existing compatibility data require placement in the ERDF trench. The compatibility of the new compounds with the liner system components will be evaluated on a case-by-case basis as required (e.g., review by a qualified chemist for similarity with compounds whose effect on HDPE is known).

4.12.5.3 Synthetic Liner Strength. The synthetic 1 iner components will be subjected to stresses from several sources over the life of the ERDF trench. The components will be selected and the trench will be designed to prevent failure that would compromise the ability of the liner system to contain the waste. The strength values used in the various definitive design analyses will be the manufacturer's reported value from strength tests (puncture resistance [ASTM D-4833 (ASTM 1993)] and thickness tests [ASTM 5199

(ASTM 1993) ]) performed by the manufacturers. An appropriate factor of safety will be incorporated into the liner system design to account for long-term stresses.

The types of stresses and design approaches identified at the present time are described in the following sections. Other types of stresses and design approaches may be identified and addressed during the definitive design. 
4.12.5.3.1 Self-Weight. The interface friction angles within the geosynthetic layers w111 be specified sufficlently higher (including an appropriate factor of safety) than the slope angle so that there will be no tensional stresses in the liner due to self-weight. Consequently, it is not anticipated that any special design approaches will be required to account for stresses due tc self-weight.

4.12.5.3.2 Height of Overlying Material. On the side slopes, the weight of the operations layer will be supported in part by the geosynthetic liner system. The interface friction angles within the geosynthetic layers will be specified sufficiently higher than the slope angle (including an appropriate factor of safety) so that tensile stresses due to overlying loads will not be occur. This allows the operations layer to be placed on the sideslopes of the trench without changing the factor of safety.

When the ERDF trench is full and the cover is in place, the liner system will experience a certain amount of static load from the overlying waste, fill, and cover materials. Potential fallure modes from this type of loading include excessive compression of the geonets and puncture of the flexible membrane liners. Geonets will be selected to provide adequate drainage under load (Section 4.12.5.1.2). The secondary geomembrane will be bedded on a smooth low-permeability soll and covered by a geotextile cushion. The primary geomembrane will be sandwiched between two geotextiles. Therefore, the potential for puncturing the geomembrane liners is minimal. Adequate long-term strength and stiffness of these geosynthetics will be determined from standard analyses using appropriate factors of safety.

4.12.5.3.3 Operational Stresses. Operational stresses are imposed primarily by equipment operating on top of the 1 iner system during both construction and waste placement.

Construction procedures for spreading and compacting the operations layer will use low-ground-pressure bulldozers, careful blading techniques, smooth-drum vibratory rollers, and minimum required thicknesses of soil under construction equipment to reduce the stress on the liner and minimize the risk of damage. These techniques are discussed in more detail in Section 4.12.7. Techniques for placing the gravel drainage layers will be similar. In addition, the waste will be placed in such a way to minimize downdrag forces at the toe of the sideslopes.

During waste piacement, the 0.9-meter- (3-foot-) thick operations layer will provide adequate protection on the floor, side slopes, and access ramp of the trench (Section 4.12.3.5). The operations layer will be placed (as trench construction progresses) over the entire trench before filling operations begin.

4.12.5.3.4 Thermal Stresses. Geosynthetics have relatively large coefficients of thermal expansion and therefore can undergo significant dimensional changes from ambient temperature variations. Sufficient slack will be maintained during the installation of the geomembranes to prevent excessive stress before placement of the operations layer. The 0.9 -meter52 (3-foot-) operations layer that will be installed after the geomembrane is 
1 placed will provide adequate insulation to minimize the stress due to thermal

2 expansion. An assessment of the adequacy of the operations layer in

3 minimizing thermal stresses in the 1 iner before waste placement will be

4 conducted during definitive design.

4.12.5.3.5 Settlement stresses. As the waste and backfill settle, the liner components on the stde slopes could expertence tenston in response to downdrag forces. The amount of tension will depend on the amount of settlement. The magnitude of the settlement and resulting tension during 10 waste placement is expected to be minimal because of the compaction and/or 11 subsidence control measures conducted as waste is placed during trench operations. Sufficient compaction will be accomplished by operating vibratory compaction equipment over the deposited waste. With these operations, it is expected that the liner system will accommodate the residual small settlements that may occur, because geosynthetic ma:erials are typically quite flexible and can strain significantly without compromising their function. Settlement potential will be evaluated during the definitive design process when the waste and backfill characteristics are defined more completely.

As described in Section 4.12.4.4.2, consolidation of the foundation is not expected because of the dense nature of the foundation soils, and the fact that the foundation solis have been previously loaded by the soils removed from the excavation. The load on the native foundation material due to the weight of the waste and cover material will be approximately the same as the load due to the overlying soll before excavation of the trench. Therefore, consolidation of the foundation is expected to have minimal effect on the liner components.

4.12.5.3.6 Dynamic Stresses. The primary hazard with respect to dynamic stresses is from ground accelerations produced by seismic events (earthquakes). Partially filled trench cells will be most affected by these events. The potential for disruption by faulting is not considered a significant risk at this time because the only fault on the Hanford Facility that shows evidence of movement within the past 13,000 years is the fault at Gable Mountain. The Gable Mountain fault is located approximately 8 kilometers (5 miles) north of the ERDF (WHC 1994a).

Despite relatively high interface friction angles within the liner system, displacements and damage (such as tearing of the fiexible membrane liner) could occur given sufficiently large magnitudes and frequencies of shaking. However, the potential for this type of damage to the ERDF trench is considered negligible because historical seismic activity on the Hanford Facility has been low, and the probability of exceeding even the relatively low acceleration of 0.05 times the acceleration of gravity $[0.5$ meter ( 1.6 feet) per second per second] is only 0.002 per year (WHC 1994a; Youngs et a1. 1985). As stated in Section 4.12.3.3.3, during definitive design of the ERDF, the yield acceleration for the trench will be calculated and compared to the accelerations expected in the DBE. The materials specified for the liner system may be modified if warranted by the results of the analyses. 
4.12.5.3.7 Seams. Typically, geosynthetics are supplied in rolls several meters (feet) wide. To cover the slopes and floor of the ERDF trench, the material from several rolls will be joined together producing a large number of seams. Appropriate seaming procedures, careful workmanship by specialists experienced in this technology, and effective third-party quality assurance and quality control will produce seams that are stronger than the surrounding material. An effective CQA program will be developed to ensure the strength of the seams. The program will include destructive shear and peel tests [ASTM D-413 and/or D-413 (ASTM 1993)] and nondestructive air lance and vacuum box tests. The criteria for determining the adequacy of the seam construction will be included in the CQA plan for the liner system discussed in Section 4.12.7.

4.12.5.4 Synthetic Liner Bedding. The lowest synthetic liner is the secondary HDPE geomembrane, which will be placed directly on the soll liner of the low-permeability layer. The soll liner will consist of a silty fine sand soil amended by mixing with bentonite. Larger particles will be excluded from the soll layer because the larger particles might puncture the overlying geomembrane. Additionaliy, the surface of the low-permeability soll liner will be rolled with a smooth steel drum roller before placing the secondary HDPE geomembrane. Consequently, the risk of this layer puncturing the overlying geomembrane is considered negligible.

The bedding material for the primary geomembrane will differ depending on its position within the trench. On the side slopes, the primary liner wili rest on the geocomposite that forms the leak detection/secondary leachate collection system. The geocomposite will consist of an HDPE geonet with a nonwoven geotextile thermally bonded to both sides. The geocomposite will rest directly on the secondary geomembrane on the trench side siopes.

On the floor of the trench, the primary HDPE geomembrane will rest on a geotextile cushion, which will separate the geomembrane from the underlying gravel drainage layer of the leak detection/secondary leachate collection system.

The risk of puncture from above for both the primary and secondary geomembrane will be reduced by two methods: (1) on the trench floor, a geotextile cushion will be placed between the geomembranes and their respective overlying gravel drainage layers; and (2) on the side slopes, a geocomposite will be used between the two geomembranes and between the primary geomembrane and the overlying operations layer.

The operations layer will provide a measure of protection for the geomembranes from damage due to the operation of vehicles and waste placement equipment in the trench.

\subsubsection{Soll Liners. The ERDF trench will be lined completely with a} 0.9 -meter- (3-foot-) thick low-permeability soil layer placed on the foundation materials (the subgrade) (Figure 4-3). This layer will have an in-place hydraulic conductivity of $1 \times 10^{-7}$ centimeters per second $\left(3 \times 10^{-4}\right.$ feet per day) or less, and will act, in conjunction with the secondary HDPE geomembrane, to inhibit leachate migration. 
The low-permeability soil layer will be constructed using a silty fine sand soil amended by mixing with bentonite. It is anticipated that the soil component of the soil/bentonite mixture will consist of silt or silty fine sand excavated during construction of the trench. The soil will be mixed with the bentonite before placement during construction of the low-permeability layer. The optimum percentage of bentonite will be determined during definitive design of the liner systems.

The native soil will be mixed with enough bentonite to lower the hydraulic conductivity of the mixture to $1 \times 10^{-7}$ centimeters per second $\left(3 \times 10^{-4}\right.$ feet per day) or less at the minimum design density. The percentage of bentonite will depend on the properties of hoth the soil and the bentonite itself and will be determined by laboratory testing (particularly moisture-density and permeability) of candidate mixtures.

To ensure that the soil layer achieves a hydraulic conductivity less than or equal to $1 \times 10^{-7}$ centimeters per second ( $3 \times 10^{-4}$ feet per day), the soil/bentonite mixture will be placed in lifts of limited thickness (to be defined in the CQA plan) on the underlying foundation materials and compacted to the appropriate specifications. The optimum moisture content, density, and compaction requirements of the low-permeability soil layer will be determined during definitive design of the liner systems. A discussion of specific testing that might occur to determine the soil properties is included in Section 4.12.5.5.1.

4.12.5.5.1 Material Testing Data. To perform the engineering analyses required to determine whether the soil/bentonite mixture proposed for use in constructing the low-permeability soil layer will meet the liner system design criteria and to develop construction specifications, a variety of 1aboratory tests will be performed on the native soil material and the admix material. The laboratory tests could consist of the following (note that other tests could be added, or the following list could be revised, based on final design criteria):

- Atterberg limits using ASTM D-4318 (ASTM 1993) for classification and qualitative engineering analyses of the soil/bentonite admix and any cohesive soils found in the soil component. Atterberg limits will not be conducted on the silty-fine sands used in the admix.

- Particle-size distribution using ASTM D-422 (ASTM 1993) for classification and qualitative engineering anaiyses of the silty-fine sand component of the admix

- Moisture-density relationships using ASTM D-1557 (ASTM 1993) for establishing field compaction specifications and preparing samples for other tests. The moisture-density relationships will be performed on the soil/bentonite admix only.

- Permeability using ASTM D-5084 (ASTM 1993) to confirm design criteria and to establish (in conjunction with moisture-density data) field compaction specifications for the soil/bentonite admix material 
DOE/RL-94-40, Rev. 0

06/94

- Strength parameters using ASTM D-2850 and D-3080 (ASTM 1993) to provide values for engineering analyses involving low-permeability liner system stability

- Consolidation behavior using ASTM D-2435 (ASTM 1993) to provide data for engineering analyses related to subsidence.

With respect to dispersion of the soil material from flow through the liner, the relatively high degree of compaction is expected to maximize the bonding forces between the clay particles. Consequently, significant dispersion is unlikely. With respect to piping, calculated fluid velocities in this very low-permeability material will be too low to move the soil particles. Hence, piping is not considered a potential problem. At the present time, no testing for dispersion or piping is planned. A detailed analysis of dispersion and piping potential will be performed only if the actual properties of the soil material indicate a potential problem.

During placement of the low-permeability soil layer, several field and laboratory tests will be performed to confirm that the in-place properties of this material meet the design specification (refer to Section 4.12.7). The testing program might include (based on design specifications) the following:

- In situ density using the nuclear moisture/density gauge [ASTM D-2922 (ASTM 1993)] to confirm that compaction (hence, permeability, strength, and consolidation) requirements are being satisfied

- Laboratory tests for moisture content of soil liner samples using ASTM D-2216 (ASTM 1993) to calculate actual dry densities and confirm that placement specifications are being satisfied.

Once satisfactory compaction has been achieved, samples of the soil liner will be collected using thin-wall tube samplers and taken to a laboratory where permeability tests will be performed. The hydraulic conductivity of the soil liner samples will be determined using ASTM D-5084 (ASTM 1993) to confirm that in-place permeability is less than $1 \times 10^{-7}$ centimeters per second $\left(3 \times 10^{-4}\right.$ feet per day).

Before constructing the low-permeability soil liner, a full-scale test pad will be constructed using the proposed soil/bentonite admix, construction equipment, and placement techniques. This testing will be used to determine the time constraints for placement, the optimum lift height, the required number of passes to achieve compaction, and similar information necessary to establish construction procedures.

In the foregoing discussions, the proposed test methods are presented for illustrative purposes only and could be modified or replaced as appropriate for site-specific conditions and information needs.

4.12.5.5.2 Soil Liner Compatibility Data. The issue of compatibility between the soil liner and the leachate relates to permeability changes in the soil liner caused by physical (e.g., clogging, solution) and chemical (e.g., ion exchange) interactions. An increase in permeability to above the 
1 required minimum value [ $1 \times 10^{-7}$ centimeters per second $\left(3 \times 10^{-4}\right.$ feet per day)]

2 would dictate changes in the liner system design and/or materials to satisfy

3 regulations. At the present time, it is anticipated that the compatibility of

4 the soil liner material with the concentration and characteristics of the

5 waste constituents, and the potentially generated leachate, will be determined

6 by reviewing data from tests previously conducted on the Hanford Facility.

7 Results of compatibility tests previously conducted at the Hanford Facility

8 are available in the report titled Soil Liner/Leachate Compatibility Testing

9 in Support of Project W-025 Radioactive Mixed Waste Disposal Facility

10 (WHC 1992h).

4.12.5.5.3 Soil Liner Thickness. The proposed 0.9 meter ( 3 foot) thickness for the low-permeability soil layer of the ERDF represents a conservative design criteria for use in this type of facility. An engineering evaluation of the adequacy of the soil liner thickness is not required and will not be conducted.

4.12.5.5.4 Soil Liner Strength. The expected loads on the liner system are discussed in Section 4.12.3.3. Significant stresses in the soil liner are expected to result primarily from the weight of the overlying waste and cover material. Stability of the side slope soil liner will be analyzed as discussed in Section 4.12.4.4.4, using material properties derived from laboratory tests as described in Section 4.12.5.5.1. A standard bearing capacity analysis, also using material properties derived from the laboratory tests, will also be performed for the low-permeability layer under operating loads (e.g., construction equipment and waste placement equipment). Instability should not be a problem given reasonably expected values of cohesion and friction angle.

Strength of the low-permeability soil liner under postclosure loading conditions will be evaluated using standard bearing capacity analyses with material properties derived during the laboratory testing program.

4.12.5.5.5 Engineering Report. An engineering report containing descriptions and results of the testing and analyses described in Section 4.12 .5 will be prepared. This engineering report will be submitted for review to the appropriate regulatory agencies.

\subsubsection{Liner System, Leachate Collection/Detection System}

The components of the primary leachate collection and removal system and the leak detection/secondary leachate collection system and their position within the overall liner system are shown in Figure 4-3. The purpose of the primary leachate collection and removal system is to provide sufficient permeability and storage volume to collect and retain for subsequent disposal, in a timely manner, any and all fluids falling on or moving through the waste in the ERDF trench. The purpose of the leak detection/secondary leachate collection system is to ensure timely detection, collection, and removal of any liquids that migrate through the primary liner. 
DOE/RL-94-40, Rev. 0

06/94

Although the ERDF trench will be a single continuous trench, the floor of the trench will be divided into leachate collection cells to allow for staged construction and to minimize the amount of leachate generated during ERDF trench operations. The use of cells also shortens the flow paths for leachate and allows for the design and construction of multiple sumps of moderate size rather than one or two very large sumps. The trench floor will be divided into leachate collection cells that will be approximately 152 meters (500 feet) on each side. Figure 4-4 shows the layout of the proposed leachate collection cells.

Conceptual plans call for the development of the ERDF trench on a cell-by-cell basis. Initially, a small number of cells (2 to 4 ) will be excavated and lined. Additional cells will be excavated and lined as needed. The amount of trench excavated always will exceed the amount lined by a margin sufficient to safely separate future excavation and liner construction activities from waste placement operations.

The primary and secondary liner and leachate collection systems within each cell will slope to a sump area at the toe of the trench side slope. Two separate and hydraulically isolated sumps will be located within the sump area. One sump will be located above the primary geomembrane, and will collect leachate flow from the primary leachate collection system. The second sump will be located between the primary and secondary geomembranes, and will provide leak detection and collection (refer to cross-section detail 4 on Figure 4-4). The liner and leachate collection systems are described in Section 4.12.3.

Riser pipes will lead from each sump up the side slope of the trench. Submersible pumps will be lowered into position in each of the sumps through the riser pipes. The pumps will discharge into a gravity-drained pipe that will lead to the leachate storage area. Gravity drainage will minimize the possibility of leachate flowing back into the trench. Leachate levels in the sumps will be monitored and used to control the pumps. Each leachate collection area will have an independent control system located at the top of the side slope. Instrument readings also will be transmitted to a central station at the ERDF. The pumps will be installed in such a way that the pumps can be removed for required maintenance or replacement. The capacity of the pumps will be determined during definitive design, based on the capacity and filling rate of the associated sump.

4.12.6.1 System Operation and Design. System operation and design information is presented in the following sections.

4.12.6.1.1 Primary System. The side slopes and floor of the ERDF trench have different primary leachate collection and removal system components. on the floor of the trench, the system will consist of, from the bottom up, a geotextile cushion, a gravel drainage layer, and a geotextile filter/separator. On the side slopes, the system will consist of an HDPE geonet with a nonwoven geotextile thermally bonded to each side. In the following paragraphs, the primary leachate collection system on the trench floor is discussed first, followed by an explanation of the system on the side slopes, and information concerning the primary sump. 
DOE/RL-94-40, Rev. 0

$06 / 94$

4.12.6.1.1.1 Trench Floor. The primary function of the geotextile at the base of the system is to provide a cushion to prevent the gravel drainage layer from puncturing the underlying primary geomembrane. Leachate from the overlying trench operations will be collected within the gravel drainage layer. This layer will be 0.3 -meters (1-foot) thick, and will be composed of uniformly-graded fine gravel with a hydraulic conductivity of at least 0.01 centimeter per second (28 feet per day). Rounded to subangular grave1 particles will be used to avoid potential damage to the underlying primary geomembrane. The median grain size will be established during definitive design of the trench. The drainage layer will be designed to have adequate capacity to function under the worst-case leachate collection scenario. This scenario is the occurrence of the 25-year, 24-hour storm just after the first waste is placed, while the remainder of the trench is open.

The 25-year, 24-hour storm represents a conservative DBE for run-on/run-off control at the ERDF.

If preliminary analyses show that the gravel drainage layer alone is not sufficient to remove the expected quantity of leachate generated by the worst-case scenario storm (described previously), a drain pipe system could be installed within the drainage layer to increase leachate flow capacity.

The pipe system will function to shorten the transit time to the primary sump by reducing the flow path through the granular material. The size, construction materials, and position of the piping will be determined during definitive design.

A geotextile filter/separator will overlie the gravel drainage layer. The function of the geotextile is to prevent overlying operations layer materials from infiltrating into the gravel drainage layer, that could result in the clogging of the drainage layer. The selection of the opening size of the geotextile will be coordinated with the selection of grain size distribution in the operations layer to minimize the potential for clogging.

The primary leachate collection system components (as well as the entire liner system) will be laterally continuous and cover the entire trench. As shown in Figures 4-2, 4-3, and 4-4, the trench floor (and leachate collection systems) within the leachate collection cells will be graded such that the leachate will flow to sumps within the individual cells.

North-south flow within the individual leachate collection cells will be controlled by a crest in the middle of the trench floor. This crest will be located along the east-west axis of the trench and will run the entire length of the trench. The trench floor within each cell will be sloped away from this crested area, toward the side slopes. The sumps within the leachate collection cells will be located at the toe of the side slopes. The current design is for the trench floor to be sloped one percent from the central axis (east-west trending crest) towards each of the sumps.

In an east-west direction, the sumps will be located in the approximate center of the leachate collection cells and at the toe of the side slopes. Adjacent to the side slopes, the trench typically will be sloped perpendicular to the side slope and toward the sump, at a 2 percent slope. The exceptions to this are cells 1 and 2, where the primary and secondary sumps will be 
1 located at the intersection of two side slopes. In cells 1 and 2, the trench

2 floor will be sloped perpendicular to the side slope and toward the sump (in

3 the corner of the cel1) at a 1 percent slope. The proposed drainage slopes

4 are shown in Figure 4-4.

5

6

7

4.12.6.1.1.2 Trench Side Slopes. The proposed design shows the primary leachate collection and removal system extending up the side slopes to the top of the trench. The geocomposite proposed for the side slopes has been selected because it will be stable on the side slope ( 3 horizontal to 1 vertical) and will be easy to place. These factors make the geocomposite more feasible for leachate drainage and removal than granular materials on the side stopes.

Based on the proposed layout of the leachate collection cells, side slopes will be present on two sides of cells 1,2, and the final two cells at the east end of the trench (possibly cells 29 and 30), and on one side of cells 3 through 28 (Figure 4-4). Where the side slopes meet the trench bottom, the geocomposite material will extend approximately 1.5 meters ( 5 feet) onto the base of the gravel drainage layer; the geocomposite will be cut at this location. In this position, the geonet will be hydraulically connected to the gravel drainage layer at the base of the trench. Therefore, leachate collected in the geonet will flow into the gravel drainage layer, then to the sump.

The physical and chemical characteristics of the geocomposite materials will be selected during final design. Section 4.12 .5 presents the criteria that will be used in selecting the geosynthetic materials to be used in the geocomposite.

4.12.6.1.1.3 Sumps. Water draining through the primary leachate collection system will flow to a primary sump within the associated leachate collection cell. Except for the cells at the ends of the trench, the sumps will be placed in the center of each cell in an east-west direction. In the north-south direction, the sump will be located at the toe of the trench side slope. This placement of the sump will facilitate leachate collection and removal. Sump capacity, geometry, and materials of construction will be determined during definitive design.

The primary sumps will be monitored regularly for the presence of leachate throughout the life of the ERDF trench. When the leachate depth on the liner exceeds 0.3 meter ( 1 foot), leachate will be pumped into a holding tank before testing, treatment (if required), and appropriate disposal. Pump size will depend on the capacity and filling rate of each sump and will be sufficient to remove excess leachate from the worst-case design event in a few days at the most. Holding tank sizes will be sufficient to accommodate the entire volume of the design storm collected in the catchment area serviced by the sump. The volumes of these tanks will be determined during definitive design.

4.12.6.1.2 Secondary System. In spite of the use of adequate materials and careful design and construction techniques, the possibility that small amounts of leakage might migrate through the primary geomembrane liner must be 
1 considered. The purpose of the leak detection/secondary leachate collection

2 system is to capture all liquids that could pass through the primary liner

3 system and to allow the timely detection, collection, and removal of those

4 liquids. The components and construction of the leak detection/secondary

5 leachate collection and removal system will be similar to the primary system.

6 However, because the secondary system will manage only liquids that leak through the primary liner, rather than all of the leachate generated in the trench, the leak detection/secondary leachate collection system is expected to manage a substantially smaller leachate volume than the primary system.

As shown in Figure 4-3, the leak detection/secondary leachate system on the trench floor will consist of, from the bottom up, a geotextile cushion, a gravel drainage layer, and a second geotextile cushion. On the side slopes, the system will consist of an HDPE geonet with a nonwoven geotextile thermaily bonded to each side.

The primary function of the two geotextile cushions is to form a barrier between the gravel drainage layer and the adjacent primary and secondary geomembranes, thereby preventing puncturing of the geomembranes. Any leachate that might penetrate through the primary geomembrane will be collected within the gravel drainage layer. This layer will be $0.3-$ meter (1-foot) thick, and will be composed of uniformly-graded fine gravel with a hydraulic conductivity of at least 0.01 centimeter per second (28 feet per day). Rounded to subangular gravel particles will be used to avoid potential damage to the underlying secondary geomembrane. The median grain size will be established during definitive design of the trench.

Because the expected volumes of leachate penetrating the primary geomembrane are expected to be small, there is no anticipated need for any additional drain pipe system in the leak detection/secondary leachate collection system.

Proposed slopes in the trench floor and sump locations were discussed previously (Section 4.12.6.1.1) for the primary leachate collection system. These slopes and sump locations will be the same for the secondary system. Liquids in the leak detection system will flow to sumps that will be sized to promote rapid detection of secondary leachate. The secondary sump will be monitored regularly for the presence of leachate. When the leachate depth on the liner exceeds 0.3 meter ( 1 foot), leachate will be pumped into a holding tank before testing, treatment (if required), and safe disposal. The final sizes of the sumps and the capacity of the leak detection sump pumps will be determined during definitive design and will be based on the results of the action leakage rate (ALR) calculations described in the following.

Despite all efforts to properly design and construct the primary liner to prevent infiltration of leachate, some leakage of leachate might occur through the primary liner. As part of the definitive design of the liner system, an ALR calculation will be conducted to determine the maximum design flow rate that the leak detection system described previously can remove without the fluid head on the bottom geomembrane exceeding 0.3 meter ( 1 foot). The ALR 51 will be calculated using the EPA guidance documents (e.g., EPA 1992a). The 
1 design, construction, and operation of the leak detection system. Note that

2 the ALR is based on the flow capacity of the leak detection system rather than 3 on the amount of liquids expected to leak through the primary liner. The 4 definitive design of the liner system will ensure that the pumping capacity of 5 the leak detection sump is greater than the ALR.

As described previously, a certain amount of leakage through the primary liner system is possible and the volume of this leakage will be monitored throughout the operation of the ERDF trench. The ALR value described previously also will be used as a threshold value for determining whether the amount of leakage indicates that the primary liner is not functioning normally. A response action plan will be prepared to establish actions that will be taken if the volume of leachate penetrating the primary liner indicates that the leakage rate exceeds the ALR. The intent of the response action plan is to ensuris that any leachate that does leak through the primary liner will not migrate out of the trench and into the environment.

An ERDF-specific response action plan will be prepared before the start of operations that will describe how and when the regulatory authorities will be notified in the event that the ALR is exceeded, and wil1 indicate that assessments, monitoring, and evaluations will occur to determine the location, size, and cause of any leak. The plan also will provide a listing of preferred options for remediation of a potential leak. An example of a remedial action that might be used if the ALR is exceeded in a particular cell is the placement of a geomembrane cover over the waste in that cel1. This cover would direct infiltration into adjacent cells. Waste placement could be resumed until the cell was full and the low-permeability interim cover installed. In general, the selected remediation efforts will be those that are easiest to implement, with more difficult or expensive options to be applied only if earlier approaches do not achieve expected results.

4.12.6.2 Equivalent Capability of Synthetic Drainage Material. The equivalent capacity of the primary and secondary systems is discussed in the following sections.

4.12.6.2.1 Primary System. As noted in Section 4.12.6.1.1, the primary leachate collection system on the side slopes of the trench will consist of an HDPE geonet with a nonwoven geotextile thermally bonded to each side. In the definitive design of the trench, this geocomposite will be shown to have a transmissivity equivalent to a 0.3 -meter- (1-foot-) thick granular drainage layer with a hydraulic conductivity of 0.01 centimeter per second ( 28 feet per day). The demonstration of equivalent transmissivity will be based on manufacturer's specifications and engineering analyses.

4.12.6.2.2 Secondary System. The geocomposite selected for the leak detection/secondary leachate collection system on the side slopes of the trench is physicaliy the same as the primary geocomposite. Additionally, the performance requirements for the secondary geocomposite are the same. Therefore, the equivalent capacity demonstration described in Section 4.12.6.2.1 also will apply to the secondary leachate collection system. 
DOE/RL-94-40, Rev. 0

$06 / 94$

4.12.6.3 Grading and Drainage. Drainage within individual leachate collection cells is discussed in Section 4.12.6.1.1 for the primary leachate collection system and in Section 4.12.6.1.2 for the secondary leachate collection system. Over each leachate collection cell, the base of both the primary and secondary leachate collection systems will have a 1 percent slope towards the sumps. A final grading plan will be prepared as part of the definitive design of the ERDF trench.

The conceptual design indicates that the development of the ERDF trench will proceed on a cell-by-cell basis. Development of the trench leachate collection cells is discussed in Section 4.12.6. During each stage, the liner system at the eastern edge of each cel1 wi11 extend at least 6.1 meters (20 feet) beyond the crest separating (along the east-west axis) adjacent cells (Figure 4-5). This will prevent run-on water from unlined areas of the trench from entering the leachate collection systems in the developed cells. The liner will be temporarily terminated by extending the geotextiles in the iner system to cover the other more vuinerable layers. The entire edge will be covered with a protective layer of soil. During the next stage of construction, the existing liner will be uncovered and joined with new material for the new cell.

4.12.6.4 Maximum Leachate Head. During the definitive design of the ERDF trench, calculations will be made using the geometry of the leachate collection system, the flow rate of the leachate collection system, the size of the primary drain pipe system (if used), the capacity of the primary sump, and the flow rate of the sump pumps to ensure that the amount of leachate generated during a worst-case design storm event will not result in more than 0.6 meter ( 2 feet) of head above the primary geomembrane. Depths in the primary sumps could exceed this value for short periods while pumping is underway. The control system for the pumps will be equipped with an alarm to indicate faijure so that malfunctioning pump can be replaced as soon as possible. Because the primary liner will be overlain by a 0.9-meter(3-foot-) thick operations layer, the leachate that accumulates up to 0.6 meter ( 2 feet) above the primary liner will not be in contact with the remediation waste. The proposed maximum leachate head limit might be reduced within individual cells if monitoring of the leak detection/secondary leachate collection system for that cell indicates that leakage throughout the primary liner is exceeding 80 percent of the ALR.

4.12.6.5 System Compatibility of Materials and Waste. A discussion of the compatibility of the synthetic materials used in the leachate collection/detection system with the leachate was provided in Section 4.12.5.2. Compatibility testing of the piping used for transfer of leachate from the sump area to leachate storage and to the waste water treatment building may be performed, as this piping will not be readily accessible for maintenance. If a piping network is required in the primary gravel drainage layer of the leachate collection system, the pipes will be composed of HDPE (same as the other synthetic liner components). As described in Chapter 3.0, Section 3.3, one of the factors in determining the waste acceptance criteria for the ERDF will be protection of the integrity of the trench liner system from potentially damaging types and concentrations of 
DOE/RL-94-40, Rev. 0

$06 / 94$

1 chemical constituents in both the waste and leachate generated from the waste.

\subsubsection{System Strength and Stability of System Drainage Layers.} The stability of drainage layers and the strength of the drain pipe system are discussed in the following sections.

4.12.6.6.1 Stability of Drainage Layers. The geocomposite proposed for the side slopes of the trench should provide a stable base on the side slopes ( 3 horizontal to 1 vertical) of the trench. At this time, it appears that anticipated loads on the side slopes of the trench can be accommodated easily by commercially available geocomposites. Stresses on the side slope liner components, methods of analysis, and expected performance are discussed in Sections 4.12.3.3 and 4.12.5.3.

On the floors of the leachate collection cells, the primary concern relates to the weight of the overlying material when the ERDF trench has been filled and closed. Stresses in the synthetic liner components and expected responses are discussed in Section 4.12.5.3. With respect to the gravel drainage layers, the main stability factor is bearing capacity. For the anticipated types of material and relatively low loads, bearing capacity is expected to be adequate. Standard foundation analyses will be performed to confirm this assumption.

4.12.6.6.2 Strength of Piping. Sizing and analysis of the trench riser pipes housing submersible pumps will be performed as part of the definitive design, once the gravel drainage layer and sump capacities have been

finalized. This analysis will consider allowable deformations for each piping element in the leachate collection and removal systems. Load calculations, as proposed in Section 4.12.3.3, will be used with industry standard pipe schedules to specify pipes with adequate factors of safety.

If a piping network is required in the gravel drainage layers of the primary or secondary systems, the analyses and specifications described previously also will be applied to the drainage network.

4.12.6.7 Prevention of Clogging. The final design of the geotextile layers in the primary leachate collection system will include analyses of these layers as filters for the retention of overlying operations layer materials. There are no plans to conduct clogging tests at this time. Instead, a conservative analytical method [ASTM D-4751 (ASTM 1993)] will be used to evaluate the apparent opening size versus the particle size of the material in the operations layer to maximize the reliability of the primary leachate collection and removal system. The chemical compatibility of the geotextiles in the primary leachate collection system with the expected leachate will be analyzed in the final design as discussed in Section 4.12.5.2. 
It is not expected that the secondary leachate collection and removal system will clog due to overlying sediment infiltration. This is because the secondary system will be overlain by a HDPE primary geomembrane and three layers of geotextiles. Only severe and unexpected damage to the primary geomembrane would allow sediments to enter the secondary system.

4.12.6.8 Management of Leachate. The leachate collected in the sumps of the liner system will be pumped out of the sumps and up the side slope of the trench via discharge lines in the riser pipes. At the top of the trench, the 10 leachate will discharge to a gravity drained collector pipe that runs parallel 11 to the long axis of the trench. The collector pipe will convey the leachate

12 to the leachate storage tanks located near the southwest corner of the trench. The conceptual design of the ERDF indicates that the leachate storage tanks will be modutanks or a similar design. The tanks will be constructed with rigid walls and have double HDPE liners with leak detection. The collected leachate will be pumped to the waste water treatment bullding (refer to Section 4.14.4) for treatment. The final design of the leachate conveyance system and the leachate collection area will be conducted during definitive design of the ERDF.

\subsubsection{Liner System, Construction, and Maintenance}

This section discusses liner system construction and maintenance. The conceptual 1 iner (primary and secondary) systems are described in Section 4.12 .3 and are shown in Figure 4-3. The actual components of these systems will be selected during the definitive design process, based on performance requirements related to trench geometry, waste compatibility with synthetic materials, and material properties of soil components of the iner systems. Because these factors currently have not been defined, specific materici and construction specifications, maintenance procedures, and quality control plans cannot be completed at this time. Once the components of the liner sysiams are adequately defined, the construction and maintenance procedures ciscribed in the following sections will be fully developed and finalized, ano incorporated into this application. Only industry-proven materials and construction methods will be used.

\subsubsection{Material Specifications. Material specifications are described in} the following paragraphs.

4.12.7.1.1 Synthetic Liners. The current conceptual design proposes two geomembrane Tiners consisting of HDPE. As described in Sections 4.12.5.2, 4.12.5.3, and 4.12.5.4, final selection of the liner material will be based on liner/leachate compatibility and liner strength. Following final selection, material specifications for each synthetic component of the liner system will be prepared and submitted for regulatory agency acceptance.

4.12.7.1.2 Soll Liners. The current conceptual design proposes a low-permeability soll layer as the base component in the trench liner system. As described in Section 4.12.5.5, final design of the soil liner material will 51 be based on laboratory testing and field studies. Once the final design is 
1 established, material specifications for the soil components of the 1 iner

2 system will be prepared and submitted for regulatory agency acceptance.

4.12.7.1.3 Leachate Collection and Removal System. The proposed primary and secondary leachate collection and removal systems are described in Sections 4.12 .3 and 4.12.6. Candidate matertals have been proposed for the following liner/leachate collection system components: the drainage gravel will be hard, durable, rounded to subangular, and chemically inert; and the geomembranes, geonet and drainage pipes (if required) w111 be HDPE.

The materials to be used for all of the iner/leachate collection system components will be defined during definitive design. Once the components of the liner systems are adequately defined, the material specifications for individual leachate collection and removal system components will be developed, finalized, and submitted for regulatory agency acceptance.

4.12.7.2 Construction Specifications. The actual components of the 1 iner system foundation, soll liner, synthetic liners, and leachate collection and removal systems will be selected during the final design process. Once the components of the 1 iner and leachate collection systems adequately are defined, construction specifications will be developed, finalized, and submitted for regulatory agency acceptance.

4.12.7.3 Construction Quality Control Program. A detailed CQA plan will be prepared for the ERDF trench and will be submitted for regulatory review before construction of the ERDF trench. The CQA plan will be prepared in accordance with the technical guidance documents (EPA 1993, EPA 1986a).

\subsubsection{Leachate Collection/Detection System Maintenance. Accessible} components of the leachate collection and removal systems will be maintained regularly to ensure their continued integrity during ERDF operations and the postclosure care period. During trench operations, the leachate collection and removal systems will be inspected regulariy, as described in Chapter 6.0, Section 6.2. During the postclosure care period, maintenance of the passive protection systems generally will be performed on an as-needed basis. Maintenance of the mechanical systems, such as pumps and certain sampling devices, will be performed regularly.

Maintenance reports will be prepared to document all maintenance activities. The maintenance reports will reference the initiating inspection report in the inspection log, and will incorporate by reference all maintenance records to provide a comprehensive documentation of all maintenance activities. The maintenance reports and accompanying records will be maintained current and will be available for examination during the operating and postclosure care periods. All postclosure maintenance records will be maintained by the contact 1isted in Chapter 11.0, Section 11.11.4.

4.12.7.5 Liner Repairs During Operations. Damage to the 1iner system during operation of the ERDF trench is not expected because the presence of the 0.9-meter- (3-foot-) thick operations layer that will be placed over the entire liner before commencing waste placement. However, it is possible that the liner could be damaged because of accidental excavation of the operations layer (or some other problem). As a result, a plan will be developed during 
DOE/RL-94-40, Rev. 0

$06 / 94$

definitive design of the ERDF trench that w111 describe the procedures that will be followed to uncover the liner system, assess the potential damage, and conduct repairs if necessary.

\subsubsection{Run-on and Run-off Control Systoms}

A general description of proposed run-on and run-off control systems is discussed in the following sections. A specific surface water management plan will be developed as part of the ERDF trench definitive design. For the ERDF trench, storm water run-on, run-off, and detention design wili be equivalent to the requirements of 40 CFR 264 and WAC 173-303.

4.12.8.1 Run-on Control System. A perimeter run-on diversion system will be located along the outer margin of the ERDF trench to prevent run-on generated by precipitation from entering the active portions of the trench. Before placement of the final cover on the trench, the perimeter run-on diversion system also will act as run-off control for precipitation falling on the upper interim cover that covers the waste in completed portions of the trench. Run-on control might not be required for the southern edge of the trench because the southern edge of the trench might be higher than the adjacent ground surface. However, run-off from the interim cover that flows toward the south must still be managed. The specific design for the run-on control system along the southern edge of the ERDF trench will be determined during definitive design.

Because the waste in the completed portions of the trench will be covered with an interim cover, or upper interim cover and a low-permeability layer (refer to Section 4.12.9), the run-off from the interim cover will not contact the waste material. A low-permeability layer will be placed on top of the upper interim cover annually. The combination of the interim cover and the low-permeability cover is referred to as the final interim cover. The surface water management plan for the ERDF will describe methods for ensuring that storm water run-off from waste management areas is collected separately from run-off from nonwaste management areas. It is anticipated that the precipitation collected in the run-on diversion system of the ERDF trench will be from nonwaste management areas of the ERDF. As a result, it is not anticipated that the storm water collected in the run-on diversion system will require sampling or treatment before discharge to a detention pond for metering to an existing drainage channel. The discharge point will be determined during detailed design of the surface water management system.

After the final cover has been placed on a portion of the trench, run-on control to the final cover and run-off control from the final cover will be controlled by a perimeter drainage system designed for the final cover (Chapter 11.0, Section 11.10.5.5). Because part of the trench still may be in operation after the final cover has been placed on part of the trench, the definitive design of the ERDF trench will include discussions of how the run-on control system for the working part of the trench will be integrated with the run-on control system for the final cover. The method for inteyrating the run-on control systems will be incorporated into the surface water management plan. 
1 4.12.8.1.1 Design and Performance. Final design of the run-on diversion 2 system for the ERDF trench has not been conducted. The final design of the 3 system will use data complled in the Climatological summary for the Hanford 4 Area (PNL 1983), and w111 conform to 40 CFR 264 and WAC 173-303 standards. 5 Conceptual design and performance standards are outlined in the following 6 paragraph.

7

The diversion system controlling run-on to active portions of the trench will be constructed parallel to, and a minimum of 0.9 meter ( 3 feet) from, the outside edge of the liner system anchor trench. The diversion system wili be constructed around the entire perimeter of the trench. The diversion system will form a barrier to surface flows, preventing run-on from reaching the perimeter of the active region of the ERDF trench. Unless it is determined to be necessary, the diversion system will not be 1 ined. The diversion system will be sized to have a minimum of 9 centimeters ( 3.5 inches) of freeboard when carrying the peak flow from the 25-year, 24-hour storm [3.9 centimeters (1.56 inch) precipitation (PNL 1983)]. The system also w111 be designed so that no system-related hydraulic gradients will affect the function of the adjacent ERDF trench.

4.12.8.1.2 Calculation of Peak Flow. Because the run-on diversion system for the ERDF trench also will be used to manage run-off from the interim cover in completed portions of the trench, the sizing of the run-on diversion system will be based on expected peak fiow from both the catchment area and from the maximum area of the trench that will be covered with an interim cover. The requirements for acceptable freeboard also will be included. The peak discharge will be determined through the use of computer modeling during detalled design of the storm water management system.

Flow calculations for the primary leachate collection and removal system will include the worst-case precipitation inflow from the margin of the trench that is not intercepted by the trench run-on control system.

4.12.8.2 Run-off Control system. There will be no run-off from the active portions of the ERDF trench because the active portion will be located below grade, and all precipitation that falls within the trench will be managed in the leachate collection system. Run-off from those portions of the trench covered by the interim cover will be managed in the same diversion system that manages run-on to the trench. The run-off from the those portions of the trench covered with the final cover is discussed in Section 11.10.5.5.1.

4.12.8.2.1 Design and Performance. There will be no run-off from the active portions of the ERDF trench. Therefore, the design and performance requirements of this section are not applicable.

4.12.8.2.2 Calculation of Peak Flow. There will be no run-off from the active portions of the ERDF trench. Therefore, the calculations of peak flow are not applicable.

4.12.8.3 Management of Collection and Holding Units. The storm water collected in the run-on diversion system will not receive run-off from waste management areas of the ERDF and therefore is not expected to contain waste 

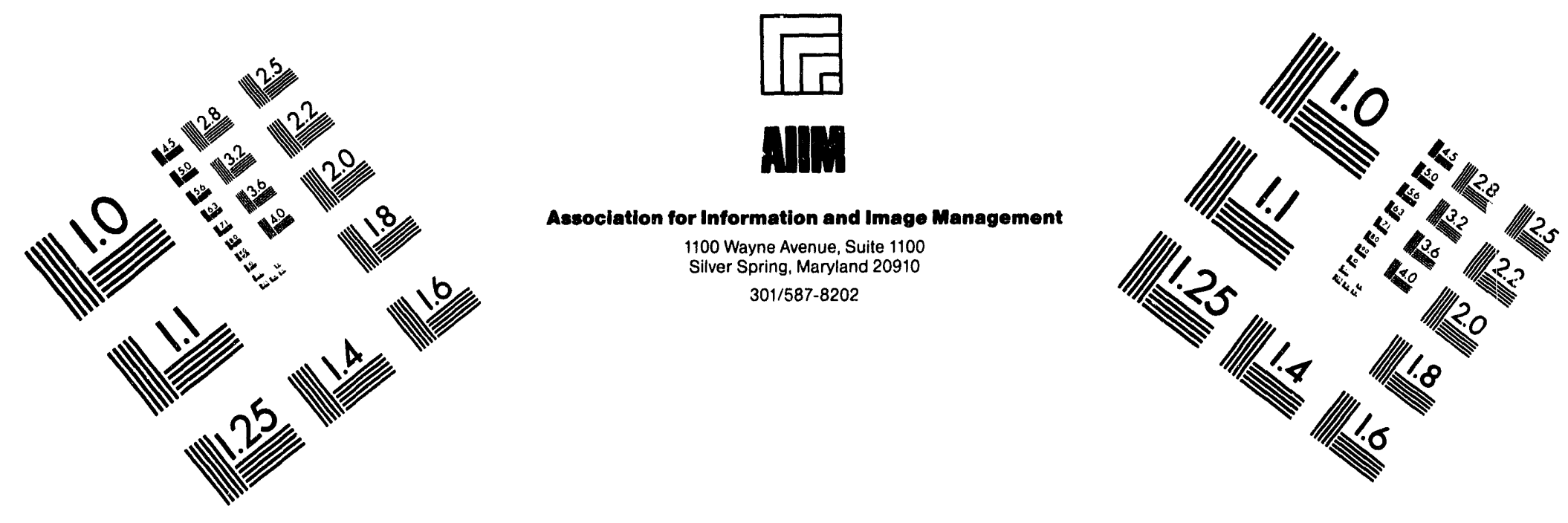

\section{Centimeter}

$\begin{array}{llllllllllllllll}1 & 2 & 3 & 4 & 5 & 6 & 7 & 8 & 9 & 10 & 11 & 12 & 13 & 14 & 15 & \mathrm{~mm}\end{array}$

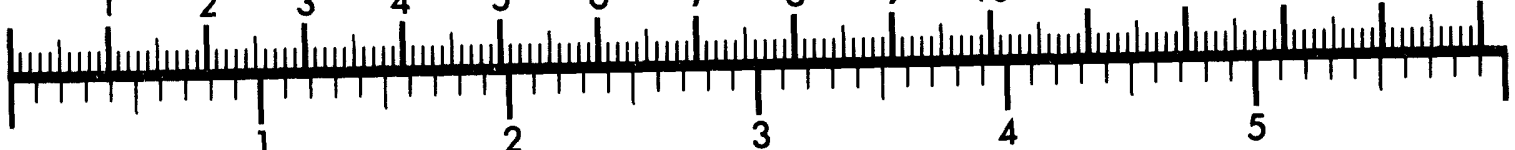
Inches
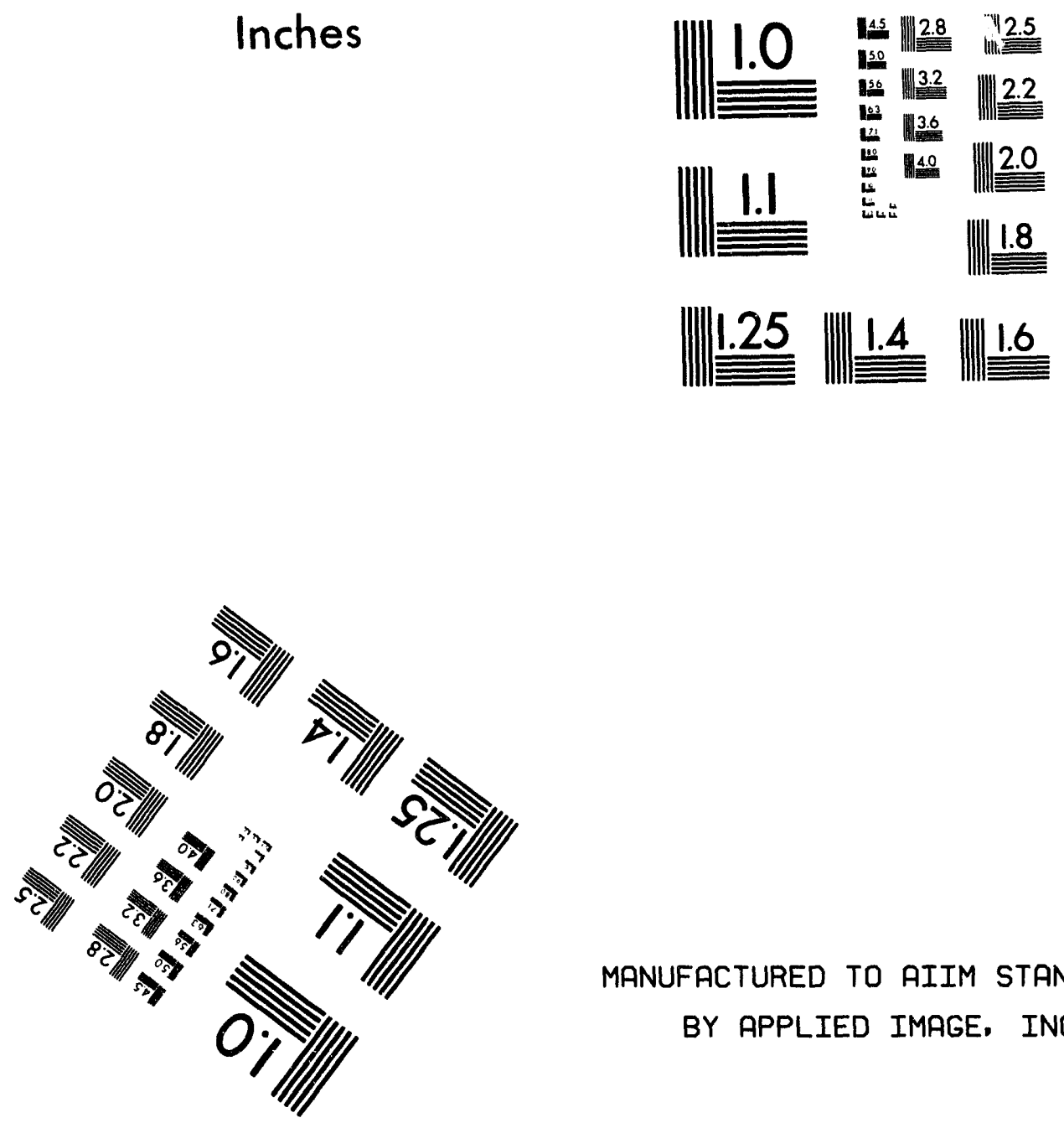

MANUFACTURED TO AIIM STANDARDS BY APPLIED IMAGE. INC.

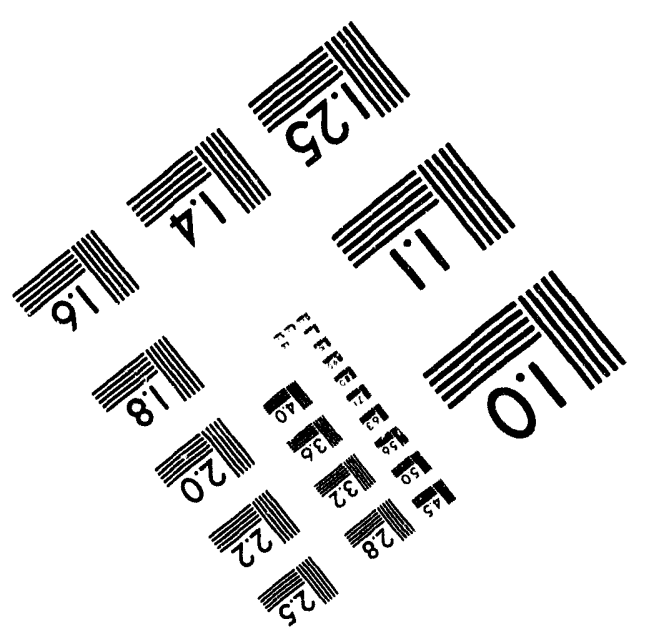



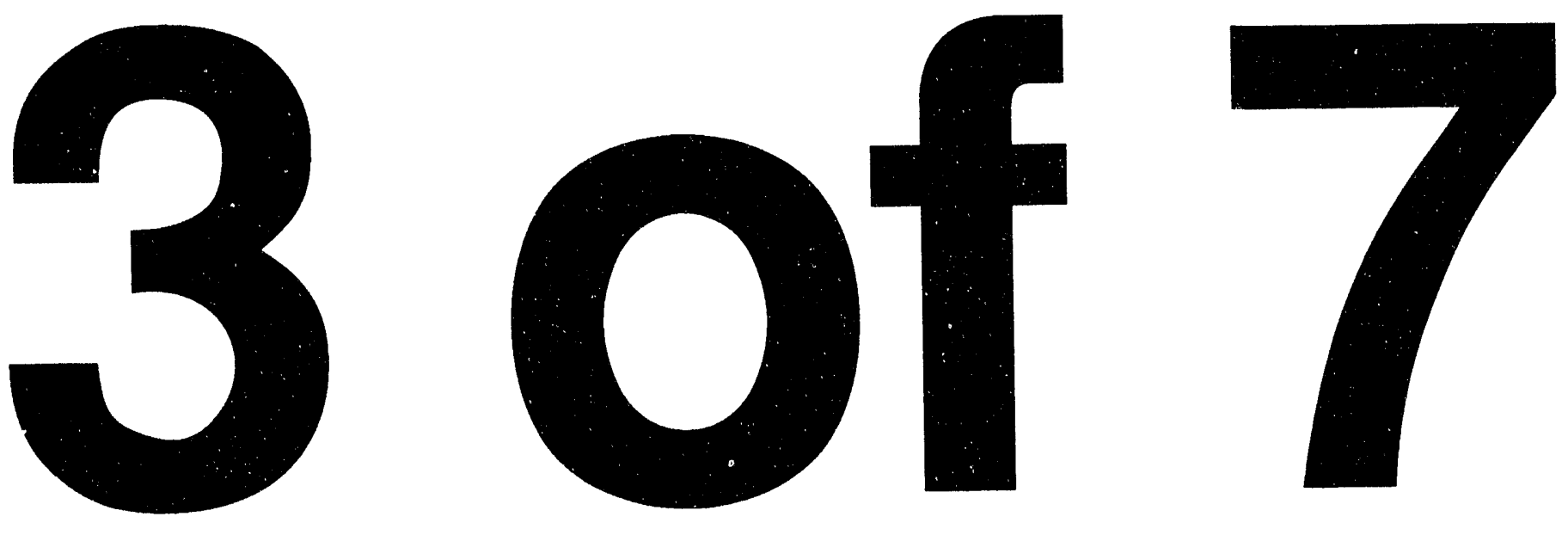
constituents. As a result, this storm water will not require sampling or treatment before discharge. The conceptual design of the ERDF includes the use of a detention pond to allow the collected run-off to be metered before controlled discharge to an existing drainage channel. The discharge point will be determined during detailed design of the surface water management system.

Storm water that falls within the active portion of the ERDF trench will be collected and managed within the trench leachate collection system. The collection and disposition of the storm water run-off from the other waste management areas (i.e., ERDF support units) are discussed in Section 4.14. In general, the run-off from the other waste management units will be considered as potentially containing waste constituents and will be collected separately and conveyed to RCRA-compliant tanks for detention. A surface water management plan will be prepared as part if the ERDF definitive design. This plan will contain detailed designs (i.e., capacities, construction specifications, etc.) for any collection and holding units (e.g., tanks), and will describe the maintenance of these units.

4.12.8.4 Construction of Run-on/Run-off Control. The structure that will comprises the run-on diversion system most likely will be excavated with a dozer or grader. Quality control will include surveying of the channel centerline and channel depth to ensure adherence to channel slope and capacity specifications.

Based on the relatively flat topography at the ERDF site, it is unlikely that the run-on diversion system will be lined. If lining is required, granular soil, asphalt, or other material will be used. Analys is and selection of a lining system, if required, will be performed during definitive design.

Precise details of channel locations and alignments and of any special construction considerations for particular reaches of the channel will be described in the surface water management plan. A CQA plan will be developed to ensure that the run-on diversion system construction is in accordance with design requirements (refer to Section 4.12.7).

4.12.8.5 Maintenance of Run-on/Run-off Control. Maintenarice of the run-on diversion system mainly will involve repairing sections of channel where erosion has become excessive and cleaning areas of accumulation. The diversion system will be designed to be stable while conveying the 25-year, 24-hour storm run-off. However, high-intensity, short-duration thunderstorms and large, infrequent precipitation events might lead to momentary velocities greater than those for which the system is designed. Monthly monitoring of the diversion system through the wet season and quarterly for the remainder of the year will be performed initially to ensure that eroding areas are located and repaired. If operating experience indicates that less frequent inspections would be adequate, the inspection schedule may be modified. : All maintenance or repairs of the system will be inspected by a quality control engineer for conformance to original specifications. 
1 If extensive physical maintenance of the run-on diversion system is

2 required, the surface water management $p l a n$ will be used as a guide to ensure

3 that changes or repairs are consistent with overall system design and

4 performance standards.

\subsubsection{Control of Wind Dispersal}

The remediation waste to be managed in the ERDF includes bulk soils containing particulate matter that may be subject to wind dispersal if preventative measures are not taken. The measures planned to prevent the wind dispersal of remediation waste include both operational controls and engineering controls. The operational controls include the use of dust suppressants and the engineering controls include the placement of an interim cover. Both types of measures are discussed in the following sections.

Because of the potential for wind dispersal of hazardous/dangerous waste constituents, air monitoring for worker safety and contaminant release wil1 be corducted at the ERDF. An air monitoring plan will be developed that will specify the type, location, and frequency of air monitoring that will be conducted and identify the constituents that will be monitored.

4.12.9.1 Dust Suppressants. The conceptual plan for the operation of the ERDF trench includes the use of dust suppressants to control the wind dispersal of remediation waste. Dust suppressants may be applied to the waste as the waste is discharged from the containers to the ERDF trench, and possibly as the waste is spread and compacted. In addition, dust suppressants will be applied to the exposed waste on the working face of the trench on an as-needed basis (daily at a minimum). This will prevent both the overnight wind dispersal of waste and dispersal during the downtime between the two daily shifts. The Dust Suppressant Pilot Study for the Environmental Restoration Disposal Facility (DOE-RL 1994b) identifies potential dust control agents that can be applied to waste soils placed in the ERDF trench. The study included bench scale wind tunnel tests using various dust suppressants and methods of application under a variety of meteorological conditions. The results of the study indicated that calcium lignosulfonate, acrylic emulsion, and possibly magnesium chloride potentially may be effective low cost products for use on nontraffic areas of the ERDF (such as the waste on the active face of the trench). The results of this study should be considered as a screening evaluation to identify the most promising dust suppressants for initial use at the ERDF. The application rates and other parameters for actual use of the dust suppressants will be adjusted based on the results of dust monitoring during ERDF operation to ensure that dust emissions are within acceptable limits.

4.12.9.2 Interim Cover and Final Interim Designs. The conceptual design of the ERDF trench includes the placement of interim covers (Figure 4-2).

The purpose of the interim covers is to prevent wind dispersal of waste, to provide a clean operating surface for the vehicles carrying waste, and to minimize the amount of precipitation reaching the waste. 
The interim cover will consist of approximately 0.6 meter ( 2 feet) of clean soil that will be placed on the remediation waste daily. Placement of the remediation waste within the 21.3 meter ( 70 foot) deep ERDF trench will occur in two 10.6 meter (35 foot) lifts. At the end of each day, the interim cover will be placed on those areas where the top of the spread and compacted remediation waste has reached either the 10.6 or the 21.3 meter (35 or 70 foot) levels. The waste on the upper surface of the waste at the 21.3 meter ( 70 foot) level will be sloped downward from the center to the edges of the trench at a 2 percent slope. Note that the 21.3 meter (70 feet) level is measured at the edges of the trench and that the upper surface of waste along the center line of the trench actually will be approximately 4.2 meters ( 14 feet) higher than it is at the edges of the trench.

The interim cover will be placed at a constant thickness so that the top of the interim layer preserves the 2 percent slope.

A low-permeability layer will be placed annually on top of the upper interim cover and will consist of a layer of asphalt, or other material such as a geomembrane. If a geomembrane is used, it will be covered with a layer of clean soil to prevent wind damage and to minimize weathering and deterioration. The combination of the low-permeability layer and the upper interim cover is called the final interim cover. The detailed final design of the low-permeability layer will be determined during the definitive design of the ERDF trench.

4.12.9.3 Other Dust Control Measures. In addition to the use of dust suppressants and an interim cover, a maximum wind speed at which waste placement operations at the ERDF trench must stop will be determined during the definitive design stage. In addition to the maximum wind speed criteria, ERDF personnel will cease waste placement operations in the event they determine that it is unsafe to continue operations because of climatic conditions, e.g., extremely cold temperatures, unrelated to wind speed.

In addition to the control of wind dispersal of remediation waste, measures will be taken to control the spread of dust from nonwaste and noncontaminated gravel surface haul roads, and travel areas on the trench floor and the interim cover. This will be accomplished by both operational controls and maintenance of the roads and travel surfaces. The operational controls will include limiting the maximum vehicle speed to minimize dust generation while maintaining the project schedule. The maintenance of the gravel roads and travel surfaces will occur regularly and will include surface grading, placement and compaction of additional gravel or cover material on deteriorated areas, and the appication of water or other dust suppressant materials. The roads might not require much dust control during the winter months, or if an effective dust suppressant is used throughout the year.

\subsubsection{Liquids in the Environmental Restoration Disposal Facility Trench}

The ERDF waste acceptance criteria (Chapter 3.0) indicates that no waste containing free liquids will be accepted at the ERDF trench. Therefore, the specific requirements for the acceptance of 1 iquids in landfills do not apply to the ERDF trench. 


$$
\text { DOE/RI-94-40, Rev. } 0
$$

$06 / 94$

\subsubsection{Containerized Waste as Applied to Environmental Restoration Disposal Facility Remediation Waste}

Most waste will be transported to the ERDF trench in bulk quantities, within reusable containers with a volume of approximately 26.75 cubic meters ( 35 cubic yards). An estimated 98 percent of the waste will consist of contaminated soil that will be unloaded from the waste containers at the crest of the trench working face before being spread over the face. These waste containers will be decontaminated and re-used.

An estimated 2 percent of the waste containers are expected to be singleuse and/or disposable containers. The void spaces in single-use/disposable containers used to manage remediation waste will be filled with inert material or waste before arrival at the ERDF. These containers will be delivered to the floor of the working trench, where the containers will be off-loaded by a crane, forklift, or other type of equipment. Any voids created by the placement of these disposable containers will be filled before the bulk fill advances over the waste. Demolition debris may also require subsidence control measures after placement on the trench floor.

\subsubsection{Special Waste Management Plan for Units Containing Waste F020, F021, F022, F023, F026, and F027}

'According to the conceptual design for the ERDF trench, hazardous/dangerous waste types F020, F021, F022, F023, F026, and F027, as defined in 40 CFR $261.31(\mathrm{a})$ and WAC 173-303-082, will not be accepted for placement at the trench. Therefore, the specific requirements for managing these wastes do not apply to the ERDF trench.

\subsubsection{Prevention of Reaction of Ignitable, Reactive, and Incompatible Waste in the Environmental Restoration Disposal Facility}

Under the 40 CFR 264.552 and WAC 173-303-646 CAMU regulations, specifically under the regulations defining the expanded CAMU concept [40 CFR 264.552(a)(1) and (2) and WAC 173-303-646(4)(b) and (c)], a CAMU is not considered a land disposal unit, or considered a unit subject to the MTRs. Therefore, the regulations that prohibit the placement of ignitable or reactive waste in 1 andfills and the placement of incompatible waste within the same landfil1 cell do not apply to the ERDF trench. However, hazardous/dangerous waste will be managed at the ERDF, and the operation of the ERDF trench must be protective of human health and the environment. Therefore, the following measures will be taken to prevent the reaction of ignitable, reactive, and incompatible waste within the ERDF trench.

- Ignitable and reactive remediation waste will be prohibited from placement in the ERDF trench. This prohibition will be included within the ERDF waste acceptance criteria. The ERDF waste acceptance criteria are described in Chapter 3.0, along with the procedures that will be used to ensure that remediation waste that does not meet the 
30

criteria is not accepted for placement in the ERDF trench. The operators of the remediation sites may request a variance from the prohibition on placement of reactive or ignitable waste on a case-bycase basis. The request for variance will be evaluated by the ERDF operators and appropriate regulatory authorities to determine whether to allow a variance for placement in the ERDF trench.

- To mitigate the adjacent placement of incompatible waste from different remediation sites within the ERDF cells, an operations plan will be developed for the ERDF trench. The operations plan will include a waste placement procedure that will describe the placement techniques that will be used to prevent the reaction of incompatible waste that has been $p$ laced in the trench. Any treatment of incompatible waste will occur before transport to the ERDF.

\subsection{ADDITION OF CORRECTIVE ACTION MANAGEMENT UNITS}

For the purposes of this application, the CAMU includes the entire 4.14 square kilometer ( 1.6 square mile) area of the ERDF. However, the conceptual design for the ERDF indicates that the ERDF trench is the only portion of the CAMU in which remediation waste will be left in place after closure. If at some time in the future it is determined that additional landbased units are required to facilitate ERDF operations (e.g., surface impoundments for managing leachate or potentially contaminated run-off), all of the information to demonstrate that the unit(s) meet CAMU decision criteria will be submitted to the appropriate regulatory authority for review and approval.

\subsection{DESCRIPTION OF ENVIRONMENTAL RESTORATION DISPOSAL FACILITY SUPPORT UNITS}

This section provides a brief description of the support units that will be used in the operation of the ERDF. The information is included to demonstrate that the design and construction of the ERDF support units are adequate to ensure that waste management activities associated with placement of remediation waste in the ERDF trench will not create unacceptable risks to humans or the environment resulting from exposure to hazardous/dangerous waste or hazardous/dangerous constituents. The ERDF support units also will facilitate the implementation of reliable, effective, protective, and cost-effective remediation because the support units will be designed and constructed specifically to support the management of the remediation waste generated from remediation sites. The use of support units that are designed specifically for the ERDF and are located within the CAMU will expedite the timing of remedial activity implementation by ensuring that all required activities effectively can be accomplished within a compact area.

Although the EKDF support units described in Section 4.14 , e.g., the waste water treatment building and the decontamination building, are physically located within the proposed CAMU, these support units will maintain their separate regulatory identity as required in 40 CFR 264.552 and 
1 WAC 173-303-646. The design, operation, and permitting (if required) of these

2 support units will meet all RCRA Subtitle $C$ requirements. The regulatory

3 status of the support units will be determined during definitive design. If

4 it is determined that the ERDF support units always will manage

5 hazardous/dangerous waste for 90 days or less, those units can be operated as

6 generator accumulation units. If hazardous/dangerous waste will be managed

7 for greater than 90 days, applications providing the information required to

8 obtain a dangerous waste permit will be submitted to Ecology for review and

9 approval before managing RCRA hazardous/dangerous remediation waste in the

10 support units.

11

12

13

14

15

19

The descriptions provided throughout this section are based on a conceptual design for the ERDF because detailed design information is not yet available. The definitive design for the ERDF is in progress and, when complete, will include detailed information concerning the design, construction, and operation of the ERDF support units. Figure 4-6 provides a generalized flow diagram for waste management at the ERDF.

\subsubsection{Rail and Tractor Trailer Container Handling Areas}

Remediation waste will be placed in containers at the generation point. The volume of the reusable waste containers will be approximately 26.75 cubic meters ( 35 cubic yards). The primary method of transporting the containers of remediation waste to the ERDF will be by rail. However, some containers also will be transported by tractor trailer. As described in the following, areas will be constructed to: transfer the full waste containers from the railcars or remediation site tractor trailers to dedicated ERDF transport vehicles; empty the contents of the containers into the ERDF trench (or place the entire container in the trench if it is a single-use container); and load the empty, decontaminated container back on to a railcar or tractor trailer for the return trip to the remediation site. A description of the design of the container handling area is provided as follows. A description of the operation of the area is provided in Section 4.15 .

A single railroad track will be used to convey full waste containers from the remediation sites to the ERDF. A circular route will be constructed in the vicinity of the ERDF so that locomotives will not be required to back up or turn around. As shown in Figure 4-1, a portion of the circular route will parallel the boundary of the ERDF trench and will be of sufficient length to accommodate both the full waste container unloading area and the empty decontaminated container loading area described in Section 4.14.1.1. The tractor/trailers conveying full waste containers from the remediation sites to the ERDF will travel over two lane asphalt paved roads designed to adequately support the gross weight of the loaded vehicles.

4.14.1.1 Loaded Rail Car and Tractor Trailer Transfer/Unloading Area. The conceptual design of the ERDF includes a single transfer pad that will be used to off-load full waste containers from both railcars and tractor/trailers. The full waste container transfer pad, which will be located near the ERDF trench (Figure 4-1), will be constructed of asphalt pavement with sufficient 52 strength to support the weight of a full container combined with the weight of 
1 any of the three types of vehicles that will operate on the pad. These

2 include the remediation site tractor/trailers, the wheeled container handlers

3 used to off-load the containers, and the ERDF-dedicated tractor/trailers that

4 will transport the containers to the trench.

The pad will be bordered by an off-loading rail siding connected to the main circular track. The siding will be a pass-through style capable of managing 17 container railcars plus an engine. The exact size of the full waste container transfer pad has not been established, but it is anticipated that it will be approximately six railcars long and wide enough to allow easy off-loading of the containers from the railcars and remediation site tractor trailers. Note that neither the railcar siding nor the full waste container transfer pad are intended to be used as a permitted hazardous/dangerous waste container storage area because under normal operating routine, storage of waste containers will not occur. The railcars will be unloaded at the transfer area and the full waste containers will be transported to the ERDF trench by ERDF-dedicated tractor trailers immediately after unloading from the railcar or tractor trailer. A small portion of the pad may be designated as a 90-day generator accumulation area to manage those full waste containers that require additional documentation before placement in the ERDF trench. Containers that cannot be adequately documented will be returned to the remediation site before expiration of the 90-day limit. The generator accumulation area also may be used occasionally to store containers of spill residue during characterization.

To minimize the potential for release of hazardous/dangerous waste or constituents due to the operation of the full waste container transfer pad, the pad will be constructed so that all precipitation that falls on the railcar siding and the asphalt surface of the pad will be collected and segregated from the run-off from other parts of the ERDF. The disposition of precipitation collected from the pad will be determined by sampling and analysis (refer to Chapter 3.0 for more discussion on sampling and analysis of run-off). A comprehensive precipitation monitoring $p 1$ an will be developed and submitted to the appropriate regulatory authorities for review and approval before managing hazardous/dangerous waste at the ERDF.

4.14.1.2 Trailer Tipping Area. The trailer tipping area will not be a permanent unloading pad. Instead, the trailer tipping area will consist of the portion of the interim cover that is located adjacent to the working face of the trench. The trailer tipping area will move as the filling of the trench progresses. The area will contain up to four 45,400-kilogram [100,000-pound (50-ton)] capacity trailer tippers that will be capable of elevating one end of a loaded container to dump the contents while the container is still mounted on the transport trailer. Each trailer tipper will be equipped with an appurtenance capable of spraying dust suppressants on the waste as the waste is discharged from the container. Because the tipping area will be moved, the trailer tippers will be designed to be relocated by a dedicated ERDF truck-tractor, like those used to transport waste containers. The final design requirements for the trailer tippers will be determined during definitive design of the ERDF trench. 
1 4.14.1.3 Empty Contaminated Container Transfer Area. Once the waste

2 container has been emptied, the container will be transported to the

3 decontamination building (refer to Section 4.14.2). An inspection conducted

4 at the trench working face will determine whether the amount of residual

5 material in the container warrants supplementary residual removal activities

6 such as scraping with a backhoe bucket or washing with high pressure water.

7 Residual waste removal will occur before storage (for less than 90 days) in

8 the empty contaminated container transfer area. The procedures used for

9 visually inspecting the interior of the empty containers and the criteria to be used to determine if additional removal or residual material is required will be developed as an ERDF trench operations procedure. The procedures and criteria will be submitted to the appropriate regulatory authorities for review and approval before accepting remediation waste at the ERDF.

The empty contaminated container transfer pad will be located outside the decontamination building (refer to Figure 4-1). The exact size of the pad has not been established. However, it is anticipated that the pad will be large enough to allow simultaneous offloading of contaminated containers from two ERDF dedicated tractor trailers as well as storage space for 30 contaminated containers awaiting decontamination. The pad will be constructed so that all precipitation that falls on the asphalt surface of the pad will be collected and segregated from the run-off from other parts of the ERDF. The disposition of precipitation collected from the pad will be determined by sampling and analysis. The asphalt pavement will be capable of supporting the weight of an empty container combined with the weight of either the wheeled container handlers or the ERDF dedicated tractor trailers.

\begin{abstract}
4.14.1.4 Empty Decontaminated Container Transfer Area. After a waste container has been emptied and its external surfaces decontaminated, the container will be stored (for less than 90 days) at an outdoor covered area near the decontamination building (Figure 4-1). The empty decontaminated container transfer pad will be used to move containers for reuse from the storage area onto either railcars or tractor trailers for the return trip to the remediation sites for reuse. The pad will consist of an asphalt paved area (with load bearing capacity to accommodate its activities) adjacent to the storage area and near the on-loading rail siding connected to the main circular track. The siding will be a pass-through style capable of storing 17 container railcars plus an engine. The exact size of the full waste container transfer pad has not been established, but it is anticipated that it will be approximately six railcars long and 32 meters (106 feet) wide (sufficient to permit a wheeled container handler to rotate $180^{\circ}$ ). Because the transfer pad will store only decontaminated containers, any precipitation that falls on the pad will not require sampling to determine the appropriate disposition. Instead, the precipitation will be ccllected and routed to the detention storage pond that will store run-off from the nonwaste management areas of the ERDF.
\end{abstract}

\title{
4.14.2 Decontamination Building
}

The decontamination building will be located near the ERDF trench 51 52 (Figure 4-1). The decontamination building will be used to clean empty, 
1 reusable waste containers; operations vehicles; and emergency vehicles used in

2 the operation of the ERDF. As described in the following sections, the major

3 components of the decontamination building are the conveyor system and the

4 water recycling system. The design of the floor and sumps of the

5 decontamination building will incorporate RCRA MTRs for tanks because the

6 floors and sumps are likely to manage liquid hazardous/dangerous waste. The

7 components of the water recycling system will al so meet the RCRA MTRs for hazardous/dangerous storage tanks and ancillary equipment.

The conceptual design of the decontamination building indicates that it will be a rectangular structure approximately 30 meters (100 feet) wide and 67 meters ( 219 feet) long. The building will be constructed of reinforced concrete block with a reinforced concrete floor and foundation. There will be an outdoor wash pad and four indoor wash bays.

The outdoor wash pad will be used for washing the exterior of ERDF-dedicated vehicles if the vehicle must be removed from the ERDF for maintenance or repairs that cannot be conducted in the field. The decontamination of this equipment will be completed at T Plant before performing the maintenance (DOE-RL 1994a). The wash pad also will be used to clean any emergency vehicles that need to leave the ERDF. The vehicles will be washed with high pressure water from a high pressure washer permanently mounted just inside the decontamination building. The rinsate will be collected on the pad and will drain to a sump. The sump will be equipped with a pump to transfer the rinsate to the water recycling system (described in Section 4.14.2.2).

The four indoor wash bays will be located in the central portion of the building. The wash bays will be parallel to each other and to the long axis of the building. The partitions between the wash bays will be concrete block with a waterproof coating. The container washing process will be completely automated and will use high pressure water and possibly a detergent/chemical mix. The wash will be followed by two water rinses. The rinsate will collect on the concrete floor of each wash bay and flow to a sump. The rinsate will be recycled (Section 4.14 .2 .2 ).

The containers will pass through the drying room that will be equipped with two blowers for drying the containers. The first blower will use room temperature air to remove a majority of the moisture and the second blower will use hot air to remove the remaining moisture.

A radiation survey room will be located in the building. The survey room will be equipped with an automated radiological survey system that will be used to determine if the decontamination of the container was adequate. Containers that have not been adequately cleaned will be sent through the decontamination process again.

To minimize the potential for release of hazardous/dangerous constituents, the concrete floor of the entire decontamination building and the outdoor wash pad will be underlain by a secondary containment/leak collection system that will flow to a sump to allow removal of any liquid that

52 leaks through the floor. It is anticipated that this secondary containment 
1 system also will extend far enough to provide protection for the waste water 2 treatment building described in Section 4.14.4. The design and construction 3 of the secondary containment system for these ERDF support units will be 4 finalized during the definitive design of the ERDF.

A covered storage area located outside of the decontamination building will be used to store the clean containers before transport to remediation sites for reuse. The storage area will be approximately 4.6 meters wide (15 feet) and 137 meters (450 feet) long. The storage area will be near the empty decontaminated container transfer pad. Precipitation that does blow into the covered storage area will not require sampling to determine the appropriate disposition because the storage area will store only decontaminated containers. Instead, the precipitation will be collected and routed to the detention storage pond that stores run-off from the nonwaste management areas of the ERDF.

4.14.2.1 Conveyor System. The containers being cleaned in the decontamination building will be carried through the entire process on an automated conveying system. Each wash bay will be equipped with its own conveyor. Wash bay conveyors will start outside at one end of the bays, and will move the containers through the wash bay. The starting point for each conveyor will be staggered to ensure easy access for the wheeled container handlers to place the containers on the belt. After cleaning the container, each wash bay conveyor will deposit the container on to a collection conveyor located at the opposite end of the building. The collection conveyor will deposit the container on a third conveyor that will pass the container through the air drying and radiation survey areas and out to the covered storage area.

Each conveyor will be a belt-drive roller type suitable for moving a 4,540 kilogram ( 10,000 pound) container. The conveyors will be equipped with guides to keep the containers centered and to keep the containers from turning on the conveyor. The rollers will be a pair of 0.6 -meter- (2-foot-) wide rollers with one set of rollers under each side of the container. The drive belt will be able to be retracted to stop the container as needed to allow a radiation survey to be conducted.

4.14.2.2 Water Recycling System. To reduce the amount of water required for decontamination building, it is anticipated that the rinsate from the container washing operation will be recycled. The recycling system will consist of a rinsate collection system, a treatment system, and a storage tank.

Rinsate from the cleaning operations will be collected on the concrete floor of the wash bays and directed to one or more drains located in each bay. The rinsate will flow by gravity to a sand trap where heavy solid materials will be captured. The sand trap will be cleaned daily. The overflow from the sand trap will be pumped to a cyclone separator to remove the remaining heavy materials and to a settling tank where additional suspended particles will be removed. The overflow from the settling tank will be pumped through filters and into a storage tank where the overfiow can be reused. Additional treatment steps (such as reverse osmosis) can be added to the system if operations show that further treatment is needed. The solids and blowdown 
DOE/RL-94-40, Rev. 0

$06 / 94$

1 waste water generated in the cyclone settling tank and filter will be directed to the waste water treatment building described in Section 4.14.4.

The floor of the entire decontamination building and all of the associated floor drains and pipes will be underlain by a secondary containment/leak collection system that flows to a sump to allow removal of any liquid that leaks through the floor.

\subsubsection{Mobile Decontamination Unit}

Two mobile decontamination units will be used for field decontamination of dedicated ERDF vehicles and equipment to allow for servicing. Each unit will be a standard self-contained, industrial use, high-pressure, low-volume water washer with hot water and detergent options. Each water washer will be mounted on the bed of a truck along with a water source.

\subsubsection{Waste Water Treatment Building}

The waste water treatment building will be used to treat leachate generated in the ERDF trench, blowdown waste water, and solids from the decontamination building water recycling system, and possibly contaminated run-off collected from the ERDF support units. The treatment building will be located near the ERDF trench and the decontamination building. The design of the equipment, storage tanks, package treatment plant, evaporation tanks, and ancillary equipment used in the waste water treatment building described in the following will incorporate RCRA MTRs for tanks and ancillary equipment because these are likely to manage liquid hazardous/dangerous waste.

The waste water treatment building will consist of a 1,325-1iter (350-gallon) fiberglass storage/surge tank, a package waste water plant (conceptually using the reverse osmosis process), a series of evaporation tanks, and ancillary pipe and pump systems. A characterization of the leachate that will be generated in the ERDF trench has not been conducted. As a result, the size of the treatment system required and the adequacy of the reverse osmosis process to treat the waste has not been evaluated.

A treatability study will be performed on synthesized waste water and an evaluation of the reverse osmosis process will be conducted during definitive design of the ERDF. The equipment in the waste water treatment building will be underlain by a secondary containment system.

Treated waste water will be directed to evaporation tanks located near the treatment building and the empty contaminated container transfer area. The conceptual design indicates that shallow tanks that are 0.9 meter ( 3 feet) deep and 46 meters (150 feet) in diameter will be used for evaporation. The conceptual design indicates that these tanks will be modutanks equipped with hard sides and double HDPE liners with a leak detection system. The final design and the exact number of tanks required to provide adequate surface area for evaporation will be determined during definitive design of the ERDF. 
As the design of the treatment system and the quality of the effluent from the system will be characterized during definitive design, and a determination will be made regarding whether the treated effiuent from the waste water treatment building can be used for other purposes. It may be possible to use the effluent in lieu of raw water for cleaning containers at the decontamination building, dust control within the ERDF, and cement/grout mixing water at the subsidence control plant.

\subsubsection{Subsidence Control Plant}

The subsidence control plant will be located near the ERDF trench (Figure 4-1). The batch plant will be used to supply a flowable subsidence control material, conceptually consisting of flowable Portland cement and possibly augmented by the use of flyash from the 200 areas Powerhouse. The subsidence control material will be used to fill void spaces in irregularly shaped bulk debris placed in the ERDF trench. If the void spaces were left unfilled, the spaces might collapse or allow the soil surrounding the debris to flow into the space. This could result in long-term subsidence or differential settlement of the waste that could threaten the integrity of the final cover. Debris that requires subsidence control measures will be taken to the floor of the trench before unloaded from the container.

The conceptual cesign indicates that the subsidence control plant must have a minimum capacity output of 30 cubic meters ( 40 cubic yards) per batch, but still be capable of producing batches in quantities less than capacity. The daily capacity of the subsidence control plant will be at least 107 cubic meters (140 cubic yards). The subsidence control material produced at the subsidence control plant will be delivered to the toe of the working face of the trench via an ERDF dedicated mixing truck. The material will be used to fill the void spaces of the debris before placing a cover or additional waste material.

\subsection{ENVIRONMENTAL RESTORATION DISPOSAL FACILITY OPERATIONS}

This section provides a brief description of the operations that will be conducted at the ERDF, as depicted in Figure 4-6. The information is included to demonstrate that the operation of the ERDF and the associated support structures can meet the CAMU designation criteria in 40 CFR 264.552 and WAC 173-303-646. The specific criterion addressed is that the waste management activities associated with the ERDF wi11 not create unacceptable risks to humans or the environment resulting from exposure to hazardous/dangerous waste or hazardous/dangerous constituents.

The descriptions provided in the following sections are a brief summary of the ERDF operations as described in the conceptual design report 48 (DOE-RL 1994a). 
DOE/RL-94-40, Rev. 0

06/94

\subsubsection{Waste Transport to the Environmental Restoration Disposal Facility}

Waste generated at various remediation sites on the Hanford Facility will be placed in containers at the generation point. Each container will be capable of holding approximately 26.75 cubic meters ( 35 cubic yards) of waste. The containers of waste will be loaded onto a railcar or the trailer of a tractor-trailer combination at the remediation site and transported to the ERDF by rail or roadway.

\subsubsection{Loaded Rail and Tractor Trailer Container Transfer/Unloading Area}

The railcars and tractor trailers carrying the loaded containers will arrive at the loaded waste container transfer/unloading pad located near the ERDF trench (Figure 4-1). Wheeled container handlers will be used to transfer the waste containers from the railcars or tractor trailers to the dedicated ERDF tractor trailers. The ERDF will be equipped with automated data processing and control equipment to ensure complete and consistent documentation of waste entering the ERDF. The dispatcher who will supervise the operation of the transfer area will have access to automated equipment at both the remediation site and the ERDF.

\subsubsection{Transport of Waste Within the Environmental Restoration Disposal Facility}

The dedicated ERDF tractor trailers will transport the containers of waste from the transfer area to the ERDF trench along dedicated paved haul roads. Once inside the ERDF trench, the tractor trailers will travel on compacted gravel ramps and on top of the compacted interim cover material. Containers of waste that will be placed in the as-received condition will be taken to the appropriate trailer tipper for unloading. Single-use containers and containers managing waste that require subsidence control measures will be taken to the floor of the trench for unloading and special handling.

After the waste has been unloaded from the container, the interior of the empty container will be inspected visually to determine whether supplementary residual material removal techniques are required. If additional removal is required, removal will be accomplished at the working face, or the dedicated ERDF tractor trailer will deliver the container to the outdoor wash pad at the decontamination building for residual removal. If residual removal is not required, the dedicated ERDF tractor trailer will deliver the container to the empty contaminated container transfer area adjacent to the decontamination building. The containers will be off $\cdot$ loaded by wheeled container handlers either directly to the wash bay conveyor or stored temporarily at the transfer area. The tractor trailer will return to the loaded waste container transfer/unloading area. Tractor trailers that off-load single-use containers will return directly to the loaded waste container transfer/unloading area. 
DOE/RL-94-40, Rev. 0

41

42

43

44

\subsubsection{Naste Placement Operations}

Waste placement operations will include container unloading, spreading, and compaction of the waste. Waste container unloading operations will take place under the supervision of an engineer or a working face supervisor who will direct the dedicated ERDF tractor trailer carrying the containers to the appropriate tipping location. The method for discharging waste will depend on whether or not the waste can be discharged in the as-received condition. Waste that does not require subsidence control measures or special handling will be unloaded at trailer tippers located at the crest of the trench working face. The tractor trailer will back onto the tipper and disconnect from the trailer. The tipper will elevate the front end of the trailer so that the waste discharges to the trench. A dust suppressant material will be sprayed on the waste as it is discharged.

Containers of waste that require subsidence control measures will be unloaded at the toe of the working face using the self-tipping mechanism of the trailer. The waste will be dumped paraliel to the toe of the fill and the tractor will move forward to spread the waste and ensure that all of the waste is removed from the container. The subsidence control material will be placed around the remediation waste before advancing the fill over the material. Single-use and/or disposable containers and containers requiring special handling will be unloaded on the operations layer and placed at the toe of the working face using a crane.

Waste that has been unloaded at the top of the working face will be spread by dozer tractors. One dozer will spread the waste down the working face to a designated 1 ift depth and slope. A second dozer will be used to ensure that the top portion of the waste is maintained at the appropriate level. Compaction of each lift of waste material will be accomplished by vibratory compaction equipment operated over the deposited waste.

Waste unloaded at the toe of the slope will not require any further spreading other than that provided by the unloading action of the tractor/trailer. Irregularly shaped debris will not be compacted. Instead, subsidence control material will be placed over and around the waste before placing cover material. Waste placed in single-use containers or special handling areas will not be spread or compacted. Void spaces in the single-use containers will have been filled before arrival at the ERDF.

\subsubsection{Subsidence Control Operations}

The subsidence control measures used for irregular shaped waste will occur after the waste has been deposited on the trench floor. The subsidence control material will be mixed in the subsidence control plant and transferred to a mixer/transport truck. The mixer/transport truck will deliver the material to the toe of the workins face. The flowable subsidence control material will be unloaded onto waste using the mixer drum and an unloading chute. The mixer/transport truck will return to the subsidence control plant. 
DOE/RL-94-40, Rev. 0

$06 / 94$

\subsubsection{Daily Dust Suppressant}

Daily, or more frequently as needed, the exposed waste on the working face of the trench will be covered by a dust suppressant material. The material will be applied by high-pressure spray equipment operating on clean operational cover/interim cover or clean areas of the trench floor.

\subsubsection{Interim Cover Placement}

A 0.7-meter- (2-foot-) thick interim cover will be placed at the 10.6 meter (35 foot) and 21.3 meter ( 70 foot) levels of the waste in the ERDF trench. The interim cover will prevent wind dispersal of waste and provide a clean working surface for the dedicated ERDF tractor/trailers carrying waste containers. The interim cover will be extended over the waste daily. The materials for the interim cover will be taken from stock piles and loaded into conventional dump trucks by frontend loaders. The dump trucks will transport. the material into the trench and dump the material near the edge of the existing interim cover and the current working face. The material will be spread and compacted by a dozer pulling a vibratory roller compactor.

The traveled areas of the interim cover will be maintained by surface grading. Additional cover material will be spread and compacted on deteriorated portions of the interim cover as needed. Dust suppression materials may be applied to the operational cover to control the dispersal of noncontaminated dust.

\subsubsection{Final Interim Cover Placement}

A low-permeability layer will be placed annualiy on top of the upper interim cover. The combination of the upper interim cover and the low-permeability layer is called the final interim cover. The conceptual design of the low-permeability layer indicates the layer will consist of either a layer of asphalt or other material such as a geomembrane. The exact type of materials to be used for the low permeability layer and the method of placement will be determined during definitive design.

\subsubsection{Dust Control Operations}

The dust control operations to be conducted (discussed previously) can be divided into two categories. The first category is the measures that will be taken to prevent the wind dispersal of remediation waste and waste constituents. The second category is the measures that will be taken to minimize dust generated from gravel roadways and the interim cover material.

The conceptual plan for reducing the wind dispersal of remediation waste during the operation of the ERDF trench includes the use of dust suppressants. The dust suppressants will be applied to the waste as the waste is discharged from the containers to the ERDF trench, and possibly as the waste is spread 
1 and compacted. Dust suppressants al so will be applied daily at a minimum to the exposed waste on the working face of the trench.

The wind dispersal of remediation waste also will be reduced through the use of a interim cover that will be placed daily on those areas where the top of the spread and compacted remediation waste has reached either the 10.6 or the 21.3 meter ( 35 or 70 foot) levels. The top of the clean soil layer will be used as a traffic surface for the next day's waste unloading operations.

In addition to the use of dust suppressants and an interim cover, a maximum wind speed at which waste placement operations at the ERDF trench must stop will be determined during definitive design. In addition to the maximum wind speed criteria, the ERDF personnel will cease waste placement operations in the event they determine that it is unsafe to continue operations because of the climatic conditions, e.g., extremely zold temperatures, unrelated to wind speed.

The first method used to control the spread of dust from nonwaste/noncontaminated gravel surface haul roads and travel areas on the trench floor and the interim cover will be to limit the speeds of vehicles traveling in these areas. Maintenance of the gravel roads and travel surfaces also will be used to control the spread of dust. The maintenance activities that will occur regularly include surface grading. and the application of water or other dust suppressant materials to the roadways and travel surfaces.

\subsubsection{Decontamination Operations}

The decontamination building, described in Section 4.14.2, will be used to clean empty, reusable, waste containers, operations vehicles, and emergency vehicles used in the operation of the ERDF.

Empty contaminated containers will be loaded onto a conveyer system that will advance the containers through the wash bays of the decontamination building. An automatic system will be used to wash, rinse, and air dry the containers. Automatic equipment also will be used to conduct a survey for radioactive contamination at the conclusion of the cleaning process. If the container meets the decontamination criteria, the conveyor system will transport the container to a covered storage area for transport back to the remediation sites for reuse. If, upon visual inspection, the container does not meet the decontamination criteria, the container will be removed from the conveyor and reloaded at the start of the process. Manual cleaning will be conducted for any container that cannot be decontaminated adequately by the automatic system.

The exteriors of vehicles and equipment leaving the site will be washed with high-pressure water from a high-pressure washer that is mounted permanently just inside the decontamination building. Two mobile decontamination units will be used for field decontamination of dedicated ERDF vehicles and equipment that require minor service while inside the ERDF.

A truck mounted high-pressure, low-volume water washer with hot water and detergent options will be used to clean the vehicles or equipment. 
1

\section{4.15.11 Equipment Maintenance}

6 10

11 established for the ERDF equipment.

Equipment maintenance operations potentially to be conducted at the ERDF may include vehicle and equipment refueling, vehicle and equipment fluids and filter replacement, tire service, field replacement of electronic/instrument equipment, and bench repairs of electronic equipment. Predictive mainteriance, preventative maintenance, and corrective maintenance programs will be 


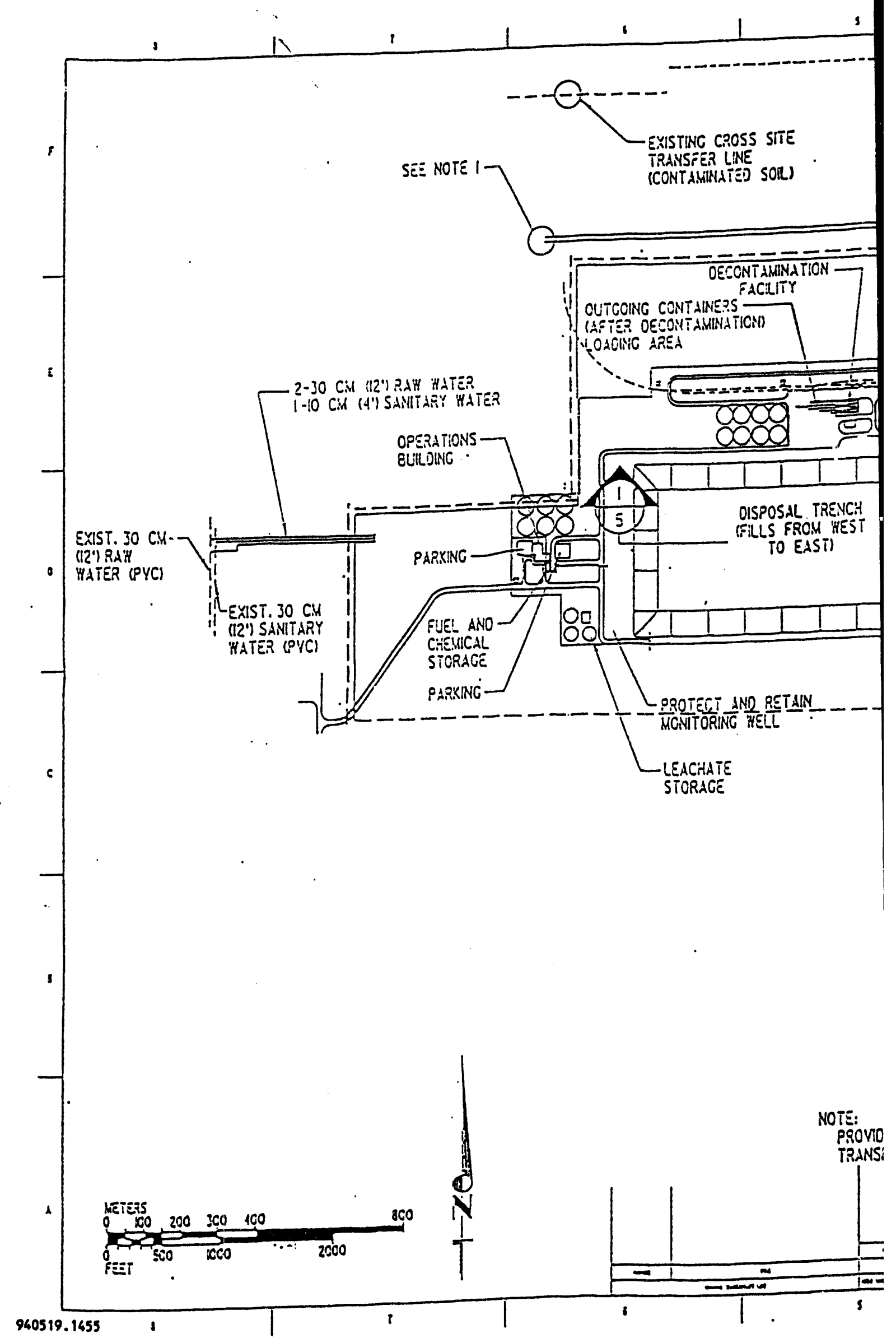




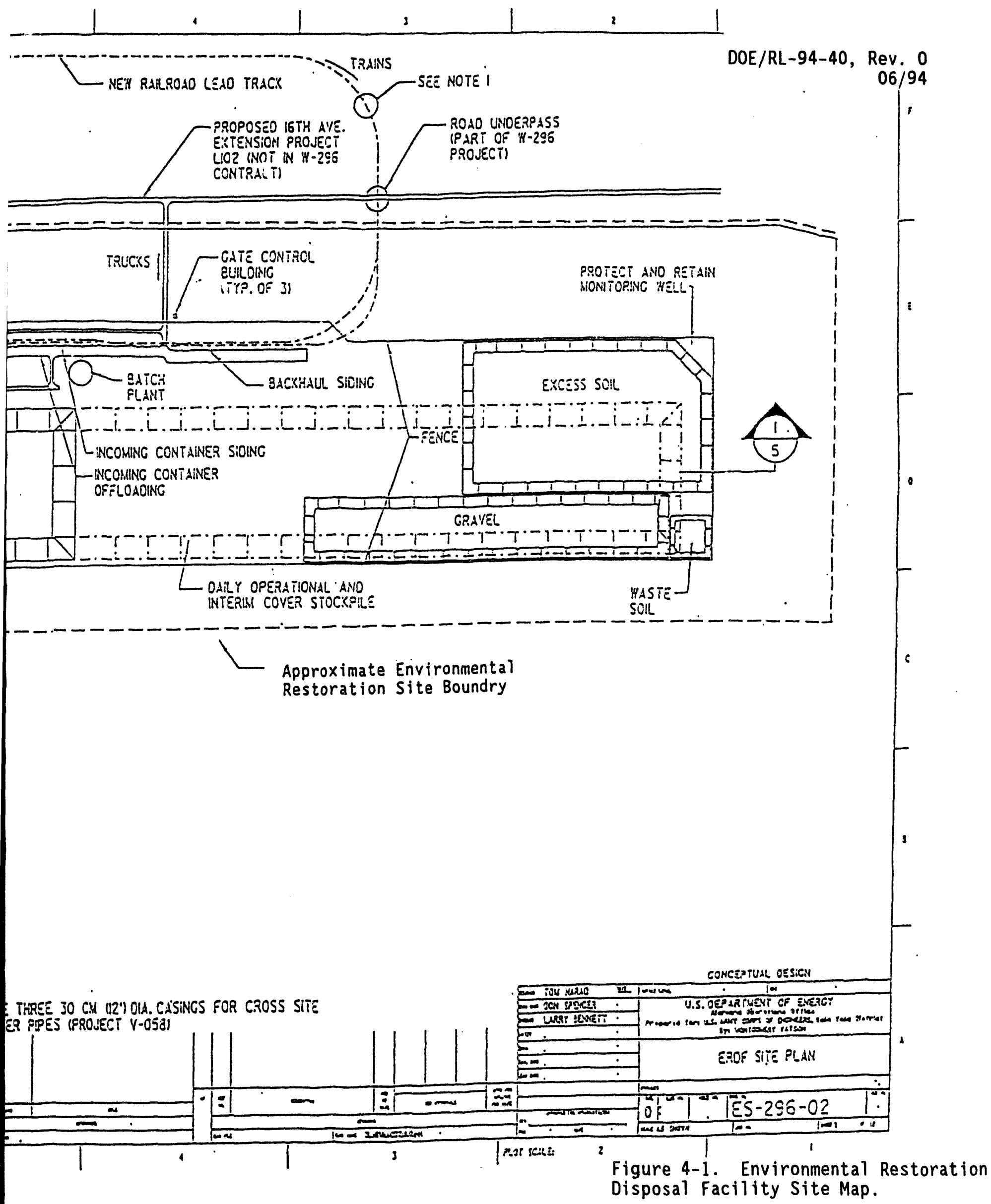

F4-1 


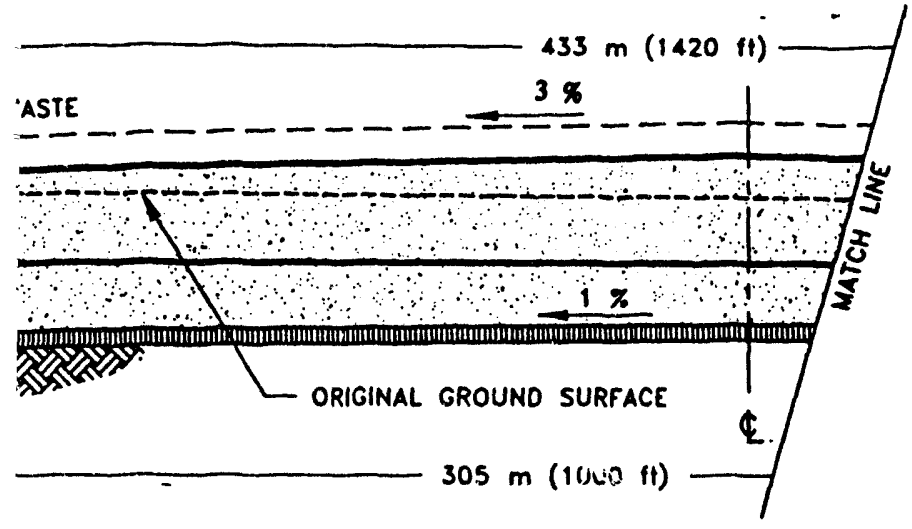

\section{SOUTH}

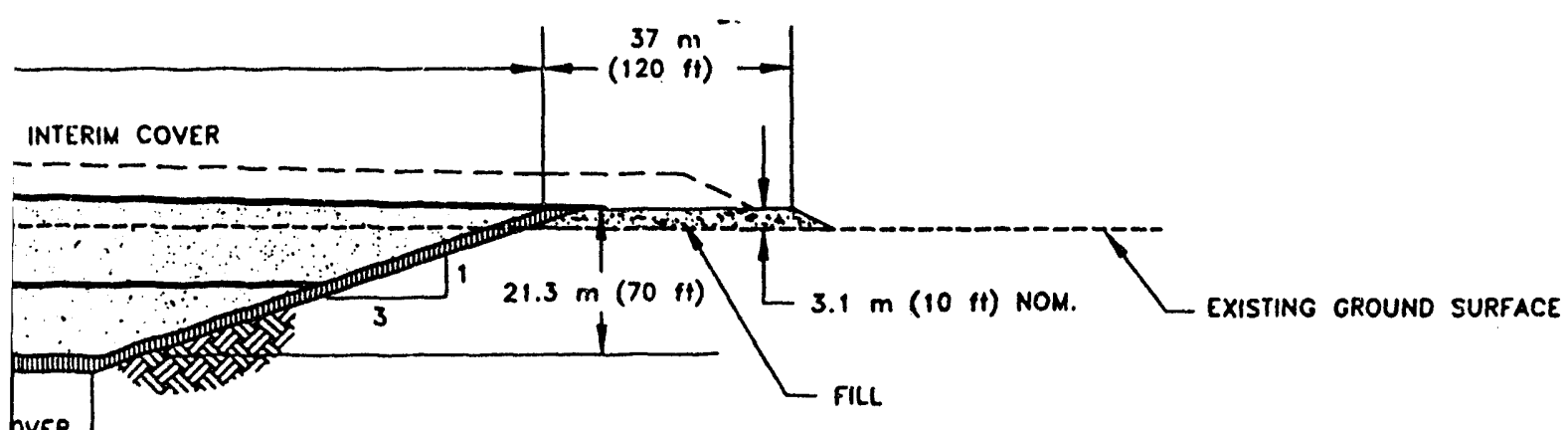

PVER

\section{ENCH SECTION}

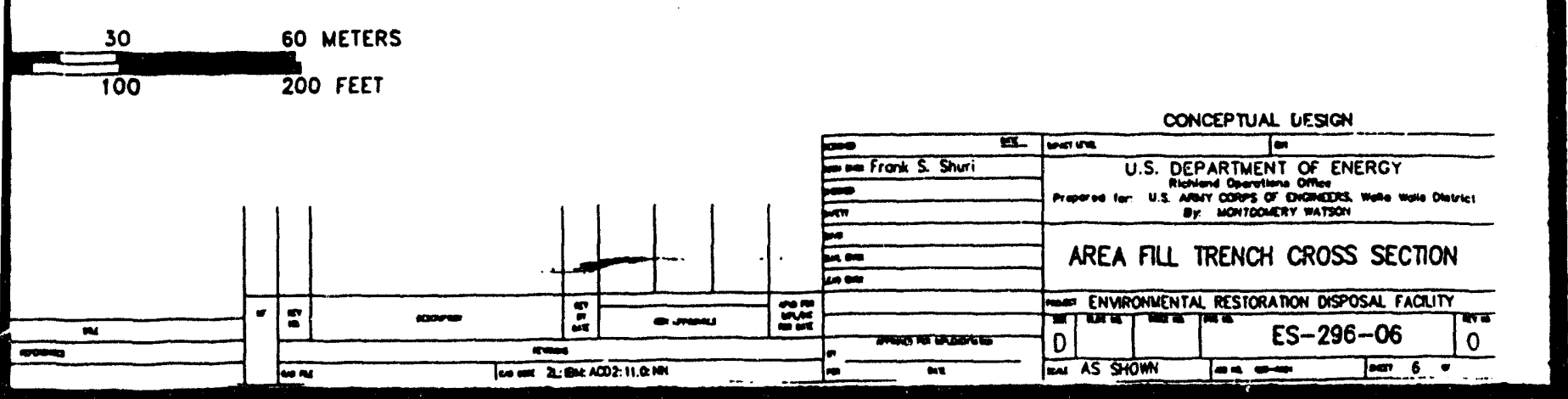

Figure 4-2. Environmental Restoration Disposal Facility Trench Cross Section. 


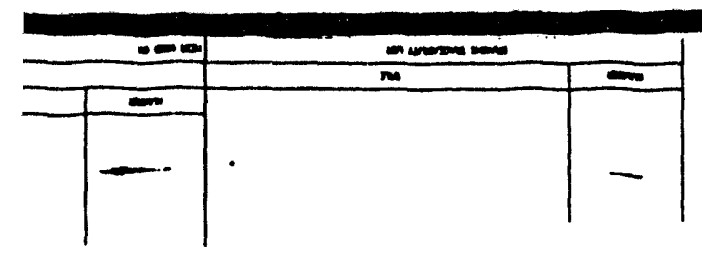

$\underbrace{0}_{0}$
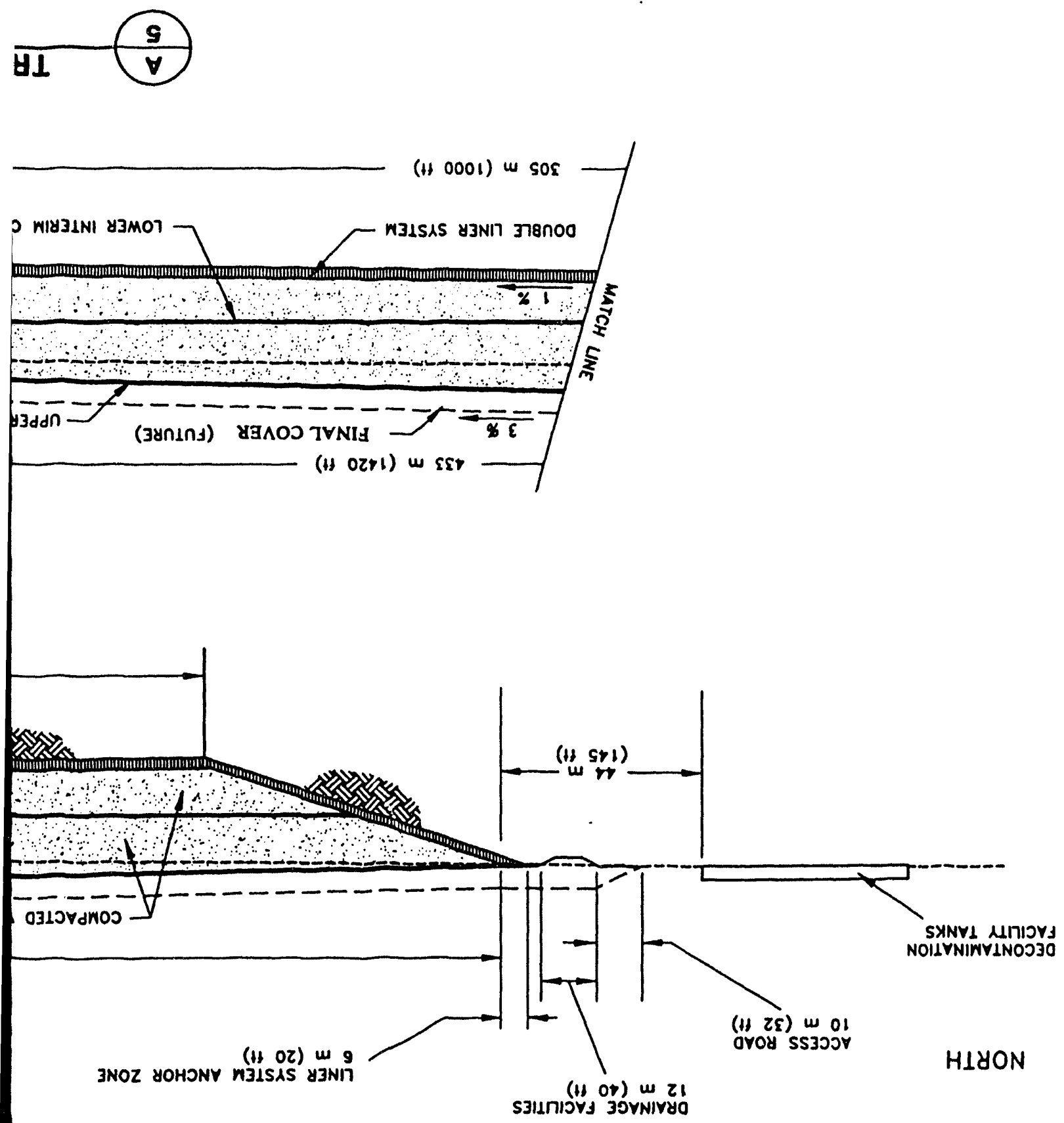


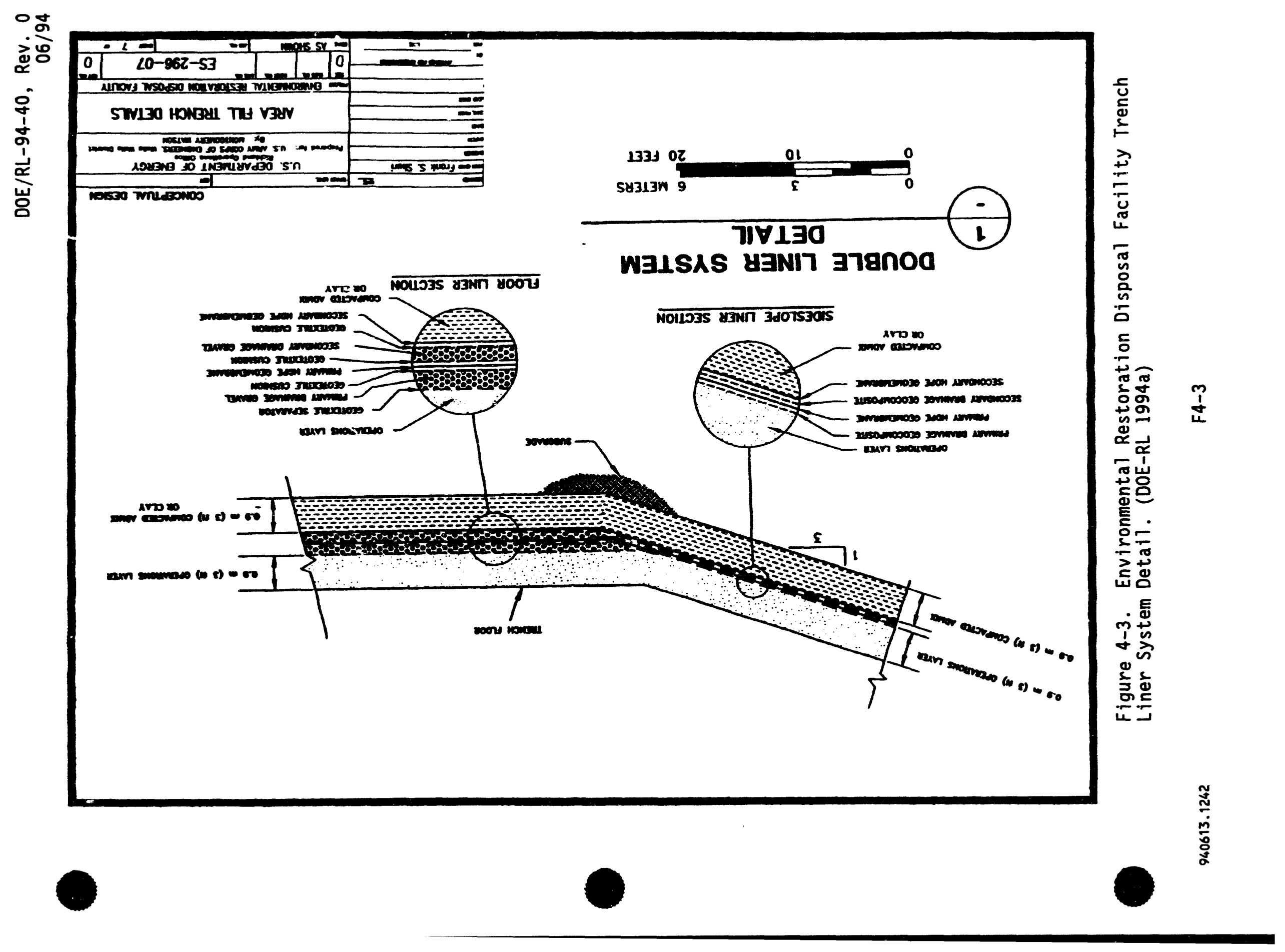




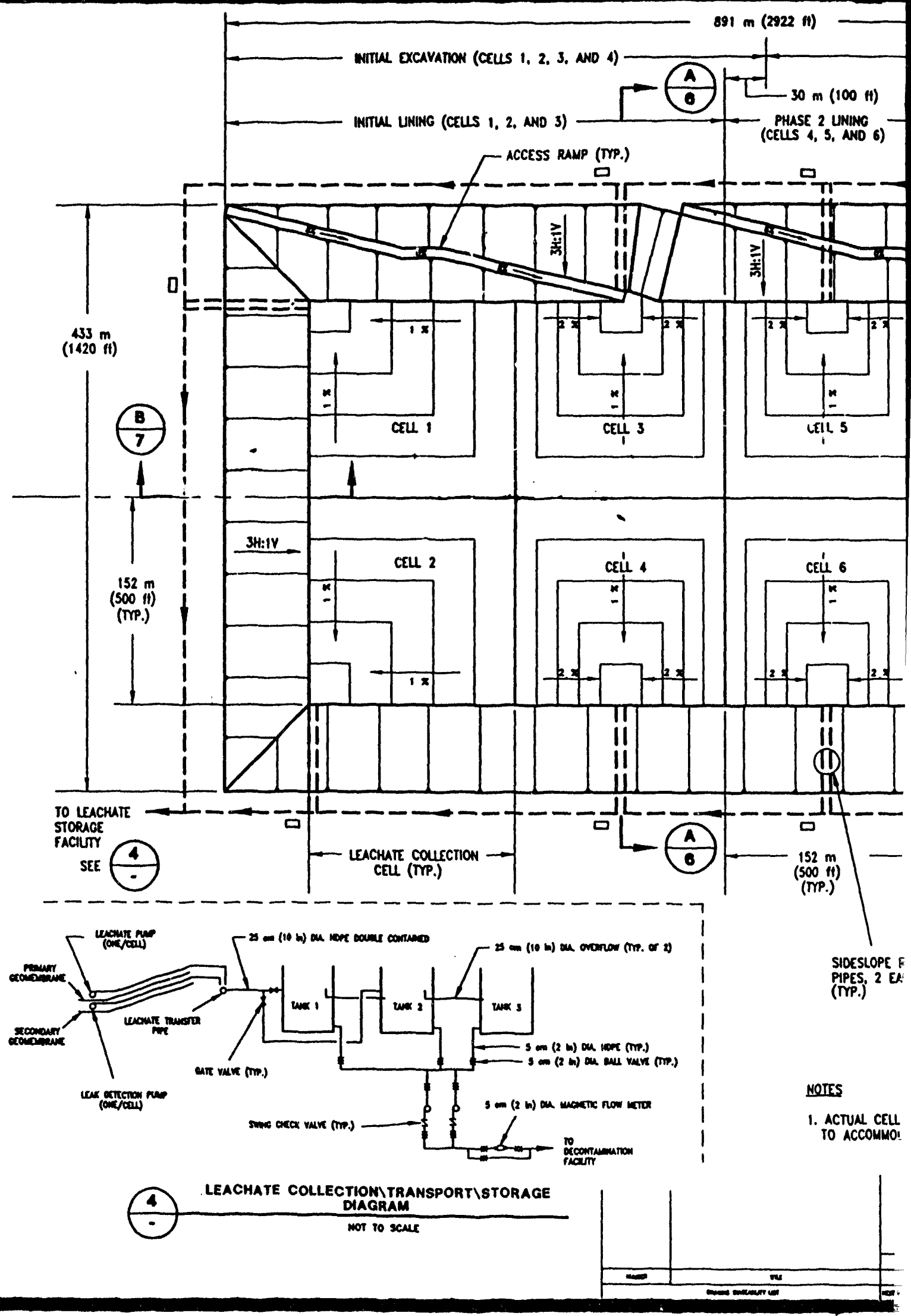


DOE/RL-94-40, Rev. 0 $06 / 94$
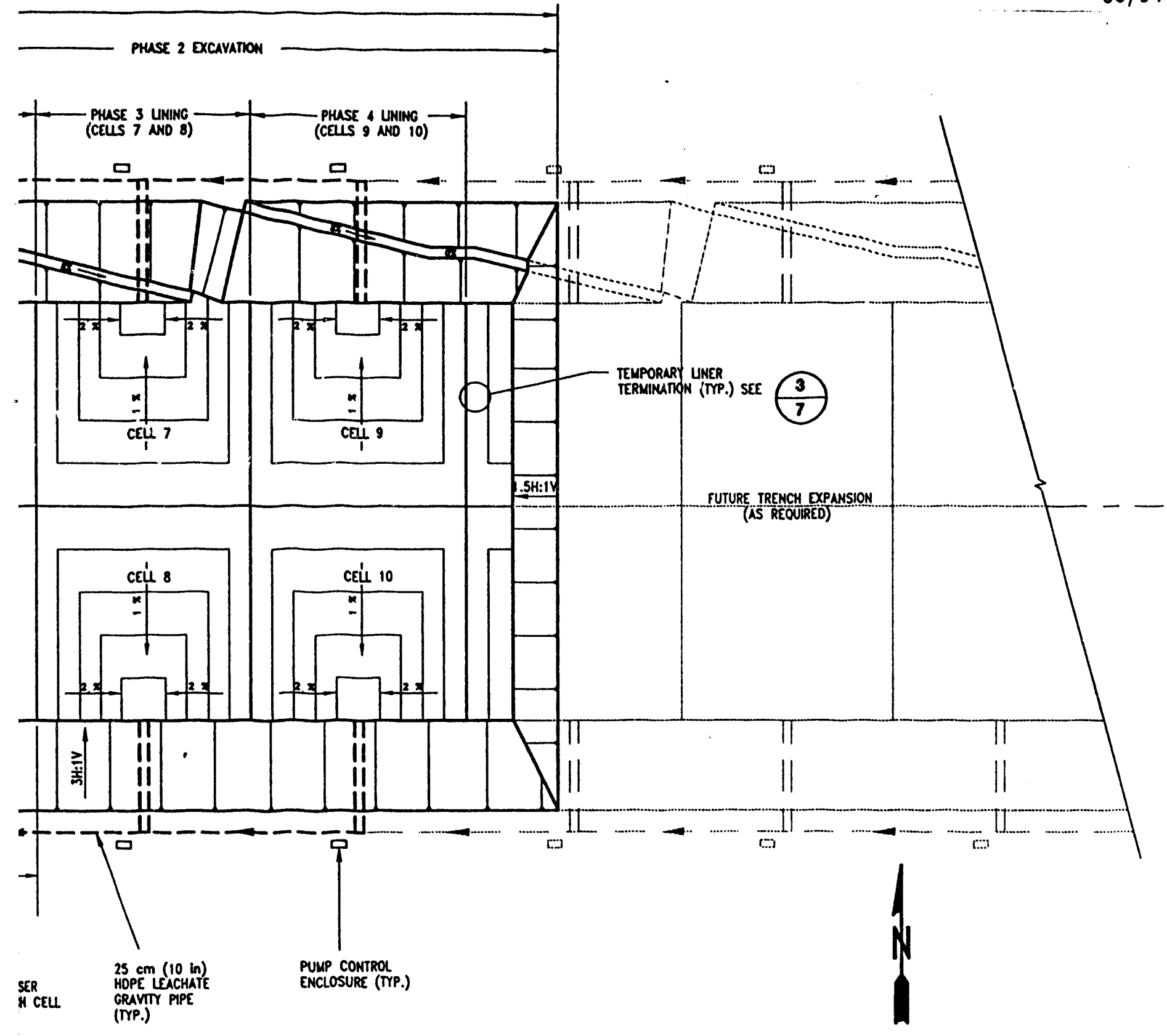

FLOOR SLOPES MAY VARY SUGHTY FROM THOSE SHOWN ITE RISE IN TRENCH ELEVATION FROM WEST TO EAST.

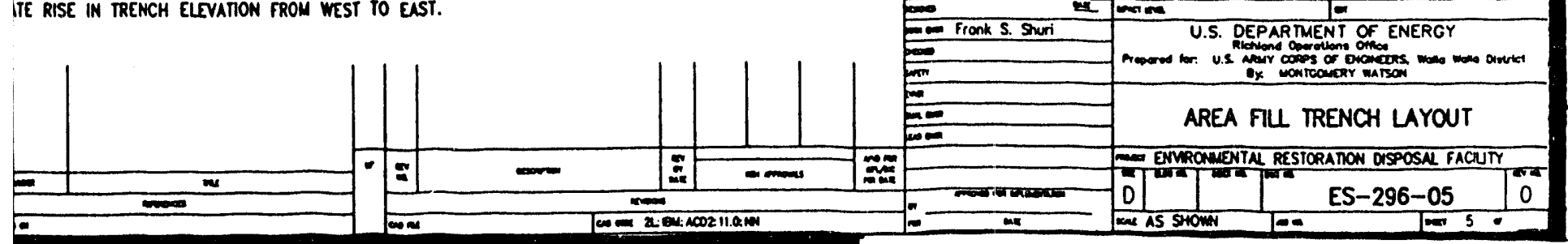

Figure 4-4. Plan View of the Environmental Restoration Disposal Facility Trench Leachate Collection Cells. 
DOE/RL-94-40, Rev. 0

06/94

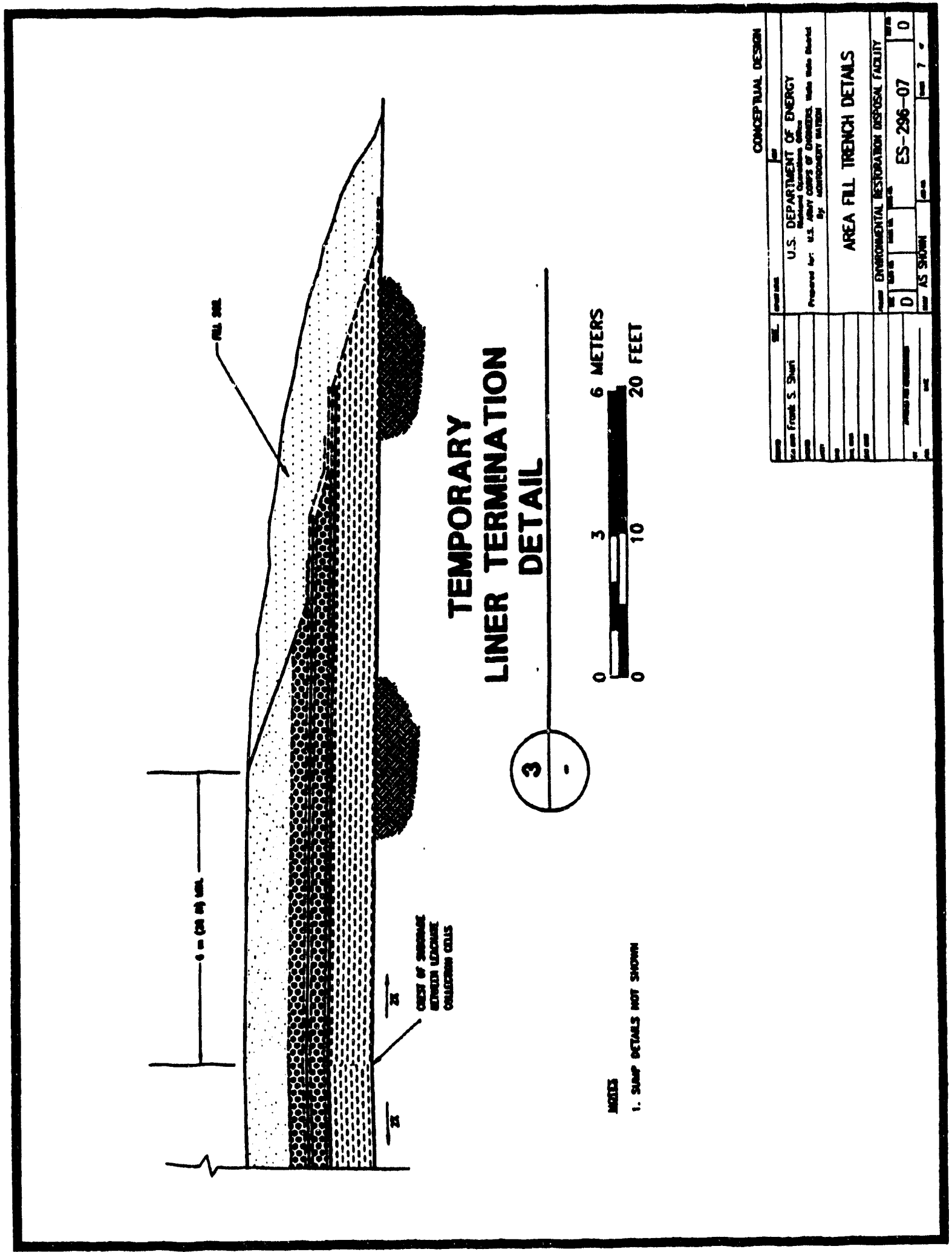

Figure 4-5. Environmental Restoration Disposal Facility Trench Temporary Liner Terminator Detail. (DOE-RL 1993a) 


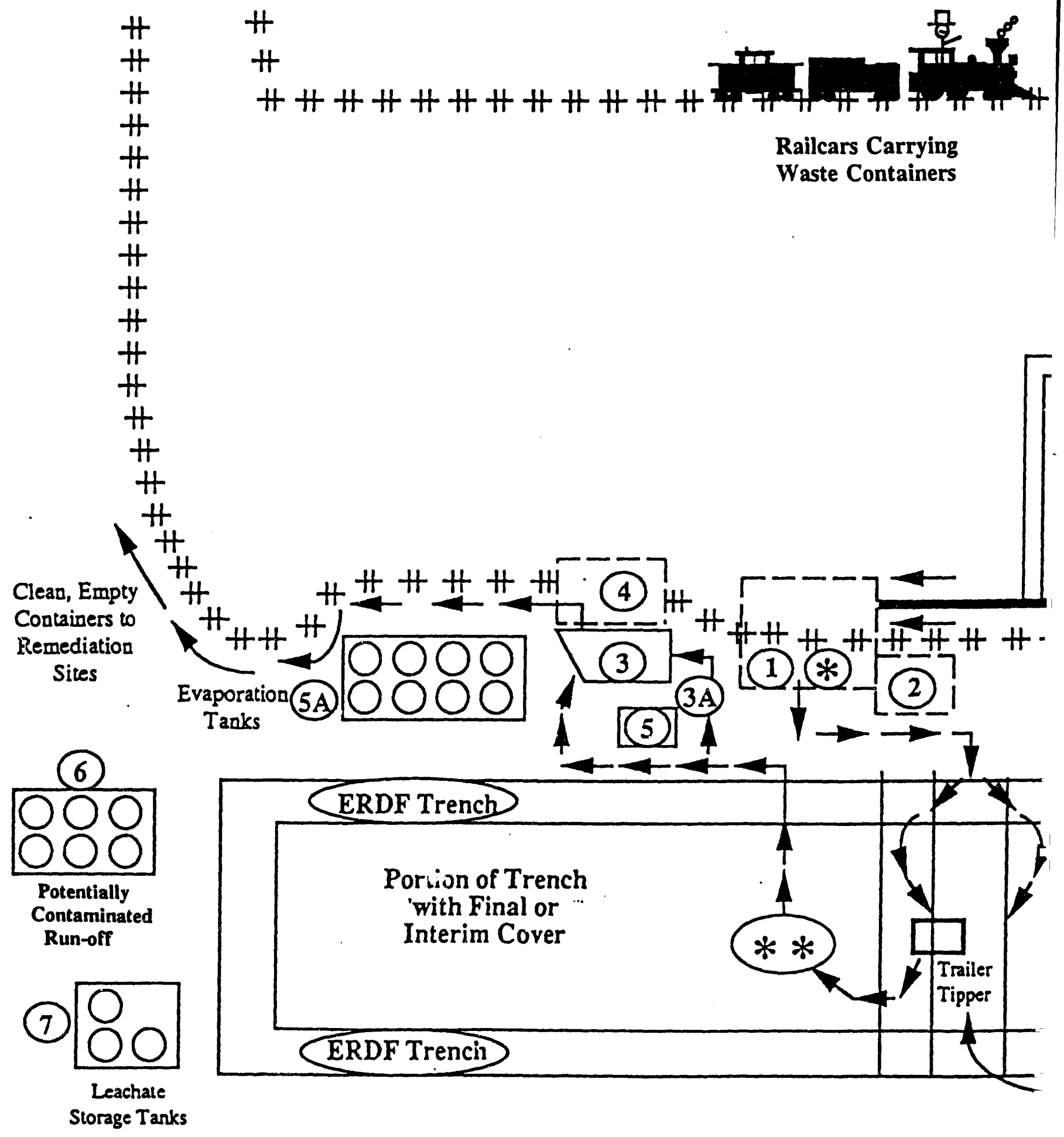




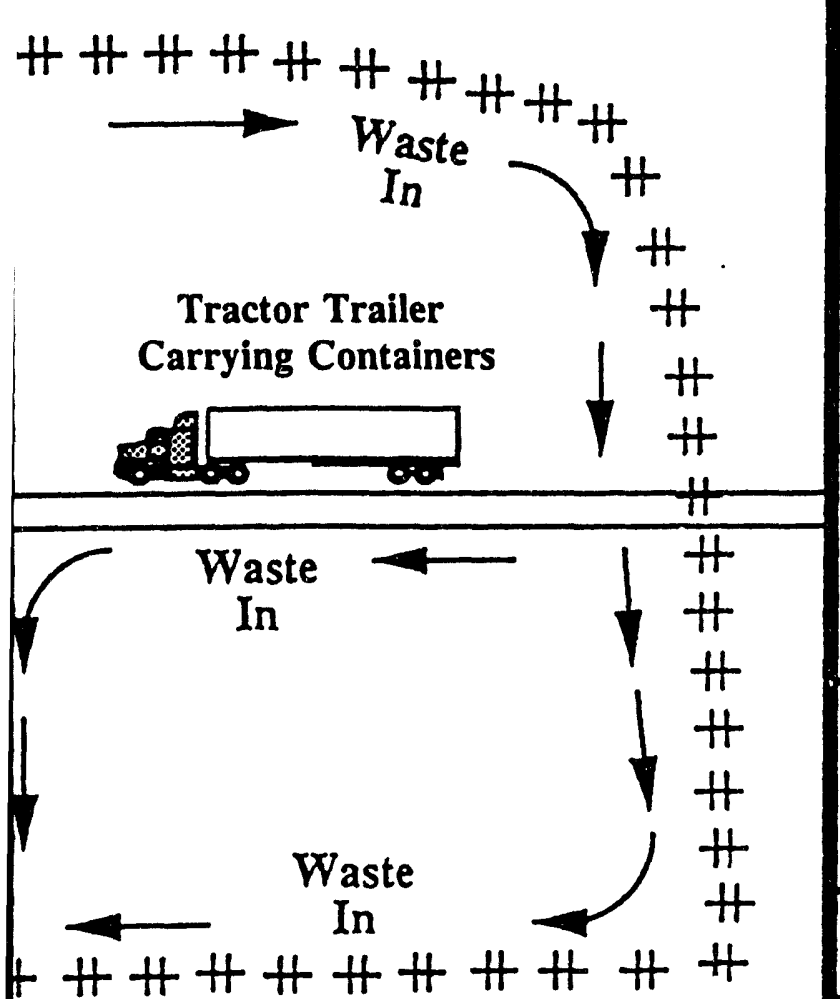

(1) Loaded Rail and Tractor Trailer Transfer/Unloading Area Design - Precipitation collected and segregated Permits - Generator accumulation storage

* Container contents confirmed; if suspect stored at (2)

2) Temporary Container Storage Area at Unloading Area (if required) Design - Precipitation collected and segregated

Permits - Generator accumulation storage or RCRA hazardous waste operating permit

Containers either - Go back to remediation site or continue to ERDF trench trailer tipper or bottom of trench face

*\% Visual Inspection of Empty Container

A lot of residue - Container scraped or sent to outdoor wash pad (3A)

Not much residue - Container to Decontamination Building (3)

(3) Decontamination Building

Design - The floor and sumps must meet RCRA tank MTRs

Permits - Generator accumulation storage or RCRA hazardous waste operating permit

3A Outdoor Container Wash Pad must meet RCRA tank MTRs

(4) Empty Decontamination Container Transfer Area

Design - No requirements for collecting precipitation

Permits - None required

5) Waste Water Treatment Building

Receives waste water for leachate storage tanks (7)

Potentially contaminated run-off tanks (6)

Decontamination Building blowdown (3)

Design - RCRA hazardous waste tank MTRs

Permits - Generator accumulation storage or RCRA

hazardous waste operating permit

(5A) Evaporation tanks
Evaporates or

Excavated but

Unlined Trench

Go to Bottom of

Working Face
Infiltrates

Infiltrates

6) Potentiallv Contaminated Run-off Storage Tanks

Design - Six tanks that meet RCRA hazardous waste tank MTRs

Permits - Generator accumulation storage or RCRA hazardous waste operating permit

(7) Leachate Storage Tanks

Design - Three tanks that meet RCRA hazardous waste tank MTRs

Permits - Generator accumulation storage or RCRA

hazardous waste operating permit

Figure 4-6. Environmental Restoration

Disposal Facility Generalized

Operational Flow Diagram. 
Table 4-1. Chapter 4.0 Cross-Reference Table.

([ ] - Denotes location of information in Ecology Part B checklist)

(sheet 1 of 2)

\begin{tabular}{|c|c|c|c|}
\hline ERDF out line chapter* & $\begin{array}{l}\text { Specifically required } \\
\text { by camu regulation? }\end{array}$ & $\begin{array}{c}\text { Washington State } \\
\text { CAMU Regulations** } \\
173-303 \\
\end{array}$ & $\begin{array}{l}\text { Federal } \\
\text { CAMU regulations } \\
40 \text { CFR } \\
\end{array}$ \\
\hline 4.0 Process Information [D] & & & \\
\hline $\begin{array}{l}4.1 \text { Containers [D-1] } \\
\text { WAC } 173-303-680 \\
40 \text { CFR } 264.170-40 \text { CFR } 264.178 \\
\end{array}$ & No & N/A under 646 & N/A under 264.552 \\
\hline $\begin{array}{l}4.2 \text { Tank Systens [D-2] } \\
\text { WAC } 173-303-640 \\
40 \text { CFR } 264.190 \\
40 \text { CFR } 264.191 \\
\end{array}$ & No & N/A under 646 & N/A under 264.552 \\
\hline $\begin{array}{l}4.3 \text { Waste Piles [D-3] } \\
\text { HAC 173-303-660 } \\
40 \text { CFR } 264.191 \\
40 \text { CFR } 264.250-40 \text { CFR } 264.259 \\
\end{array}$ & No & N/A under 646 & N/A under 264.552 \\
\hline $\begin{array}{l}4.4 \text { Surface Impoundments }[D-4] \\
\text { WAC } 173-303-650 \\
40 \text { CFR } 264.220-231\end{array}$ & Ho & N/A under 646 & N/A under 40 CFR 264.552 \\
\hline $\begin{array}{l}4.5 \text { Incinerators [D-5] } \\
\text { WAC 173-303-670 } \\
40 \text { CFR } 264.340-351 \\
\end{array}$ & No & N/A under 646 & N/A under 264.552 \\
\hline $\begin{array}{l}4.6 \text { Landfills }[D-6] \\
\text { WAC 173-303-665 } \\
40 \text { CFR } 264.300-i 34.317\end{array}$ & No & N/A under 646 & N/A under 264.552 \\
\hline $\begin{array}{l}4.7 \text { Land Treatmen: [D-7] } \\
\text { WAC 173-303-655 } \\
40 \text { CFR } 264.270-264.283 \\
\end{array}$ & No & N/A under 646 & N/A under 264.552 \\
\hline $\begin{array}{l}4.8 \text { Miscellaneous Units [D-8] } \\
\text { WAC } 173-303-680 \\
40 \text { CFR } 264.600-264.603 \\
\end{array}$ & No & N/A under 646 & N/A under 264.552 \\
\hline $\begin{array}{l}\text { 4.9 Drip Pads } \\
40 \text { CFR } 264.510-264.574\end{array}$ & No & N/A under 646 & N/A under 264.552 \\
\hline $\begin{array}{l}4.10 \text { Air Emissions Standards for } \\
\text { Process Vents } \\
40 \text { CFR 264.1030-264.1037 }\end{array}$ & No & N/A under 646 & N/A under 264.552 \\
\hline $\begin{array}{l}4.11 \text { Air Emissions Standards for } \\
\text { Equipment Leaks } \\
40 \text { CFR 264.1050-264.1057 }\end{array}$ & No & N/A under 646 & N/A under 264.552 \\
\hline $\begin{array}{l}4.12 \text { ERDF Trench } \\
\text { WAC } 173-303-806(4)(h) ; \\
\text { WAC } 173-303-665(2) \\
\text { WAC } 173-303-810(13)\end{array}$ & Yes & $\begin{array}{l}646(5)(a)(i)-(v i i) \\
646(5)(b)(i i)\end{array}$ & $\begin{array}{l}264.552(c)(1)-(7) \\
264.552(e)(2) \\
\text { Criteria } 1-7\end{array}$ \\
\hline 4.13 Other CAMUs & $\begin{array}{l}\text { No--information is } \\
\text { provided in support of } \\
\text { CAMU criteria }\end{array}$ & $N / A$ & N/A \\
\hline
\end{tabular}


Table 4-1. Chapter 4.0 Cross-Reference Table.

([ ] - Denotes location of information in Ecology Part $B$ checklist)

(sheet 2 of 2 )

\begin{tabular}{|c|c|c|c|}
\hline ERDF outl ine chapter* & $\begin{array}{l}\text { Specifically required } \\
\text { by cand reoulation? }\end{array}$ & $\begin{array}{c}\text { Washington State } \\
\text { CAMM Regulations"* } \\
173-303\end{array}$ & $\begin{array}{l}\text { Federal } \\
\text { CAMU regulations } \\
40 \text { CFR } \\
\end{array}$ \\
\hline $\begin{array}{l}4.14 \text { Description of ERDF Support } \\
\text { Facilities }\end{array}$ & $\begin{array}{l}\text { No-- information is } \\
\text { provided in support of } \\
\text { cam criteria }\end{array}$ & $646(5)(a)(i)$ and $(i i)$ & $\begin{array}{l}264.552(c)(1) \text { and (2) } \\
\text { CAMU Criteria } 1 \text { and } 2\end{array}$ \\
\hline 4.15 ERDF operations & Yes & $\begin{array}{l}646(5)(a)(i),(i i),(i v), \\
(v), \text { and (vi) } \\
646(5)(b)(i i)\end{array}$ & $\begin{array}{l}264.552(c)(1),(2),(4), \\
(5) \text {, and (6) } \\
264.552(e)(2) \\
\text { cam Criteria 1, 2, 4, 5, } \\
\text { and } 6\end{array}$ \\
\hline
\end{tabular}

- The sections of this application are based on the Ecology Part B Checklist. The referenced regulations, both state (WAC 173-303) and federal (40 CFR 260-270), provide the specific requirements that typically are incorporated in these sections.

* Assumes that Washington State has received HSWA authority. 
Table 4-2. Data Requirements and Test Methods for Foundation Materials.

\begin{tabular}{|c|c|c|c|}
\hline $\begin{array}{c}\text { Data requirement/ } \\
\text { application }\end{array}$ & $\begin{array}{c}\text { Pertinent } \\
\text { chapters }\end{array}$ & Test method & Comments \\
\hline $\begin{array}{l}\text { In situ density: } \\
\text { Settlement } \\
\text { Bearing capacity } \\
\text { Side-siope stability }\end{array}$ & $\begin{array}{l}4.12 \cdot 4 \cdot 2.2 \\
4.12 \cdot 4 \cdot 4.2 \\
4.12 \cdot 4 \cdot 4.3 \\
4.12 .4 .4 .4 \\
4.12 \cdot 4 \cdot 4.8\end{array}$ & $\begin{array}{l}\text { Standard } \\
\text { penetration, } \\
\text { ASTM D } 2167 \\
\text { California sampler, } \\
\text { modified ASTM D } 1586 \\
\text { Large-diameter } \\
\text { sampler, } \\
\text { modified ASTM D } 1586 \\
\text { Bulk density }\end{array}$ & $\begin{array}{l}\text { Borehole } \\
\text { Borehole } \\
\text { Borehole } \\
\text { Laboratory }\end{array}$ \\
\hline $\begin{array}{l}\text { Foundation material strength: } \\
\text { Bearing capacity } \\
\text { Side-slope capacity }\end{array}$ & $\begin{array}{l}4 \cdot 12 \cdot 4 \cdot 2 \cdot 2 \\
4.12 \cdot 4 \cdot 4 \cdot 3 \\
4.12 \cdot 4 \cdot 4 \cdot 4\end{array}$ & $\begin{array}{l}\text { Triaxial test, } \\
\text { ASTM D } 4767 \\
\text { Calcium Carbonate } \\
\text { Content } \\
\text { ASTM D } 4373 \\
\end{array}$ & $\begin{array}{l}\text { Laboratory } \\
\text { Laboratory }\end{array}$ \\
\hline $\begin{array}{l}\text { Foundation permeability: } \\
\text { Pressure dissipation }\end{array}$ & $\begin{array}{l}4.12 \cdot 4 \cdot 2.4 \\
4.12 \cdot 4 \cdot 3 \cdot 4 \\
4.12 \cdot 4 \cdot 4 \cdot 2 \\
4.12 \cdot 4 \cdot 4 \cdot 5\end{array}$ & $\begin{array}{l}\text { Hydraulic } \\
\text { Conductivity } \\
\text { of Unsaturated Soils } \\
\text { American Society } \\
\text { of Agronomy, } 1986 \\
\end{array}$ & In situ \\
\hline $\begin{array}{l}\text { Natural moisture content: } \\
\text { Support data for other tests }\end{array}$ & $\begin{array}{l}4.12 \cdot 4 \cdot 2 \\
4.12 \cdot 4.3 \\
4.12 \cdot 4 \cdot 4 \\
\end{array}$ & $\begin{array}{l}\text { Moisture content } \\
\text { test, } \\
\text { ASTM D } 2216 \\
\end{array}$ & Laboratory \\
\hline $\begin{array}{l}\text { Particle-size distribution: } \\
\text { Material characterization } \\
\text { Liquefaction potential } \\
\text { Support data for other tests }\end{array}$ & $\begin{array}{l}4.12 \cdot 4.2 .2 \\
4.12 \cdot 4.3 .1 \\
4.12 \cdot 4 \cdot 4.2 \\
4.12 .4 .4 .3 \\
4.12 .4 .4 .4 \\
4.12 .4 .4 .5 \\
4.12 .4 .4 .6\end{array}$ & $\begin{array}{l}\text { Particle-size } \\
\text { analysis, } \\
\text { ASTM D } 422 \\
\text { Fine fraction of } \\
\text { Soils, } \\
\text { ASTM D } 1140\end{array}$ & $\begin{array}{l}\text { Laboratory } \\
\text { Laboratory }\end{array}$ \\
\hline
\end{tabular}


CONTENTS

5.0 GROUNDWATER MONITORING . . . . . . . . . . . . 5-1

5.1 EXEMPTION FROM GROUNDWATER MONITORING REQUIREMENTS . . . . . . 5-1

5.2 INTERIM STATUS PERIOD GROUNDWATER MONITORING DATA . . . . . . . 5-1

5.3 ENVIRONMENTAL SETTING AND AQUIFER IDENTIFICATION . . . . . . 5-1

5.3.1 Physiographic and Geomorphic Setting of the

Hanford Region ............. . 5-2

5.3.2 Ecological Setting/Climate... . . . . . . . 5-2

5.3.3 Regional Geology................ . 5-3

5.3.3.1 Stratigraphy .............. 5-3

5.3.3.2 Structural Geology . . . . . . . . . . . 5-6

5.3.3.3 Seismicity and the 0ccurrence of Faults . . . 5-7

5.3.4 Regional Hydrogeology ........... 5-8

5.3.5 Uppermost Aquifer: Environmental Restoration

Disposal Facility Area Geology and Hydrology . . . . . 5-10

5.3.5.1 Environmental Restoration Disposal
Facility Area Geology . . . . . . . 5-10

5.3.5.2 Environmental Restoration Disposal

Facility Area Hydrology ......... . 5-13

5.4 EXISTING GROUNDWATER CONTAMINATION . . . . . . . . . 5-15

5.5 GROUNDWATER MONITORING PROGRAM . . . . . . . . . . . . 5-18

5.5.1 Programmatic Requirements for Groundwater

Monitoring Under the Corrective Action

Management Unit Regulations ..... . . . . . . 5-18

5.5.2 Indicator Parameters ............... . 5-23

5.5.3 Waste Characteristics ............. 5-24

5.5.4 Description of Wells .............. 5-24

5.5.4.1 Well Depths............... 5-24

5.5.4.2 Well Installation, Sampling Method, and

Equipment Decontamination . . . . . . 5-24

5.5.4.3 Well Development ............ 5-26

5.5.4.4 Surveying ............... 5-26

5.5.5 Sampling and Analysis Plan . . . . . . . . . . 5-27

5.5.5.1 Sampling . . . . . . . . . . . . . 5-27

5.5.5.2 Sample Preservation and Shipment . . . . 5-27

5.5.5.3 Analytical Methods ............ . 5-28

5.5.5.4 Chain-of-Custody Requirements . . . . . . 5-28

5.5.5.5 Sampling Frequency .. . . . . . . . . 5-28

5.5.5.6 Reporting Requirements . . . . . . . . 5-28

5.5.6 Statistical Assessment of Required Data . . . . . . 5-28

5.5.7 Compliance Monitoring Program . . . . . . . . . 5-30

5.5.8 Corrective Action Program . . . . . . . . . . 5-30 
5A MONITORING WELL LOG AND CONSTRUCTION INFORMATION ....... APP 5A-1

5B MONITORING EFFICIENCY MODEL INFORMATION: USER'S MANUAL . . . APP 5B- 1

5C GROUNDWATER SAMPLING AND ANALYSIS PLAN FOR THE.

ENVIKONMENTAL RESTORATION DISPOSAL FACILITY

APP $5 C-i$

5-1. Location of the Columbia Intermontane Province

5-2. Geomorphic and Structural Setting of the Pasco Basin

F5-1

5-3. Stratigraphic Nomenclature for Geologic Units in the

Pasco Basin...................... F5-3

5-4. Top of the Uppermost Basalt Structure Contour Map of the

Central Hanford Facility . . . . . . . . . . . . . . F5-4

5-5. Areal Distribution of Hydraulic Conductivity for the

Unconfined Aquifer at the Hanford Facility . . . . . . . . F5-5

5-6. Water Table Map of the Hanford Facility, January $1944 . .2 .$. . . F5-6

5-7. Water Table Map of the Hanford Facility, June 1993 . . . . . . . F5-7

5-8. Topographic and Geomorphic Features in the West-Central

Portion of the Hanford Facility . . . . . . . . . . . . F5-8

5-9. Cross-Section P1 an Map . . . . . . . . . . . . . . . . F5-9

5-10. Explanation of Symbols Used in Cross Sections . . . . . . . F5-10

5-11. North-South Geologic Cross Section Through the

Eastern Portion of the Environmental Restoration Disposal

5-12. West-East Geologic Cross Section Through the Southern

Portion of the Environmental Restoration Disposal

Facility (B-B') . . . . . . . . F5-12

5-13. North-South Geologic Cross Section Through the Western

Portion of the Environmental Restoration Disposal

Facility $\left(C-C^{\prime}\right)$

5-14. Water Table Map Beneath the Environmental Restoration

Disposal Facility

5-15. Hydrograph for We11 699-35-70 near the Environmental
Restoration Disposal Facility . . . . . . . . . . F5-15

5-16. Chromium Groundwater P1ume Map................ . . F5-16

5-17. Nitrate Groundwater Plume Map ............. . . . . F5-17

5-18. Carbon Tetrachloride Groundwater Plume Map . . . . . . . . . . F5-18

5-19. Chloroform Groundwater Plume Map ............... . F5-19

5-20. Trichloroethylene Groundwater Plume Map . . . . . . . . . F5-20

5-21. Tritium Groundwater Plume Map ................ . . F5-21

5-22. Gross Beta Groundwater Plume Map ................... . . F5-22

5-23. Technet ium-99 Groundwater Plume Map . . . . . . . . . . . . F5-23

5-24. Iodine-129 Groundwater Plume Map ............. . . F5-24 
5-25. Gross Alpha Groundwater Plume Map ... . . . . . . . . F5-25

5-26. Uranium Groundwater Plume Map . . . . . . . . . F5-26

5-27. Location of Environmental Restoration Disposal

Facility Monitoring Wells . . . . . . . . . F5-27

5-28. Schematic Diagram of a Typical Shallow Groundwater

Monitoring Well . . . . . . F5-28

5-29. Example Specification Data Sheet for Groundwater

Monitoring Well ................ F5-29

\section{TABLES}

5-1. Chapter 5.0 Cross-Reference Table . . . . . . . . . T5-1

5-2. Hydraulic Parameters for Various Areas and Geologic Units

on the Hanford Facility ......... . T5-2

5-3. Well Construction Information for Environmental Restoration Disposal Facility Groundwater Monitoring Wells ........ T5-3

5-4. Contaminant Transport Input Parameters to Monitoring Efficiency Model . . . . . . . . . T5-4

5-5. Groundwater Monitoring Network Analyticai Parameters . . . . . T5-5

5-6. Environmental Investigation Control Procedures ....... T5-6 
DOE/RL-94-40, Rev. 0

This page intentionally left blank. 


$$
\text { DOE/RL-94-40, Rev. } 0
$$

\subsection{GROUNDWATER MONITORING}

As a RCRA CAMU, the ERDF would be required to include groundwater monitoring, as stated in 40 CFR 264.552(e)(3)( 1 and 11 ) and WAC 173-303-646(5)(b)(i1i): "(Groundwater monitoring must be performed that is sufficient to)... continue to detect and characterize the nature, extent, concentrations, direction, and movement of existing releases of hazardous constituents in groundwater from sources located within the CAMU; and detect, and subsequently characterize releases of hazardous constituents to groundwater that may occur from areas of the CAMU in which waste will remain in place after closure of the CAMU." This chapter discusses groundwater monitoring to be performed at the ERDF. Table 5-1 is a regulatory crossreference table. The DOE Order 5820.2A requires protection of groundwater resources in accordance with federal, state, and local requirements.

Implementation of groundwater monitoring in accordance with this chapter will meet federa1, state, and local, and, hence, DOE Order requirements. Also, groundwater monitoring requirements under TSCA are met by the implementation of this monitoring program.

\subsection{EXEMPTION FRON GROUNDWATER MONITORING REQUIREMENTS} the ERDF.

No exemption from groundwater monitoring requirements is requested for

\subsection{INTERIM STATUS PERIOD GROUNOWATER MONITORING DATA}

The ERDF will not be a RCRA/WAC land disposal unit for which interim status groundwater monitoring is required. Interim status groundwater monitoring is required for TSD units that are active before issuance of a final permit, but because the ERDF is yet to be constructed and no waste is in place, there is no need to collect interim status-type data. However, the occurrence of preexisting groundwater contamination below the ERDF emanating from sources outside the ERDF has been noted, and is discussed in Section 5.4 .

\subsection{ENVIRONMENTAL SETTING AND AQUIFER IDENTIFICATION}

The following section contains information on the environmental setting of the Hanford Facility, including information on the physiographic, geomorphic, and environmental setting; ecological setting and climate; regional geology and hydrogeology; and identification of the uppermost aquifer. This information is provided to facilitate the evaluation of the ERDF in accordance with the requirements of 40 CFR 264.552 (d) and (e) and WAC 173-303-646(5) (b). 
5.3.1 Physlographic and Geomorphic Setting of the Hanford Region

The Hanford Facility is situated within the Pasco Basin, which is one of a number of structural and topographic depressions located within the Columbia Basin Subprovince of the Columbia Intermontane Physiographic Province. The location of the Columbia Basin Subprovince is shown in Figure 5-1. The dominant geologic characteristics of the Columbia Intermontane Province resulted from flood basalt volcanism and regional deformation that occurred from 17.5 to 14.5 milliton vears ago (PNL 1989; WHC 1991b). The Columbia Intermontane Province is distinguished primarily by its relatively uniform rock type and undeformed nature with respect to adjacent provinces that developed under different tectonic and climatic settings. Within the Columbia Intermontane Province, the term Columbia Plateau is used informally to designate the area that is covered by the Columbia River Basalt Group (DOE-RL 1994d).

The Pasco Basin is bounded on the north by the Saddle Mountains; on the west by Umtanum Ridge, Yakima Ridge, and the Rattlesnake Hills; on the south by Rattlesnake Mountain and the Rattlesnake Hills; and on the east by the Palouse Slope, as shown in Figure 5-2 (PNL 1989; WHC 1991b). The physiography of the Hanford Facility is dominated by the low-relief plains of the Central Plains physiographic region and a few basaltic ridges of the Yakima folds physiographic region (Gable Mountain-Umtanum Ridge, Yakima Ridge, and Rattlesnake Hills) that rise above these plains in the western portion of the Hanford Facility (PNL 1989).

The geomorphology of the Hanford Facility is characterized by unique 1 and forms created primarily by pleistocene cataclysmic flooding. These include anastomosing flood channels, bergmounds, and giant flood bars. The cold creek Bar occurs at the ERDF area, and was created by multiple flood events. In addition, eolian activity in the Columbia Basin is a major geomorphic agent, producing sheet sands that can blanket the surface topography.

The elevation along the Columbia River ranges from 107 to 122 meters (350 to 400 feet) above mean sea level within the Hanford Facility. Steep embankments rise approximately 9 to 24 meters (30 to 80 feet) upwards along sections of the Columbia River in the northern end of the Hanford Facility along the 100 Areas. The 200 Areas are located on a plateau ranging in elevation from approximately 183 to 230 meters (600 to 750 feet) above mean sea level. Significant topographic features on the Hanford Facility include Gable Mountain and Gable Butte, both of which are located between the 200 Areas and 100 Areas. Gable Mountain Gap drops to an elevation of approximately 125 meters (405 feet) between Gable Mountain and Gable Butte (WHC 1991b).

\subsubsection{Ecological Setting/Climate}

The ecological setting and climate is summarized in Chapter 2.0. Additional detailed information is presented in numerous references (WHC 1994C and DOE-RL 1994d). 
DOE/RL-94-40, Rev. 0

\subsubsection{Regional Geology}

Regional geology around the Hanford Factlity has been extensively studied and is well documented (1.e., PNL 1989; WHC 1991b). The following is a synopsis of regional geologic conditions, as extracted from the aforementioned documents.

The Hanford Factlity lies in the Pasco Basin near the eastern limit of the Yakima Fold Belt. As discussed previousiy, the Pasco Bas in is a structural depression bounded by anticlinal ridges on the north, west, and south and a monocline on the east. The Pasco Basin is divided by the Gable Mountain anticline and the Wahluke syncline to the north, and the Cold Creek syncline to the south (Figure 5-2).

The Hanford Factlity is underlain by Miocene-age basalt of the Columbia River Basalt Group and late Miocene to Pleistocene suprabasalt sediments. The basalts and sediments thicken into the Pasco Bas in and generally reach maximum thicknesses in the Cold Creek syncline. Cenozoic-age sedimentary and volcaniclastic rocks underlying the basalts are not exposed at ground surface at or near the Hanford Facility (WHC 1991b).

5.3.3.1 Stratigraphy. The subsurface geology underlying the Hanford Facility consists of numerous formally and informally (i.e., Hanford formation) recognized stratigraphic units. Figure 5-3 11lustrates the stratigraphic nomenclature of the Miocene to Holocene-age geologic units within the Pasco Basin. Nomenclature used in the past for geologic units is provided, as well as current nomenclature. These geologic units are comprised of three major groups: (1) the Columbia River Basalt Group, (2) the Ellensburg Formation, and $(3)$ the suprabasalt sediments.

5.3.3.1.1 Columbia River Basalt Group. The Columbia River Basalt Group is comprised of an assemblage of tholeitic, continental flood basalts that are Miocene in age. These flows cover an area of more than 163,700 square kilometers (63,000 square miles) in Washington, Oregon, and Idaho and have an estimated volume of approximately 174,300 cubic kilometers $(41,800$ cubic miles) (WHC 1991b). The Columbia River Basalt Group formally is divided into five formations. From youngest to oldest, these include: Imnaha Basalt, Picture Gorge Basalt, Grande Ronde Basalt, Wanapum Basalt, and Saddle Mountains Basalt. Of these, only the Grande Ronde, Wanapum, and Saddle Mountains Basalts are present in the Pasco Basin.

The Grande Ronde Basalt is the most extensive and voluminous formation within the Columbia River Basalt Group and represents about 87.5 percent by volume of this group. The Saddle Mountains Basalt forms the uppermost basalt unit in the Pasco Basin, except along some of the bounding ridges where Wanapum and Grande Ronde Basalts are exposed (DOE-RL 1994d).

5.3.3.1.2. Ellensburg Formation. The Ellensburg Formation includes volcaniclastic and siliciclastic rocks that are interbedded with the Columbia River Basalt Group in the central and western parts of the Columbia Plateau. The volcaniclastic rocks consist of primary pyroclastic air fall deposits and reworked epiclastics derived from volcanic terrains west of the Columbia 
1 Plateau. The siliciclastic rocks consist of clastic, plutonic, and

2 metamorphic detritus derived from the Rocky Mountain terrain. The age of the

3 Ellensburg Formation is principally Miocene, although locally it could be

4 equivalent to early P1iocene. The thickest accumulations of the Ellensburg

5 Formation lie along the western margin of the Columbia Plateau, where Cascade

6 Range volcanic and volcaniclastic materials interfinger with the Columbia

7 River Basalt Group. Within the Pasco Basin, deposits of the Ellensburg

8 Formation are restricted primarily to the Wanapum and Saddle Mountains

9 Basalts. The lateral extent and thickness of interbedded sediments generally increase upward in the section (Reidel and Fecht 1981). On the Hanford Facility, the three uppermost units of the Ellensburg Formation include the Levey interbed (a tuffaceous sandstone and fine-grained tuffaceous siltstone), the Rattlesnake Ridge interbed (consisting of a lower clay or tuffaceous sandstone, a middle micaceous-arkosic and/or tuffaceous sandstone, and an upper tuffaceous siltstone to sandstone), and the Selah interbed (a mixture of silty to sandy vitric tuff, arkosic sands, tuffaceous clays, and locally thin stringers of predominantly basaltic graveis). The Levey interbed occurs between the Ice Harbor and Elephant Mountain member of the Columbia River Basalts, while the Rattlesnake Ridge occurs between the Elephant Mountain and Pomona members and the Selah is between the Pomona and Esquatzel members of the Columbia River Basalts.

5.3.3.1.3 Suprabasalt Sediments. The suprabasalt sedimentary sequence at the Hanford Facility is approximately 230 meters $(750$ feet) thick in the west-central Cold Creek syncline, and pinches out against the anticlinal ridges that bound the Pasco Basin. The suprabasalt sediments were derived from a variety of depositional environments, and the late Miocene to Pliocene age fluvial-lacustrine Ringold Formation and Pleistocene-age glaciofluvial Hanford formation dominate the preserved stratigraphic record for these sediments (Brown 1959; Routson and Fecht 1979; WHC 1991b). The Plio-Pleistocene unit, early Palouse soil, and pre-Missoula gravels occur locally between the Hanford and Ringold Formations.

The late Neogene (late Miocene to Pliocene) sediments deposited above the Columbia River Basalt Group are represented by the Ringold Formation within the Pasco and Quincy Basins of the central Columbia Plateau (Grolier and
Bingham 1978; Newcomb et al. 1972). The fluvial-1acustrine Ringold Formation was deposited by the ancestral Columbia River and its tributaries in east-west trending valleys formed during development of the Yakima folds. While outcrop of the Ringold Formation is limited to the White Bluffs within the central Pasco Basin and to the Smyrna and Taunton benches within the Othello Basin, extensive data on the Ringold Formation also are available from boreholes in these basins.

The Ringold Formation is classified into three facies associations paleogeography during Ringold time. Section Type I, comprised of gravel and associated sand and silt, represents a migrating channel deposit of the major, thoroughgoing, ancestral Columbia and/or Snake River systems confined to the central portion of the Pasco Basin. Section Type II is comprised mostly of overbank sand, silt, and clay deposited along the margins of the basin, beyond the influence of the main channel. Section Type III, a fanglomerate, occurs 
1 locally around the extreme margins of the basin, and is comprised of mostly

2 angular basaltic debris derived from side-stream alluvium shed off bedrock

3 ridges. Significant stratigraphic variation within units of the Ringold is 4 apparent (Ta1lman et a1. 1981).

The Ringold Formation on the Hanford Facility is up to 185 meters (600 feet) thick in the deepest part of the Cold Creek syncline south of the 200 West Area and 170 meters (560 feet) thick in the western Wahluke syncline near the 100-B Arei. The Ringold Formation pinches out against the Gable Mountain, Yakima Ridge, Saddle Mountains, and Rattlesnake Mountain anticlines. It is largely absent in the northern and northeastern parts of the 200 East Area and adjacent areas to the north in the vicinity of West Pond. The Ringold Formation consists of semi-indurated clay, silt, pedified mud, fine to coarse-grained sand, and granule to cobble gravel. These were formally divided into five units (basal, lower, middle, upper, and fanglomerate), which have been reclassified into the nomenclature presented in Figure 5-3.

The late Pliocene to early Pleistocene generally is characterized as a period of regional incision on the Columbia Plateau. Within the Pasco Basin, this is reflected by the abrupt termination and erosional nature of the top of the Ringold Formation (Bjornstad 1985; Brown 1960; Newcomb et al. 1972). Following incision, a well-developed soil formed atop the eroded surface. Thin alluvial deposits, situated stratigraphically between the Ringold Formation and Hanford formation, are found throughout the Pasco Basin. These deposits are referred to informally as (1) the Plio-Pleistocene unit, (2) pre-Missoula gravels, and (3) early Palouse soil.

The Plio-Pleistocene unit occurs disconformably upon the Ringold in the 200 West Area, and is up to 25 meters ( 82 feet) thick. It is comprised of a basaltic and calcrete facies. The quartzose pebble to cobble gravels of the pre-Missoula gravels (PSP\&L 1982), which can occur above or lateral to the Plio-Pleistocene unit, are up to 25 meters ( 82 feet) thick, and contain less basaltic sediments than underlying Ringold gravels and overlying Hanford formation deposits. The Missoula gravels have a distinctive white or bleached color, and sharply truncate underlying strata. These gravels are not apparent in all areas throughout the Hanford Facility, and the lateral continuity of the units relative to the Plio-Pleistocene and Palouse is questionable.

The early Palouse soil consists of up to 20 meters (65 feet) of silt and fine-grained sand that generally overlies the Plio-Pleistocene unit, or, if present, the Missoula gravels. In the western Cold Creek syncline around the 200 West Area, the Palouse soil occurs immediately above the Plio-Pleistocene unit (Tallman et a1. 1981; Bjornstad 1984; DOE 1988).

The Hanford formation was deposited following the post-Ringold period of erosion and subsequent deposition of the Plio-Pleistocene unit, Missoula gravels, and Palouse soil. The Quaternary Hanford sequence, which has not been formally recognized as a formation, consists of gravel-dominated, and sand-and silt-dominated sequences formed by a variety of depositional processes. In the central Columbia Plateau, the Hanford formation was deposited primarily by proglacial cataclysmic flooding, with lesser amounts of 
1 fluvial, alluvial, and eolian deposition below, between, and above flood 2 deposits.

Above the Hanford formation, alluvium is present as a surficial deposit along major river and stream courses. Varying thicknesses of loess or sand mantie much of the Columbia Plateau. Active and stabilized sand dunes are widespread at ground surface in the Pasco Basin.

5.3.3.1.4 Soils. The soils present at the Hanford Fa:ility have been investigated and mapped by Hajek (1966) and Kocher et al. (1921). The soils present in the north-central portion of the Hanford Facility include Burbank Loamy sand, Rupert sand, Ephrata sandy loam, Ephrata fine sandy loam, Ephrata sand, Winchester sand, and Winchester fine sand. The soils of the Winchester series are basaltic, loose, and open, and have low moisture-holding capacity. The Ephrata series overlay a substratum of gravels and sand and are somewhat calcareous. The gravely phase and the heavy phase of the Ephrata fine sandy loam are reported by Kocher et a1. (1921) to be the soils of greatest agricultural significance in Benton County (DOE-RL 1994d).

According to a study conducted by the Western States Land Grant Universities and Colleges and Soil Conservation Service (1964), the soils of the Hanford Facility are largely entisols (immature soils) formed on unconsolidated upland materials and eolian sands with few clearly-defined horizons. The regosols occur on glaciofluvial deposits that have been continualiy shifted and sorted by wind erosion and deposition. These soils support a shrub-steppe vegetation community, and are principally used for grazing and limited irrigated crop production.

5.3.3.2 Structural Geology. The Columbia Plateau is bounded on the west by the Cascade Range, on the north by the Okanogan Highlands, on the east by the Northern Rocky Mountains and Idaho Batholith, and on the south by the High Lava Plains and Snake River Plain. The Columbia Plateau consists of three informal structural subprovinces: Palouse, Blue Mountains, and Yakima Fold Belt. The subprovinces are delineated on the basis of their structural fabric, unlike the physiographic provinces that are defined on the basis of landforms. The Hanford Facility is located near the junction of the Yakima Fold Belt and the Palouse Subprovinces. The Pasco Basin occurs within the Yakima Fold Belt province, which is characterized by a series of continuous, narrow asymmetric anticlines approximately 5 to 30 kilometers ( 3 to 19 miles) wide and less than 1 kilometer ( 0.6 miles) high, and is one of the larger structural basins in the Columbia Plateau (DOE-RL 1994d).

5.3.3.2.1 Cold Creek Syncline. The Cold Creek syncline lies between the Umtanum Ridge-Gable Mountain uplift and the Yakima Ridge uplift.

The 200 Areas occur along the northern flank of this syncline, the location and attitude of which are shown in Figure 5-4. The Cold Creek syncline is an asymmetric and relatively flat-bottomed structure, with bedrock on the northern flank of the syncline dipping gently (approximately $5^{\circ}$ ) to the south. The 300 Area lies at the eastern end of the Cold Creek syncline where it merges with the Pasco syncline (DOE-RL 1994d). 
DOE/RL-94-40, Rev. 0

06/94

The Yakima Barricade geophysical anomaly occurs on the west side of the cold Creek syncline and coincides with a west-to-east change in hydraulic gradient. Data suggest that this feature is either a steeply dipping fold or a high-angle fault that formed during the late Miocene to early Pliocene; movement ended by late Pliocene (DOE-RL 1994d).

5.3.3.2.2 Untanum Ridge-Gable Mountain Structural Trend. The Umtanum Ridge-Gable Mountain structural trend is a segmented anticlinal ridge, extending for a length of 136 kilometers ( 85 miles) in an east-west direction and passing north of the 200 Areas and south of the 100 Areas. The location of the ridge is shown on Figure 5-4. This structure consists of five segments. From the west, Umtanum Ridge plunges eastward and joins the Gable Mountain-Gable Butte segment just east of the western boundary of the Hanford Facility. The eastern-most segment, the southeast anticline, trends southeast off the eastern boundary of the Gable, Juntain-Gable Butte segment.

5.3.3.2.3 Yakima Ridge. The Yakima Ridge extends west of Yakima, Washington, to the center of the Pasco Basin, where it forms the southern boundary of the Cold Creek syncline. The eastern-most surface expression of the Yakima Ridge uplift is represented by an anticline that plunges eastward into the Pasco Basin (Myers et a1. 1979). The eastern extension of Yakima Ridge is mostly buried, beneath a cover of suprabasalt sediments.

\subsubsection{Seismicity and the Occurrence of Faults. Most known faults within} the Hanford Facility are associated with anticlinal fold axes and are thrust or reverse faults (although normal faults do exist), which probably were formed concurrently with the folding (DOE 1988). Strike-slip faults have not been observed within the Pasco Basin. Wrench faults have been observed along ridges at boundaries between geometrically coherent segments of the structures (i.e., in the Saddle Mountains), but these faults are confined to the individual structures (DOE-RL 1994d).

In general, it has been found that, for structures within the Hanford Facility area, the greatest deformation occurs in the hinge area of the anticlinal ridges and decreases with distance from that area. Accordingly, the greatest amount of tectonic jointing and faulting occurs in the hinge zone and decreases toward the gently dipping limbs. These faults usually exhibit low dips with small displacements, could be confined to the layer in which they occur, and die out with no recognizable displacement (DOE 1988; DOE-RL 1994d).

Eastern Washington (and especially the Columbia Plateau region) is a seismically inactive area when compared to the rest of the western United States. The closest regions of historic moderate-to-large earthquake generation are in western Washington and Oregon, western Montana, and eastern Idaho. The most significant seismic event near the Hanford Facility was the 1936 Milton-Freewater, Oregon, earthquake that had a magnitude of 5.75 and occurred more than 90 kilometers ( 54 miles) away. The largest Modified Mercalli Intensity was felt at Walla Walla, Washington, and was VII. This event was approximately 105 kilometers (63 miles) from the Hanford Facility. 


\subsubsection{Regional Hydrogeology}

The principal surface water feature of the Pasco Basin is the Columbia River. In the Pasco Basin, the Columbia River is joined by three major tributaries: the Yakima River, Snake River, and Walla Walla River. No perennial streams originate in the Pasco Basin (DOE-RL 1994d). Additional detail concerning regional surface hydrology is presented in Chapter 2.0 , as well as numerous references (i.e., DOE-RL 1994d). Potential perching horizons in the vadose zone on the Hanford Facility include the Plio-Pleistocene unit and the early Palouse soil (DOE-RL 1993b). The units are primarily present in and around the 200 West Area but also can be found elsewhere on the Hanford Facility. On the 200 Areas Plateau, the units pinch out between 200 West and 200 East Areas.

The hydrogeology of the Pasco Basin is characterized by a multi-aquifer system consisting of four hydrogeologic units corresponding to the upper three formations of the Columbia River Basalt Group (Grande Ronde Basalt, Wanapum Basalt, and Saddle Mountain Basalt) and the suprabasalt sediments. The basalt aquifers consist of the tholeiftic flood basalts of the Columbia River Basalt Group and relatively minor amounts of intercalated fluvial and volcaniclastic sediments of the Ellensburg Formation. Confined zones in the basalt aquifers are present in the sedimentary interbeds and/or interflow zones occurring between dense basalt flows. The main water-bearing portions of the interflow zones are networks of interconnecting vesicles and fractures of the flow tops and flow bottoms (DOE 1988). The suprabasalt sediment, or uppermost aquifer system, consists of fluvial, lacustrine, and glaciofluvial sediments.

This aquifer is regionally unconfined and contained largely within the Ringold and Hanford formations.

Local recharge to the shallow basalt aquifers results from infiltration of precipitation and run-off along the margins of the Pasco Basin, and in areas of artificial recharge where a downward gradient from the unconfined aquifer system to the uppermost confined basalt aquifer might occur. Regional recharge of the deep basalt aquifers is inferred to result from interbasin groundwater movement originating northeast and northwest of the Pasco Basin in areas where the Wanapum and Grande Ronde Basalts crop out extensively (DOE 1988). Groundwater discharge from shallow basalt aquifers is probably to the overlying aquifers and to the Columbia River. The discharge area(s) for the deeper groundwater system is uncertain, but flow is inferred to be generally southeastward with discharge thought to be south of the Hanford Facility (WHC 1991b; PNL 1993).

Erosional windows through dense basalt flows occur occasionally, and might allow direct interconnection between the uppermost aquifer system and underlying confined basalt aquifers in these locations. Graham et al. (1984) reported that some contamination was present in the uppermost confined aquifer (Rattlesnake Ridge interbed) south and east of Gable Mountain Pond, presumably due to downward contamination flow through erosional windows. Graham et al. (1984) evaluated the hydrologic relationships between the Rattlesnake Ridge interbed aquifer and the unconfined aquifer in this area and delineated a potential area of intercommunication beneath the northeast portion of the 200 East Area. 
The uppermost aquifer system is regionally unconfined beneath the Hanford Facility and lies at depths ranging from less than ( 0.3 meter) (1 Foot) below ground surface near West Lake and the Columbia and Yakima Rivers, to greater than 106.7 meters ( 350 feet) in the central portion of the Cold Creek syncline. Groundwater in this aquifer system occurs within the glaciofluvial sands and gravels of the Hanford formation and the fluvial/lacustrine sediments of the Ringold Formation.

The position of the water table in the southwestern Pasco Basin is generally within Ringold fluvial gravels. In eastern portions of the Pasco Basin, the water table is generaliy within the Hanford formation. However, the main body of the unconfined aquifer generally occurs within the Ringold Formation in the Pasco Basin (WHC 1991b).

Hydraulic conductivity estimates for the uncenfined aquifer have been mapped over the Hanford Facility, as shown in Figure 5-5 (DOE 1988).

The hydraulic conductivities were obtained from pumping tests and are not layer specific, but apply to the combined conductivity of all layers stressed during the test. The hydraulic conductivity ranges from approximately $10^{-3}$ to 10 centimeters per second ( 10 to $10^{3}$ feet per day), reflecting heterogeneity of the material. Transmissivities vary widely regionally because of the variable saturated thickness of the unconfined aquifer (DOE-RL 1994d). Table 5-2 presents the hydraulic parameters for specific geologic units underlying the Hanford Facility (WHC 1991b). The hydraulic conductivities for the Hanford formation vary from approximately 150 to 6,100 meters (500 to 26,300 feet) per day while hydraulic conductivity of the Ringold Formation gravel facies is also highly variable [ 6 to 180 meters (20 to 600 feet) per day], but less than that of the Hanford Facility (Graham et al. 1981).

The base of the uppermost aquifer system is defined as the top of the uppermost basalt flow. However, fine-grained overbank and lacustrine deposits in the Ringold Formation locally form confining layers for Ringold fluvial gravels. The uppermost aquifer system is approximately 152.4 meters (500 feet) thick near the center of the Pasco Basin.

Sources of natural recharge to the uppermost aquifer system are rainfall and run-off from the higher bordering elevations (including the Saddle Mountains, Umtanum and Yakima ridges, and Rattlesnake Hi11s), water infiltrating from small ephemeral streams, and river water along influent reaches of the Yakima and Columbia rivers (DOE-RL 1994d). The movement of precipitation through the unsaturated (vadose) zone has been studied at several locations on the Hanford Facility (i.e., PNL 1987). Gee et al. (1992) indicates that recharge rates in the vadose zone on the Hanford Facility range from more than 100 millimeters (4 inches) per year to near zero, based on lysimeter data. Also, Pacific Northwest Laboratory (PNL) (1987) concluded that no downward percolation of precipitation occurs on the 200 Areas Plateau where the sediments are layered and vary in texture, and that all moisture penetrating the soil is removed by evapotranspiration. Downward water movement below the root zone is common in the 300 Area, where soils are coarse-textured and precipitation was above normal during this study (WHC 1991b). 
Artificial recharge of the uppermost aquifer system occurs from the disposal of large volumes of waste water on the Hanford Facility (principally in the 200 Areas), and from large irrigation projects surrounding the Hanford Facility. Artificial recharge from the 200 Areas waste water disposal facilities is estimated to be approximately 10 times the natural recharge on the Hanford Facility (Graham et al. 1981). From the recharge areas to the west, groundwater flows downgradient in the uppermost aquifer to the discharge areas, primarily along the Columbia River. Figures 5-6 and 5-7 illustrates the groundwater table for the Hanford Facility during the January of 1944 and June of 1993, respectively. Effluent disposal on the Hanford Facility altered hydraulic gradients and fiow directions. Before operations on the Hanford Facility began in 1944 (Figure 5-6), the hydraulic gradient in all but the southwestern-most portion of the Hanford Facility was approximately 1.5 meters per kilometer ( 5 feet per mile). Regional groundwater flow was generally toward the east-northeast at that time, although flow north of Gable Mountain was more to the north. Groundwater flow north of Gable Mountain now trends in a more northeasterly direction as a result of groundwater mounding in the 200 Areas and flow through Gable Gap. South of Gable Mountain, flow is interrupted locally by the groundwater mounds in the 200 Areas. There is a component of groundwater flow to the north between Gable Mountain and Gable Butte from the 200 Areas. The historical groundwater flow patterns are described more fully in publ ished reports (WHC 1991a; PNL 1989; DOE-RL 1993a; and DOE-RL 1993b).

Waste waters discharged on the Hanford Facility have reached the unconfined aquifer and the confined aquifer of the Rattlesnake Ridge interbed. The primary constituents that have reached the upper confined aquifer and the uppermost aquifer system are tritium, iodine-129, ruthenium-106, technetium-99, uranium, nitrate, and chromium (DOE 1986). The groundwater is routinely and extensively monitored to record the movement of contaminants and to determine any impact from the Hanford Facility to the public. Groundwater monitoring reports are produced annually. Preexisting groundwater contamination is discussed more thoroughiy in Section 5:4.

\subsubsection{Uppermost Aquifer: Environmental Restoration Disposal Facility Area Geology and Hydrology}

The hydrogeology of the ERDF area is described in this section. Information on the geology and hydrogeology is summarized from the site characterization plan (WHC 1994C). Recent data gathered since the publication of the site characterization plan were incorporated into this document.

\subsubsection{Environmental Restoration Disposal Facility Area Geology.}

The topography and principal geomorphic features of the ERDF site are shown in Figure 5-8. The site is on the south slope of the Cold Creek bar, and the Hanford formation is the principal geologic unit at the surface. Other surficial materials include stabilized sand dunes and active sand dunes. The surficial units are underlain by 159 to 177 meters (521 to 580 feet) of suprabasalt sediments that rest on top of the Elephant Mountain Member of the

51 Columbia River Basalt Group (Figures 5-9 through 5-13). These sediments 
DOE/RL-94-40, Rev. 0

$06 / 94$

1 the Plio-Pleistocene unit, the Ringold upper unit, Ringold gravel unit $E$, the

2 Ringold lower mud sequence, and Ringold gravel unit $A$.

The ERDF will be in a transitional zone between stratigraphic characteristics of the 200 West and 200 East Areas. Some units present in the western part of the ERDF site are not present in the eastern part because of erosion. Each geologic unit and its stratigraphic characteristics are discussed in the following sections.

The stratigraphy of the subsurface is based on information obtained primarily by cable tool drilling techniques with samples logged by the driller. Often, the only readily available information about a sample is the grain size of the material. A diagram illustrating the lithologic variations is presented in the Site Characterization P1 an using grain size data; however, subtle differences between the units are not easily detected. Recent well drilling confirmed the absence of the P1io-Pleistocene unit, early Palouse soil, and the upper Ringold Formation on the east side of the ERDF. The Hanford formation in the area is, however, less silty than previously thought.

5.3.5.1.1 Basalt Geology and Structure. The Elephant Mountain Member is the uppermost basalt and is continuous beneath the ERDF (Figures 5-4, 5-11, 5-12, and 5-13). There is no evidence of significant erosion in the top of the Elephant Mountain Member and no indication of erosional windows through the basalt in the underlying Rattlesnake Ridge interbed. The basalt dips to the south into the Cold Creek syncline (Figure 5-4) about 60 meters per kilometer ( 317 feet per mile). The Elephant Mountain Member is about 39 meters (128 feet) thick in the area based on data acquired from well 699-29-70A.

5.3.5.1.2 Ringold Formation. The Ringold Formation in the ERDF area is divided (in ascending order) into the fluvial gravels of unit $A$, the paleosol and lacustrine muds of the lower mud sequence, the fluvial gravels of unit $E$, and the sands and lesser muds of the upper unit. Fluvial gravel units B, C, and $D$ are not found in the area (Figures 5-11, 5-12, and 5-13). The Ringold Formation generally dips to the south and its thickness ranges from 71.6 to 110.6 meters (235 to 363 feet).

The Ringold A gravel unit overlies basalt and ranges in thickness from 15.2 to 36 meters ( 50 to 118 feet). The fluvial gravels and intercalated sands of unit $A$ thicken and dip to the south and southwest towards the axis of the Cold Creek syncline (WHC 1991d). The top of the unit is planar, dipping to the west and southwest (WHC 1991d). Gravel unit A corresponds to the lower basal unit (DOE 1988).

The lower mud sequence overlies the $A$ gravel unit and is 8.2 to 30 meters (27 to 95 feet) thick. The lower mud sequence consists of overbank and lacustrine deposits (WHC 1991d).

The Ringold $E$ gravel unit overlies the lower mud sequence and ranges in thickness from 18.6 to 83.2 meters ( 61 to 273 feet). This gravel has been partially eroded by cataclysmic flooding during the Pleistocene under most of 
1 the ERDF area. Fluvial gravel unit E corresponds to the middle Ringold unit 2 as defined by the DOE (1988).

3

4

Overlying the $E$ gravel unit is the upper Ringold unit that ranges in thickness from 0 to 12.8 meters ( 0 to 42 feet). The upper Ringold is present in the western part of the ERDF and pinches out to the east and south. The upper Ringold unit consists of fluvial sands, overbank deposits, and lacustrine sediments as originally defined by Newcomb (1958).

5.3.5.1.3 Plio-Pletstocene Unit. The Plio-Pleistocene unit overlies the Ringold E gravel unit and ranges in thickness from 0 to 10.7 meters $(0$ to 35 feet). This unit is present mostly in the 200 West Area and pinches out to the south and east in the ERDF area. The unit consists of carbonate-rich strata interbedded with carbonate-poor 1 ithologies. The unit is laterally discontinuous as reflected in its very irregular thickness (WHC 1991d). The unit is interpreted to be a weathering surface developed on the top of the Ringold Formation (PNL 1990). The Plio-Pleistocene unit and the upper Ringold unit are present above the unconfined aquifer and could be a perched unit below the ERDF.

5.3.5.1.4 Early Palouse Soil. The early Palouse soil is largely restricted to the vicinity of the 200 West Area and is up to 20 meters (65.6 feet) thick (WHC 1991d). The unit is present on the extreme western side of the ERDF site but pinches out to the south, east, and southeast. The early Palouse soil consists of unconsolidated muddy sand to sandy mud and is interpreted to be an early Pleistocene loess (PNL 1990). The upper contact of the unit is poorly defined and sometimes grades lateraily into the silty facies of the Hanford formation (WHC 1991d).

5.3.5.1.5 Hanford Formation. The Hanford formation is found throughout the ERDF area (Figures 5-11, 5-12, and 5-13), and ranges in thickness from 41.1 to 97.2 meters (135 to 319 feet). The thickest part of the formation is found on the north side of the ERDF on the Cold Creek bar and thins to the south. The Hanford formation is divided into three facies:

(1) gravel-dominated, (2) sand-dominated, and (3) silty (WHC 1992b). Under the ERDF site, the two principal facies are sand-dominated and silty. Thin gravel-dominated facies are present in the north part of the ERDF site but pinch out to the south. This gravel is about 6 to 9 meters (20 to $30 \mathrm{feet}$ ) thick and is found at the surface or immediately underlying Holocene sand dune deposits. At the US Ecology, Inc., site, the Mount St. Helens $S$ set volcanic ash layer is about 8 centimeters ( 3 inches) thick, is present at an elevation of 214 to 216 meters (702 to 710 feet) above mean sea level (Bergeron et al. 1987), and can be seen in the disposal trenches. The ash is located within the sand-dominated facies at the US Ecology, Inc. site. This ash is believed to be approximately 13,000 years old (Mullineaux et a1. 1978). Also found throughout the ERDF site are clastic dikes within the Hanford formation.

The silty facies consist of thinly bedded, plane-laminated and ripple cross-laminated silt and fine- to coarse-grained sand that commonly displays normally graded rhythmites (Myers et 21. 1979; DOE 1988). These facies are equivalent to Touchet beds and were deposited under slackwater conditions and in back-flooded areas (DOE 1988). 
DOE/RL-94-40, Rev. 0

$06 / 94$

1 The sand-dominated facies are the principal facies under the ERDF site.

2 These factes consist of fine- to coarse-grained sand and granule gravel

3 displaying plane lamination and bedding and less commonly plane bedding and

4 channel-fill sequences in outcrop (WHC 1992b). The laminated sand facies were

5 deposited adjacent to main flood channelways during the waning stages of

6 flooding. The Mount St. Helens $S$ set ash is located within the sand-dominated

7 facies at the US Ecology, Inc. site.

The gravel-dominated facies generally consist of coarse-grained basaltic sand and granule-to-boulder gravel (WHC 1992b). These facies are relatively thin at the ERDF site and pinch out rapidiy to the south of the Cold Creek bar.

Clastic dikes are present in the Hanford formation sediments at the ERDF site. Clastic dikes commoniy are vertical to irregularly shaped dipping fissures filled with sand, silt, clay, and gravel. At the surface, these dikes form polygonal patterns. Clastic dikes have been observed in each of the open trenches at the US Ecology, Inc. site to depths of at least 13.7 meters (45 feet) (Bergeron et a1. 1987).

5.3.5.1.6 Holocene Deposits. Longitudinal sand dunes mantle the Hanford formation in the ERDF area. The height of the dunes ranges from 1.5 to 3 meters (5 to 10 feet). These northeast-southwest trending features have been deposited since the pleistocene and cover most of the site. The dunes sometimes contain Mazama ash indicating an age of 6,800 years before present (Bergeron et al. 1987). Occasionally, the stabilized dunes are transected by roads where large blowout areas are formed.

5.3.5.1.7 Geomorphic Features. The ERDF site lies along the southern edge of a giant Pleistocene flood bar referred to as the Cold Creek bar. Based on internal structures, this flood bar is interpreted to represent deposits of multiple floods (DOE 1988). South of the bar, the Central Hanford Sand Plain is composed of laminated sands with minor silts (DOE 1988). Northeast-southwest trending longitudinal sand dunes also mantle the sand plain.

5.3.5.2 Environmental Restoration Disposal Facility Area Hydrology. The hydrogeology of the ERDF is described in this section. Information on the geology and hydrogeology is summarized from the site characterization plan (WHC 1994C). Recent data gathered since the publication of the site characterization plan were incorporated into this document.

5.3.5.2.1 Surface Water. The ERDF will be located within the Cold Creek watershed. Cold Creek is an ephemeral stream. A discussion of the Cold Creek watershed and probable flood risks is detailed by PNL (1981) and summarized in the following paragraphs.

The 870 square kilometer (336 square mile) watershed of Cold Creek drains into the Yakima River about 1.6 kilometers (1 mile) upstream from Horn Rapids Dam (PNL 1981). Cold Creek has two distinct reaches: an upper and lower reach. The reaches are separated by an area, located on either side of 52 Route 240, where there is no clearly defined channel. Using conservative 
41

42

43

44

45

46

47

48

49

50

51 52 estimates of stream and precipitation parameters presented by PNL (1981), it is reasonable to conclude that it is unlikely that flooding would occur in the area occupled by the ERDF.

5.3.5.2.2 Vadose Zone. The vadose zone beneath the ERDF site ranges between 67.7 and 105.5 meters (222 and 346 feet) thick and consists of the following units based on lithology at nearby weils and depth to water: Hanford formation (sand dominated factes), Plio-Pleistocene, upper Ringold, and Ringold gravel unit $E$ (Figure 5-3). A description of these units can be found in Section 5.3.5.1. The Plio-Pleistocene unit and upper Ringold were not found while drilling wells 699-34-61 and 699-38-61 (refer to Section 5.5.1 for information pertaining to these wells). Flow characteristics through the vadose zone depend on the physical properties. Physical properties data collected during ERDF site characterization activities for the vadose zone are currently being complled and will be presented in the Site Characterization Plan. Preliminary data from recent characterization activities confirm the lack of perched water in the vadose zone and generally low soll moisture content. Selected borehole samples were analyzed for particle-size distribution, porosity, bulk density, moisture content, saturated hydraulic conductivity, unsaturated hydraulic conductivity, moisture potential curves, calcium carbonate content, and soil matric potential. These data will be used to aid in correlation of the hydrogeologic materials between boreholes as well as determine rates of moisture movement in the vadose zone. A general discussion of the vadose zone is described in the hydrogeologic model for the 200 East and 200 West aggregate area reports (WHC 1992e, 1992f).

5.3.5.2.3 Uppermost Aquifer System. The general hydrostratigraphy of the uppermost aquifer system is described in a standardized text (WHC 1991b). The uppermost aquifer system beneath the ERDF site consists of the fluvial gravels of the Ringold Formation based on geologic and hydrologic information from wells. Units within the uppermost aquifer system that could act as an aquitard or confining unit are the silts of the Piio-Pleistocene and upper Ringold unit and the Ringold lower mud. Lithologies of these units are discussed in Section 5.3.5.1. Units that might act as perched water zones include the Plio-Pleistocene and early Palouse soll (DOE-RL 1993h). However, available data (WHC 1994C) indicate that perched water zones are not present below the ERDF.

The hydraulic conditions of the aquifer system beneath the ERDF consist of unconfined hydraulic conditions in the uppermost saturated unit and confined hydraulic conditions beneath a confining unit. The uppermost saturated unit beneath the ERDF is Unit $E$ of the Ringold Formation (Figure 5-3). The predominant suprabasalt confining unit in the 200 East and 200 West Areas is the lower mud unit of the Ringold Formation. The lower mud unit is known to occur at the western side of the site but the lateral extent of this unit is not known. If the lower mud unit is present, it is likely that the hydraulic condition of Ringold unit $A$ is confined. These confined conditions exist in the 200 East and 200 West Areas (WHC 1992d; WHC 1992e, 1992f).

The uppermost aquifer system (Ringold Formation) below the ERDF is separated from the underlying confined Rattlesnake Ridge interbed aquifer by 
1 the Elephant Mountain Member of the Saddle Mountains Basalt. In areas north

2 of the 200 East Area, erosional windows in the Elephant Mountain Member might

3 facilitate hydraulic comunication between the Rattlesnake Ridge interbed and

4 the Ringold Formation. However, erosional windows are not known to exist

5 beneath the ERDF, and the units are not believed to be hydraulically connected

6 below the ERDF. A downward vertical hydraulic gradient exists between the

7 uppermost aquifer system and the underlying confined Rattlesnake Ridge

8 interbed aquifer in the vicinity of the 200 Areas (WHC 1991b; DOE-RL 1993a;

9 DOE-RL 1993b).

10

11

12

13

14

15

16

17

18

19

20

21

22

23

24

25

26

27

28

29

30

Aquifer properties of transmissivity and hydraulic conductivity for the uppermost aquifer in the 200 East and 200 West Areas have been summarized (WHC 1992e, 1992f). Site-specific data are not avallable for the aquifer beneath the ERDF. Recent testing at well 699-32-72B yielded an estimated transmissivity of 464.5 square meters (5,000 square feet) per day for the unconfined aquifer (upper Ringold Formation). Wells 299-W21-1 and 699-33-56 were completed in unit E, are located near the ERDF, and were aquifer tested in 1958 and 1973, respectively. The unconfined aquifer at wells 299-W21-1 and 699-33-56 exhibited transmissivity values of 2,700 square meters (29,000 square feet per day) and 1,950 square meters per day (21,000 square feet) per day, respectively (WHC 1992e, 1992f; PNL 1973; Bierschenk 1957).

Groundwater flow beneath the ERDF is predominantly from the west to the east (Figure 5-14). Elevation of the water table has risen significantly since the 1950's as indicated by water level changes in well 699-35-70 (Figure 5-15). The water level rise of over 15 meters (50 feet) occurred from 1950 to the late 1960's when the level appeared to have stabilized. The initial rise was due to the start up of waste water units in the 200 West Area. In the mid 1980 's, the water level began a slight decline, probably due to the decreased discharge to the 200 West Area waste water units. As water level continues to decline, groundwater flow is likely to acquire a more easterly flow below the ERDF (WHC 1994C). The historical groundwater flow patterns are described more fully in Section 5.3.4 and in supporting documents (WHC 1991b); PNL 1989; DOE-RL 1993a).

\subsection{EXISTING GROUNDWATER CONTAMINATION}

The following paragraphs contain information on the present groundwater contamination on the Hanford Facility and the proposed method of determining background groundwater quality below the ERDF. This information is necessary to develop the groundwater monitoring network for the ERDF in accordance with the requirements of 40 CFR 264.552(d) and (e) and WAC 173-303-646(5)(b).

The groundwater quality on the Hanford Facility has been monitored for years as part of five groundwater quality monitoring programs including: the operational groundwater monitoring network (OGWMN); RCRA; CERCLA; the PNL'S environmental monitoring program; and the sanitary water quality surveillance program administered by the Hanford Environmental Health Foundation (HEHF). These programs all help determine the impact of past, present, and future waste disposal practices on human health and the environment across the Hanford Faciltty (DOE-RL 1993a, 1993b). Groundwater wells were installed on 
1 the Hanford Facility beginning in 1944. Currently, there are approximately

225 active groundwater monitoring wells located in the vicinity of the ERDF.

3 The following information was extracted from published documents (WHC 1994C);

4 WHC 1993d; DOE-RL 1993a, 1993b; WHC 1993d).

Eighteen constituents occur in distinct and mappable (i.e., at least one plume detected in multiple-wells that are semicontiguous) groundwater contaminant plumes below the 200 Areas. Constituents present in these plumes include arsenic, chromium, cyanide, fluoride, nitrate, carbon tetrachloride, chloroform, trichloroethylene, tritium, gross beta, cobalt-60, strontium-90, technet fum-99, fodine-129, cesium-137, gross alpha, uranium, and plutontum-239 and 240 . It should be noted that all of these plumes emanate from activities within the 200 Areas, but none of the plumes emanate from sources within the ERDF area.

of the 18 contaminants detected, 11 occur in plumes that are near or extend into the area of the ERDF. Constituents comprising these 11 plumes include chromium, nitrate, carbon tetrachloride, chloroform, trichloroethylene, tritium, gross beta, technetium-99, lodine-129, gross alpha, and urantum. Figures 5-16 through 5-26 show the plume configuration for these contaminants. The following provides a short discussion on each plume.

The remaining seven constituents present in groundwater below the 200 Areas (arsenic, cyanide, fluoride, cobalt-60, strontium-90, cesium-137, and plutonium-239 and 240) are not expected to impact the ERDF, for various reasons. The cyanide, cobalt-60, strontium-90, cesium-137, and plutonium-239 and 240 contaminant plumes are located entirely within the 200 East Area and are migrating away from the ERDF to the east. Although arsenic plumes are located within both the 200 East and 200 West Areas, the plumes within the 200 East Area are migrating away from the ERDF to the east, while the plumes in the 200 West Area are located upgradient and are anticipated to migrate to the east along a course parallel to the ERDF. The fluoride contaminant plume is located entirely within the 200 West Area, but is upgradient of the ERDF and is anticipated to migrate to the east along a course parallel to the ERDF. Because these seven contaminant plumes are not anticipated to impact the ERDF, these plumes will not be discussed further. However, a complete discussion of each contaminant plume can be found in other documents (WHC 1993d).

Chromium occurrence is shown in Figure 5-16. In the 200 West Area, the drinking water standard of 50 parts per billion is exceeded in the center of the plume; however, concentrations exceeding the regulatory level have not been detected with in the ERDF boundaries. The highest average concentration within the 200 West Area is 323 parts per billion. The leading edge of one chromium plume extends into the western portion of the ERDF.

Nitrate occurrence is shown in Figure 5-17. Nitrate contamination is widespread in the 200 West Area, with the highest average concentrations reaching 1,322 parts per million. The nitrate plume also extends into the northern portion of the ERDF, where the drinking water standard of 45 parts per million might be exceeded. Although nitrate plumes have been detected 
1 beneath the 200 East Area, the plumes are migrating to the east and do not

2 impact the ERDF area.

3

Carbon tetrachloride occurrence is shown in Figure 5-18. Carbon tetrachloride has been detected in the majority of the 200 West Area, with highest average concentrations reaching 6,559 parts per billion. Discussion of the extent and potential source facilities for the carbon tetrachloride can be found in published reports (DOE-KL 1991). The leading edge of the carbon tetrachloride plume has migrated into the northern portion of the ERDF area.

Chloroform occurrence is shown in Figure 5-19. The maximum average value in the plume is 1,595 parts per billion. Although chloroform is not a widespread contaminant in the area near and around the ERDF, there is a potential for the presence of chloroform within the ERDF because of the detection of the constituent in two wells in the southern portion of 200 West Area. Chloroform concentrations detected in the two wells were lower than the drinking water standard of 100 parts per billion.

Trichloroethylene occurrence is shown in Figure 5-20. Trichloroethylene and chloroform occupy nearly the same area in the southern portion of 200 West Area. The concentrations detected were greater than the drinking water standard of 5 parts per billion. Trichloroethylene also has been detected adjacent and west of the northwestern border of the ERDF area.

Tritium occurrence is shown in Figure 5-21. Tritium contamination appears to be widespread beneath the area of the ERDF in concentrations exceeding the drinking water standard of 20,000 picocuries per 1iter. The maximum average tritium concentration beneath the ERDF is 6,193,000 picocuries per liter. The origin of the plume is within the 200 West Area downgradient of numerous cribs associated with S Plant and the decommissioned U Pond. Tritium plumes also have been detected beneath the 200 East Area; however, these plumes are migrating to the east and do not impact the ERDF.

The distribution of beta-emitting radionuclides is shown in the gross beta plume map (Figure 5-22). The highest average beta-emitting concentrations $(3,272$ picocuries per liter) occur with in the larger plume located at the northwest corner of the ERDF. Beta-emitting radionuclides also have been detected beneath the 200 East Area, but do not impact the ERDF because of the eastward migration of the plumes.

Technetium-99 and iodine-129 are contributors to the beta-emitting plume, as shown in Figures 5-23 and 5-24, respectively. Maximum average concentrations of technetium-99 in excess of 25,000 picocuries per liter have been detected at the center of the large plume. As shown in Figure 5-24, the iodine-129 plume has migrated extensively throughout the ERDF area.

The highest average concentration for the contaminant ( 30 picocuries per liter) occurs approximately 550 meters (1,800 feet) from the 200 West Area boundary. Iodine-129 also has been detected beneath the 200 East Area; however, the plumes are migrating to the east and do not impact the ERDF.

Gross alpha and uranium occurrence is shown in Figures 5-25 and 5-26, respectively. These plumes virtually cover the same area and extend into the 
area of the ERDF with concentrations at the drinking water standards (15 picocuries per liter for gross alpha and 40 picocuries per liter for uranium). The two alpha-emitting radionuclides responsible for the contamination are uranium and plutonium. Maximum average concentrations within the large gross alpha plume exceed 2,300 picocurles per liter. Gross alpha plumes also have been detected beneath the 200 East Area; however, these plumes are migrating to the east and do not appear to impact the ERDF. Three plumes of uranium contamination with detections in excess of the drinking water standard of 40 picocuries per liter have been mapped in the groundwater beneath the 200 West Area.

\subsection{GROUNDWATER MONITORING PROGRAM}

Groundwater monitoring of a CAMU is mandated under 40 CFR 264.552(e) and WAC 173-303-646. As described within the CAMU preamble (58 FR 29), the "permit or order must establish the groundwater monitoring requirements for each CAMU", and hence the inclusion of a groundwater monitoring plan within the CAMU application facilitates this decision making process. The CAMU preamble indicates that groundwater monitoring requirements as specified in today's rule are not detalled, specific requirements addressing the numerous technical elements of installing and operating an effective groundwater monitoring system. Rather, the requirements provide general standards of performance for such systems; detailed specifications or performance standards for groundwater monitoring will be specified in the permit or order, based on site-specific information and conditions. This statement indicates that specific groundwater monitoring requirements for a CAMU purposely were excluded from the regulations allowing for custom tailoring of the groundwater monitoring plan to meet programmatic goals or standards.

\subsubsection{Programmatic Requirements for Groundwater Monitoring Under the Corrective Action Management Unit Regulations}

The following are the performance standards that the proposed groundwater monitoring system must meet [40 CFR 264.552(c) and (e)] and

WAC $173-303-646(5)(b)$ :

"Requirements for groundwater monitoring that are (should be) sufficient to:

(i) Continue to detect and to characterize the nature, extent, concentration, direction, and movement of existing releases of hazardous constituent in groundwater from sources located within the CAMU

(ii) Detect and subsequently characterize releases of hazardous constituents to groundwater that may occur from areas of the CAMU in which waste will remain in place after closure of the CAMU."

The proposed groundwater monitoring program for the ERDF is included in this section. Although the ERDF is yet to be constructed and thus potential 
DOE/RL-94-40, Rev. 0

$06 / 94$

1 contamination emanating from the unit cannot be present, upgradient

2 groundwater data indicate that plumes exist below the ERDF, emanating from

3 areas upgradient of the ERDF. Therefore, to meet requirement (i) the proposed

4 groundwater monitoring program includes determination and assessment of

5 upgradient groundwater quality as it relates to potential releases from the

6 ERDF. The proposed groundwater monitoring program is based upon RCRA Guidance

7 (EPA 1986b) and WAC 173-160 requirements relative to well construction,

8 monitored horizon, etc., as this level of detail is required to meet the performance standard presented in requirement (ii).

Groundwater Monitoring Network. The ERDF groundwater monitoring network consists of five currently existing wells and six proposed wells (Figure 5-27). Each of the six proposed wells will be constructed in accordance with RCRA and WAC standards (refer to Table 5-3), as described in Srction 5.5.4. Existing wells to be incorporated in the groundwater monitoring network for the ERDF are wells 299-W22-42, 299-W27-1, 699-38-61, 699-34-61, and UP1-7. Proposed wells to be installed are designated A-E and well 699-SDF-9 in Table 5-3, until permanent well number assignments are made.

As shown in Figure 2-27 and Table 5-3, the upgradient groundwater monitoring network consists of wells 299-W27-1, A, 299-W22-42, B, and UP1-7. Wells $C, D, E, 699-38-61,699-34-61$, and 699-SDF-9 comprise the downgradient network. Available well completion and construction information for each existing well is included in Appendix 5A.

Based on available cross-sectional information and geologic description in the well construction logs, each of the proposed groundwater monitoring wells are screened across the water table (uppermost aquifer) within the Ringold Formation, Unit E. The north-south cross-sections, Figures 5-11 and 5-13, clearly show that the same unit is being monitored (i.e., the water table is planar, the geological descriptions of the unit being monitored is similar between wells, and monitored units geologically correlate between wel1s). The east-west cross-section, Figure 5-12, also shows that the same geologic units being monitored between wells.

Upgradient Network: Discussion and Justification. The upgradient well network is designed to detect and monitor upgradient groundwater qual ity relative to the ERDF. The ERDF is directly downgradient of many 200 West Area units that are the source of preexisting groundwater contamination currently present below the ERDF (as discussed in Section 5.4). All upgradient wells chosen for the ERDF are located with in the groundwater flow path between the 200 West Area and the ERDF. In addition, the upgradient wells are located to monitor migration of the 11 contaminant plumes (discussed in Section 5.4.1) into the ERDF. All but one of the upgradient monitoring wells, well 299-W27-1, are constructed to standards in WAC 173-160 and in RCRA guidance (EPA 1986b). Proposed wells $A$ and $B$ will be installed before acceptance of RCRA remediation waste at the ERDF.

Although not constructed to RCRA and WAC standards, wel1 299-W27-1 design is sufficient to allow collection of sufficient quality groundwater data. Available well construction information for this well is presented in 52 Appendix 5A. We11 299-W27-1 has a 25.4-centimeter (10-inch) outercasing 
cemented to 6 meters (20 feet) below ground surface. A perforated 20.3-centimeter (8-inch) carbon steel casing was installed to 46 meters (150 feet) below ground surface. Inside of this casing, a 15.2-centimeter (6-inch) carbon steel casing originally was installed to 78 meters (257 feet), but was pulled back to 65 meters ( 212 feet) and cemented in place at this depth. A 15.24-centimeter (6-inch) telescoping casing (blank) was installed from approximately 64 to 66 meters (211 to $216 \mathrm{feet}$ ), below which is a telescoping \#10 slot screen that is 6 meter (20 feet) long. A 4.5-meter (15-foot) long blank occurs below the screen. No sand pack was installed around the screen (which is allowed, under these site conditions, by WAC 173-160). Although screen material is not known, the \#10 well slot standard and use of blank material above and below the screen is common construction for stainless steel well screens. Based on this information, groundwater samples acquired from this well will be of sufficient quality to meet quality assurance requirements (refer to Section 5.5.5)

The upgradient groundwater monitoring network was selected to monitor preexisting contaminant plumes and any others that might enter below the ERDF area from upgradient sources. As presented in Figures 5-16 through 5-26, 11 contaminant plumes occur immediately upgradient or below the ERDF; the selected upgradient network provides comprehensive coverage of preexisting contamination. Also, these wells are located along the western margin of the ERDF immediately adjacent to the ERDF boundary, and thus monitor groundwater quality immediately upgradient of the ERDF. The upgradient wells selected will monitor currently existing contamination below the ERDF, with the following coverage, although all wells will be monitored for the constituents present in Section 5.5.2:

- Wel1 299-W27-1 will monitor chromium, nitrate, chloroform, trichloroethylene, and tritium groundwater contamination.

- Proposed monitoring well A will monitor chromium, trichloroethylene, chloroform, carbon tetrachloride, nitrate, tritium, and iodine-129 groundwater contamination.

- Well 299-W22-42 well monitor nitrate, carbon tetrachloride, gross alpha, gross beta, tritium, technetium-99, and iodine-129 groundwater contamination.

- Proposed monitoring well B will monitor nitrate, carbon tetrachloride, gross alpha, gross beta, technetium-99, and iodine-129 groundwater contamination.

- UP1-7 will monitor gross alpha, iodine-129, gross beta, tritium,carbon tetrachloride, and nitrate groundwater contamination.

The upgradient network also was selected to monitor groundwater contamination occurring upgradient from the ERDF, but not yet present within groundwater below the ERDF, including uranium and trichloroethylene. Comparison of existing plume location and groundwater flow from the 200 West Area indicates that the selected upgradient monitoring network provides comprehensive monitoring along the immediate western boundary of the ERDF and 
1 is capable of monitoring all currently preexisting plumes below or upgradient 2 of the ERDF. Monitoring well UP1-7 currently is more 'across gradient' than 3 upgradient relative to the ERDF, but monitors preexisting contamination that 4 occur below the northern margin of the ERDF.

Downgradient Network: Discussion and Justification. Figure 5-27 presents the downgradient groundwater monitoring network. A11 of the six wells in the downgradient monitoring network are (or will be) constructed to meet RCRA and WAC requirements and guidelines (Table 5-3 and Appendix 5A). A11 wells are (or will be) screened across a 6.1-meters (20-foot) interval spanning the uppermost water-bearing interval, or the appropriate length to accommodate groundwater level fluctuations. Examination of Figure 5-27 shows that a nearRCRA standard we 11 699-35-59 occurs nearly adjacent to the proposed we $11 \mathrm{D}$. Well 699-35-59 is a US Ecology well, used to monitor an area east of the ERDF. Because avallability of this well for inclusion in the ERDF monitoring network cannot be determined at this time, installation of well $D$ is proposed. If access to well 699-35-59 can be obtained, proposed well $D$ will be not installed. Proposed monitoring well $D$ will be installed before acceptance of RCRA remediation waste in the ERDF trench. Proposed wells $C$ and $E$ will be installed if groundwater flow direction changes occur. Discussion of and justification for this is presented in the following paragraph.

Determination of the downgradient groundwater monitoring network was accomplished using the MEMO (Model), developed by Golder Associates (1992). The user manual for this model is presented in Appendix 5B. The model is based on two-dimensional analytical solution of Domenico and Robbins (1985). A description of the model and input parameters are included in Appendix 5B. The contaminant transport input parameters used for simulating the efficiency of the network at the ERDF are listed in Table 5-4. The transport parameters are conservative and were used for other simulations in the 200 Areas.

The MEMO model was developed to assist in the design and location of monitoring well networks. The model simulates the migration of hypothetical contaminant plumes from a site and quantifies the efficiency of alternative monitoring well network designs in detecting the plumes. Monitoring efficiency is defined as the ratio of the area of detection to the total area of the potential source. For example, an efficiency of 90 percent predicts that releases occurring over 90 percent of the site would be detected by the monitoring wells, while releases occurring over the remaining 10 percent would not be detected.

The model efficiency determination is based on one of two solution parameters:

1. Whether a plume is detected by the monitoring well network before it crosses a specified buffer zone boundary

2. Whether a plume is detected before it migrates for a specified time.

The model provides a basis for optimizing the proposed well network design; wells can be added or deleted to optimize the network efficiency. Maps of the site showing areas from which releases would be detected by a 
given well network are produced, providing insight into the benefits of adding, deleting, or moving specific wells. Consequently, the use of the model reduces the uncertainties inherent in proposing monitoring well network designs.

The MEMO input for the ERDF uses a grid that starts the simulation at the west end of the trench and proceeds to the east. This direction of simulation is identical to the direction in which waste will be placed within the ERDF trench. Input parameters include the coordinates for source area, line of compliance, buffer zone, well locations, groundwater flow direction, and contaminant transport parameters. The buffer, zone used in the simulations was approximately 150 meters (500 feet) east of -the ERDF 1 ine of compliance, as defined in the Tri-Party Agreement. Although different zones of groundwater flow may be represented in the MEMO model, the current groundwater flow direction is predominantly to the east, and only one groundwater flow direction zone was used in the simulation. Conservative contaminant transport parameters were used and are listed in Table 5-4. Values of dispersivity were estimated from those associated with existing contaminant plumes in the 200 Areas. Four wells were included in the simulated network: wells $699-34-61,699-38-61,699-S D F-9$, and $D$. Because groundwater flow direction in the 200 Areas has changed with different recharge/discharge events (Section 5.3.5.2.3), three simulations were run assuming different overall flow direction below the ERDF: directly east $\left(0^{\circ}\right), 5^{\circ}$ north of east, and $5^{\circ}$ south of east $\left(355^{\circ}\right)$.

The results of the model varied with each of the three flow directions modeled. The efficiency of the four well network simulated varied from 99 , 78 , and 96 percent, using flow directions of $0^{\circ}$ directly to the east, $5^{\circ}$ north of east, and $5^{\circ}$ south of east, respectively. Monitoring well efficiency of over 90 percent is consiciered to be acceptable. Therefore, a downgradient well network consisting of wells D, 699-38-61, 699-SDF-9, and 699-34-61 has an efficiency of 99 percent with groundwater flow in its current direction (east).

Groundwater flow directions are expected to change from its current easterly flow because of the decline of groundwater mounds present in the 200 Areas. The 1944 groundwater flow map (Figure 5-6) indicates groundwater flow direction beneath the ERDF will shift to a more southerly direction with decline in mounding and return to preoperational conditions. The MEMO model results indicate that well $E$ would be necessary to ensure monitoring well efficiency if flow shifted to the south, while well $\mathrm{C}$ is necessary if groundwater flow shifted to the north.

Efficiency estimates were calculated assuming that the ERDF trench is completely full. If network efficiency also is calculated assuming that only the west end of the trench contains waste and assuming groundwater flow is to the east, a monitoring well network consisting of wells $D, 699-38-61$, 699-SDF-9, and 699-34-61 sti11 offers efficiency of over 99 percent. However, if shifts in groundwater flow direction occur to the north or south $5^{\circ}$, wells $C$ and $E$ al so would be necessary to detect releases from the partially filled trench. Based on these data, wells 699-38-61, 699-SDF-9, 699-34-61, and D will compromise the initial downgradient monitoring network. Proposed 
1 monitoring wells $C$ and $E$ will be installed, as warranted, based on groundwater 2 flow direction changes. Groundwater flow beneath the ERDF will be evaluated 3 annually, with wells $C$ and $E$ installed if groundwater flow direction changes 4 are detected that warrant their construction (i.e., flow direction changes of $5 \pm 2^{\circ}$ north or south, and that indicate that fiow direction changes are not 6 temporary).

\subsubsection{Indicator Parameters}

Groundwater extracted from the ERDF groundwater monitoring wells will be analyzed for the parameters presented as follows and in Table 5-5: (The numbers in parentheses following the analytes are the method detection limits for these parameters, in micrograms per liter, unless otherwise indicated.)

1. Upgradient groundwater contaminants: chromium (10), nitrate (500), carbon tetrachloride (5), chloroform (15), trichloroethylene (5), tritium (to be determined), gross beta ( 8 picocuries/liter), technetium-99 (to be determined), iodine-129 (to be determined), gross alpha (4 picocuries per liter), uranium (.7)

2. Indicator parameters: temperature, $\mathrm{pH}$ (field and laboratory), specific conductance (field and laboratory), total dissolved solids, total suspended solids, total organic carbon, total carbon, total organic halogen

3. Representative parameters in waste: benzene (5), bromoform (5), chlorobenzene (5), 1,2 dichloroethane (5), cis-1,1 dichloroethylene (5), trans-1,1 dichloroethylene (5), 1,2 dichloropropane (5), acetonitrile (10), ethylbenzene (5), 1,1,2,2-Tetrachloroethane (5), tetrachloroethylene (5), toluene (5), vinyl chloride (10), xylene (5), naphthalene (10), copper (10), cadmium (2), lead (5), chloride $(500)$, sulfate $(500)$, beryllium (3), radium (1 picocurie per liter), cyanide (10), mercury $(0.1)$, silver $(10)$, fluoride $(500)$, sodium (200), representative PCBs.

Groundwater collected from both upgradient and downgradient wells will be monitored for all constituents listed.

Parameters 1 isted in item 1 , were selected to ensure that all preexisting groundwater contamination will be monitored throughout the ERDF monitoring network. Parameters shown in item 2 were selected to provide broad indicator parameter data, particularly for upgradient wells, so that any additional constituents that could occur in upgradient groundwater will be detected. Parameters in item 3 were selected because these are representative of constituents anticipated to be present within waste; this 11st (together with items 1 and 2) constitute all parameters analyzed for at the LLBG, which has accepted waste that is likely to be very similar to that emplaced in the ERDF. Modification of the analytical suite presented in items 1 through 3 , might occur before initiation of waste acceptance at the ERDF, to include any additional necessary parameters, based on new waste analysis data acquired after submission of this application. 
DOE/RL-94-40, Rev. 0

$06 / 94$

\subsubsection{Waste Characteristics}

The ERDF will manage remediation waste from cleanup of RCRA and CERCLA past-practice waste sites. There are 78 remediation sites on the Hanford Facility that include, collectively, over 1,000 individual waste sites. Solid waste occurring at these remediation sites includes nonradioactive nonhazardous waste, nonradioactive hazardous waste, TSCA regulated waste, low-level radioactive waste (LLW), and transuranic (TRU) radioactive waste. The TRU waste will not be managed at the ERDF. The LLW is subdivided as contact-handled or low-activity (surface dose rate <200 millirem per hour) and remote-handled or high-activity (surface dose rate $\geq 200$ millirem per hour). The LLW also may be classified as mixed waste if regulated hazardous/dangerous waste components are present. The majority of the waste has sufficientiy low concentrations of radionuclides to be considered low-activity, although a small percentage is considered high-activity waste. Other waste includes solid waste from landfills and demolition debris, but it must be emphasized that only remediation waste will be managed in the ERDF. Hazardous/dangerous waste constituents, including metals and organic solvents are found in some of the waste. A more detailed discussion of the remediation waste that is expected to be present is provided in Chapter 3.0 .

\subsubsection{Description of Wells}

New wells constructed to monitor the ERDF will meet RCRA guidance and WAC requirements and guidance regarding well construction (Figure 5-28). Well depths, materials of construction and well installation/sampling materials are discussed in the following sections. Of the 11 wells included in the ERDF groundwater monitoring network (Table 5-3), six are yet to be installed. Wells 699-38-61 and 699-34-61 were installed using methods described in the site characterization plan (WHC 1994C), and the new wells will be constructed following the same guidelines for well installation, sampling, surveying, and development.

5.5.4.1 Well Depths. Boreholes will be drilled to a depth of at least 5.8 meters ( 19 feet) below the water table. Boreholes will be completed as WAC and RCRA-compliant groundwater monitoring wells in the unconfined aquifer. The necessity of modifying the well screen length to accommodate potential water level changes through time currently is being assessed.

5.5.4.2 Well Installation, Sampling Method, and Equipment Decontamination. The purpose of well construction is two fold: to provide access, through drilling, for characterization of the subsurface geology and to provide access for collection of groundwater samples. Boreholes will be drilled to a depth of at least 5.8 meters (19 feet) below the water table. Boreholes will be completed as RCRA and WAC-compliant groundwater monitoring wells in the unconfined aquifer. The completed wells have been, or will be, located so as not to interfere with the operation of the ERDF.

Well construction will be in accordance with the generic specification for groundwater monitoring wells (WHC 1992C). The specification provides 
DOE/RL-94-40, Rev. 0

$06 / 94$

1 requirements for construction of groundwater monitoring wells within the

2 Hanford Facility, including the following:

- Specifications for site preparation

- Drilling boreholes

- Collecting sediment samples

- Installation and removal of temporary well casing

- Disposition of purgewater

- Completion of final monitoring structure

- Development of monitoring intervals

- Installation of the sampling pump

- Surveying the completed well for location and elevation.

Requirements and guidance pertaining to well design were obtained from WAC 173-160, 40 CFR 264.97(c), and the EPA (1986b). Quality assurance requirements also apply [Ecology et al. 1994 and WHC $1992 \mathrm{~g}$. Procedures for controlling the well site activities are given in the Environmental

Investigations and Site Characterization Manual (EII) (WHC 1989a) and are listed in Table 5-6. If contamination is encountered that is determined to be significant enough to require changes in the well design or well location, Ecology an :/or EPA will be notified.

New wells most likely will be drilled with a cable tool rig. If another method of drilling is chosen, it will have the same advantages as the cable tool method: (1) drill cuttings can be easily contained (important in potentially contaminated material); (2) representative geologic samples can be collected; (3) moisture samples can be collected from above the water table; (4) disturbance to the borehole wall is minimized; (5) a straight, plumb borehole is produced; and (6) groundwater quality is not affected by drilling fluids other than water or air.

Drill cuttings will be handled in accordance with EII 4.2, "Interim Control of Unknown, Suspected, Hazardous and Mixed Waste" (WHC 1989a). If the level of contamination is significant enough to require changes in well design or well location, Ecology will be notified before making the changes.

All drilling rigs and peripheral equipment (such as drill tools, cables, and temporary casing) will be steam cleaned before drilling each borehole in accordance with EII 5.4, "Field Cleaning and/or Decontamination of Equipment" (WHC 1989a). The addition of water to the borehole will be kept to a minimum or avoided. This will minimize well development pumping after wells are completed and minimize the chances of driving any vadose zone contaminants into the groundwater.

Temporary carbon steel casing (or other EPA/Ecology-approved well materials) with a minimum diameter of 20 centimeters ( 8 inches) will be driven to total depth as each borehole is advanced. A temporary 20 centimeter ( 8 inch) diameter telescoping screen may be installed for aquifer testing if necessary. After the borehole has been drilled to its total depth, the final well casing and screen will be installed and the temporary carbon steel casing will be removed as the filter pack and annular seal materials are placed in 
DOE/RL-94-40, Rev. 0

$06 / 94$

1

2

3

4

the annular space. If a temporary screen is used, the screen will be left in place.

It is expected that the completed well will consist of a 10.2 centimeter (4 inch) diameter stainless steel continuous wire wrapped screen with bottom cap connected to a stainless steel riser (Figure 5-28). A filter pack will be installed in the annulus between the screen and the formation. This is accomplished by placing the sand filter pack in the annulus between the temporary 20.3-centimeter (8-inch) casing and the permanent casing and screen as the temporary casing is withdrawn. The onsite hydrogeologist will determine the screen slot size and the filter pack size and will document per EII 6.7, "Documentation of Well Drilling and Completion Operations" (WHC 1989a). The filter pack will be placed from the base of the well to a height that is 0.9 meter ( 3 feet) to 1.5 meter ( 5 feet) above the top of the well screen. The weil will be bailed or pumped after emplacement of the filter pack to stabilize the pack. A minimum of 113.5 to 270.3 1iters (30 to 45 gallons) of formation water will be removed and recorded on the daily log (refer to Section 5.5.4.3 for disposition of water).

A 0.9-meter (3-foot) to 1.5-meter (5-foot) thick bentonite pellet seal will be placed on top of the filter pack. The annulus between the top of the bentonite pellet seal and $3.1 \pm 0.6$ meter $(10 \pm 2$ feet) below ground surface will be filled with bentonite. Cement grout will be installed to within 0.9 meter ( 3 feet) of the ground surface. The well casing will extend 0.3 meter ( 1 foot) to 0.6 meter ( 2 feet) above ground surface and will be protected by an outer stainless steel casing and locking cap. The casing will be set into the ground and cemented in place within a 1.2 meter ( 4 feet) by 1.2 meter (4 feet) concrete pad with surface well protection will be provided by four posts. The protective casing will be permanently marked with a well identification number. A brass survey marker will be placed in the concrete pad on the north side of the well. Construction information for new monitoring wells is provided in Table 5-3.

Data sheets, as shown in Figure 5-29, are used to document we11 requirements for new wells.

5.5.4.3 Well Development. The wells will be developed following completion. Wells will be developed using the procedures described in EII 10.4, "Well Development Activities" (WHC 1989a). If the water cannot be developed to a turbidity of <5 NTU, an explanation will be provided and documented by the site hydrogeologist. All groundwater discharged from the well during development will be disposed of in accordance with onsite guidelines and procedures [e.g., EII 10.3 and EII 10.4 (WHC 1989a), as listed in Table 5-6, or equivalent procedures]. Purgewater will be managed in accordance with Tri-Party Agreement designations, and in accordance with the Strategy for Handling and Disposing of Purgewater at the Hanford Site, Washington (WHC 1989b).

5.5.4.4 Surveying. After monitoring well installation is completed, the well will be surveyed for location and elevation by qualified surveyors per WHC (1992c). The elevation of the top of the stainless steel protective casing and of a brass marker set in the concrete pad will be determined within 
10.3 centimeter ( 0.01 foot). A mark will be placed on the casing to indicate

2 the location surveyed. The horizontal location of the centerline of the well

3 will be determined to the nearest 0.03 meter $(0.1$ foot). All elevations will

4 be referenced to the National Geodetic Vertical Datum of 1929 in feet and the

5 North American Vertical Datum of 1988 in meters and all horizontal positions

6 reported in the Washington Coordinate System of 1983, south zone (1991) in

7 meters.

8

9

10

11

12

13

14

15

16

17

18

\subsubsection{Sampling and Analysis Plan}

This section discusses the groundwater sampling and analysis plan. Groundwater samples representative of the uppermost aquifer beneath ERDF will be obtained for the purpose of determining present groundwater quality before use of the ERDF trench, as well as during the operational and postclosure period(s) of the ERDF to detect potential hazardous/dangerous constituent releases. Appendix 5C includes groundwater sampling and analys is plan.

Quality assurance and quality control are significant elements of any sampling and analysis program. The ERDF sampling and analysis program will follow the Quality Assurance Project Plan for RCRA Groundwater Monitoring Activities (WHC 1992g).

Dedicated sampling equipment will be provided for each well in the ERDF groundwater monitoring network, thus minimizing the potential for cross-contamination between weils. The specific type of pump or other dedicated sampling device currently is being evaluated, and will be determined before installation of the appropriate device within groundwater monitoring wells. Any dedicated sampling system will be installed in the monitoring wells as soon as possible after construction and well development are complete.

5.5.5.1 Sampling. The depth to water will be measured before and after the wells are purged. The wells will be purged and samples will be collected after at least three borehole volumes have been removed, when specific conductance and $\mathrm{pH}$ have stabilized, or (in the case of wells completed in very low-permeability materials) after the well has recharged.

5.5.5.2 Sample Preservation and Shipment. Preservation of the samples will be conducted according to approved procedures, in accordance with EPA guidelines. Prelabeled sample bottles containing the appropriate preservative are supplied by PNL for each monitoring well. Immediately after collection, the sample bottles are placed in sealed, insulated coolers packed with ice to cool them to approximately $4^{\circ} \mathrm{C}$. The coolers are transported to the lead laboratory for analysis. Field parameter record forms are attached to the sealed containers. The temperature of the samples inside the coolers is measured upon receipt at the laboratory. If the temperature is approximately $4^{\circ} \mathrm{C}$ and some of the original unmelted ice is found to remain in the cooler, the samples are considered to have been maintained at the appropriate temperature during the time the samples were in the cooler. 
1 5.5.5.3 Analytical Mothods. Samples will be analyzed from all groundwater 2 monitoring wells in conformance with SW-846 (EPA 1986c), or other appropriate 3 methodologies. Analysis will be performed for the parameters presented in 4 Section 5.5.2.

5.5.5.4 Chain-of-Custody Requirements. Chain-of-custody procedures will be followed in collecting data to ensure the integrity of groundwater samples 8 from the time of collection through laboratory analysis and data reporting.

9 This program will include sample labels, sample seals, field record forms, 10 chain-of-custody forms, sample analysis request forms, and laboratory 11 acceptance procedures.

12

13

14

15

5.5.5.5 Sampling Frequency. The wells in the groundwater monitoring network initially will be sampled quarterly for 1 year to determine groundwater quality beneath the ERDF. Samples will continue to be collected and analyzed from the existing wells on a semi-annual basis (twice a year). Based on data acquired through the operating period of the ERDF, monitoring frequency could warrant modification. Proposed modification to the sampling and analysis frequency will be provided to the applicable regulatory agencies before initiation.

5.5.5.6 Reporting Requirements. The results of the sampling and analysis of the wells in the groundwater network will be reported quarterly for the first year and semi-annually thereafter, and shall include an evaluation of the results and monitoring network. Quarterly reports of sampling results and an annual evaluation of sampling results and monitoring network will be provided as part of the quarter $7 y$ and annual RCRA groundwater monitoring reports published by DOE-RL (e.g., DOE-RL 1993f).

\subsubsection{Statistical Assessment of Required Data}

Because implementation of a groundwater monitoring program sufficient to detect releases from the ERDF CAMU is required under 40 CFR 264.552, the method to determine whether a release has occurred must be developed. Statistical evaluation of groundwater quality data will be performed to determine whether a release has occurred. The following parameters will be used in the statistical assessment:

- Upgradient groundwater contaminants: chromium, nitrate, carbon tetrachloride, chloroform, trichloroethylene, tritium, gross beta, technetium-99, iodine-129, gross alpha, uranium

- Indicator parameters: temperature, $\mathrm{pH}$ (field and laboratory), specific conductance (field and laboratory), total dissolved solids, total suspended solids, total organic carbon, total carbon, total organic halogen

- Parameters in waste: benzene, bromoform, chlorobenzene, 1,2 dichloroethane, cis-1,1 dichloroethylene, trans-1,1 dichloroethylene, 1,2 dichloropropane, acetonitrile, ethylbenzene, 1,1,2,2-tetrachloroethane, tetrachloroethylene, toluene, 
vinyl chloride, xylene, naphthalene, copper, cadmium, lead, chloride, sulfate, berylitum, radium, cyanide, mercury, silver, fluoride, sodium.

The appropriate statistical test will be determined based on the first 4 quarters of data collected, and will be submitted to the appropriate regulatory agency for approval before implementation. The statistical method will be determined and approved before emplacement of first waste within the ERDF trench. The statistical method used will be one of the following:

- A parametric analysis of variance (ANOVA) followed by multiple comparison procedures to identify any statistically significant evidence of releases

- ANOVA based on ranks followed by multiple comparison procedures to identify statistically significant evidence of releases

- A tolerance or prediction interval procedure in which an interval for each constituent is established from the distribution of the upgradient (background) data, and the level of each constituent in the groundwater monitoring well is compared to the upper tolerance or prediction 1 imit

- A control chart approach that gives control limits for each constituent

- Another statistical method that is demonstrated appropriate for the data and is approved by the regulatory agency $(s)$.

Any statistical method chosen will be conducted separately for each hazardous/dangerous constituent. The method will also be appropriate for the distribution of hazardous/dangerous constituents. The method also will account for data below the limit of detection that are protective of human health and the environment. Any practical quantification limit (PQL) used in the statistical method will be the lowest concentration level that can be reliably achieved within specified limits of precision and accuracy during routine laboratory operating conditions. If necessary, the statistical method will include procedures to control or correct for seasonal and spatial variability as well as temporal correlation of the data. The groundwater monitoring data collected will be maintained in the ERDF operating record (Chapter 12.0, Section 12.4.2.2).

Because preexisting groundwater contamination is present in the area, continued reevaluation of upgradient groundwater quality is necessary. Upgradient groundwater quality may change as a result of fluctuations in upgradient plume concentration and flow direction. Therefore, upgradient groundwater quality may require modification from quarter to quarter when used in statistical comparisons with downgradient groundwater quality, so that releases from the ERDF trench w111 be accurately detected. A supplemental statistical method for assessing background groundwater quality in conjunction with downgradient comparisons may be necessary, and will be developed, if required, before acceptance of first waste in the ERDF trench. The method 
1 will be provided to the approprlate regulatory agency, for review before 2 implementation, and will use one of the five selected methods previously 3 mentioned.

\subsubsection{Compliance Monitoring Program}

Because the ERDF is not a TSD unit, implementation of a specific compliance monitoring program is not required. Also, the CAMU regulations Preamble (58 FR 29) states that the regulation "does not address the responsibilities of the owner/operator to continue monitoring or releases that are not assoclated with CAMUs; nor does it address the question of whether groundwater remediation is necessary." As indicated in Chapter 11.0, groundwater monitoring will continue during the postclosure phase.

However, CAMU criteria imply that protectiveness of human health and the environment must be maintained, particularly during the operational period. Groundwater monitoring will be maintained throughout the operational period, with statistical assessment of upgradient versus downgradient water quality to determine if contaminant releases have occurred from the ERDF. Should a statistically significant change in constituent concentration directly attributable to a release from the ERDF be detected, a modified groundwater monitoring program plan will be submitted at that time. This modification will include criteria/standards that, when exceeded, would warrant implementation of a corrective action program.

\subsubsection{Corrective Action Progran}

As indicated previously, because the ERDF is not a TSD unit, implementation of a specific corrective action program is not mandated. Also, the CAMU regulations Preamble (58 FR 29) states that the regulation "does not address the responsibilities of the owner/operator to continue monitoring or releases that are not associated with CAMUs; nor does it address the question of whether groundwater remediation is necessary."

Should a release be detected, a modified groundwater monitoring program will be submitted (Section 5.5.7). However, determination of the need for corrective action will be based on ongoing corrective action programs for groundwater contamination released from TSD units in the area (Section 5.4), as well as overall programmatic goals of the Hanford Facility. It is not possible to determine these data at this time, and therefore it is inappropriate to commit to a specific corrective action program within this application. Should a specific corrective action program become necessary, a corrective action program plan will be submitted to the appropriate agency for approval before implementation. 
DOE/RL-94-40, Rev. 0

06/94

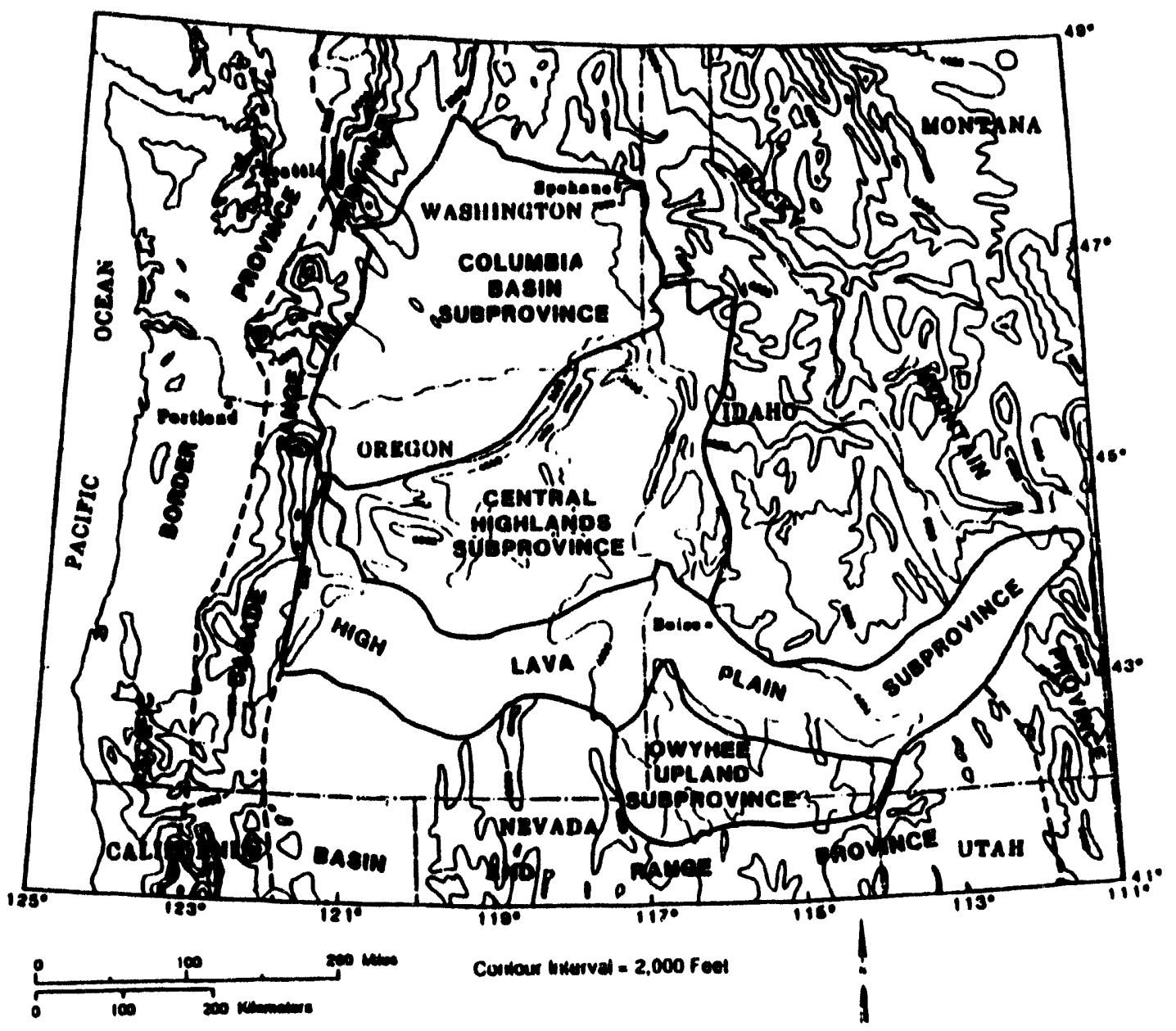

Figure 5-1. Location of the Columbia Intermontane Province (PNL 1989). 


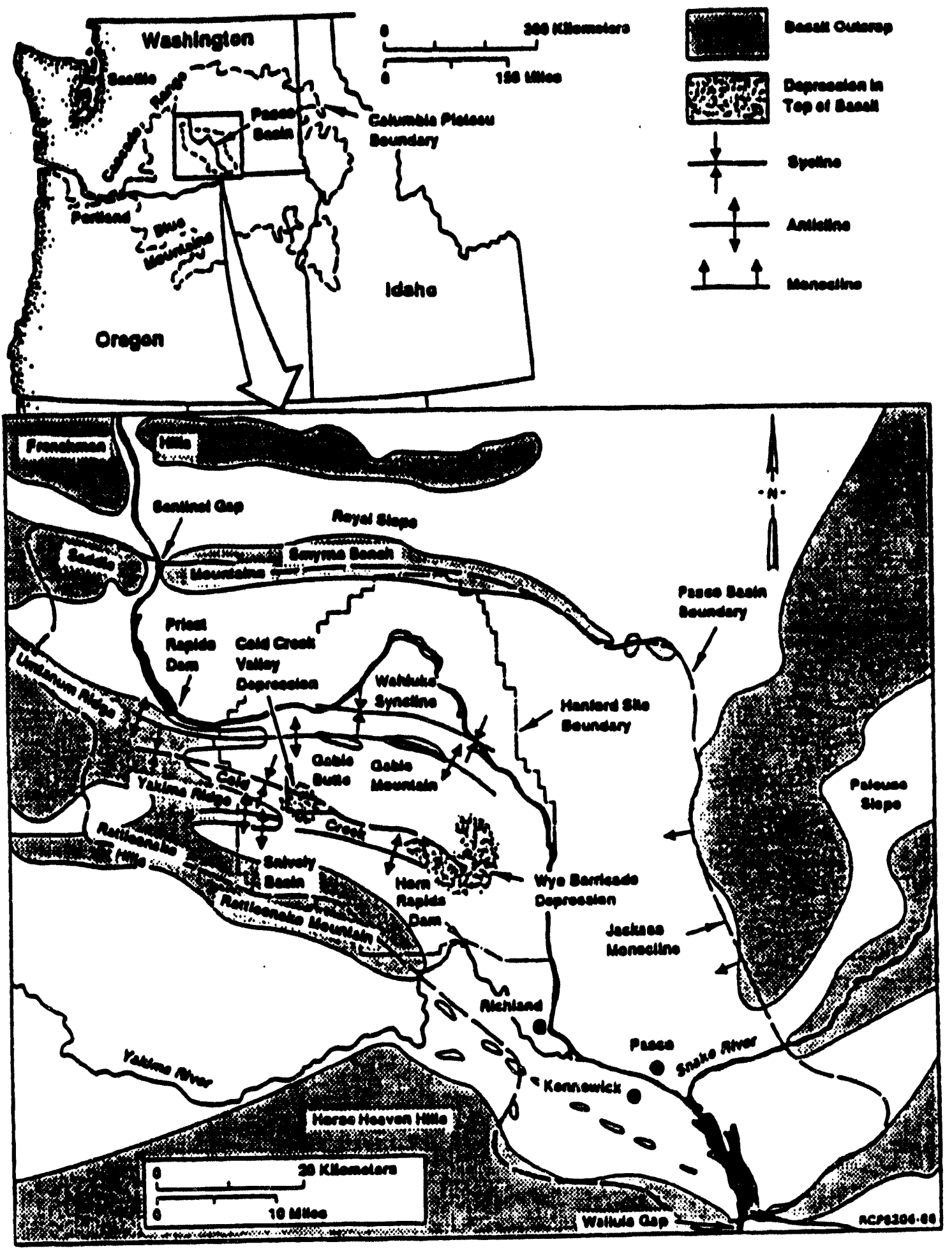

Figure 5-2. Geomorphic and Structural Setting of the Pasco Basin (WHC 1991b). 


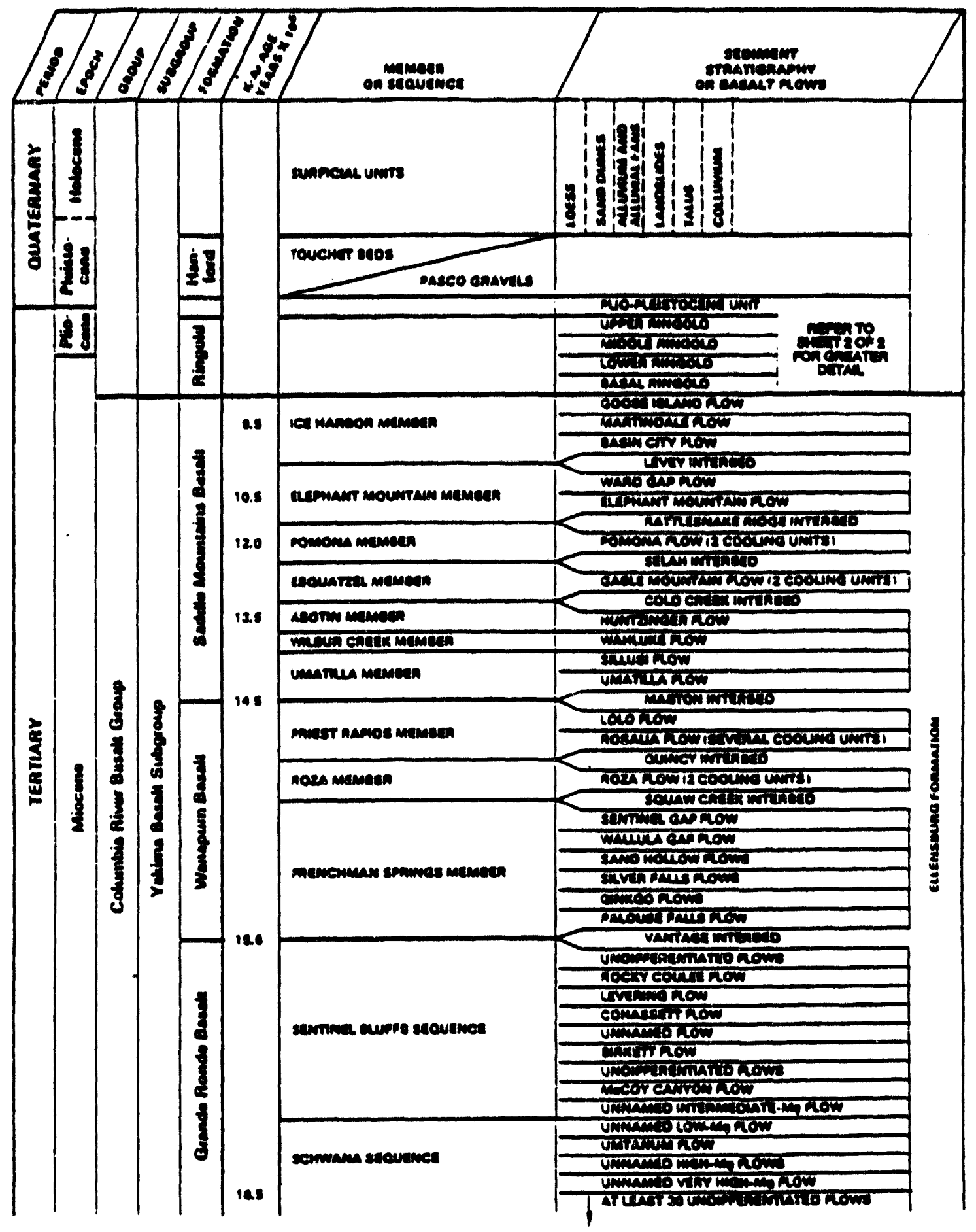

Figure 5-3. Stratigraphic Nomenclature for Geologic Units in the Pasco Basin. (Modified after PNL 1989) (sheet 1 of 2) 


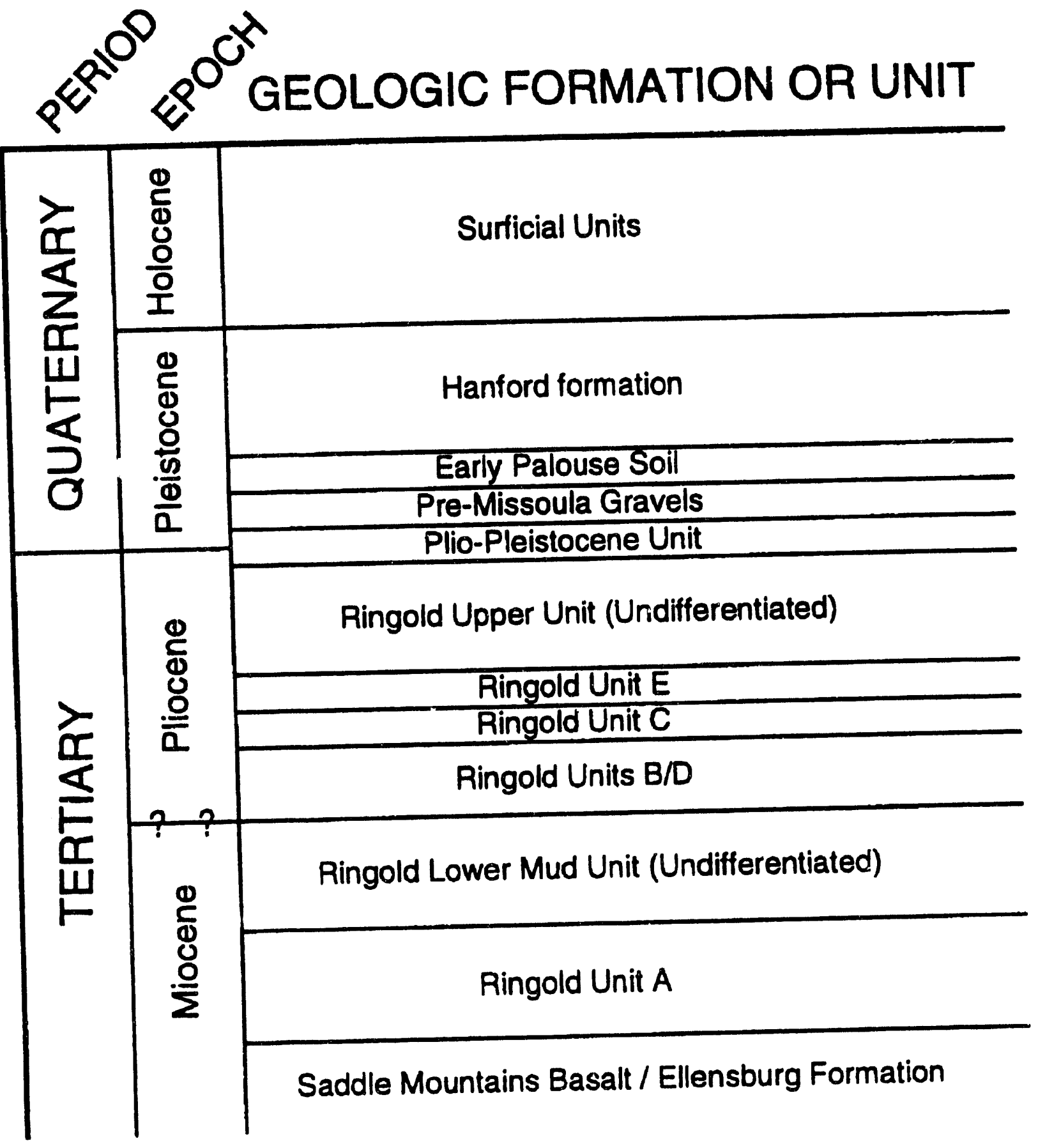

Figure 5-3. Stratigraphic Nomenclature for Geologic Units in the Pasco Basin. (Modified after PNL 1989) (sheet 2 of 2) 


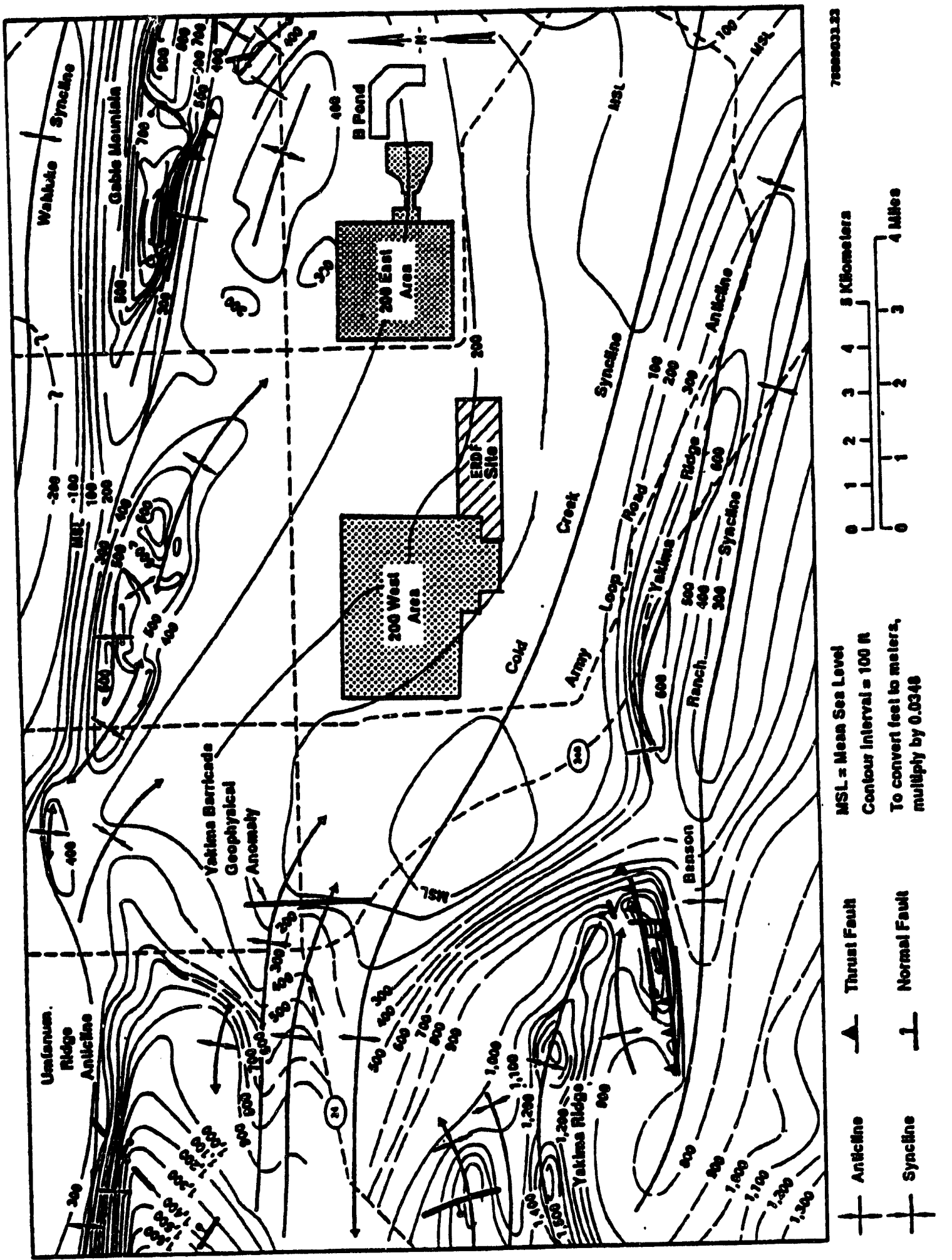

Figure 5-4. Top of the Uppermost Basalt Structure Contour Map of the Central Hanford Facility (WHC 1994C). 


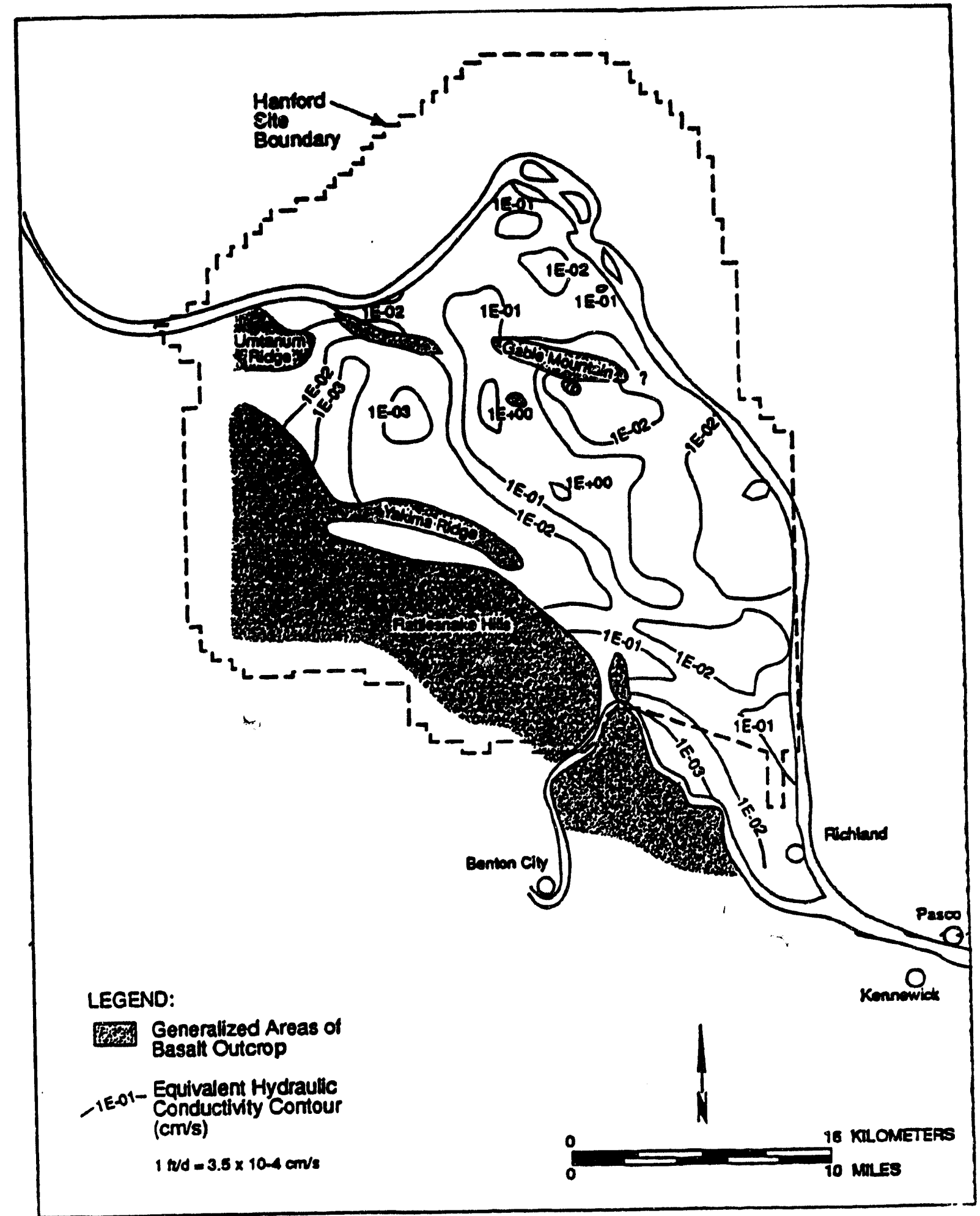

Figure 5-5. Areal Distribution of Hydraulic Conductivity for the Unconfined Aquifer at the Hanford Facility (DOE-RL 1994d). 
DOE/RL-94-40, Rev. 0 06/94

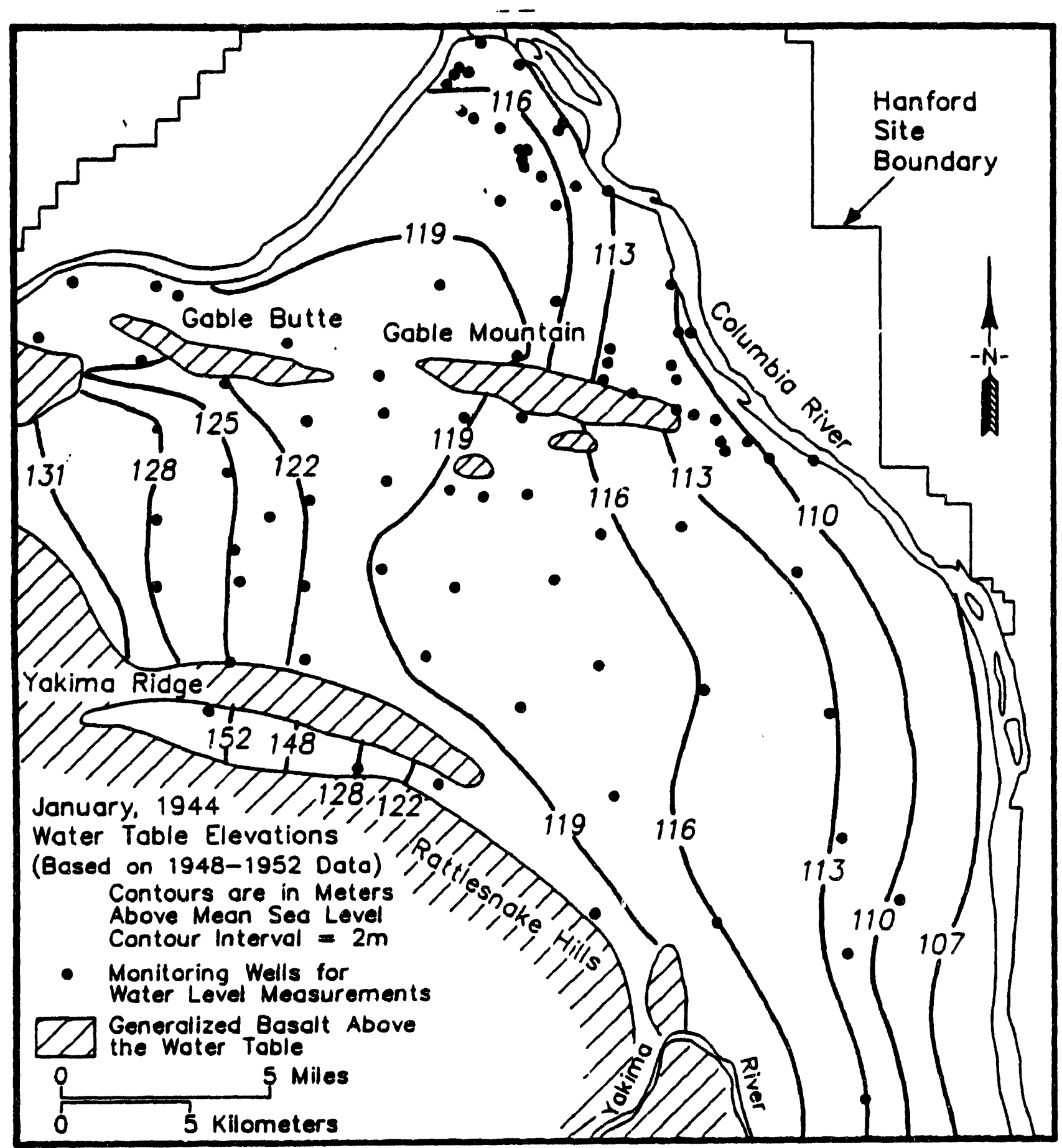

Figure 5-6. Water Table Map of the Hanford Facility, January 1944 (WHC 1991b). 
DOE/RL-94-40, Rev. 0

06/94

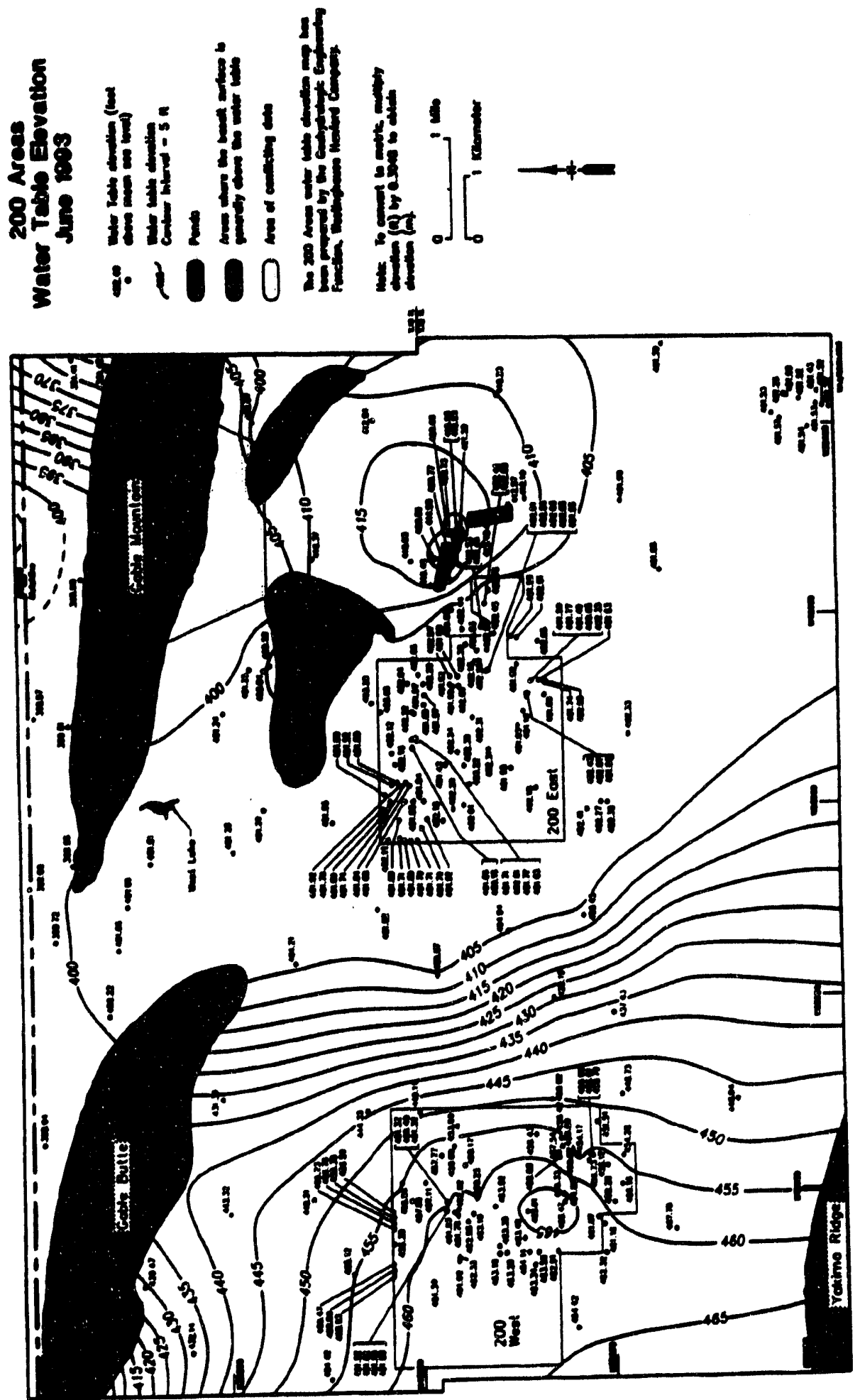

Figure 5-7. Water Table Map of the Hanford Facility, June 1993 (DOE-RL 1994d). 


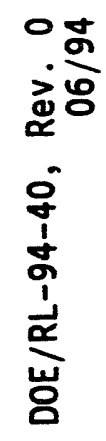

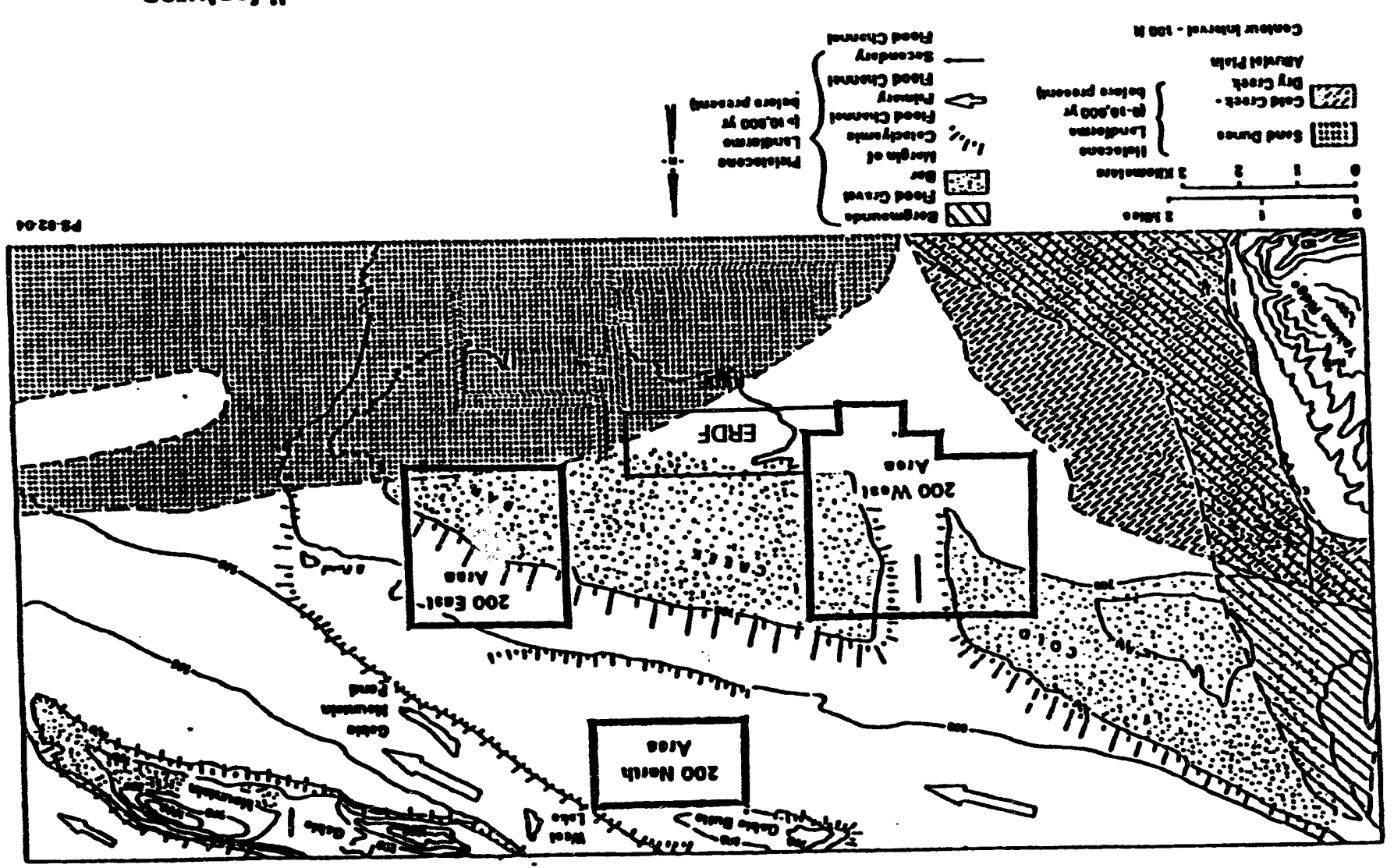




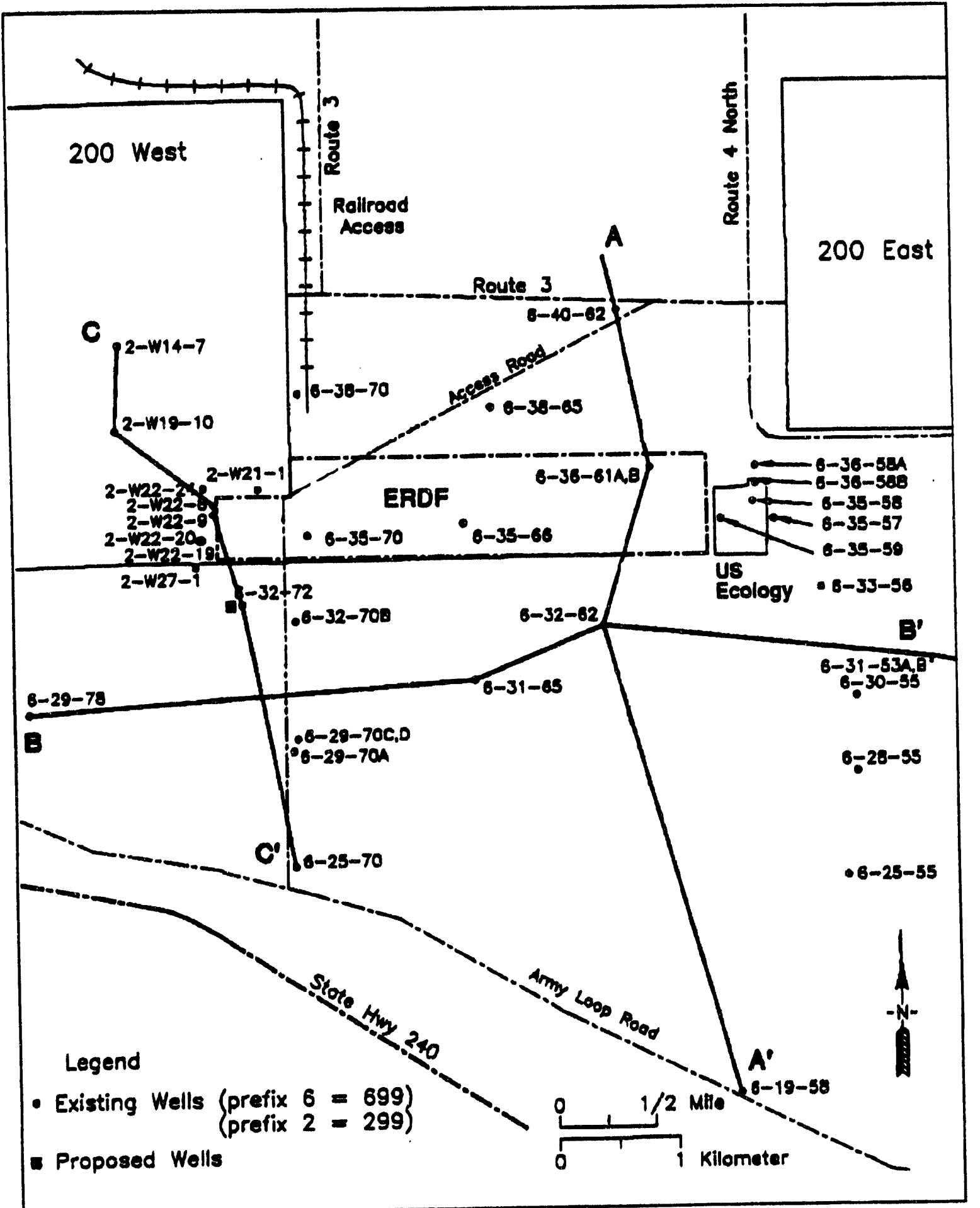

39405077.20

Figure 5-9. Cross-Section P1an Map (WHC 1994C). 


\section{Explanation}

Additional Lithologic Symbols,

Grain Size Scale. Indicotes

includes subordinote Lithologles Dominant Litholooy in Interval

- Clay-rich

$\sim$ Sint-rich

$\because \because$. Sondy

$\therefore::$ Pebbly

$\because \because \bullet$ Bouldery

$=-=$ Pedogenic Calcium Corbonate

$x^{x} x^{x}$ Paleosol

yty Basalt

$1,1,1$ Cernented

$+t$ Tuffs

Other Symbola - Formational Contoct. ? where inferred
Unit Contoct, ? where inferred

\section{Abbreviations}

PM - Pre-Missoula grovels

PP - Plio-Pleistocene/eorty Palouse interval

UR - Upper unit, Ringold Formation

$E$ - Unit $E$, Ringold Formation

C - Unit C, Ringold Formation

D - Unit D. Ringold Formotion

B - Unit B, Ringold Formotion

LM - lower Mud unit. Ringold Formation

A - unit A. Ringold Formation

Figure 5-10. Explanation of Symbols Used in Cross Sections (WHC 1994c). 

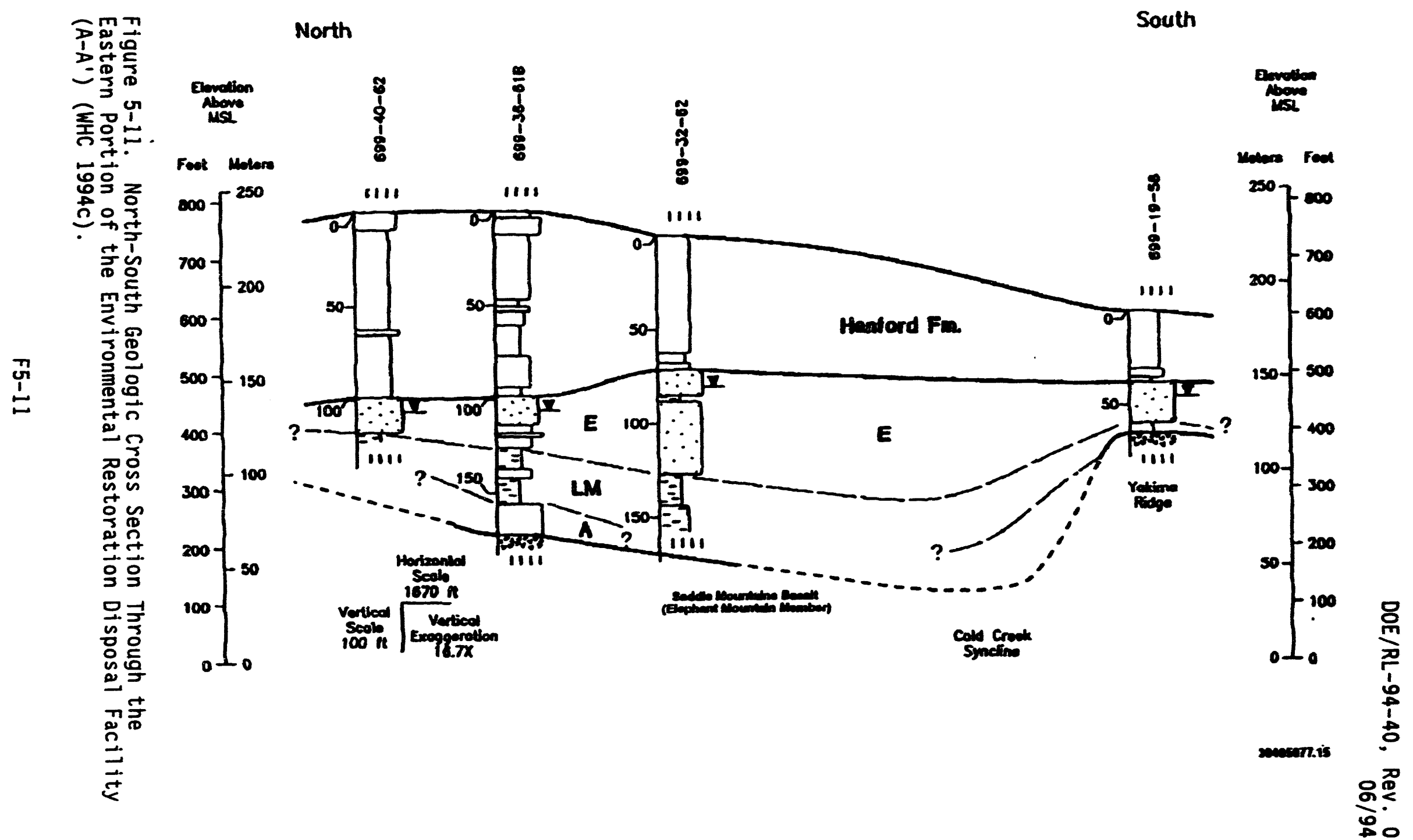
in

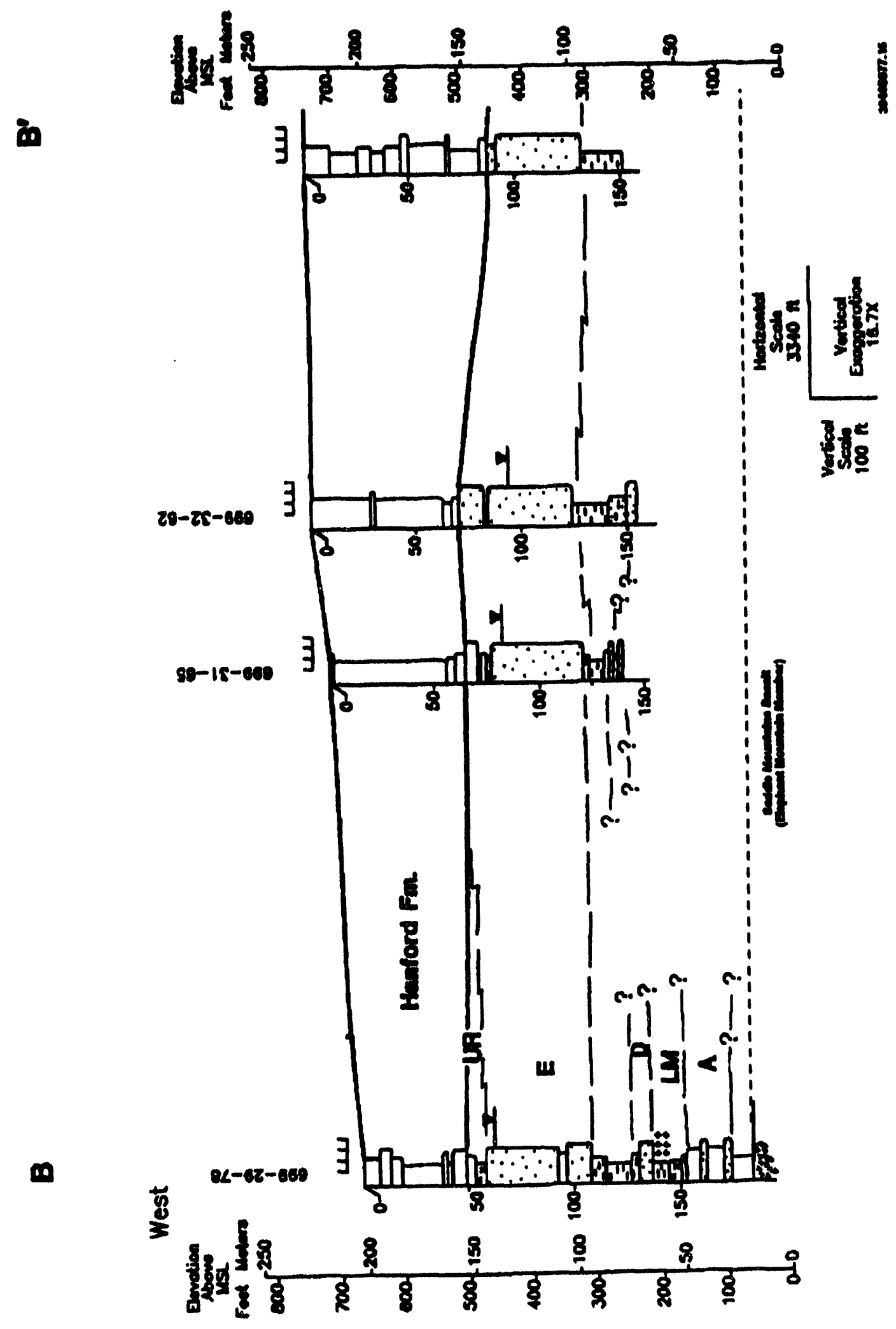

06/94

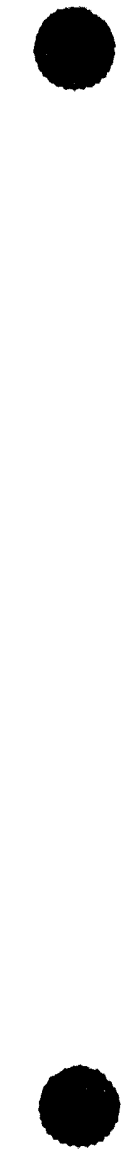

Figure 5-12. West-East Geologic Cross Section Through the Southern Portion of the Environmental Restoration Disposal Facility (B-B') (WHC 1994C). 
DOE/RL-94-40, Rev. 0

06/94

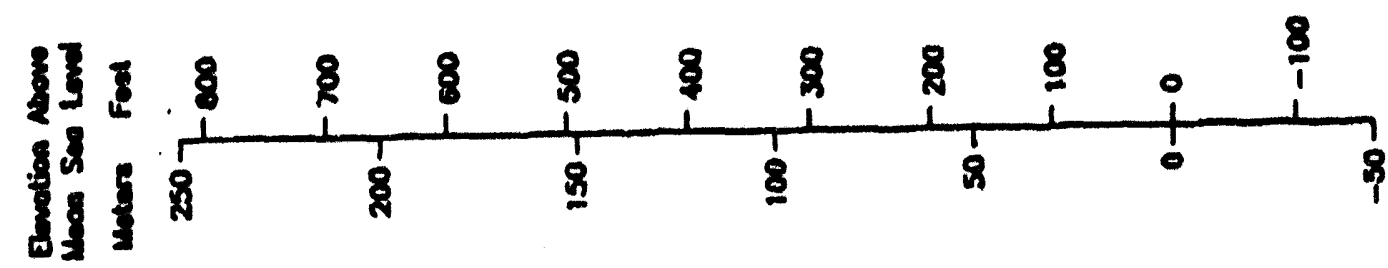

8 疍
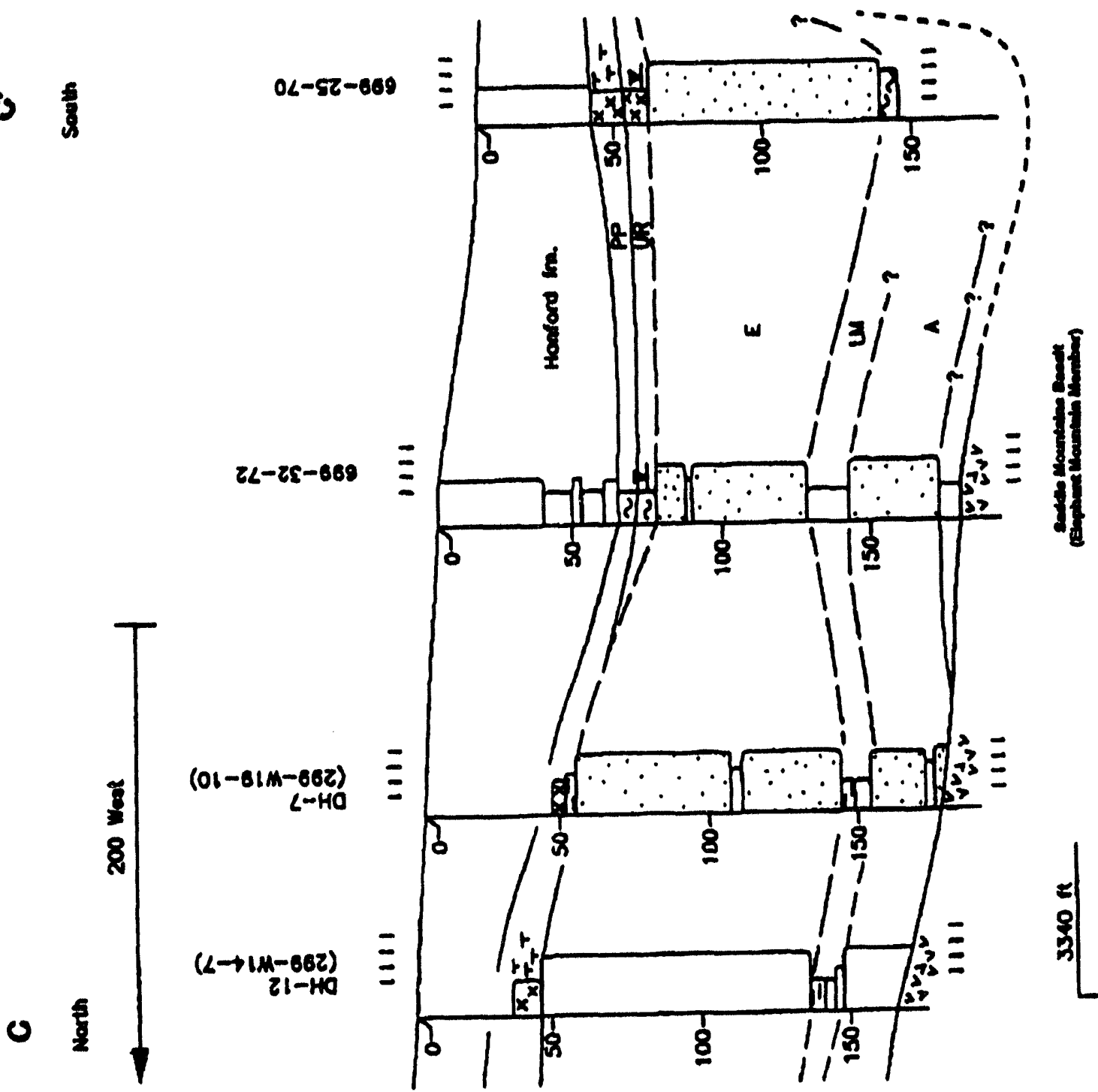

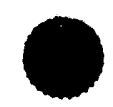
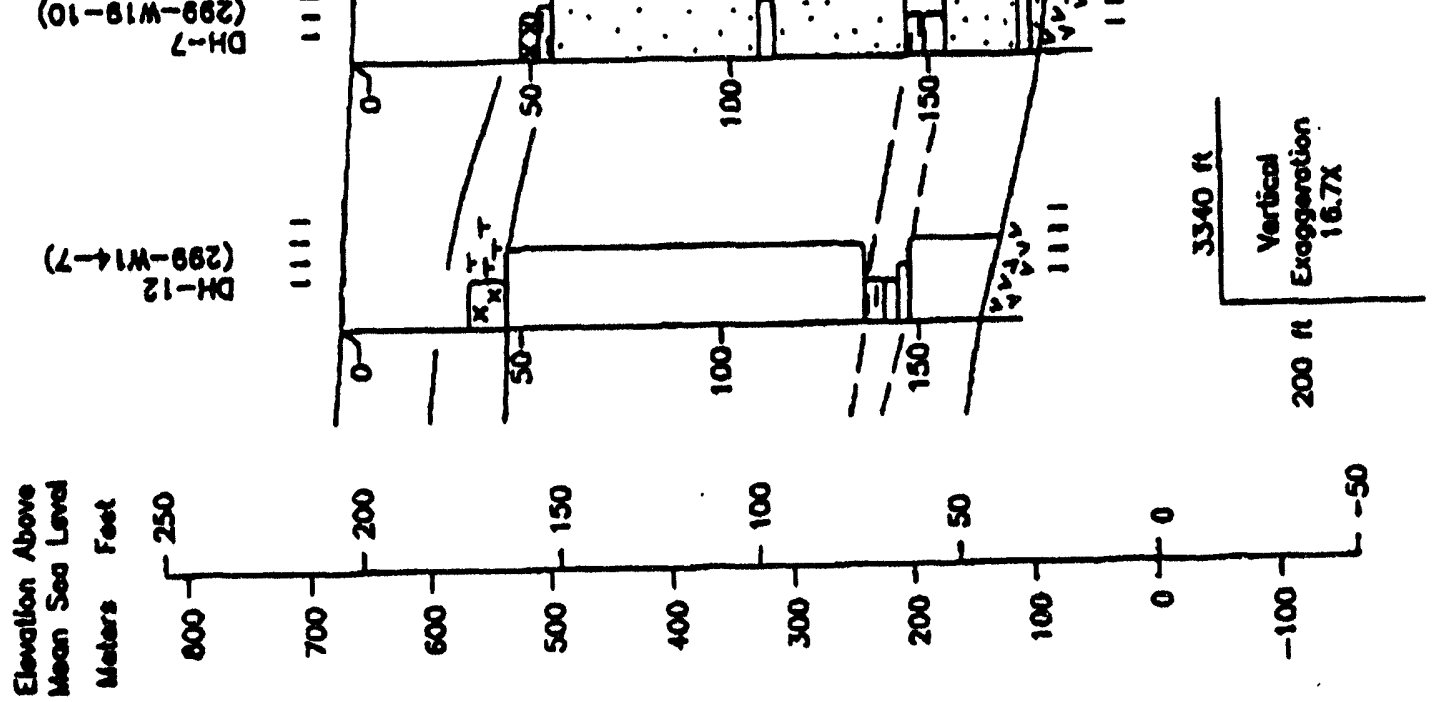

Figure 5-13. North-South Geologic Cross Section Through the Western Portion of the Environmental Restoration Disposal Facility (C-C') (WHC 1994C). 

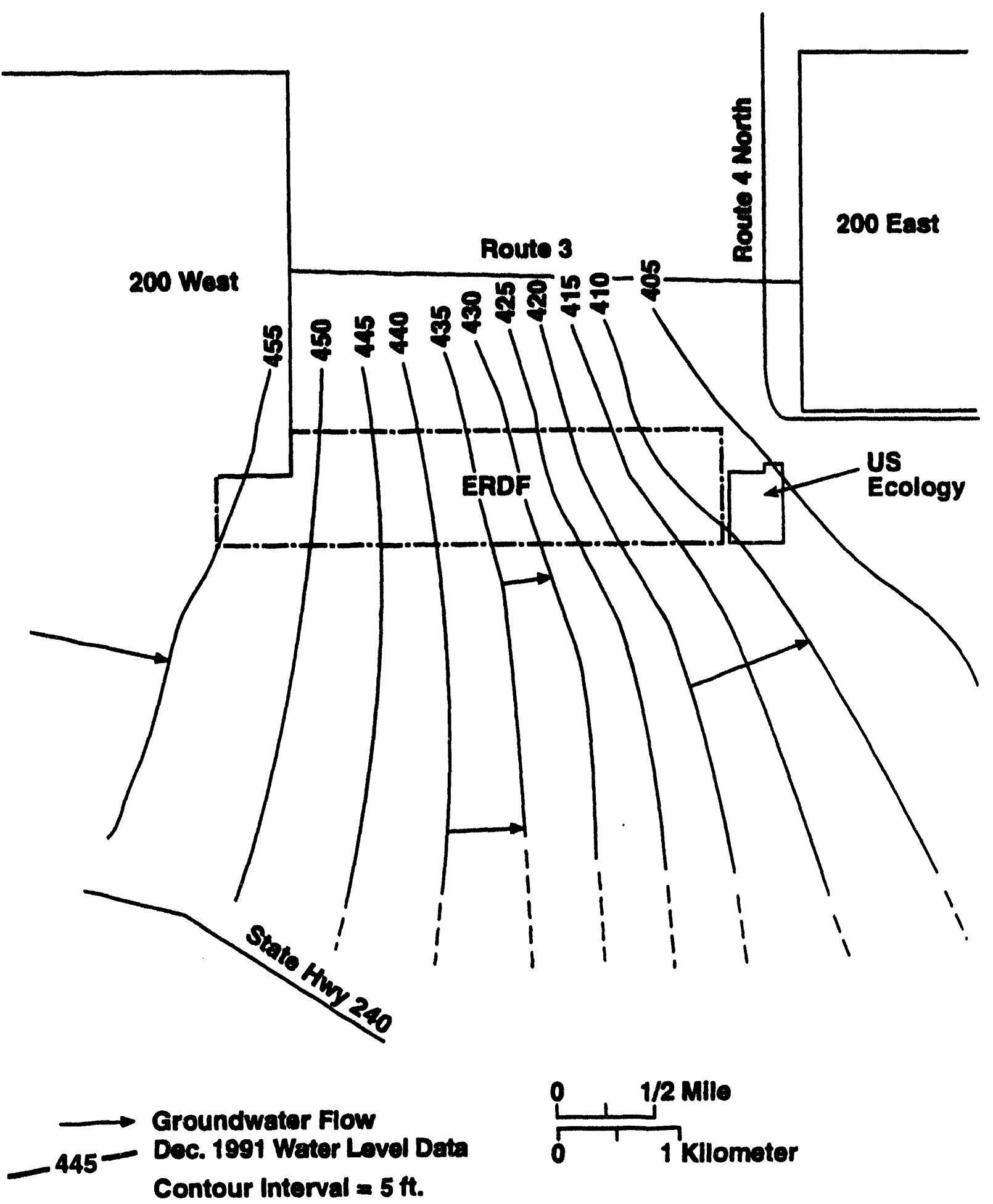
Contour Interval $=5 \mathrm{ft}$.

3905077.11

Figure 5-14. Water Table Map Beneath the Environmental Restoration Disposal Facility (WHC 1994C). 


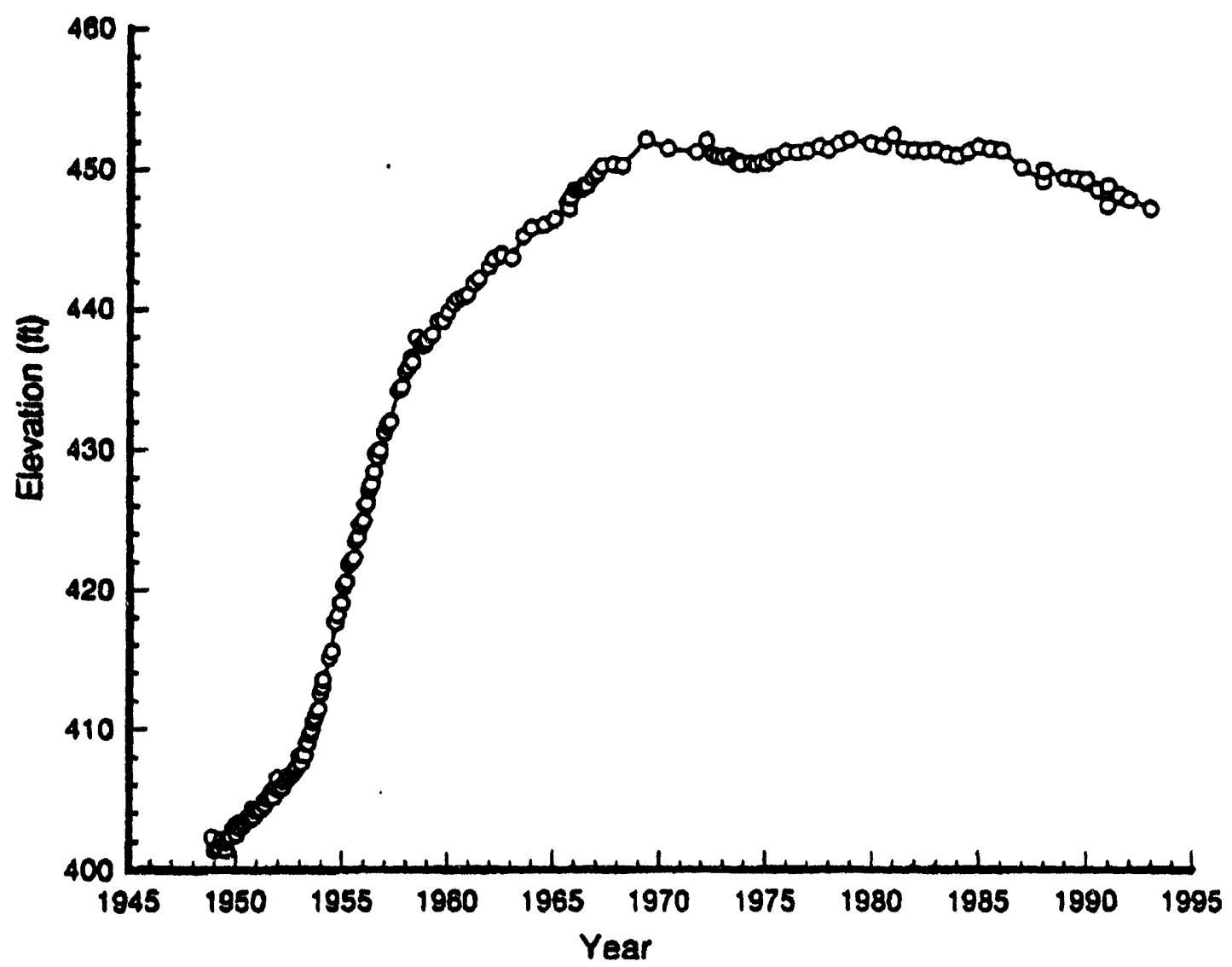

39405077.18

Figure 5-15. Hydrograph for Well 699-35-70 near the Environmental Restoration Disposal Facility (WHC 1994C). 


$$
\text { DOE/RL-94-40, Rev. } 0
$$
06/94

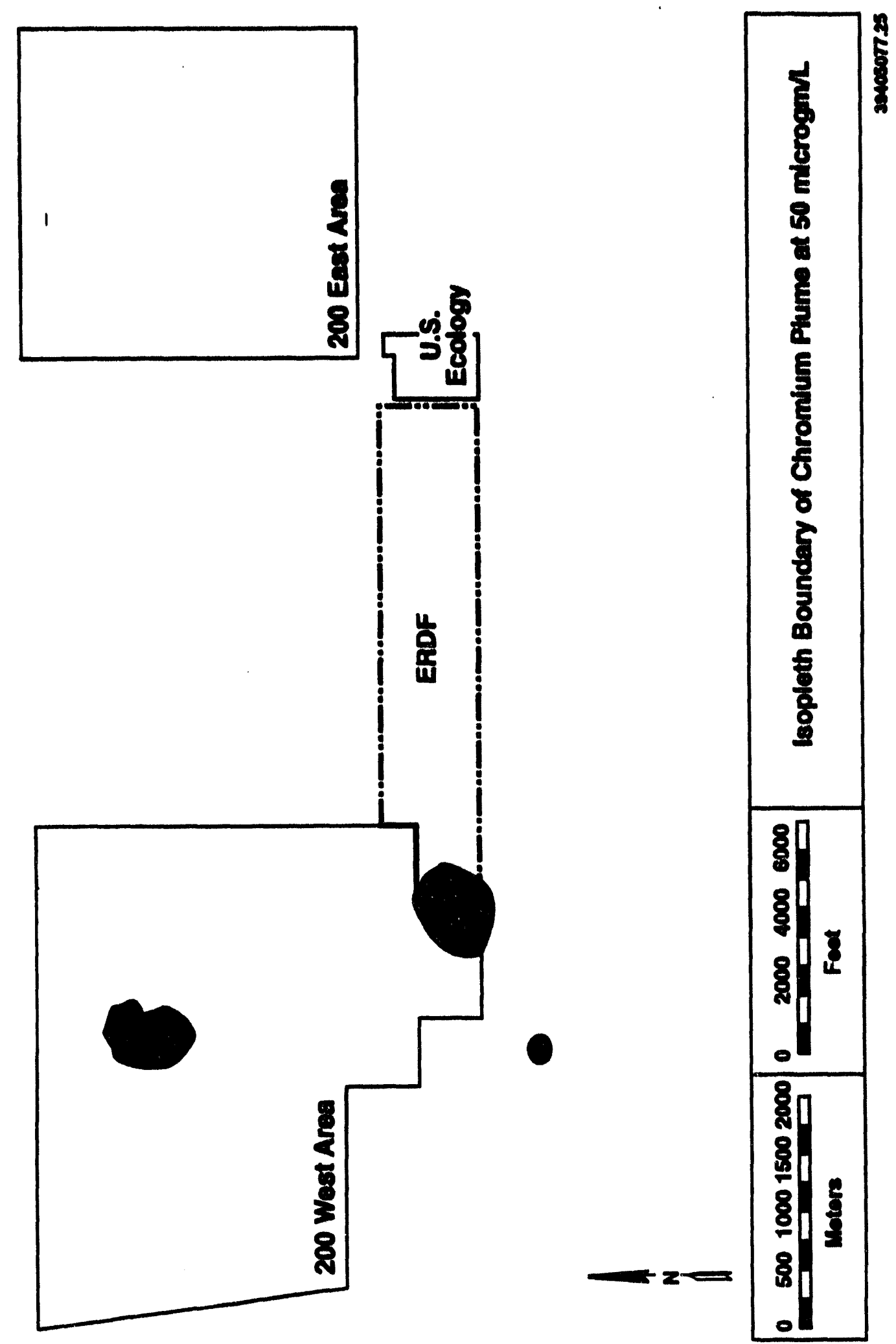

Figure 5-16. Chromium Groundwater Plume Map (WHC 1994C). 
DOE/RL-94-40, Rev. 0

06/94
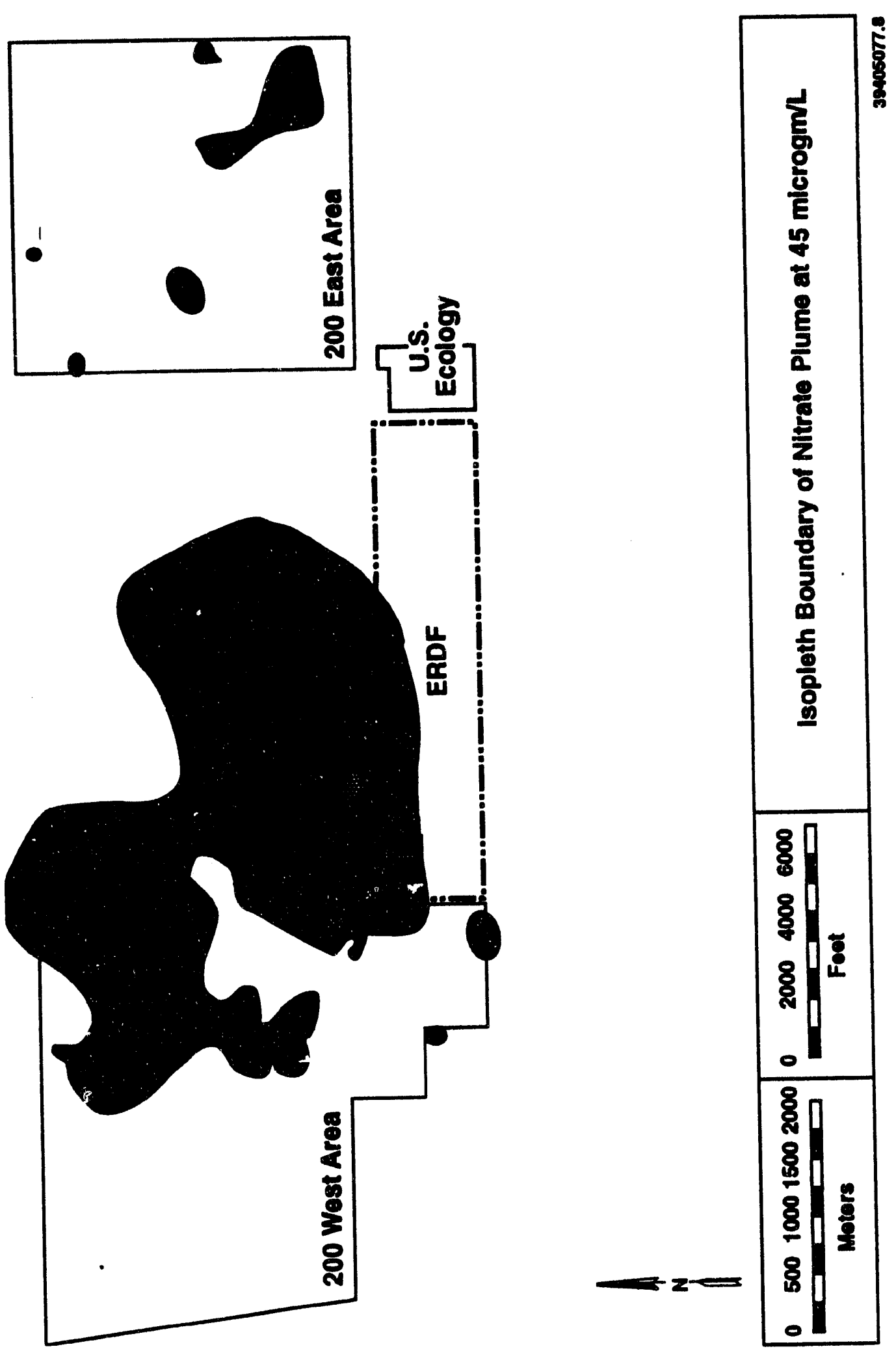

Figure 5-17. Nitrate Groundwater Plume Map (WHC 1994C). 


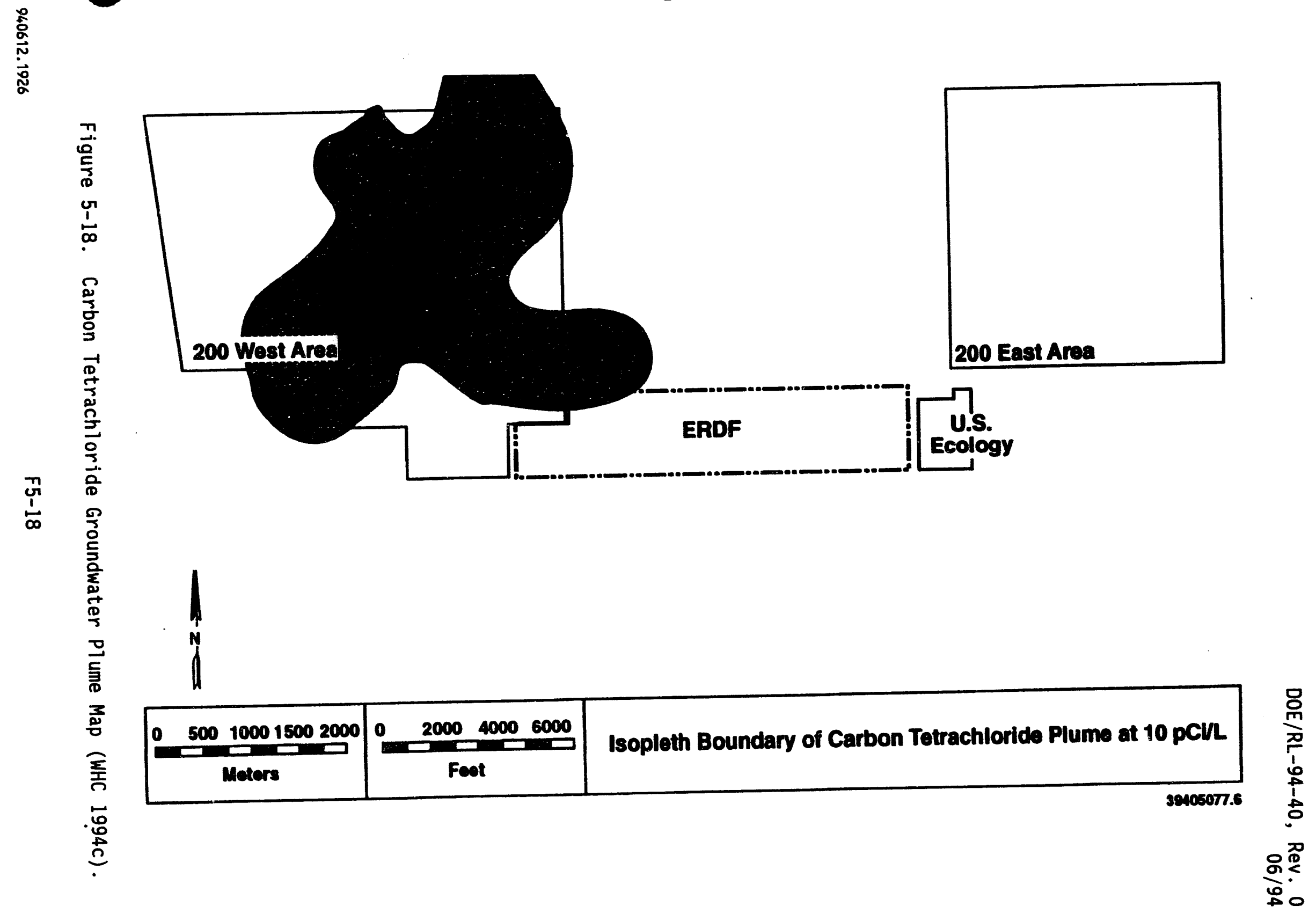




\section{O}

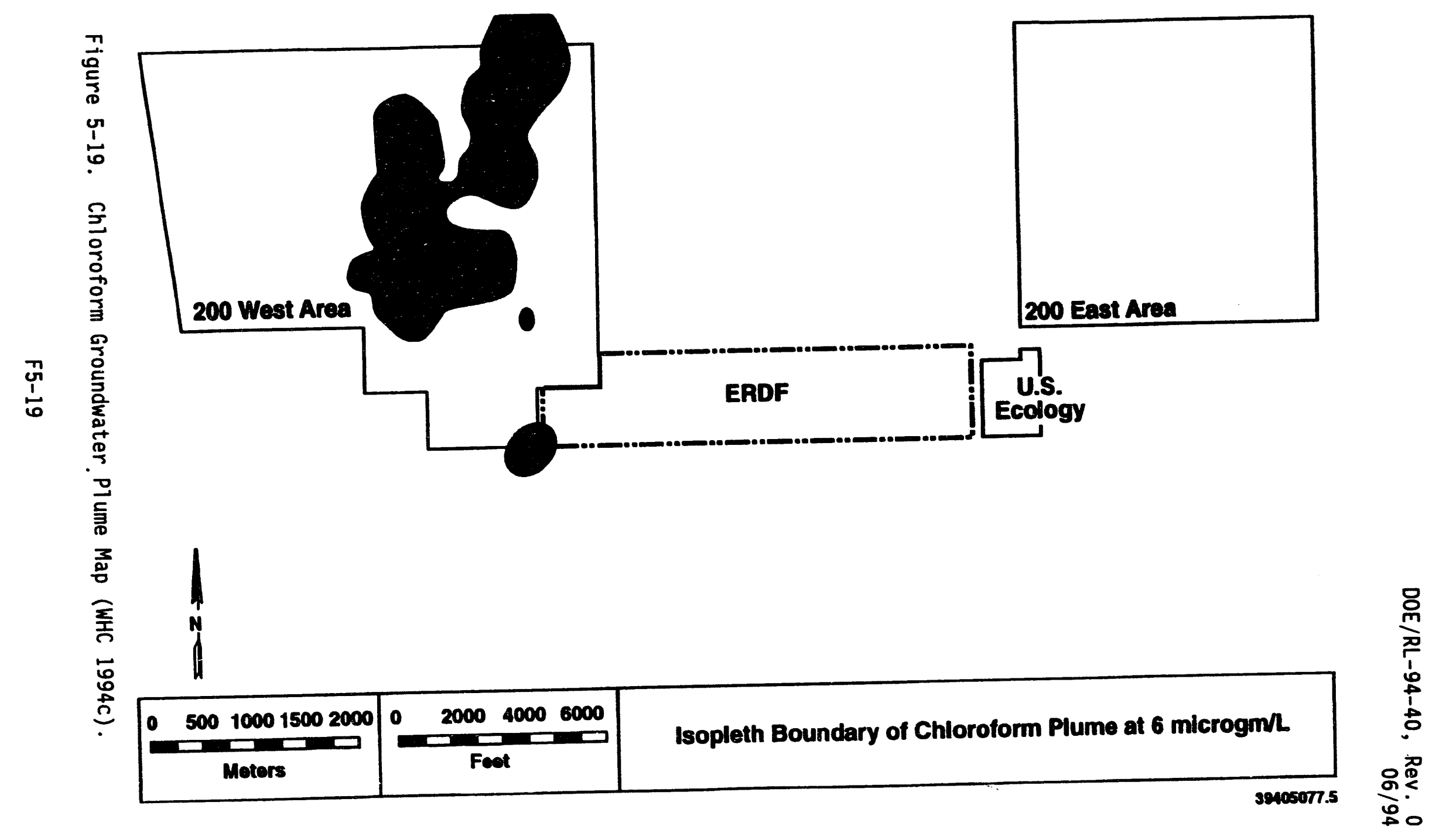


DOE/RL-94-40, Rev. 0

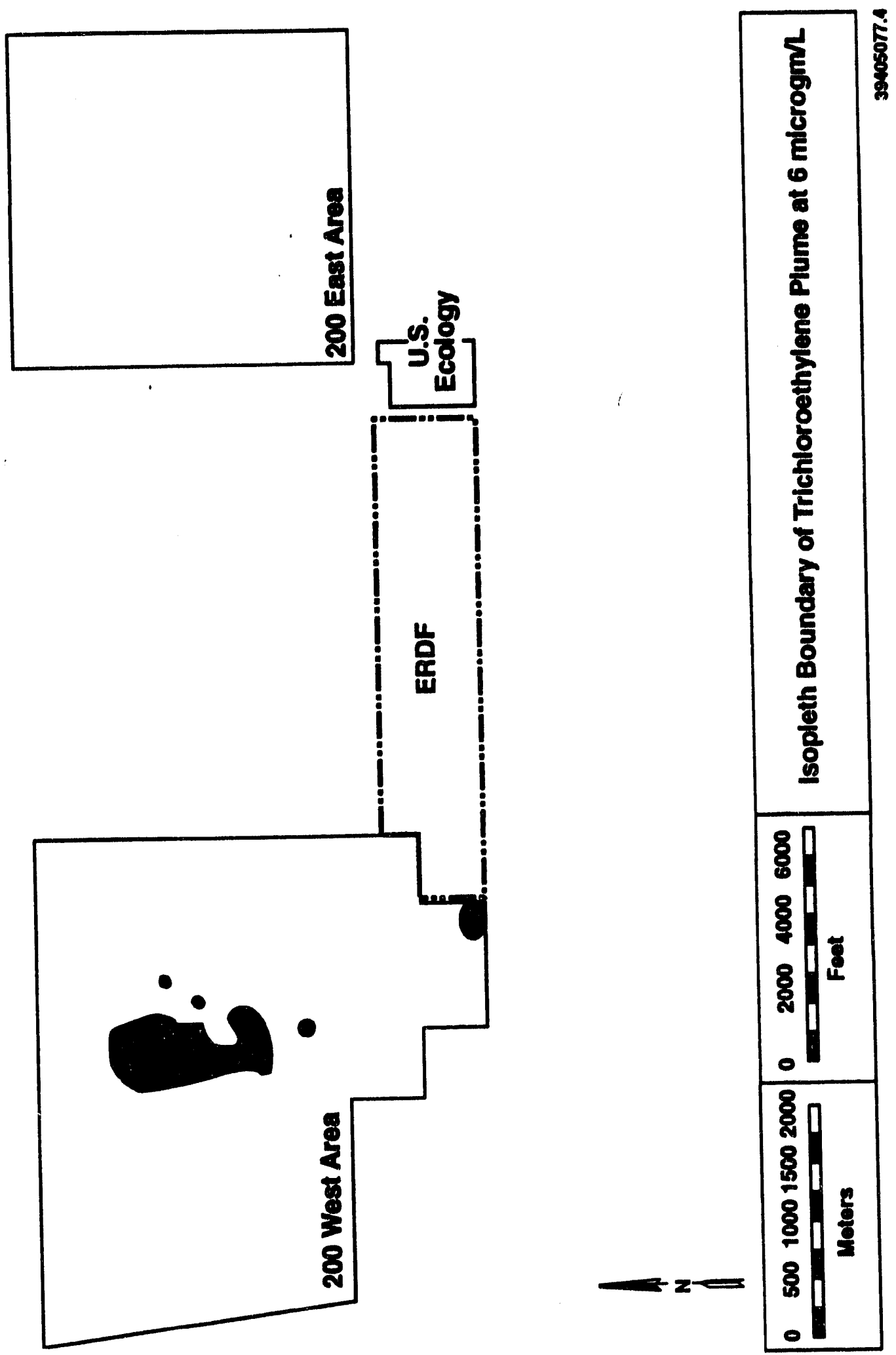

Figure 5-20. Trichloroethylene Groundwater Plume Map (WHC 1994C). 


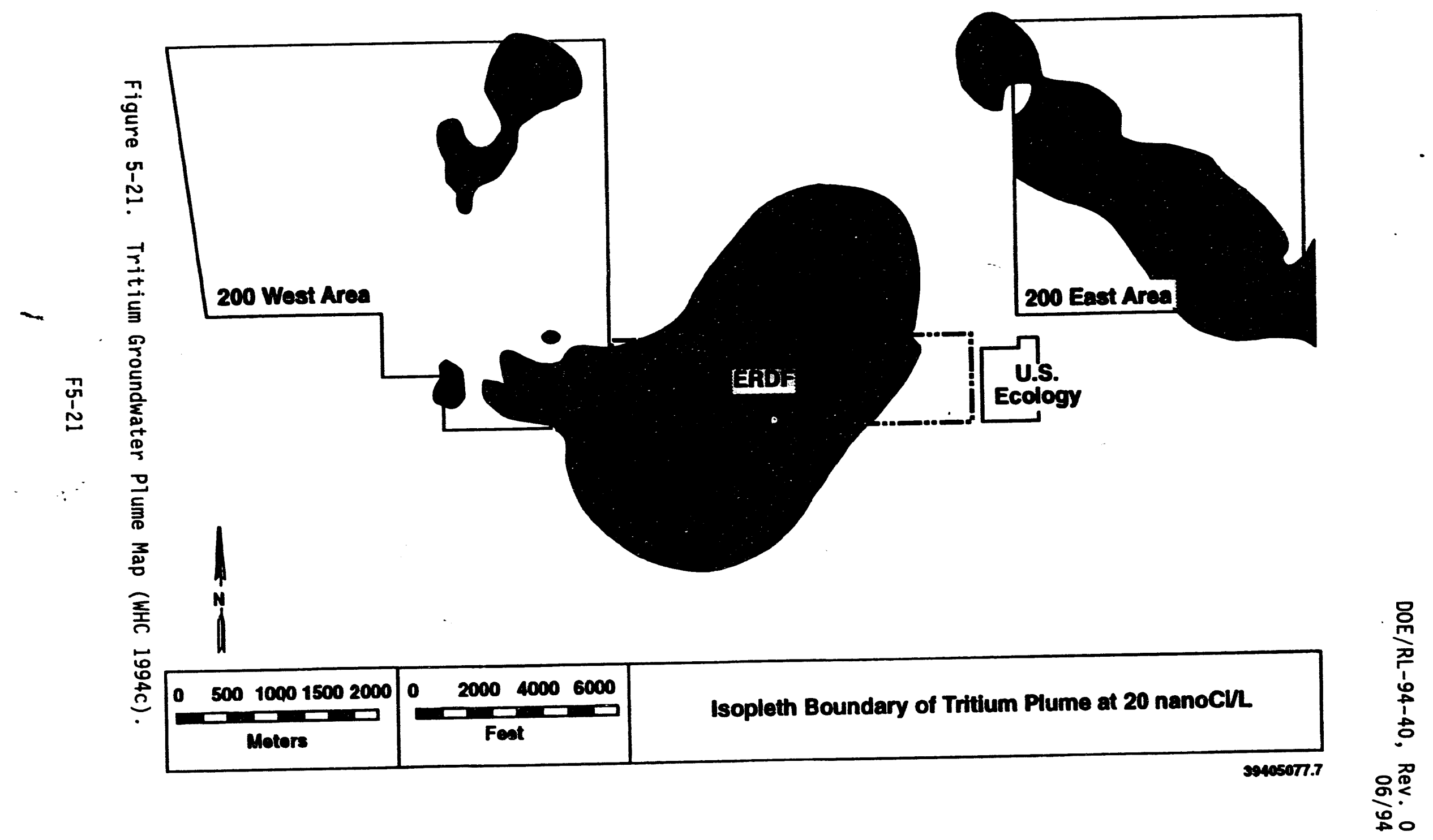


DOE/RL-94-40, Rev. 0
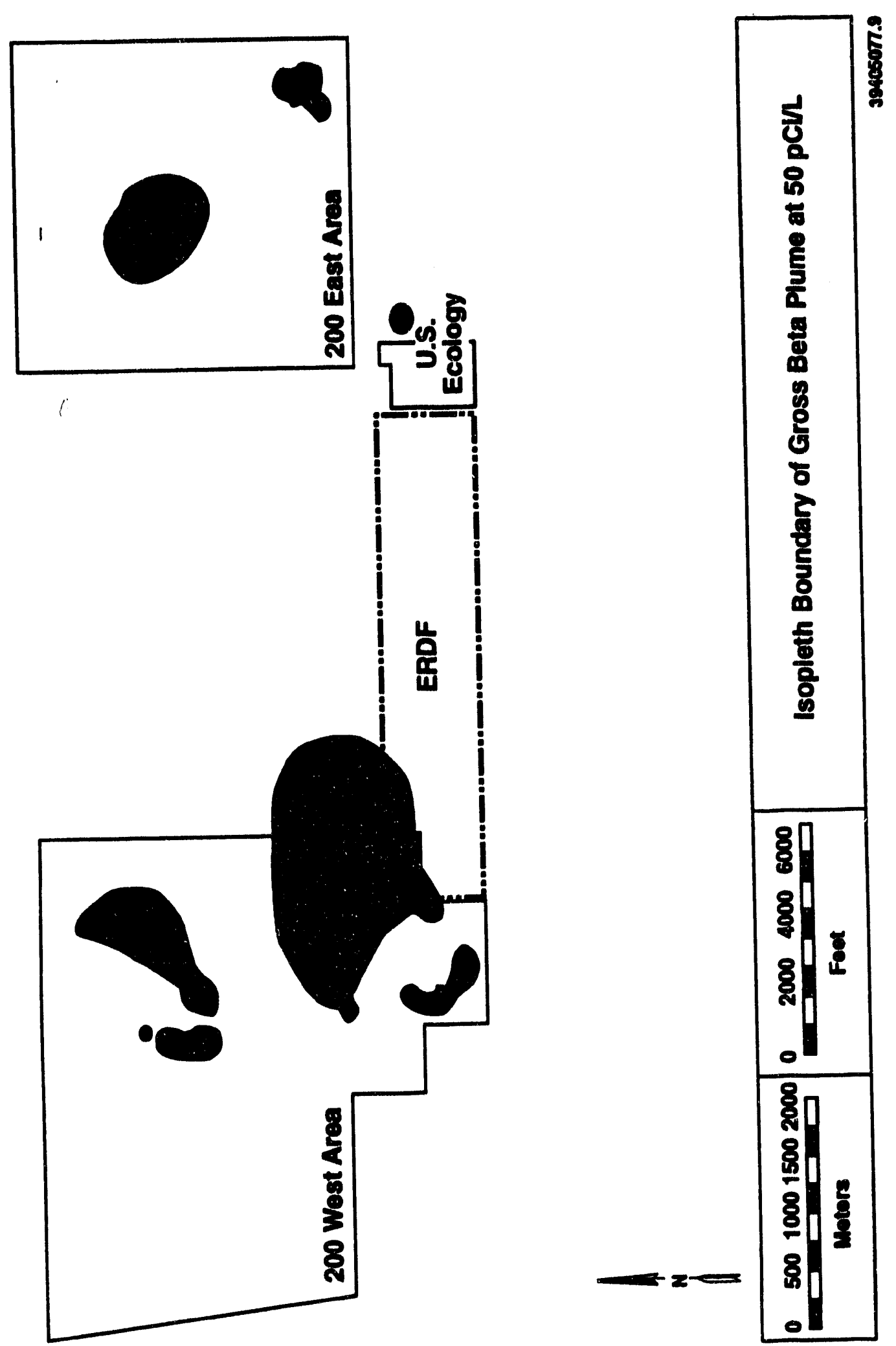

Figure 5-22. Gross Beta Groundwater Plume Map (WHC 1994C). 
DOE/RL-94-40, Rev. 0
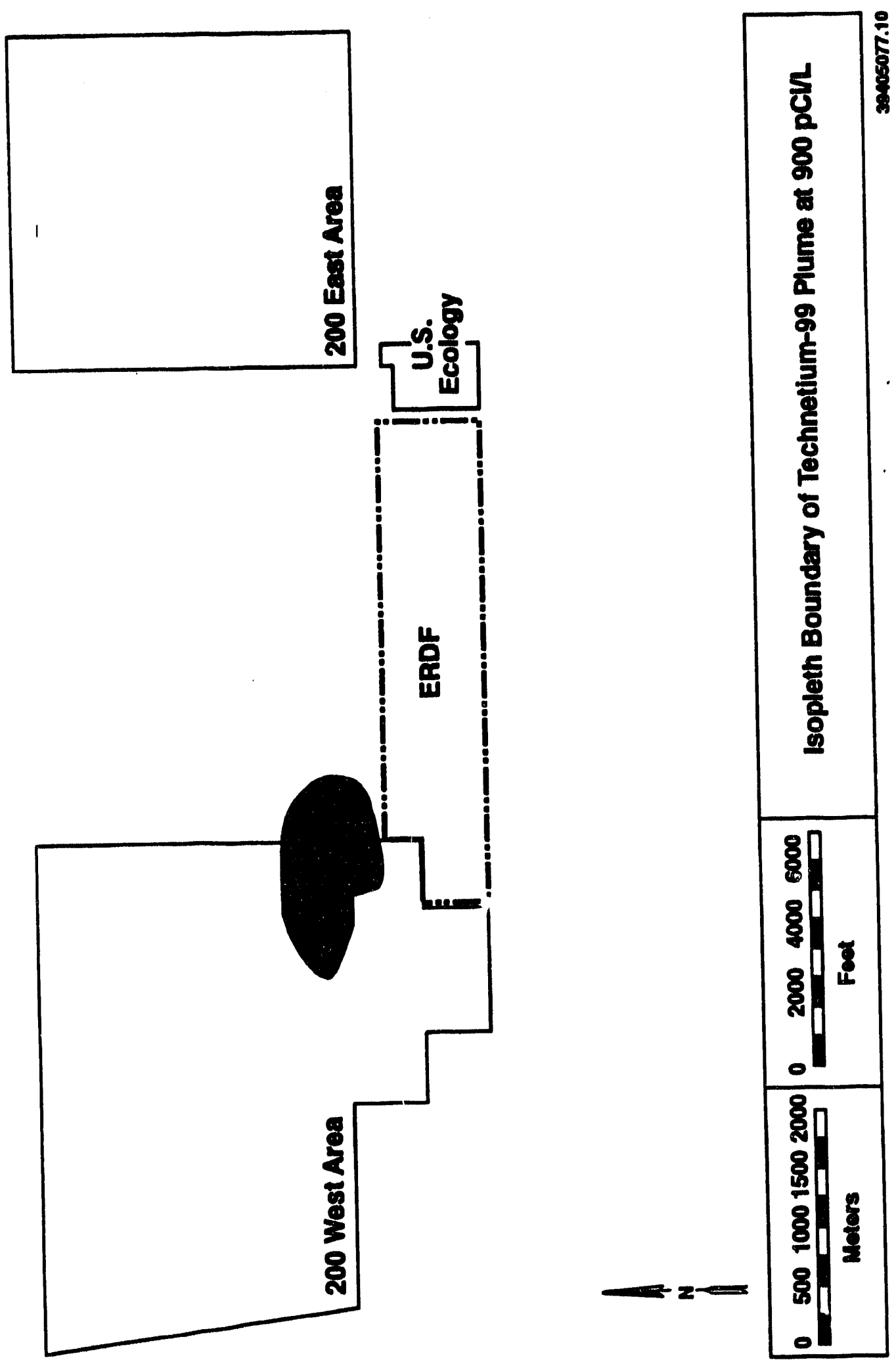

Figure 5-23. Technetium-99 Groundwater Plume Map (WHC 1994C). 
DOE/RL-94-40, Rev. 0

$06 / 94$

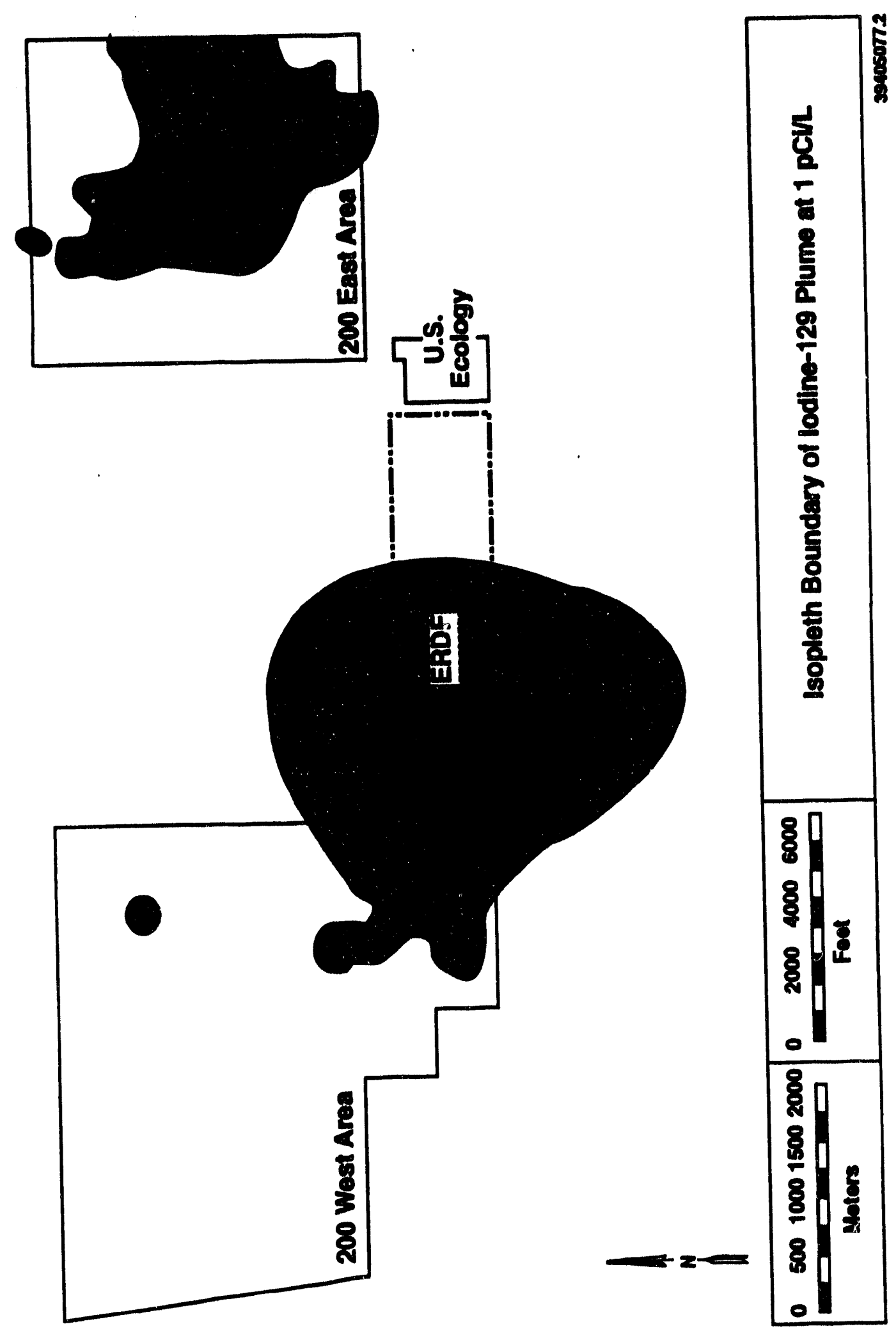

Figure 5-24. Iodine-129 Groundwater Plume Map (WHC 1994c). 
DOE/RL-94-40, Rev. 0
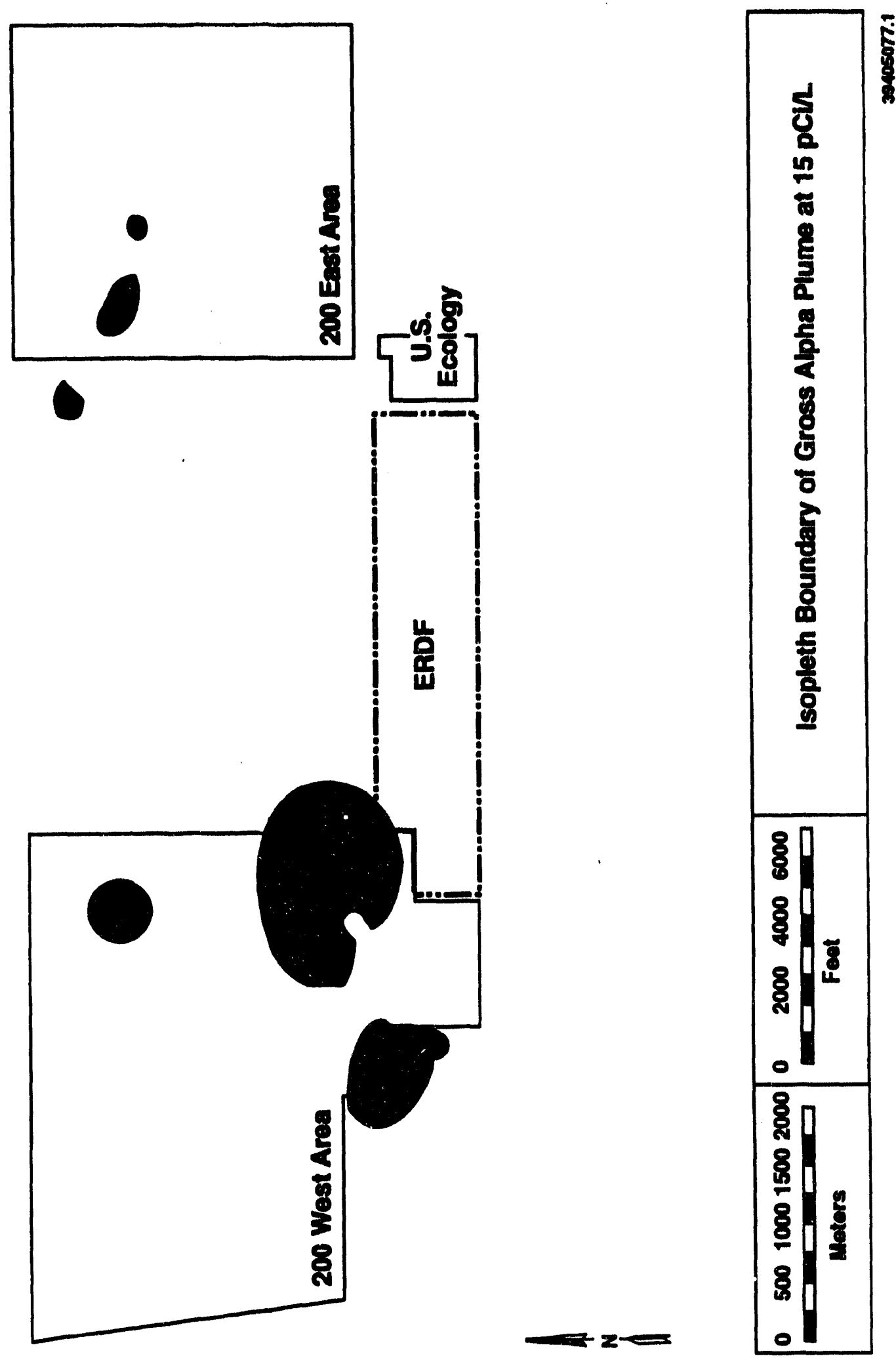

Figure 5-25. Gross Alpha Groundwater Plume Map (WHC 1994C). 
DOE/RL-94-40, Rev. 0

$06 / 94$

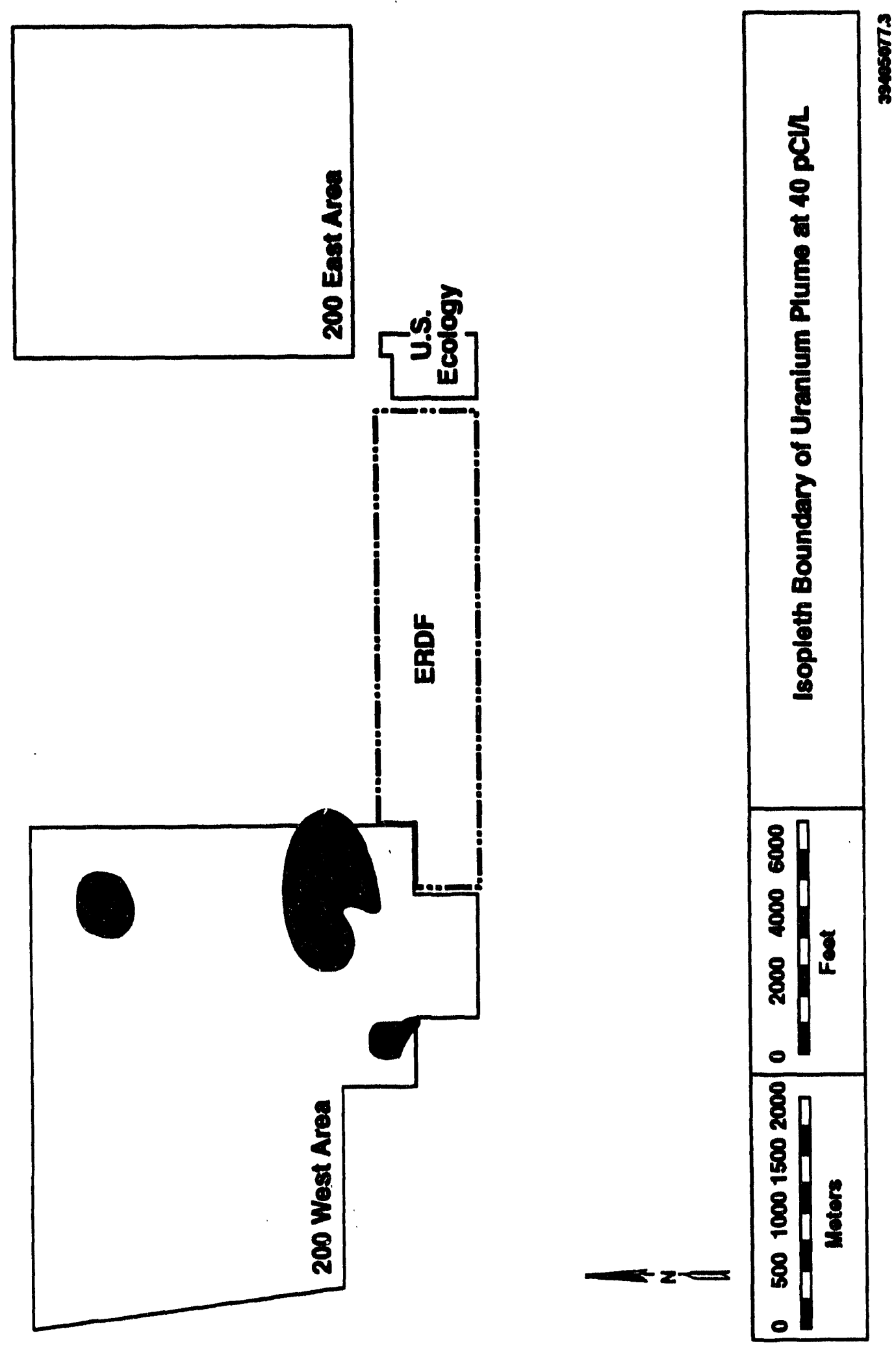

Figure 5-26. Uranium Groundwater Plume Map (WHC 1994C). 


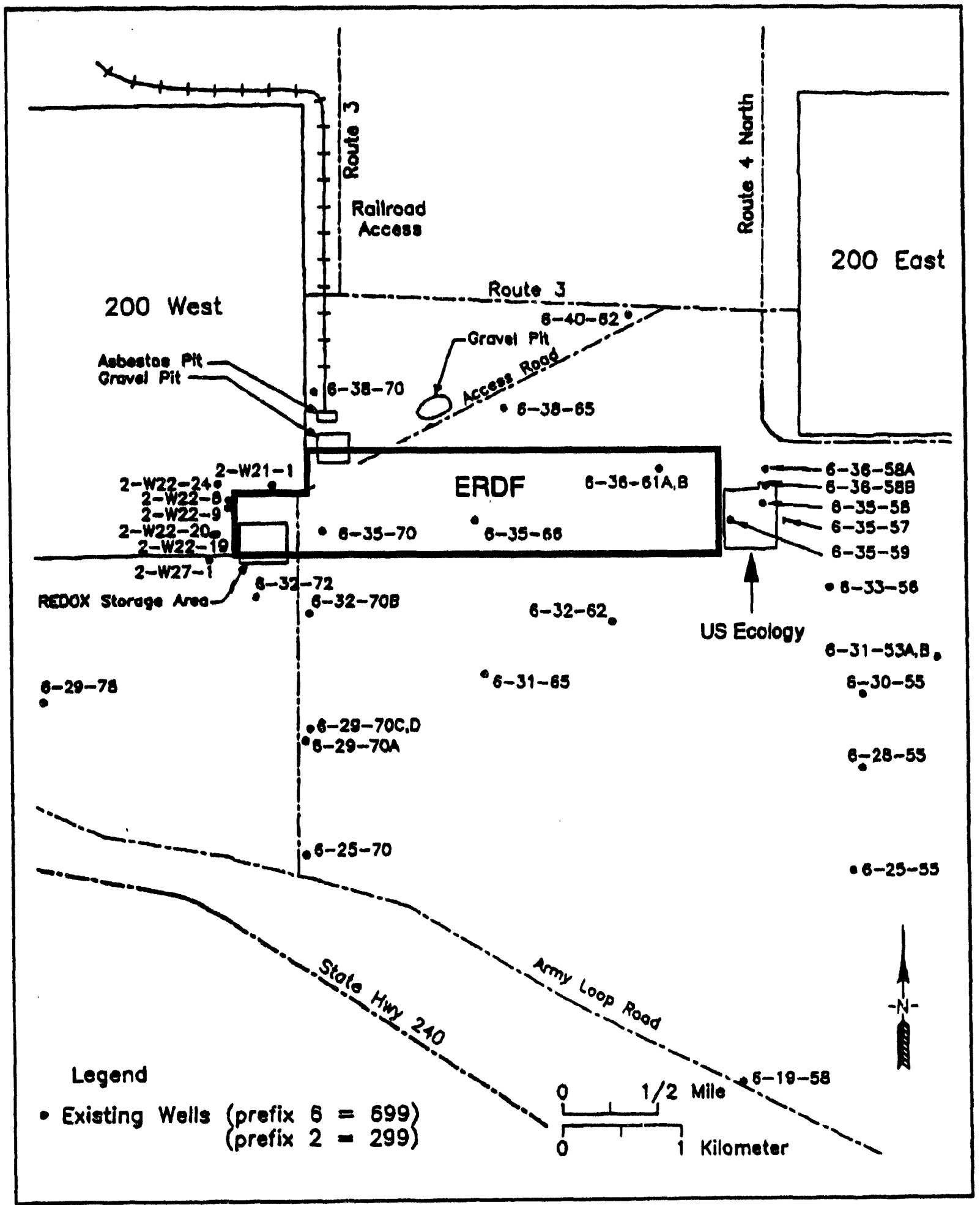

39405077.19

Figure 5-27. Location of Environmental Restoration Disposal Facility Monitoring Wells (WHC 1994d). 


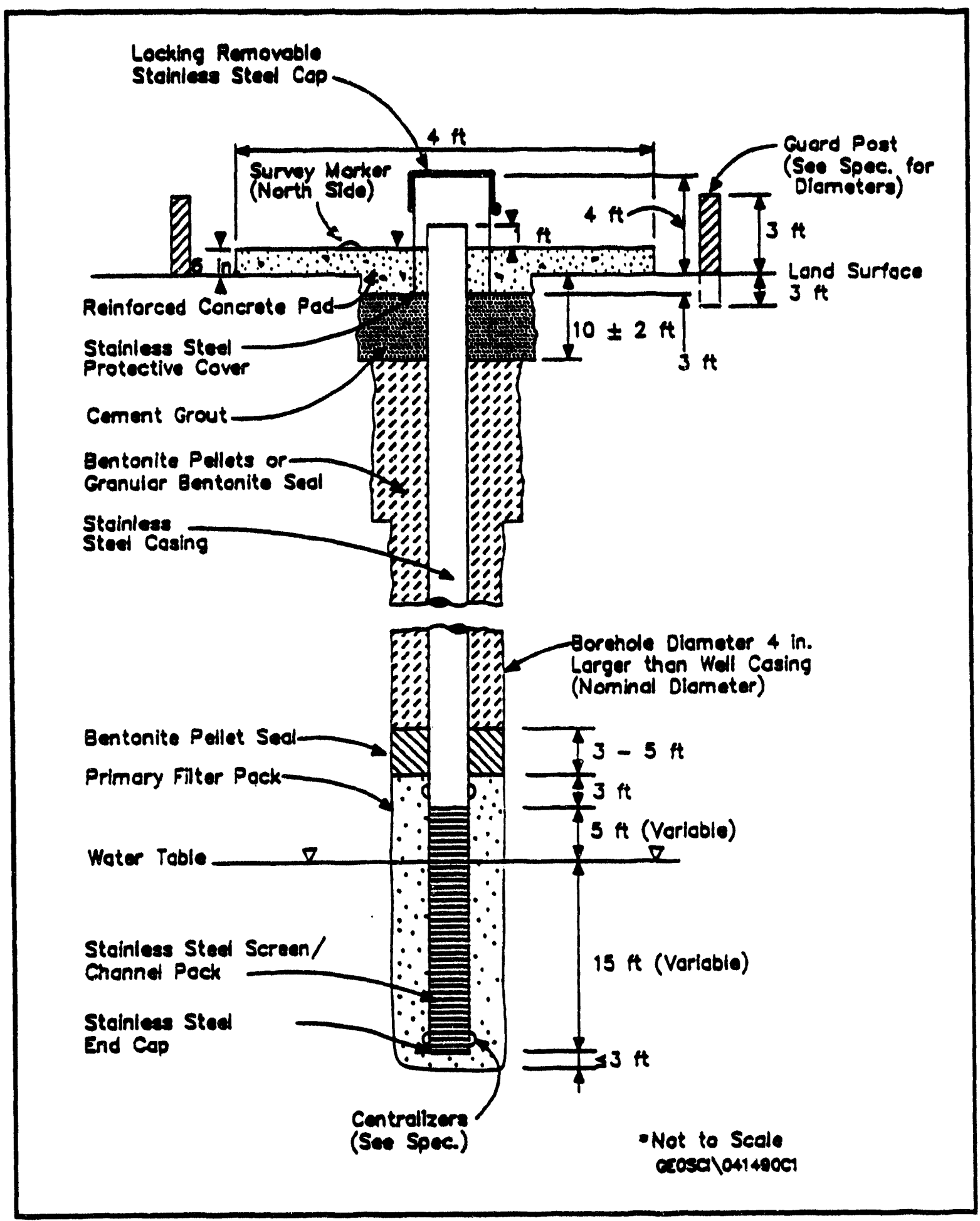

Figure 5-28. Schematic Diagram of a Typical Shallow Groundwater Monitoring Wel1 (WHC 1992C). 


\section{DATA SHEET FOR GROUNOWATER MONITORIMG MELLS AT THE (FACILITY)}

\section{Milestone M-XX-XX}

1. LOCATION:

2. TEMPORARY CASING SIZE AND SCHEDULE:

3. APPROXIMATE WELL DEPTH:

4. SPECIAL IMSTRUCTIONS: (Include details such as well specification, desired order that wells are to be drilled, expected perched water zones, estimated number of spitt-spoon samples, critical start and completion dates, and any other pertinent information that may impact drifling).

5. APPLICABLE DOCUMENTS: (Include groundwater monitoring plans and work plans).

6. WELL NUMBERS, LOCATIONS, PROPOSED DEPTH, TYPE, AND SCREEN LENGTHS:

Mell Number Coordinates Depth. EI Desion Type Screen Lenath. FI

Figure 5-29. Example Specification Data Sheet for Groundwater Monitoring Well. 
Table 5-1. Chapter 5.0 Cross-Reference Table. ([ ] - Denotes location of information in Ecology Part B checklist)

\begin{tabular}{|c|c|c|c|}
\hline ERDF outline chapter & $\begin{array}{l}\text { Specifically required } \\
\text { by cavil requlation? }\end{array}$ & $\begin{array}{l}\text { Washington State } \\
\text { CAMU Regulations"*t } \\
173-303\end{array}$ & $\begin{array}{c}\text { Federal } \\
\text { CAMU regulations } \\
40 \text { CFR } \\
\end{array}$ \\
\hline \multicolumn{4}{|l|}{ 5.0 Groundwater Monitoring [E] } \\
\hline $\begin{array}{l}5.1 \text { Excemption from Groundwater } \\
\text { Monitoring Requirements [E-1] } \\
\text { WAC 173-303-645 } \\
40 \text { CFR } 264.90(\text { b) (1) }\end{array}$ & No & $N / A$ & $N / A$ \\
\hline $\begin{array}{l}5.2 \text { Interim Status Period } \\
\text { Groundwater Monitoring Date [E-2] } \\
\text { HAC } 173-303-645 \\
40 \text { CFR } 264.90-40 \text { CFR 264.94 }\end{array}$ & No & $M / A$ & $N / A$ \\
\hline $\begin{array}{l}5.3 \text { Envirommental setting and } \\
\text { Aquifer Identification }[E-3 \text { ] } \\
\text { WAC } 173-303-645 \\
\text { WAC } 173-303-806(4)(a)(x x)(8) \\
40 \text { CFR } 270.14(c)(2)\end{array}$ & $\begin{array}{l}\text { No-- information is } \\
\text { provided in support of } \\
\text { CAMU criteris }\end{array}$ & $\begin{array}{l}646(5)(a)(i), \text { (ii), (iv), } \\
\text { (vi), and (vii) }\end{array}$ & $\begin{array}{l}264.552(0)(1),(2),(4), \\
(6),(7) \\
\text { CAMU Criteria } 1,2,4,6,7\end{array}$ \\
\hline $\begin{array}{l}5.4 \text { Groundwater auality } \\
\text { [Not in checkl ist] } \\
\text { WAC } 173-303-645 \\
\text { WAC } 173-303-806(4)(a)(x x)(D) \\
\text { WAC } 173-303-9905 \\
\text { WAC } 173-303-070 \\
40 \text { CFR } 270.14(c)(2),(4) \&(7) \\
261 \text {, Appendix VIII }\end{array}$ & $\begin{array}{l}\text { No-- information is } \\
\text { provided in support of } \\
\text { CAM criteria }\end{array}$ & $\begin{array}{l}646(5)(a)(i),(i i),(i v), \\
\text { (vi), and (vii) } \\
\end{array}$ & $\begin{array}{l}264.552(e)(1),(2),(4), \\
(6),(7) \\
\text { CANU Criteria 1, 2, 4, 6,7 }\end{array}$ \\
\hline $\begin{array}{l}\text { 5.5 Grouncwater Monitoring } \\
\text { Program } \\
\text { [Not in checklist] } \\
40 \text { CFR 264.90-101 }\end{array}$ & Yes & $\begin{array}{l}646(5)(a)(i) \text { and (ii) } \\
646(5)(b)(i i i)\end{array}$ & $\begin{array}{l}264.552(c)(1) \&(2) \\
264.552(e)(3) \\
\text { CAMU Criteria } 1 \text { and } 2\end{array}$ \\
\hline
\end{tabular}

* The sections of this application are based on the Ecology Part $B$ Checklist. The referenced regulations, both state (WAC 173-303) and federal (40 CFR 260-270), provide the specific requirements that typically are incorporated in these sections.

tw Assumes that Washington State has received HSWA authority. 

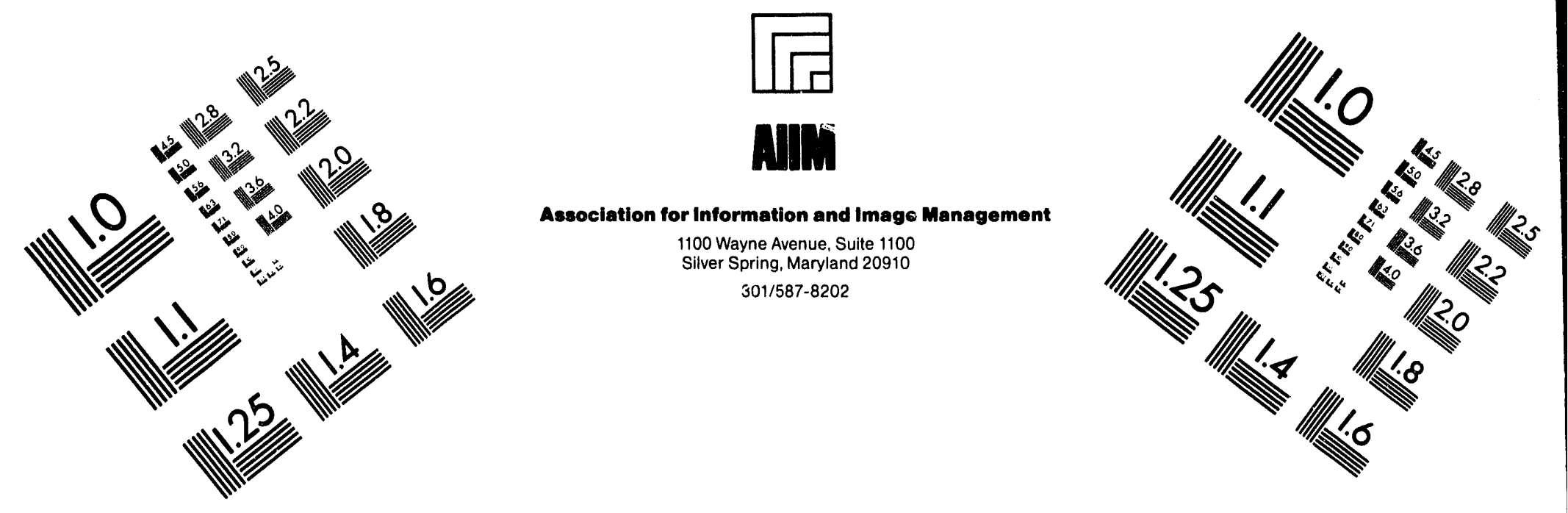

\section{Centimeter}

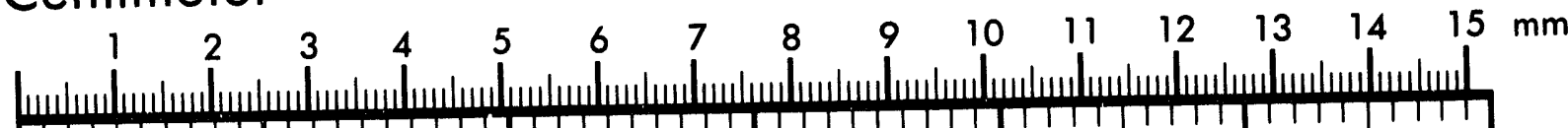

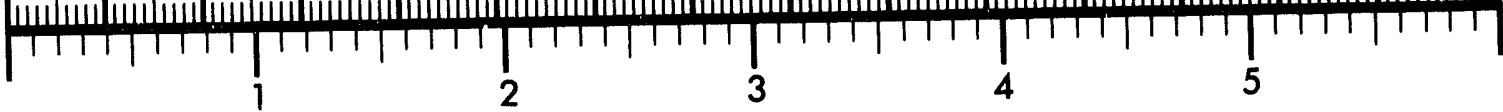
Inches
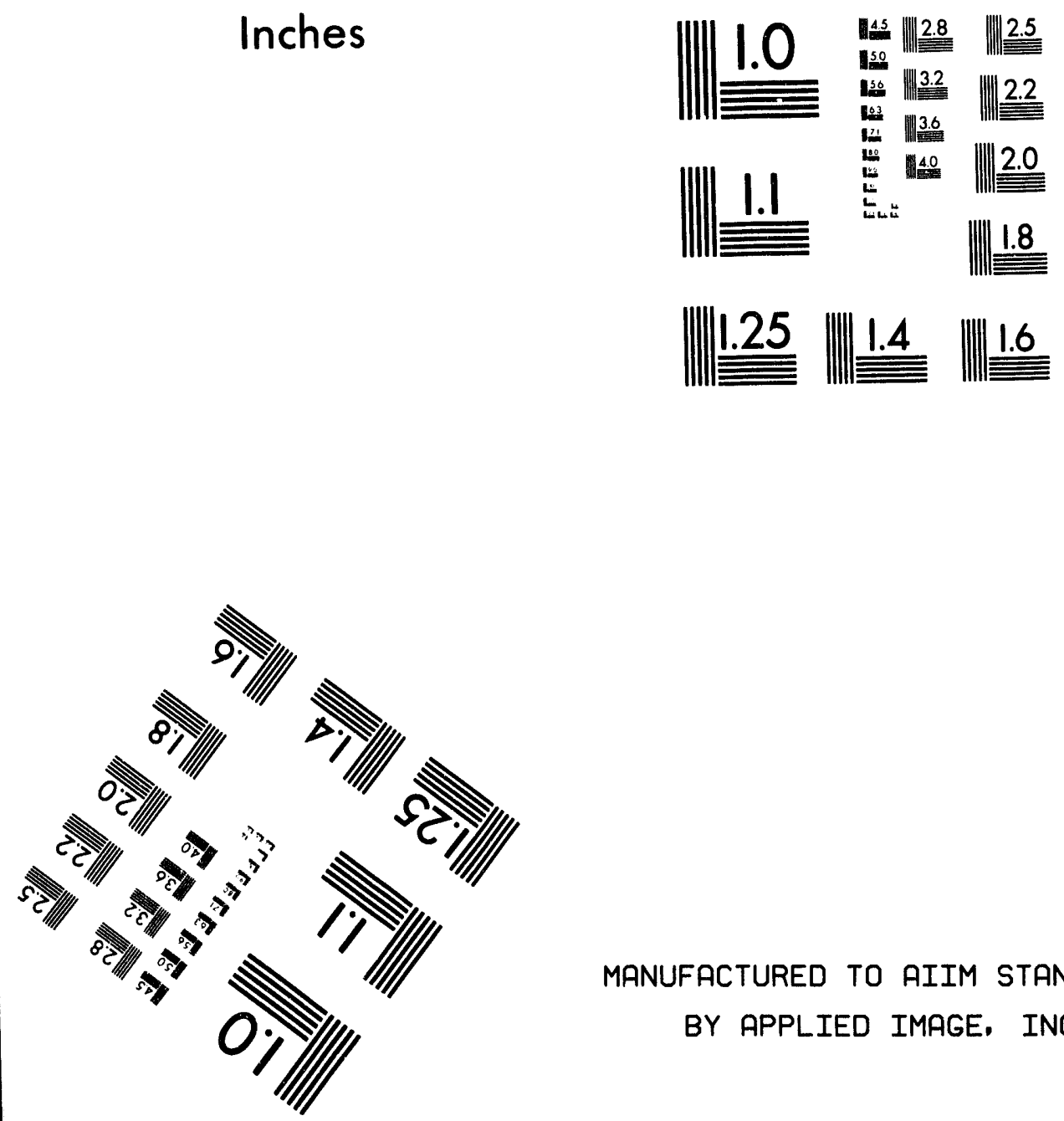

MANUFACTURED TO AIIM STANDARDS

BY APPLIED IMAGE. INC.

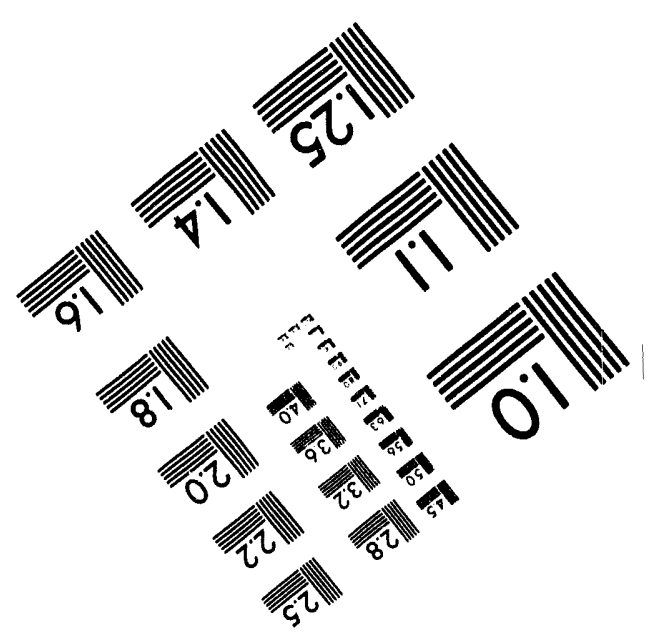



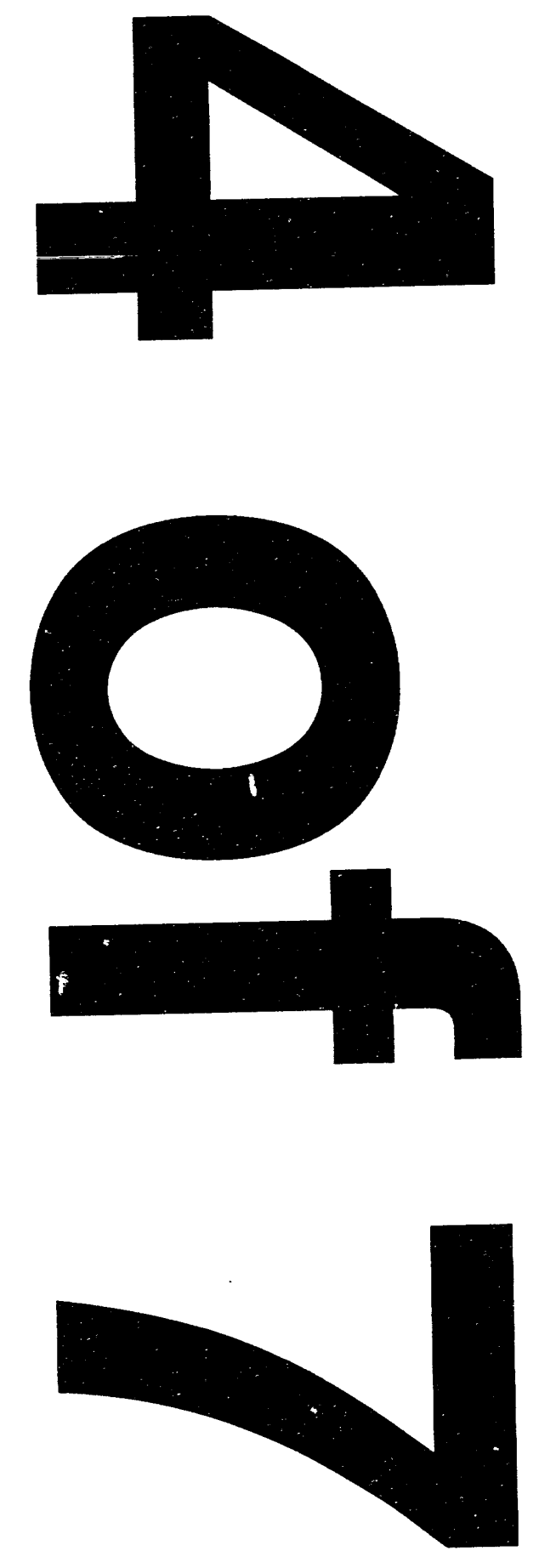
Table 5-2. Hydraulic Parameters for Various Areas and Geologic Units on the Hanford Facility?.

\begin{tabular}{|c|c|c|c|c|c|}
\hline Location & Interval tested & $\begin{array}{c}\text { Hydraul ic } \\
\text { conduct ivity } \\
\text { (feet per day) } \\
\end{array}$ & $\begin{array}{c}\text { Transmissivity } \\
\text { (square feet } \\
\text { per day) }\end{array}$ & $\begin{array}{l}\text { Effective } \\
\text { porosity }\end{array}$ & Data source \\
\hline 100 Area & $\begin{array}{l}\text { Ratt lesnake } \\
\text { Ridge interbed }\end{array}$ & $0-100$ & & $<10$ percent & $\begin{array}{l}\text { Gephart et al. } \\
\text { (1979) }\end{array}$ \\
\hline Hanford Site & $\begin{array}{l}\text { Saddle Mountain } \\
\text { Basalt flowtop }\end{array}$ & $10^{-2} \cdot 10^{-6}$ & & 5 percent & Cushing (1989) \\
\hline 100 Area & $\begin{array}{l}\text { Ringold } \\
\text { Formation FSE }\end{array}$ & $29-1,297$ & $5,750-26,700$ & & $\begin{array}{l}\text { Lijkala et al. } \\
\text { (1988) }\end{array}$ \\
\hline 200 Area & $\begin{array}{l}\text { Rattlesnake } \\
\text { Ridge interbed }\end{array}$ & & $8 \cdot 1,165$ & & $\begin{array}{l}\text { Graham et al. } \\
(1984)\end{array}$ \\
\hline 200 East Area & $\begin{array}{l}\text { Elephant } \\
\text { Mountain } \\
\text { Interflow Zone }\end{array}$ & & $7.5 \cdot 6,120$ & & $\begin{array}{l}\text { Graham et al. } \\
(1984)\end{array}$ \\
\hline Hanford Site & Selah interbed & & $3 \times 10^{-5}$ & & $\begin{array}{l}\text { Graham et al. } \\
(1984)\end{array}$ \\
\hline 200 West Area & $\begin{array}{l}\text { Ringold } \\
\text { Formation FSE }\end{array}$ & $0.6-200$ & & & $\begin{array}{l}\text { Last et al. } \\
\text { (1989) }\end{array}$ \\
\hline 1100 Area & $\begin{array}{l}\text { Ringold } \\
\text { Formation } \\
\text { FSC/FSB }\end{array}$ & $3 \times 10^{-1}-5$ & & & $\begin{array}{l}\text { Lindberg and } \\
\text { Bond (1979) }\end{array}$ \\
\hline 1100 Area & $\begin{array}{l}\text { Ringold } \\
\text { Formation } \\
\text { overbank } \\
\text { deposits } \\
\end{array}$ & $\begin{array}{l}8 \times 10^{-4} \\
1 \times 10^{-1}\end{array}$ & & & $\begin{array}{l}\text { Lindberg and } \\
\text { Bond (1979) }\end{array}$ \\
\hline 300 Area & Levey interbed & $0.01-1,000$ & & & DOE/RL (1990) \\
\hline 300 Area & $\begin{array}{l}\text { Ringold } \\
\text { Formation }\end{array}$ & $1.9 \cdot 10,000$ & & & DOE/RL (1990) \\
\hline 300 Area & $\begin{array}{l}\text { Hanford } \\
\text { formations }\end{array}$ & $11,000-50,000$ & & & DOE/RL $(1990)$ \\
\hline
\end{tabular}

1 Source: WHC 1991b. 
Table 5-3. Well Construction Information for Environmental Restoration Disposal Facility Groundwater Monitoring Wells.

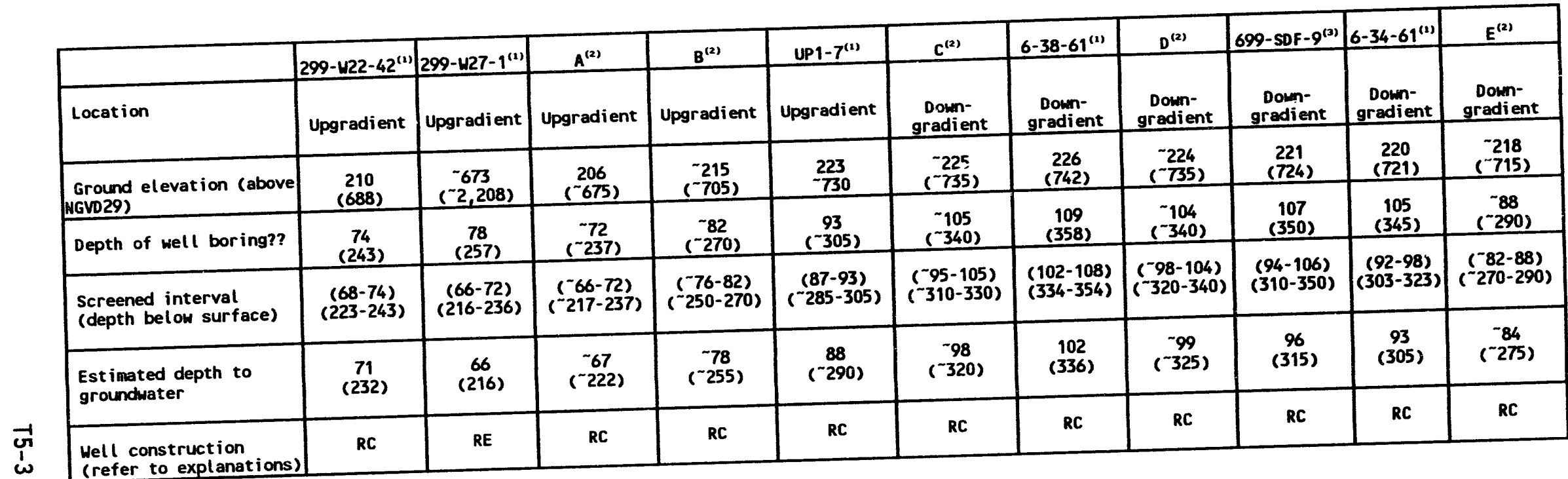

(1) = Currently existing well.

(2) = To be installed.

(3) = To be installed, if 6-35-59 available, will use and not install 699-SDF-9.

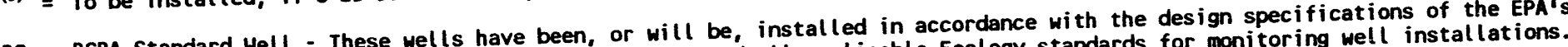
Enforcement Guidance Document (TEGD) (OSWER 9950.1) and all applicable Ecology standards for monitoring well installatingent $\begin{aligned} & \text { RE = } \text { RCRA Equivalent Well - These wells have been constructed } \\ & \text { data quality objectives of the RCRA standard wells (RC). }\end{aligned}$

\begin{tabular}{lll}
\multicolumn{3}{c}{ Coordinates } \\
\hline (WCS 835 & (1991) meters \\
\hline $299-$ W27-1 & $N 133750.35$ & E567575.12 \\
$299-$ W22-42 & $N 134452.20$ & E56r623.16 \\
$699-38-61$ & $N 134997.269$ & E571219.118 \\
$699-34-61$ & $N 133809.837$ & E571395.849
\end{tabular}


Table 5-4. Contaminant Transport Input Parameters to Monitoring Efficiency Model.

\begin{tabular}{|l|c|}
\hline \multicolumn{1}{|c|}{ Input parameters } & Value \\
\hline Dilution contour & $1.0 \times 10 \mathrm{E}-3$ \\
\hline Longitudinal dispersivity & 8.5 meters (27 feet) \\
\hline Transverse dispersivity & 2.5 meters (8 feet) \\
\hline Source width & 6 meters (19 feet) \\
\hline Groundwater flow direction & \begin{tabular}{c}
${ }^{2}$ East, \begin{tabular}{c|} 
with a $5^{\circ}$ variation to the \\
north and south
\end{tabular} \\
\hline Average contaminant velocity
\end{tabular} \\
\hline
\end{tabular}

1 Additional input parameters used in the MEMO calculations included the coordinates for the source area, line of compliance, buffer zone, and wells.

2 Present groundwater flow direction beneath the ERDF is between 0 and $5^{\circ}$ north of east. The groundwater flow direction in January 1994 was between 0 and $5^{\circ}$ south of east. 
Table 5-5. Groundwater Monitoring Network Analytical Parameters.

\begin{tabular}{|c|c|c|c|c|c|}
\hline \multicolumn{2}{|c|}{ Upgradient contaminants } & \multicolumn{2}{|c|}{ Indicator parameters } & \multicolumn{2}{|c|}{$\begin{array}{l}\text { Representative constituents in ERDF } \\
\text { waste }\end{array}$} \\
\hline Const i tuent & $\begin{array}{c}\begin{array}{c}\text { Method } \\
\text { detection } \\
\text { limit }\end{array} \\
\end{array}$ & Const i tuent & $\begin{array}{c}\begin{array}{c}\text { Method } \\
\text { detection } \\
\text { limit }\end{array} \\
\end{array}$ & Constituent & $\begin{array}{c}\begin{array}{c}\text { Method } \\
\text { detection } \\
\text { limit }\end{array} \\
\end{array}$ \\
\hline chromium & 10 & temperature & $\ldots$ & benzene & 5 \\
\hline nitrate & 500 & $\mathrm{pH}$ (field and (ab) & $\cdots$ & bromoform & 5 \\
\hline carbon tetrachloride & 5 & $\begin{array}{l}\text { specific conductance } \\
\text { (field and (ab) } \\
\end{array}$ & $\cdots$ & chlorobenzene & 5 \\
\hline chloroform & 15 & total dissolved solids & $\cdots$ & 1,2 dichloroethane & 5 \\
\hline trichloroethylene & 5 & total suspended solids & $\cdots$ & cis $-1,1$ dichloroethylene & 5 \\
\hline tritium & TBD & total organic carbon & -- & $\begin{array}{l}\text { trans }-1,1 \\
\text { dichloroethylene }\end{array}$ & 5 \\
\hline gross beta & $8 \mathrm{pCi} / \mathrm{L}$ & total carbon & $\cdots$ & 1,2 dichloropropane & 5 \\
\hline technet ium-99 & TBD & total organic halogen & $\cdots$ & acetonitrile & 10 \\
\hline iodine-129 & TBD & $=-$ & $\cdots$ & ethylbenzene & 5 \\
\hline gross a!pha & $4 \mathrm{pCi} / \mathrm{L}$ & $\cdots$ & $\cdots$ & $\begin{array}{l}1,1,2,2- \\
\text { Tetrachloroethane }\end{array}$ & 5 \\
\hline uranium & 0.7 & $\cdots$ & $\therefore$ & tetrachloroethylene & 5 \\
\hline$\cdots$ & $\cdots$ & 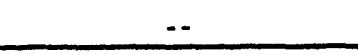 & $\cdots$ & toluene & 5 \\
\hline$\cdots$ & - & $\ldots$ & $\cdots$ & vinyl chloride & 10 \\
\hline$\ldots$ & $\cdots$ & $\ldots$ & $\cdots$ & xylene & 5 \\
\hline$\cdots$ & $\cdots$ & $\cdots$ & $\cdots$ & naphthalene & 10 \\
\hline$\cdots$ & $\cdots$ & $\ldots$ & $\cdots$ & copper & 10 \\
\hline$\ldots$ & $\cdots$ & $\cdots$ & $\therefore$ & cadnium & 2 \\
\hline$\cdots$ & $\cdots$ & $\therefore$ & $\cdots$ & lead & 5 \\
\hline$\cdots$ & $\ldots$ & $\ldots$ & $\cdots$ & chloride & 500 \\
\hline.- & $\cdots$ & $\cdots$ & $\cdots$ & sulfate & 500 \\
\hline$\ldots$ & $\cdots$ & $\ldots$ & $\cdots$ & beryllium & 3 \\
\hline$\ldots$ & $\cdots$ & $\cdots$ & $\cdots$ & radium & $1 \mathrm{pCi} / \mathrm{L}$ \\
\hline$\cdots$ & $\cdots$ & 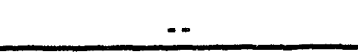 & $\ldots$ & cyanide & 10 \\
\hline$\cdots$ & $\cdots$ &.- & $\cdots$ & mercury & 0.1 \\
\hline$\cdots$ & $\cdots$ & $\cdots$ & $\ldots$ & silver & 10 \\
\hline -. & $\ldots$ & $\ldots$ & - & fluoride & 500 \\
\hline$\cdots$ & $\cdots$ & $\cdots$ & $\cdots$ & sodium & 200 \\
\hline$\ldots$ & $\cdots$ & 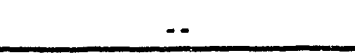 & $\cdots$ & representative PCBs & $\cdots$ \\
\hline
\end{tabular}

$T B D=$ To be determined. 
Table 5-6. Environmental Investigation Control Procedures'.

\begin{tabular}{|c|c|}
\hline Number & Title \\
\hline $\begin{array}{l}\text { Est } 1.2 \\
\text { EII } 1.6\end{array}$ & $\begin{array}{l}\text { Preparation and Revision of Enviromental Investigations Instructions } \\
\text { instruction Change Authorizations. }\end{array}$ \\
\hline $\begin{array}{ll}\text { EII } & 1.4 \\
\text { EII } & 1.5\end{array}$ & $\begin{array}{l}\text { instruction Change Authorizations. } \\
\text { pleld Logbooks }\end{array}$ \\
\hline $\begin{array}{ll}\text { EII } & 1.6 \\
\text { EII } & 1.7\end{array}$ & $\begin{array}{l}\text { Records Processing } \\
\text { Indoctrinution, Training and oulification }\end{array}$ \\
\hline EII 1.7 & $\begin{array}{l}\text { Indoctrination, Training and oullification } \\
\text { primery and secondary Docement Revis and Control }\end{array}$ \\
\hline Ell 1.9 & Primary and Secondary Document Review and Control \\
\hline EII 1.10 & Identifying, Evaluating and Documenting Suspect Waste Sites \\
\hline E11 1.11 & Technical Oeta Management \\
\hline Elt 2.1 & Preparation of Hezardous Waste Operations Perwits \\
\hline EII 2.2 & Occupational Heal th Monitoring \\
\hline EII 2.3 & $\begin{array}{l}\text { Adninistration of Radiation Surveys to Support Emviromental Charecterization Work on the } \\
\text { Henford Site }\end{array}$ \\
\hline EII 3.2 & Calibration and Control of Monitoring Instruments \\
\hline$E 114.2$ & Interim Control of Unknown, Suspected Hazardous and Mixed Weste \\
\hline EII 5.1 & Chain of Custody \\
\hline EII 5.2 & Soil and sediment sempling \\
\hline Ell 5.4 & Field Cleaning and/or Decontemination of Equipment \\
\hline El1 5.5 & 1706KE Laboratory Decontomination of RCRA/CERCLA SEspling Equipment \\
\hline EII $5.7 A$ & Manford Geotechnical Semple Library Control \\
\hline Ell 5.8 & Groundwater sempl ing \\
\hline EII 5.10 & Semple Identification and Data Entry into MEIS Database \\
\hline E11 5.11 & semple Packaging and Shipping \\
\hline Ell 5.12 & Air Quality sampling of Ambient and Downwind air we Maste Sites \\
\hline E11 5.13 & Drum sempling \\
\hline E11 5.14 & Drum Handling \\
\hline EII 6.1 & Activity Reports of Field Operations \\
\hline EII 6.6 & Ground Water Well cheracterization and Evaluation \\
\hline E11 6.7 & Resource Protection Hell and Test Borehole orilling \\
\hline EJ) 6.8 & Mell Completion \\
\hline E1\$ 9.1 & Geologic Losging \\
\hline EII 10.1 & Aquifer Testing \\
\hline Ett 10.2 & Meesurement of Ground-Woter Levels \\
\hline Elt 10.3 & Purge Water Menagement \\
\hline Ell 10.6 & Well Development Activities \\
\hline EII 11.1 & Geophysical Looging \\
\hline
\end{tabular}

1 Source: WHC 1989a. 
6.0 PROCEDURES TO PREVENT HAZARDS . . . . . . . . . . . . . . 6-1

6.1 SECURITY ................ 6-1

6.1.1 Security Procedures and Equipment . . . . . . . . 6-1

6.1.1.1 24 Hour Surveillance System ......... . 6-1

6.1.1.2 Barrier and Means to Control Entry . . . . . 6-1

6.1.1.3 Warning Signs............. . 6-2

6.1 .2 Waiver............... . 6-2

6.2 INSPECTION SCHEDULE ............... 6-2

6.2.1 General Inspection Requirements .......... 6-2

6.2.1.1 Types of Problems ............ 6-2

6.2.1.2 Frequency of Inspections .........6-6-3

6.2.2 Specific Process Inspection Requirements . . . . . . . 6-3

6.2.2.1 Container Inspection ...........6-3

6.2.2.2 Tank System Inspection ......... 6-3

6.2.2.3 Waste Pile Inspection ...........6-3

6.2.2.4 Surface Impoundment Inspection ....... 6-3

6.2.2.5 Incinerator Inspection .......... 6-3

6.2.2.6 Landfill Inspection . . . . . . . . . . 6-3

6.2.2.7 Land Treatment Facility Inspection . . . . 6-4

6.2.2.8 Environmental Restoration Disposal

Facility Trench Inspection ....... . 6-4

6.3 WAIVER OR DOCUMENTATION OF PREPAREDNESS AND PREVENTION

REQUIREMENTS . . . . . . . . . . . . . . 6-6

6.3.1 Equipment Requirements . . . . . . . . . . . . .6-6

6.3.1.1 Internal Communication . . . . . . . . 6-6

6.3.1.2 External Communications . . . . . . . . 6-6

6.3.1.3 Emergency Equipment . . . . . . . . . 6-6

6.3.1.4 Water for Fire Control . . . . . . . . . 6-7

6.3.2 Access Requirements .............. 6-7

6.4 PREVENTIVE PROCEDURES, STRUCTURES, AND EQUIPMENT . . . . . . 6-7

6.4.1 Unloading Operations . . . . . . . . . . . . . . 6-7

6.4.2 Run-0ff ................... . 6-8

6.4.3 Water Supplies . . . . . . . . . . . . . . . . . 6-8

6.4.4 Equipment and Power Failure .......... . . 6-8

6.4.5 Personnel Protection Equipment ......... 6-8

6.5 PREVENTION OF REACTION OF IGNITABLE, REACTIVE, AND

INCOMPATIBLE WASTE .......... 6-9

6.5.1 Precautions to Prevent Ignition or Reaction of

Ignitable or Reactive Waste ....... . . 6-9

6.5.2 General Precautions for Handling Ignitable or

Reactive Waste and Mixing of Incompatible Waste . . . 6-9 
DOE/RL-94-40, Rev. 0

$06 / 94$

1

2

3

4 6-1. Chapter 6.0 Cross-Reference Table . . . . . . . . . . . . . . . . . T6-1

5 6-2. Inspection Schedule for the Environmental Restoration

6 Disposal Facility. . . . . . . . . . . . . . . . T6-2

\section{TABLES}




$$
\text { DOE/RL-94-40, Rev. } 0
$$

\subsection{PROCEDURES TO PREVENT HAZARDS}

The CAMU requirements of CFR 264.552 and WAC 173-303-646 40 contain no specific mandate to describe procedures to prevent hazards (i.e., security measures, inspection procedures, operational procedures, and equipment). The CAMU, however, is required to meet overall regulatory objectives of WAC 173-303-646, 40 CFR 270.42(c), and 40 CFR 264.552(c) that specify that the CAMU be constructed and operated in a manner that is protective of human health and the environment. For this reason, a description of procedures to prevent hazards is provided to demonstrate that the ERDF will be operated to minimize exposure of the general public and operating personnel to radioactive and/or hazardous/dangerous waste. Table 6-1 is a regulatory cross-reference table.

The procedures presented in this chapter will apply to operation of the ERDF, and do not address those for support units because these support units cannot be included in the ERDF, by definition. However, operation of support units will be governed by ERDF operations, which will be developed, thus ensuring that operation of the ERDF, on the whole, will meet CAMU standards. Information presented in this chapter was derived in part from the LLBG dangerous waste permit application (DOE-RL 1989) and the ERDF conceptual design report (DOE-RL 1994a), as wel1 as RCRA and WAC requirements (EPA 1992b; Ecology et a1. 1994).

\subsection{SECURITY}

The following sections describe security measures, equipment, and warning signs used to control entry to the ERDF.

\subsubsection{Security Procedures and Equipment}

The following sections describe the 24-hour surveillance system, barrier, and warning signs that will be used to piovide security and control access to the ERDF.

6.1.1.1 24 Hour Surveillance System. The entire Hanford Facility is a controlled access area. The Hanford Facility maintains around-the-clock surveillance for the protection of government property, classified information, and special nuclear materials. The Hanford Patrol maintains a continuous presence of protective force personnel to provide additional security.

6.1.1.2 Barrier and Means to Control Entry. The entire trench area will be protected from inadvertent entry by fencing that is approximately 3 meters (10 feet) high. The fencing will be chain link with barbed wire. Lighting will be provided around the entire perimeter of the fenced site. Three main gated entries will be provided; each gate will have a control point with limited entry during operations and security locks on unmanned gates. During offshift hours, access will be controlled by the shift manager. Gate control 
DOE/RL-94-40, Rev. 0

$06 / 94$

points will use preengineered metal buildings to monitor access to the unit.

These control point buildings will be equipped with electricity, heat, air conditioning, and communication systems.

In addition to the fencing, all building exterior doors will be provided with security locks. The exterior of buildings will be illuminated and exterior lighting will be controlled automatically by photoelectric sensors.

6.1.1.3 Warning Signs. The active portions of the ERDF will be within chained or fenced radiation zones with radiation signs every 30 meters

( 98 feet) along the chain or fence. The signs will be visible from all angles of approach, with a minimum size of 17.8 centimeters by 25 centimeters

( 7 inches by 10 inches). Each active area used for the storage or management of mixed waste will be posted with a sign, in English, reading,

"DANGER-UNAUTHORIZED PERSONS KEEP OUT," in red and black letters on a white background. In addition to these signs, the fences around the ERDF will be posted with signs warning against unauthorized entry. The signs will be in English and visible from all angles of approach.

\subsubsection{Waiver}

Waivers of the security procedures and equipment requirements for the ERDF are not requested. Therefore, the requirements of this section are not applicable to the ERDF.

\subsection{INSPECTION SCHEDULE}

The following sections describe the method and schedule for inspection of the ERDF. While not specifically mentioned in 40 CFR 264.552 (c), the purpose of inspection procedures at the ERDF will be to prevent malfunctions and deteriorations, human errors, and discharges that might cause or lead to the release of radioactive or hazardous/dangerous waste to the environment or pose a threat to human health. Abnormal conditions identified by inspections will be corrected on a schedule that prevents hazards to workers, the public, and the environment.

\subsubsection{General Inspection Requirements}

The content and frequency of ERDF inspections are described in this section. The schedule and inspection reports will be kept at the ERDF operations building. The records will be retained for a minimum of 5 years from the date of inspection. Table 6-2 provides a summary inspection schedule for the ERDF.

6.2.1.1 Types of Problems. The types of problems that will be looked for during the inspection will be listed in the inspection schedule, provided as Table 6-2. Information from inspections wil1 be recorded on inspection

51 reports that will be maintained by operating personnel, and may be evaluated 


$$
\text { DOE/RL-94-40, Rev. } 0
$$

1 by the appropriate agency upon request. The report forms will be used in the 2 field to initiate corrective action if necessary.

3

6.2.1.2 Frequency of Inspections. The frequency of inspection of each item is 1 isted in the inspection schedule. The inspection frequency is based on the rate of possible deterioration of the equipment and the probability of an environmental or human health incident if the deterioration, malfunction, or operator error goes undetected between inspections.

Areas subject to spills (i.e., the unloading areas) will be inspected daily. The ERDF trench will be inspected weekly. In addition, the active and inactive (i.e., closed) portions of the ERDF trench will be inspected for run-on, run-off, and erosion problems after a significant precipitation or windstorm event.

\subsubsection{Specific Process Inspection Requirements}

The following sections describe specific process inspection requirements for the ERDF.

6.2.2.1 Container Inspection. Operation of the ERDF will not likely involve container storage for a period greater than 90 days, therefore the storage area is not subject to WAC 173-303-630 or 40 CFR 264 Subpart I requirements. Containers will be inspected at the remediation site and containers found unacceptable for management at the ERDF will remain at the remediation site.

6.2.2.2 Tank System Inspection. Operation of the ERDF may involve the storage of waste in tank systems subject to WAC 173-303-640 or 40 CFR 264 Subpart $\mathrm{J}$ requirements. Tank system inspections will be addressed, as applicable, in a separate document.

6.2.2.3 Waste Pile Inspection. Operation of the ERDF will not involve the placement of waste in piles subject to WAC 173-303-660 or 40 CFR 264 Subpart $L$ requirements. Therefore, waste pile inspections are not applicable.

6.2.2.4 Surface Impoundment Inspection. Operation of the ERDF does not involve the placement of waste in surface impoundments subject to WAC 173-303-650 or 40 CFR 264 Subpart $K$ requirements. Therefore, the inspection requirements of this section are not applicable.

6.2.2.5 Incinerator Inspection. Operation of the ERDF will not involve the incineration of waste. Therefore, the inspection requirements of WAC 173-303-670 and 40 CFR 264 are not app]icable.

6.2.2.6 Landfill Inspection. In accordance with the definitions provided in 40 CFR 260.10, a CAMU, such as in the ERDF, will not be considered a RCRA landfill. Therefore, the landfill inspection requirements of this section are not directly applicable, although the requirement were used as a guide to develop CAMU inspection requirements presented in Section 6.2.2.8. 
DOE/RL-94-40, Rev. 0

$06 / 94$

1 6.2.2.7 Land Treatment Facility Inspection. Operation of the ERDF will not

2 likely involve the land treatment of waste subject to WAC 173-303-655 or

3 WAC 173-303-806(4)(g)(ii)(D) or 40 CFR 264 Subpart M requirements. Therefore,

4 this section is not applicable.

6.2.2.8 Environmental Restoration Disposal Facility Trench Inspection. Inspection of the ERDF trench will comply with WAC 173-303-646 and 40 CFR $264.552(c)$. Inspections will be necessary to demonstrate that the ERDF will be constructed and operated in a manner that will not create unacceptable risks to humans or to the environment, and that waste placed in the ERDF will be managed and contained to minimize future releases.

6.2.2.8.1 Run-On and Run-off Control System. The ERDF will employ run-on and run-off control systems. Inspection details for these systems will be provided before waste acceptance at the ERDF. The following is a brief discussion of the run-on and run-off system.

The ERDF site will be located on semiarid land typical of the Hanford Facility. The natural downward slope is from northeast to southwest. The ERDF will be near the top of a plateau and is not located in any river or stream floodplain. The ERDF site will be graded to keep all offsite storm water and snow melt from entering the site. All potentially contaminated storm water and snow melt will be contained and sampled to determine if treatment is needed. If treatment is not needed, the water will be released.

The storm water run-off from clean areas of the ERDF will be collected and routed through ditches to a lined detention storage pond. The clean areas include the areas north of the south railroad track and clean areas within the ERDF, including portions of the ERDF trench that have been filled and closed with an interim cover. This water will be metered and discharged to an existing drainage channel in a controlled manner.

Portions of the storm water run-off also might need to be treated. The storm water run-off from potentially contaminated areas will be collected separately and routed to separate tanks for detention. The potentially contaminated areas include the container transfer areas, container decontamination buildings, waste haul routes, and parking areas located between the rail lead track and the trench. Potentially contaminated run-off will be minimized. This water will be sampled and uncontaminated drainage will be released to natural drainage areas near the southwest side of the trench. If the sampling indicates that treatment is needed, the water will be pumped to either the waste water treatment plant, the subsidence control plant, or into tankers for offsite treatment. However, it is not anticipated that this run-off will need treatment as it normally will not be contaminated.

6.2.2.8.2 Leak Detection System. A final design for the leak detection system has not been completed. The inspection details will be provided before initiation of waste acceptance at the ERDF. Conceptual design of the proposed system is described briefly in Section 6.2.2.8.4 and in further detait in Chapter 4.0 . 
DOE/RL-94-40, Rev. 0

$06 / 94$

1 6.2.2.8.3 Wind Dispersal Control system. The wind dispersal control 2 system currently is being developed. The inspection details for this system 3 will be provided before initiation of waste acceptance at the ERDF. The Dust 4 Suppressant Pilot Study for the Environmental Restoration Disposal Facility 5 (DOE-RL 1994b) identifies potential dust control agents that could be applied 6 to waste soils managed in the ERDF. The study includes benchscale wind tunnel 7 tests using various dust suppressants and methods of application under a 8 variety of meteorological conditions. The results of the study indicate that 9 calcium lignosulfonate, acrylic emulsion, and possibly magnesium chloride potentially may be effective low-cost products for use on the nontraffic areas of the ERDF. The results of the study should be considered a screening evaluation to identify the most promising dust suppressant for initial use at the ERDF. The final choice of dust suppressant will occur during definitive design.

6.2.2.8.4 Leachate Collection and Removal System. A final design for the leachate collection and removal system has not been completed. The system design will be provided before waste acceptance at the ERDF. The leachate collection sumps will be inspected weekly, and the entire leachate collection system inspected monthly. Conceptual design of the proposed system is described briefiy in the following and in Chapter 4.0.

The ERDF trench will employ a double-liner system as mandated by the Tri-Party Agreement. From the bottom up, the 1 iner system components will consist of: (1) a low-permeability bentonite-soil mixture; (2) HDPE geomembrane; (3) on the side-slopes, a geocomposite leak detection layer consisting of a nonwoven geotextile thermally bonded to each side of an HDPE geonet; (4) on the floor of the trench, a gravel leak detection layer; (5) a primary HDPE geomembrane similar to the secondary liner; (6) on the sideslopes, a geocomposite drainage layer for leachate collection similar to the leak detection layer; (7) on the floor of the trench, a gravel layer for leachate collection (pipes could be included in this layer if high flow capacity is required); and (8) a 0.9 -meter- (3-foot-) thick operations layer to prevent mechanical and frost damage to the liner system.

The ERDF trench floor will be divided into 152 meter (500 foot) square leachate collection cells. The liner system in each leachate collection cell will slope to a sump area at the toe of the side slope. There will be two separate sumps. The first sump will be located above the primary liner to collect leachate. The second sump will be located between the two liners to provide leak detection. The sumps will be physically and hydraulically isolated from each other.

Riser pipes will lead from each sump up the side slope of the trench. Submersible pumps will be lowered into position in each sump through the riser pipes. The pumps will discharge into a gravity-drained pipe that will flow to the leachate storage area. Gravity drainage will be reliable and will minimize the possibility of leachate flowing back into the trench. Leachate levels in the sumps will be monitored and used to control the pumps. Each leachate collection area will have an independent control system located at the top of the side slope. 
Gravity piping will convey the leachate to three storage tanks located near the southwest corner of the trench. The tanks will be the same type as used for the decontamination waste water. Each tank will have the capacity to store 1,500 cubic meters $(400,000$ gallons) of leachate. The tanks will be sized so that two tanks can be used to facilitate cleaning and maintenance. The third tank will be a spare.

\subsection{WAIVER OR DOCUMENTATION OF PREPAREDNESS AND PREVENTION REQUIREMENTS}

The following sections document the preparedness and prevention measures taken at the ERDF. No waiver is requested.

\subsubsection{Equipment Requirements}

The following sections describe the internal and external communications and emergency equipment at the ERDF that also will be used, as appropriate, at the ERDF.

6.3.1.1 Internal Communication. The ERDF will use a combination of telephone communications, radio communications, computer [Hanford Local Area Network, (HLAN)], and alarm systems (audible throughout the ERDF) to provide immediate emergency instruction to personnel. Buildings will have telephones and public address systems. Personnel at the ERDF will use hand-held or vehicle two-way radios during work assignments to maintain internal communications with shift supervisors located nearby in the operations support buildings. The public address system will be equipped with external speakers to provide communications to areas directly adjacent to the buildings. An emergency fire alarm system will be installed in each building at the ERDF. This system will consist of a fire alarm control panel with standby battery power and auxiliary relays to activate radio fire al arm signals to the 200 Areas Hanford Fire
Department. Each building fire suppression system will operate individually.

6.3.1.2 External Communications. Buth the telephone system and the radio system described previously can be used by ERDF personnel to summon emergency assistance. All ERDF personnel will have immediate access to either a telephone or a two-way radio. External communications will be provided through a telephone system to be installed in the operations buildings at the ERDF. Hanford Facility emergency telephone number (911) is dialed if assistance is needed in the field.

6.3.1.3 Emergency Equipment. Emergency equipment will be available for use at the ERDF. The Hanford Facility maintains a sufficient inventory of heavy equipment. The Hanford Facility relies primarily on the Hanford Fire Department to control fires. The Hanford Fire Department is capable of providing rapid response (less than 10 minutes) to fires at the ERDF. Portable fire extinguishers will be provided on motorized equipment and vehicles. Personnel will be trained in the use of emergency equipment (Chapter 8.0 addresses training information). 
DOE/RL-94-40, Rev. 0

$06 / 94$

6.3.1.4 Water for Fire Control. Buildings will have fire sprinklers connected to a raw water supply system. Water for fire control in other areas of the ERDF, including the ERDF trench, will be supplied by the main raw water line connected to adequately spaced fire hydrants located near the operations and decontamination buildings. The hydrants will be capable of providing water at a rate of 3,800 liters ( 1,000 gallons) per minute.

Hanford Fire Department fire trucks also could supply water for fires requiring high water volume and pressure. Water could be supplied by the following equipment.

- Each fire station normally has a truck equipped with a hydraulically operated aerial ladder, and one pumper (backup fire engine, without a boom, that is used if the aerial ladder is inoperable). Fire engines have a pumping capacity of at least 5,700 liters $(1,500$ gallon:) of water per minute.

- Other fire protection equipmeni uses chemicals rather than water as an extinguishing media.

\subsubsection{Access Requirements}

Access roads to and within the ERDF will be of adequate width and surfacing to allow the unobstructed movement of personnel, fire protection equipment, or spill control equipment to any area of operation in an emergency. Buildings will be adequately separated from each other to allow movement of personnel and equipment to al1 areas of the ERDF. Sufficient space will be maintained in around the unloading areas and active areas of the ERDF, including the ERDF trench, to allow for unobstructed movement of emergency equipment in the event of an emergency incident.

\subsection{PREVENTIVE PROCEDURES, STRUCTURES, AND EQUIPMENT}

The following sections describe preventive procedures, structures, and equipment.

\subsubsection{Unloading Operations}

Waste is expected to arrive at the ERDF in both single-use and reusable containers. These containers will arrive at the railhead on either railcars or remediation site tractor/trailers. Once at the ERDF, the containers will be loaded, using wheeled container handlers, onto ERDF-dedicated tractor/ trailers. The waste will be transported to the ERDF trench over dedicated haul roads. Reusable containers, which will contain bulk waste, will be emptied using the trailer tippers. Bul' materials will be dumped, spread, and compacted. Once empty, the reusable waste containers will be delivered to the decontamination building for decontamination, placed back on the railcar or remediation site tractor/trailer, and returned to the remediation site. 
other forms of waste, such as single-use/disposable containers, will be placed on the trench floor or the top of the first waste lift. Irregularly shaped objects such as demolition debris will undergo subsidence control, if required, to fill voids that would otherwise cause excessive settlement. During waste placement, dust will be controlled by the use of clean soil covers, dust suppressants, sprays on dumping equipment, or similar measures.

The ERDF trench will be filled from west to east. Waste will be placed in two levels, each 11 meters ( 35 feet) high. The top of each bench will be covered with a layer of clean soil to provide a traffic surface and prevent contaminated dust emissions. The upper surface of the waste and overlying interim cover will be sloped at 2 percent as required for drainage to perimeter ditches. A final interim cover that includes a low-permeability layer will be emplaced annually.

\subsubsection{Run-0ff}

Run-on and run-off controls are discussed in Section 6.2.2.8.1.

\subsubsection{Water Supp?ies}

Precautions will be taken at the ERDF to ensure that contamination of groundwater at the ERDF is prevented. These precautions include the following: (1) placement of an interim cover on completed portions of the trench; (2) placement of a low-permeability final cover on the completed ERDF trench; and (3) operation of a decontamination and waste water treatment system. The design and operation of the ERDF is intended to minimize the generation of potentially contaminated leachate and to prevent its migration into groundwater resources in the local area. Operations described in Chapter 4.0 are designed to protect local water supplies while site conditions (Chapters 5.0 and 15.0 ) al so will mitigate contaminant migration through surface water and groundwater.

\subsubsection{Equipment and Power Failure}

Loss of electrical power to the operations building will not have any significant effect on operations, particularly those at the ERDF. Loss of electrical power to the container decontamination building would result in an operations slowdown or stoppage but would not present a safety problem. A $500 \mathrm{kV}$ emergency backup diesel generator will be available to provide backup power to the operations building ventilation system and other critical items. Backup, spare units will be available for failed mechanized equipment.

\subsubsection{Personnel Protection Equipment}

As a minimum, all personnel may be required to wear radiation protection coveralls, gloves, and a cloth cap when working at the ERDF trench. Air monitoring will be performed with constant air monitors and grab samplers. 
1 In addition, various types of respiratory devices will be available if

2 required. Personnel will be directed to use a particular type of respiratory

3 device, depending on the specific respiratory hazard that exists. Areas that

4 require respiratory protective equipment will be designated by barriers and 5 signs, and access will be controlled.

Available respiratory protection equipment will include the following:

- Airpacks

- Filter masks with a graphite filter (for removing particulates from the respiratory stream)

- Face masks with cartridges that react with various chemical fumes (used in special circumstances)

- Full-face masks, with hoses attached to a class D air supply, also will be available when needed.

The use of all respirators will be in compliance with the must recent version of the Industrial Safety Manual, Volume 3, Respirator Manual (WHC 1991c) or an equivalent onsite procedure. Adherence to this manual ensures compliance with all applicable federal, state, and DOE regulations.

\subsection{PREVENTION OF REACTION OF IGNITABLE, REACTIVE, AND INCOMPATIBLE WASTE}

The following section describes prevention of reaction of ignitable, reactive, and incompatible waste.

\subsubsection{Precautions to Prevent Ignition or Reaction of Ignitable or Reactive Waste}

Ignitable and reactive waste will not be accepted for placement in the ERDF trench. Chapter 3.0 describes in detail the types of waste that can be placed into the ERDF and waste acceptance criteria for the ERDF.

\subsubsection{General Precautions for Handling Ignitable or Reactive Waste and Mixing of Incompatible Waste}

Ignitable, reactive, or incompatible waste will not be accepted for placement in the ERDF trench, except as detailed in Chapters 3.0 and 4.0 . Chapter 3.0 describes in detail the types of waste that can be placed into the ERDF. 
DOE/RL-94-40, Rev. 0

$06 / 94$

This page intentionally left blank. 
Table 6-1. Chapter 6.0 Cross-Reference Table.

([ ] - Denotes location of information in Ecology Part B checklist)

\begin{tabular}{|c|c|c|c|}
\hline ERDF out line chapter & $\begin{array}{l}\text { Specifically required } \\
\text { by CAMU regulation? }\end{array}$ & $\begin{array}{c}\text { Washington State } \\
\text { CAMU Regulations** } \\
173-303 \\
\end{array}$ & $\begin{array}{l}\text { Federal } \\
\text { CAMU regulations } \\
40 \text { CFR }\end{array}$ \\
\hline \multicolumn{4}{|c|}{ 6.0 Procedures to Prevent Hazards [F] } \\
\hline $\begin{array}{l}6.1 \text { Security [F-1] } \\
\text { WAC } 173-303-806(4)(a)(\text { iv) } \\
\text { WAC } 173-303-310 \\
40 \text { CFR } 270.14(b)(4) \\
40 \text { CFR } 264.14\end{array}$ & $\begin{array}{l}\text { No--information is } \\
\text { provided in support os } \\
\text { CAMU criteria }\end{array}$ & $646(5)(a)(i)$ and $(i i)$ & $\begin{array}{l}264.552(c)(1) \\
\text { CAMU Criteria } 1 \text { \& } 2\end{array}$ \\
\hline $\begin{array}{l}6.2 \text { Inspection Schedule [F-2] } \\
\text { WAC } 173-303-806(4)(a)(v) \\
\text { WAC } 173-303-320 \\
\text { WAC } 173-303-665(4)(b) \\
40 \text { CFR } 264.15 \\
40 \text { CFR } 270.14(b)(5) \\
40 \text { CFR } 264.303(b) \\
\end{array}$ & $\begin{array}{l}\text { No-- information is } \\
\text { provided in support of } \\
\text { CAMU criteria }\end{array}$ & $646(5)(a)(i)$ and $(i i)$ & 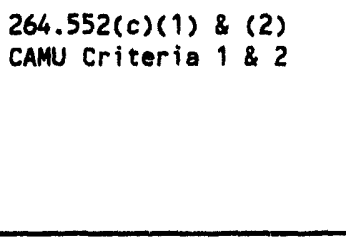 \\
\hline $\begin{array}{l}\text { 6.3 Waiver or Documentation of } \\
\text { Preparedness and Prevention } \\
\text { Requirements [F-3] } \\
\text { WAC } 173-303-806(4)(a)(v i) \\
\text { WAC } 173-303-340(1)(a)-(d) \\
40 \text { CFR } 270.14(b) \\
40 \text { CFR } 264.30-35 \\
\end{array}$ & $\begin{array}{l}\text { No--information is } \\
\text { provided in support of } \\
\text { CAMU criteria }\end{array}$ & $646(5)(a)(i)$ and $(i i)$ & 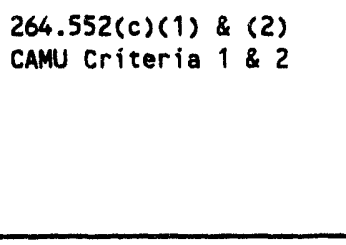 \\
\hline $\begin{array}{l}6.4 \text { Preventive Procedures, } \\
\text { Structures and Equipment [f-4] } \\
\text { WAC } 173-303-806(4)(\mathrm{a})(\mathrm{vi} i \mathrm{i}) \\
\text { (A)-(E) } \\
40 \text { CFR } 270.14(\mathrm{~b}) \text { (8) }\end{array}$ & $\begin{array}{l}\text { No--information is } \\
\text { provided in support of } \\
\text { CAMU criteria }\end{array}$ & $646(5)(a)(i)$ and $(i i)$ & $\begin{array}{lll}264.552(c)(1) & \& & (2) \\
\text { CAMU Criteria } & 1 \& 2\end{array}$ \\
\hline $\begin{array}{l}\text { 6.5 Prevention of Reaction of } \\
\text { Ignitable, Reactive and } \\
\text { Incompatible Waste (F-5] } \\
\text { WAC } 173-303-806(4)(a)(\text { iv) } \\
\text { WAC } 173-303-395(1)(a)-(c) \\
40 \text { CFR } 270.14(b)(9) \\
40 \text { CFR } 264.17(a)-(b) \\
40 \text { CFR } 264.176-177 \\
40 \text { CFR } 264.198-199 \\
40 \text { CFR } 264.229-230 \\
40 \text { CFR } 264.281-282 \\
40 \text { CFR } 264.312-313 \\
\end{array}$ & $\begin{array}{l}\text { No-- information is } \\
\text { provided in support of } \\
\text { CAMU criteria }\end{array}$ & $646(5)(a)(i)$ and $(i i)$ & $\begin{array}{l}264.552(c)(1) \&(2) \\
\text { CAMU Criteria } 1 \& \& 2\end{array}$ \\
\hline
\end{tabular}

* The sections of this application are based on the Ecology Part B Checklist. The referenced regulations, both state (WAC 173-303) and federal (40 CFR 260-270), provide the specific requirements that typically are incorporated in these sections.

** Assumes that Washington State has received HSWA authority. 
Table 6-2. Inspection Schedule for the Environmental Restoration Disposal Facility. (sheet 1 of 2)

\begin{tabular}{|c|c|c|}
\hline Frequency & Item & Types of problems \\
\hline Each workday & $\begin{array}{l}\text { Waste loading/unloading } \\
\text { areas }\end{array}$ & $\begin{array}{l}\text { Check for spills, debris; } \\
\text { check for accessibility, } \\
\text { obstructions }\end{array}$ \\
\hline Each workday & $\begin{array}{l}\text { Fences, gates, locks, } \\
\text { barrier separating } \\
\text { construction areas from } \\
\text { waste management areas }\end{array}$ & $\begin{array}{l}\text { Check for unsecured gates, } \\
\text { fences, locks; missing } \\
\text { damaged operational area } \\
\text { barrier }\end{array}$ \\
\hline Each workday & $\begin{array}{l}\text { Daily top of trench } \\
\text { cover }\end{array}$ & $\begin{array}{l}\text { Check that clean } \\
\text { operational material } \\
\text { covers waste at end of } \\
\text { each day }\end{array}$ \\
\hline Each workday & Working face of trench & $\begin{array}{l}\text { Check that the waste } \\
\text { placed in trench is coated } \\
\text { with dust suppressant or } \\
\text { covered with clean soil at } \\
\text { the end of each day }\end{array}$ \\
\hline Each workday & $\begin{array}{l}\text { Internal/external } \\
\text { communications devices } \\
\text { (telephones, public } \\
\text { address, and 2-way } \\
\text { radios) }\end{array}$ & $\begin{array}{l}\text { Check that systems are } \\
\text { operational }\end{array}$ \\
\hline Weekly & Fences, gates, locks & $\begin{array}{l}\text { Check for corrosion, } \\
\text { damage }\end{array}$ \\
\hline Weekly & Warning signs & $\begin{array}{l}\text { Check for damage, } \\
\text { illegibility, absence of } \\
\text { signs }\end{array}$ \\
\hline $\begin{array}{l}\text { Weekly and after } \\
\text { storms }\end{array}$ & $\begin{array}{l}\text { Run-on/run-off control } \\
\text { deterioration, damage }\end{array}$ & $\begin{array}{l}\text { Check for sediment } \\
\text { clogging, check system for } \\
\text { potential malfunctions, } \\
\text { erosion }\end{array}$ \\
\hline $\begin{array}{l}\text { Week } 7 y \text { and after } \\
\text { storms }\end{array}$ & $\begin{array}{l}\text { Leachate collection and } \\
\text { leak detection systems }\end{array}$ & $\begin{array}{l}\text { Check that systems are } \\
\text { operational and have not } \\
\text { been tampered with; check } \\
\text { for signs of overfiow at } \\
\text { leachate collection tanks; } \\
\text { check for the accumulation } \\
\text { of leachate in the sumps }\end{array}$ \\
\hline $\begin{array}{l}\text { Weekly and after } \\
\text { storms }\end{array}$ & ERDF trench & $\begin{array}{l}\text { Check for signs of } \\
\text { erosion, settling, or } \\
\text { subsidence }\end{array}$ \\
\hline
\end{tabular}


Table 6-2. Inspection Schedule for the Environmental Restoration Disposal Facility. (sheet 2 of 2)

\begin{tabular}{|c|c|c|}
\hline Frequency & Item & Types of problems \\
\hline Weekly & $\begin{array}{l}\text { Waste haul roads in ERDF } \\
\text { area }\end{array}$ & $\begin{array}{l}\text { Check for soft spots, } \\
\text { ruts, erosion, waste or } \\
\text { debris in road }\end{array}$ \\
\hline Weekly & $\begin{array}{l}\text { Portable lighting at } \\
\text { ERDF and in trench }\end{array}$ & $\begin{array}{l}\text { Check that lighting is } \\
\text { operational }\end{array}$ \\
\hline Weekly & $\begin{array}{l}\text { Container-handling } \\
\text { devices (wheeled } \\
\text { handlers, trailer } \\
\text { tippers) }\end{array}$ & $\begin{array}{l}\text { Check that equipment is } \\
\text { operational and undamaged }\end{array}$ \\
\hline Weekly & $\begin{array}{l}\text { HEPA filters in heavy } \\
\text { equipment used in trench }\end{array}$ & $\begin{array}{l}\text { Check that filters are } \\
\text { operational, and not } \\
\text { clogged or spent }\end{array}$ \\
\hline Weekly & $\begin{array}{l}\text { Fire extinguishers } \\
\text { (operat ions building and } \\
\text { trench heavy equipment) }\end{array}$ & $\begin{array}{l}\text { Check that fire } \\
\text { ext inguishers are charged } \\
\text { and undamaged }\end{array}$ \\
\hline Weekly & Fire alarm system & $\begin{array}{l}\text { Check that system is } \\
\text { operational and battery } \\
\text { backup at ERDF is provided }\end{array}$ \\
\hline Weekly & $\begin{array}{l}\text { Respiratory protection } \\
\text { equipment }\end{array}$ & $\begin{array}{l}\text { Check for damage or } \\
\text { inadequate supplies }\end{array}$ \\
\hline Monthly & $\begin{array}{l}\text { Leachate collection } \\
\text { system }\end{array}$ & $\begin{array}{l}\text { Check for integrity and } \\
\text { functionality }\end{array}$ \\
\hline
\end{tabular}




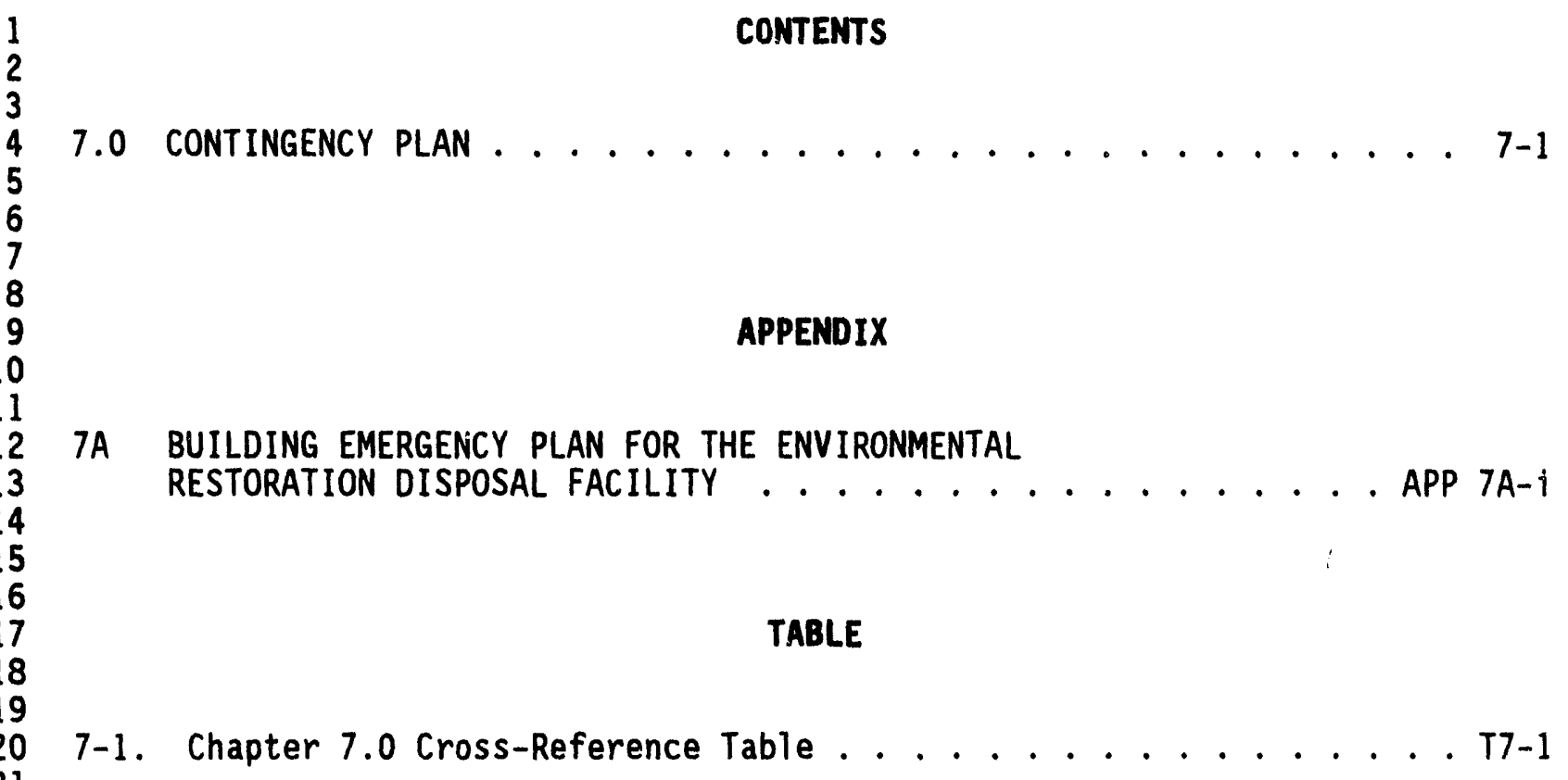

APPENDIX

\section{TABLE}

7-1. Chapter 7.0 Cross-Reference Table . . . . . . . . . . . T7-1

21 


$$
\text { DOE/RL-94-40, Rev. } 0
$$

\section{7.e CONTINGENCY PLAN}

Once incorporated via permit modification or order, the ERDF will operate under the Hanford Facility Contingency Plan (DOE-RL 1993g). Also, a ERDF

Building Emergency Plan will apply to operation of the ERDF and is indicated

in Appendix 7A. The provisions of these plans will be carried out immediately

8 whenever there is a fire, explosion or release of hazardous waste or hazardous

9 waste constituents from the ERDF that could threaten human health or the

10 environment. The plans will be implemented as described in Appendix $7 A$.

11 Table $7-1$ is a regulatory cross-reference table.

12 
DOE/RL-94-40, Rev. 0

$06 / 94$

1
2
3
4
5

This page intentionally left blank. 
Table 7-1. Chapter 7.0 Cross-Reference Table.

([ ] - Denotes location of information in Ecology Part B checklist)

\begin{tabular}{|c|c|c|c|}
\hline ERDF outl ine chapter* & $\begin{array}{l}\text { Specif ically required } \\
\text { by cam regulation? }\end{array}$ & $\begin{array}{c}\text { Washington State } \\
\text { CAMU Regulations** } \\
173-303 \\
\end{array}$ & $\begin{array}{c}\text { Federal } \\
\text { CAMU regulations } \\
40 \text { CFR } \\
\end{array}$ \\
\hline $\begin{array}{l}7.0 \text { Contingency Plan } \\
\text { WAC } 173-303-806(4)(a) \\
\text { WAC } 173-303-350(2)(3)(4)(5) \\
\text { WAC } 173-303-340(4) \\
\text { WAC } 173-303-360(1)(2) \\
40 \text { CFR } 270.14(b)(7) \\
40 \text { CFR } 264.50-40 \text { CFR } 264.56 \\
40 \text { CFR } 264.37\end{array}$ & $\begin{array}{l}\text { No-- information is } \\
\text { provided in support of } \\
\text { CANU criteria } \\
\text { (Refer to Appendix 7A) }\end{array}$ & $646(5)(a)(i)$ and (ii) & $\begin{array}{rlll}264.552(c) & (1) & \& & (2) \\
\text { CAMU Criteria } & 1 & \&\end{array}$ \\
\hline
\end{tabular}

- The sections of this application are based on the Ecology Part B Checklist. The referenced regulations, both state (WAC 173-303) and federal (40 CFR 260-270), provide the specific requirements that typically are incorporated in these sections.

** Assumes that Washington State has received HSWA authority. 
DOE/RL-94-40, Rev. 0

06/94

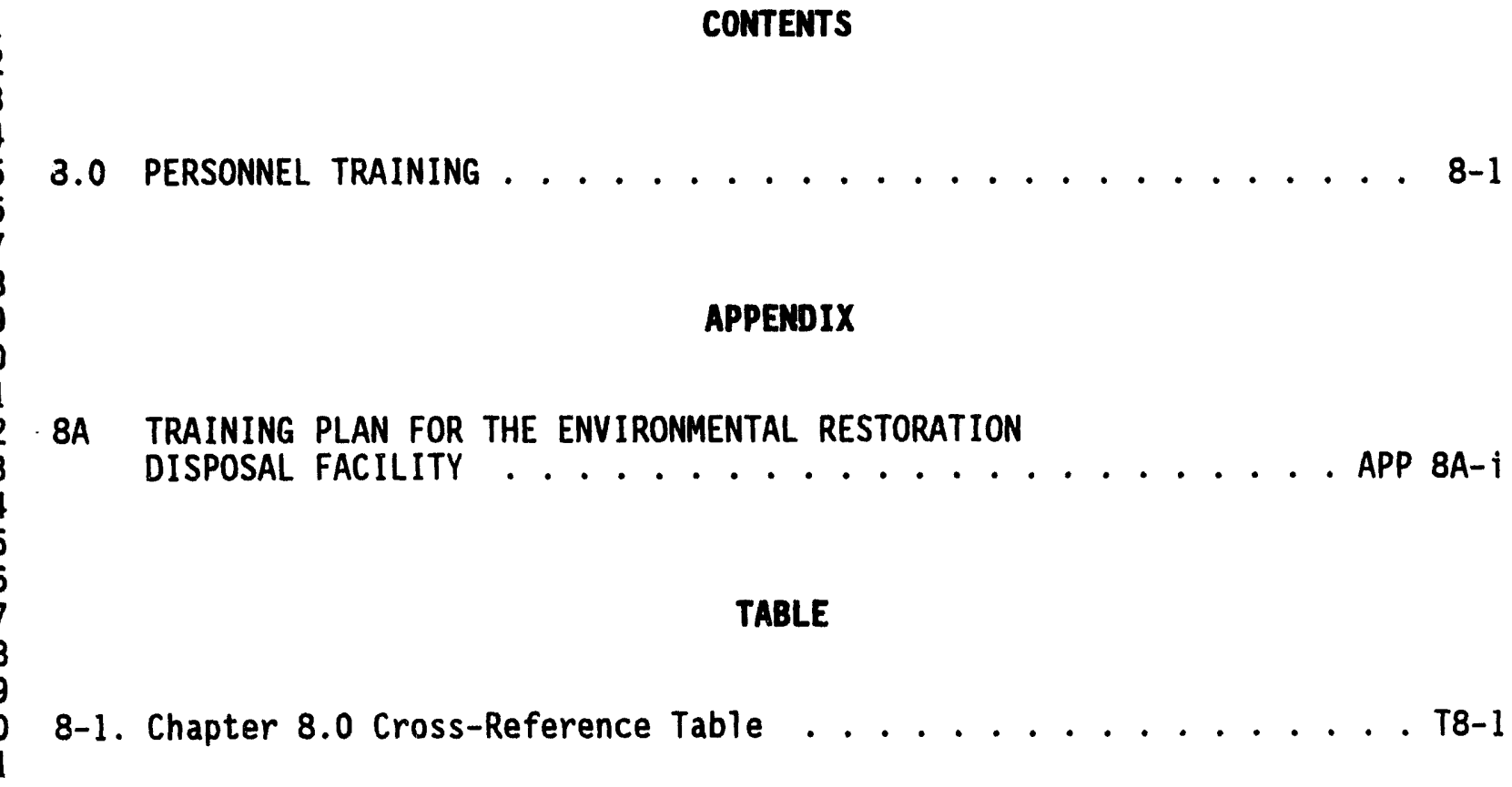




$$
\text { DOE/RL-94-40, Rev, } 0
$$

06/94

This page intentionally left blank. 


\subsection{PERSONNEL TRAINING}

Appendix $8 \mathrm{~A}$ outlines the training program that has been developed for the Solid Waste Disposal Division (SWDD) waste management units, which will be implemented for the ERDF. The ERDF will not be a RCRA TSD unit, but is defined as a RCRA CAMU. Though not explicitly required for a CAMU in 40 CFR 264.552, the SWDD training program developed for SWDD TSD units will be implemented for the ERDF because it supports the criteria determination and performance standards of a CAMU. Table $8-1$ is a regulatory cross-reference table.

The training program is designed to be compliant with all applicable federal, state, and the DOE-RL training requirements. The training program complies with requirements contained within WAC-173-303-330 and 40 CFR 265.16 for the development of a written dangerous waste training program.

The training program is designed to prepare employees to manage and maintain SWDD units in a safe, effective, efficient, and environmentaliy-sound manner. In addition to preparing employees to manage and maintain SWDD units under normal conditions, the training program ensures that employees are prepared to respond in a prompt and effective manner should off-normal or emergency conditions occur.

This training $p l a n$ in Appendix $8 A$ is divided into four sections. The first part describes the RCRA training program, while the second describes the non-RCRA programs which are closely related to the RCRA programs. The remaining sections provide additional information supplementing the RCRA requirements. All parts are included in Appendix $8 \mathrm{~A}$. Because Appendix $8 \mathrm{~A}$ is part of a separate training manual, the page numbering, referencing, etc. within the plan are not sequential. 
DOE/RL-94-40, Rev. 0

06/94

1
2
3
4
5

This page intentionally left blank. 
Table 8-1. Chapter 8.0 Cross-Reference Table.

([ ] - Denotes location of information in Ecology Part B checklist)

\begin{tabular}{|c|c|c|c|}
\hline ERDF out line chapter & $\begin{array}{l}\text { Specifically required } \\
\text { by cann regulation? }\end{array}$ & $\begin{array}{c}\text { Washington State } \\
\text { CAMU Regulations** } \\
173-303\end{array}$ & $\begin{array}{l}\text { Federal } \\
\text { CAMU regulations } \\
40 \text { CFR } \\
\end{array}$ \\
\hline $\begin{array}{l}8.0 \text { Personnel Training [H] } \\
\text { WAC 173-303-806(4)(a)(vi i) } \\
\text { WAC } 173-303-330(1)-(3) \\
40 \text { CFR } 270.14(b)(12) \\
40 \text { CFR } 264.16 \\
40 \text { CFR } 264.16(a)(1) \\
40 \text { CFR } 264.16(d)(1)-(4) \\
40 \text { CFR } 264.16(e)\end{array}$ & $\begin{array}{l}\text { No--information is } \\
\text { provided in support of } \\
\text { CAMU criteria } \\
\text { (Refor to Appendix } 8 A \text { ) }\end{array}$ & $646(5)(a)(i)$ and (ii) & $\begin{array}{l}264.552(c)(1) \&(2) \\
\text { CAMU Criteria } 1 \& 2\end{array}$ \\
\hline
\end{tabular}

* The sections of this application are based on the Ecology Part B Checklist. The referenced regulations, both state (WAC 173-303) and federal (40 CFR 260-270), provide the specific requirements that typically are incorporated in these sections.

** Assumes that Washington State has received HSWA authority. 
DOE/RL-94-40, Rev. 0 $06 / 94$

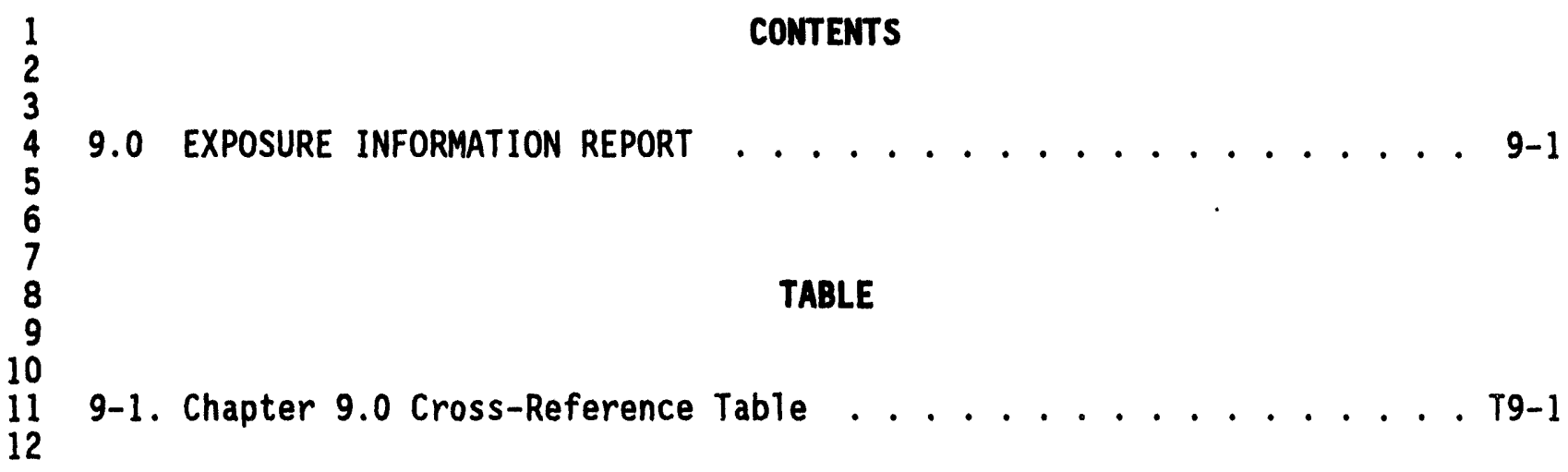


DOE/RL-94-40, Rev. 0

06/94

1
2
3
4
5

This page intentionally left blank. 
DOE/RL-94-40, Rev. 0

06/94

\subsection{EXPOSURE INFORMATION REPORT}

Under the WAC, the RCRA TSD units seeking to permit landfills or surface impoundments must provide exposure information "on the potential for the public to be exposed to hazardous waste or hazardous constituents through releases related to the unit" (Ecology et al. 1994). Specifically, information pertaining to potential releases, potential pathways, and the potential magnitude and nature of human exposure to sald releases must be addressed within Part B dangerous waste permit application documentation.

As a CAMU, the ERDF will not be a RCRA TSD unit, and therefore is not required to fulfill regulatory reporting requitrements to provide exposure information as stated in 40 CFR $270.10(j)$. However, CAMU decision criteria, presented in 40 CFR 264.552(c) and WAC 173-303-656(5)(a) and discussed in Chapter 15.0 of this CAMU appitication, states that "waste management activities associated with the CAMU shall not create unacceptable risks to humans or to the environment... (and) areas within the CAMU where waste remain in place after closure of the CAMU shall be managed and contained as to minimize future releases, to the extent practicable." To meet this criteria, the potential for releases/release pathways and potential human risk must be discussed, and in Chapter 15.0 of this application, CAMU evaluation criteria addresses these concerns. Table 9-1 is a regulatory cross-reference table. Exposure information for RCRA TSD units present within the boundary of the ERDF will be provided in separate documentation. 
DOE/RL-94-40, Rev. 0

06/94

1
2
3
4
5

This page intentionally left blank. 
Table 9-1. Chapter 9.0 Cross-Reference Table. ([ ] - Denotes location of information in Ecology Part B checklist)

\begin{tabular}{|c|c|c|c|}
\hline ERDF outline chepter" & $\begin{array}{l}\text { Spacifically required } \\
\text { by cainu requlation? }\end{array}$ & $\begin{array}{c}\text { Washington state } \\
\text { CANU Regulationa*t } \\
173-303\end{array}$ & $\begin{array}{l}\text { Foderal } \\
\text { CAN regulations } \\
40 \text { CFR } \\
\end{array}$ \\
\hline $\begin{array}{l}9.0 \text { Exposure Information Report } \\
\text { [Not in checkl ist] } \\
40 \mathrm{CFR} 270.10(\mathrm{j})\end{array}$ & Refor to Chepter is & $646(5)(a)(1)$ and $(1 i)$ & $\begin{array}{lll}264.552(c)(1) & (2) \\
\text { canim Criteria } 1: 2\end{array}$ \\
\hline
\end{tabular}

* The sections of this application are based on the Ecology Part B Checklist. The reforenced regulations, both state (WAC 173-303) and federal (40 CFR 260-270), provide the apacific requirements that typically are incorporated in these sections.

* Assumes that Washington State hes received HSWA authority. 


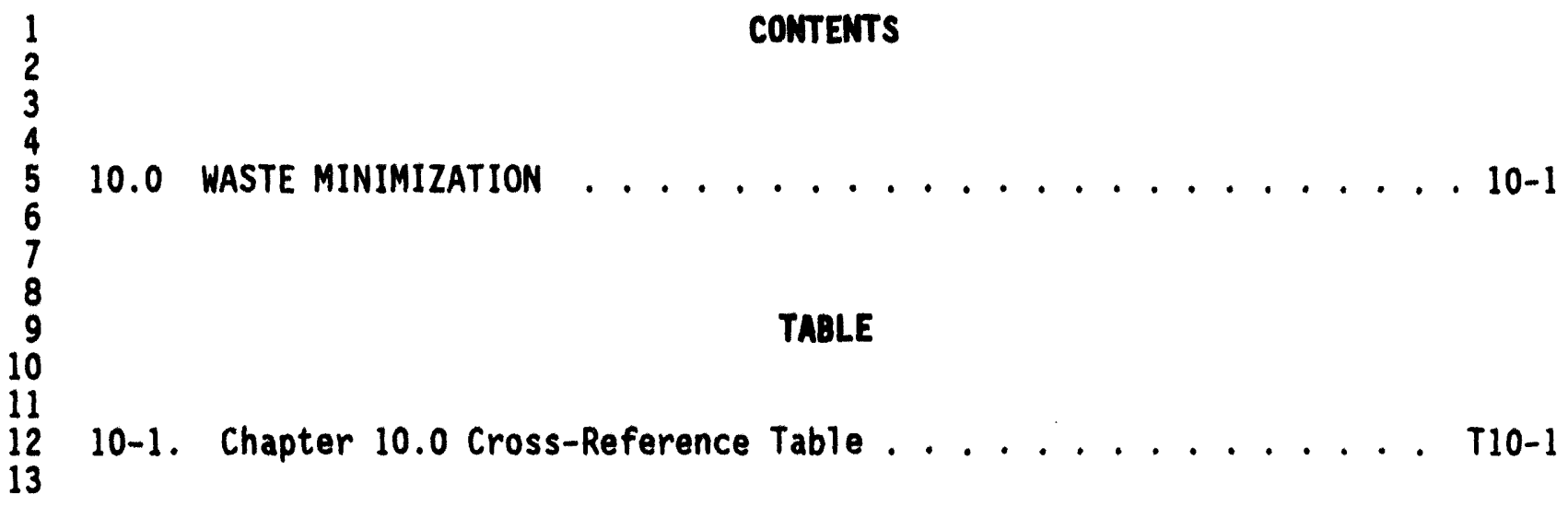


DOE/RL-94-40, Rev. 0

This page intentionally left blank. 
DOE/RL-94-40, Rev. 0

$06 / 94$

\subsection{WASTE MINIMIZATION}

Waste minimization is required for all RCRA TSD factlities, as defined in 40 CFR 264.73(a) and 264.73(b)(9). Because the ERDF CAMU will not be a RCRA TSD facllity, compliance with these requirements is not directly mandated for CAMUs. However, the concept of waste minimization is inherent in the CAMU regulations. The CAMU Decision Criteria No. 6 [40 CFR 264.552 (c)(6) and WAC 173-303-646(5)(a)(vi)] indicates that means should be taken to "reduce the ...volume... of wastes that remain in place after closure of the CAMU" indicating that volume reduction/minimization is a goal of CAMU operations. Specific waste management activities to this end are discussed in Chapter 4.0 of this CAMU application, while decision criteria pertaining to this requirement are discussed in Chapter 15.0, CAMU evaluation criteria.

Waste minimization will be implemented for ERDF support units, although these units are not included as part of the CAMU application. Requirements for these units will follow those outlined in 40 CFR 264.73(a) and $264.73(\mathrm{~b})(9)$ as necessary. 40 CFR 264.73(a) states that the "owner or operator must keep a written operating record at his facility." 40 CFR 264.73 (b)(9) states:

"a certification by the permittee no less often than annually, that the permittee has a program in place to reduce the volume and toxicity of hazardous waste that he generates to the degree determined by the permittee to be economically practicable; and the proposed method of treatment, storage, or disposal is that practicable method currently available to the permittee which minimizes the present and future threat to human health and the environment".

A certification that the ERDF support units have a waste minimization program in place will be entered, annually, into the ERDF operating record (Chapter 12.0). Table 10-1 is a regulatory cross-reference table. 
DOE/RL-94-40, Rev. 0

06/94

This page intentionally left blank. 
Table 10-1. Chapter 10.0 Cross-Reference Table.

([ ] - Denotes location of Information in WAC Part B checklist)

\begin{tabular}{|c|c|c|c|}
\hline ERDF outl ine Chapter & $\begin{array}{l}\text { Specifically Required } \\
\text { by CAMU Regulation? }\end{array}$ & $\begin{array}{c}\text { State of Washington } \\
\text { CAM Regulations } \\
173-303 \\
\end{array}$ & $\begin{array}{c}\text { Federal } \\
\text { CAMU Regulations } \\
40 \text { CFR } \\
\end{array}$ \\
\hline $\begin{array}{l}10.0 \text { Haste Minimization Plan } \\
\text { [Not in HaC checklist] } \\
40 \text { CFR } 264.73(b)(9)\end{array}$ & No & $N / A$ under 646 & N/A under 264.552 \\
\hline
\end{tabular}

* The sections of this application are besed on the WAL Part B Checklist. The referenced regulations, both state (LAC 173-303) and federal (40 CFR 260-270), provide the specific requirements that are typically incorporated in these sections.

* Assunes that the State of Washington has received HSWA authority. 

5 6

\section{CONTENTS}

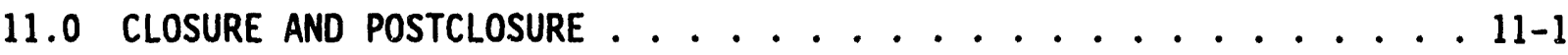

11.1 CLOSURE PLANS FOR CONTAINERS, TANK SYSTEMS, WASTE PILES, SURFACE IMPOUNDMENTS, INCINERATORS, LAND TREATMENT, LANDFILLS AND MISCELLANEOUS UNITS . . . . 11-2

11.2 POSTCLOSURE/CONTINGENT POSTCLOSURE PLANS FOR

TANK SYSTEMS, WASTE PILES, SURFACE IMPOUNDMENTS, LAND TREATMENT, LANDFILLS AND MISCELLANEOUS UNITS . . . . 11-2

11.3 NOTICES REQUIRED FOR DISPO AL FACILITIES ......... 11-3

11.4 CERTIFICATION OF COMPLETION OF POSTCLOSURE CARE . . . . . 11-3

11.5 ClOSURE COST ESTIMATE .............. . 11-3

11.6 FINANCIAL ASSURANCE MECHANISM FOR CLOSURE . . . . . . . 11-4

11.7 POSTClOSURE COST ESTIMATE . . . . . . . . . . 11-4

11.8 FINANCIAL ASSURANCE MECHANISM FOR POSTCLOSURE CARE . . . . 11-5

11.9 LIABILITY REQUIREMENTS ............... 11-5

11.10 CLOSURE PLAN FOR ENVIRONMENTAL RESTORATION DISPOSAL

FACILITY TRENCH ................. 11-5

11.10 .1 Closure Performance Standard . . . . . . . . .

11.10.1.1 Removal or Decontamination

Standard . . . . . . . . 11-8

11.10.1.2 Contaminant Transport Modeling

Results ......... 11-8

11.10.2 Partial Closure Activities ........... . 11-9

11.10 .3 Maximum Waste Inventory .......... 11-11

11.10.4 Inventory Remova1, Disposal or

Decontamination of Equipment, Structures

and Soils ................. 11-11

11.10.5 Procedures for Closing the Environmental

Restoration Disposal Facility Trench . . . . . 11-12

11.10.5.1 Disposal Impoundments ...... . 11-12

11.10.5.2 Environmental Restoration Disposal Facility Trench

Cover Design ....... . 11-12

11.10.5.3 Minimization of Liquid

Migration . . . ...... 11-19

11.10.5.4 Maintenance of Final Cover . . . . 11-19

11.10.5.5 Drainage and Erosion . . . . . . . 11-22

11.10.5.6 Settlement and Subsidence . . . . 11-24

11.10.5.7 Cover Permeability . . . . . . . 11-25

11.10 .5 .8 Freeze/Thaw Effects ....... 11-25 
11.10.6 Schedule for Closure ............ 11-26

11.10.6.1 Partial Closure .......... 11-26

11.10.6.2 Final Closure .......... . 11-26

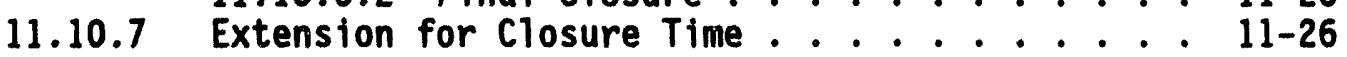

11.10 .8 Amendments to Closure Plan .......... 11-26

11.10.9 Certification of Closure ........... 11-27

11.10.10 Notice to Local Land Authority . . . . . . . . 11-27

11.11 POSTCLOSURE PLAN . . . . . . . . . . . . . . . 11-28

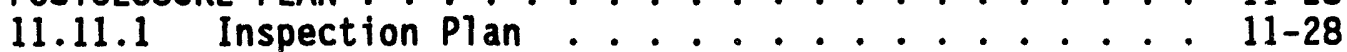

11.11.1.1 Security Control Devices . . . . . 11-28

11.11.1.2 Erosion Damage .. . . . . . . . 11-28

11.11.1.3 Cover Settlement, Subsidence,

and Displacement $\cdot$.

11.11.1.4 Vegetative Cover Condition ..... 11-29

11.11 .1 .5 Animal Activity ........ 11-29

11.11.1.6 Cover Drainage System Functioning - 11-29

11.11.1.7 Leachate Collection/Detection and

Removal System ......... 11-30

11.11.1.8 Monitoring Well Condition .... 11-30

11.11.1.9 Benchmark Integrity .. . . . . . 11-30

11.11.1.10 Inspection Training and Frequency . 11-30

11.11.2 Postclosure Monitoring Plans ......... . 11-30

11.11.2.1 Leachate Collection/Detection and Removal ........ 11-30

11.11.2.2 Groundwater Monitoring . . . . . . 11-30

11.11.3 Maintenance Plan .............. . 11-31

11.11.3.1 Security............. . 11-31

11.11.3.2 Erosion Damage ......... 11-31

11.11.3.3 Cover ........... . 11-32

11.11.3.4 Animal Activity ......... . 11-33

11.11.3.5 Cover Drainage System . . . . . 11-33

11.11.3.6 Leachate Collection/Detection

and Removal System ....... 11-33

11.11.3.7 Monitoring Wells ......... . 11-33

11.11 .4 Postclosure Contact ............ 11-34

11.12 ClOSURE AND POSTCLOSURE DOCUMENTATION . . . . . . . 11-34

\section{FIGURES}

\section{1-1. Cross-Sectional View of the Environmental Restoration}

Disposal Facility Final Cover

F11-1

11-2. Plan View of Environmental Restoration Disposal

Facility Showing Incremental Placement of Final Cover . . . . Fll-2 
1

TABLE

2

3

4 11-1. Chapter 11.0 Cross-Reference Table . . . . . . . . . . T11-1 5 


\section{DOE/RL-94-40, Rev. 0 \\ 06/94}

This page intentionally left blank. 
DOE/RL-94-40, Rev. 0

$06 / 94$

\subsection{CLOSURE AND POSTCLOSURE}

This chapter describes the planned activities and performance standards for the closure and postclosure of the ERDF trench. The plan demonstrates that the performance standards for CAMU closure and postclosure presented in 40 CFR 264.552 and WAC 173-303-646 will be met. Because there is no guidance for a CAMU closure and postclosure plan, the ERDF closure and postclosure plan has been formatted to assist reviewers who are familiar with the RCRA application format in locating specific types of information. However, it must be noted that under the 40 CFR 264.552 and WAC 173-303-646 CAMU regulations, the ERDF is not considered a land disposal unit or considered a unit subject to MTRs. As a result, the ERDF is not subject to the closure and postclosure requirements of 40 CFR 264 subpart G and WAC 173-303-806 (4)(a)(xiij) and 610 (Table 11-1). The closure and postclosure of the ERDF trench will meet the applicable requirements of TSCA (40 CFR 761) if remediation waste with PCB concentrations above 50 parts per milition are placed in the ERDF trench.

To demonstrate that the CAMU closure performance standards will be met, ERDF-specific plans must be developed. To demonstrate that the ERDF will meet the CAMU closure performance standards, this ERDF closure and postclosure plan has drawn upon the technical requirements for closure and postclosure of hazardous/dangerous waste land disposal units because these requirements represent a conservative approach to closure and postclosure.

Although a conservative final cover (equivalent to the current standard RCRA 1 and disposal unit final cover) has been proposed for the ERDF, it must be noted that research is being conducted to determine if there are alternate final cover designs that may be more appropriate for use on the Hanford Facility. A request to modify the final cover design may occur before final closure of the ERDF if an alternative design is developed that meets the CAMU closure performance standards, and the alternative design is reviewed and approved by the appropriate regulatory agencies.

This ERDF closure plan presents a preliminary design and construction plan for the ERDF trench final cover. Development of a detailed design for the ERDF trench final cover is scheduled to be completed at least 180 days before the planned start of construction of the final cover. A detailed engineering design report describing the final cover design and specifications will be prepared and submitted to the appropriate regulatory agencies for approval after the definitive design of the ERDF trench is complete.

The detailed final cover design will support the CAMU decision criteria by ensuring that the final cover meets the closure performance standards for a CAMU as presented in 40 CFR 264.552 and WAC 173-303-646. A detailed final cover installation plan and a CQA plan also will be prepared and submitted for regulatory review and approval at least 180 days before construction of the ERDF trench final cover.

This closure plan is based on information from the following sources: the conceptual design report (DOE-RL 1994a) and the LLBG dangerous waste permit application (DOE-RL 1989). The following EPA publications regarding 
DOE/RL-94-40, Rev. 0

$06 / 94$

design, construction, and closure of hazardous waste land disposal units also were used to create this plan: Design, Construction and Maintenance of Cover Systems for Hazardous Waste, An Engineering Guidance Document (EPA 1987a); Guide to Technical Resources for the Design of Land Disposal Facilities (EPA 1988); Requirements for Hazardous Waste Landfill Design, Construction and Closure (EPA 1989b); Quality Assurance and Quality Control For Waste Containment Facilities (EPA 1993); Design and Construction of RCRA/CERCLA Final Covers (EPA 1991a); and Construction Quality Assurance for Hazardous Waste Disposal Facilities (EPA 1986a).

\subsection{ClOSURE PLANS FOR CONTAINERS, TANK SYSTEMS, WASTE PILES, SURFACE IMPOUNDMENTS, INCINERATORS, LAND TREATMENT, LANDFILLS AND MISCELLANEOUS UNITS}

Under the 40 CFR 264.552 and WAC 173-303-646 CAMU regulations, specifically under the regulations defining the expanded CAMU concept [40 CFR 264.552(a) (1) and (2) and WAC 173-303-646(4)(b) and (c)], a CAMU is not considered a land disposal unit or considered a unit subject to the MTRs. Therefore, the specific requirements for closure plans for containers, tank systems, waste piles, surface impoundments, incinerators, land treatment, landfilis and miscelianeous units do not apply to closure of the ERDF trench. Instead, the ERDF trench will comply with the closure requirements of 40 CFR 264.552(e)(4) and WAC 173-303-646(5) (Section 11.10).

The nonland-based ERDF support units described in Chapter 4.0, Section 4.14, that are physically located within the proposed CAMU, will maintain their separate regulatory identity. Information regarding applicable permitting and closure requirements for these support units will be submitted to the appropriate regulatory authorities in a separate document $(s)$.

\subsection{POSTCLOSURE/CONTINGENT POSTCLOSURE PLANS FOR TANK SYSTEMS, WASTE PILES, SURFACE IMPOUNDMENTS, LAND TREATMENT, LANDFILLS AND MISCELLANEOUS UNITS}

Under the 40 CFR 264.552 and WAC 173-303-646 CAMU regulations, specifically under the regulations defining the expanded CAMU concept [40 CFR 264.552(a)(1) and (2) and WAC 173-303-646(4)(b) and (c)], a CAMU is not considered a land disposal unit or considered a unit subject to the MTRs. Therefore, the specific requirements for postclosure and contingent postclosure plans for landfills do not apply to postclosure of the ERDF trench. Instead, the ERDF trench will comply with the postclosure requirements of 40 CFR $264.552(\mathrm{e})(4)$ and WAC 173-303-646(5) (Section 11.10).

Again, the nonland-based ERDF support units described in Chapter 4.0, Section 4.14 , that are physically located within the proposed CAMU, will maintain their separate regulatory identity. Information regarding applicable permitting and postclosure requirements for these support units will be submitted to the appropriate regulatory authorities in a separate $\operatorname{document}(\mathrm{s})$, as necessary. 


$$
\text { DOE/RL-94-40, Rev. } 0
$$

06/94

1

\subsection{NOTICES REQUIRED FOR DISPOSAL FACILITIES}

Under the 40 CFR 264.552 and WAC 173-303-646 CAMU regulations, specifically under the regulations defining the expanded CAMU concept [40 CFR 264.552(a)(1) and (2) and WAC 173-303-646(4)(b) and (c)], a CAMU is not considered a land disposal unit or considered a unit subject to the MTRs. Therefore, the specific notification requirements for closure and postclosure of hazardous/dangerous waste disposal facilities do not apply to closure of the ERDF. Instead, the ERDF trench will comply with the closure and postclosure requirements of 40 CFR 264.552(e)(4) and WAC 173-303-646(5) as shown in Sections 11.10 and 11.11 of this document. Descriptions of the types of notices and certifications that will be submitted at the time of final closure of the ERDF trench are provided in Sections 11.10.9, 11.10.10, and 11.12 .

The nonland-based ERDF support units described in Chapter 4.0, Section 4.14, that are physically located within the proposed CAMU, will maintain their separate regulatory identity. Information regarding applicable permitting and closure notices for these support units will be submitted to the appropriate regulatory authorities in a separate document(s), as necessary.

\subsection{CERTIFICATION OF COMPLETION OF POSTCLOSURE CARE}

Under the 40 CFR 264.552 and WAC 173-303-646 CAMU regulations, specifically under the regulations defining the expanded CAMU concept [40 CFR 264.552(a) (1) and (2) and WAC 173-303-646(4)(b) and (c)], a CAMU is not considered a land disposal unit or considered a unit subject to the MTRs. Therefore, the specific requirements for postclosure certifications applicable to land disposal units do not apply to the ERDF trench. Instead, the ERDF trench will comply with the postclosure requirements of 40 CFR $264.552(e)(4)$ and WAC 173-303-646(5) as shown in Sections 11.10 and 11.11 of this document. Descriptions of the types of notices and certifications that will be submitted at the time of completion of postclosure activities at the ERDF are provided in Section 11.12.

The nonland-based ERDF support units described in Chapter 4.0, Section 4.14, that are physically located within the proposed CAMU, will maintain their separate regulatory identity. Information regarding applicable permitting and closure notices for these support units will be submitted to the appropriate regulatory authorities in a separate document $(s)$, as necessary.

\subsection{CLOSURE COST ESTIMATE}

Under the 40 CFR 264.552 and WAC 173-303-646 CAMU regulations, specifically under the regulations defining the expanded CAMU concept [40 CFR 264.552(a)(1) and (2) and WAC 173-303-646(4)(b) and (c)] a CAMU is not considered a land disposal unit or considered a unit subject to the MTRs. 
1 Therefore, the requirement for a closure cost estimate applicable to 1 and 2 disposal units does not apply to closure of the ERDF Trench. However, the 3 DOE-RL has agreed to provide projections of the anticipated cost for closure 4 of the ERDF on an annual basis in a separate report. Submittal of this report 5 to the appropriate regulatory authority will take place on October 30 of each 6 year, starting with the year after the issuance of the initial Hanford 7 Facility Permit.

The nonland-based ERDF support units described in Chapter 4.0, Section 4.14, that are physically located within the proposed CAMU, will maintain their separate regulatory identity. Information regarding applicable permitting and closure cost estimates requirements for these support units will be submitted to the appropriate regulatory authorities in a separate document(s), as necessary.

\subsection{FIMANCIAL ASSURANCE MECHANISM FOR CLOSURE}

Under the 40 CFR 264.552 and WAC 173-303-646 CAMU regulations, specifically under the regulations defining the expanded CAMU concept [40 CFR 264.552(a)(1) and (2) and WAC 173-303-646(4)(b) and (c)], a CAMU is not considered a land disposal unit or considered a unit subject to the MTRs. Therefore, the requirement for a financial assurance mechanism applicable to land disposal units for closure does not apply to closure of the ERDF trench.

The nonland-based ERDF support units described in Chapter 4.0, Section 4.14, that are physically located within the proposed CAMU, will maintain their separate regulatory identity. Information regarding applicable permitting and financial assurance requirements for these support units will be submitted to the appropriate regulatory authorities in a separate document(s), as necessary.

\subsection{POSTCLOSURE COST ESTIMATE}

Under the 40 CFR 264.552 and WAC 173-303-646 CAMU regulations, specifically under the regulations defining the expanded CAMU concept [40 CFR 264.552(a)(1) and (2) and WAC 173-303-646(4)(b) and (c)], a CAMU is not considered a land disposal unit or considered a unit subject to the MTRs. Therefore, the requirement for a postclosure cost estimate applicable to 1 and disposal units does not apply to the ERDF trench. However, the DOE-RL has agreed to provide projections of the anticipated cost for postclosure of the ERDF trench on an annual basis in a separate report. Submittal of this report to the appropriate regulatory agency will take place on October 30 of each year, starting with the year after the issuance of the initial Hanford Facility Permit.

The nonland-based ERDF support units described in Chapter 4.0, Section 4.14, that are physically located within the proposed CAMU, will maintain their separate regulatory identity. Information regarding applicable permitting and postclosure cost estimates requirements for these support units wi11 be submitted in a separate document(s), as necessary. 
DOE/RL-94-40, Rev. 0

$06 / 94$

\subsection{FIMANCIAL ASSURANCE MECHANISN FOR POSTCLOSURE CARE}

Under the 40 CFR 260.10 definitions and the 40 CFR 264.552 and

WAC 173-303-646 CAMU regulations, specifically under the regulations defining the expanded CAMU concept [ 40 CFR 264.552(a)(1) and (2) and

WAC 173-303-646(4)(b) and (c)], a CAMU is not considered a 1 and disposal unit or considered a unit subject to the MTRs. Therefore, the requirement for a financial assurance mechanism for postclosure care applicable to land disposal units does not apply to the ERDF trench.

The nonland-based ERDF support units described in Chapter 4.0, Section 4.14 , that are physically located with in the proposed CAMU, will maintain their separate regulatory identity. Information regarding applicable permitting and postclosure financial assurance requirements for these support units wili be submitted to the appropriate regulatory authorities in a separate document (s), as necessary.

\subsection{LIABILITY REQUIREMENTS}

Under the 40 CFR 260.10 definitions and the 40 CFR 264.552 and WAC 173-303-646 CAMU regulations, specifically under the regulations defining the expanded CAMU concept [ 40 CFR 264.552(a)(1) and (2) and WAC 173-303-646(4)(b) and (c) ], a CAMU is not considered a land disposal unit or considered a unit subject to the MTRs. Therefore, the liability requirements applicable to land disposal units do not apply to the ERDF trench.

The nonland-based ERDF support units described in Chapter 4.0, Section 4.14 , that are physically located within the proposed CAMU, will maintain their separate regulatory identity. Information regarding applicable permitting and liability requirements for these support units will be submitted to the appropriate regulatory authorities in a separate $\operatorname{document}(s)$, as necessary.

\subsection{CLOSURE PLAN FOR ENVIRONMENTAL RESTORATION DISPOSAL FACILITY TRENCH}

The ERDF will manage remediation waste that could contain both a hazardous/dangerous waste component and a radioactive component. This closure plan has been developed to close the ERDF trench in a manner that meets the 40 CFR 264.552(e)(4) and WAC 173-303-646(5) CAMU closure performance standards described in the following sections. Because the ERDF also will manage waste with a radioactive component, closure of the unit also will be responsive to directives of the DOE concerning radioactive waste, particularly applicable DOE Orders. The licensing requirements of the U.S. Nuclear Regulatory

Commission for land disposal of radioactive waste generally are not applicable to the activities. 
DOE/RL-94-40, Rev. 0

06/94

\subsubsection{Closure Performance Standard}

The 40 CFR 264.552(e)(4)(1) CAMU closure performance standards state that "Closure of Corrective Action Management Units shall:

- Minimize the need for further maintenance

- Control, minimize, or eliminate, to the extent necessary to protect human health and the environment, for areas where waste remain in place, postclosure escape of hazardous waste, hazardous constituents, leachate, contaminated run-off, or hazardous waste decomposition products to the ground, to surface waters, or to the atmosphere."

The WAC 173-303-646(5)(b)(iv) (closure) and 646(5)(d) (postclosure) of a CAMU include essentially the same performance standards for dangerous waste and dangerous waste components.

In addition, the final closure of the ERDF will meet the following waste management performance objectives of the DOE Order 5820.2A, Radioactive Waste Management:

- "Protect public health and safety in accordance with standards spectfied in applicable DOE Orders

- Ensure that the external effective equivalent dose is less than 25 millitrem per year to any member of the public from exposure to radioactive materlals that might be released from the waste into surface water, groundwater, soils, plants, and animals

- Ensure that the committed effective dose equivalents received by individuals who inadvertently might intrude into the facility after the loss of active institutional control (100 years) will not exceed 100 millitrem per year for continuous exposure and $500 \mathrm{~m} 111$ irem for a single acute exposure

- Protect groundwater resources, consistent with federal, state, and local requirements."

Final compliance with the DOE waste management performance objectives is not a requirement for this CAMU application and will not be demonstrated here. Compliance of the closure system presented in this application with the objectives of the radiological performance standards will be evaluated before construction of the final cover. If the proposed cover does not meet the objectives, an enhanced cover design will be developed and proposed in an amended closure plan that will be submitted to the appropriate regulatory authorities for review and approval.

It is the intent of this chapter to demonstrate that the CAMU closure performance standards will be met through the use of physical and institutional controls. The remediation waste remaining in the ERDF trench at closure will be isolated from precipitation, erosion, and human and animal intrusion through the use of a final cover, fencing, warning signs, 
DOE/RL-94-40, Rev. 0 $06 / 94$

1 survelllance, and maintenance. Because specific guldance is not available for 2 closure and postclosure of CAMUs, conservative designs (equivalent to the 3 current requirements for RCRA land disposal units) have been proposed for the 4 ERDF trench.

Because remediation waste to be placed in the ERDF trench will be generated over a relatively long period, the construction of the final cover may occur incrementally, rather than waiting until the entire trench is filled to place the final cover. As described in Section 11.10.2, the final cover may be constructed after a specified number of trench leachate collection cells are filled and graded. Incremental placement of the final cover will ensure ongoing protection of human heaith and the environment.

Although a conservative final cover (equivalent to the current standard RCRA land disposal unit final cover) has been proposed for the ERDF, it must be noted that research is being conducted to determine if there are alternate final cover designs that may be more appropriate for use on the Hanford Facility. A request to modify the final cover design may occur before final closure of the ERDF if an alternative design is developed that meets the CAMU closure performance standards, and the alternative design is reviewed and approved by the appropriate regulatory agencies.

Liquid migration through the final cover will be minimized by the use of a multilayer design (Figure 11-1). The lowest layer is a low-permeability layer consisting of a composite of a low-permeability soll layer in direct contact with a low-permeability geomembrane. The final cover will be designed to have a hydraulic conductivity of less than or equal to that of the trench itner system described in Chapter 4.0. The waste materials will be stabilized as required through compaction and void space filling to provide a stable foundation for the cover.

Prevention of liquid migration will be enhanced by the use of a high-permeability drainage layer above the geomembrane that will intercept infiltrated water and rapidly drain the water off of the cap. This will minimize the hydraulic head on the geomembrane and the time that infiltrated water is in contact with low-permeability layer. The drainage layer also is expected to serve as a partial capillary barrier under the arid conditions on the Hanford Facility. A geosynthetic or granular filter layer will be placed above the drainage layer to prevent clogging of the drainage layer by the overlying surface soil layer.

The upper/surface soil layer will consist of soil with sufficient thickness to afford frost protection and a grain size distribution that will enhance moisture retention in the shallow root zone of the perennial grasses where moisture will be available for evapotranspiration.

Maintenance needs will be minimized through the use of low-cover slope angles and shallow-rooted perennial grasses. The grasses are expected to reduce liquid migration through the final cover and help stabilize the slopes against erosion. A maximum siope of 3 percent will be used to ensure adequate ifquid run-off while minimizing surface erosion. The low-slope angles and 
DOE/RL-94-40, Rev. 0

$06 / 94$

1 revegetation also will minimize the visual impact of the final cover and 2 return the 1 and to the general appearance and use of the surrounding desert.

11.10.1.1 Removal or Decontamination Standard. At the time of final closure of the ERDF, decontamination of the equipment and structures used during the placement of waste in the ERDF trench will be performed following standard onsite procedures to ensure worker safety and prevent cross-contamination. The disposition of equipment and structures that cannot be decontaminated to Hanford Facility operational standards will depend on whether or not the material is determined to be remediation waste. If the material is designated as remediation waste, it will be placed within the ERDF trench. If the material is not remediation waste, the disposition of the material will be in accordance with appropriate regulatory requirements.

If areas of soil contamination are discovered during the closure of structures used during operation of the ERDF, the contaminated soil will be removed to cleanup levels that are calculated using residential exposure assumptions according to the Washington State Model Toxics Control Act of 1990 (WAC 173-340), or other approprlate levels available at the time of closure. The appropriate regulatory authority will be contacted to determine whether the contaminated soil can be designated as remediation waste. If the contaminated soil is considered remediation waste, the soil will be placed in the ERDF trench. If the soil is not remediation waste, the disposition of the soil will be in accordance with appropriate regulatory requirements in effect at the time of closure.

11.10.1.2 Contaminant Transport Modeling Results. Various cover and unit designs have been modeled to identify chemical and radiological contaminants at the ERDF that potentially might pose risk to human health and the environment. The modeling was conducted as part of the RI/FS for the ERDF (the relationship between RCRA and CERCLA at the ERDF is discussed in Chapter 1.0). One of the designs evaluated included the use of a RCRAcompliant double liner system as described in Chapter 4.0, and the use of a final cover that was very similar to design of the final cover proposed in this chapter. The final cover used in modeling that was most similar to the proposed final cover was called a 'modified RCRA barrier' in which a standard RCRA barrier was modified to suit the arid conditions on the Hanford Facility while maintaining the same overall low-hydraulic conductivity. The modifications include replacing the geomembrane portion of the low-permeability layer with an asphait layer. Other modifications included expansion of the typical single component drainage layer to a multiple layer drainage system designed to form a capillary break, and the use of an admixture of gravel in a silt matrix to form the top layer to maximize evapotranspiration and minimize infiltration in the Hanford Facility-specific climatic conditions.

The results of the modeling indicated that this combination exhibited 'high long-term performance' and that the design is highly protective of human heaith and the environment. The modeling results indicate that the use of a double-liner system and a modified RCRA final cover substantially will reduce the possibility that the waste or leachate will enter the soil column and 
1 groundwater. The RI/FS modeling also has shown that, given this design, the

2 potential for releases to occur that impact groundwater quality is minimal.

\subsubsection{Partial Closure Activities}

"Partial closure is defined in 40 CFR 260.10 and WAC 173-303-040 as closure of one (or more) units at a facility where other hazardous/dangerous waste management units will continue to operate." In this sense, partial closure of the ERDF will not occur, but when final closure of the ERDF trench occurs, it may constitute partial closure of the Hanford Facility because other hazardous/dangerous waste management units may remain open. Part of the filled trench will be covered perlodically with the final cover, but the ERDF trench will not be closed until completion of the corrective/remedial actions at the remediation sites that requi e the trench for placement of remediation waste. It must be pointed out that the RCRA-regulated support units may close before complete final closure of the ERDF trench. However, the discussion in this section focuses on closure of the ERDF trench within the context of closure of the Hanford Facility as a whole.

It is probable that the environmental restoration of the Hanford Facility remediation sites will take in excess of 20 years and it is planned that the ERDF trench will remain in operation during the entire remediation process. Current plans call for the final cover to be constructed on an incremental basis to ensure protection of human health and the environment by helping control, minimize, or eliminate the escape of hazardous/dangerous waste, hazardous/dangerous constituents, leachate, contaminated run-off, or hazardous/dangerous waste decomposition products prior to final closure of the ERDF.

Before the incremental placement of the final cover, a final interim cover will be placed on the ERDF trench to minimize the release of hazardous/dangerous waste or hazardous/dangerous constituents unt il the final cover is constructed. The final interim cover will consist of the interim cover combined with a low-permeability layer. As portions of the trench reach final capacity, the upper surface of the waste will be covered with an interim cover, that will be a 0.6-meter- (2-foot-) thick layer of clean native soil. This interim cover will prevent wind dispersion of the waste. Because of the rate of filling of the trench, it is expected that placement of the interim cover will be conducted on a nearly daily basis.

To further minimize erosion of the upper interim cover and help reduce leachate generation within the waste that has been placed in the trench, a low-permeability layer will be placed on top of the interim cover annualiy. The design of this low-permeability layer is discussed in Chapter 4.0, Sections 4.12.9.2, and Section 11.10.5.2.2.1. The combination of interim cover and the low-permeability layer constitutes the final interim cover, which must not be confused with the final cover discussed in the following and in Section 11.10.5.2.

The date of final closure of the ERDF trench cannot be stated because the total amount of remediation that will be required on the Hanford Facility has 
1 not been completely determined. However, the estimated date of final closure 2 of the ERDF trench is sometime after the year 2020. If, for unforeseen

3 reasons, authorization to continue operation until that time is not granted, final closure will occur earlier.

The maximum extent of operations that will be unclosed during the active life of the ERDF trench wil1 be an area approximately 433 meters $(1,420$ feet), which is the width of the trench, by 912 meters $(3,000$ feet) long.

The 433 meter by 912 meter area $(1,420$ feet by 3,000 feet) is the approximate area covered by 12 cells/individual leachate collection areas. Although the ERDF trench will be a single continuous trench, the floor of the trench will be divided into leachate collection cells that are approximately 152 meters (500 feet) square. The use of leachate collection cells is required to limit the amount of leachate resulting from precipitation events and allow the construction of the trench to be conducted in phases. Initially, a small number of cells will be excavated, lined, and filled. Additional cells will be excavated and lined as additional remediation waste is generated. The estimate of maximum extent of unclosed operations is based on having 10 leachate collection cells at final grade and ready to receive the final cover, with two leachate collection cells still open and receiving waste. Figure 11-2 shows the leachate collection cells and the incremental placement of the final cover.

The final cover will be constructed after 10 individual leachate collection cells of the trench have reached final grade and enough area of the next leachate collection cells have been filled to allow construction of the final cover to proceed without interfering with waste placement operations (refer to Figure 11-2). The 10 cell increment for construction of the final cover was chosen because this represents approximately one-third of the conceptual design length of the trench. This increment will allow for early protection of human health and the environment while having only three seam areas where older liner components must be joined to new components. The seams where previously installed liners meet new liner materials might provide potential weak zones in the final cover. A detailed final cover installation plan and a cover CQA plan will be prepared and will define the procedures required to connect the new final cover components to the existing final cover components without creating a weak zone in the liner. These plans will be submitted to the appropriate regulatory authorities for review and approval at least 180 days before construction of the ERDF trench final cover.

It is anticipated that the exposed edges of the incrementally constructed final cover will be covered with a protective soil layer, that also will create a berm to prevent run-off over the edge of the final cover.

The protective soil layer will be removed before adding a new section of final cover. The soil components of the cover could be joined by creating steps in the older portion of the cover material. The top of the steps can be roughened before placing and compacting the new cover soil material. Seams in the synthetic cover materials can be overlapped or seamed at varying intervals from the underlying seam locations to ensure that all of the synthetic material seams are not along one vertical plane.

51 


$$
\begin{array}{r}
\text { DOE/RL-94-40, Rev. } 0 \\
06 / 94
\end{array}
$$

\subsubsection{Maximum Waste Inventory}

The final total volume of waste to be placed in the ERDF trench cannot be determined precisely because the total volume of remediation waste that will be generated is not known. However, the ERDF trench has been designed to accept an estimated total maximum waste inventory of up to 21.4 million cubic meters ( 28 million cubic yards). It is anticipated the waste placed in the ERDF trench will be generated over a period in excess of 20 years. The anticipated maximum annual volume of waste to be placed in the ERDF is $1,758,500$ cubic meters $(2,300,000$ cubic yards) (DOE-RL 1994a). However, the annual waste volumes can be expected to vary significantly from this maximum quantity based on the extent of remediation activities in any given year.

\subsubsection{Inventory Removal, Disposal or Decontamination of Equipment, Structures and Soils}

Placement of waste in the ERDF trench will involve the use of structures and numerous pieces of equipment. At the time of closure, all equipment and structures used during operation and closure of the ERDF will be decontaminated to ensure that direct contact will not pose a threat to human health or the environment. Decontamination of equipment and structures will be conducted in accordance with standard Hanford Facility procedures. Routine decontamination generally will be accomplished by one of the following methods:

- Washing items in nonphosphate detergent and tap water

- Rinsing or washing down three times with tap water

- Wiping with nonflammable, nontoxic cleaning solution.

A decontamination building and an outdoor washpad will be used during operation of the ERDF (refer to Chapter 4.0, Section 4.14). It is anticipated that these structures will be available during closure of the ERDF.

The disposition of equipment and structures such as those associated with ERDF support units that cannot be decontaminated to Hanford Facility operational standards will depend on whether or not the material is determined to be remediation waste. If the material is designated as remediation waste, it will be placed within the ERDF trench. If the material is not remediation waste, the disposition of the will be in accordance with appropriate regulatory requirements.

The detailed procedures for confirming decontamination of the equipment and structures to Hanford Facility operational standards will be developed during preparation of the final trench cover installation plan. The detailed procedures will be provided to the appropriate regulatory agencies for review and approval at least 180 days before implementation.

A health and safety plan will be prepared for the closure of the ERDF, and provided before initiation of ERDF closure. The closure of the ERDF and the decontamination or removal and disposal of equipment, structures, and/or soils will be conducted in accordance with the DOE Order 5480.1B, 
DOE/RL-94-40, Rev. 0

$06 / 94$

1 DOE Order 5480.3, and the Occupational Safety and Health Administration

2 hazardous waste operations and emergency response regulations

3 (29 CFR 1910.120).

7

8

\subsubsection{Procedures for Closing the Environmental Restoration Disposal Facility Trench} sections.

Procedures for closing the ERDF trench are discussed in the following

11.10.5.1 Disposal Impoundments. The operation of the ERDF does not involve the use of disposal impoundments. Therefore, the requirements of this section are not relevant to the ERDF.

11.10.5.2 Environmental Restoration Disposal Facility Trench Cover Design. To satisfy the CAMU closure performance standards of 40 CFR 264.552(4) and WAC 173-303-646(5), the trench will be equipped with a final cover. Although the CAMU regulations do not specify the type of cover required, the CAMU closure performance standards are very similar to those for a hazardous/dangerous waste land disposal unit. As a result, the ERDF trench final cover design has drawn upon the technical requirements for final covers for hazardous/dangerous waste land disposal units because these requirements represent a conservative approach to closure and postclosure.

Although a conservative final cover (equivalent to the current standard RCRA land disposal unit final cover) has been proposed for the ERDF, it must be noted that research is being conducted to determine if there are alternate final cover designs that may be more appropriate for use at the Hanford Facility. A request to modify the final cover design may occur before final closure of the ERDF if an alternative design is developed that meets the CAMU closure performance standards, and the alternative design is reviewed and approved by the appropriate regulatory agencies.

The conceptual design for the ERDF trench final cover proposed in this chapter was determined from EPA guidance for the design, construction and closure of hazardous/dangerous waste disposal units. The final cover design is conceptual because detailed design data for the trench itself will not be available until completion of the ERDF trench definitive design. A detailed engineering design report describing the final cover design and providing engineering support calculations will be prepared and submitted to the appropriate regulatory agencies for approval after completion of the definitive design of the ERDF trench. This will be accomplished at least 180 days before the planned start of construction of the final cover. The detailed final cover design will be prepared in accordance with the most current technical documents (Section 11.0).

A detailed final cover installation plan and a CQA plan also will be prepared and submitted for regulatory review at least 180 days before construction of the ERDF trench final cover. The cover installation and CQA plans will be prepared in accordance with the technical guidance documents (i.e., EPA 1993; and EPA 1986a). 
11.10.5.2.1 General Description. The trench final cover will be a multilayer system consisting of soil and geosynthetic materials. Each layer will perform a different function that, when combined, results in the minimization of infiltration of liquids into the waste while also minimizing the need for long-term maintenance. A generalized cross-section of the proposed final cover is shown in Figure 11-1. The main layers of the final cover will include the following:

- A surface soll layer designed to promote water storage to provide a suitable medium for vegetation growth, that will reduce erosion and increase evapotranspiration

- A sandy soil drainage layer below the surface soil layer designed to collect precipitation that percolates through the surface soil

- A geosynthetic or granular filter layer placed above the drainage layer to prevent clogging of the drainage layer by the overlying surface soll layer

- A low-permeability layer consisting of a composite geomembrane/ low-permeability soil layer designed to prevent moisture from reaching the waste.

The final cover will be sloped at a grade of 3 percent to facilitate drainage without causing excessive erosion. Precipitation that percolates through the surface soil layer into the drainage layer will flow laterally down the slope to a perimeter subsurface drainage system. The subsurface drainage system will have a perforated pipe that extends around the perimeter (toe) of the final cover to collect run-off from the drainage layer and convey it away from the ERDF trench. Surface water run-off from the final closure cover will be collected and discharge via surface drainage ditches.

The surface drainage ditch flow directions and discharge areas shown on Figure 11-2 are conceptual. A surface water management plan that will include detailed run-off analysis, pipe/ditch sizing and grade, and identification of appropriate discharge areas will be prepared as part of a detailed final cover design.

As discussed in Section 11.10.2, the ERDF trench will be equipped with an interim cover during operation. The final interim cover will consist of an upper interim cover layer and a low-permeability layer. The purpose of the interim cover is to reduce leachate generation and wind dispersal of waste before placement of the final cover. Because the upper interim cover of the final interim cover will be constructed of material that will not meet the requirements of a low-permeability soil layer (Section 11.10.5.2.2.3), the final interim cover cannot take the place of the low-permeability layer of the final cover. As a result, all of the layers of the final cover will be constructed above the final interim cover.

The riser pipes for the leachate collection and removal systems will penetrate the final cover to allow for leachate monitoring and removal during the postclosure period. Penetrations through those final cover components that comprise the moisture barrier will be accomplished without compromising 
1 the effectiveness of the cover. Access to the riser pipes for monitoring, 2 maintenance, and leachate removal will be provided by roadways designed to 3 prevent damage to the cover. Penetration and roadway details will be 4 developed as part of the detailed final cover design process.

11.10.5.2.2 Cover Components. As described previously, the final cover will consist of several layers that will be constructed on top of the final interim cover. The following sections present the general purpose, description, and construction of each component. Material specifications, construction procedures, and quality assurance and quality control will be described in the detailed final cover design, and in the cover installation and CQA plans.

11.10.5.2.2.1 Waste, Operational Cover, and Interim Cover Placement. Although the placement of the waste and the construction of the final interim cover are not part of the final cover, the proper placement and construction of these layers is critical to the success of the final cover in meeting the CAMU closure performance standards. As currently anticipated, the majority of the waste placed in the ERDF trench will be contaminated soil. The waste will be emplaced, spread, and compacted using conventional equipment to approximately 95 percent of Modified Proctor [ASTM D-1557 (ASTM 1993)] to minimize settlement.

Single-use containers that are expected to comprise less than 3 percent of the total waste volume will be placed in the cell and surrounded and covered by cover material, to prevent tipping and crushing. Note that all void spaces within a single-use container will be filled with inert material before receipt at the ERDF. Subsidence control measures will be taken to eliminate void spaces in irregularly shaped debris placed in the ERDF trench. Current plans call for subsidence control to be accomplished using grout to fill voids and surround the irregularly shaped waste. The use of grout to prevent subsidence does not constitute grouting for treatment or permanent disposal.

The upper surface of waste placed in the ERDF trench will be sloped from the center to the edges of a cell at a 2 percent grade. The waste will be covered with a 0.6-meter- (2-foot-) thick layer of clean native soil as an upper interim cover. The soil will be spread and compacted by a vibratory roller compactor. Annually, the top surface of the upper interim cover will be finish graded to a 2 percent slope and covered with a low-permeability layer, thus creating a final interim cover. The low-permeability layer of the final interim cover will be either a layer of asphalt or some other material such as a geomembrane. The detailed final design of the low-permeability interim cover layer will be determined during the definitive design of the ERDF trench.

The 2 percent grade on the waste and the final interim cover were specified because the most likely Hanford Facility-specific alternate final cover design uses a 2 percent slope. Because a request to modify the closure plan to use the alternative cover likely is to be to made to the appropriate regulatory authorities before placement of the final cover, and if that

52 alternative cover is approved for use, it will be easier to have the waste and 
1 final interim cover already at the correct final slope for placement of the

2 alternative cover. As noted in Section 11.1.5.2.1, the proposed RCRA-

3 equivalent final cover proposed in this document will have a 3 percent slope.

4 The difference between the slope of the waste/final interim cover and the

5 slope of the final cover will be adjusted by use of a native soil grade layer

6 at the base of the final cover as described in the following section.

11.10.5.2.2.2 Native Soll Grade Final Layer. The difference in slope between the 2 percent grade on the top of the interim cover and the 3 percent slope of the final cover layers will be made up using a grade layer of native soil that will be placed on top of the final interim cover to achieve the desired slope. The native soil grade layer will taper from a maximum of approximately 2.1 meters ( 7 feet) at the center of the trench to zero thickness along the outermost edges of the cover.

The soll for the grade layer will consist of reasonably we11-graded material with a minimum of 5 percent fines, to 711 ow for effective compaction. Field studies will be performed to locate candidate deposits for the grade layer material. The field studies could consist of evaluating existing data pertaining to surficial deposits, conducting surface mapping and sampling, laboratory testing such as grain size distribution, and possibly limited drilling. The exact studies and laboratory tests to be used will be detailed during the detailed design of the final cover system.

The method of material placement, lift thickness, moisture content, and compaction requirements al so will be determined during detalled final cover design. The grade layer will be compacted to ensure a stable base for the overlying low-permeability soil. The proposed native soil material, construction equipment, and placement techniques will be used during construction of the full-scale test pad for the final cover. The test pad will be constructed before installation of the final cover. This testing will be used to determine the time constraints for placement, the optimum lift height, the required number of passes to achieve compaction, the moisture-density relationships, and similar information necessary to establish quality control specifications.

11.10.5.2.2.3 Low-Permeability Soil Layer. At the time of construction of the final cover, a 0.6 -meter- (2-foot-) thick layer of low-permeability soil will be placed over the final interim cover/native soil grade layer to minimize infiltration of water. This layer is intended to serve as a barrier to long-term infiltration, should the overlying geomembrane be damaged or deteriorate. The use of a low-permeability soil layer is consistent with industry standards for final covers on hazardous/dangerous waste land disposal units.

The low-permeability soil layer will be constructed using either a natural clay soil or a silty soil amended by mixing with bentonite.

If a natural clay soil is used, it is likely that the material will have to be transported from offsite to the ERDF. The physical and chemical parameters required for the natural clay soil as well as the source of the material will be chosen during detailed design of the final cover. 
DOE/RL-94-40, Rev. 0

$06 / 94$

If a soil/bentonite mixture is used, the soll component will consist of silt or silty sand from a suitable borrow source. The maximum particle size will be determined during definitive design and will be chosen to exclude larger particles that could reduce the overall hydraulic conductivity of the mixture or puncture the overlying geomembrane. The soil will be mixed with the bentonite before placing the material. The optimum percentage of bentonite will be determined during detailed design of the final cover.

To ensure that the soll layer achieves a hydraulic conductivity less than or equal to $1 \times 10^{-7}$ centimeters per second $\left(3 \times 10^{-4}\right.$ feet per day), the natural clay soil or soil/bentonite mixture will be placed in lifts of limited thickness on the surface of the final interim cover, or the interim cover, and compacted to the appropriate specifications. Because of the almost flat slope of the interim cover, it is not likely that any special techniques will be required to prevent sliding along the interface with inderlying layers. The optimum moisture content, density, and compaction requirements of the low-permeability soil layer will be determined during the detailed design of the final cover using laboratory tests in accordance with the most recent EPA/Ecology guidance.

The adequacy of the density and hydraulic conductivity of each compacted lift will be determined using procedures and frequencies specified in the CQA plan. Materials that do not meet the in-place permeability and density requirements will be recompacted or replaced as appropriate and the tests repeated. The top surface of the low-permeability layer will be rolled with a smooth drum roller to provide a flat, even surface for the overlying geomembrane.

Before constructing the final cover, a full-scale test pad of the entire cover system will be constructed. As part of the test, the proposed low-permeability soil, construction equipment, and placement techniques will be used. This testing will be used to determine the time constraints for placement, the optimum lift height, the required number of passes to achieve compaction, the permeability-density relationships, and similar information necessary to establish quality control specifications.

11.10.5.2.2.4 Geomembrane Liner. A geomembrane 1 iner will be placed over the low-permeability soil layer as a barrier to surface water infiltration. The geomembrane will consist of a $40 \mathrm{mil}(0.1$ centimeter, 0.04 inch) HDPE sheet. The 40 mil thickness is twice that recommended by the EPA guidance, but is considered appropriate to reduce the risk of damage during construction and during subsequent operation from such hazards as settlement, roots, and burrowing animals. The HDPE has been selected because HDPE is highly resistant to normal weathering and chemical deterioration. If necessary, compatibility tests (e.g., EPA Method 9090) with fertilizers and herbicides that will be used to establish vegetative cover will be performed as part of the final material selection process to confirm that HDPE is suitable. Physical and mechanical properties of the HDPE sheet, such as thickness, strength, and vapor transmission, can be confirmed by conformance testing (to ASTM and other standard tests as appropriate) on samples of 51 material received at the site, as necessary. A geomembrane liner that does 
DOE/RL-94-40, Rev. 0

06/94

1

2

3

4

5

6

not meet manufacturer's or design specifications will be rejected. The HDPE sheet is available from a variety of manufacturers.

The placement of the HDPE sheet on the prepared low-permeability sotl layer surface will be conducted under detalled quality assurance and quality control procedures to be developed as part of the detailed final cover design, and specified in the cover installation and CQA plan(s).

11.10.5.2.2.5 Drainage Layer. Any water that percclates through the overlying surface soil layer will be conveyed laterally off of the final cover via the drainage layer. The water will flow into the subsurface drainage system located along the outer edges of the ERDF trench. Thus, the drainage layer will prevent hydraulic pressure from building up directly on the geomembrane liner; thereby, eliminating one set of forces that could drive moisture through the geomembrane liner and underlying low-permeability soil layer.

The drainage layer will be 30-centimeters (12-inches) thick and probably will consist of clean, poorly graded coarse sand (Unified Soll Classification) that has a hydraulic conductivity of at least $1 \times 10^{-2}$ centimeters per second ( 30 feet per day). The sand will be screened from native soils and washed if necessary to remove fine material that might clog the drainage layer. The source of the drainage material will depend on the distribution of suitable alluvial deposits on the Hanford Facility, the relative costs of screening and hauling, and the need for washing. Field studies will be performed to locate candidate deposits and laboratory testing, such as grain size distribution and hydraulic conductivity, will be used to determine screening and washing requirements. The exact studies and laboratory tests to be used will be developed during the detailed design of the final cover system.

The drainage layer will be placed in a single 30-centimeters- (1-foot-) thick lift to minimize the possibility of damage to the underlying geomembrane. The sand will be dumped and carefully spread in the up-slope direction by sma11, low-ground pressure bulldozers using placement techniques that will avoid dragging the sand along the geomembrane. A smooth, drum vibratory roller wili be used to compact the sand and provide a flat surface for the overlying geotextile.

11.10.5.2.2.6 Geotextile. A geotextile layer will be placed over the drainage layer to prevent fine material in the overlying surface soil layer from washing into and clogging the drainage layer. The geotextile also will provide support for the overlying soil during placement, so that the poorly graded, cohesionless drainage layer is not pushed aside or worked into the bottom of the soil layer.

The geotextile will consist of either a woven or nonwoven fabric with sufficient hydraulic conductivity across the plane of the fabric to accommodate the maximum expected water flow through the surface soil layer. In addition, the pore size of the fabric will be appropriate to retain the fine materials in the overlying soil without long-term fabric clogging.

Finally, the geotextile will be compatible with the components of its chemical 
1 environment such as soll chemistry, fertilizers, and herbicides.

2 If necessary, laboratory tests (e.g., EPA Method 9090) will be performed to

3 confirm chemical stability. For these reasons, the geotextile will be

4 selected during detailed final cover design when the characteristics of the

5 surface soll layer have been fully determined.

The placement of the geotextile on top of the drainage layer will be conducted under detalled quality assurance and quality control procedures to be developed as part of the detailed final cover design and specified in the cover installation and CQA plan(s).

11.10.5.2.2.7 Surface Soll Layer. A 0.91-meter- (3-foot-) thick layer of surface soll will be placed over the geotextile to prevent damage to the underlying liner components due to erosion or other mechanical processes. The surface soll also will protect the low-permeability soll layer from freezing, because freezing could disrupt the internal structure of the low-permeability soil and severely reduce its effectiveness as a moisture barrier. In addition, the surface soil will retain a significant fraction of normal precipitation for evaporation and (via the vegetative cover) transpiration back to the atmosphere. Finally, the surface soil layer will provide a suitable medium for plant growth.

During detailed final cover design, a source of material for the surface soll will be identified and classifted. An attempt will be made to find a suitable medium-textured soil such as a loam for the surface soil. Laboratory tests (particularly grain size distribution, moisture-density, and hydraulic conductivity) will be conducted to characterize the material. The tests also will be used to determine what level of compaction can be conducted to optimize erosion control (balancing infiltration versus run-off) while still allowing plant root development. To help prevent penetration of the geomembrane and low-permeability soil layers by burrowing animals, 4.5 centimeter ( 2 inch) diameter or larger cobbles will be added to the lower 46 centimeters (18 inches) of the surface soil. A determination of whether a top soil layer is required and studies to find an appropriate source of top soil will be made during the detailed design of the final cover.

The surface soil layer will be placed in approximately 30.5 centimeter ( 1 foot) lifts to avoid damage to the underlying geotextile. The soil will be dumped and carefully spread in the up-slope direction by small, low-ground pressure bulldozers using placement techniques that will avoid dragging the soil across the geotextile. Compaction will be conducted using sheepsfoot or rubber tire rollers to the density determined by testing. Compaction will not be conducted on the uppermost $11 \mathrm{ft}$ to facilitate establishment of the vegetative cover. Fertilizers and/or other additives will be added to the upper lift soil at the time of placement, if necessary, to support the vegetative cover.

A full-scale test pad will is constructed before construction of the final cover. As part of the testing, the proposed surface soil material, construction equipment, and placement techniques will be used. This testing will be used to determine the time constraints for placement, the optimum 1 ift height, the required number of passes to achieve compaction, the 
DOE/RL-94-40, Rev. 0

$06 / 94$

1 moisture-density relationships, and similar information necessary to establish

2 qualtty control specifications.

11.10.5.2.2.8 Vegetative Cover. The vegetative cover will perform three functions. First, the plants will return water stored in the surface soll back to the atmosphere. This will significantly decrease the net infiltration and reduce the amount of molsture avaliable to penetrate the cover. Second, the vegetation will help stabilize the surface soll component of the final cover against wind and water erosion. Finally, the vegetative cover will restore the appearance of the 1 and to a more natural condition.

The selection of vegetative species to be used for the vegetative cover will be made after a comprehensive search, conducted as part of the detailed final cover design. A mixture of several types of wheatgrasses might provide the most dppropriate vegetative cover. Thickspike wheatgrass is a native to the Pasco Basin and is well suited for wind erosion control in deep sandy soils. Siberian wheatgrass has been successfully used for reseeding burial grounds at the Hanford Facility. Both of these species are perennial.

Before seeding, the upper surface of the sotl layer could be loosened by disking or other means if the layer has compacted naturally following placement. The soll will be molstened before or immediately after seeding. Mulch could be used to prevent excessive moisture loss. If wheatgrasses are used, the vegetative cover will be planted in the fall. If the final cover is completed in the winter or spring, an annual cereal ryegrass will be planted to control wind erosion during the summer. The need for irrigation of the vegetative cover will be estabilished during detailed design of the final cover or at the time of planting.

11.10.5.3 Minimization of Liquid Migration. One of the primary objective of the final cover system design is minimization of water migration into the waste where contaminants might be leached from the waste. Because the ERDF trench will be equipped with a final cover that is equivalent or more protective than those recommended for hazardous/dangerous waste disposal unit final covers, engineering calculations and/or modeling will not be required to demonstrate that the cover will provide long-term minimization of liquid migration through the cover.

11.10.5.4 Maintenance of Final Cover. The proposed final cover is intended to function effectively with minimal ongoing maintenance. Various types of natural processes that could damage the final cover were considered when choosing the proposed final cover design. The processes are described in the following sections along with a discussion of how the proposed final cover design will minimize their impact. Methods for detecting final cover damage and general maintenance procedures are presented in Section 11.11 .

11.10.5.4.1 Wind Erosion. The principal hazard associated with wind erosion is removal of the final cover surface soll layer, eventually causing exposure of the geomembrane liner and low-permeability soll layer to the elements. This potentially could lead to breaching of these moisture barriers that could allow water to reach the waste. The design of the final cover helps mitigate the effects of wind erosion by using a 0.9 -meter- (3-foot-) 
thick surface soll layer rather than the 0.6-meter- (2-foot-) thick surface layer required under MTRs. The effect of wind erosion also will be mitigated through the use of a vegetative cover on the surface so11. As described in Section 11.10.5.5.3, the detalled final cover design will be evaluated for potential damage from wind erosion.

11.10.5.4.2 Hater Erosion. The potential hazard associated with water erostion is also the eventual breach of the barriers to molsture infiltration. The damage might occur uniformly over a wide area (sheet erosion) or might be concentrated in a local area (gullying).

The design of the final cover minimizes the potential for water erosion by:

- Limiting the surface slopes to 3 percent

- Employing a 0.9-meter- (3-foot-) surface soll layer

- Providing a drainage system for run-on/run-off control

- Compacting the lower lifts of the surface soll layer in a way that promotes significant infiltration rather than excessive run-off

- Establishing a vegetative cover to slow surface run-off.

As described in Section 11.10.5.5.3, the detailed final cover design will be evaluated for potential erosion damage from overall soll erodability, sheet flow and gullying.

11.10.5.4.3 Deep-Rooted Plants. The potential hazard from deep-rooted plants involves roots penetrating the geomembrane liner and the

low-permeability soil layer. This could provide a pathway for surface water to infiltrate the waste. In addition, hazardous/dangerous constituents might be absorbed by the roots and brought to the ground surface where these constituents would be released to the environment. Plants common to the ERDF area are reported to have roots up to 2.4 meters ( 8 feet) deep, which is sufficient to penetrate the entire final cover.

The design of the final cover will minimize the potential for problems with deep-rooted plants by incorporating the following items into the final cover design.

- Using a high-permeability drainage layer beneath the surface soil layer. The high-permeability layer will have much less water retention capacity than the surface soil. As a result, it is expected that vegetation preferentially will occupy the surface soil layer and will not have an affinity for growing into the usually dry drainage layer.

- Using a geomembrane that is expected to provide some resistance to root penetration. 
11.10.3.4.4 Burrowing Animals. Small animals indigenous to the Hanford Factlity have been reported to burrow to depths of more than 1.8 meters ( 6 feet). This is suffictent to breach the geomembrane liner and at least part of the low-permeability soll layer. Therefore, the integrity of these barriers could be compromised and a pathway could be provided for water infiltration.

The design of the final cover will minimize the potential for intrusion by burrowing animals by:

- Incorporating cobbles into the lower lifts of the surface soil layer

- Using a poorly graded, cohestonless drainage layer above the geomembrane that should prove unstable for burrows and thus discourage animal intrusion.

11.10.5.4.5 Subsidence and settlement. Subsidence and settlement refer to vertical downward displacement of the ground surface. One of the major causes of subsidence of a final cover is a decrease in volume of the underlying waste. As discussed in Section 11.10.5.2.2.1, the waste soll placed in the ERDF trench will be compactad to minimize settlement. Void spaces within containers will be filled with inert material before receipt at the ERDF. Subsidence control measures will be taken to eliminate void spaces in irregularly shaped debris placed in the ERDF trench. Current plans call for subsidence control to be accomplished using cement grout to fill voids and surround the irregularly shaped waste. The use of cement grout to prevent subsidence does not constitute grouting for treatment (1.e., stabilization) or permanent disposal. If brush or vegetation is placed in the ERDF trench, the material will be distributed throughout the working face to minimize local and total waste settlement. As a result of careful placement of waste, decrease in the volume of the waste is not expected to be a major source of settlement or subsidence.

The use of proper placement and compaction techniques during construction of both the final interim cover and the native soll grade layer above the final interim cover will help ensure that the settlement and subsidence of these layers are minimized. Proper construction of these layers also will provide an adequate foundation for the final cover.

In addition to proper placement of the materials within the trench, the time between waste and operation cover placement and the construction of the final cover will allow some settling of the waste to occur before placing the final cover. Because the settling of coarse-grained material occurs relatively rapidly, it is expected that most of the settling of the relatively coarse-grained waste and interim cover materials will occur relatively rapidiy. The final cover design itself minimizes the effects of subsidence and settlement in two ways. First, the soil layers comprising the final cover will be adequately compacted so that an insignificant amount of settlement will occur within these layers. Second, the geomembrane and the low-permeability soll layers will be relatively flexible and will accommodate strains without failure. 
11.10.5.4.6 Selsmic Events. The primary hazard from seismic events is the effects of ground accelerations. Disruption by faulting is not considered a significant risk because no major faults have been identified in the vicinity of the ERDF. The only fault on the Hanford Facility that shows evidence of movement within the past 13,000 years is the fault at Gable Mountain that is approximately 8 kilometers $(5 \mathrm{miles})$ north of the ERDF (WHC 1994a). Displacements and damage to the geomembrane portion of the final cover could occur given suffictently large seismic events if the interface friction angles between the geomembrane and the low-permeability soll layer are exceeded during the event. The damage could result in breaching of the geomembrane and significantly increase the amount. of water infiltrating the waste.

The proposed final cover design includes relatively flat slopes that would require higher ground accelerations to induce permanent displacements when compared to steeper slopes. Consequently, the risk of seismically induced damage to the final cover is considered to be quite smal1. However, a more rigorous seismic evaluation to determine yield accelerations of the final cover and corresponding probability of exceedence of the Hanford Facility DBE will be performed once the detailed final design has been completed. If necessary, textured HDPE or smooth HDPE with a nonwoven geotextile continuousiy bonded to it can be used to increase the interface friction with the low-permeabilitty soll layer.

11.10.5.5 Drainage and Erosion. Drainage of surface water from the cover and control of cover erosion from the effects of water and wind will be controlled through the cover design. The testing and analyses discussed in this section will help demonstrate that the proposed final cover will provide adequate drainage while minimizing eroston.

11.10.5.5.1 Cover Drainage and Run-on Control. Drainage of any precipitation that infiltrates through the surface soil layer will be provided by an underlying 30-centimeter- (1-foot-) thick drainage layer of clean, poorly graded sand. The drainage layer will be protected from clogging by a geotextile placed between that layer and the overlying surface soil layer. The base of the drainage layer will be a low-permeability geomembrane sloped at a 3 percent grade toward the edge of the cover. The slope of the drainage layer will convey water to a peripheral, belowgrade drainage feature that contains the same clean, poorly-graded sand drainage layer. The bottom of the drainage feature also will be lined with a geomembrane, above which rests a perforated drainage pipe. The perforated drainage pipe conveys the water by gravity to a release point to be determined during detailed design of the final cover.

The precipitation that falls on the cover and flows as sheet flow down the surface of the final cover will discharge into the surface drainage system of the run-on/run-off control system. The surface drainage ditches will discharge to the area-wide surface water control system. The surface drainage

49 system could consist of open ditches lined with coarse sand or fine gravel.

51 high-intensity, short-duration thunderstorms. The final design of the 
1 drainage features and the run-on/run-off control system will be conducted 2 during detalled final cover destgn.

The design of the surface run-off drainage ditches will be based on peak discharge computations. The peak discharge of drainage from the surface of the final cover is expected to occur during winter periods of rain-induced rapid snowmelt. In addition to managing run-off from the surface of the final cover, the surface drainage ditches also will be used to prevent run-on to the final cover from the upgradient side of the ERDF trench. Because the surface drainage ditches also will be used to prevent run-on to the cover, the peak discharge will include run-on toward the final cover as well as run-off from the final cover. The peak discharge will be determined through the use of computer modeling during detalled design of the final cover. Conservative values for storm events, snow depths, soll types, vegetative cover, and geometry of the cover will be used as input data for the model. The run-on and run-off control system surface drainage ditches will be sized to allow a minimum of 9 .centimeters $(0.3$ foot) of freeboard when carrying the peak design flow.

11.10.5.5.2 Water Erosion. Erosion of the final cover by water is expected to by minimized by the combined use of low-slope angles, soil compaction, and vegetative covers as described in Section 11.10.5.2. The cover run-on controls described previously are expected to effectively eliminate erosion from surface run-on. Therefore, the analysis of the final cover design for erosion potential oniy will consider surface water run-off.

The final cover design will be evaluated for water erosion from surface water run-off by considering soll erodability, sheet flow, and gully erosion. Soil erodability will be evaluated using the universal soil loss equation developed by the U.S. Department of Agriculture (USOA 1978) and recommended in EPA guidance manuals.

Input data requirements for the universal soil loss equation include parameters related to the cover soil layer properties, the cover slope, cover length, and cover vegetation.

In addition to erodability, the final cover design will be evaluated for stability from sheet flow and gully formation. The sheet flow analysis will be performed to determine if the 3 percent grade of the final cover can withstand overland or sheet flow with a minimum of erosion. The Rational Method will be used to determine sheet flow discharge (Nelson and Abt 1986). Conservative values for storm events and slope length will be used to obtain the flow velocity at the foot of the slope. The flow velocity will be compared to the allowable design flow velocity for the soil used on the upper cover layer.

11.10.5.5.3 Wind Erosion. Erosion of the final cover by wind is expected to be minimized by the same factors that protect the cover from water erosion. These factors include the use of low-slope angles, soll compaction, and vegetative covers. 
The cover design will be evaluated for wind erosion using the wind erosion equation recommended in EPA guidance and modified for use in Washington State. Conservative values will be used for the input data requirements such as cover soil layer properties, cover surface roughness, cover field length, climate, and cover vegetation. The resulting value for tons of soil lost per acre per year will be compared to the EPA recommended limit of 1,814 kilograms ( 2 tons) per acre per year. The wind erosion evaluation will be conducted during detailed final cover design.

11.10.5.5.4 Total Erosion. On completion of the soil erosion evaluation during detailed final cover design, the sum of net cover erosion will be compared to the EPA recommended limit of 1,814 kilograms (2 tons) per acre per year for total erosion. If the EPA recommended 1 imit is exceeded, changes in the final cover design to correct the problem will be evaluated during detailed design.

11.10.5.6 Settlement and Subsidence. Settlement and subsidence refer to vertical downward displacement of the ground surface. If subsidence occurs more or less uniformly over a relatively large area, strains at any point in the liner system will be relatively small and are not expected to cause serious problems to the final cover. However, significant differential subsidence occurring over a short distance could seriously damage the cover if the displacements were large.

The following are several mechanisms that potentially could cause subsidence.

- Consolidation--Primary consolidation refers to a decrease in overall volume as water migrates out of the soil over time in response to increased load. This behavior is significant in low-permeability cohesive soils (clays and silts) but is not expected to be significant in the well draining (granular) contaminated soils that will makeup the majority of the waste material in the ERDF trench. Secondary consolidation refers to deformation of the solid portion of the waste mass once primary consolidation has transferred load to this matrix. Again, this phenomenon predominantly occurs in fine-grained cohesive soils. Secondary consolidation also is not considered to be a significant potential problem for the waste or cover materials in the ERDF because of the granular nature of the waste soils and the compaction that will be conducted during placement.

- Creep--Creep refers to time-dependent deformation under load. Generally, creep is a type of plastic deformation that redistributes stresses in local areas. Creep is not expected to be significant in the soils of the final cover or the contaminated soils that will make up the majority of the waste material in the ERDF trench. This is because the loads imposed by the cover are relatively low, much of the contaminated soils already will have been in place for a number of years before constructing the final cover so that most soil creep already will have occurred; and the sands, gravels and cobbles that make up the contaminated soil generally are strong, highly elastic materials that are not prone to creep. 
- Liquefaction--Liquefaction occurs in loose, poorly graded granular materials that are saturated and subjected to shaking (typically from earthquakes, blasting, or pile driving). Saturated soils are susceptible because of high dynamic pore pressures that temporarily lower the effective stresses. During this process, the soil particles are rearranged into a more dense configuration, with a resulting decrease in volume. The foundation materials for the ERDF trench are not expected to be susceptible to liquefaction because the materials are relatively well-graded, unsaturated, and relatively dense. The waste contaminated soils and the soil portions of the final cover should not be susceptible to liquefaction because the soil will be compacted during placement.

Settlement and subsidence are not expected to impair the ability of the final cover to minimize infiltration. The potential for settlement and subsidence of the ERDF trench foundation, waste materials, and final cover will be evaluated more fully during detailed final cover design.

\subsubsection{Cover Permeability. The final cover system should provide a} permeability less than or equal to that of the liner system to avoid the potential for ponding of infiltrating fluids within the waste.

The conservative bottom liner system design used at the ERDF trench will incorporate a low-permeability layer that is a composite low-permeability soil/geomembrane layer. Because the proposed final cover system design incorporates essentially the same low-permeability layer as the bottom liner and will be constructed to the same specifications, it is expected that the perineability of the proposed final cover will be the same as that of the bottom liner.

11.10.5.8 Freeze/Thaw Effects. The expansions and contractions accompanying cyclic freezing and thawing of pore water within the low-permeability soil layer of the final cover could disrupt the cover structure and increase the permeavility of that layer. To minimize this effect, the thickness of the cover materials overlying the low-hydraulic conductivity soil and geomembrane layers will be sufficient to protect those layers from frost.

Subsurface soil temperatures have been recorded at the Hanford Meteorological Station since 1952 (PNL 1983). The lowest temperature recorded at 1 meter ( 3 feet) below the ground surface was $0^{\circ} \mathrm{C}\left(32^{\circ} \mathrm{F}\right)$, which occurred only once over the monitoring period. It can be concluded that the zone of frost penetration does not extend farther than 1 meter ( 3 feet) below grade. 42 Therefore, the 1.3 meter (4 foot) depth to the low-permeability soil layer is 43 expected to provide adequate protection against frost effects. The design of 44 the final cover to minimize erosion also will help maintain an adequate 45 protective thickness over the low-permeability soil layer. 
DOE/RL-94-40, Rev. 0

06/94

\subsubsection{Schedule for Closure} sections.

Partial closure and final closure are discussed in the following

11.10.6.1 Partial Closure. "Partial closure" is defined in 40 CFR 260.10 and WAC 173-303-040 as closure of one (or more) units at a facility where other hazardous/dangerous waste management units will continue to operate. In this sense, partial closure of the ERDF will not occur, but when final closure of the ERDF trench occurs, it may constitute partial closure of the overall Hanford Facility.

11.10.6.2 Final Closure. The date of final closure of the ERDF trench cannot be stated because the total amount of remediation that will be required on the Hanfird Facility has not been completely determined. However, the estimated date for beginning the final closure of the ERDF is the year 2020.

At the present time, it is anticipated that the construction of the final closure cover will be conducted in stages as the ERDF trench is filled. Although the ERDF trench will be a single continuous trench, the floor of the trench will be divided into leachate collection cells, that are approximately 152 meters (500 feet) square. The use of leachate collection cells is required to limit the amount of leachate resulting from precipitation events and allow the closure of the trench to be conducted in phases. Initially, a small number of cells (two to four) will be excavated and 1 ined. Additional cells will be excavated and lined as additional remediation waste is generated. The final cover construction will be initiated after 10 individual leachate collection cells of the trench have reached final grade, and enough area of the next leachate collection cells have been filled to allow construction of the final cover to proceed without interfering with the waste placement operations. It is anticipated that construction of the first increment of the final cover will not begin until at least 5 years after the start of operations.

\subsubsection{Extension for Closure Time}

Under the 40 CFR 264.552 and WAC 173-303-646 CAMU regulations, specifically under the regulations defining the expanded CAMU concept [40 CFR 264.552(a)(1) and (2) and WAC 173-303-646(4)(b) and (c)], a CAMU is not considered a land disposal unit or considered a unit subject to the MTRs. Therefore, the specific requirements for time allowed for closure and petitions for extension of closure time applicable to land disposal units do not apply to closure of the ERDF.

\subsubsection{Amendments to Closure Plan}

Under the 40 CFR 264.552 and WAC 173-303-646 CAMU regulations, specifically under the regulations defining the expanded CAMU concept [40 CFR 264.552(a)(1) and (2) and WAC 173-303-646(4)(b) and (c)], a CAMU is not considered a land disposal unit or considered a unit subject to the MTRs. 
1 Therefore, the specific requirements for amendments to a closure plan

2 applicable to land disposal units do not apply to closure of the ERDF.

3 However, because the CAMU is likely to be incorporated into the Hanford

4 Facility Permit, a Class 3 permit modification may be required in the event

5 that changes are required to the approved closure plan. In the event that

6 changes to the approved closure plan are required, an amended plan will be

7 submitted to the appropriate regulatory authorities for review and approval.

\subsubsection{Certification of Closure}

Under the 40 CFR 264.552 and WAC 173-303-646 CAMU regulations, specifically under the regulations defining the expanded CAMU concept [40 CFR 264.552(a)(1) and (2) and WAC 173-303-646(4)(b) and (c)], a CAMU is not considered a land disposal unit or considered a unit subject to the MTRs. Therefore, the specific requirements for closure certification do not apply to closure of the ERDF. However, on completion of closure of the ERDF, the DOE-RL will complete a certification of closure. The certification will state that final closure of the ERDF has been completed in accordance with the approved closure $p 1$ an and will be signed by an authorized representative of the DOE-RL and by an independent, registered professional engineer. The signed certification and documentation supporting the closure certification will be retained by the DOE-RL and will be available to the regulatory authorities for inspection upon request. This documentation wi11 be maintained by the postclosure contact identified in Section 11.11.4.

\subsubsection{Notice to Local Land Authority}

Under the 40 CFR 264.552 and WAC 173-303-646 CAMU regulations, specifically under the regulations defining the expanded CAMU concept [40 CFR 264.552(a) (1) and (2) and WAC 173-303-646(4)(b) and (c)], a CAMU is not considered a land disposal unit or considered a unit subject to the MTRs. Therefore, the specific requirements for survey plats and notices to local land authority applicable to land disposal units do not apply to closure of the ERDF. However, after completion of the closure activities at the ERDF, the DOE-RL will record a "notation on the deed, or on some other instrument that normally is examined during title search, that will in perpetuity notify a potential purchaser of the property" where the ERDF is located, and will include the following information.

- The record will show the ERDF and the surrounding 1 and that have been used to manage hazardous/dangerous waste.

- A survey plat, indicating the dimensions and locations of the ERDF with respect to permanently surveyed benchmarks, prepared by a certified professional land surveyor will be included. The survey plat will include a record of the type, location, and quantity of waste placed in the ERDF to the extent that the information exists.

- A note will be included that indicates that the property has been used for waste disposal and that postclosure use of the property can never 
be allowed to disturb the integrity of the final cover, liners, or other components of the containment system unless it can be demonstrated that any proposed disturbance will not increase the risk to human health and the environment, or it is necessary to reduce a threat to human health and the environment.

\subsection{POSTCLOSURE PLAN}

After placement of the first increment of the final cover and continuing after final closure of the ERDF, the DOE-RL will comply with all postclosure requirements of the 40 CFR 264.552 and WAC 173-303-646 CAMU regulations including maintenance and monitoring throughout the postclosure care period. Such care will include maintaining the integrity and effectiveness of the final cover, maintaining and monitoring the leak detection system, continuing to operate the leachate collection and removal system until leachate is no longer detected, maintaining and monitoring the groundwater monitoring system, preventing run-on and run-off from eroding or otherwise damaging the finat cover, and protecting and maintaining surveyed benchmarks used in locating the ERDF. Although the length of the postclosure care period is not specified in the CAMU regulations, the postclosure care will be continued by the DOE-RL for a minimum of 30 years. After 30 years, an evaluation of the data collected during postclosure monitoring and inspections will be made to determine whether the frequency of postclosure inspections and monitoring can be reduced.

\subsubsection{Inspection Plan}

Inspections will be conducted routinely to ensure continued integrity of the cover after the first increment of the final cover has been installed and will continue throughout the postclosure care period. The inspections will be conducted in accordance with the following procedures and schedules, and the results of each inspection will be recorded in a permanent $10 \mathrm{~g}$ book. The log book will be maintained current and will be available for examination during the postclosure care period. Subsequent maintenance activities are described in Section 11.11.3.

11.11.1.1 Security Control Devices. The ERDF is located within an area of the Hanford Facility that will be patrolled by protective force personnel. The ERDF trench will be bounded by a chain link fence with locked gates and warning signs to prevent unauthorized intrusion or access. The perimeter fence will be inspected monthly for indications of damage. Any observed damage will be noted in the inspection log books and promptly repaired as described in Section 11.11.3.

11.11.1.2 Erosion Damage. Erosion of the ERDF trench final cover could occur through the actions of run-off, run-on, and wind. Soil loss over the final cover will be detected by visual inspections performed at least quarterly, or more frequently if indicated by the final cover design or ongoing experience. Inspectors will check for sheet erosion or gullying and the integrity of run-off and run-on control measures. The inspectors will note any 
1 observations in an inspection log book and the damage will be promptly 2 repaired as described in Section 11.11.3.

3

Soll loss over large areas of the cover will be detected by measurements of relative elevation differences between survey monuments located on a 30.43-meter- (100-foot-) grid spacing on the cover. The measurements will be conducted annually during the first 5 years after closure and every 2 years thereafter. During this process, representative cover surface elevations near each survey monument, as well as the elevation of the monument itself, will be measured. Changes since the last measurement will be calculated and entered in an inspection log book. If soil level changes between the monument and the cover surface elevation are detected, erosion is indicated.

Siltation of the cover run-on drainage ditches by wind-blown sand and debris will be detected by quarterly visual inspections. Inspectors will check for sand or debris covering the gravel ditch lining and will record any observations of accumulations in an inspection $\mathrm{log}$ book.

11.11.1.3 Cover Settlement, S1 idence, and Displacement. Visual inspections of the covers for severe subsidence will be conducted quarterly and immediately following seismic events. Accelerometers will be mounted in the vicinity of the ERDF to record the amplitude and frequency of surface accelerations during seismic events. The need for inspection following such an event will be based on the recorded accelerations and the threshold for significant accelerations will be determined in a seismic evaluation of the final cover design. Inspectors will check for ground fractures and surface displacements of the cover materials and will note any observations in an inspection log book. The damage will be addressed as described in Section 11.11 .3

Settlement or subsidence over large areas of the cover will be detected by annual measurements during the first 5 years after closure, when most settlement is expected to occur. Measurements will be performed every 2 years thereafter. During the survey, the relative differences in elevation between the monuments will be measured. Changes in monument elevations since the last measurement will be calculated and entered in an inspection log book. If changes are detected, settlement or subsidence is indicated.

11.11.1.4 Vegetative Cover Condition. Visual inspection of the vegetative cover will be performed at least monthly, or more frequently, based on the final cover design and ongoing experience until the vegetation is established, and quarterly thereafter. Inspectors will check on the condition and density of the vegetative cover, and note the presence of any deep-rooted plants. The inspector's observations will be recorded in an inspection log book.

11.11.1.5 Animal Activity. Visual inspection of the covers for evidence of burrowing animals will be performed quarterly. The previously mentioned chain link perimeter fence will preclude access for most medium and large animals. The inspector's observations will be recorded in an inspection log book.

11.11.1.6 Cover Drainage System Functioning. Visual inspection of the cover drainage system will be performed quarterly. The cover will be checked for 
1 signs of drainage system blockage, such as unusually damp soil, ponded water

2 or ice, localized settlement, or displacements. The outlet drain also will be 3 visualiy checked for indications of blockage. The inspector's observations 4 will be recorded in an inspection log book.

\subsubsection{Leachate Collection/Detection and Removal System. Visual} inspections of the leachate collection/detection and removal system will be performed quarterly and at the time of each leachate collection and removal. The tubing, pumps, and piping will be inspected for leaks, damage, corrosion, or blockage. The inspector's observations will be recorded in an inspection $\log$ book.

11.11.1.8 Monitoring Well Condition. Each of the ERDF groundwater monitoring wells will have a locking clasp welded to the cap and casing. Each well will be equipped with a padlock to prevent unauthorized access. The wells will be surrounded by four steel guardposts to prevent damage from vehicles. The well condition, locks, guardposts, and pump connectors will be inspected semiannualiy for damage at the time of groundwater sampling. Problems or damage will be noted in an inspection log book.

11.11.1.9 Benchmark Integrity. Visual inspections of benchmark integrity will be made annually, at the time of the erosion and settlement surveys describe in Sections 11.11 .1 .2 and 11.11.1.3. Any changes in the elevation of the benchmarks that might indicate a loss of integrity will be noted in an inspection log book. Benchmarks found as a result of the survey to have significantly changed location or elevation will be closely evaluated and confirmed.

11.11.1.10 Inspection Training and Frequency. The ERDF postclosure inspections will be conducted by ERDF operators who have been trained in accordance with Appendix 8A.

\subsubsection{Postclosure Monitoring Plans}

The following sections discuss the postclosure monitoring plans. Postclosure monitoring will begin after the installation of the first increment of the final cover and continue throughout the postclosure care period.

11.11.2.1 Leachate Collection/Detection and Removal. During the postclosure care period, operation of the leachate collection/detection and removal system described in Chapter 4.0 will continue to allow for the detection of possible leachate migration after closure. Quantities of liquid removed from each system and dates of removal will be recorded and maintained with the inspection records.

11.11.2.2 Groundwater Monitoring. For the first 5 years following closure, the DOE-RL will continue to conduct semi-annual monitoring unless the frequency of monitoring has been changed (refer to Chapter 5.0, Section 5.5.5.5). After 5 years, the frequency of groundwater monitoring will be reevaluated based on leachate generation and groundwater monitoring data. 
DOE/RL-94-40, Rev. 0

1 If necessary, an alternative postclosure monitoring program will be proposed

2 to the appropriate regulatory authority for review and approval. It is

3 possible that leachate generation data might indicate earlier modification of

4 the postclosure plan. If warranted, a modified plan could be submitted before

5 the 5 year postclosure period.

\subsubsection{Maintenance Plan}

The cover, groundwater monitoring system, and leachate collection system will be maintained regularly to ensure continued integrity after the installation of the first increment of the final cover and throughout the postclosure care period. Maintenance activities generally will be triggered by the inspection activities discussed in Section 11.11.1. Maintenance of the passive protection systems generally will be performed on an as-needed basis. Maintenance of the mechanical systems, such as pumps and certain sampling devices, will be performed regularly as specified in Hanford Facility procedures, or if component failure occurs. All maintenance records will be maintained by the contact listed in Section 11.11.4. Maintenance reports will be prepared to document all such activities. The maintenance reports will reference the initiating inspection report in the inspection $10 \mathrm{~g}$, and will incorporate by reference all maintenance records to provide a comprehensive documentation of all maintenance activities. The maintenance reports and accompanying records will be maintained current and will be available for examination during the postclosure care period.

11.11.3.1 Security. Security control will be provided by Hanford Facility protective force personnel, fences, locked gates, and warning signs. The warning signs will be placed at the ERDF trench boundaries. The Hanford Facility protective force personnel, locked gates, and fences will be part of the ERDF normal security requirements. Maintenance of the fences, gates, locks, and warning signs will be performed as required to maintain their integrity. All security control maintenance activities will be recorded in maintenance reports.

11.11.3.2 Erosion Damage. Cover maintenance to repair erosion damage will be initiated whenever a soil loss from erosion of more than 25.4 centimeters (10 inches) is detected.

Maintenance initially will consist of replacing the lost cover material. Depending on the cause of damage, various activities could be performed subsequentiy. If the vegetative cover was not well established, it might be reseeded and additional fertilizer and/or irrigation applied until the vegetation is firmly established. Alternatively, different, more suitable plant species could be identified and substituted. If the soll texture is the primary factor, a layer of coarser material such as fine gravel could be spread on the ground surface to act as a resistant layer. This latter approach could be the most useful for treating areas of local soil loss. If the damage resulted from inadequate run-on control, the run-on control trenches and berms will be cleaned, repaired, and strengthened as required. All erosion damage maintenance activities will be documented in maintenance 
1 reports, which will reference the initiating inspection report and any 2 supporting documents.

Maintenance of the cover run-off/run-on drainage ditches will be initiated by an inspection report that sufficient sand and debris have accumulated to significantly reduce ditch capacity, an overflow has occurred, or severe erosion was observed. Maintenance action levels will be determined as part of the comprehensive surface water control plan to be prepared during final cover design. The maintenance will consist of removing the accumulated materials and/or returning the ditches to approximately their original crosssections. All maintenance activities will be documented in maintenance reports.

11.11.3.3 Cover. Cover evaluation will be initiated whenever subsidence or settlement of more than 0.3 meter ( 1 foot) is detected. Maintenance will then be performed as needed (and described in the following paragraphs).

Minor settlement will be corrected by adding surface soil to return the cover surface to design grade and by revegetating disturbed areas. Severe settlement resulting in local ponding of water on the geomembrane will be corrected by removing the cover layers down to the flexible membrane liner as described $f_{1 i}$ the following paragraphs.

Subsidence, differential settlement, and severe areal settlement will require removing the cover layers down to the flexible membrane liner. If the flexible membrane liner is severely strained, has failed, or is below adequate grade, the liner will be removed. In this case, the low-permeability soil layer will be inspected and, if significantly disrupted, will be recompacted to original specifications and grades. Grouting the underlying waste fill al so might be performed at this time if considered necessary to prevent recurrence of the problem. The flexible membrane liner will be replaced by patching, employing the same quality assurance, quality control, and inspection levels used for the original installation. The overiying soil and geotextile layers will be replaced to original specifications and grades, and the disturbed areas of the cover will be revegetated.

All settlement, subsidence, and displacement damage maintenance activities will be documented in maintenance reports that will incorporate, by reference, any supporting documents.

Maintenance of the vegetative cover will be performed if the vegetation is not sufficiently established to minimize erosion damage and if the presence of deep-rooted species is detected. Although it currentiy is believed that a vegetative cover density of approximately 20 percent will be sufficient, the actual extent of vegetation required to minimize erosion damage will be determined through experience during the postclosure care period. Maintenance of the vegetative cover will include reseeding and application of additional fertilizer, mulch, and irrigation. Alternatively, different, more suitable plant species may be identified and substituted. If the presence of deep-rooted plants is detected, the plants will be destroyed by hand removal and/or application of selective herbicides. All vegetative cover maintenance activities will be documented in maintenance reports. 
DOE/RL-94-40, Rev. 0

$06 / 94$

1 11.11.3.4 Animal Activity. Burrowing animals will be trapped and removed 2 from the site. Large burrows within the cover will be filled with surface 3 cover soll. Criteria will be developed to determine whether detection of a 4 burrow requires inspection of the condition of the geomembrane liner of the 5 final cover. All maintenance activities from burrowing animals will be 6 documented in maintenance reports.

11.11.3.5 Cover Drainage System. Maintenance of the cover drainage system is expected to be limited to the ditch and outlet drain pipe systems.

All blockages will be removed using methods that minimize disturbance to the cover. Blockages that cannot be removed by in-pipe techniques will be repaired by excavating the damaged sections. All repairs will meet the same equipment spectfications and employ the same quality assurance, quality control, and inspection levels used for the original installation. If the flexible membrane liner is encountered in the excavation, the liner will be evaluated for damage and patched as required before backfilling. The overlying soll will be replaced to original specifications and grades, and the disturbed areas of the cover will be revegetated.

Maintenance could be required for the drainage layer if the drainage layer should become clogged by fine materials washing through the overlying geotextile. The damage will be corrected by removing the cover layers down to the flexible membrane liner in the affected portion of the cover.

The flexible membrane liner will be evaluated for damage and patched as required before reinstalling the overlying cover layers. The specifications for the overlying cover layers will be revised if necessary to avoid further drainage layer clogging. The overlying cover layers will be replaced to original and/or revised specifications and grades, and the disturbed areas of the cover will be revegetated.

All cover drainage system maintenance activities will be documented in maintenance reports that wi11 incorporate, by reference, any supporting documents.

\subsubsection{Leachate Collection/Detection and Removal System. Maintenance} activities could be required for the tubing, pumps, and piping system of the leachate collection/detection and removal system. Because most of the leachate collection tubing will be below the waste, repairs will be limited to in-pipe methods to avoid disturbing the waste. Pumps and other mechanical devices will be regularly maintained following Hanford Facility procedures. The piping system and associated valves will be repaired or replaced as required. All leachate collection/detection and removal system maintenance activities will be documented in maintenance reports.

11.11.3.7 Monitoring Wells. Maintenance will be required for the monitoring well security equipment, the downhole tubing and screens, and the pumps. Damaged security equipment will be repaired or replaced as required. Downhole tubing and screens could be damaged from dislocation or corrosion over the postclosure care period. If the damage is sufficient to materially effect the integrity of the samples, the monitoring well will be replaced with a new installation. The new installation will be constructed under the same 52 specifications as the original wells, and in the same general locations. 
1 The sampling pumps will be maintained regularly following Hanford Facility procedures. All monitoring well maintenance activities will be documented in maintenance reports.

\subsubsection{Postclosure Contact}

The following office (or their successors) will be the official contacts for the ERDF during the postclosure care period:

U.S. Department of Energy

Richland Operations office

P.0. Box 550

Richland, Washington 99352

\subsection{CLOSURE AND POSTCLOSURE DOCUMENTATION}

Under the 40 CFR 264.552 and WAC 173-303-646 CAMU regulations, specifically under the regulations defining the expanded CAMU concept [40 CFR 264.552(a)(1) and (2) and WAC 173-303-646(4)(b) and (c)], a CAMU is not considered a land disposal unit or considered a unit subject to the MTRs. Therefore, the specific requirements for notices to local 1 and authority applicable to land disposal units do not apply to closure of the ERDF. However, after completion of the closure activities at the ERDF, the DOE-RL will record a "notation on the deed", or on some other instrument that normally is examined during title search that will in perpetuity notify a potential purchaser of the property where the ERDF is located, and will include the following information.

- The record will show the location of the ERDF and the surrounding land that have been used to manage hazardous/dangerous waste.

- A survey plat, indicating the dimensions and locations of the ERDF with respect to permanently surveyed benchmarks, prepared by a certified professional 1 and surveyor will be included. The survey plat will include a record of the type, location, and quantity of waste placed in the ERDF to the extent that the information exists.

- A note will be included that indicates the property has been used for waste disposal and that postclosure use of the property can never be allowed to disturb the integrity of the final cover, liners or other components of the containment system unless it can be demonstrated that any proposed disturbance will not increase the risk to human health and the environment, or it is necessary to reduce a threat to human health and the environment. 
DOE/RL-94-40, Rev. 0

06/94

COVER MATERIAL

MATERIAL THICKNESS

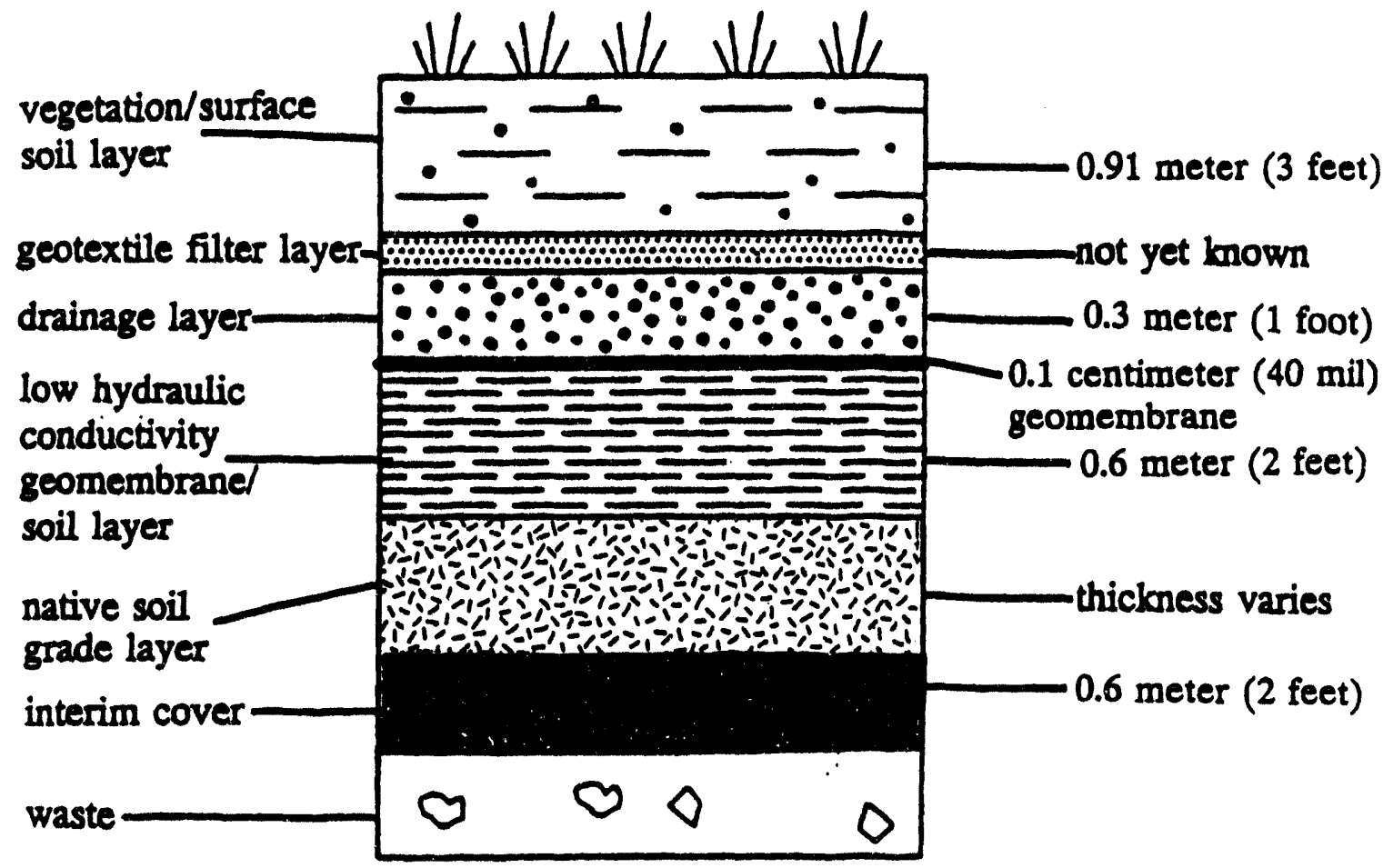

Figure 11-1. Cross-Sectional View of the Environmental Restoration Disposal Facility Final Cover. 


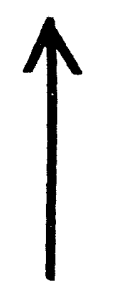

Legend

North $\leftarrow$ Drainage from final cover

$\leftarrow$ Drainage from trench and run-on control

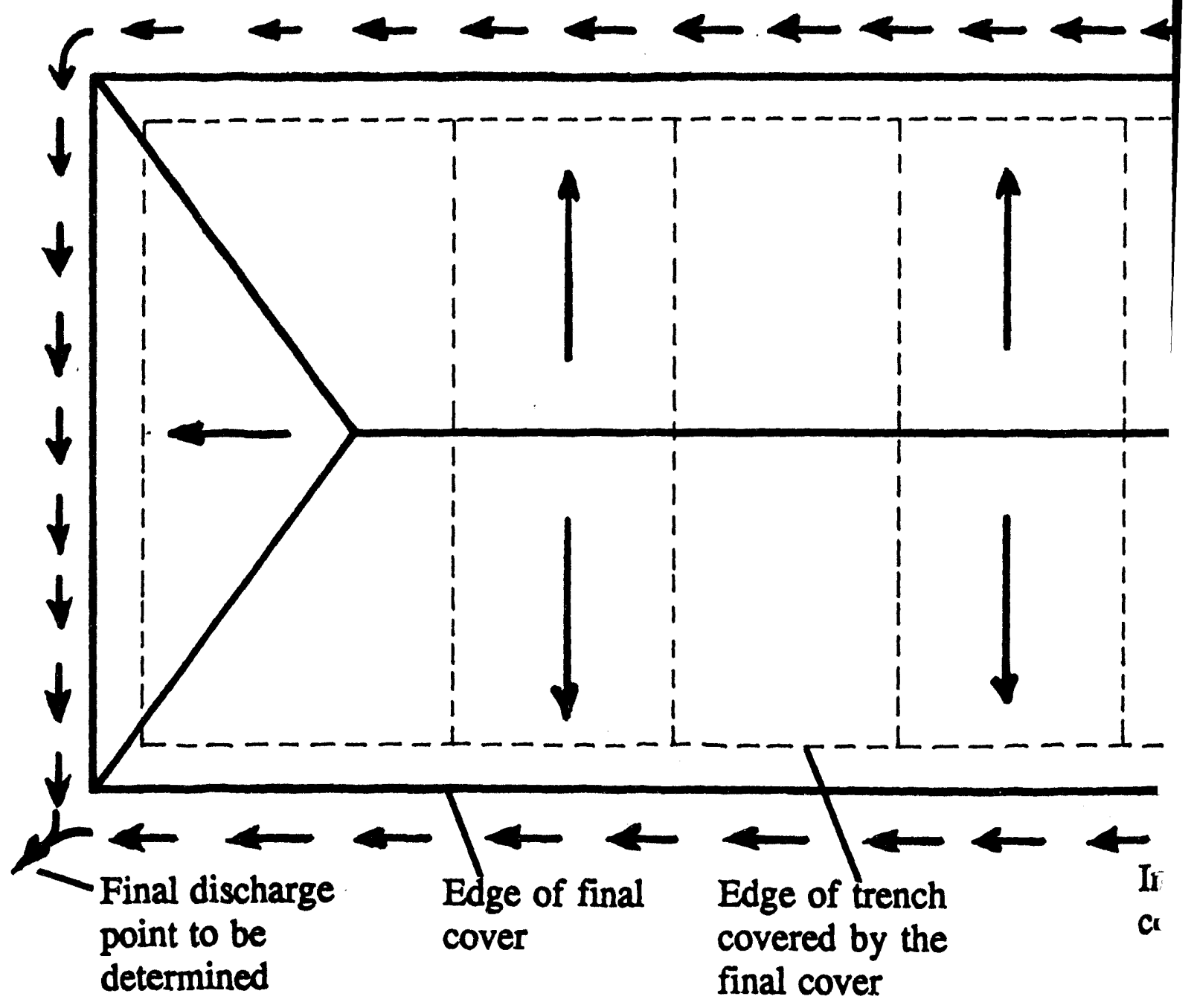


DOE/RL-94-40, Rev. 0

pe of connection be determined

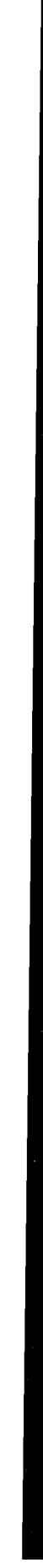

\section{Leachate} collection sumps 
DOE/RL-94-40, Rev. 0

$06 / 94$

Table 11-1. Chapter 11.0 Cross-Reference Table.

([ ] - Denotes location of information in Ecology Part B checklist)

(sheet 1 of 4 )

\begin{tabular}{|c|c|c|c|}
\hline ERDF out l ine chapter* & $\begin{array}{l}\text { Specifically required } \\
\text { by canu regulation? }\end{array}$ & $\begin{array}{c}\text { Washington State } \\
\text { CAMU Regulati ons } \\
173-303 \\
\end{array}$ & $\begin{array}{c}\text { Federal } \\
\text { CAMu regulations } \\
40 \text { CFR } \\
\end{array}$ \\
\hline \multicolumn{4}{|l|}{11.0 Closure and Postclosure [I] } \\
\hline $\begin{array}{l}11.1 \text { Closure for Containers, } \\
\text { Tank Systems, Waste Piles, } \\
\text { Surface Impoundments, Land } \\
\text { Treatment, Landfills, and } \\
\text { Miscellaneous Units } \\
{[1-1 d(1)-1-1 d(6)]} \\
\text { WAC } 173-303-630(10) \\
\text { WAC } 173-303-640(8) \\
\text { WAC } 173-303-650(6) \\
\text { WAC } 173-303-655(8) \\
\text { WAC } 173-303-660(9) \\
\text { WAC } 173-303-665(6) \\
\text { WAC } 173-303-670(8) \\
40 \text { CFR } 264.178 \\
40 \text { CFR } 264.197 \\
40 \text { CFR } 264.228 \\
40 \text { CFR } 264.258 \\
40 \text { CFR } 264.280 \\
40 \text { CFR } 264.310 \\
40 \text { CFR } 264.351 \\
40 \text { CFR } 264.575 \\
\end{array}$ & No & N/A under 646 & N/A under 264.552 \\
\hline $\begin{array}{l}11.2 \text { Postclosure/Contingency } \\
\text { Postclosure for Tank Systens, } \\
\text { Waste Piles, Surface } \\
\text { Impoundments, Incinerators, Land } \\
\text { Treatment, Landfills and } \\
\text { Miscellaneous Units [1-2] } \\
\text { WAC } 173-303-610(8)(a) \text { and (b) } \\
\text { WAC } 173-303-640(8)(b) \\
\text { WAC } 173-303-650(6) \\
\text { WAC } 173-303-655(8) \\
\text { WAC } 173-303-660(9) \\
\text { HAC } 173-303-665(6) \\
\text { WAC } 173-303-670(8) \\
\text { WAC } 173-303-680(4) \\
40 \text { CFR } 264.228 \\
40 \text { CFR } 264.258 \\
40 \text { CFR } 264.603 \\
40 \text { CFR } 264.280 \\
40 \text { CFR } 264.310 \\
40 \text { CFR } 264.351 \\
40 \text { CFR } 264.525\end{array}$ & No & N/A under 646 & N/A under 264.552 \\
\hline $\begin{array}{l}11.3 \text { Notices Required for } \\
\text { Disposal Facilities }[1-3] \\
\text { WAC } 173-303-610(6) \\
\text { WAC } 173-303-610(11) \\
\text { WAC } 173-303-610(7) \\
\text { WAC } 173-303-610(10) \\
40 \text { CFR } 264.119\end{array}$ & No & N/A under 646 & N/A under 264.552 \\
\hline
\end{tabular}


Table 11-1. Chapter 11.0 Cross-Reference Table.

([ ] - Denotes location of information in Ecology Part B check $]$ ist) (sheet 2 of 4 )

\begin{tabular}{|c|c|c|c|}
\hline ERDF out line chapter* & $\begin{array}{l}\text { Specifically required } \\
\text { by CAMU regulation? }\end{array}$ & $\begin{array}{c}\text { Washington State } \\
\text { CAMU Regulations } \\
173-303 \\
\end{array}$ & $\begin{array}{l}\text { Federal } \\
\text { CAMM regulations } \\
40 \text { CFR } \\
\end{array}$ \\
\hline $\begin{array}{l}\text { 11.4 Certification of Completion } \\
\text { of Postel osure Care } \\
\text { [Not in checkl ist] } \\
\text { WAC } 173-303-610(11) \\
40 \text { CFR } 264.120 \\
\end{array}$ & No & N/A under 646 & N/A under 264.552 \\
\hline $\begin{array}{l}11.5 \text { Closure Cost Estimate } \\
\text { [I-4] } \\
\text { WAC } 173-303-620(3) \text { and }(1)(c) \\
\text { WAC } 173-303-806(4)(a)(x V) \\
40 \text { CFR } 264.142 \\
40 \text { CFR } 270.14(b)(15) \\
\end{array}$ & No & N/A under 646 & N/A under 264.552 \\
\hline $\begin{array}{l}11.6 \text { Financial Assurance } \\
\text { Mechanism for Closure [I-5] } \\
\text { WAC } 173-303-620(4) \\
\text { WAC } 173-303-806(4)(a)(x v) \\
40 \text { CFR } 264.143 \\
40 \text { CFR } 264.146\end{array}$ & No & N/A under 646 & N/A under 264.552 \\
\hline $\begin{array}{l}11.7 \text { Postclosure Cost Estimate } \\
{[1-6]} \\
\text { WAC } 173-303-806(4)(a)(x v i) \\
\text { HAC } 173-303-620(5) \\
40 \text { CFR } 264.144 \\
40 \text { CFR } 270.14(b)(16)\end{array}$ & No & N/A under 646 & N/A under ? $? 64.552$ \\
\hline $\begin{array}{l}11.8 \text { Financial Assurance } \\
\text { Mechanism for Postclosure Care } \\
{[I-7]} \\
\text { WAC } 173-303-806(a) \text { (xvi) } \\
\text { WAC } 173-303-620(6) \\
40 \text { CFR } 264.145 \\
40 \text { CFR } 264.146 \\
\end{array}$ & No & N/A under 646 & N/A under 264.552 \\
\hline $\begin{array}{l}11.9 \text { Liability Requirements } \\
{[1-8]} \\
\text { WAC } 173-303-806(a)(x v i i) \\
\text { WAC } 173-303-620(8) \\
40 \text { CFR } 264.147\end{array}$ & No & N/A under 646 & N/A under 264.552 \\
\hline
\end{tabular}


Table 11-1. Chapter 11.0 Cross-Reference Table. ([ ] - Denotes location of information in Ecology Part B check 1 ist) (sheet 3 of 4 )

\begin{tabular}{|c|c|c|c|}
\hline ERDF out l ine chapter* & $\begin{array}{l}\text { Specifically requi red } \\
\text { by cam regulation? }\end{array}$ & $\begin{array}{l}\text { Washington State } \\
\text { CAMU Regulations** } \\
173-303\end{array}$ & $\begin{array}{l}\text { Federal } \\
\text { CAMU regulations } \\
40 \text { CFR }\end{array}$ \\
\hline $\begin{array}{l}11.10 \text { Closure Plan for ERDF CAN } \\
\text { Trench } \\
\text { [Not in checklist] } \\
\text { WAC } 173-303-806(4)(a)(x i i i) \\
\text { WAC } 173-303-610 \\
\text { WAC } 173-303-610 \\
\text { WAC } 173-303-610 \\
\text { WAC } 173-303-665(6) \\
\text { WAC } 173-303-806(4)(c)(i v) \\
\text { WAC } 173-303-665(8)(a)(v i i j) \\
\text { WAC } 173-303-665(6)(a) \\
\text { WAC } 173-303-610(3)(a)(v i i) \\
\text { WAC } 173-303-610(4) \\
\text { WAC } 173-303-610(4)(a) \\
40 \text { CFR } 270.14(b) 13 \\
40 \text { CFR } 264.112(a)(1) \&(2) \\
40 \text { CFR } 264.112(b)(1)-(6) \\
40 \text { CFR } 264.114 \\
40 \text { CFR } 264.310 \\
40 \text { CFR } 270.21(e) \\
40 \text { CFR } 270.20(f) \\
40 \text { CFR } 264.310(a) \\
40 \text { CFR } 264.310(a)(1)-(5) \\
40 \text { CFR } 264.112(b)(6) \\
40 \text { CFR } 264.112(b)(2) \\
40 \text { CFR } 264.113(a) \& \text { (b) }\end{array}$ & Yes & $\begin{array}{l}646(5)(a)(i),(i i) \text {, and (iv) } \\
646(5)(b)(i v) \\
646(5)(c)\end{array}$ & $\begin{array}{l}264.552(c)(1),(2), \text { and }(4) \\
264(e)(2),(3)(i i), \text { and }(4) \\
\text { CAMU Criteria } 1,2 \text {, and } 4\end{array}$ \\
\hline $\begin{array}{l}11.11 \text { postclosure Plan [l-2] } \\
\text { WAC } 173-303-610(8)(\mathrm{a}) \\
\text { WAC } 173-303-665(6) \\
\text { WAC } 173-303-806(4)(\mathrm{d})(\mathrm{vii}) \\
\text { WAC } 173-303-806(4)(\mathrm{e})(\mathrm{ix}) \\
\text { HAC } 173-303-866(4)(\mathrm{h})(\mathrm{v}) \\
40 \text { CFR } 264.118 \\
40 \text { CFR } 264.119 \\
40 \text { CFR } 264.197(\mathrm{~b}) \\
40 \text { CFR } 264.197(\mathrm{c})(2) \\
40 \text { CFR } 264.310(\mathrm{~b}) \\
40 \text { CFR } 270.14(\mathrm{~b})(13) \\
40 \text { CFR } 270.17(f) \\
40 \text { CFR } 270.18(\mathrm{~h}) \\
40 \text { CFR } 270.20(f) \\
40 \text { CFR } 270.20(\mathrm{~g}) \\
40 \text { CFR } 270.21(\mathrm{e}) \\
40 \text { CFR } 270.23(\mathrm{a})(3)\end{array}$ & Yes & $\begin{array}{l}646(5)(a)(i),(i i), \text { and (iv) } \\
646(5)(b)(i i i)(B) \\
646(5)(b)(i v)\end{array}$ & $\begin{array}{l}264.552(c)(1)-(7) \\
264.552(e)(4)(i v) \\
\text { CAMU Criteria } 1-7\end{array}$ \\
\hline
\end{tabular}


Table 11-1. Chapter 11.0 Cross-Reference Table.

([ ] - Denotes location of information in Ecology Part $B$ check 1 ist) (sheet 4 of 4 )

\begin{tabular}{|c|c|c|c|}
\hline ERDF outl ine chapter* & $\begin{array}{l}\text { Specifically required } \\
\text { by CAMU regulation? }\end{array}$ & $\begin{array}{c}\text { Washington State } \\
\text { CAMU Regulations* } \\
173-303\end{array}$ & $\begin{array}{l}\text { Federal } \\
\text { CAMU regulations } \\
40 \text { CFR } \\
\end{array}$ \\
\hline $\begin{array}{l}11.12 \text { Closure and Postclosure } \\
\text { Documentation [I-3] } \\
\text { WAC } 173-303-610(7) \\
\text { WAC } 173-303-610(9) \\
\text { WAC } 173-303-610(10) \\
\text { WAC } 173-303-610(11) \\
40 \text { CFR } 270.14(b)(14) \\
40 \text { CFR } 264.119\end{array}$ & No & N/A under 646 & N/A under 264.552 \\
\hline
\end{tabular}

* The sections of this application are based on the Ecology Part B Checklist. The referenced regulations, both state (HAC 173-303) and federal (40 CFR 260-270), provide the specific requirements that typically are incorporated in these sections.

** Assumes that Washington State has received HSWA authority. 
1

4

\section{CONTENTS}

12.0 REPORTING AND RECORDKEEPING . . . . . . . . . . . 12-1

12.1 NOTIFICATION OF DANGEROUS WASTE ACTIVITIES . . . . . . 12-1

12.2 TREATMENT, STORAGE, AND DISPOSAL REQUIREMENTS . . . . . . 12-1

12.3 IMMEDIATE REPORTING . . . . . . . . . . . . . 12-1

12.4 ENVIRONMENTAL RESTORATION DISPOSAL FACILITY REPORTING

AND RECORDKEEPING REQUIREMENTS ............. . 12-2

12.4.1 Reporting Requirements ............ 12-2

12.4.1.1 Waste Transfer Reports . . . . . . . 12-2

12.4.1.2 Annual Environmental Restoration

Disposal Facility Waste Reports . . . . 12-3

12.4.1.3 Groundwater Monitoring Notification

Reports ............ 12-3

12.4.1.4 Contingency Plan Incident Records ..... 12-3

12.4.1.5 Closure Reports ............ . 12-4

12.4.1.6 Postclosure Reports ........ . . 12-5

12.4.1.7 Proposed Subpart S Reporting

Requirements .......... 12-6

12.4.2 Recordkeeping Requirements ............ 12-6

12.4.2.1 Facility Plans ......... 12-6

12.4.2.2 Operating Records ......... 12-6

12.4.2.3 Miscellaneous Support Recordkeeping . . . 12-8

\section{TABLE}

12-1. Chapter 12.0 Cross-Reference Table .......... . T12-1 


$$
\text { DOE/RL-94-40, Rev. } 0
$$

06/94

1

2

3

4

This page intentionally left blank. 
DOE/RL-94-40, Rev. 0

06/94

\subsection{REPORTING AND RECORDKEEPING}

The RCRA TSD reporting requirements are well documented in 40 CFR 264.70, and in WAC 173-303 (Table 12-1). Although these reporting requirements are not explicitly required for CAMUs, applicable reports that will be provided and maintained for the ERDF have been included in the following sections.

The CAMU regulations, 40 CFR 264.552 and WAC 173-303-646, do not explicitly define reporting and recordkeeping requirements for CAMUs. Proposed Subpart S Rules, as presented in the Federal Register (55 FR 145), provide the basis for development of the recently promulgated CAMU regulations, but do not afford specific information concerning reporting requirements. The Proposed Subpart $S$ Rules state that the following three notifications may be required: (1) notification of groundwater contamination; (2) notification of air contamination; and (3) notification of residual contamination, including deed notation (or similar device) of buried contamination and indication of the types, concentrations, and locations of hazardous waste and hazardous constituents. These three notification requirements are addressed in Section 12.4.1.

The following reports and recordkeeping activities for the ERDF are based upon those for RCRA/TSD units. These reports and recordkeeping activities have been modified, however, to meet CAMU requirements, as impiied within 40 CFR 264.552 and WAC 173-303-646.

\subsection{NOTIFICATION OF DANGEROUS WASTE ACTIVITIES}

Notification of dangerous waste activities as described in WAC 173-303-290 is not required for the ERDF because it will not accept waste shipments from offsite generators or from a foreign source.

\subsection{TREATMENT, STORAGE, AND DISPOSAL REQUIREMENTS}

Reporting and recordkeeping specific to TSD units are not applicable to the ERDF, as it is not a RCRA TSD, as defined in 40 CFR 264 and WAC 173-303. However, several of these requirements were used as a basis for developing the ERDF reporting requirements, as described in Section 12.4 .

\subsection{IMMEDIATE REPORTING}

A1though CAMU regulations do not require immediate reporting, it will be included to fulfill CAMU Decision Criteria 2 [40 CFR 264.552(c)(2)) and WAC 173-303-646(5)(a)(iii)]: "waste management activities associated with the CAMU shall not create unacceptable risks to humans or the environment resulting from exposure to hazardous waste or hazardous constituents."

In the event of any noncompliance at the ERDF with the Hanford Facility Permit that might endanger human health and the environment, the DOE-RL will 
verbally report the incident to Ecology and the EPA. Any such information will be reported within 24 hours after the DOE-RL becomes aware of the circumstances of the noncompliance. The immediate verbal report will contain all the information needed to determine the nature and extent of any potential threat to human health and the environment.

\subsection{ENVIRONMENTAL RESTORATION DISPOSAL FACILITY REPORTING AND RECORDKEEPING REQUIREMENTS}

Information obtained, retained, and reported for the ERDF must include those data that demonstrate compliance with CAMU criteria performance standards. Particularly, sufficient information must be obtained to ensure the following: (1) the ERDF operates effectively; (2) waste placed in the ERDF is characterized appropriately so they can be safely managed during the operational phase and closure and postclosure periods; and (3) the location of waste placement within the ERDF is known and understood such that appropriate long-term management can be achieved. The following reporting and recordkeeping requirements wil1 provide this information for hazardous/dangerous waste transported to and managed in the ERDF. The ERDF also wi11 manage TSCA remediated waste, and reporting and recordkeeping requirements applicable to management of this waste in a CAMU will be provided and implemented before acceptance of this remediation waste at the ERDF.

\subsubsection{Reporting Requirements}

This section discusses the reporting requirements that are applicable to the ERDF, which ensure that the CAMU criteria will be met. The following are included in the reporting requirements:

- Waste transfer reports

- Annual ERDF waste reports

- Groundwater monitoring notification reports

- Contingency plan incident records

- Closure reports

- Postclosure reports.

Biennial reports specific to the ERDF are not explicitly required, but the information normally required by the EPA to be included in these reports will be provided in the above-mentioned annual ERDF waste reports.

12.4.1.1 Waste Transfer Reports. Onsite waste transfer documentation for waste shipped on Hanford Facility roadways will be kept as good management practice. The specific information to be provided for each waste shipment, as wel1 as ERDF internal waste management and tracking systems, are described in Chapter 3.0, Section 3.2 of this application. Additional details relative to the specific reporting and recordkeeping that will be maintained for the ERDF will be provided before initiation of waste acceptance. 
1

30

The Hanford Facility has methods in place for tracking onsite waste shipments. A description of the waste tracking system that will be used at the ERDF is described in Chapter 3.0, Section 3.2.3.2 of this application.

\subsubsection{Annual Environmental Restoration Disposal Facility Waste Reports.} The Hanford Facility is required to submit annual dangerous waste reports for onsite activities, pursuant to WAC 173-303-390. Although not explicitly required for the ERDF, an annual ERDF waste report w111 be submitted by March 1 of each year. This report will include the following information:

- Name and location of the unit

- Calendar year covered by the report

- Sources of waste emplaced in the ERDF

- Description of the waste received at the ERDF during that calendar year.

12.4.1.3 Groundwater Monitoring Notification Reports. Quarterly reports of groundwater sampling results and an annual evaluation of these sampling results are not explicitiy required under 40 CFR 264.552 or WAC 173-303-646. However, quarterly and annual reports are prepared documenting Hanford Facility groundwater monitoring data (i.e., in RCRA groundwater monitoring projects), and it is appropriate to inciude the semiannually-collected ERDF data in these reports. The ERDF groundwater quality data will be included in the quarterly and annual reports published by the DOE-RL. Specifically, these reports will include both sampling results and an evaluation of the sampling results.

12.4.1.4 Contingency Plan Incident Records. In the event of an incident occurring at the ERDF that requires initiation of the emergency plan, the Building Emergency Director or coordinator, will notify the Occurrence Notification Center (376-2900).

If the ERDF stops operating in response to a fire, an explosion, or a release that could present a hazard to human health and the environment, the building emergency director or coordinator will notify the DOE-RL, via ERDF line management, that the ERDF is operation: and the emergency cleanup is complete, before commencing operations.

The DOE-RL also will provide three types of notifications pertinent to the ERDF: the incident assessment report, a 15 day report and an ERDF restart notification. Detalls of these notifications are provided in the following sections.

12.4.1.4.1 Incident Assessment Report. The Occurrence Notification Center (376-2900) immediately will notify affected county emergency management, Ecology and/or the EPA, and the individual designated as the on-scene coordinator for the southeastern Washington area of the National Response Center (1-800-424-8802) if a fire, an explosion, or a release at the 
1 ERDF could threaten human health and the environment outside of the Hanford

Facility. The report will contain the following information:

- Name and telephone number of reporter

- Name of the unit (ERDF)

- Time and type of incident

- Name and quantity of material(s) involved to the extent. known

- Extent of injuries if any

- Possible hazards to human health and the environment outside of the ERDF, including hazardous/dangerous constituents.

12.4.1.4.2 15-Day Report. The DOE-RL will provide a written report within 15 days of any incident that requires implementation of the contingency plan. The report will include the following:

- Name, address, and telephone number of owner/operator

- Name, address, and telephone number at the ERDF

- Date, time, and type of incident

- Name and quantity of materials involved

- Extent of injuries if any

- Assessment of actual or potential hazards to human health and the environment where this is applicable

- Estimated quantity and disposition of recovered material that resulted from the incident

- Cause of the incident

- Method of remediation

- Description of corrective action taken to prevent recurrence of the incident.

12.4.1.4.3 Restart Notification. If the ERDF stops operations in response to a fire, an explosion, or a release that could present a hazard to human health or the environment, the DOE-RL will notify the appropriate local authorities and regulators before operations are resumed in the affected area(s). The notification will indicate that cleanup procedures are complete and that emergency equipment is clean and fit for its intended use.

12.4.1.5 Closure Reports. Reports that will be provided regarding the closure of the ERDF trench will include the following: 
- Notification of beginning of closure

- Certification of closure

- The survey plat.

12.4.1.5.1 Notification of Closure. At least 60 days before the date on which final closure of the last ERDF trench cell is expected to begin, the appropriate regulatory agency witl be notified in writing.

12.4.1.5.2 Certification of Closure. Within 60 days of completion of final closure of the last ERDF trench cell, a certification signed by the DOE-RL and an independent registered professional engineer wili be submitted to the regulatory authority. The certification will be sent by registered mail or an equivalent delivery service and will state that the ERDF was closed in accordance with the approved closure plan. Documentation supporting the independent registered engineer's certification will be supplied upon request of the regulatory authority.

12.4.1.5.3 survey Plat. On submission of the closure certification, a survey plat indicating the location and dimensions of the ERDF will be submitted to the appropriate regulatory authorities. The survey plat will be prepared and certified by a professional land surveyor. The plat will contain a note that states the DOE-RL's obligation to restrict disturbance of the ERDF.

\subsubsection{Postclosure Reports. Postclosure reports will include the} following:

- Location records

- Notice in deed

- Postclosure care completion certification.

12.4.1.6.1 Location Records. Not later than 60 days after the submission of the closure certification, the DOE-RL will submit to the local zoning authority a record of the type, location, and quantity of dangerous waste disposed of at the ERDF.

12.4.1.6.2 Notice in Deed. Within 60 days of the certification of closure of the ERDF, the DOE-RL will sign, notarize, and file for recording a notice indicating that the disposal of dangerous waste has occurred at the ERDF and the location of the waste management activities. The notice will be sent to the Auditor of Benton County, P.0. Box 470, Prosser, WA, with instructions to record this notice in the General Index. This type of document is normally reviewed in property title searches.

12.4.1.6.3 Postclosure Care Completion Certification. No later than 60 days after completion of the postclosure care period for the ERDF, the DOE-RL will submit to the regulatory authority by registered mail or an equivalent delivery service, a certification that the postclosure care was performed in accordance with the approved postclosure plan. The certification will be signed by the DOE-RL and an independent registered professional engineer. Documentation supporting the engineer's certification will be furnished upon request. 
1 12.4.1.7 Proposed Subpart S Reporting Requirements. The proposed Subpart S 2 rules state that the following notifications be submitted: (1) notification 3 of groundwater contamination; (2) notification of air contamination; and

4 (3) notification of residual contamination. Because subpart $S$ is not final, 5 these notifications are not required. However, information pertinent to these 6 notification requirements will be submitted as part of other reports to be 7 submitted. Groundwater contamination can be assessed based on data included 8 in annual and quarterly groundwater reports (Section 12.4.1.3). Releases to 9 both air and groundwater may be included in contingency plan incident records

\subsubsection{Recordkeeping Requitements}

Recordkeeping requirements for TSD units are not directly applicable to the ERDF. However, because the ERDF is a large-scale operation that involves detailed operating records, specific information/data will be obtained and retained. This information is discussed in the following sections.

12.4.2.1 Facility Plans. To ensure safe and appropriate operation of the ERDF and to support CAMU Deciston Criteria requirements, the following plans will be included among those that will be required to be kept on the Hanford Facility:

- Hanford Facility Contingency PI an and amendments, and ERDF emergency plan (as discussed in Chapter 7.0 of this application)

- Training Plan

- Interim cover, closure, and postclosure plans

- Inspection plans.

Copies of these plans will be maintained for the active life of the ERDF, with the exception of inspection plans that are maintained for 5 years after inspections have been made. The specific location will be provided before waste acceptance at the ERDF. Modifications or amendments required as a result of changing regulatory and operational requirements will be submitted to the regulatory authority and added to the plans maintained at the ERDF.

12.4.2.2 Operating Records. Operating records typically are required for TSD units to detail and record activities. Although operating records are not specifically mandated for CAMUs, maintenance of these records relative to ERDF operations is necessary because of the large-scale and long-term waste management activities intended at the ERDF. Further, maintenance of ERDF records will ensure that all activities are appropriately documented, so that: (1) the ERDF is operated in a safe fashion to mitigate ongoing/future releases; (2) remediation activities are expedited; and (3) treatment activities, as applicable, are appropriately recorded. 
Operating records to be maintained at the ERDF include the following:

- Description and quantity of waste shipment to be managed in the ERDF including the date and method of emplacement

- Location, content and quantity of waste buried within the ERDF

- Waste analysis results

- Inspection records

- Waste minimization certification for the ERDF

- Groundwater monitoring results

- Contingency plan incident records.

Land disposal restrictions (LDRs) records will not be maintained, as emplacement of waste within the ERDF is not considered land disposal under RCRA and WAC regulations.

12.4.2.2.1 Waste Description and Quantity. The description and quantity of each waste to be deposited within the ERDF will be maintained in the ERDF operating records. Waste transfer and onsite waste tracking records, describing the types and quantities of remediation waste managed on a per load basis, are to be maintained as part of the operating record.

12.4.2.2.2 Waste Location. The location of each waste shipment and the quantity managed within the ERDF will be documented and maintained daily as described in Chapter 3.0. If remediation waste shipments from different remediation units are accepted during an individual day, the location of each load within the ERDF will be identified. The quantity of waste within each load will be recorded.

12.4.2.2.3 Waste Analysis. Waste analysis records of the remediation waste managed in the ERDF will be included in the operating record. The waste analysis information will be acquired from each remediation site. Specific recordkeeping procedures for the ERDF will be provided before initiation of waste acceptance at the ERDF.

12.4.2.2.4 Inspection Records. Inspection records will be maintained as part of the operational records for 5 years from the inspection date. The records will include the following:

- Date and time of inspection

- Inspectors's printed name and handwritten signature

- Notations of observations

- Date and nature of any repairs or other remedial actions.

12.4.2.2.5 Waste Minimization Cortification. Annually, a certification by the DOE-RL that the Hanford Facility (including the ERDF) is in compliance with waste minimization requirements is entered into the Hanford Facility 
DOE/RL-94-40, Rev. 0

$06 / 94$

operating record. A copy of this record will be included in the ERDF operating records.

12.4.2.2.6 Groundwater Monitoring Results. Groundwater monitoring results will be included within the annual and quarterly reports, discussed in Section 12.4.1.3. The ERDF reports will be included in the quarterly and annual reports.

12.4.2.2.7 Contingency Plan Incident Records. Records documenting the details of any incidents requiring implementation of the contingency $p$ lan at the ERDF will be maintained in the ERDF operating record. Events requiring implementation of the contingency plan or building emergency $p l$ an are recorded in the butlding manager's $10 \mathrm{~g}$ book, and the $\log$ book is audited to ensure that incidents were reported and handled properly. The Butlding Emergency Director or line management documents all situations requiring contingency $p l a n$ implementation on an event fact sheet and a copy of the event fact sheet is retained at the ERDF as part of the operating record. In addition to these records, occurrence reports will be generated to document incidents, including those that are judged too minor to require the implementation of the contingency plan, but that are identified as offnormal events, unusual occurrence, or emergencies.

12.4.2.3 Miscellaneous Support Recordkeeping. Miscellaneous support records will be kept, including training records. Because the unit is a CAMU, records concerning closure and postclosure cost estimates and certification(s) are not explicitly required, and liability coverage documentation is not required for federal facilities. However, although the ERDF is exempt from the closure and postclosure cost estimate requirements, the DOE-RL will submit an annual report updating the projections of anticipated costs for closure and postclosure of the ERDF. This report will be submitted annually to the appropriate regulatory authority. This report will be submitted on october 30 of each year, starting with the year after the issuance of the Hanford Facility Permit. Certification records are not required for the ERDF (Chapter 14.0). In accordance with 40 CFR 264.140(C) and WAC 173-303, liability documentation is not required for federaliy-owned facilities such as the Hanford Facility.

12.4.2.3.1 Training Records. Training records of each employee will be maintained at the ERDF. Training records, which include employee name and waste management position, document that employees have received the training required for that position. Training records on current employees will be kept until closure of the ERDF, while training on former employees are kept for 3 years from the date the employee last worked at the ERDF. Official training records are maintained for the ERDF waste management employees in the Training Records Information System. This database will be maintained by the Training Records Organization in accordance with the requirements of the Privacy Act of 1974. Presently, the training records of individual employees are available for inspection purposes through the Freedom of Information Act of 1966 . The DOE-RL is seeking authorization through the U.S. Department of Energy-Headquarters to amend the systems notice under the Privacy Act to allow regulatory agencies 'routine use' access to training records. 

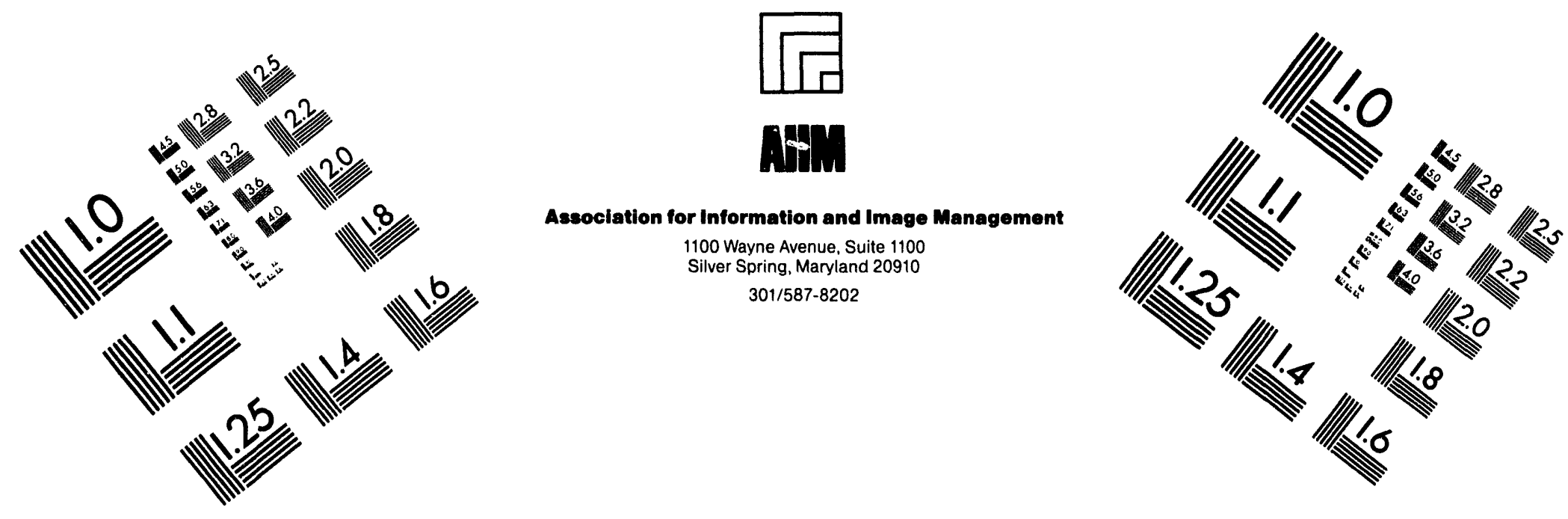

Centimeter

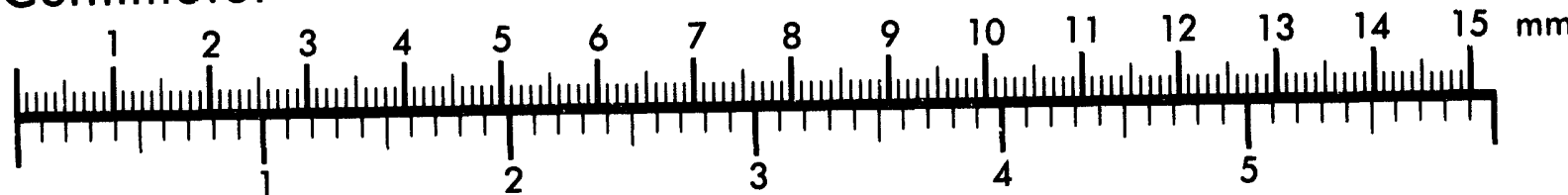

Inches
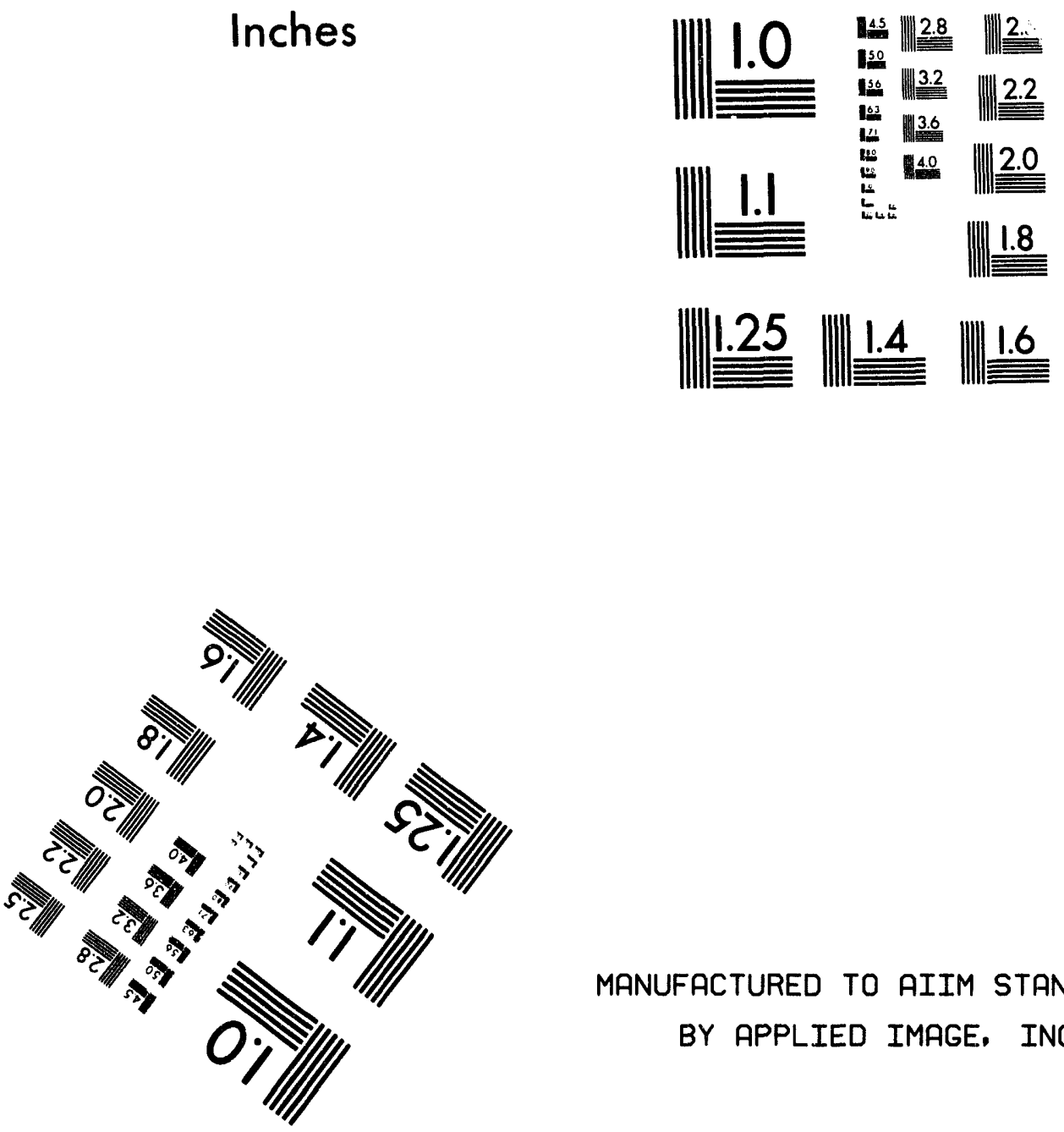

MANUFACTURED TO AIIM STANDARDS

BY APPLIED IMAGE, INC.

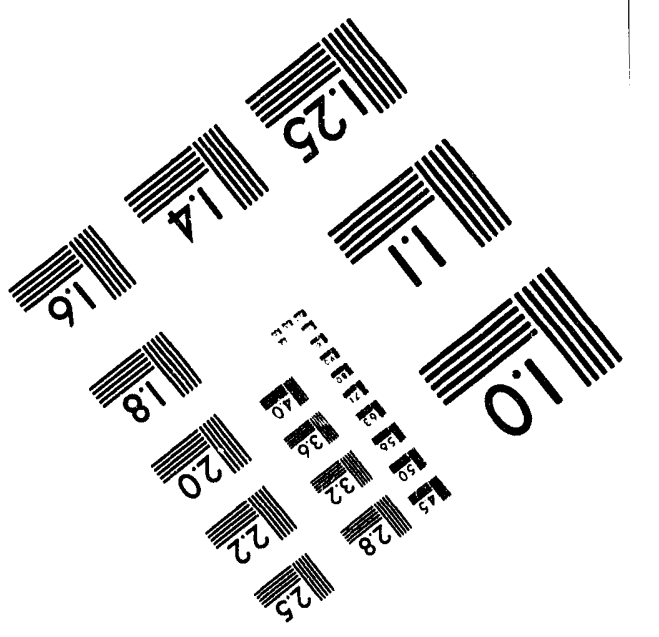



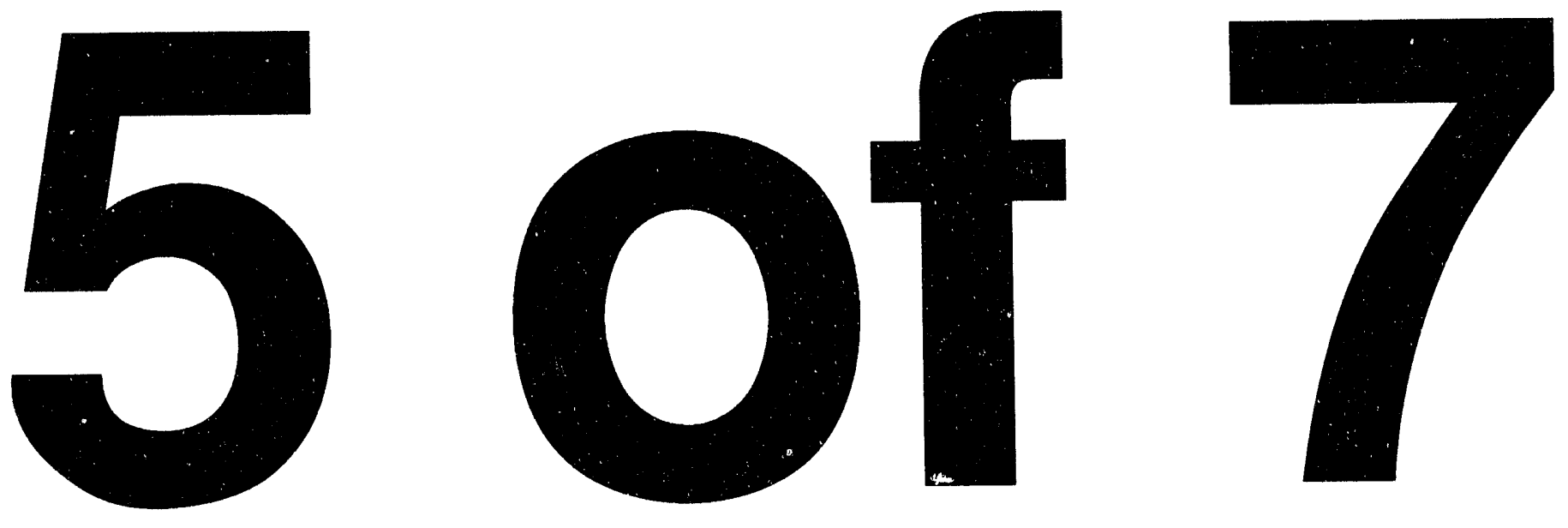
Table 12-1. Chapter 12.0 Cross-Reference Table.

([ ] - Denotes location of information in Ecology Part B checklist)

\begin{tabular}{|c|c|c|c|}
\hline ERDF outline chapter* & $\begin{array}{l}\text { Specifically required } \\
\text { by Camy regulation? }\end{array}$ & $\begin{array}{c}\text { Hashington State } \\
\text { CAMU Regulations** } \\
173-303\end{array}$ & $\begin{array}{c}\text { Federal } \\
\text { CAMU regulations } \\
40 \text { CFR } \\
\end{array}$ \\
\hline \multicolumn{4}{|c|}{ 12.0 Reporting and Recordkeeping [Not in checklist] } \\
\hline $\begin{array}{l}12.1 \text { Notification of Dangerous } \\
\text { Waste Activities }\end{array}$ & No & N/A & N/A \\
\hline $\begin{array}{l}12.2 \text { Treatment, Storage, and } \\
\text { Disposal Requirements }\end{array}$ & No & N/A & N/A \\
\hline $\begin{array}{l}12.3 \text { Immediate Reporting } \\
40 \text { CFR } 264.56 .(d)\end{array}$ & $\begin{array}{l}\text { No- - information is } \\
\text { provided in support of } \\
\text { CAMU criteria }\end{array}$ & $646(5)(a)(i i)$ & $\begin{array}{l}264.552(c)(2) \\
\text { CAMU Criteria } 1 \text { and } 2\end{array}$ \\
\hline $\begin{array}{l}\text { 12.4 Environmental Restoration } \\
\text { Disposal Facility Reporting and } \\
\text { Recordkeeping Requirements }\end{array}$ & $\begin{array}{l}\text { No-- information is } \\
\text { provided in support of } \\
\text { CAMU criteria }\end{array}$ & $646(5)(a)(i)$ and $(i i)$ & $\begin{array}{l}264.552(c)(1) \text { and }(2) \\
\text { CAMU Criteria } 1 \text { and } 2\end{array}$ \\
\hline
\end{tabular}

* The sections of this application are based on the Ecology Part B Checklist. The referenced regulations, both state (WAC 173-303) and federal (40 CFR 260-270), provide the specific requirements that typically are incorporated in these sections.

** Assumes that Washington State has received HSWA authority. 


\section{CONTENTS}

13.0 OTHER RELEVANT LAWS . . . . . . . . . . . . . . . . . . . . . . . 13.1 THE ATOMIC ENERGY ACT OF $1954 \ldots \ldots$. . . . . . . . . . 13-1

13.2 THE CLEAN AIR ACT OF $1977 \ldots \ldots$. . . . . . . . . . . . .

13.3 CLEAN WATER ACT OF $1977 \ldots \ldots$. . . . . . . . . 13-3

13.4 WASHINGTON STATE WATER POLLUTION CONTROL ACT . . . . . . 13-3

13.5 SAFE DRINKING WATER ACT OF $1974 \ldots \ldots$ 13-3

13.6 ENDANGERED SPECIES ACT OF $1973 \ldots \ldots \ldots$

13.7 FISH AND WILDLIFE COORDINATION ACT OF $1934 \ldots$ 13-4

13.8 NATIONAL HISTORIC PRESERVATION ACT OF $1906 \ldots$. . . . . . 13-4

13.9 WILD AND SCENIC RIVERS ACT OF $1968 \ldots \ldots \ldots$ 13-5

13.10 THE TOXIC SUBSTANCES CONTROL ACT OF $1976 \ldots \ldots$ 13-5

13.11 MODEL TOXICS CONTROL ACT OF 1990, AS AMENDED . . . . . 13-6

13.12 STATE ENVIRONMENTAL POLICY ACT . . . . . . . . . . . 13-7

13.13 OTHER REQUIREMENTS . . . . . . . . . . . . . 13-7

\section{TABLES}

13-1. Chapter 13.0 Cross-Reference Table . . . . . . . . . . . T13-1

13-2. Toxic Substances Control Act Polychiorinated Biphenyl and Asbestos Cross-Reference Table . . . . . . . . . T13-2 
DOE/RL-94-40, Rev. 0

06/94

1

2

3

This page intentionally left blank. 
DOE/RL-94-40, Rev. 0

$06 / 94$

\subsection{OTHER RELEVANT LAWS}

The 40 CFR 264.552 and WAC 173-303 provides flexibility relative to RCRA requirements for a CAMU, but does not exclude the CAMU from complying with other applicable regulations and relevant laws. Relevant environmental laws and regulations have been reviewed, with the necessary permits and approvals determined.

This chapter provides a summary of the regulatory review performed to ensure that other applicable regulations have been examined and compliance strategies developed for meeting these requirements. The major environmental laws evaluated include the following, all as amended:

- Atomic Energy Act of 1954

- The Clean Air Act of 1977

- The Clean Water Act of 1977

- Washington State Water Pollution Control Act

- Safe Drinking Water Act of 1974

- The Endangered Species Act of 1973

- The Fish and Wildlife Coordination Act of 1934

- The National Historic Preservation Act of 1966

- Wild and Scenic Rivers Act of 1968

- The Toxic Substance Control Act of 1976

- The Model Toxics Control Act of 1990.

A summary of the relationship among the CAMU regulations, RI/FS process, National Environmental Policy Act (NEPA) of 1969 roadmap and proposed plan, which are included in the Regulatory Package, also is included.

Table 13-1 presents a cross-reference among CAMU regulations, and RCRA and WAC TSD requirements for complying with other relevant laws. Although this application will be used to assess whether the substantive requirements of RCRA CAMU have been met as an ARAR under CERCLA (as well as the RCRA CAMU application), this chapter is not meant as a discussion of CERCLA ARARs. Applicable, relevant and appropriate law/regulations evaluated under CERCLA are discussed within the RI/FS document (DOE-RL 1994d). Rather, this chapter describes those regulations that must be complied with when the ERDF is permitted under RCRA for the acceptance of RCRA past-practice waste.

\subsection{THE ATOMIC ENERGY ACT OF 1954}

The Atomic Energy Act provides that the U.S. Atomic Energy Commission (succeeded by the DOE for conducting nuclear defense and research and development activities at the Hanford Site) is authorized to develop and implement regulations to govern activities related to the design, location, and operation of DOE sites, to protect health, and to minimize danger to life or property. The radioactive component of mixed waste is interpreted by the DOE to be regulated under the Atomic Energy Act; the nonradioactive dangerous component of mixed waste is interpreted to be regulated under the RCRA and WAC 173-303. 
1

2

The DOE has issued several orders to govern the activities of its sites and to manage the health protection aspects of mixed waste. These orders provide for a consistent approach to managing waste that results from DOE activities. The orders set radiation exposure limits and concentration guidelines to minimize exposure to radiation and detail the standards and procedures for managing mixed waste.

\subsection{THE CLEAN AIR ACT OF 1977}

The Clean Air Act establishes a federal and state cooperative scheme to control the airborne emission of pollutants and prevent further deterioration of air quality, by achieving and setting standards for abating air pollution, and maintaining the federally mandated national ambient air quality standards. Air standards are implemented and enforced primarily by state and local authorities. The Washington State clean air regulations address control of nearly 700 air pollutants including radioactive airborne emissions, ozonedepleting substances, and pollutants suspected of causing global warming. Compliance with these regulations requires specific actions before construction, startup, and normal operations of facilities (i.e., notices of construction, registration, annual reporting, air operating permit applications, etc.). The regulations require prior approval by one or more clean air agencies before any construction or modification is begun that would supply any significant increase in emissions.

The ERDF will comply with applicable federal, state, and local requirements to control and abate airborne emissions of pollutants, including the following.

- General regulations for sources of air pollutants (WAC 173-400 through 495) established under the authority of the Washington Clean Air Act (Revised Code of Washington [RCW] 70.94). A notice of construction and new source review, under WAC 173-460 (controls for new sources of toxic air pollutants), is required for the ERDF before acceptance of RCRA past-practice remediation waste.

- National Emission Standards for Hazardous Air Pollutants (40 CFR 61) and National Emission Standards for Radionuclide Emissions from U.S. Department of Energy Facilities ( 40 CFR 61, Subpart H). An approval to construct from the EPA is required for the ERDF before acceptance of RCRA past-practice remediation waste. Documentation of this nature is not explicitly required under CERCLA.

- Radiation Protection Air Emissions (WAC 246-247) regulates radioactive air emissions and has adopted the federal radionuclide National Emission Standards for Hazardous Air Pollutants (NESHAP) requirements. Under RCW, Nuclear Energy and Radiation, RCW 70.98 of the Washington Clean Air Act, the Department of Health's statutory mandate is established to regulate and enforce the standards of WAC 173-480. A radiation protection air emissions notice of construction is required for the ERDF before acceptance of RCRA past-practice remediation 
DOE/RL-94-40, Rev. 0

$06 / 94$

waste. Documentation of this nature is not explicitly required under CERCLA.

- Benton-Franklin Counties Air Pollution Control Authority general regulation 1 (1993).

\subsection{CLEAN WATER ACT OF 1977}

Operation of the ERDF will not result in the discharge of effluent to a surface water body requiring a National Pollutant Discharge Elimination System permit; therefore, no permits or review pursuant to the Clean water Act are applicable. However, should discharge of storm water to the ground be designated within the forthcoming Definitive Design Report for the ERDF, a Storm Water Discharge Plan will be submitted.

\subsection{WASHINGTON STATE WATER POLLUTION CONTROL ACT}

Discharge to soil is not planned as part of the ERDF; therefore, a permit application for a State Waste Discharge Permit, authorized by the Washington State Water Pollution Control Act, RCW 90.48 and WAC 173-216 is not required. Applicable permits relative to support operations for the ERDF will be obtained as required.

\subsection{SAFE DRINKING WATER ACT OF 1974}

The Safe Drinking Water Act regulates discharges to groundwater by way of injection wells. Support operations for the ERDF will include septic systems that are Class $V$ injection wells. Appropriate permits and/or documentation will be obtained for these support units, but the ERDF trench itself does not include any injection wells. Therefore, the Safe Drinking Water Act does not apply to the ERDF trench.

\subsection{ENDANGERED SPECIES ACT OF 1973}

The ERDF is located between the 200 East and 200 West Areas. Chapter 2.0 provides location information, as well as a detailed discussion of site environmental conditions including habitat types and areas, wildlife associations and uses, and available habitats. The June 1993 ecological survey (WHC 1993a) indicated that, relative to other portions of the 200 Areas, the ERDF site examined was relatively undisturbed. The survey also indicated that the area includes sagebrush habitat, which the dwarf evening primrose (a species of concern) relies upon, and construction of the ERDF would disturb this habitat. The Washington State Department of Fish and Wildlife has designated the shrub-steppe community in the ERDF area a Priority Habitat within the state. The survey did not indicate that any endangered or threatened species of plants or animals occurred within the ERDF area.

However, some animal species of concern, such as a pair of nesting long-billed curlews, were identified. 
The ERDF site occurs in a relatively small portion of the Hanford Facility and, hence, likely does not play a significant role in the overall ecology of the Hanford Facility due to the ERDF's relative size. No listed endangered or threatened species or their habitats are expected to be affected by ERDF activities, or those activities associated with the ERDF. However, the 1993 ecological survey (WHC 1993a) stated that construction will disturb the sagebrush habitat that species of concern rely upon. The survey recommended that consultations among the DOE-RL, the U.S. Department of Interior, and the Washington State Department of Fish and Wildlife take place to discuss the ERDF; these consultations are in progress. Additionally, a comprehensive baseline survey of the ERDF will be completed, as discussed in the site characterization plan (WHC 1994C).

\subsection{FISH AND WILDLIFE CONRDINATION ACT OF 1934}

The ERDF will not involve the impoundment, diversion, or other control or modification of any body of water. Therefore, no permits or review pursuant to this statute are applicable. Also, activities associated with the ERDF do not involve the impoundment, diversion, or other control or modification of any body of water, and no permits or review pursuant to this statute are applicable relative to these ERDF support units.

\subsection{NATIONAL HISTORIC PRESERVATION ACT OF 1966}

In the area near and around the ERDF, nine isolated artifacts, (three prehistoric and six historic), and five sites (one paleontologic, one with prehistoric and historic/modern components, and three historic), were recorded. Of these, three sites (HP-93-001, HT-93-080, and HT-93-081) do not meet any of the criteria necessary for listing on the National Register of Historic Places (National Register). The White Bluffs road crosses near the ERDF, and is a former Indian trail that has been in use since antiquity. This road has played a role in Euro-American immigration, development, and agriculture, and is considered eligible for the National Register of Historic Places. However, the road does not cross through the ERDF. The research potential of the five sites and of all but one of the nine isolated artifacts (isolates) has been exhausted through recordation and collection. South of the ERDF, HT-93-083, a wooden structure, and HT-93-084, a site associated with HT-93-083, by themselves, do not retain nationally significant information (WHC 1994b, d, and e).

The ERDF will not effect any properties eligible for the National Register because the ERDF will lie south and east of White Bluffs road. The ERDF will have no effect on sites HT-93-083 and HT-93-084 because these sites are well south of the ERDF site boundary. The Hanford Cultural Resources Laboratory (HCRL) will issue an updated survey report in early 1994, and results of this report will be included in a modification to this application, if applicable.

A11 necessary mitigation to preserve or protect any recent discoveries 51 52 
1 directed to watch for additional cultural properties during excavation

2 activities. If properties are discovered, personnel from the HCRL and the 3 DOE-RL will assess the significance of the find and will contact the State 4 Historic Preservation Officer.

\subsection{WILD AND SCENIC RIVERS ACT OF 1968}

The ERDF will not affect any rivers presently designated under the Wild and Scenic Rivers Act. Action relative to requirements under this Act are not warranted.

\subsection{THE TOXIC SUBSTANCES CONTROL ACT OF 1976}

The TSCA was enacted to protect human health and the environment by requiring that specific chemicals be tested and regulations restricting their processing and use be implemented. The objectives of the Act include the development of adequate data to determine the human health and environmental effects of chemicals, and to control any chemicals that present an unreasonable risk of injury. The section of the Act most relevant to the ERDF involves the emplacement of remediation waste that may contain polychlorinated biphenyls (PCBS) and asbestos. The regulations promulgated to prescribe the TSCA methods for disposal of PCBs is 40 CFR 761 ; regulations pertinent to disposal of asbestos are contained in 40 CFR 763.

As discussed in Chapter 3.0 of this application, the ERDF will receive PCBs and asbestos waste. TSCA is the primary regulatory tool for PCBs, and 40 CFR 761 presents TSCA regulations for the manufacturing, processing, distribution in commerce, and use prohibitions of PCBs. PCBs are also regulated under RCRA, but to a much lesser extent that TSCA. The RCRA LDRS pertain to PCBs when the PCBs are hazardous wastes (e.g., because the PCBs exhibit a characteristic of a hazardous waste or they have been mixed with a listed hazardous waste). Also, the RCRA LDR California list regulates halogenated organic compounds that include PCBs, when present in hazardous waste. Because the ERDF does not involve land disposal, LDRs do not apply automatically to PCBs that are a hazardous waste.

Subparts A, B, C, and $H$ of 40 CFR 763 are reserved and are therefore not applicable. Although Subpart E of 40 CFR 763 is not applicable, Appendix D to Subpart $E$ address important issues related to the transport and placement of asbestos waste, which include recordkeeping, waste handling and waste transport. Waste placement issues include selecting a placement facility, receiving asbestos waste, waste placement and covering, controlling public access, and recordkeeping. In addition, Appendix $D$ of 40 CFR 763 states the EPA has established asbestos placement requirements for active and inactive placement sites under NESHAPs (40 CFR Part 61, Subpart M), and specifies general requirements for sol id waste placement under RCRA (40 CFR 257). Because this section of the application pertains to TSCA regulations, these NESHAPs, asbestos, and RCRA solid waste requirements are not addressed. 
Placement of waste in a CAMU is not land disposal, and therefore, management of hazardous waste containing PCBs in the ERDF is not considered land disposal under RCRA. However, both the asbestos and PCB regulations frequently refer to the term "disposal". Because the CAMU is not a disposal unit, the term disposal should be interpreted as "placement". This change in the reading of the regulations in no way alters the meaning and effectiveness of the TSCA regulations relative to PCB and asbestos disposal. As such, the original intent of the TSCA regulations is satisfied.

The TSCA asbestos regulations are presented in 40 CFR 763. The TSCA asbestos regulations pertain to schools, state and local government employees, as well as the manufacture, import, process, and distribution of asbestos and asbestos-containing products. Asbestos is also regulated under CERCLA but to a much lesser extent than TSCA. Under CERCLA, asbestos (in a friable form) is considered to be a hazardous substance and has a reportable quantity of 1 pound. The National Response Center and appropriate state and local officials must be notified under these circumstances. Although asbestos is regulated under TSCA and CERCLA, NESHAP is the primary authority for regulation of asbestos. Asbestos handling, reporting, recordkeeping, and placement requirements for active and inactive placement sites are established under NESHAPS (40 CFR 61, Subpart $M$ ).

Table 13-2 is an overview TSCA roadmap, showing where general requirements of the TSCA regulations are addressed within the application. General data gaps relative to TSCA are also presented in this table, and should be assessed within the context of the overall data gaps present in this application. As applicable, this roadmap will be modified and detailed (i.e., to include more asbestos-related issues) before acceptance of RCRA remediation waste, as the ERDF waste management strategy for PCBs and asbestos is refined.

\subsection{MODEL TOXICS CONTROL ACT OF 1990, AS AMENDED}

The MTCA establishes administrative processes and standards to identify, investigate, and clean up facilities within the state of Washington where hazardous substances have come to be located. It defines the role of the department and encourages public involvement in decision making at these facilities.

The Washington Hazardous Waste Cleanup Regulations for CAMUs, WAC 173-303-646, establishes requirements for corrective action of releases of hazardous/dangerous waste and hazardous/dangerous constituents, including releases from solid waste management units. Specifically, the regulation states that the owner/operator of a facility may be required to fulfil his corrective action responsibilities under the MTCA, and/or by implementation of a CAMU. The regulations go on to state that "in the case of facilities seeking a permit....corrective action requirements imposed pursuant to the Model Toxics Control Act of 1990 (will be included in) the permit at the time of permit issuance."

51 
This application provides information to support issuance of a CAMU permit modification for management of remediation waste, and the ERDF is not (in and of itself) an area that requires remediation under MTCA. Rather, the ERDF is proposed to manage remediation waste from the Hanford Facility. Therefore, the MTCA does not directly apply to the ERDF.

\subsection{STATE ENVIRONMENTAL POLICY ACT}

The State Environmental Policy Act of 1971, WAC-197-11-960, requires evaluation of environmental impacts associated with a project before approval. The State Environmental Policy Act checklist that outlines how Act requirements have been met, was provided as Appendix $B$ to the ERDF Notice of Intent (WHC 1994b)

\subsection{OTHER REQUIREMENTS}

The ERDF is intended to manage both CERCLA and RCRA past--practice remediation waste. Because it may not be possible to obtain the permits and associated permit modifications before the Tri-Party Agreement-mandated September 1996 startup date, the DOE-RL wi11 seek to construct and operate the unit as a CERCLA facility until appropriate RCRA permitting has been obtained.

To receive CERCLA waste, an RI/FS process has been used to determine the optimal unit design considerations. The Tri-Party Agreement mandated use of a specific design for initial trench construction, however, which is presented in Chapter 4.0 of this application. A proposed plan will be prepared that outlines the ERDF effort, which eventually will be provided to the public for comment. The regulatory package will include a "NEPA Roadmap" where in the location of NEPA-required documentation will be indicated. A ROD will be prepared by the EPA, perhaps incorporating elements of the proposed plan; it is intended that the ROD be in place before initiation of ERDF construction. Throughout the proposed plan and ROD (document), it is intended that the ERDF will meet all necessary regulatory requirements to receive CERCLA waste in September of 1996. Because the ERDF initially will be a CERCLA facility, RCRA will be an ARAR and any ancillary support units (that could require RCRA permitting if the units managed RCRA waste) will meet the substantive requirements of RCRA. This means that these units wi11 be constructed and operated in compliance with RCRA, but RCRA documentation (i.e., permitting) is not required to manage CERCLA waste in the unit(s).

Parallel to this effort, the DOE-RL will seek and obtain all necessary permit modifications to operate the ERDF as a RCRA CAMU. It is assumed that a Hanford Facility Permit will be issued before the need for acceptance of RCRA past-practice waste in the ERDF, as RCRA requires that the ERDF and requisite support units be permitted before to operation. Because the ERDF and support units will have been constructed and operated in compliance with RCRA, it is not anticipated that any modification of the units, other than acquisition of permit documentation, will be required. 


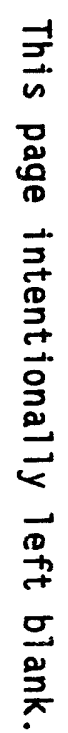


Table 13-1. Chapter 13.0 Cross-Reference Table.

([ ] - Denotes location of information in Ecology Part B checklist)

\begin{tabular}{|c|c|c|c|}
\hline EROF out l ine chapter* & $\begin{array}{l}\text { Specifically required } \\
\text { oy calm regulation? }\end{array}$ & $\begin{array}{c}\text { Washington State } \\
\text { CAMU Regulations** } \\
173-303 \\
\end{array}$ & $\begin{array}{l}\text { Federal } \\
\text { CAMU regulations } \\
40 \text { CFR } \\
\end{array}$ \\
\hline $\begin{array}{l}13.0 \text { Other Relevant Laws [J] } \\
\text { WAC } 173-303-806(4)(a)(x i x) \\
40 \text { CFR } 270.14(b)(20)\end{array}$ & No & N/A & $N / A$ \\
\hline
\end{tabular}

* The sections of this application are based on the Ecology Part B Checklist. The referenced regulations, both state (WAC 173-303) and federal ( 40 CFR 260-270), provide the specific requirements that typically are incorporated in these sections.

** Assumes that Washington State has received HSWA authority. 
Table 13-2. Toxic Substances Control Act Polychlorinated Biphenyl and Asbestos Cross-Reference Table. (sheet 1 of 3 )

\begin{tabular}{|c|c|}
\hline TSCA PCB Requlation & CAMU Permit Application \\
\hline 761.40 Marking requirements (re: marking) & Chapter 12.0 (as applicable) \\
\hline 761.45 Marking formats (re: marking) & Chapter 12.0 (if applicable) \\
\hline $\begin{array}{l}761.60(\mathrm{a})-(\mathrm{d}) \text { and }(\mathrm{g}) \text { Placement requi rements (re: } \\
\text { placement method, concentrations and test methods) }\end{array}$ & Chapters 3.0 and 4.0 \\
\hline $\begin{array}{l}761.60(f) \text { Placement requirements (re: written } \\
\text { notices) }\end{array}$ & Chapter 12.0 \\
\hline $\begin{array}{l}761.60 \text { (i) Placement requirements (re: approval } \\
\text { authority) }\end{array}$ & Chapter 12.0 \\
\hline $\begin{array}{l}761.65 \text { (a) Storage for placement (re: storage } \\
\text { period) }\end{array}$ & N/A \\
\hline $\begin{array}{l}761.65(b) \text { and }(c)(1)-(2) \text { storage for placement (re: } \\
\text { storage facility specifications and storage) }\end{array}$ & N/A \\
\hline $761.65(\mathrm{c})(3)$ Storage for placement (re: marking) & $N / A$ \\
\hline $\begin{array}{l}761.65(c)(4) \text { Storage for placement (re: } \\
\text { decontamination) }\end{array}$ & N/A \\
\hline $\begin{array}{l}761.65(c)(5) \text { storage for placement (re: leak } \\
\text { checks) }\end{array}$ & N/A \\
\hline $\begin{array}{l}761.65(c)(6) \text { and ( } 7) \text { Storage for placement (re: } \\
\text { shipping) }\end{array}$ & N/A \\
\hline $\begin{array}{l}761.65(c)(7)(i i) \text { storage for placement (re: SPCC } \\
\text { P(an) }\end{array}$ & N/A \\
\hline $\begin{array}{l}761.65(c)(8)-(9) \text { and (d) Storage for placement (re: } \\
\text { recordkeeping and written approval) }\end{array}$ & N/A (unless storage at ERDF required) \\
\hline $761.65(e)$ Storage for placement (re: closure) & N/A (unless storage at ERDF required) \\
\hline $\begin{array}{l}761.65(f) \text { Storage for placement (re: closure cost } \\
\text { estimate) }\end{array}$ & N/A \\
\hline $\begin{array}{l}761.65(h) \text { storage for placement (re: closure } \\
\text { certification) }\end{array}$ & N/A \\
\hline $\begin{array}{l}761.75(b) \text { Chemical waste landfills (re: technical } \\
\text { requirements for placement) }\end{array}$ & Chapter 4.0 \\
\hline $761.75(b)(1)$ & Chapters 4.0 and 5.0 \\
\hline $761.75(b)(2)$ & Chapter 4.0 \\
\hline $761.75(b)(3)$ & Chapter 5.0 \\
\hline $761.75(b)(4)$ & Chapter 2.0 \\
\hline $761.75(b)(5)$ & Chapter 2.0 \\
\hline $761.75(b)(6)$ & Chapters 2.0 and 5.0 \\
\hline $761.75(b)(7)$ & Chapter 4.0 \\
\hline $761.75(b)(8)$ & Chapter 4.0 \\
\hline $\begin{array}{l}761.75(c) \text { Chemical waste landfills (re: written } \\
\text { approval and information required for submission) }\end{array}$ & $\begin{array}{l}\text { Chapters } 1.0,2.0 \text {, Appendix } 2 A \text {, Chapters } 3.0,4.0 \text {, } \\
12.0 \text {, and } 13.0\end{array}$ \\
\hline 761.79 Decontamination (re: decontamination) & Chapter 4.0 \\
\hline
\end{tabular}


Table 13-2. Toxic Substances Control Act Polychlorinated Biphenyl and Asbestos Cross-Reference Table. (sheet 2 of 3 )

\begin{tabular}{|c|c|}
\hline TSCA PCB Regulation & CAMU Permit Application \\
\hline $\begin{array}{l}761.125(a)-(c) \text { Requirements for PCB spill cleanup } \\
\text { (re: PCB spill cleanup) }\end{array}$ & Chapter 6.0 \\
\hline $\begin{array}{l}761.130 \text { sempl ing requirements (re: sempl ing spill } \\
\text { areas to verify cleanup level) }\end{array}$ & Chapters 3.0 and 6.0 \\
\hline $\begin{array}{l}761.180 \text { (a) Recorda and monitoring (re: PCBs and PCB } \\
\text { ltems in service or projected for placement; annual } \\
\text { records (including manifests and certificates of } \\
\text { Placement), and written annual document log] }\end{array}$ & $N / A$ \\
\hline $\begin{array}{l}761.180(b) \text { Records and monitoring (re: Placement } \\
\text { and storers of PCB waste; annual records (including } \\
\text { manifests and Certificates of placement), written } \\
\text { annual document log, and annual report) }\end{array}$ & Chapter 12.0 \\
\hline $\begin{array}{l}761.180(d) \text { Records and monitoring [re: Chemical } \\
\text { waste landfill facilities; water analys is and } \\
\text { operations records] }\end{array}$ & Chapter 12.0 \\
\hline $\begin{array}{l}761.180(f) \text { Records and monitoring [re: Retention of } \\
\text { special recoicis by storage and placement facilities } \\
\text { (all documents, correspondence, data and } \\
\text { applications)] }\end{array}$ & Chapter 12.0 \\
\hline $\begin{array}{l}761.202 \text { EPA identification numbers (re: general, } \\
\text { prohibitions) }\end{array}$ & $\begin{array}{l}\text { Not in application (will be provided before waste } \\
\text { acceptance, if appl icable to ERDF) }\end{array}$ \\
\hline $\begin{array}{l}761.205 \text { Notification of PCB waste activity (EPA } \\
\text { Form } 7710-53 \text { ) (re: notification) }\end{array}$ & $\begin{array}{l}\text { Not in application (will be provided before } \\
\text { operation, if applicable to ERDF) }\end{array}$ \\
\hline $\begin{array}{l}761.207 \text { The manifest-general requirements (re: EPA } \\
\text { form } 8700-22 \text { ) }\end{array}$ & $\begin{array}{l}\text { Pertinent to offsite shipment: not applicable to } \\
\text { ERDF. Refer to Chapter } 2.0 \text { for waste tracking } \\
\text { that might follow process outlined in WHC-CM-7-5, } \\
\text { as applicable. }\end{array}$ \\
\hline 761.208 Use of the manifest (re: manifest) & $\begin{array}{l}\text { Pertinent to offsite shipment: applicability to } \\
\text { ERDF must be determined. Will follow process } \\
\text { outlined in WHC-CM-7-5, as applicable. }\end{array}$ \\
\hline $\begin{array}{l}761.209 \text { Retention of manifest records (re: manifest } \\
\text { recordkeeping) }\end{array}$ & $\begin{array}{l}\text { Pertinent to offsite shipment applicability to } \\
\text { ERDF must be determined. Will follow process } \\
\text { outl ined in WHC-CM-7-5, as applicable. }\end{array}$ \\
\hline $\begin{array}{l}761.210 \text { Manifest discrepancies (re: manifest } \\
\text { discrepancies) }\end{array}$ & $\begin{array}{l}\text { Pertinent to offsite shipment applicability to } \\
\text { ERDF must be determined. Will follow process } \\
\text { outlined in WHC-CM-7-5, as applicable. }\end{array}$ \\
\hline $\begin{array}{l}761.211 \text { Unmanifested waste report (re: unmanifested } \\
\text { waste report) }\end{array}$ & $\begin{array}{l}\text { Pertinent to offsite shipment appl icability to } \\
\text { ERDF must be determined. Will follow process } \\
\text { outlined in WHC-CM-7-5, as appl icable. }\end{array}$ \\
\hline 761.215 Exception report (re: exception report) & $\begin{array}{l}\text { Pertinent to offsite shipment applicability to } \\
\text { ERDF must be determined. Will follow process } \\
\text { outl ined in WHC-CM-7-5, as apol icable. }\end{array}$ \\
\hline $\begin{array}{l}761.218 \text { Certificate of placement (re: certificate } \\
\text { of placement) }\end{array}$ & $\begin{array}{l}\text { Should be provided before acceptance of RCRA past- } \\
\text { practice waste, if applicable to management in the } \\
\text { ERDF. }\end{array}$ \\
\hline
\end{tabular}




\begin{tabular}{|l|l|}
\hline \multicolumn{1}{|c|}{ TSCA Asbestos Regulation } & \multicolumn{1}{|c|}{ CAMU Permit Application } \\
\hline $\begin{array}{l}\text { subpart D-Reporting Commercial and Industrial Uses } \\
\text { of Asbestos }\end{array}$ & $\begin{array}{l}\text { Not applicable because the manufacturing, } \\
\text { importing, or processing of asbestos is not } \\
\text { involved. }\end{array}$ \\
\hline Subpart E-Asbestos-Containing Materials in Schools & Not applicable because schools are not involved. \\
\hline $\begin{array}{l}\text { subpart F-Friable Asbestos-Containing Materials in } \\
\text { Schools }\end{array}$ & Not applicable because schools are not involved. \\
\hline Subpart G-Asbestos Abatement Projects & $\begin{array}{l}\text { Not applicable because state or local government } \\
\text { employees are not involved. }\end{array}$ \\
\hline $\begin{array}{l}\text { subpart I-prohibition of Manufacture, Importation, } \\
\text { Processing, and Distribution in Commerce of Certain } \\
\text { Asbestos-Containing Products; Labelling } \\
\text { Requirements }\end{array}$ & $\begin{array}{l}\text { Not applicable because the manufacturing, } \\
\text { importing, processing, and distribution in } \\
\text { commerce of asbestos-containing products is not } \\
\text { involved. }\end{array}$ \\
\hline
\end{tabular}




\section{- DOE/RL-94-40, Rev. 0}

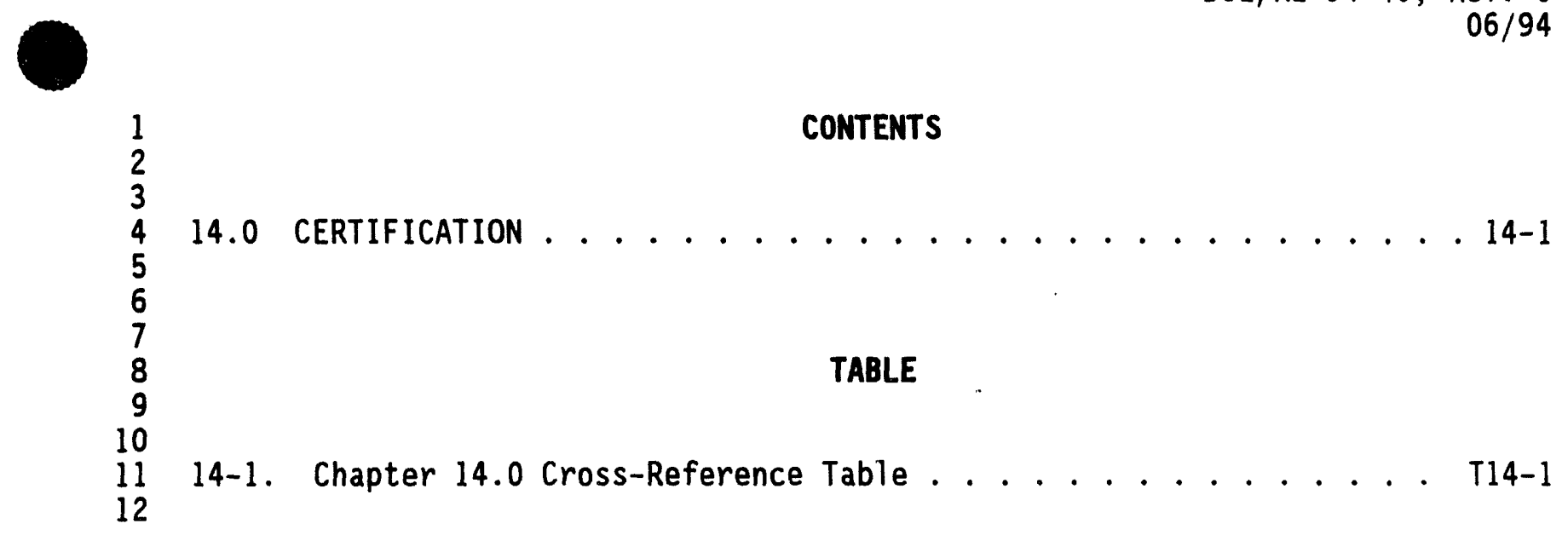


This page intentionally left blank. 
DOE/RL-94-40, Rev. 0

06/94

1

2

3

4

16

17

18

\subsection{CERTIFICATION}

The WAC 173-303-810(13) indicates that all applications and associated reports submitted to Ecology include a certification statement. Because, as a CAMU, the ERDF will not be a RCRA/WAC TSD unit and the Hazardous and Solid Waste Amendments (HSWA) of 1984 regulations do not specifically require that associated documentation be certified. Also, the CAMU regulations presented in 40 CFR 264.552 and WAC 173-303-646 (Table 14-1) do not indicate that specific certification statements are required for CAMU information; corrective action documents typically do not include this requirement. Certification requirements for TSD units present within the boundary of the ERDF will be addressed in a separate application.

However, when and if Ecology receives authority for CAMU, and this application is submitted to Ecology, the application will contain a certification statement. 
DOE/RL-94-40, Rev. 0

This page intentionally left blank. 
Table 14-1. Chapter 14.0 Cross-Reference Table.

([ ] - Denotes location of Information in Ecology Part B checklist)

\begin{tabular}{|l|l|l|l|}
\hline \multicolumn{1}{|c|}{ ERDF Outline Chapter* } & $\begin{array}{c}\text { Specifically Required } \\
\text { by CAMU Regulation? }\end{array}$ & $\begin{array}{c}\text { Washington State } \\
\text { CAMU Regulations** } \\
\text { 173-303 }\end{array}$ & $\begin{array}{c}\text { Federal } \\
\text { CAMU Regulations } \\
\text { 40 CFR }\end{array}$ \\
\hline $\begin{array}{l}14.0 \text { Certification [K] } \\
\text { WAC } 173-303-810(13) \\
40 \text { CFR } 270.11(\mathrm{a})\end{array}$ & No & N/A & N/A \\
\hline
\end{tabular}

- The sections of this application are based on the Ecology Part B Checklist. The referenced regulations, both state (WAC 173-303) and federal (40 CFR 260-270), provide the specific requirements that typically are incorporated in these sections.

** Assumes that the Washington State has received HSWA authority. 
DOE/RL-94-40, Rev. 0

$06 / 94$

\section{CONTENTS}

15.0 DECISION CRITERIA FOR CORRECTIVE ACTION MANAGEMINT UNIT . . . . . 15-1

15.1 CORRECTIVE ACTION MANAGEMENT UNIT DECISION CRITERIA

DISCUSSIONS . . . . . . . . . . . . . . . 15-1

15.1.1 Corrective Action Management Unit Decision

Criterion No. I . . . . . . . . . . . . . 15-1

15.1.1.1 Hanford Facility Setting and Site

Environmental Conditions ...... . 15-1

15.1.1.2 Environmental Restoration Disposal

Facility Design, Operation, and

Management ........ . . 15-3

15.1.1.3 Closure and Postclosure Design ... . . 15-3

15.1.1.4 Qualitative Risk . . . ....... . 15-4

15.1.1.5 Contaminant Transport Modeling Results . . 15-5

15.1.1.6 Cost-Effectiveness of the Unit Relative

to Other Designs .. . . . . . . 15-5

15.1.1.7 Decision Criterion No. 1 Summary . . . . 15-6

15.1.2 Corrective Action Management Unit Decision

Criterion No. 2............ . . 15-7

15.1.2.1 Environmental Restoration Disposal

Facility Operations and Design . . . . 15-8

15.1.2.2 Qualitative Risk and Contaminant

15.1.2.3 Decision Criterion No. 2 Summary ... . 15-10

15.1.3 Corrective Action Management Unit Decision

Criterion No. 3.............. 15-11

15.1.3.1 Use of the 200 Areas for the

Environmental Restoration Disposal

Facility Versus offsite Facilities

and Other Hanford Facility Areas ... . 15-11

15.1.3.2 200 Areas Location Evaluations .... 15-12

15.1.3.3 Consolidation of Waste at a

Central Area .......... 15-13

15.1.3.4 Use of Contaminated Areas ...... . . 15-13

15.1.3.5 Environmental Restoration Disposal

Facility Unit Design and Modeling

Results............. 15-14

15.1.3.6 Decision Criterion No. 3 Summary .. . 15-14

15.1.4 Corrective Action Management Unit Decision

Criterion No. 4.............. 15-14

15.1.4.1 Envirunmental Restoration Disposal
Facility Unit Design ....... 15-15

15.1.4.2 Closure and Postclosure ........ . . 15-15

15.1.4.3 Contaminant Transport Modeling . . . . 15-17

15.1.4.4 Decision Criterion No. 4 Summary . . . 15-17 
DOE/RL-94-40, Rev. 0

$06 / 94$

CONTENTS (cont)

15.1.5 Corrective Action Management Unit Decision

Criterion No. 5. . . . . . . . . . . . 15-18

15.1.5.1 The Environmental Restoration

Disposal Facility and Tri-Party

Agreement ............ 15-18

15.1.5.2 Decision Criterion No. 5 Summary . . . 15-19

15.1.6 Corrective Action Management Unit Decision

Criterion No.6............... 15-19

15.1.6.1 Environmental Restoration Disposal

Facility's Role in the Remedial

Program Process . . . . . . . . . . 15-20

15.1.6.2 Specific Technological

Considerations/Limitations . . . . 15-21

15.1.6.3 Placement of High Volume-Low

Concentration Waste in the

Environmental Restoration

Disposal Facility.......... . 15-22

15.1.6.4 Modeling Results ........... . 15-22

15.1.6.5 Decision Criterion No. 6 Summary . . . 15-22

15.1.7 Corrective Action Management Unit Decision

Criterion No. 7 ............... 15-23

15.1.7.1 Size of the Environmental Restoration

Disposal Facility Relative to Areas

Requiring Remediation....... 15-23

15.1.7.2 Decision Criterion No. 7 Summary .. . . 15-24

15.2 INFORMATION THAT MUST BE ADDRESSED IN THE REGULATORY

PACKAGE AS MANDATED BY THE TRI-PARTY AGREEMENT . . . . . 15-24

\section{FIGURES}

15-1. Base Case and Area Fill Trench Cross-Section ......... . F15-1

15-2. Remediation Process for the Hanford Facility CERCLA

Past-Practice Remediation Sites . . . . . . . . . . . F15-2

15-3. Corrective Action Process for the Hanford Facility RCRA

Past-Practice Remediation Sites. . . . . . . . . . . F15-3

15-4. Remedial Evaluation Criteria for Remedy Selection at

Hanford Facility CERCLA Past-Practice Remediation Sites . . . F15-4

15-5. Corrective Measures Evaluation Criteria for Remediation of

Hanford Facility RCRA Past-Practice Sites ... . . . . . F15-5 
DOE/RL-94-40, Rev. 0

$06 / 94$

\section{TABLES}

15-1. Chapter 15.0 Cross-Reference Table . . . . . . . . . . . T15-1

15-2. Cost Comparison of the Environmental Remediation Disposal

6 Facility Configuration Options ............ T15-2

7 15-3. Preliminary Screening Surmary . . . . . . . . . . . T15-3

8 
DOE/RL-94-40, Rev. 0

06/94

This page intentionally left blank. 


$$
\text { DOE/RL-94-40, Rev. } 0
$$

\subsection{DECISION CRITERIA FOR CORRECTIVE ACTION MANAGEMENT UNIT}

For the regulatory agency(s) to evaluate the viability of the ERDF as a CAMU, seven specific criteria must be met. Information sufficient to demonstrate that the CAMU criteria have been met has been included in the preceding chapters. In addition, the preceding chapters include information that the owner/operator is required to provide under 40 CFR 264.552(d) and WAC 173-303-646(5)(e). Data requirements 1isted in 40 CFR $264.552(\mathrm{e})$ and WAC $173-303-646(5)$ (b) al so were addressed.

\subsection{CORRECTIVE ACTION MANAGEMENT UNIT DECISION CRITERIA DISCUSSIONS}

The following sections discuss each of the CAMU decision criteria, indicating how material in this application and associated references demonstrate that each of the CAMU criteria have been met. This requirement is unique to the CAMU regulations, as shown in Table 15-1.

\subsubsection{Corrective Action Management Unit Decision Criterion No. 1 40 CFR 264.552(c)(1) [WAC 173-303-646(5)(a)(i)]}

CAMU Decision Criterion No. 1 states: The CAMU shall facilitate the implementation of reliable, effective, protective, and cost-effective remedies. The ERDF setting and environmental conditions support this criterion because the ERDF will be relatively distant from major population areas, will be topographically isolated, and will occur in an area with a deep water table and minimal annual precipitation; thus enhancing the reliability, effectiveness, and protectiveness of the ERDF. The design, operation, and management of the ERDF trench and support units will ensure that the ERDF wi11 offer near-term and relative long-term protectiveness, and that safeguards will be in place (i.e., contingency plans) to ensure that operation of the ERDF does not jeopardize human health and the environment. Closure and postclosure of the ERDF will ensure long-term reliability, effectiveness, and protectiveness of the ERDF through effective final cover design and postclosure monitoring programs. All of these factors contribute to low-qualitative risk for the ERDF relative to releases via air, surface water, soil, and groundwater pathways, which is supported by contaminant transport modeling results. Further, the ERDF is the most cost-effective alternative when compared to offsite shipment or onsite management of remediation waste at multiple units (i.e., management at the remediation sites). These factors that support CAMU Criterion No. 1 are discussed in more detail in the following section.

15.1.1.1 Hanford Facility Setting and Site Environmental Conditions. The ERDF will be located in the 200 Areas. This area is over 32 kilometers (20 miles) from the nearest population center (Richland, Washington), and is topographically isolated upon a plateau, as discussed in detail in

Chapter 2.0. The ERDF also will be over 11.3 kilometers ( 7 miles) from the Columbia River at its closest point. Much of the waste that will be shipped to the ERDF are immediately adjacent to the Columbia River. Depth to 
1 groundwater below the ERDF is almost 300 feet belowground surface. Geologic 2 units immediately underlying the ERDF (after construction) consist of finer 3 grained sands/silts/clays that might impede downward contaminant migration. 4 (Refer to Chapter 5.0 for additional information concerning site geologic and 5 hydrologic conditions at the ERDF.) Because the Hanford Facility receives an 6 average of only 16 centimeters (6.3 inches) of precipitation per year, 7 downward infiltration of rainwater is not anticipated to be significant, based 8 upon results from the ERDF RI/FS (DOE-RL 1994d). When combined with ERDF design (refer to Section 15.1.1.2 and Chapter 4.0), this factor substantially minimizes the potential for contaminant migration to groundwater from the ERDF.

As described previously, a groundwater monitoring program will be inplace to ensure that any releases from the ERDF are detected. However, groundwater modeling results (Section 15.1.1.5) indicate that contaminant transport within the vadose and saturated zones is minimal to nonexistent un to 500 years in the future. The ERDF groundwater contaminant transport deling results are based on and support the specific risk assessment criteria identified in the Tri-Party Agreement. These criteria are as follows.

- The point of assessment is the boundary (i.e., edge) of the unit.

- The risk assessment period for radionuclides is 10,000 years.

- The risk-based compliance standard is $10^{-5}$ for the first 100 years and $10^{-4}$ thereafter.

Therefore, site environmental conditions, together with design considerations, minimize the potential for contaminant migration to soil and groundwater.

No federally-endangered species occur in the ERDF area, as discussed in Chapters 2.0 and 13.0. A preliminary ecological survey of the 200 Areas Plateau in the vicinity of the ERDF location the presence of state and/or federal plant and animal species of concern, and of habitat for an animal species of concern. It should be recognized that the DOE-RL plans to conduct a baseline ecological survey in the near future, the results of which will be incorporated in subsequent documents and oesign/construction activities. It also is important to note that the 4.14 square kilometer ( 1.6 square mile) area of the ERDF represents less than 0.3 percent of the overal1 Hanford Facility and would not play a significant role in the overall ecology on the Hanford Facility.

Construction and operation of the ERDF will not involve the impoundment, diversion, or other control or modification of any body of water. The ERDF will not affect any rivers presently designated under the Wild and Scenic Rivers Act. However, remediation waste will be accepted from remediation sites adjacent to a section of the Columbia River that is being considered for designation under this Act. Therefore, the ERDF will provide a location for remediation waste placement that is more protective of human health and the environment than leaving the waste beside the river. The ERDF also will facilitate the return of the river to its natural state by removing 
DOE/RL-94-40, Rev. 0

$06 / 94$

1 contamination away from the river banks. Although winds can exceed

2128 kilometers (80 miles) per hour at the Hanford Facility (Chapter 2.0,

3 Section 2.11), dust suppression and other actions (including cessation of

4 operations under certain wind conditions) will be taken to mitigate

5 contaminant migration in the air pathway during the operational and closure

6 periods.

15.1.1.2 Environmental Restoration Disposal Facility Design, Operation, and Management. As indicated in Chapter 4.0, an MTR design will be used for the ERDF trench. Use of the MTR trench design will offer significant protection during the operational period because underlying soil will not come in contact with overlying waste material. Further, collection of any leachate will divert potentially contaminated waters that could migrate downward, again providing protectiveness to the local (underlying) environment. Although the iner system is not intended to function intact for thi entire risk assessment period referenced in the Tri-Party Agreement, use of this system offers at least near-term (approximately 30 years) protection, while providing data that can be used to understand leachate generation, etc., that may be used to further evaluate the effectiveness of the overlying interim, final interim, and final covers (Chapter 11.0).

The proposed interim cap also will offer significant short-term protectiveness to the underiying soil environment, and will minimize leachate generation during the operational period. As noted in Chapter 4.0, details regarding ERDF design will be provided in forthcoming revisions to this application.

Proper waste management and operation also will ensure the effectiveness and protectiveness of the ERDF, particularly in the short term. As discussed in detail in Section 15.1.2, the operations pian will detail operational and management requirements for the ERDF. This CAMU application includes specific procedures (Chapter 6.0) "hat will be enacted to ensure safe operation of the ERDF, including security and safety considerations. The building emergency plan and the Hanford Facility Contingency Plan (Chapter 7.0) will ensure that the ERDF has measures in place to lessen the potential impact on human health and the environment.

While remediation waste treatment will $\mathrm{nn}^{+}$. occur at the ERDF, waste treatment wili be considered under the remedy selection process for each remediation site, and will be performed, as necessary, before shipment of remediation waste to the ERDF. Section 15.1.6 discusses waste treatment.

15.1.1.3 Closure and Postclosure Design. As discussed in Chapter 11.0, the final cover design will protect against downward infiltration of surface waters, thus minimizing potential contaminant migration. (CAMU Criterion No. 4 discusses in more detail how the final cover design supports the CAMU Designation Criteria.) The effectiveness of the final cover is well documented and accepted by the regulatory community throughout the United States for closure of RCRA landfills.

As indicated in 40 CFR 264.552(e) and WAC 173-303-646, closure design is a critical element of the CAMU, but also allows for flexibility in final cover 
DOE/RL-94-40, Rev. 0

$06 / 94$

1 design (relative to the classic RCRA-equivalent final cover). The RI/FS (DOE-RL 1994d) has proposed alternative designs that offer equivalent or more protectiveness than a RCRA-compliant final cover, and this application may be modified to include an alternative design that would afford equal or greater protection. Also, although the RI/FS modeled a somewhat different final cover design than that which is presented in this application (refer to

Section 15.1.1.5), overall both designs provide relatively equivalently, lowpermeability. Regardless, the design presented in this application or an alternative design will meet the CAMU criterion of relative long-term (postclosure) effectiveness.

15.1.1.4 Qualitative Risk. A formal risk assessment is not required under the CAMU regulations, nor under the proposed Subpart $S$ rulings. Instead, both indicate that a qualitative (rather than quantitative) assessment of relative risk may be performed. The information presented within this application and data presented in this section demonstrate that the ERDF will offer a protective method of isolating material from the general environment in a cost and time effective manner, without endangering human health and the

environment. Contaminant migration via the following potential contaminant migration routes will be minimized by design, operation, and closure plans, as well as by site environmental conditions.

- Air pathway--Dust suppression, other operational activities, and cover design will control dust generation during the operational, closure, and postclosure periods.

- Surface water pathway--The control, recycling, and treatment of water used during operations, as well as run-off water, will ensure that there is minimal/no discharge to waters of the state.

- Soil pathway--Operational procedures, such as those for decontamination and spill cleanup, will prevent contaminants from entering the soil column; leachate collection and other design/operational activities (the current ERDF trench liner system design is based on MTR requirements) will cuitail downward contaminant migration to the vadose zone.

- Groundwater pathway--Operational considerations, including establishment of appropriate waste acceptance criteria, ensure that soil and, hence, groundwater contamination will not occur (as defined within the ERDF RI/FS risk assessment periods). A groundwater monitoring program will ensure that if a release does occur, the release is detected so that corrective action may be taken if necessary.

Also, risk-based modeling results were used to develop waste acceptance criteria, as discussed in Chapter 3.0. Establishing acceptable

hazardous/dangerous waste concentrations from risk-based maximum allowable concentrations in groundwater (as per Tri-Party Agreement requirements) ensure that no waste will be placed in the ERDF that would compromise human health and the environment (DOE-RL 1994d). 
DOE/RL-94-40, Rev. 0

$06 / 94$

1 15.1.1.5 Contaminant Transport Modeling Results. As part of the RI/FS, 2 various designs were modeled to identify chemical and radiological

3 contaminants at the ERDF that potentially may pose a risk to human health and

4 the environment. Included in the evaluated designs was one very similar to

5 that proposed within this application: MTR liner, RCRA-compliant cap (called

6 the Modified RCRA Barrier System), and area fill excavation (a modified

7 excavation methodology that likely will be used for the ERDF trench).

Results of this modeling indicated that this combination exhibits "high long-term (in excess of 100 years) performance". However, this design proved to be of relatively higher cost when compared to other designs (e.g., thick soil cover and no liner), and is 'redundant' in terms of protection. Preliminary modeling data indicate that alternative designs may offer equal protectiveness, with greater cost-effectiveness. This application may be revised to refiect an alternative that is equally or more protective once appropriate supporting data are generated. Nevertheless, the existing modeling data indicate that the current ERDF design will be highly protective of human health and the environment.

15.1.1.6 Cost-Effectiveness of the Unit Relative to Other Designs. As discussed in Chapter 1.0, the preliminary screening of remedial alternatives indicates that removal of contaminated material from the remediation sites will likely be required. Because the CAMU is to facilitate the implementation of cost-effective remedies, the cost of various waste management options, when compared to use of the ERDF, can be considered. Therefore, the cost-effectiveness of the ERDF is discussed in the following relative to: offsite versus onsite management of remediation waste; waste management in a single unit versus waste management in multiple onsite units, and ERDF trench design versus alternative designs.

15.1.1.6.1 Offsite Versus Onsite Management. The environmental restoration activities in the Hanford 100, 200, and 300 Areas are expected to produce large volumes of waste material (refer to Chapters 2.0,3.0, and 4.0). When evaluating management options for these extremely large quantities of remediation waste, the cost of offsite transport was considered.

Transportation of this large volume of waste to an offsite facility proved not only be very costly (even if there was adequate offsite capacity), but also would present an unacceptable safety hazard to human health and the environment (i.e., should an accident occur en-route). As a result, onsite disposal of remediation waste was determined to be the best alternative.

15.1.1.6.2 Waste Management in a Single Environmental Restoration Disposal Facility Site versus Multiple Sites. The use of several smaller waste management sites, as opposed to a single larger site such as the ERDF, was considered. However, it was estimated that the cost of several smaller sites would be approximately $\$ 58 \mathrm{million}$ greater than that for a single, larger site [refer to Chapter 7.0 of the siting Evaluation Report (WHC 1992d) for additional detailsj. Therefore, the single, larger ERDF site was determined to be more cost-effective when compared to use of several smaller sites. 
DOE/RL-94-40, Rev. 0

$06 / 94$ Options. Chapter 6.0 of the Engineering Study for the Conveyor and Area Fill Systems for the Environmental Restoration Waste Disposal Facility (DOE-RL 1993c) provides various ERDF designs. The 'base case' (consisting of a relatively shallow multiple trench system) was compared wich three different configurations (area fill trenches $A, B$, and $C$ ) that were single trenches of increasing depth [10 meters (33 feet), 15 meters (50 feet), and 21 meters (70 feet) ] respectively], as shown in Figure 15-1. Area fill trench $C$ design is the proposed ERDF trench design presented in this application.

Cost estimates for each of the four trench designs were developed and compared. First, liner costs for the three area fill trenches and the base case were generated and compared, as these costs represent a major portion of the total trench cost. Area fill trench $C$, which is the proposed ERDF design, would cost up to $\$ 202$ million less than the base case (which assumed multiple small trenches). This cost evaluation is summarized in Table 15-2.

Excavation costs were evaluated next. Only area fill trench A excavation costs were compared with the base-case excavation costs because excavation costs for all the area fill trench designs were comparable. These cost estimates indicated that excavation of single area fill trench $A$ would be approximately $\$ 22$ million less than the base case, which considered excavation of multiple smaller trenches.

Finally, the costs for final cover emplacement over the four trench designs were calculated, assuming that the Hanford Barrier would be used in a 11 cases. These costs are presented in Table 15-2. Data indicated that the cost for installing a final cover (i.e., the Hanford Barrier) over the basecase trenches would be over $\$ 700$ miliion greater than the cost to install the same barrier over single area fill trench $C$.

To summarize, these cost estimates indicate that the area fill trench configuration is more cost effective than the base case, and the area fill trench $C$ configuration to be used by the ERDF is the most cost-effective area fill trench design.

It is possible that alternative trench designs may be developed in the future as part of the definitive design. However, some technical constraints relative to trench design are apparent. For example, while trenches of greater depth are technologically feasible, the performance of trenches deeper than 21 meters (70 feet) with respect to groundwater protection remains to be evaluated. Performance evaluation of deeper trenches continues; as appropriate, this application may be revised to incorporate new performance data. Any change to design would afford protectiveness and effectiveness performance equivalent to the design proposed in this application.

15.1.1.7 Decision Criterion No. 1 Summary. These discussions demonstrate that the ERDF will be protective of human health and the environment and will facilitate a reliable, effective, protective, and cost-effective remedy. This decision is supported by the determinations that the ERDF will: 
DOE/RL-94-40, Rev. 0

06/94

43

- Isolate hazardous/dangerous waste materials to a single, manageable area

- Remove hazardous/dangerous material from the environment that is currently in locations significantly closer (therefore, presenting a greater potential threat) to environmental receptors

- Contain hazardous/dangerous material within a unit designed to offer both long-term and short-term protectiveness of the environment through engineering controls

- Use waste acceptance criteria that restrict placement to only that remediation waste that can be managed safely within the ERDF

- Provide operational activities, including those to be used during waste transport and emplacement, that are sufficiently rigorous to ensure that workers are protected from exposure to hazardous/dangerous waste

- Use the Hanford Facility Contingency Plan, as well as ERDF-specific emergency plans, to ensure that sufficient mechanisms are in place to protect human health and the environment if a release occurs

- Be located in an area underlain by geologic materials that offer significant isolation from the water table; the permeability of underlying vadose zone material/aquifers is such that contaminant migration within the water-bearing interval to the discharge point (Columbia River) would be slower than if materials were left at their existing locations closer to the river

- Demonstrate effectiveness through documented performance of the ERDF design, as well as preliminary modeling results; the ERDF is intended to isolate hazardous/dangerous material from humans and the environment, with a design (MTR-compliant) ensuring near-term isolation, and final cover design ensuring long-term isolation

- Be much more cost-effective than transporting waste offsite or constructing numerous waste management sites at the individual remediation sites.

\subsubsection{Corrective Action Management Unit Decision Criterion No. 2 [40 CFR 264.552(c)(2)] [WAC 173-303-646(5)(a)(ii)]}

CAMU Decision Criterion No. 2 states that: Waste management activities associated with the CANU shall not create unacceptable risk to humans or to the environment resulting from exposure to hazardous wastes or hazardous constituents. Design and operation of the ERDF facilitates this criterion because the safe operation and effective design of the ERDF will reduce the potential for contaminant release, thus lessening the chance for contaminant migration. Through the implementation of operation $\mathrm{plan}(\mathrm{s})$, personnel training, emergency $\mathrm{plan}(\mathrm{s})$, and procedures to prevent hazards, unacceptable risk to workers will be prevented. The ERDF design and operations (e.g., 
double-liner leachate collection and dust suppression), including those for the ERDF trench and support units, will offer protection of human health and the environment so that waste management activities do not pose an unacceptable threat. In a qualitative sense, all of these factors will reduce the potential risk to environmental receptors caused by waste management activities at the ERDF. These factors that support CAMU Decision Criterion No. 2 are discussed in more detail in the following sections.

15.1.2.1 Environmental Restoration Disposal Facility Operations and Design. The operations plan will be developed before commencement of ERDF operation. This plan will describe waste management and operational activities, as well as the work force required to perform operation activities in a safe and efficient manner compatible with Hanford Facility operations. This plan also will detail waste transportation routes and practices (within the ERDF) as well as waste placement activities that will ensure minimal risk to the workers and general environment. While the plan is required by DOE Order 5820.2A, the plan serves a dual purpose by demonstrating that operation of the ERDF will proceed in a manner to meet the standards of CAMU Decision Criterion No. 2.

Proper training of the work force, implementation of plans to address emergency situations, and implementation of preventive measures to mitigate hazards are all important elements to ensure that CAMU Decision Criterion No. 2 standards are met. Training requirements, contingency $p l a n(s)$, and procedures to prevent hazards (as designated in the Hanford Facility Permit) will apply to the ERDF.

Chapters 6.0, 7.0, and 8.0 address ERDF-specific personnel training, emergency plans, and preventative procedures for the ERDF in addition to those that would be required as part of the Hanford Facility Permit. Although inclusion of these sections within the CAMU application is not specifically required under 40 CFR 264.552 and WAC 173-303-646, this information is provided to demonstrate that appropriate measures will be taken to safeguard human health and the environment. Chapter 6.0., which details ERDF-specific procedures to prevent hazards, indicates that steps will be in place to avoid the development of hazardous situations. Specifically, ERDF security, inspection schedules, and preventive procedures during loading/unloading of waste are presented in this chapter. Personnel will also undergo ERDFspecific training (refer to Appendix 8A) to ensure that personnel are trained to meet the specific ERDF operational requirements. Appendix $7 A$ includes an emergency plan that addresses how emergency situations would be handled within the ERDF trench and supporting units. If required by the findings of the baseline ecological survey (refer to Section 15.1.1.1), operational plans and preventative procedures will be implemented to mitigate habitat disturbance and destruction.

Other elements of the ERDF design and operation are particularly protective of human health and the environment. For example, transportation of remediation waste from the remediation sites to the ERDF will be performed in a manner protective of human health and the environment. Waste will be transported primarily by railcar to divert waste transport from roadways with automobile traffic. Once waste arrives at the ERDF, dust suppression 
1 (e.g., spraying of waste with water) during unloading and waste emplacement

2 wili ensure minimal exposure through the air pathway, which will be the

3 primary exposure route of concern to workers during the operational phase.

4 Further, concentrating the waste management activities at a single location

5 (i.e., the ERDF) rather than multiple locations will allow for more efficient

6 oversight of the waste management activities. In addition, management of

7 waste at a single location reduces the potential for unintentional releases;

8 the risk potential increases as the opportunity for release increases

9 (i.e., via a greater number of waste management locations).

The conceptual design report (DOE-RL 1994a) states that numerous measures will be in-place to prevent the uncontrolled release of dangerous/hazardous constituents and radioactivity to the environment during and after trench operations, including the use of:

- A RCRA-compliant trench liner system with leachate collection and leak detection systems

- Decontamination building, with waste water treatment system

- A RCRA-compliant barrier, or a more protective barrier

- Dust suppressants, which will be sprayed onto the trench working face on an as-needed basis (daily, at a minimum)

- Interim covers (refer to Chapter 4.0) placed on completed areas of each lift

- Water or dust suppressants, as necessary, to be added to the waste surface as it is emplaced.

There also are numerous measures associated with ERDF support units that will ensure further protection of human health and the environment. Measures identified in the conceptual design report to prevent the uncontrolled release of constituents to the environment from the operations building include:

- Use of HVAC interlocks to ensure proper functioning of exhaust systems and maintenance of proper air balance

- Use of multiple HEPA filter stages on dedicated room HVAC systems only

- Monitoring of differential pressure and air exhausted to the environment

- Application of administrative controls, such as development of an operating procedure to implement periodic tests to prevent the use of faulty filters.

Measures identified in the conceptual design report to prevent uncontrolled releases to the environment from the decontamination building include the use of: 
- HVAC interlocks to ensure proper functioning of exhaust systems and maintenance of proper air balance

- Multiple HEPA filter stages

- Waste water collection and treatment

- Liner(s) under buildings to collect any waters that might escape surface containment.

15.1.2.2 Qualitative Risk and Contaminant Migration Pathways. As indicated previously, the ERDF design and operation offer significant protection to human health and the environment during the operational period, thus reducing risk to environmental receptors in a qualitative manner. Because dust suppressants (discussed in Chapter 4.0) will be applied throughout the operations process, contaminant transport via the air pathway will be minimized. The proposed double-1iner system will collect any leachate generated during the operational period that, in turn, substantially will reduce the possibility that the waste or leachate will enter either the soil column or groundwater. Although RI/FS modeling has shown that, given the ERDF design, the potential for releases that impact groundwater quality is minimal; groundwater monitoring is proposed throughout the operational period to detect any releases (Chapter 5.0).

The ERDF support operations may use significant quantities of water (e.g., for decontamination), but the ERDF treatment and waste water systems will ensure that all effluent is managed appropriately and will not be discharged to waters of the state. Therefore, in a qualitative sense, contaminant migration within the air, surface water, soil, and groundwater pathways is reduced substantially by design/operation considerations. This will reduce risk to environmental receptors via various exposure routes, such as inhalation (contaminants in air) and ingestion (contaminants in soil or groundwater).

15.1.2.3 Decision Criterion No. 2 Summary. The ERDF will ensure that waste management activities associated within the ERDF will not create unacceptable risks to humans or the environment resulting from exposure to hazardous waste or hazardous constituents because, the ERDF will:

- Offer a design (double liner) that mitigates the potential for contaminant migration into soil and groundwater during the operational phase

- Use an operations plan that ensures the ERDF will be managed in a safe manner

- Employ mitigation measures to minimize the potential for contaminant transport in air throughout the ERDF and supporting operations, including dust suppression, use of HEPA filters, etc.

- Ensure that ERDF personnel are appropriately trained and that procedures are in place to make sure that hazards will not arise 


$$
\text { DOE/RL-94-40, Rev. } 0
$$

06/94

- Use in-place methods and plans that will be followed in the event that an emergency response is warranted, and will remedy the situation before human heaith and the environment are endangered.

\subsubsection{Corrective Action Management Unit Decision Criterion No. 3 [140 CFR 264.552(c)(3)] [WAC 173-303-646(5)(a)(i1i)]}

CAMU Decision Criterion No. 3 states: The CAMU shall include uncontaminated areas of the facility only if including such areas for the purpose of managing remediation waste is more protective than management of such waste at contaminated areas of the facility. The ERDF will not occur in an area with preexisting soll contamination. However, the ERDF will be in an area specifically selected by stakeholders as being desirable for waste management, and numerous sites were evaluated within this area to derive the current ERDF location. Waste management will be facilitated by the consolidation of waste in a central area, and use of the ERDF also is supported by the environmental setting, as discussed in Section 15.1.1. A1so, the ERDF will allow waste to be removed from its current close proximity to the Columbia River. It also must be noted that preexisting groundwater contamination from sources upgradient of the ERDF occur in groundwater below the ERDF; therefore, the ERDF will not occur in a pristine location. These factors that address CAMU Decision Criterion No. 3 are discussed in more detail in the following sections.

\subsubsection{Use of the 200 Areas for the Environmental Restoration Disposal} Facility Versus offsite Facilities and Other Hanford Facility Areas. As the first step in addressing this criterion, offsite waste management was considered. However, with respect to Hanford Facility remediation requirements and the potential for onsite waste placement, offsite waste management presented several disadvantages [additional discussion of these disadvantages can be found in the ERDF RI/FS (DOE-RL 1994d)].

Section 15.1.1.6.1 presented a brief discussion of the disadvantages of using an offsite waste management facility relative to cost, but the following disadvantages also are apparent.

- There is very limited nationwide landfill capacity to handle the expected large quantities of Hanford Facility remediation waste, particularly mixed waste.

- The potential for transportation-related accidents would increase because of the much longer transport time to an offsite facility.

- Public opposition to offsite transport from people near receiving landfills and along transportation routes is likely to be high.

- Significant administrative difficulties are expected in removing waste from the Hanford Facility.

For these reasons, offsite disposal was not considered a viable alternative and was not retained. 
Next, use of the Hanford Facility area for waste management was considered. The Hanford Future Site Uses Working Group (the Group), consisting of business, civic, labor, tribal, and government stakeholders chartered with identifying and developing future Hanford Facility uses, proposed that the 200 Areas Plateau be reserved for waste management. In arriving at its recommendation that the 200 Areas Plateau be used for waste management, the Group determined that other areas of the Hanford Facility had higher future use values, and that these other areas should be remediated.

The Group also recommended that waste management activities at the 200 Areas Plateau be concentrated within a 1 imited area, 1.e., the central portion of the plateau. This central portion of the plateau was defined as the "squared off" boundaries of the existing 200 East and 200 West Areas, expanded slightly eastward, and incorporating a buffer zone to minimize risks. Additional detalis on the Group's recommendations can be found in Future for Hanford: Uses and Cleanup, A Final Report of the Hanford Future Site Uses Working Group (Eastern Washington University 1992). Siting factors and locations evaluated by the DOE-RL were based on the Group's recommendation that the 200 Areas Plateau be used for waste management.

\subsubsection{200 Areas Location Evaluations. As described in the Siting} Evaluation Report for the Environmental Restoration Storage and Disposal Facility (WHC 1994d), three locations (Sites 1, 2, and 3) in the central portion of the Hanford Facility were evaluated as potential locations. Site 1 is located in an area immediately northwest of the 200 West Area, while Site 2 is located to the north of the 200 West Area and the area between 200 West and East Areas. Site 3 occuples a portion of the 1 and formerly leased to the Washington State, borders the US Ecology, Inc. facility (Appendix 2A), and is the current ERDF location described in this application.

As the first step in the assessment of these sites, the sites were evaluated against a list of 22 screening criteria (Table 15-3). Site 3 is partially within the waste management area recommended by the Group, while Sites 1 and 2 occur outside of this recommended area, but are essentially within the group's recommended buffer area. As a result of this screening, Site 2 was eliminated from further consideration because archaeological and/or historical sites were located in the area. This evaluation also considered a variety of ecological criteria, including the presence of endangered species and endangered species habitats. Endangered species and their habitats were not identified within 0.4 kilometer $(0.25 \mathrm{mile})$ of Site 3 , the proposed ERDF location [refer to the siting evaluation report (WHC 1994d)].

Sites 1 and 3 were evaluated using weighted criteria, which considered the following factors [refer to Chapter 5.0 of the siting evaluation report for additional details]:

- Human health and environmental protection (60 percent)

- Acceptability of the site for the disposal of hazardous, radioactive, and mixed waste

- Potential human health and environmental consequences of this disposal

- Quantification or radiation dose to an offsite individual 
- Natural topographic and geologic conditions

- Depth to groundwater and the presence of existing groundwater contamination

- Regulatory, construction, and operating criteria (40 percent)

- Permitting requirements

- Support bulldings, roads, railroads, and utilities

- Operational factors regarding the volume, distance, and types of waste to be transported.

The Site 1 score generated by the Working Group was 85 out of a possible 100, while Site 3 scored 100 . Therefore, results of this scoring showed that Site 3 was preferable to Site 1 on the basis of these criteria.

Smaller sites located within the 200 Areas also were evaluated as potential ERDF locations, as part of the siting evaluation report (WHC 1994d). However, several factors weighed against the use of these smaller locations. The following is a summary of major factors weighing against the use of these smaller locations [refer to Chapter 7.0 of the siting evaluation report for additional details].

- On an individual basis, the smaller sites could not accommodate all of the necessary structures to accommodate the projected remediation waste volume.

- Future expansion of the ERDF, if required, would be constrained by the smaller size of the locations evaluated.

- The use of these sites would impact several Tri-Party Agreement milestones (including construction and use of the ERDF).

15.1.3.3 Consolidation of Waste at a Central Area. In addition to the siting factors discussed previously, the use of a single facility minimizes the longterm potential for release and offers better long-term reliability by providing a single area for waste placement construction, maintenance, and monitoring. This is because as the number of waste sites used for waste placement, disposal, or closure in-place increases (i.e., using the various 100,200 , and 300 Areas for remediation waste disposal), the potential for unforeseen release also increases even in areas with well-designed systems/facilities. In addition, the use of a single facility ensures that there is one focus for all long-term care and monitoring responsibilities and efforts, as opposed to the multiple foci incumbent with the use of several sites. Also, information presented in Section 15.1.1 indicates that the ERDF is located in an optimal site relative to its environmental setting and distance from major population centers. Perhaps most importantly, the ERDF is over 11 kilometers ( 7 miles) from the Columbia River, and consolidation of waste at a central area would remove and isolate waste from current locations next to the river.

15.1.3.4 Use of Contaminated Areas. In addition to being located within the limits of the waste management area, preexisting groundwater contamination occurs below Site 3, which is the current ERDF location. The site 
characterization plan (WHC 1994c) describes groundwater contaminant plumes (e.g., tritium and lodine-129) below the ERDF. (Refer to Chapter 5.0, Section 5.4 for additional discussion of preexisting groundwater contamination.) Therefore, portions of the proposed ERDF area already are contaminated, and the ERDF is not proposed for an entirely 'clean' area.

\subsubsection{Environmental Restoration Disposal Facility Unit Design and Modeling} Results. The ERDF RI/FS (DOE-RL 1994d) presents contaminant transport modeling results that support the ability of the proposed ERDF design/operations to achieve the levels of risk-based protection established within the Tri-Party Agreement $\left(10^{-5}\right.$ to 100 years, $10^{-4}$ thereafter at the unit boundary). This discussion will be revised to include additional supporting information as the RI/FS (DOE-RL 1994d) is updated.

15.1.3.6 Decision Criterion No. 3 Summary. In conclusion, the ERDF will include uncontaminated areas of the Hanford Facility, but inclusion of such areas for the purposes of managing remediation waste is more protective than leaving waste at contaminated areas because the ERDF wi11:

- Include land areas below which groundwater contamination has been documented

- Be located within an area of the Hanford Facility identified by the Hanford Future Site Uses Working Group as the recommended waste management area, and in an area with favorable environmental setting

- Offer a significantly greater level of protection than allowing waste to remain along the Columbia River

- Enhance long-term control, management, and reliability (refer to Section 15.1.1) through the use of a single area for waste placement in a specified location, as opposed to remediation waste disposal throughout the 100, 200, and 300 Areas

- Be sited and operated to minimize habitat destruction.

\subsubsection{Corrective Action Management Unit Decision Criterion No. 4} [40 CFR 264.552(c)(4)] [WAC 173-303-646(5)(a)(iv)]

CAMU Decision Criterion No. 4 states: Areas within the CAMU, where waste remain in-place after closure of the CAMU, shall be managed and contained so as to minimize future releases to the extent practicable. The ERDF trench and final cover design, as well a postclosure activities, support this criterion. Specifically, the double-liner leachate collection system will remove potentially contaminated liquids that could migrate downward and release hazardous/dangerous constituents to the groundwater. Also, the final cover [as well as interim cover(s)] will mitigate precipitation infiltration that could mobilize contaminants from waste. Postclosure activities, including maintenance of the final cover, leak detection system, groundwater monitoring, and ernsion protection will help ensure that waste remaining in place after closure is not mobilized, thus minimizing the potential for future releases. 
1 Contaminant transport modeling also indicates that using measures such as the 2 proposed final cover will minimize the potential for future releases. These 3 factors that support CAMU Criterion No. 4 are discussed in more detail in the 4 following sections.

15.1.4.1 Environmental Restoration Disposal Facility Unit Design. The first element that demonstrates conformance with this decision criterion is ERDF

8 liner design (refer to Chapter 4.0 for additional design details). While the

9 liner is not intended to last several thousand years, it will offer near-term ( 30 years after closure) protection that could extend into the foreseeable future (1.e., several hundred years).

15.1.4.1.1 Liner System. The ERDF liner will be constructed to satisfies MTR requirements, as mandated by the Tri-Party Agreement. As noted in the ERDF RI/FS (DOE-RL 1994d), this design offers significant postclosure protection that could extending to the foreseeable future. The major components of this liner system include:

- A 1-meter- (3-foot-) thick base consisting of a bentonite-soil mixture having a hydraulic conductivity of $1 \times 10^{-7}$ centimeters per second or less

- Two HDPE geomembranes

- Geocomposite and gravel/crushed stone leak detection layers

- A 1-meter-(3-foot-) thick operations layer (consisting of soil) to prevent damage to the liner system during waste placement.

To facilitate collection of any precipitation or drainage, the ERDF construction will include individual cells [approximately 152 meters ( 500 feet) on each side], which will slope inward toward cell liquid collection sumps.

15.1.4.1.2 Leachate Collection System. Leachate, and any 1 iquid collected throughout the period of waste placement, will be collected in holding tanks (sized to contain the entire volume of a 25-year precipitation event falling on three cells). The collected leachate will be treated, evaporated, or otherwise managed in accordance with RCRA and WAC requirements.

15.1.4.1.3 Environmental Restoration Disposal Facility Interim and Final Interim Covers. Before installation of the final cover and as waste is emplaced, an interim cover (described in Chapter 4.0) and final interim cover will be installed to minimize leachate production during the operational phase. The final interim cover will incorporate a low-permeability layer, and will mitigate infiltration.

15.1.4.2 Closure and Postclosure. As detailed in Chapter 11.0, the ERDF will be closed in a manner that meets the requirements of 40 CFR 264.552(e) (4) and WAC 173-303-646(5). Conformance with these requirements will be attained through the use of a multi-layer final cover. The lowest layer of this final cover will consist of a low-permeability layer that may be a composite of 
1 natural (e.g., soil) material and a synthetic material (e.g., geomembrane, 2 asphalt). The hydraulic conductivity of the layer will be less than or equal 3 to $1 \times 10^{-7}$ centimeters per second $\left(3 \times 10^{-4}\right.$ feet per day). The prevention of 4 liquid migration through the cover will be enhanced through the use of a high 5 hydraulic conductivity drainage layer placed above the low-conductivity layer to intercept infiltrated water and rapidly drain it off the cap. The uppermost layer above the drainage layer will consist of soil with sufficient thickness to afford frost protection, and a grain-size distrit.etion that will enhance moisture retention in the shallow root zone of perenn al grasses. The final cover will be placed over waste materials and clean soils that have been compacted to prevent subsidence and settlement. In addition, the final cover will be constructed with features to ensure drainage control, prevent biointrusion (i.e., burrowing animals), facilitate the growth of a vegetative cover, and control wind and water erosion.

The features described demonstrate that the proposed final design cover for the ERDF will be of sufficiently low-permeability to impede infiltration of precipitation; therefore, the ERDF will offer long-term protection of human health and ti. environment. However, as discussed in Chapter 11.0, the RI/FS may recommend an alternative barrier design. This application may be revised to reflect this alternative design, when appropriate supporting data have been acquired to fully demonstrate that the alternative design meets the CAMU criteria.

Chapter 11.0, Section 11.11, details the ERDF postclosure plan(s). As described, the postclosure plan addresses the following elements that will ensure long-term reliability and effectiveness of the ERDF:

- Maintenance of the integrity and effectiveness of the final cover

- Maintenance and monitoring of the leak detection system

- Operation of the leachate collection and removal system until reachate is no ?onger detected

- Maintenance and monitoring of the groundwater monitoring system

- Prevention of erosion or other damage to the final cover

- Protection and maintenance of the surveyed benchmarks that locate the ERDF.

These postclosure care activities will be performed as specified in Chapter 11.0. Specific postclosure plans that address these activities will be developed and used to ensure postclosure reliability and effectiveness of the ERDF. The following postclosure plans are described in Chapter 11.0, Section 11.11:

- Inspection plan, to include:

- Security control devices

- Erosion damage

- Cover settlement, subsidence, and displacement 
- Vegetative cover condition

- Animal activity (i.e., burrowing)

- Cover drainage system functioning

- Leachate collection/detection and removal system

- Groundwater monitoring well condition

- Benchmark integrity

- Postclosure monitoring plans, to include:

- Leachate collection/detection and removal

- Groundwater monitoring

- Maintenance plan, to include:

- ERDF security

- Erosion damage

- Vegetative cover condition

- Final cover

- Animal damage

- Cover drainage system

- Leachate collection/detection and removal system

- Groundwater monitoring wells.

15.1.4.3 Contaminant Transport Modeling. Groundwater modeling was performed as part of the ERDF RI/FS (DOE-RL 1994d). Various final cover designs and liner configurations were used in the modeling, including a cap design that offers infiltration protection comparable to that provided by the design in this application (Chapter 11.0). Results of the modeling indicate that, based on the known maximum contaminant concentrations in remediation waste analyzed to date, only carbazole, 4-chloro-3-methylphenol, carbon-14, chromium-51, and various metals, inorganics, and radionuclides (e.g., chromium) will exceed de minimis values. Of these, the calculated travel times to the ERDF compliance boundary for only fluoride, nitrite, 4-chloro-3-methylphenol, carbon-14, technetium-99, antimony, arsenic, chromium-VI, and selenium were less than 10,000 years. These data were used, in conjunction with liner compatibility and operational considerations, to develop waste acceptance criteria that ensure contaminant migration will not occur from the ERDF through the vadose zone and in groundwater to the ERDF boundary within the timeframes mandated by the Tri-Party Agreement.

15.1.4.4 Decision Criterion No. 4 Summary. The previous discussions, with the additional details provided in Chapters 4.0 and 11.0 and the ERDF RI/FS (DOE-RL 1994d), demonstrate that waste to remain in-place after closure of the ERDF will be managed and contained so as to minimize future releases to the extent practicable because the ERDF will:

- Provide controls to ensure long-term reliability of design, including monitoring of leachate generation over a 30-year period that will demonstrate the final cover design effectiveness

- Incorporate design elements that ensure long-term waste management effectiveness 
DOE/RL-94-40, Rev. 0 06/94

4

- Effectively protect human health and the environment as shown by the contaminant transport modeling results.

\subsubsection{Corrective Action Management Unit Decision Criterion No. 5 [40 CFR 264.552(c)(5)] [WAC 173-303-646(5)(a)(v)]}

CAMU Decision Criterion No. 5 states: The CAMU shall expedite the timing of remedial activity implementation when appropriate and practicable.

The ERDF will facilitate the timing of Hanford Facility remediation because the ERDF will provide a waste management location that will be ready in time to accept waste from remediation site cleanup, which is scheduled to begin in 1996. While the ERDF is required under the Tri-Party Agreement and is recognized as necessary within this Agreement, it also will facilitate timely cleanup because construction of remediation site-specific disposal units would require extensive effort and expense, and could not be achieved in time to meet the Tri-Party Agreement cleanup milestones. These factors that support CAMU Criterion No. 5 are discussed in more detail in the following sections.

\subsubsection{The Environmental Restoration Disposal Facility and Tri-Party}

Agreement. As indicated in the Tri-Party Agreement modification dated January 25, 1994, removal actions resulting from 100 and 300 Areas RODs are expected to produce large volumes of hazardous, radioactive, and mixed waste. Remediation waste generation will begin in September 1996. Milestones established within the Tri-Party Agreement call for remediation on a specific schedule, with the first ROD to be issued in 1994. It is apparent that the ROD likely will call for placement of remediation waste within a centralized facility (in accordance with the Group recommendations, and for reasons cited within other CAMU Decision Criteria in this section). A facility capable of receiving large quantities of these remediation wastes will be needed on the Hanford Facility at that time.

If the ERDF is ready to receive waste when remediation of the first remediation site begins, this will facilitate the timing of Hanford Facility remediation by providing a timely waste management option. The criticality of initiating the ERDF in a timely fashion was emphasized within the Tri-Party Agreement: "Delay in construction of the (ERDF) facility would impact cleanup of waste sites." Therefore, use of the ERDF is in accordance with Tri-Party Agreement goals and milestones.

Construction and operation of the ERDF in stages (as waste projections are developed for each remediation site) also will facilitate timely remedial implementation. The construction of waste management facilities at each remediation site would be subject to detailed data development, review, approval, design, and construction processes stipulated under CERCLA and RCRA. Because the ERDF will be ready to accept remediated waste as early as 1996, remediation sites could be more quickly cleaned up. Further, the ERDF would offer relatively immediate isolation of the waste from the Columbia River, which supports other CAMU Decision Criteria (i.e., Criterion No. 1).

The Tri-Party Agreement indicates that there are four milestones directly associated with the ERDF. 
41

42

1. Target Milestone M-70-00-T01: Submission of a Public Involvement Plan for the ERDF on October 1993. This milestone was compieted on October 28, 1993.

2. Interim Milestone M-70-01: Submittal of a single-design ERDF draft conceptual design report for regulatory review and comment in February of 1994. This conceptual design report was provided on schedule.

3. Interim Milestone M-70-02: Submittal of information necessary for CAMU designation (40 CFR 265.552) and a CERCLA ROD for regulatory approval in April of 1994. Relative to the RCRA/CAMU portion of this information package, delivery of requistte information is proceeding on schedule.

4. Major Milestone M-70-00: The ERDF will be operational (available to receive remediation waste) in September of 1996 . To meet this major milestone that is required to ensure timely remediation of the Hanford Facility, implementation of the ERDF is required. Clearly, the Tri-Party Agreement members felt that initiation of the ERDF is required to expedite Hanford Facility cleanup, further indicating the ERDF supports CAMU Decision Criteria No. 5.

15.1.5.2 Decision Criterion No. 5 Summary. The ERDF will expedite the timing of remedial activity implementation because the ERDF will:

- Help DOE-RL meet the Tri-Party Agreement Hanford Facility cleanup schedules that could not otherwise be met without the Tri-Party Agreement-required ERDF

- Provide a single waste management location in a relatively rapid fashion, as construction of disposal facilities at each remediation site would require initiation after the RI/FS stage, and therefore could take years to start.

15.1.6 Corrective Action Management Unit Decision Criterion No. 6 [40 CFR 264.552(c)(6)] [WAC 173-303-646(e)(5)(a)(vi)]

CAMU Decision Criterion No. 6 states: The CAMU shall enable the use, when appropriate, of treatment technologies (including innovative technologies) to enhance the long-term effectiveness of remedial actions by reducing the toxicity, mobility, or volume of waste that will remain in-place after closure of the CAMU. Although waste treatment at the ERDF is not planned (refer to Chapter 3.0 for additional discussion), treatment before acceptance of waste at the ERDF may occur and depends on the results of assessments performed at each remediation site and the ERDF waste acceptance criteria. The Preamble to the CAMU regulations states that preference will be given to those remedies that use some sort of treatment technology, but goes on to indicate that treatment is not a mandate and should be decided on a case-by-case basis. This preference for treatment under the CAMU is analogous to the preference under CERCLA for treatment-based remedies. Because the need 
1 for treatment will be assessed on a remediation-site basis, the determination 2 of specific treatment that must take place at the ERDF-level could limit the 3 type of treatment that could occur at the remediation sites (i.e., could 4 exclude innovative technology development that is preferred under the CAMU 5 regulations). It is anticipated that the remediation site waste will be high-volume, low-toxicity, which is cited, within the CAMU preamble, as being the type of waste for which no treatiment may be considered. Further, modeling results indicate that treatment may not be necessary for most 100,200 , and 300 Areas waste because mobilization of this waste will not occur given the ERDF and closure designs. Therefore, remediation waste treatment at the ERDF is not necessary to facilitate the implementation of a reliable, effective, protective, and cost effective remedy based on a number of factors including:

- The role of the ERDF in the overall remediation process of the Hanford Facility, with treatment being determined on an individual remediation site-specific basis

- Technological considerations and limitations relative to implementation of treatment at the ERDF

- Placement of high-volume, low-concentration waste in the ERDF and the relationship of this type of waste to waste treatment

- Contaminant transport modeling results assuming no waste treatment.

These factors that support CAMU Criterion No. 6 are discussed in more detail in the following sections.

15.1.6.1 Environmental Restoration Disposal Facility's Role in the Remedial Program Process. Remediation waste placement at the ERDF is but one component of a complex program to complete the environmental restoration of the Hanford Facility 100, 200, and 300 Areas. While treatment is not specifically required at the ERDF, the overall remedial program process for the Hanford Facility includes the opportunity to address waste treatment during the RI/FS and RFI/CMS processes for each remediation site. This evaluation of waste treatment/disposition will include determining a particular waste stream's acceptability for placement within the ERDF. A discussion of the remedial program process and the ERDF's function within this process is found in the following paragraphs.

As stipulated in the Tri-Party Agreement, activities at each remediation site will be performed pursuant to CERCLA or RCRA. Figures 15-2 and 15-3 illustrate the overal1 CERCLA remediation and RCRA corrective action processes; these are the basic processes that have been and will be followed in conducting the 100, 200, and 300 Areas restoration programs. The ERDF is a remedial approach that will be considered under the RI/FS and remedy selection steps for the CERCLA process, and in the RFI/CMS steps for the RCRA process (a) so refer to Chapter 1.0, Figure 1-2). As shown in these diagrams, waste treatment assessments are key to the overall remediation process for each remediation site, and treatment will use a consideration within each site's ROD or permit modification. It must be noted that the RFI/CMS and RI/FS

52 processes used at each remediation site are different than that used to assess 
1 viability of the ERDF itself, as shown in Chapter 1.0, Figure 1-2 and 2 discussed in Chapter 1.0.

3

Figures 15-4 and 15-5 detail the remedial/corrective action evaluation criteria used in the CERCLA and RCRA remedy selection processes to be performed at each remediation stte. Remedy selection for the 100, 200, and 300 Areas remediation sites wili be based on these evaluation criteria. As part of the remedy selection process, two issues important to CAMU Decision Criteria must be noted.

- Remediation waste treatment/disposition that may include evaluation of treatment options will be addressed in preparing the CERCLA RODs and RCRA/dangerous waste draft permit modifications for each 100, 200, and 300 Areas remediation site.

- Remediation waste to be placed in the ERDF must meet ERDF waste acceptance criteria (refer to Chapter 3.0), and this will be a consideration when evaluating treatment options for the remediation sites. However, these criteria will not 1 imit the level of treatment performed, but will serve as guidelines for management in the ERDF.

In summary, remediation waste $p$ lacement in the ERDF is a part of the overall waste treatment/disposition evaluation process to be used in preparing the RODs/permit modifications for each remediation site. Although waste treatment is not mandated for ERDF, the need for waste treatment will be assessed on an individual remediation-site basis. Therefore, when considered in the context of overall Hanford Facility remediation activities, the ERDF would meet this decision criteria because treatment will be performed on a remediation site-by-site basis.

15.1.6.2 Specific Technological Considerations/Limitations. The remediation waste from the 100, 200, and 300 Areas is made up of a variety of waste types with a broad range of contaminants and contaminant concentrations. Evaluation of waste treatment/disposition on a remediation site-specific basis potentially provides a more effective means of addressing requirements of each waste than would be afforded by designing and constructing a single facility to handle all potential waste, considering cost, schedule, implementability, and waste volume, among other factors.

Also, consideration of waste treatment/disposition on a remediation site-specific basis (through the preparation of individual RODs/permit modifications) enhances the ability to identify and evaluate remedies including innovative technologies - specific to the remediation waste at each site. This ability to assess site-specific remedies is directly relevant to the Primary Balancing Criteria and Selection Decision Factors shown on Figures 15-4 and 15-5, respectively. It al so should be recognized that CERCLA and RCRA remediation/corrective action activities on the Hanford Facility currently planned to take place over approximately 30 years. By addressing remediation waste treatment on a site-specific basis over this period, innovative technologies (which may not even exist in research at present) available at the time of selection can be considered in selecting remedial 
1 approach. Therefore, the ERDF would foster the CAMU rule's stated interest in 2 innovative technologies that would be developed on a site-specific basis.

\subsubsection{Placement of High Volume-Low Concentration Waste in the}

Environmental Restoration Disposal Facility. As noted in Chapter 3.0, the waste accrotance criteria establish constituent concentration levels that define an overall waste stream. Although there are areas within remediation sites that contain high concentrations of constituents, overall it is anticipated that remediation waste will be characterized as low-concentration, i.e., low-toxicity.

The preamble to EPA's final CAMU rule states that "Given the example, therefore, of a situation involving large volumes of low-concentration contaminated soils or other wastes, the RA would have the discretion to evaluate containment-based remedial approaches." As discussed previously, available waste analysis data indicate that the majority of remediation site wastes will be low-concentration/toxicity. At an estimated total of more than 20 million cubic meters ( 26 million cubic yards), the remediation waste to be placed within the ERDF constitutes a large volume waste stream. Therefore, a containment-based remedial approach is appropriate to this decision criterion.

CAMU criterion No. 1 allows for consideration of overall cost when evaluating whether a unit meets CAMU standards. Treatment of a high volume of waste can be very costly, and the protectiveness achieved through treatment may not be better than that attained through waste isolation. Furthermore, the preamble to EPA's final CAMU rule states that "... this criterion does not preclude remedial actions that do not include treatment." Therefore, cost of treatment may be an element of the overall remedy selection process for remediation sites.

15.1.6.4 Modeling Results. The RI/FS (DOE-RL 1994d) modeling, while evaluating various unit and final cover design alternatives, assumed no waste treatment. The modeling, which assumed maximum waste concentrations and incorporated conservative assumptions relative to contaminant solubility, sorption, etc., showed that only a few contaminants exceeded allowable constituent concentrations at the ERDF trench boundary in 10,000 years. These modeling data were used to develop waste acceptance criteria that limit the concentrations of these constituents to levels that would prevent unacceptable contaminant migration.

Therefore, the modeling shows that the proposed ERDF design, without treatment, mitigates contaminant migration over the long-term periods (more than 100 years). The ERDF therefore is reliable, effective, and protective, and fulfills the intent of the CAMU Decision Criteria. It should be recognized that the preamble to EPA's final rule states that this decision criterion "...does not preclude remedial actions that do not employ treatment, as long as they are capable of ensuring long-term effectiveness."

15.1.6.5 Decision Criterion No. 6 Summary. The ERDF will enable the use, when appropriate, of treatment technologies (including innovative

technologies) to enhance the long-term effectiveness of remedial actions even though treatment will not occur at the ERDF because the ERDF will: 
- Be an implementation component of a broad-scale restoration program for the 100,200 , and 300 Areas, wherein remediation waste treatment/disposition will be addressed in preparing the individual remediation site RODs or permit modifications

- Allow remediation waste treatment to occur on an individual remediation site-specific basis that will enable waste treatment/disposition to be tailored (i.e., to optimize effectiveness, implementability, and cost-effectiveness) to the waste stream

- Likely accept very large quantities of low-concentration/toxicity remediation waste (the preamble to EPA's final CAMU rule cites this as a specific example of an instance in which containment-based remedial approaches may be evaluated)

- Minimize contaminant migration without the specific need and added cost of waste treatment at the ERDF, although waste treatment may occur at the remediation sites

- Reject waste that does not meet the waste acceptance criteria for management at the ERDF.

\subsubsection{Corrective Action Management Unit Decision Criterion No. 7 [40 CFR 264.552(c)(7)] [WAC 173-303-646(5)(a)(vii)]}

CAMU Decision Criterion No. 7 states: The CAMU shall, to the extent practicable, minimize the land area of the facility upon which waste will remain in-place after closure of the CAMU. The ERDF facilitates this Criterion because consolidation of waste at the ERDF would decrease the overall size of land area upon which waste could remain in place, if waste were to stay at the remediation sites. Specifically, the ERDF trench would be over 95 percent smaller than the overall remediation site area. These factors that support CAMU Criterion No. 7 are discussed in more detail in the following sections.

15.1.7.1 Size of the Environmental Restoration Disposal Facility Relative to Areas Requiring Remediation. The CAMU preamble states, in part, that "The CAMU, as presented in today's rule, will promote the consolidation of remediation waste into smaller, discrete areas of the facility, that are suitable as long-term repositories for the waste, and that can be effectively managed and monitored over the long term." (This particular discussion addresses the issue of "smaller, discrete areas," while Sections 15.1.1 and 15.1.2 address the issues of long-term effectiveness, management, and monitoring.)

The RI/FS (DOE-RL 1994d) provides the following data for the waste sites areas that would contribute remediation waste to the ERDF:

- The 100 Areas occupy approximately 11 square kilometers (4 square miles) 
DOE/RL-94-40, Rev. 0

$06 / 94$

2

- The 200 Areas cover about 16 square kilometers (6 square miles)

- The 300 Area covers approximately 1.5 square kilometers $(0.9 \mathrm{mile})$.

If, as noted, the waste at these sites were to remain in $p l a c e$ or if remediation waste were $p l a c e d$ in individual locations throughout the 100, 200, or 300 Areas, some - if not all - of these areas would be unavailable for unlimited use as requested in the Future Site Uses Working Group Final Report (Eastern Washington University 1992). Therefore, as much as 28.5 square kilometers (11 square miles) of 1 and could be unavallable for future use.

With respect to the area occupied by the ERDF, the total planned area for the ERDF is about 4.14 square kilometers ( 1.6 square miles). However, on cessation of waste disposal activities (i.e., closure) of the ERDF, the support units and equipment (e.g., decontamination building, waste unloading station, waste transport roadways, and waste handling equipment) will be decontaminated and removed from the ERDF or placed within the ERDF trench. Therefore, the final area that waste will remain in-place after ERDF closure could be as low as 1.2 square kilometers ( 0.5 square miles) (based upon initial trench designs). (Refer to Chapter 11.0 for further details on closure actions.) Section 5.4.3.1 of the conceptual design report for the ERDF (DOE-RL 1994a) presents additional details on the proposed trench and ERDF 1ayout.

Comparison of the total area if waste were to remain at the remediation sites ( 28.5 square kilometers) with that of the ERDF trench (1.2 square kilometers) indicates that consolidation of remediation waste at the ERDF could reduce the total waste area up to 95 percent. Therefore, construction of the ERDF clearly minimizes the land area on which waste will remain when compared to the total area if waste were closed at each remediation site.

15.1.7.2 Decision Criterion No. 7 Summary. The ERDF will minimize the land area on which waste will remain in-place on the Hanford Facility after closure of the ERDF because the ERDF wi11:

- Consolidate remediation waste, thus minimizing the 1 and area on which waste will remain after closure

- Facilitate subsequent reuse or release of the remediated portions of these areas by consolidating 100, 200, and 300 Areas remediation waste and maximizing the area available for reuse or release

\subsection{INFORMATION THAT MUST BE ADDRESSED IN THE REGULATORY PACKAGE AS MANDATED BY THE TRI-PARTY AGREEMENT}

The Tri-Party Agreement indicates that the application for regulatory approval will include discussion of the following:

- Siting and compatibility with the Hanford Future Site Uses Working Group Recommendations described in The Future for Hanford: Uses and Cleanup (Eastern Washington University 1992) 
- How to handle existing contaminated sites that are located within the footprint of the ERDF

- How landfill footprint is minimized

- Landfill expansion.

Siting and sompatibility with Future Uses Working Group Recommendations are presented in Sections 15.1.1, 15.1.2, and 15.1.3. Because the existing contamination at the current ERDF location consists predominantly of groundwater contamination, this issue is addressed in Chapter 5.0.

Minimization of the 1 andfill footprint and 1 andfill expansion is discussed in Chapters 2.0 and 4.0 and Section 15.1.7. 
DOE/RL-94-40, Rev. 0

1
2
3
4
5

This page intentionally left blank. 


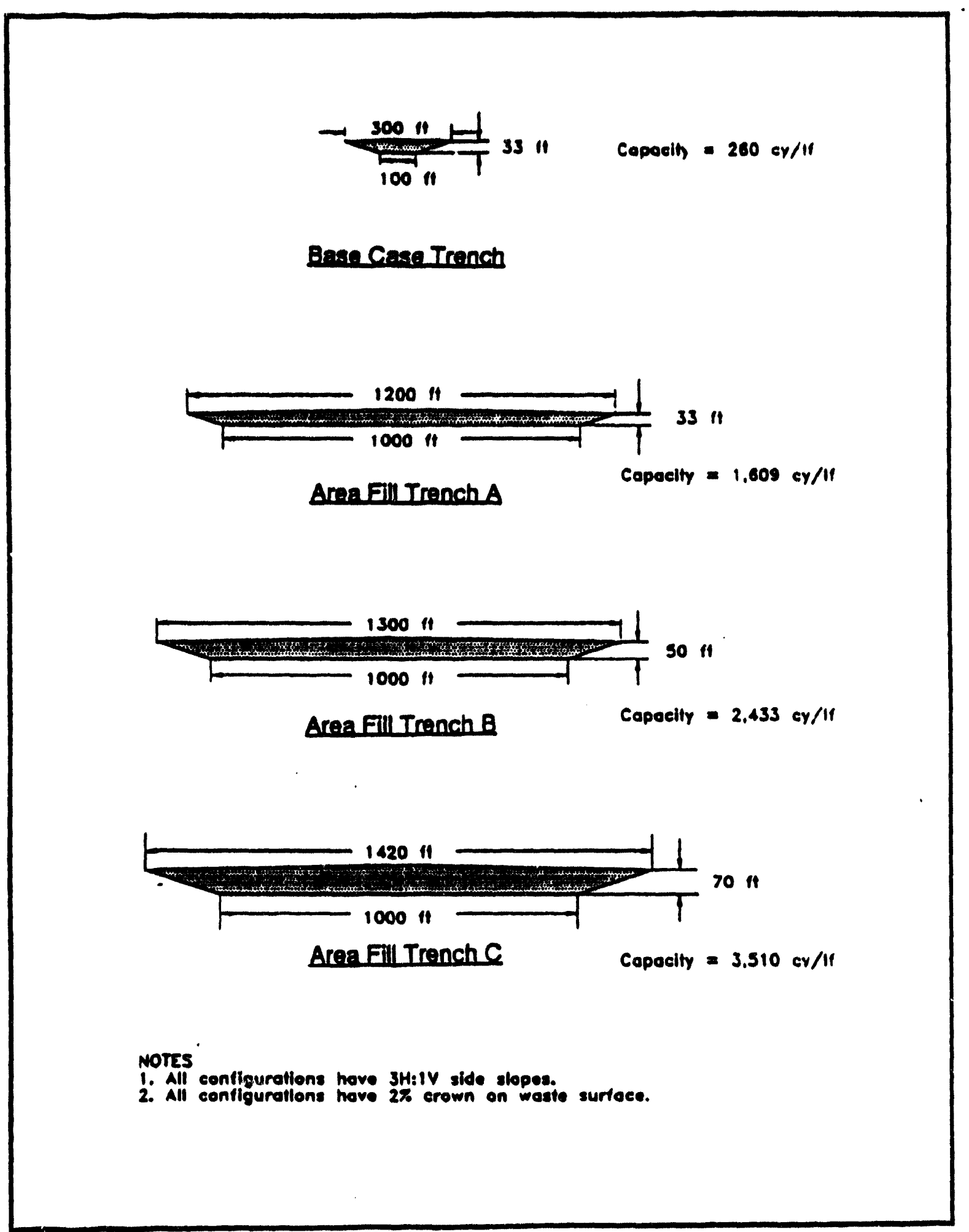

Figure 15-1. Base Case and Area Fill Trench Cross-Section. 


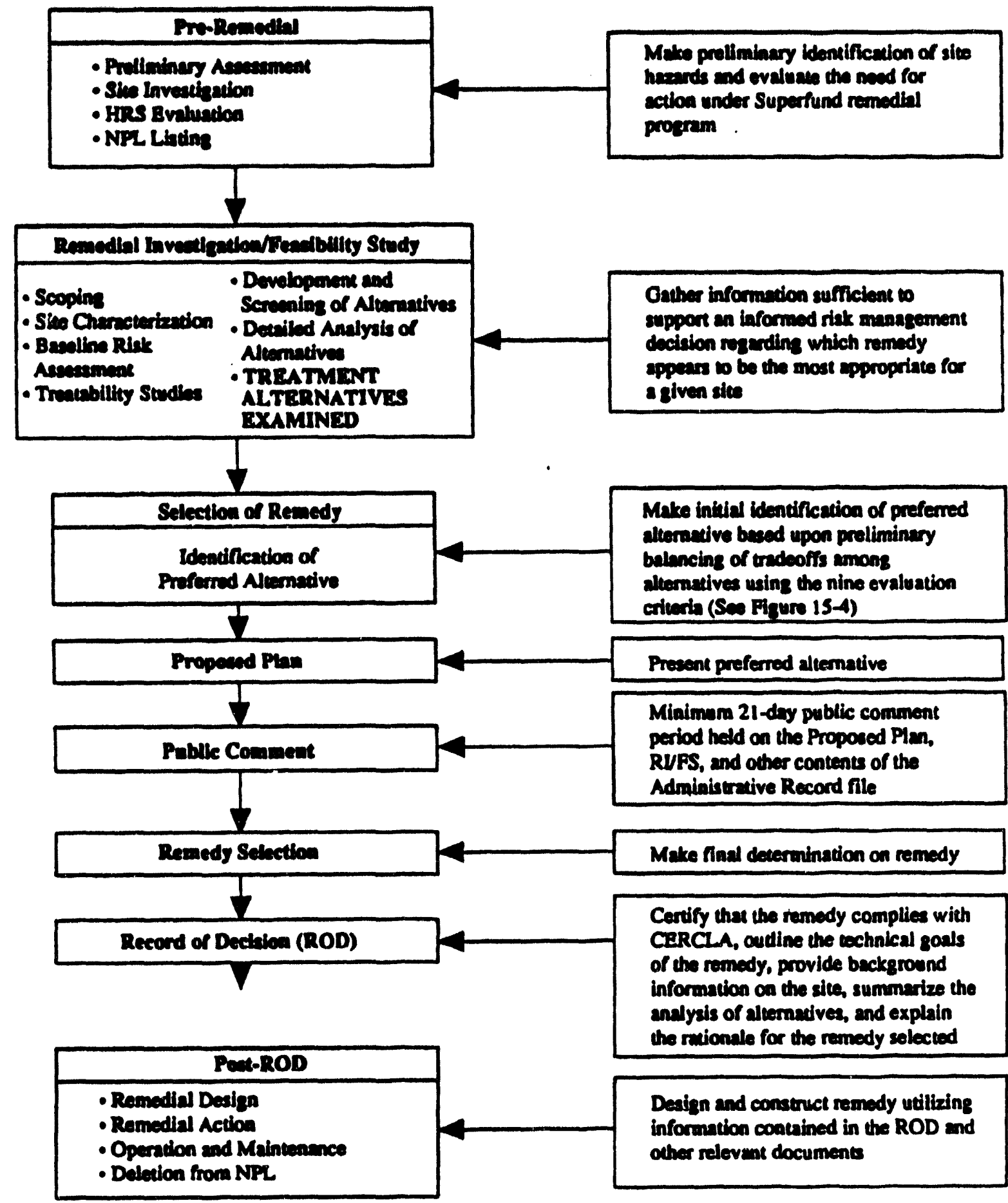

Figure 15-2. Remediation Process for the Hanford Facility CERCLA Past-Practice Remediation Sites. 
- The sdministrative rucord should be eccessible to the public during the entire corrective action process

- A Statement of Basis. typical for the RFICMS process, will be substivuced for Dran Permit Modification. in the crese of Henford

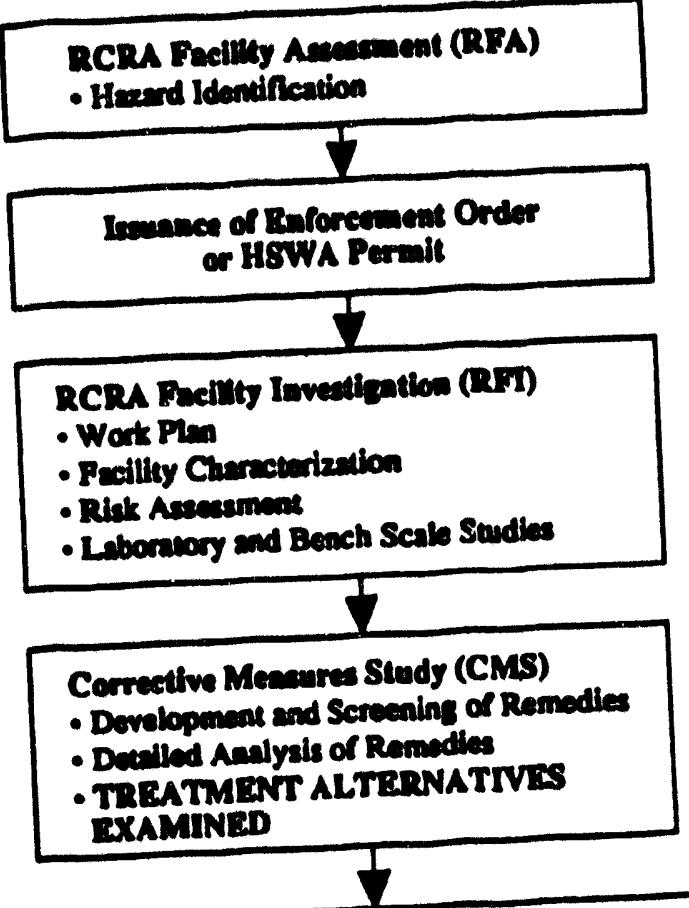

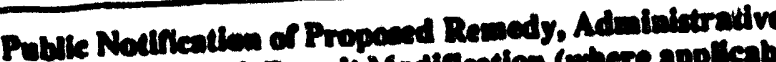
Record, and Drant Penenis Modineation (mere applleable)

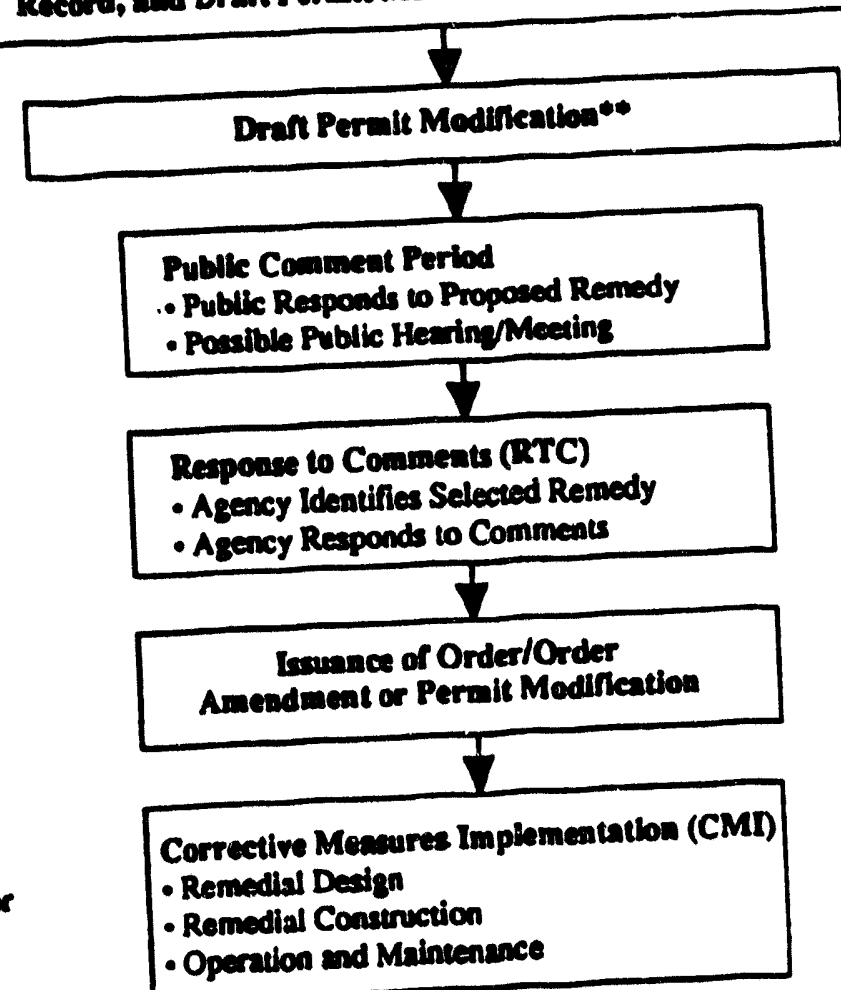

Figure 15-3. Corrective Action Process for the Hanford Facility RCRA Past-Practice Remediation Sites. 


\section{Threshold Criteria}

\section{Oranll Protection of \\ Henon IIe-lik and the Buvinoment}

- How slcemadives provide human health and environmental prosection

\section{Complianee with} ARARs

- Compliance with chemical-specific ARARs

- Compliance with ection-specific ARARs

- Compliance with bection-specific ARARs

- Compliance with other criteria, advisories, and guidences

Primary Balancing Criteria

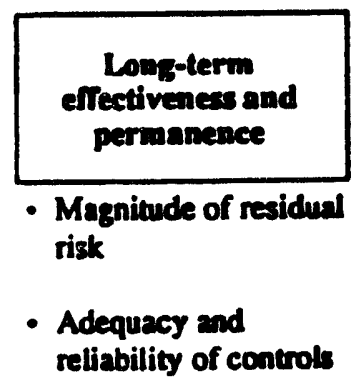

reliability of controls

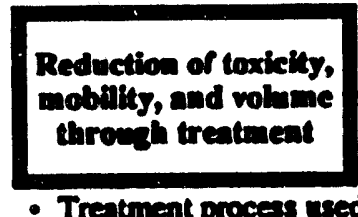

- Treatment process used and materials treated

- Amonat of haradous manerials destroyed or treated

- Dezree of expected reductions in coxicity. mobility, or volume

- Depree to which treatment is ineversible

- Type and quantity of resideala remaining after treatument

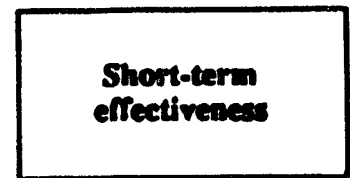

- Protection of community durine remedial ections

- Protection of workers during remedial actions

- Environmental impects

- Time until remedial action objectives are achieved

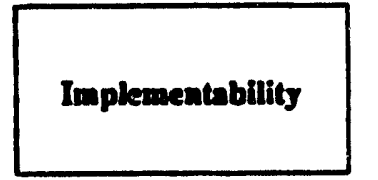

- Ability to construct and operate the technology

- Reliability of the echnolosy

- Ease of undertaking additional remedial ections, if necessary

- Ability to monitor effectiveness of remedy

- Coordination with other agencies

- Availability of off-sice treatment, storige and disposal services and ceppacily

\section{- Availability of prospective technologies}

\section{:Aodifying Criteria}

\section{- Opernting and maintenance costs \\ - Present worth cost}

\section{Stinte Acceptance}

- Features of the altemaive which the state supports

- Features of the altemative about which the state has reservations

- Elements of the alternative which the state strongly opposes
Community Acceptance

- Features of the alternative which the community supports

- Features of the alternative about which the community has reservations

- Elements of the aliemative which the community strongly opposes

Figure 15-4. Remedial Evaluation Criteria for Remedy Selection at Hanford Facility CERCLA Past-Practice Remediation Sites. 


\section{Four General Standards for Corrective Measures}

Overall procection of human healle and the enviromment

- How allernuives provide human healch and enviroumental protection

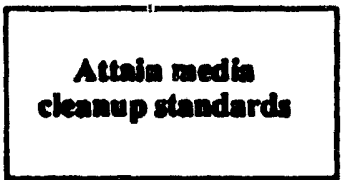

- Abiliky of alternatives to echieve the media clenmp standients prescribed in the permit modtriestion or enforcement onder

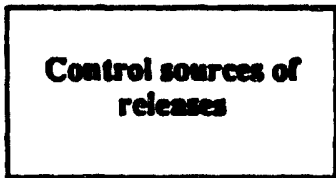

- How alcematives reduce or eliminate further relesuses to the maximum extent possible

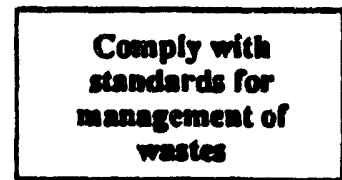

- How alcematives assure that manscement of wates is conducted in a protective manner during corrective mensures

\section{Five Selection Decision Factors}

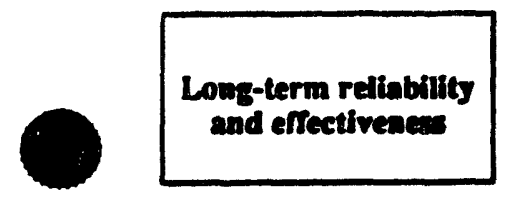

- Meznilude of residual risk

- Adequacy and reliability of controls

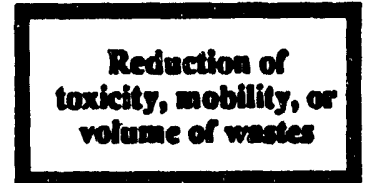

- Treatument proceess used and meterials treaced

- Amount of hrzardous materials destroyed or treated

- Degree of expected reductions in toxicity, mobility, or volume

- Dezree to which treatment is irreversible

- Type and quantity of residuals remaining after treatrnent

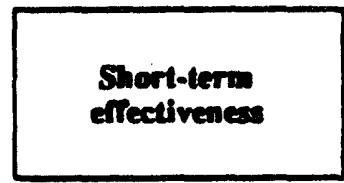

- Profection of community durine remedial actions

- Protection of workers during remedial actions

- Environmental impacts

- Time until remedial action objectives are achieved

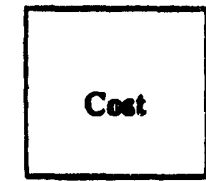

- Ability to construct and - Capieal costs opernie the technology

- Reliability of the echnology

- Operating and maintenance costs

- Eve of undertaking - Present worth additional corrective costs measures (if necessary)

- Ability 10 monitor effectiveness of remedy

- Coordination with other agencies

- Availability of off-sice treatriment storage and disposal services and specialists

- Availability of prospective technologies

Figure 15-5. Corrective Measures Evaluation Criteria for Remediation of Hanford Facility RCRA Past-Practice Sites. 
Table 15-1. Chapter 15.0 Cross-Reference Table. ([ ] - Denotes location of information in Ecology Part B check 1 ist)

\begin{tabular}{|l|l|l|l|}
\hline \multicolumn{1}{|c|}{ ERDF outline chapter* } & \multicolumn{1}{|c|}{$\begin{array}{c}\text { Specifically required } \\
\text { by CAMU requlation? }\end{array}$} & $\begin{array}{c}\text { Washington State } \\
\text { CAMU Regulations** } \\
173-303\end{array}$ & $\begin{array}{c}\text { Federal } \\
\text { CArw regulations } \\
40 \text { CFR }\end{array}$ \\
\hline $\begin{array}{l}15.0 \text { CAMU Evaluation Criteria } \\
\text { [Not in checklist] }\end{array}$ & Yes & $646(5)(a)$ & $\begin{array}{l}264.552(c) \\
\text { CAM Criteria 1-7 }\end{array}$ \\
\hline
\end{tabular}

* The sections of this application are based on the Ecology Part B Checklist. The referenced regulations, both state (WAC 173-303) and federal ( 40 CFR 260-270), provide the specific requirements that typically are incorporated in these sections.

** Assumes that Washington State has received HSWA authority. 
Table 15-2. Cost Comparison of the Environmental Remediation Disposal Facility Configuration Options.

\begin{tabular}{|l|l|l|l|l|}
\hline Configuration & \multicolumn{1}{|c|}{ Description } & $\begin{array}{c}\text { Cost } \\
\text { savings* for } \\
1 \text { iner }\end{array}$ & $\begin{array}{l}\text { Cost savings* } \\
\text { for } \\
\text { excavation }\end{array}$ & $\begin{array}{l}\text { Cost savings* } \\
\text { for final } \\
\text { cover }\end{array}$ \\
\hline Base case & $\begin{array}{l}\text { shallow, } \\
\text { multiple } \\
\text { trench system }\end{array}$ & $\$ 0$ & $\$ 0$ & $\$ 0$ \\
\hline $\begin{array}{l}\text { Area fill } \\
\text { Trench } A\end{array}$ & $\begin{array}{l}\text { single trench } \\
10 \text { meters } \\
(33 \text { feet) }\end{array}$ & $\$ 121$ million & $\$ 22$ million & $\$ 581$ million \\
\hline $\begin{array}{l}\text { Area fill } \\
\text { Trench B }\end{array}$ & $\begin{array}{l}\text { single trench } \\
15 \text { meters } \\
(50 \text { feet) }\end{array}$ & $\$ 171$ million & $\$ 22$ million** & $\$ 712$ million \\
\hline $\begin{array}{l}\text { Area fill } \\
\text { Trench } C\end{array}$ & $\begin{array}{l}\text { single trench } \\
10 \text { meters } \\
(70 \text { feet) }\end{array}$ & $\$ 202$ million & $\$ 22$ million** & $\$ 776$ million \\
\hline
\end{tabular}

* Cost savings are based on comparison to the Base Case.

** The excavation costs of area fill trenches $B$ and $C$ were not assessed; however, the excavation costs of area fill trenches $A, B$, and $C$ essentially are equivalent in comparison to the base case. 
Table 15-3. Preliminary Screening Summary.

\begin{tabular}{|c|c|c|c|}
\hline Sereening Criteria & Site 1 & Site 2 & site 3 \\
\hline $\begin{array}{l}\text { Is the area located within } 500 \mathrm{ft} \text {, of a fault that has had } \\
\text { displecement in Holocene times? [uAC } 173-303-282(6)(a)(i) \text { ] }\end{array}$ & No & No & No \\
\hline Does the aree exhibit subsidence? [MAC 173-303-282(6)(a)(ii)] & No & No & No \\
\hline $\begin{array}{l}\text { Dows the area contain slopes or soil instability? } \\
\text { WaA } 173-303-282(6)(a)(\text { ilii)] }\end{array}$ & No & No & No \\
\hline $\begin{array}{l}\text { Does the area have potential for flooding, seiche, and tsunamis? } \\
\text { [MAC } 173-303-282(6)(C)(1)(A)]\end{array}$ & No & No & No \\
\hline $\begin{array}{l}\text { Is the area located within } 500 \mathrm{ft} \text {. of peremial surface water } \\
\text { bodies? [WaC } 173-303-282(6)(C)(i)(B)(1])]\end{array}$ & No & No & No \\
\hline $\begin{array}{l}\text { Is the area located near a surface water supply for domestic use? } \\
\text { CuAC } 173-303-282(6)(c)(i)(C)]\end{array}$ & No & No & No \\
\hline $\begin{array}{l}\text { Does the depth to groundwater exceed } 50 \mathrm{ft} \text { ? } \\
\text { WWAC } 173-303-282(6)(\mathrm{C})(\mathrm{i})(\mathrm{A}) \mathrm{I}\end{array}$ & Yes & Yes & Yes \\
\hline $\begin{array}{l}\text { Are there sole source aquifers underneath/near the area? } \\
\text { [WAC } 173-303-282(6)(C)(\text { ii })(B)]\end{array}$ & No & No & No \\
\hline $\begin{array}{l}\text { Are there any groundwater managenent areas nearby? } \\
\text { [WAC } 173-303-282(6)(\text { C })(\text { ii })(C)]\end{array}$ & No & No & No \\
\hline $\begin{array}{l}\text { Is the area located within } 0.25 \text { miles from the nearest groundwater } \\
\text { intake for domsetic water? [WAC } 173-303-282(6)(c)(i i)(0) \text { ] }\end{array}$ & No & No & No \\
\hline $\begin{array}{l}\text { Are there any special groundwater protection aroas nearby? } \\
\text { [WAC } 173-303-282(6)(c)(i i)(E)]\end{array}$ & No & No & No \\
\hline $\begin{array}{l}\text { Are wetlands located within } 0.25 \text { miles of the area? } \\
\text { [WAC } 173-303-282(6) \text { (d)(i)(A)] }\end{array}$ & No & No & No \\
\hline $\begin{array}{l}\text { Are there any designated critical habitat or federally listed } \\
\text { threatened or endangered species within } 0.25 \text { miles of the area?" } \\
\text { (WAC } 173-303-282(6)(d)(i)(B)]\end{array}$ & No & No & No \\
\hline $\begin{array}{l}\text { Is there habitat designated by the Washington Department of Wildlife } \\
\text { within } 0.25 \text { miles of the area? [WAC } 173-303-282(6)(d)(i)(C)]\end{array}$ & No & No & No \\
\hline $\begin{array}{l}\text { Are there any natural areas acquired or voluntarily registered or } \\
\text { dedicated within } 0.25 \text { miles of the area? } \\
\text { [WAC } 173-303-282(6)(d)(i)(D)]\end{array}$ & No & No & No \\
\hline $\begin{array}{l}\text { Are there any state or federally designated wildlife refuge, } \\
\text { preserve, or bold eagle protection areas within } 0.25 \text { miles of the } \\
\text { area? [WAC } 173-303-282(6) \text { (d)(i)(E)] }\end{array}$ & No & No & No \\
\hline $\begin{array}{l}\text { Does the area receive greater than } 100 \text { inches of precipitation } \\
\text { annually? [WAC } 173-303-282(6)(0)]\end{array}$ & No & No & No \\
\hline $\begin{array}{l}\text { Is the area located within } 500 \text { it. of the nearest point of the } \\
\text { facility property line? [WAC } 173-303-282(7)(a)(i i)]\end{array}$ & No & No & No \\
\hline $\begin{array}{l}\text { Is the area located within } 0.25 \text { miles: (1) of state or federally } \\
\text { designated parks, recreation areas, or national monuments; (2) of } \\
\text { wilderness areas as defined by the wilderness Act of 1964; (3) of } \\
\text { land identified as prime farml and and a not ice of intent has been } \\
\text { submitted to Ecology; or (4) from residences or publ ic gathering } \\
\text { places? [WAC } 173-303-282(7) \text { (b)(i)(ii) and (iii)] }\end{array}$ & No & No & No \\
\hline $\begin{array}{l}\text { Will the facility comply/conform to DOE land use/site selection } \\
\text { requirements? [WAC } 173-303-282(7) \text { (d)DOE-RL Orders } 4320.2 \mathrm{C} \text {, and } \\
\text { DOE Order } 6430.1 A]\end{array}$ & Yes & Yes & Yes \\
\hline $\begin{array}{l}\text { Are any archaeological and historical sites located in the area? } \\
\text { [WAC } 173-303-282(7)(e)]\end{array}$ & No & Yes ${ }^{\circ}$ & No \\
\hline
\end{tabular}

- The entire Hanford Facility contains several candidate threatened or endangered species; however, none of the sites were excluded from further evaluation.

- Preliminary evaluation based on initial nomination of White Bluffs Road to National Register of Historic Places. 
1 2

4

5

6

7

9

10

11

12

17

\section{CONTENTS}

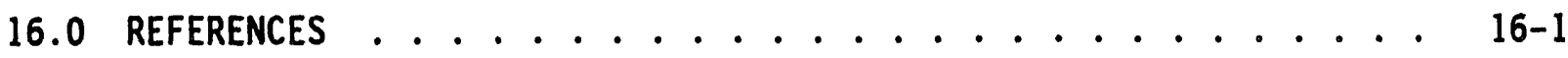

16.1 DOCUMENTS ................... 16-1

16.2 CODE OF FEDERAL REGULATIONS AND

FEDERAL REGISTER ................. . . 16-9

16.3 FEDERAL AND STATE ACTS . . . . . . . . . . . . 16-9

16.4 WASHINGTON ADMINISTRATIVE CODES ........... . 16-10

16.5 U.S. DEPARTMENT OF ENERGY ORDERS ........... . 16-11 
DOE/RL-94-40, Rev. 0

$06 / 94$

1
2
3
4
5

This page intentionally left blank. 
DOE/RL-94-40, Rev. 0

06/94

\subsection{REFERENCES}

\subsection{DOCUMENTS}

AASHTO, 1983, Standard Specification for Highway Bridges, AASHTO-HS-20-44, American Association of State Highway and Transportation Officials, Washington, D.C.

American Society of Agronomy, 1986, "Methods of Soil Analysis; Physical and Mineralogical Methods", Agronomy, No. 9, Part 1, 2nd Ed., Madison, Wisconsin.

ASTM, 1993, 1993 Annual Book of ASTM Standards, American Society for Testing and Material, Philadelphia, Pennsylvania.

Bergeron, M. P., G. V. Last, and A. E. Reisenauer, 1987, Geohydrology of a Commercial Low-Level Radioactive Waste Disposal Facility Near Richland, Washington, Prepared for US Ecology, Inc., Louisville, Kentucky.

Bierschenck, W. H. 1957, Hydraulic Characteristics of Hanford Aquifers, HW-48916, General Electric Company, Hanford Atomic Products Operation, Richland, Washington.

Bjornstad, B. N., 1984, Suprabasalt Stratigraphy Within and Adjacent to the Reference Repository Location, SD-BWI-DP-039, Rockwell Hanford Operations, Richland, Washington.

Bjornstad, B. N., 1985, "Late - Cenozoic Stratigraphy and Tectonic Evolution Within a Subsiding Basin, South-Central Washington," Geological Society of America Abstracts with Programs, Vol. 17, No. 7, pg. 524.

Brown, D. H., 1959, Subsurface Geology for the Hanford Separation Areas, HW-61780, General Electric Company, Richland, Washington.

Brown, D. J., 1960, An Eolian Deposit Beneath the 200-W Areas, HW-67549, General Electric Company, Richland, Washington.

COE, 1969, Columbia River Basin: Lower Columbia River Standard Project Flood and Probable Maximum Flood, Memorandum Report, U.S. Army Corps of Engineers, North Pacific Division, Portland, Oregon.

Daubenmire, F. R., 1970, Steppe Vegetation of Washington, Washington Agricultural Experiment Station Technical Bulletin 62, Washington Agricultural Experiment Station, Pullman, Washington.

DOE, 1986, Environmental Assessment - Reference Repository Location, Hanford Site, Washington, Volume 1, DOE/RW-0070, U.S. Department of Energy, Office of Civilian Radioactive Waste Management, Washington, D.C. 
DOE/RL-94-40, Rev. 0

$06 / 94$

1

DOE, 1988, Consultation Draft, Site Characterization Plan, Reference Repository Location, Hanford Site, Washington, DOE/RW-0164, Vols. 1-9, U.S. Department of Energy, Washington, D.C.

DOE-RL, 1989, Low-Level Burial Grounds Dangerous Waste Permit Application, DOE/RL/88-20, Rev. O, U.S. Department of Energy, Richland Operations Office, Richi and, Washington.

DOE-RL, 1991, Expedited Response Action Proposal (EE/CA \& EA) for the 200 West Area Carbon Tetrachloride P1ume, DOE/RL-91-32, Draft B, U.S. Department of Energy, Richland Operations Office, Richland, Washington.

DOE-RL, 1993a, 200 East Groundwater Aggregate Area Management Study Report, DOE/RL-92-19, Rev. 0, U.S. Department of Energy, Richland Operations Office, Richiand, Washington.

DOE-RL, 1993b, 200 West Groundwater Aggregate Area Management Study Report, DOE/RL-92-16, Rev. 0, U.S. Department of Energy, Richland Operations Office, Richiand, Washington.

DOE-RL, 1993c, Engineering Study for the Conveyor and Area Fill Systems for the Environmental Restoration Facility, DOE/RL/12074--15, Rev. 0, U.S. Department of Energy, Richland Operations Office, Richland, Washington.

DOE-RL, 1993d, Engineering Study for the Trench and Engineered Barrier Configuration for the Environmental Restoration Storage and Disposal Facility, DOE/RL/12074--13, Rev. 0, U.S. Department of Energy, Richland Operations Office, Richland, Washington.

DOE-RL, 1993e, Hanford Site Background: Part 1, Soil Background for Nonradioactive Analytes, DOE/RL-92-24, Rev. 1, U.S. Department of Energy, Richland Operations Office, Richland, Washington.

DOE-RL, 1993f, Quarterly Report of RCRA Groundwater Monitoring Data for Period Apri7 1, 1993 through June 30, 1993, DOE/RL-93-56-2, U.S. Department of Energy, Richland Operations Office, Richland, Washington.

DOE-RL, 1993g, Hanford Facility Contingency Plan, DOE/RL-93-75, U.S. Department of Energy, Richland Operations Office, Richland, Washington.

DOE-RL, 1994a, Conceptual Design Report for the Environmental Restoration Disposal Facility, DOE/RL/12@i74--28, Rev. 0, U.S. Department of Energy, Richland Operations Office, richland, Washington.

DOE-RL, 1994b, Dust Suppressani Pilot Study for the Environmental Restoration Disposal Facility, DOE/RL/12074--30, Rev. 0, U.S. Department of Energy, Richland Operations Office, Richland, Washington. 
DOE/RL-94-40, Rev. 0

$06 / 94$

DOE-RL, 1994C, Engineering Study - Load/Deformation Characteristics of Potential Waste Solls for the Environmental Restoration Disposal

Facility, DOE/RL-12074--31, Rev. 0, U.S. Department of Energy, Rich1 and Operations Office, Richland, Washington.

DOE-RL, 1994d, RI/FS for the Environmental Restoration Disposal Facility, DOE/RL-93-99, U.S. Department of Energy, Richland Operations Office, Richland, Washington.

DOE-RL, 1994e, Source Inventory Development Engineering Study, DOE/RL-12074-29, Rev. O, U.S. Department of Energy, Richland Operations Office, Richland, Washington.

Domenico, P. A. and G. A. Robbins, 1985, "A New Method of Contaminant Plume Analysis," Ground Water, Vol. 23, No. 4, pp. 476-485.

Eastern Washington University, 1992, The Future of Hanford: Uses and Cleanup, The Final Report of the Hanford Future Site Uses Working Group, Cheney, Washington.

Ecology, 1987, State of Washington Part B Permit Application Requirements, Washington State Department of Ecology, Olympia, Washington.

Ecology, EPA, and DOE, 1994, Hanford Federal Facility Agreement and Consent Order, as amended, Washington State Department of Ecology,

U.S. Environmentai Protection Agency, U.S. Department of Energy, 01ympia, Washington.

EPA, 1986a, Construction Quality Assurance for Hazardous Waste Disposal Facilities, EPA/530-SW-86-031, U.S. Environmental Protection Agency, Cincinnati, Ohio.

EPA, 1986b, RCRA Groundwater Monitoring Technical Enforcement Guidance Document, OSWER Directive 9950.1, U.S. Environmental Protection Agency, Washington, D.C.

EPA, 1986c, Test Methods for the Evaluation of Solid Waste: Physical/Chemical Methods, SW-846, 3rd. ed., U.S. Environmental Protection Agency, Washington, D.C.

EPA, 1987a, Design, Construction and Maintenance of Cover Systems for Hazardous Waste, An Engineering Guidance Document, EPA/600/2-871039, U.S. Environmental Protection Agency, Washington, D.C.

EPA, 1987b, Geosynthetic Design Guidance for Hazardous Waste Landfill Cells and Surface Impoundments, EPA/600/2-87/097, Office of Research and Development, U.S. Environmental Protection Agency, Cincinnati, Ohio.

EPA, 1988, Guide to Technical Resources for the Design of Land Disposal Facilities, EPA/625-6-88/018, U.S. Environmental Protection Agency, Washington, D.C. 
DOE/RL-94-40, Rev. 0

06/94

1

2

3

4

5

6

7

8

9

10

11

12

13

14

15

16

17

18

19

20

21

22

23

24

25

26

27

28

29

30

31

32

33

34

35

36

37

38

39

40

41

42

43

44

45

46

47

48

49

EPA, 1989a, Guidance on Preparing Superfund Decision Documents, EPA1540 G-89 007, U.S. Environmental Protection Agency, Washington, D.C.

EPA, 1989b, Requirenents for Hazardous waste Landf 111 Design, Construction and Closure, EPA/625-4-89/-22, U.S. Environmental Protection Agency, Washington, D.C.

EPA, 1991a, Design and Construction of RCRA/CERCLA Final Covers, EPA/625/4-91/025, U.S. Environmental Protection Agency, Cincinnati, Ohio.

EPA, 1991b, Guidance on RCRA Corrective Action Decision Documents, U.S. Environmental Protection Agency OSWER Directive 9902.6,

U.S. Environmental Protection Agency, Washington, D.C.

EPA, 1992a, Action Leakage Rates for Leak Detection Systems, EPA 530-R-92-004, Office of Solid Waste, Environmental Protection Agency, Washington, D.C.

EPA, 1992b, Supplemental Information on Corrective Action Management Units (CAMUS), U.S. Environmental Protection Agency, Washington, D.C.

EPA, 1993, Quality Assurance and Quality Control For Waste Containment Facilities, EPA/600/R-93/182, U. S. Environmental Protection Agency, Washington, D.C.

ERDA, 1976, Evaluation of Impact of Potential Flooding Criteria on the Hanford Project, RLO-76-4, U.S. Energy Research and Development AdministrationRichland Operations Office, Richland, Washington.

FEMA, 1980, Flood Insurance Study: Benton County Washington, Federal Emergency Management Agency, Federal Insurance Administration, Washington, D.C.

Gee, G. W., M. J. Fayer, M. L. Rockhold, and N. D. Campbel1, 1992, "Variations in Recharge at the Hanford Site", Northwest Science, Vol. 66, pp. 237-250.

Golder Associates, 1992, User's Manual, Monitoring Analysis Package, Including MEMO, Plume, and COPRO, Version 1.1., Golder Associates, Richland, Washington.

Graham, M. J., M. D. Hall, S. R. Strait, and W. R. Brown, 1981, Hydrology of the Separations Area, RHO-ST-42, Rockwell Hanford Operations, Richland, Washington.

Graham, M. J., G. V. Last, and K. R. Fecht, 1984, An Assessment of Aquifer Intercommunication in the $B$ Pond-Gable Mountain Pond Area of the Hanford Site, RHO-RE-ST-12 P, Rockweil International, Rockwell Hanford Operations, Richland, Washington. 
1 Groller, M. J. and J. W. Bingham, 1978, Geology of Parts of Grant, Adams and

2

3

4

5 Franklin Counties, East-Central Washington, Bul1. 71, Division of Geology and Earth Resources, Department of Natural Resources, State of Washington.

Hajek, B. F., 1966, Soll Survey: Hanford Project in Benton County, Washington, BNWL-243, Battelle Northwest Laboratories, Richland, Washington.

ICBO, 1991, "Earthquake Regulations", Uniform Butlding Code, UBC Section 2312, International Conference of Butiding Officials, Whittier, California.

KEH, 1993, "Design Loads for Factlittes", Hanford Plant Standards, Standard Design Criteria-4.1, HPS-DCM, Kaiser Engineers Hanford, Richiand, Washington.

Kocher, A.E., A.T. Strahorn, and M.H. Lapham, 1921, Soll Survey of Benton County, Washington, U.S. Department of Agriculture, Bureau of Solls, Washington, D.C.

Myers, C. W., S. M. Price, J. A. Cagglano, M. P. Cochran, W. J. Czimer, N. F. Davidson, R. C. Edwards, K. R. Recht, G. E. Holmes, M. G. Jones, J. R. Kunk, R. D. Landon, R. K. Ledgewood, J. T. Lillile, P. E. Long, T. H. Mitchel1, E. H. Price, S. P. Reldel, and A. M. Tailman, 1979, Geologic Studies of the Columbia Plateau--A Status Report: Richland, Washington, RHO-BWI-ST-4, Rockwell Hanford Operations, Richland, Washington.

Mullineaux, D. R., R. E. Wilson, W. F. Ebaugh, R. Fryxell, and M. Rubin, 1978, "Age of the Last Major Scabland Flood of the Columbia Plateau in Eastern Washington," Quaternary Research, Vol. 10, pp. 171-180.

Nelson, J. D. and S. R. Abt, 1986, Mini-Course 3: Application of Long-Term Stability Engineering and Design of Waste Disposal Systems, Presented at the 8th Annual Symposium on Geotechnical and Geohydrological Aspects of Waste Management, Colorado State University, Fort Collins, Colorado.

Newcomb, R.C., 1958, "Ringold Formation of the Pleistolene Age in Type Locality, The White Bluffs, Washington," American Journal of Science, Vol. 256, pp. 328-340.

Newcomb, R. C., J. R. Strand and F. J. Frank, 1972, Geology and Groundwater Characteristics of the Hanford Reservation of the U. S. Atomic Energy Commission, Washington, Geological Survey Professional Paper 717, U. S. Geological Survey, Washington, D.C.

PNL, 1973, Collection and Analysis of Pump Test Data for Transmissivity Values, BNNL-1709, Pacific Northwest Laboratory, Richland, Washington.

PNL, 1981, Flood Risk Analysis of Cold Creek Near the Hanford Site, PNL-4219, Pacific Northwest Laboratory, Richland, Washington.

PNL, 1983, Climatological Summary for the Hanford Area, PNL-4622, Pacific Northwest Laboratory, Richland, Washington. 
1 PNL, 1987, Recharge at the Hanford Site: Status Report, PNL-6043, Pacific

PNL, 1989, Hydrogeology of the 200 Areas Low-Level Burlal Grounds - An Interim Final, PNL-6820, Pacific Northwest Laboratory, Richland, Washington.

PNL, 1990, Geohydrology of the 218-W-5 Burlal Ground, 200 West Area, Hanford Site, PNL-7336, Pacific Northwest Laboratory, Richland, Washington:

PNL, 1993, Preliminary Potent lometric Map and Flow Dynanic Characteristics for the Upper-Basalt Confined Aquifer System, PNL-8869, Battelle Paciftc Northwest Laboratory, Richland, Washington.

PSPQL, 1982, Skagit/Hanford Nuclear Project, Preliminary Safety Analysis Report, Vol. 4, App. 20, Amendment 23, Puget Sound Power and Light Company, Bellevue, Washington.

Reidel, S. P., and K. R. Fecht, 1981, "Wanapum and Saddle Mountains Basalts of the Cold Creek Syncline Area," Subsurface Geology of the Cold Creek Syncline, RHO-BWI-ST-14, Rockwell Hanford Operations, Richland, Washington.

Routson, R. C. and K. R. Fecht, 1979, Soil (Sediment) Properties of Twelve Hanford Wells, With Geologic Interpretation, RHO-LD-82, Rockwell Hanford Operations, Richland, Washington.

Skaggs, R.L., and W.H. Walters, 1981, Flood Risk Analysis of Cold Creek Near the Hanford Site, PNL-4219, Pacific Northwest Laboratory, Richland, Washington.

Tallman, A. M., J. T. Lillie, and K. R. Fecht, 1981, "Suprabasalt Sediments of the Cold Creek Syncline Area," Subsurface Geology of the Cold Creek Syncline, RHO-BWI-ST-14, Rockwell Hanford Operations, Richland, Washington.

U.S. Army Corps Engineers, 1994, Environmental Restoration Disposal Facility Waste Acceptance Criteria, Rev. O, U. S. Army Corps of Engineers, Richl and, Washington.

U.S. Department of Agriculture, 1978, Predicting Rainfall Erosion Losses, A Guide to Conservation Planning, Handbook No. 537, U.S. Department of Agriculture, Washington, D.C.

U.S. Department of Commerce, 1991, 1990 U.S. Census of Population and Housing, State and County Profiles, Washington, U.S. Department of Commerce, Office of Financial Management, Washington, D.C.

Western States Land-Grant Universities and Colleges and Soil Conservation Service, 1964, Soils of the Western United States, Washington State University, Pullman, Washington. 
1 WHC, 1989a, Environmental Investigations and Site Characterization Manual,

WHC, 1989b, Strategy for Handling and Disposing of Purgewater at the Hanford Site, Washington, WHC-MR-0039, Westinghouse Hanford Company, Richland, Wasinington.

WHC, 1990, Liquid Effluent Retention Facility, 9090 Testing, WHC-SD-W105-PTP-001, Rev. 0, Westinghouse Hanford r. npany, Richland, Washington.

WHC, 1991a, 9090 Test Results, WHC-SD-W105-TD-001, Rev. 0, Westinghouse Hanford Company, Richland, Washington.

WHC, IJ91b, Geology and Hydrology of the Hanford Site: A Standardized Text for Use in Westirighouse Hanford Company Documents and Reports, WHC-SD-ER-TI-003, Westinghouse Hanford Company, Richland, Washington.

WHC, 1991c, Industrial Safety Manual, Vol. 3, Respiratory Protection Manual, WHC-CM-4-3, Westinghouse Hanford Company, Richland, Washington.

WHC, 1991d, Revised Stratigraphy for the Ringold Formation, Hanford Site, South-Central Washington, WHC-SD-EN-EE-004, Westinghouse Hanford Company, Richl and, Washington.

WHC, 1992a, Biological Assessment for Rare and Endangered Plant Species Related to CERCLA Characterization Activities, WHC-EP-0526, Westinghouse Hanford Company, Richland, Washington.

WHC, 1992b, Field Trip Guide to the Hanford Site, WHC-MR-0391, Westinghouse Hanford Company, Richland, Washington.

WHC, 1992c, Generic Specification - Groundwater Monitoring We11s, WHC-S-014, Rev. 7, Westinghouse Hanford Company, Richland, Washington.

WHC, 1992d, Geologic Setting of the 200 Area: An Update, WHC-SD-EN-TI-008, Westinghouse Hanford Company, Richland, Washington.

WHC, 1992e, Hydrogeologic Model for the 200 East Groundwater Aggregate Area, WHC-SD-EN-TI-019, Westinghouse Hanford Company, Richland, Washington.

WHC, 1992f, Hydrogeologic Model for the 200 West Groundwater Aggregate Area, WHC-SD-EN-TI-014, Westinghouse Hanford Company, Richland, Washington.

WHC, 1992g, Quality Assurance Project Plan for RCRA Groundwater Monitoring Activities, WHC-SD-EN-QAPP-001, Rev. 1, Westinghouse Hanford Company, Richland, Washington.

WHC, 1992h, Soil Liner/Leachate Compatibility Testing in Support of Project W-025 Radioactive Mixed Waste Disposal Facility, WHC-SD-W025-TRP-002, Westinghouse Hanford Company, Richland, Washington. 
DOE/RL-94-40, Rev. 0

$06 / 94$

WHC, 1992i, Status of Birds at the Hanford Site in Southeastern Washington, WHC-EP-0402, Rev. 1, Westinghouse Hanford Company, Richland, Washington.

WHC, 1992j, Vascular Plants of the Hanford Site, WHC-EP-0554, Westinghouse Hanford Company, Richland, Washington.

WHC, 1993a, Ecological Survey for the Environmental Restoration Storage and Disposal Facility, 25320-93-116, Westinghouse Hanford Company, Richland, Washington.

WHC, 1993b, Environmental Compliance, WHC-CM-7-5, Westinghouse Hanford Company, Richl and, Washington.

WHC, 1993c, Functional Design Criteria, Environmental Restoration Storage and Disposal Facility Project W-296, WHC-SD-W296-FDC-001, Rev. 1,

Westinghouse Hanford Company, Richland, Washington.

WHC, 1993d, Groundwater Field Characterization Report for the 200 Aggregate Area Management Study, WHC-SD-EN-TI-020, Rev. 0, Westinghouse Hanford Company, Richland, Washington.

WHC, 1993e, Hanford Site Solid Waste Acceptance Criteria, WHC-EP-0063-4, Westinghouse Hanford Company, Richland, Washington.

WHC, 1994a, Natura? Hazard Phenomena Mitigation with Respect to Seismic Hazards at the Environmental Restoration Disposal Facility, WHC-SD-W296-RPT-002, Rev. 0, Westinghouse Hanford Company, Richland, Washington.

WHC, 1994b, Notice of Intent to Operate the Environmental Restoration Disposal Facility, Westinghouse Hanford Company, Richland, Washington.

WHC, 1994c, Site Characterization Plan for the Environmental Restoration Disposal Facility, WHC-SD-EN-AP-128, Rev. 1, Westinghouse Hanford Company, Richland, Washington.

QHC, 1994d, Siting Evaluation Report for the Hanford Monitored Waste Disposal Complex, WHC-SD-EN-EV-009, Rev. 0, Westinghouse Hanford Company, Richland, Washington.

WHC, 1994e, State Environmental Policy Act Environmental Checklist Forms for the Environmental Restoration Disposal Facility, Rev. 0, Westinghouse Hanford Company, Richland, Washington.

Youngs, R. R., K. J. Coppersmith, M. S. Power, and F. H. Swan III, 1985, Seismic Hazard Assessment of the Hanford Region, Eastern Washington State, in the Proceedings of the DOE Natural Phenomena Hazards Mitigation Conference, Las Vegas, Nevada. 


\subsection{CODE OF FEDERAL REGULATIONS AND FEDERAL REGISTER}

\section{CFR 1910.120, Hazardous Waste Operations and Emergency Response}

40 CFR 61, National Emission Standards for Hazardous Air Pollutants

40 CFR 257, Criteria for Classification of Solid Waste Disposal Facilities and Practices

40 CFR 260, Hazardous Waste Management System - General

40 CFR 261, Identification and Listing of Hazardous Waste

40 CFR 264, Standards for Owners and Operators of Hazardous Waste Treatment, Storage, and Disposal Facilities

40 CFR 265, Interim Status Standard for Owners and Operators of Hazardous Waste Treatment, Storage, and Disposal Facilities

40 CFR 268, Land Disposal Restrictions

40 CFR 270, EPA Administered Permit Programs: The Hazardous Waste Permit Program

40 CFR 761, Polychlorinated Biphenyls (PCBs) Manufacturing, Processing, Distribution in Commerce, and Use Prohibitions

40 CFR 763, Asbestos

49 CFR 213, Track Safety Standards

55 FR 145, Page 30799, Corrective Action for Solid Waste Management Units at Hazardous Waste Management Facilities; Proposed Rule, July 27, 1990.

58 FR 29, Page 8658, Corrective Action Management Units and Temporary Units; Corrective Action Provisions; Final Rule, February 16, 1993.

58 FR 98, Page 29860, Land Disposal Restrictions for Ignitible and Corrosive Characteristic Wastes Who's Treatment Standards Were Vacated; Interim Final Rule, May 24, 1993.

\subsection{FEDERAL AND STATE ACTS}

Atomic Energy Act of 1954, 42 USC 2001 et seq.

Clean Air Act of 1977, 33 USC 7401 et seq.

Clean Water Act of 1977, 33 USC 1251 et seq.

Comprehensive Environmental Response, Compensation, and Liability Act of 1980, 42 USC 9601 et seq. 
Endangered Species Act of 1973, 16 USC 1531 et seq.

Fish and Wildlife Coordination Act of 1934, 16 USC 661 et seq.

Freedom of Information Act of 1966, as amended, 5 USC 552.

Hazardous and Solid Waste Amendments of 1984

National Environmental Policy Act

National Historic Preservation Act of 1966, 16 USC 470 et seq.

Privacy Act of 1974, 5 USC 552a.

Resource Conservation and Recovery Act of 1976, 42 USC 6901 et seq.

Safe Drinking Water Act of 1974, 42 USC $300 f$ et seq.

Shoreline Management Act of 1971

Toxic Substances Control Act of 1976, 15 USC 2601 et seq.

Washington State Model Toxics Control Act of 1990 (WAC 173-340)

Washington State National Heritage Program of 1990

Wild and Scenic Rivers Act of 1968, 16 USC 1271 et seq.

\subsection{WASHINGTON ADMINISTRATIVE CODES}

RCW 70.94, Washington Clean Air Act

RCW 70.98, Nuclear Energy and Radiation

RCW 90.48, Water Pollution Control Act

WAC 173-160, Minimum Standards for Construction and Maintenance of Wells

WAC 173-216, State Waste Discharge Permit Program

WAC 173-303, Dangerous Waste Regulations

WAC 173-340, Model Toxics Control Act Cleanup Regulations

WAC 173-460, Controls for New Sources of Toxic Air Pollutants

WAC 173-480, Ambient Air Quality Standards and emission limits for Radionuclides

50 
1 WAC 197-11, State Environmental Policy Act of 1971 (Environmental Checklist Forms)

WAC 246-247, Radiation Protection - Air Emissions

\subsection{U.S. DEPARTMENT OF ENERGY ORDERS}

5400.1, General Environmental Protection Program Requirements

5480.1B, Environmental, Safety, and Health Program for Department of Energy Operations

5480.3, Safety Requirements for the Packaging and transportation of Hazardous Materials, Hazardous Substances, and Hazardous Wastes

5484.1, Environmental Protection, Safety, and Health Protection Information Reporting Requirements

5820.2A, Radioactive Waste Management

6430.1A, General Design Criteria 


$$
\text { DOE/RL-94-40, Rev. } 0
$$

This page intentionally left blank. 
DOE/RL-94-40, Rev. 0

$06 / 94$

\section{APPENDICES}

1A CHANGE NUMBER M-70-93-01 OF THE HANFORD FEDERAL FACILITY AGREEMENT AND CONSENT ORDER (JANUARY 1994)

2A ENGINEERING DRAWINGS

2B ECOLOGICAL SURVEY OF THE ENVIRONMENTAL RESTORATION DISPOSAL FACILITY

5A MONITORING WELL LOG AND CONSTRUCTION INFORMATION

5B MONITORING EFFICIENCY MODEL INFORMATION: USER'S MANUAL

5C GROUNDWATER SAMPLING AND ANALYSIS PLAN FOR THE ENVIRONMENTAL RESTORATION DISPOSAL FACILITY

7A BUILDING EMERGENCY PLAN FOR THE ENVIRONMENTAL RESTORATION DISPOSAL FACILITY

8A TRAINING PLAN FOR THE ENVIRONMENTAL RESTORATION DISPOSAL FACILITY 
DOE/RL-94-40, Rev. 0

$06 / 94$

This page intentionally left blank. 
DOE/RL-94-40, Rev. 0

$06 / 94$

\section{APPENDIX IA}

CHANGE NUMBER M-70-93-01 OF THE HANFORD FEDERAL FACILITY AGREEMENT AND CONSENT ORDER (JANUARY 1994) 
1

2

3

4

5

6

\section{APPENDIX IA}

This appendix contains pages 61 through 64 of the Fourth Amendment to the Hanford Federal Facility Agreement and Consent Order published in January of 1994. The selected pages address the ERDF (Change Number M-70-93-01) and related interim milestones, decisions, and assumptions. 


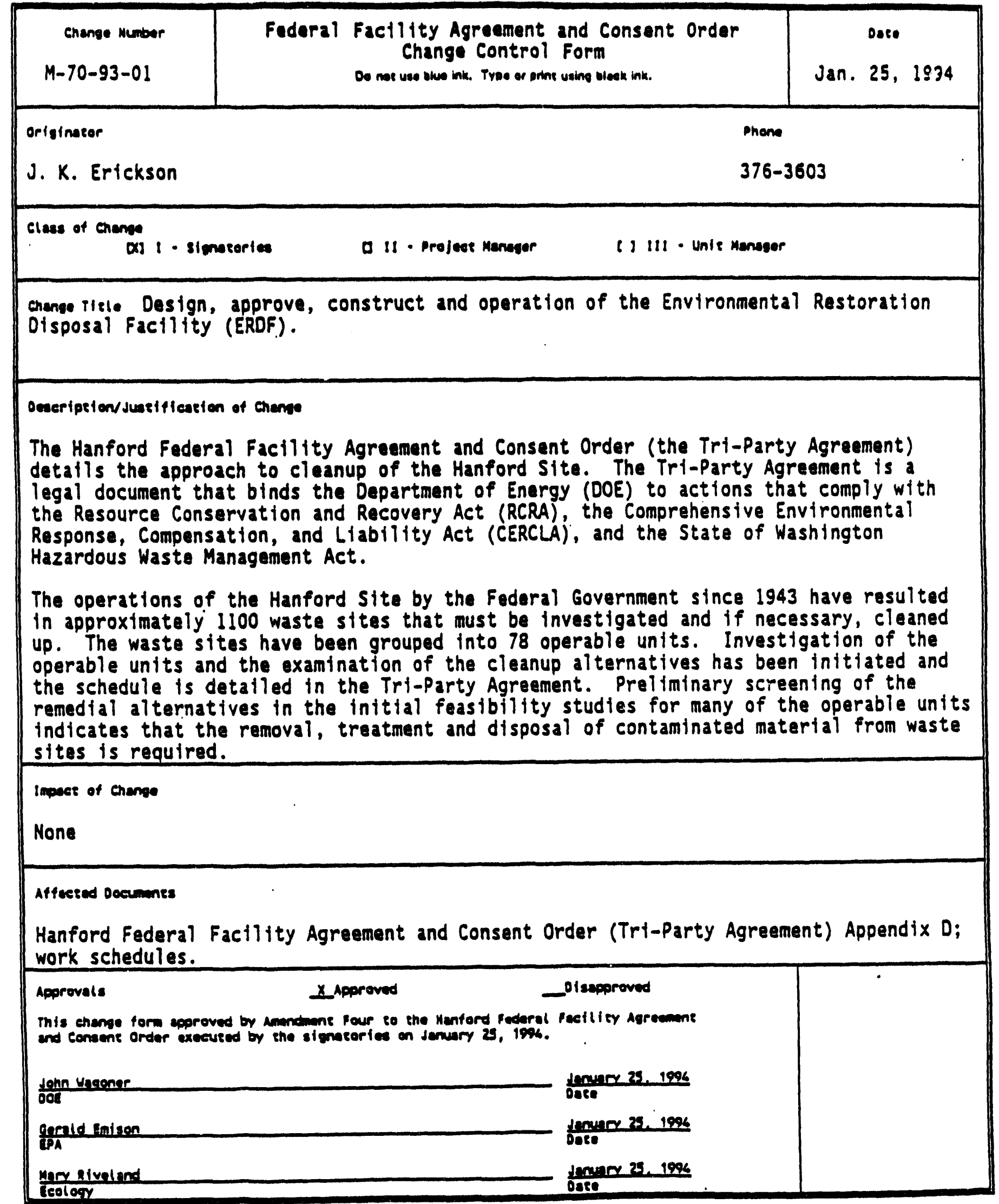




\section{ENVIRONMENTAL RESTORATION OISPOSAL FACILITY}

Removal actions resulting from 100 and 300 Area operable untt Resords of Decision (ROOs) are expected to produca large volumes of hazardous, radloactive, and mixed wasta, beginning approximately september, 1996. A disposal factlity capable of receiving large quantities of these wastes is needed at Hanford at that time. Technology does not exist to effectively treat or destroy the majority of these wastes and offesite disposal is not cost effective or accoptable for many reasons (e.g. transportation of massive quantities of waste on public highways). The Hanford Future site Uses Working Group in the report "The Future for Hanford: Uses and Cleanup", December 1992, recommends that waste management activities at the Hanford site be concentrated in the interior portion of the Central Plateau. Therefore, Ecology, EPA and DOE agree to proceed with the steps necessary to design, approve, construct and operate such a disposal facility, the Environmental Restoration Disposal Factlity (ERDF).

DOE shall prepare a comprahensive "package" for EPA and Ecology to consider in evaluating a disposal factlity. The package shall address the criterla listed in 40 CFR 264.552 (C) for Corrective Action Management Unit (CAMU) designation and a CERCLA Record of Decision (ROO). Each individual source operable unit ROO will specify how wastes from that operable unit will be treated and will reference a disposal facility, as appropriate.

Timing for the construction and operation of the facllity is eritical. The proposed plans for the operable units are due beginning in October 1994. Delay in construction of the facility would impact cleanup of the waste sites. The three parties are committed to working together to resolve issues affecting the design, construction and operation of the facility and to maintain the schedule to support the cleanup program.

The parties agree that a phased approach for construction of the disposal facility is appropriate. Design and construction of the initial phase shall be adequate for disposal of waste volumes projected to result from 100 and 300 Area RODs for operable units presently under investigation. Incremental future expansion of the facility shall be maintained such that remedial action scheduies are not adversely impacted by inadequate Hanford waste disposal capacity. Since the facility will require significant resources, a phased approach should minimize impacts on other operations such as cleanup. A phased approach will minimize the land use requirement since disposal units will be brought on ine on an "as needed basis".

The parties agree that public involvement is an essential part of the process and commit to early public participation. We agree that it is necessary to hear and consider public concarns as early as possible. A Public Involvement Plan shall be developed by the three parties in October, 1993. Public involvement will begin with the public interaction resulting from these negotiations and will continue through the design and regulatory approval process and subsequent facility expansions.

One target milestone, one major milestone and two interim milestones have been assigned to the ERDF to assure that the facility is avallable to support cleanup actions.

Target Milestone M-70-00-TO1 Due date: October 1993 Completed: 10/28/93

Submit a Public Involvement PIan for the ERDF 


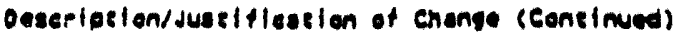

Major Milestone M-70-00

The ERDF will be operational (avallabie to recelve remediation waste) on

Septumber, 1996 Oue: Septamber 1996

Interim Milestone M-70-01 Due: February 1994

Submit a single-design ERDF Draft Conceptual Design Report (COR) for regulatory reviow and comment.

Interim Mflestone M-70-02 Due: April 1994

Submit information necessary for CAMU designation ( 40 CFR 264) and a CERCLA ROD for regulatory approval.

The following decisions and assumptions are implictt in the milestones:

- All regulatory comments to the Oraft COR will be reconclied to the satisfaction of the three agencies by April 15, 1994 to support subsaciuent ERDF milestones. If resolution is not accomplished by April 15, 1994, the PPA dispute process will govern the dectstons. The principles in the final COR shall serve as the basis for design, construction and operation.

- The definitive design package describing the form and function of the disposal factlity will be submitted to Ecology and EPA for approval three months after regulatory approval of the facility. If this is not accomplished, TPA dispute resolution will be invoked.

* A standard RCRA double flexible membrane liner (RCRA subtitle C), including a clay base and a leachate collection system, shall be used for the initial design. This design standard will be reevaluated for expansions and/or subsequent trenches.

* The disposal facility shall be designed to be cost efficient and minimize the "footprint" of the overall disposal factility.

- Regulatory authority - Approval under CERCLA ROO and/Or HSWA using the CAMU RUle, for the acceptance of Hanford-generated rumedial action waste.

* The parties agree on the following risk assessment parameters:

- The point of assessment will be the intersection of the groundwater and the vertical line drawn from the edge of the disposal facility.

- The time of assessment for radionuclides will be 10,000 years.

- The compliance standard will be 10 exp-5 for the first 100 years, 10 exp-4 thereafter.

- Based on existing analyses and data it is expected that treatment at the operable unit will generaliy be segregation, compaction, and waste volume reduction. Based on analysis of 100 Area source operabie units, all three TPA parties anticipate that mass solidification of the waste form wili not be necessary for the disposal of the bulk of the waste. 
- A pllot projes: concept for NE?A/CERCLA integration (func:ional equivaiency) will be ut llized; additional or saparate NEPA procss 3 and documentation willi not be required. The plloz projec: soncsot for NEPA/CERCLA incegration will be prasencas to the public through the Hanford Tanix Wasta Task Forsa and puoife meselngs.

- There is agratment between Ecology, EPA and OOE that inis iactil:y is crit:(cal path for Hanforo cieanup, and there is a wlllingnass by ail oarsiss 0 acjusi ipa ailesiones in the fucure (if it is neessary to reconcite unavallaollity of approprtated funds), to assure that this factlity is compieted in :ime io support 100 and 300 -Arsa RODs.

* The application for regulatory apar 11 shall include discussion of:

- Siting and compatibllity wit! recommendations described $i_{1 .}$

- Hanford Fueure Sle Uses Working Group December 1992.

"Futura for Hanford: Usas and Cleanup",

- How to handle existing contaminated sttes that are located within the footprint of the ERDF.

- How landfill footprint is mintmized.

- Landfill expansion. 
DOE/RL-94-40, Rev. 0

06/94

1
2
3
4
APPENDIX $2 \AA$

ENAINEERING DRANINGS

cyced Sepatuly

940609.1145

APP 2A-i 
1

2

$4 \mathrm{H}-6-958$

5

$6 \mathrm{H}-6-10606$

\section{APPENDIX 2A}

General Overview of Hanford Site, Rev. 5

Environmental Restoration Disposal Facility, Rev. 1 
DOE/RL-94-40, Rev. 0

$06 / 94$

1

APPENDIX 2B

ECOLOGICAL SURVEY OF THE ENVIORNIENTAL RESTORATION DISPOSAL FACILITY SITE 
DOE/RL-94-40, Rev. 0

06/94

This page intentionally left blank. 


\section{ECOLOGICAL SURVEY FORM}

REPORT *: $93-600-9$

LOCATION: TI2N R26E S8,9,15,16,17, $18,19,20,21$

PROJECT: Proposed Environmental Restoration Storage and Disposal Facility (ERSOF) Landfill Site on 200 Area Plateau

PLANT SURVEY DATE: MPRII - JUNE 1993 INVESTIGATOR: M. R. SaCXSChEWSKY

ANIMAL SURVEY DATE: APRII - JUne 1993 INVESTIGATOR: O. S. Landeen

SPECIES OF SPECIAL CONCERN OBSERVED:

PLANTS: Stalked-pod milkvetch

WILOLIFE: Long-billed curlew, loggerhead shrike, sage sparrow, grasshopper sparrow, Swainson's hawk

IS THE AREA UNDER VEGETATION MANAGEMENT: NO

OESCRIPTION OF AREA: The area surveyed is approximately six square miles of undisturbed sagebrush habitat on the 200 Area plateau (see Attachment 3 ). There are access roads in the area that lead to monitoring wells and some of the arc roads that supported the Hanford meteorology station several years ago still exist. Most of this area has not sustained significant fire damage with the exception of the southern end of the site which contains some sand dune aress which burned in 1984. The general topography of this area is not flat, consisting of several small knolls and valleys.

PLANTS OBSERYED: The stalked-pod milkvetch was the only plant species observed that occurs on a state or federal list as a species of concern. This species is a state monitor species that is fairly common throughout the 200 Area Plateau. A list of all other plant species observed is attached. (Attachment 2)

\section{WILDLIFE OBSERVED:}

Birds: Bird species observed were the western meadow lark, horned lark, white-crowned sparrow, magpie, red-tailed hawk, northern harrier, common nighthawk, barn swallow, bank swallow, and common raven.

Bird species observed that have been designated as species of concern by the state and federal governments were the long-billed curlew, sage sparrow, grasshopper sparrow, loggerhead shrike, and Swainson's hawk. Longbilled curlews are classified as a federal candidate three species $\left(F C_{3}\right.$ ) and as a state monitor (SM) species. Sage sparroiss are classified as a state candidate (SC) species. Grasshopper sparrows are classified as a state monitor (SM) species. Loggerhead shrikes are classified as a federal candidate two ( $\left.F C_{2}\right)$ species and as a state candidate (SC) species. The Swainson's hawk is classified as a federal candidate three ( $F C_{3}$ ) species and as a state candidate (SC) species. 
One pair of nesting curlews was observed at the site in the area near the sand dunes which had been burned in 1984. The area where they were observed had very litcle shrub cover and consisted mostly of grasses.

Several pairs of sage sparrows and family groups were observed in all areas where there is und isturbed sagebrush habitat. This area is probably one of the last strongholds for this species at Hanford and in the State of Washington.

Several pairs of loggerhead shrikes also utilized this area for nesting purposes. Loggerhead shrikes were found in all areas of the ERSOF. loggerhead shrikes only nest in undisturbed shrub/steppe habitat (Poole, 1992).

Grasshopper sparrows were heard early in the spring and it is possible that this area could be used for nesting by this species, however: this was not verified during these surveys.

Swainson's hawks utilize this area for hunting. The hawks actually nest at the army bunker sites adjacent to the site along army loop road.

Burrowing owls which are classified as a state candidate species were not observed during the surveys but they probably do reside in the area. Burrowing owls have been observed in this area in past years.

Mammals: Mammals known to inhabit this area based on actual observation during the surveys or direct evidence such as tracks and burrows were the Great iasin pocket mouse, badger, coyote, mule deer, and black-tailed jackrabbit. Coyotes and badgers are the principal predators, consuming such prey as rodents, insects, rabbits, birds, snakes, and lizards. The Great Basin pocket mouse is the most abundant small mamal, which thrives in sandy soils and lives entirely on seeds from local plant species.

Other mammals known to inhabit the 200 Area Plateau in general include the striped skunk, long-tailed weasel, bobcat, and various rodent species.

Reptiles and Amphibians: Reptiles observed during the surveys were the gooher snake, racer, and sideblotched lizards. Other reptiles and amphibians which are infrequently observed on the 200 Area Plateau include sagebrush lizards, short-horned lizards, western spadefoot toads, and the pacific ratelesnake.

SUMMARY AND CONCLUSIONS: The Observations of this survey are very similar to ecological surveys conducted by Pacific Norenwest Laboratory in April and June, 1993, on undisturbed sagebrush habitat in support of the Proposed Highway $240 / 200$ West Access Road, $\$ 93-$ WHC-003 which is adjacent to the ERSDF site and the Cross-Site Transfer Line, \$93-WHC-006 which is also near the ERSOF. The PNL surveys also documented the presence of loggerhead shrikes, long-billed curlews, and sage sparrows. The Cross-site transfer line survey al so documented the presence of the Owarf evening-primrose (Camissonia pygmaea) in the gravel pit approximately $1 / 2$ mile south-west of the 
200-areas fire station. This gravel pit is located just north of the proposed ERSOF landfill site. The dwar evening-primrose is listed by the Washington State Natural Heritage Program as a sensitive species.

The construction of a landfill at this site will destroy sagebrush habitat that the species of concern mentioned above rely on. Given the large size of the proposed landfill and the fact that undisturbed sagebrush habitat is depended upon by several species of concern and is becoming relatively rare in the state of Washington it is our recommendation to convene a consultation meecing with the Department of Energy, the State Department of Wildifife, and the U.S. Fish and Wild life Service to evaluate the biological importance of this site. From an ecological point of view it would be preferable to choose some of the more disturbed sites which exist in the 200 Areas as possible landfill sites.

Potential mitigating measures what could be implemented if this site is approved would include only excavating trenches on an as needed basis, revegetating with native shrubs, and having the majority of the construction activities take place from the middle of June to the end of february or early March. This timing would help avoid adverse impacts to the species of concern that utilize this area for nesting.

REFERENCES: Allen, J.N., 1980, The Ecology and Behavior of the Longbilled Curlew in Southeastern Washington, Wildlife Monographs, No. 73, 67 pp.

Landeen, D.S., A.R. Johnson, and R.M. Mitchell. 1992. Status of Birds at the Hanford Site in Southeastern Washington, WHCEP-0402 Rev 1, Westinghouse Hanford Company, Richland, Wasnington

Rogers, L.E., and W.H. Rickard, 1977. Ecology of the 200 Area Plateau Waste Management Environs, A Status Report, PNL-2053, Pacific Northwest Laboratory, Richland, Washington

Sackschewsky M.R., O.S. Landeen, J.L. Downs, W.H. Rickard, and G.l. Baird, 1992. Vascular Plants of the Hanford Site, WHC-EP-0554, Westinghouse Hanford Company, Richland, WA.

Sackschewsky, M.R., 1992. 8iological Assessment for Rare and Endangered Plant Species Related to CERCLA Characterization Activities, WHC-EP-0526, Westinghouse Hanford Company, Richland, Washington

Poole, L.O., 1992, Reproductive Success and Nesting Habitat of Loggerhead Shrikes in Shrubsteppe Communities, Masters Thesis. Washington State University, Pullman, Washington 
Schuler, C.A., W.H. Rickard, and G.A. Sargeant, 1988, Bird Associations with Shrubsteppe Plant Communities at the Proposed Reference Repository Located in Southeastern Washington, PNL-6493, Pacific Northwest Laboratories, Richland, Washington 


\begin{tabular}{|c|c|c|}
\hline \multicolumn{3}{|c|}{$\begin{array}{l}\text { PLANT SPECIES OBSERVED AT ENVIRONMENTAL RESTORATION STORAGE ANO DISPOSAL } \\
\text { FACILITY SITE }\end{array}$} \\
\hline SPECIES & FAMILY & COMMON NAME \\
\hline Cymooteris terebinthinus & Aoiaceae & Turoentine soringoarsley \\
\hline Lomatium canbyi & Aoiaceae & Canby's desertoarsley \\
\hline Lomatium macrocarpum & Aplaceae & $\begin{array}{l}\text { Large-fruited } \\
\text { desertparsley }\end{array}$ \\
\hline Achillea millefolium & Astericeae & Yarrow \\
\hline Agoseris heterophylla & Asteraceae & Mountain dandelion \\
\hline Ambrosia acanthicaroa & Asteraceae & Bur ragweed \\
\hline Artemisia tridentata & Asteraceae & Big sagebrush \\
\hline Balsamorhiza careyana & Asteraceae & Carey's bal samroot \\
\hline Chaenact is douplasii & Asteraceae & Hoary false yarrow \\
\hline Chrysothamnus nauseosus & Asteraceae & Gray raboitbrush \\
\hline Chrysothamnus viscidiflorus & Asteraceae & Green raboitbrush \\
\hline Crepis atrabaroa & Asteraceae & Hawksbeard \\
\hline Erigeron filifolius & Asteraceae & Threadieaf fleabane \\
\hline Layia glandulosa & Asteraceae & Tidytips \\
\hline Hachaeranthera canescens & Asteraceae & Hoary aster \\
\hline Townsendia florifer & Asteraceae & Showy townsend daisy \\
\hline Tragopogon dubius & Asteraceae & Salsify \\
\hline Amsinckia lycopsoides & Boraginaceae & Tarweed fiddleneck \\
\hline Amsinckia tessellata & Boraginaceae & Tessellate fiddleneck \\
\hline Cryptantha circumscissa & Boraginaceae & Matted cryptantha \\
\hline Cryptantha ptérocarya & Boraginaceae & Winged cryotantha \\
\hline Tiquilia nuttallij & Boraginaceae & Desert mat \\
\hline Descurainia pinnata & Brassicaceae & Tansy mustard \\
\hline Draba verna & Brossicaceae & Spring whitlowgrass \\
\hline Erysimum asperum & Brassicaceae & Wallflower \\
\hline sisymbrium altissimum & Brassicacase & Jim Hill mustard \\
\hline Thelypodium laciniatum & Brassicaceae & Cutleaf ladysfoot \\
\hline Arenaria franklinii & Caryophyllaceae & Sandwort \\
\hline
\end{tabular}




\begin{tabular}{|l|l|l|}
\hline \multicolumn{2}{|c|}{ PLANT SPECIES OBSERVED AT ENVIRONMENTAL RESTORATION STORAGE AND DISPOSAL } \\
\hline \multicolumn{1}{|c|}{ SPECILITY SITE } \\
\hline RUmex venosus & \multicolumn{1}{|c|}{ FAMILY } & \multicolumn{1}{c|}{ COMMON NAME } \\
\hline Deighinium nuttallianum & Polygonaceae & Winged dö̈K \\
\hline Purshia tridentata & Ranunculaceas & UDland larksour \\
\hline Comandra umbellata & Rosaceae & Antelooe bitterbrush \\
\hline Penstemon acuminatus & Santalaceae & Bastard toadflax \\
\hline Plectritis macrocera & Scrophulariaceae & Sand beardtonque \\
\hline
\end{tabular}




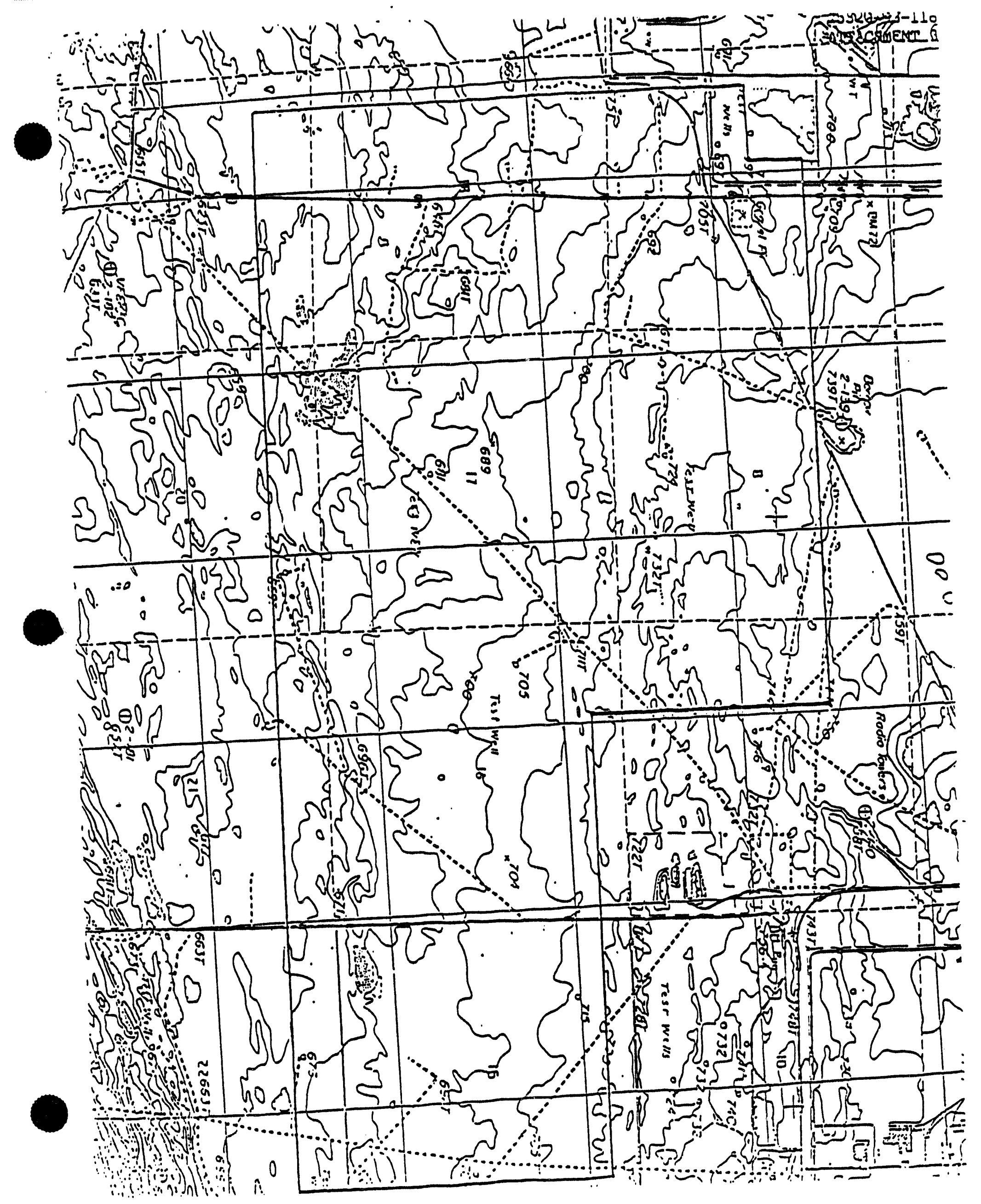


January 20, 1994

Mr. Dennis Janikowski

Westinghouse Hanford Company

N1-30

Richland, WA 99352

Dear Mr. Janikowski:

\section{INTERIM REPORT OF THE BIOLOGICAL REVIEW FOR THE ENVIRONMENTAL RESTORATION DISPOSAL FACILITY (ERDF) RAIL LINE}

This interim reporta summarizes the results of the biological review for the original rail line route pruposed for the ERDF and discusses the potential impacts of railroad construction within the overall context of the ERDF site development. The proposed ERDF area (Figure 1) was selected as a potentially suitable repository for disposal of contaminated wastes resulting from the cleanup of Hanford. The proposed rail line will serve to transport waste material to the ERDF.

The subject area was surveyed in sections on November 5, 1993 by W. H. Rickard, C. A. Brandt, J. M. Becker, and B. L. Tiller, on November 10, 1993 by C. A. Brandt, J. M. Becker, and B. L. Tiller, and on December 3, 1993 by W. H. Rickard, C. A. Brandt, J. M. Becker, and B. L. Tiller. Survey methods consisted of pedestrian transects parallel to the proposed rail line spaced at approximately $20 \mathrm{~m}$ intervals.

The objectives of this biological review were:

- to obtain an inventory of plants and animals present on or using the site

- to describe habitats on the site

- to identify species potentially using the site, based on known habitat associations, that were otherwise undetected during the survey

- to identify plant and animal species protected under the Endangered Species Act, candidates for such protection, and species listed as threatened, endangered, candidate, sensitive, or monitor by the state of Washington

- to evaluate the potential impacts of railroad construction and ERDF site development on the protected species and sensitive habitats noted above.

a The final report will incorporate the results of a biological review of the modified rail line route, which extends across the northeast portion of 200 West. 


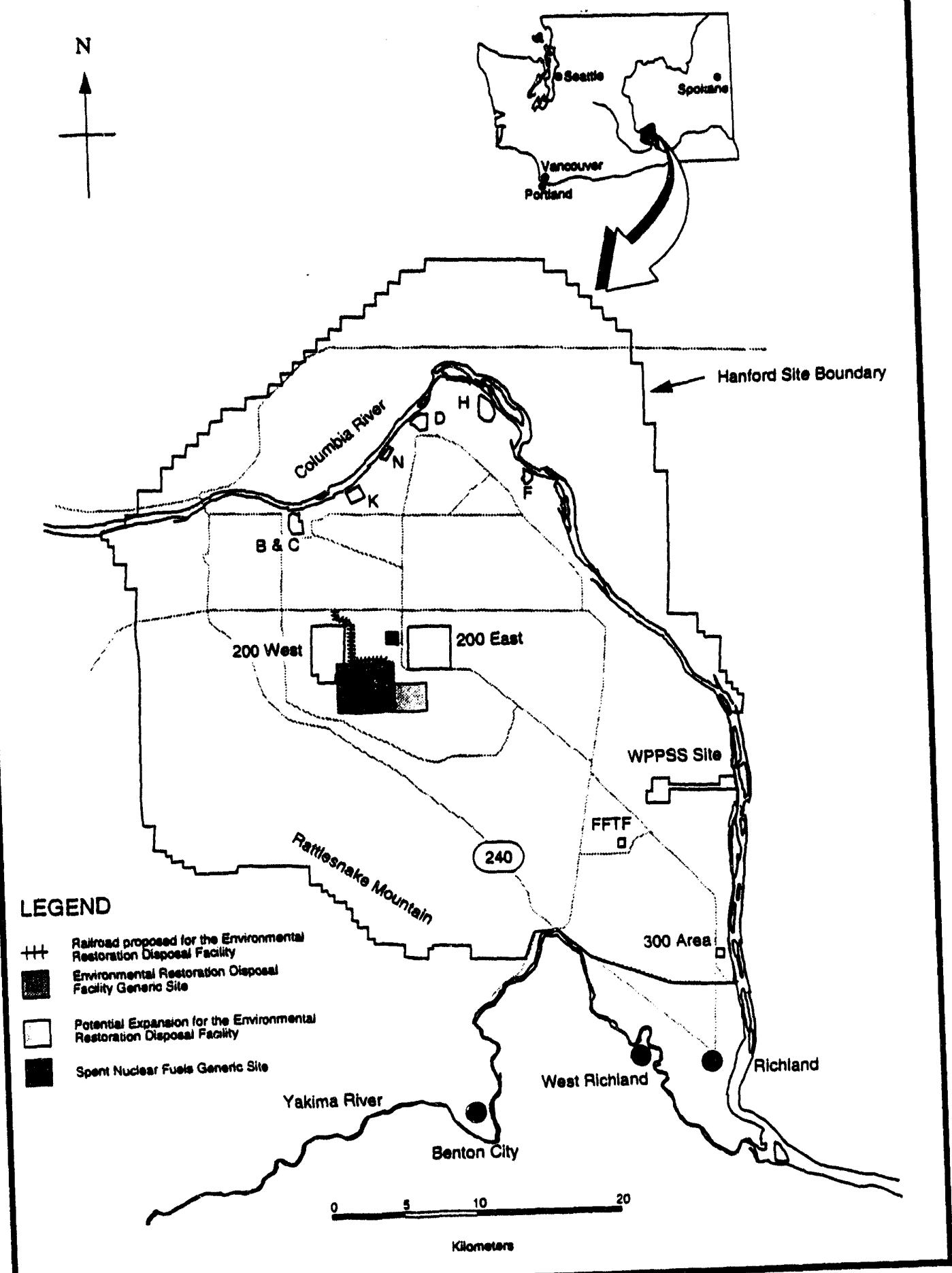

Figure 1. Location of the Generic Site Proposed for the Environmental Restoration Disposal Facility. 
Mr. Dennis Janikowakl

January 20, 1994

Page 2

Species lists were made of plants observed and animals or their sign (Tables 1 \& 2). Mammal abundances were estimated based on whether the species or its sign was abundant, common, or rare (qualitative scale). Plant abundance was estimated using the Braun-Blanquet method (Bonham 1989). Aerial photographs of the subject area were consulted to develop a habitat classification mapping of the area (Figure 2), with habitats classified according to dominant shrub and grass species, based on the BraunBlanquet results. Locations of federal and state listed plant and animal species observed during the survey were determined using the Trimble Navigation Asset Surveyor (Trimble Navigation !.td., P.O. Box 3642, Sunnyvale, CA 94088-3642), a global positioning system. A map of the subject area showing these locations (Figure 3 ) was developed using Geographical Resource and Analysis Support (GRASS version 4.1) software (U.S. Army Corps of Engineers' Construction Engineering Research Laboratory, Champaign, Illinois, 1987). An additional map was developed using GRASS which displays historic nest site locations in the vicinity of the proposed rail line and ERDF site for Swainson's hawks (Buteo swainsoni), red-tailed hawks (Buteo jamaicensis), ferruginous hawks (Buteo regalis), prairie (alcons (Falco mexicanus), northern harriers (Circus cyaneus), burrowing owls (Athene cunicularia), great horned owls (Bubo virginianus), long-eared owls (Asio otus), and loggerhead shrikes (Lanius ludovicianus) (Figure 4). Survey results and the potential impacts of railroad construction and ERDF site development are reported separately.

\section{SURVEY RESULTS}

Table 1. Plant species along the rail line proposed for the ERDF.

\begin{tabular}{|c|c|c|c|}
\hline Life form & Scientlfic name & Common name & Cover \\
\hline $\begin{array}{l}\text { Annual } \\
\text { grasses }\end{array}$ & $\begin{array}{l}\text { Bromus tectorum } \\
\text { Festuca octoflora }\end{array}$ & $\begin{array}{l}\text { cheatgrass } \\
\text { slender sixweeks }\end{array}$ & $\begin{array}{l}10-75 \\
<1\end{array}$ \\
\hline $\begin{array}{l}\text { Perennial } \\
\text { grasses }\end{array}$ & $\begin{array}{l}\text { Agropyron dasytachyum } \\
\text { Koeleria cristata } \\
\text { Oryzopsis hymenoides } \\
\text { Poa sandbergii } \\
\text { Sporobolus cryptandrus } \\
\text { Sitanion hystrix } \\
\text { Stipa comata }\end{array}$ & $\begin{array}{l}\text { thickspike wheatgrass } \\
\text { prairie junegrass } \\
\text { Indian ricegrass } \\
\text { Sandberg's bluegrass } \\
\text { sand dropseөd } \\
\text { bottlebrush squirreltail } \\
\text { neөdle-and-thread grass }\end{array}$ & $\begin{array}{l}<1 \\
<1 \\
<1 \\
10-50 \\
<1 \\
<1 \\
1-5\end{array}$ \\
\hline $\begin{array}{l}\text { Annual } \\
\text { forbs }\end{array}$ & $\begin{array}{l}\text { Ambrosia acanthicarpa } \\
\text { Amsinkia lycopsoides } \\
\text { Chorispora tenella } \\
\text { Cryptantha circumscissa } \\
\text { Descurania pinnata } \\
\text { Descurainia sophia } \\
\text { Epilobium paniculatum } \\
\text { Eriogonum vimineum } \\
\text { Gilla minutiflora } \\
\text { Holosteum umbellatum }\end{array}$ & $\begin{array}{l}\text { bur ragweed } \\
\text { tarweed fiddleneck } \\
\text { blue mustard } \\
\text { matted cryptantha } \\
\text { tansy mustard } \\
\text { flixweed } \\
\text { tall willowherb } \\
\text { broom buckwheat } \\
\text { small-flowered gilla } \\
\text { jagged chickweed }\end{array}$ & $\begin{array}{l}1-5 \\
<1 \\
<1 \\
<1 \\
<1 \\
<1 \\
<1 \\
<1 \\
<1 \\
<1\end{array}$ \\
\hline
\end{tabular}


Mr. Dennis Janikowakl

January 20, 1994

Page 3

Table 1. continued

Life form Solentlifle name

Lactuca serriola

Machaeranthera canescens

Salsola kali

Sisymbrium altissimum

Biennial

forbs

Biennial

forbs

$\begin{array}{ll}\text { Perennial } & \text { Achillea millefolium } \\ \text { forbs } & \text { Astragalus caricinusa } \\ & \text { Astragalus columbianusb } \\ & \text { Astragalus sclerocarpus } \\ \text { Balsamorhiza careyana } & \\ \text { Calochortis macrocarpus } & \text { Chaenactis douglasii } \\ & \text { Crepis atrabarba } \\ \text { Cymopterus terebinthinus } & \text { Erigeron filifolius } \\ & \text { Euphorbia sp. } \\ & \text { Lomatium sp. } \\ \text { Oenothera pallida } \\ \text { Phlox longifolia } \\ \text { Psoralea lanceolata } \\ \text { Sphaeralcea munroana }\end{array}$

Shrubs

Artemisia tridentata

Chrysothamnus nauseosus

Chrysothamnus viscidiflorus

Grayia spinosa
Commion name

prickly lettuce

hoary aster

Russian thistle

tumble mustard

hoary false-yarrow

rough wallflower

cutleaf ladysfoot mustard

yellow salsify

yarrow

buckwheat milkvetch

Columbia milkvetch

stalked-pod milkvetch

Carey's balsamroot

sagebrush mariposa lily

hoary falseyarrow

slender hawksbeard

turpentine cymopterus

threadleaf fleabane

spurge

desertparsley

pale-evening primrose

long-leafed phlox

dune scuripea

Munro's globemallow

big sagebrush

gray rabbitbrush

green rabbitbrush

spiny hopsage

$\begin{array}{llll}\text { Root } & \text { Orobanche corymbosa } & \text { flat-topped broomrape } & <1 \\ \text { parasites } & \text { Comandra umbellata } & \text { bastard toadflax } & <1\end{array}$

$\begin{array}{llll}\text { Root } & \text { Orobanche corymbosa } & \text { flat-topped broomrape } & <1 \\ \text { parasites } & \text { Comandra umbellata } & \text { bastard toadflax } & <1\end{array}$

\section{Porcent}

cover

$<1$

$<1$

$1-100$

$1-5$

$<1$

$<1$

$<1$

$<1$

$<1$

$<1$

$<1$

$<1$

$<1$

$<1$

$<1$

$<1$

$<1$

$<1$

$<1$

$<1$

$1-5$

$<1$

$<1$

$<1$

25-75

$<1$

$1-5$

$<1$

$\begin{array}{llll}\text { Root } & \text { Orobanche corymbosa } & \text { flat-topped broomrape } & <1 \\ \text { parasites } & \text { Comandra umbellata } & \text { bastard toadflax } & <1\end{array}$

a Many individuals of this species were observed and identified based on seedpod morphology. Species identification was inconclusive due to the advanced stage of decay of the above-ground portions of the plants. However, based on seedpod morphology, this species was probably not one of the three state level 3 monitor species (A. sclerocarpus, $A$. speirocarpus, or $A$. succumbens), the federal level 1 candidate and state threatened ( $A$. columbianus), or the state sensitive ( $A$.

arrectus). Species identification must be confirmed during a May or June survey. 

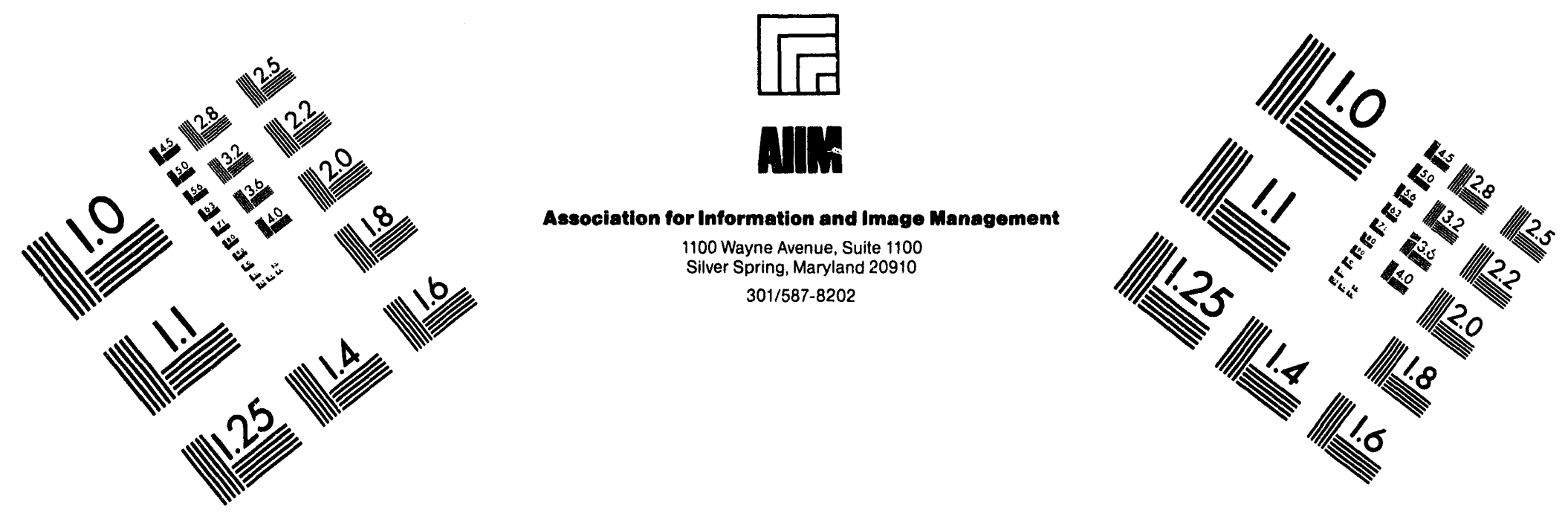

\section{Centimeter}

$\begin{array}{llllllllllllllll}1 & 2 & 3 & 4 & 5 & 6 & 7 & 8 & 9 & 10 & 11 & 12 & 13 & 14 & 15 & \mathrm{~mm}\end{array}$ L.ш

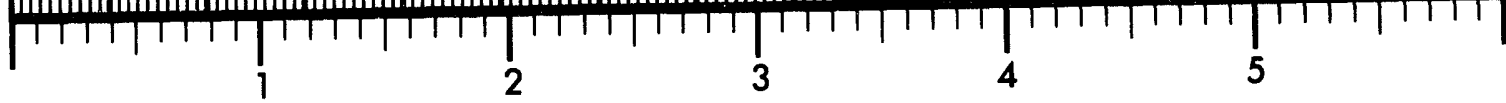
Inches
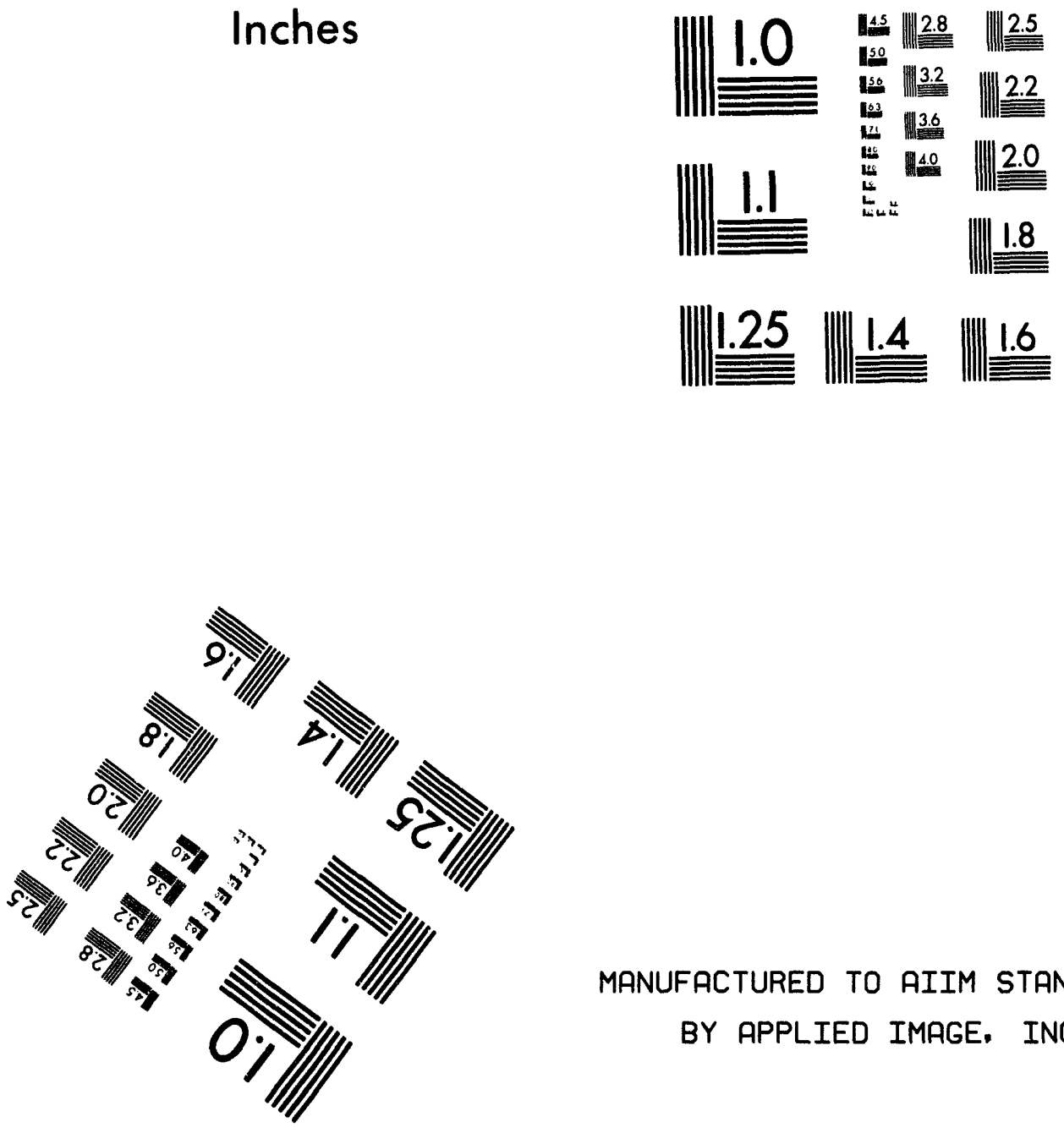

MANUFACTURED TO AIIM STANDARDS BY APPLIED IMAGE. INC.

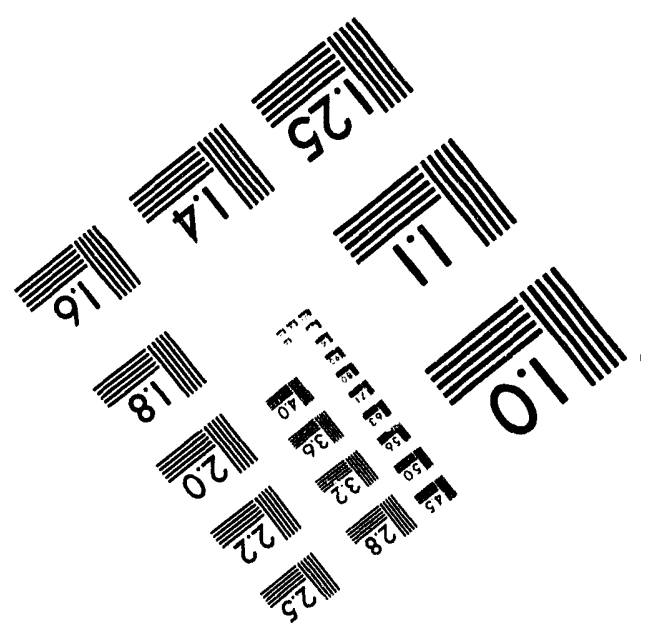



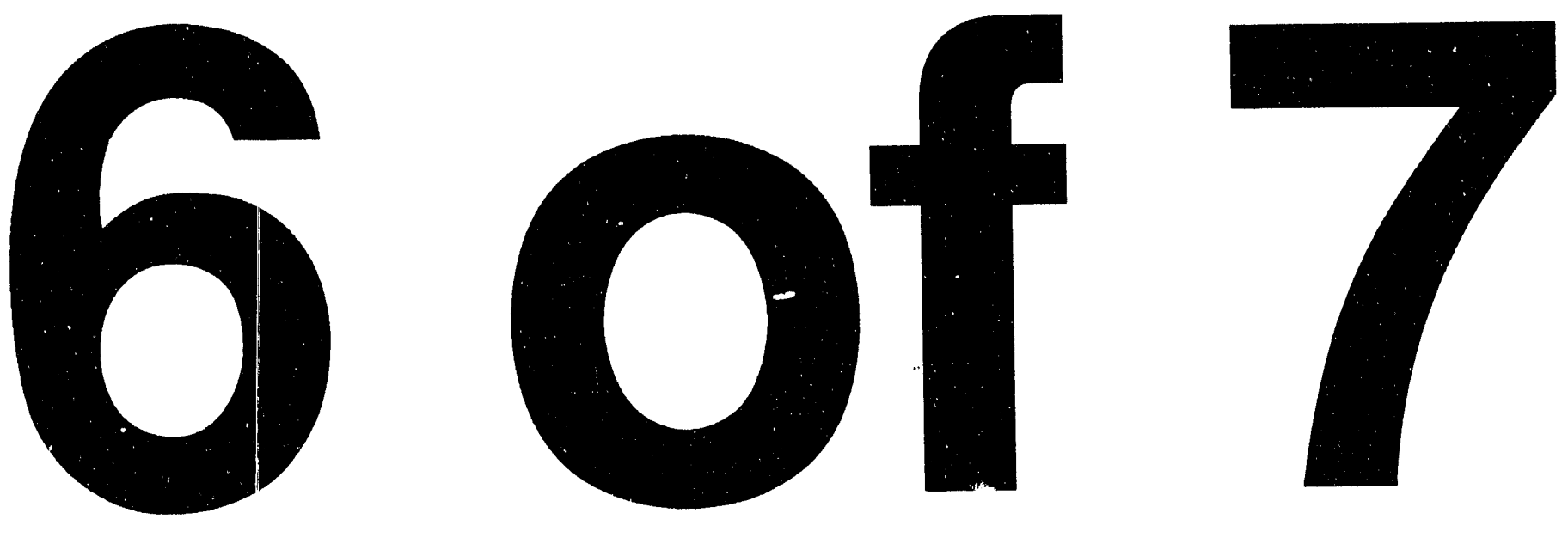
Mr. Dennis Janikowski

January 20, 1994

Page 4

Table 1. continued

b Several individuals of this species.were observed (Figure 3) and tentatively identified based on seedpod morphology. This species is listed as a federal level 1 candidate and as state threatened. Species identification was inconclusive due to the advanced stage of decay of the above-ground portions of the plants. Species identity must be confirmed in May or June.

c One individual of this species was observed and tentatively identified based on seedpod morphology. This species is listed as a state level 3 monitor species. Species identification was inconclusive due to the advanced stage of decay of the above-ground portions of the plant. Species identity must be confirmed in May or June. 


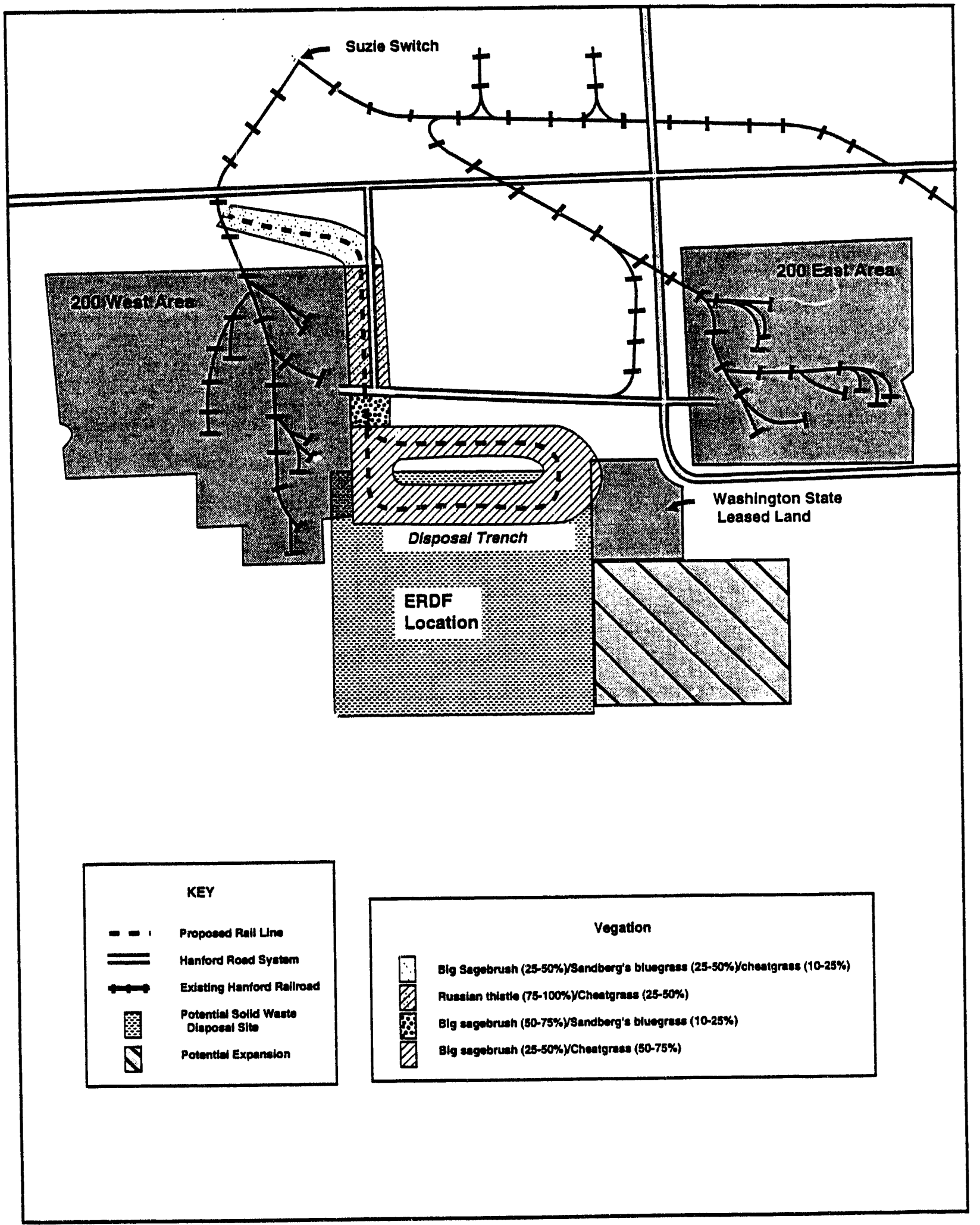

Figure 2. Plant Communities Along the Rail Line Proposed for the ERDF. Percent Cover is According to the Braun-Blanquet Scale (Bonhan 1989). 
Mr. Dennis Janikowski

January 20, 1994

Page 5

Table 2. Animal species observed or detected by sign along the rail line proposed for the ERDF.

\section{Life form Scientific name \\ Birds \\ Alectoris chukar \\ Athene cuniculariab \\ Columba livia \\ Corvus corvax \\ Eremophila alpestris \\ Lanius Iudovicianusc \\ Perdix perdix \\ Pica pica \\ Sturnella neglecta \\ Zonotrichia leucophrys}

Mammals
Canis latrans
Lepus californicus

Odocoileus hemionus

Perognathus parvus

Peromyscus maniculatus

Spermophilus sp.

Sylvilagus nuttalli

Taxidea taxus

Thomomys talpoides

Reptiles Coluber constrictord Sceloporus graciosus Uta stansburiana

\section{Common name}

chukar

burrowing owl

rock dove

common raven

homed lark

loggerhead shrike

gray partridge

black-billed magpie

western meadowlark

white-crowned sparrow

coyote

blacktail jackrabbit

mule deer

Great Basin pocket mouse

deer mouse

ground squirrel

Nuttall's cottontail

badger

northern pocket gopher
Relative

Abundance ${ }^{a}$
Common

Common-

abundant

Common

Commonabundant

Common

Common

Locally abundant

Common

Rare

racer

sagebrush lizard side-blotched lizard

a Relative abundance was noted only for mammals.

b Pellets and burrows of this species were observed (Figure 3). This species is listed as a state candidate. Abundance of this migratory species cannot be assessed until the birds return in the spring.

c Three nests of this species were observed (Figure 3). This species is listed as a federal level 2 candidate and a state candidate. Species identification was confirmed for two nests. Identification of one nest could not be confirmed due to its advanced stage of decay (Figure 3 ). The actual number of pairs potentially affected by the ERDF rail line cannot be assessed until the onset of mating and nesting in the spring.

d One carcass of this species was observed. Species identification was inconclusive due to the advanced stage of decay of the carcass. 


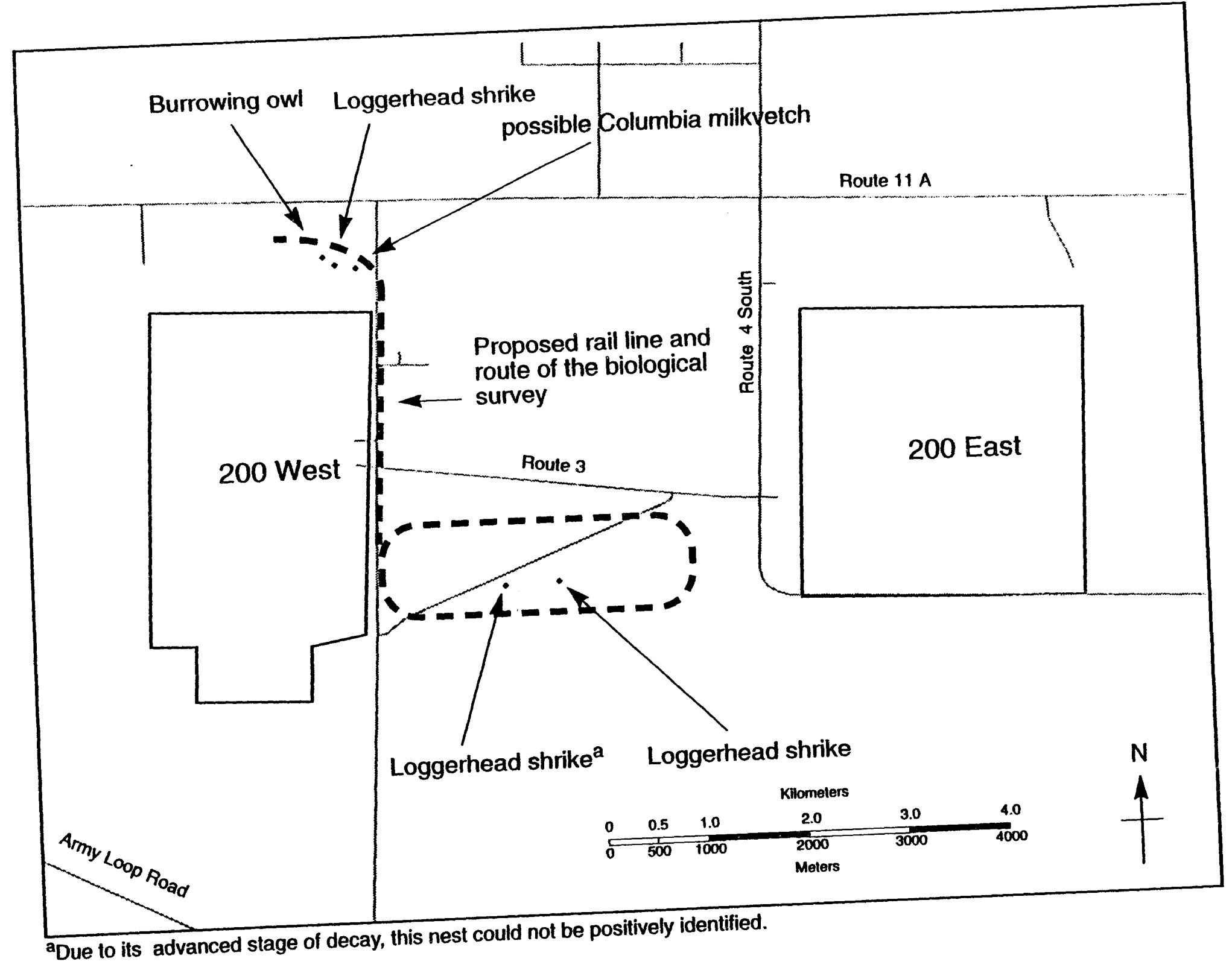

Figure 3. Locations of Federal and State Listed Animal and Plant Species Observed during the Biological Survey. 


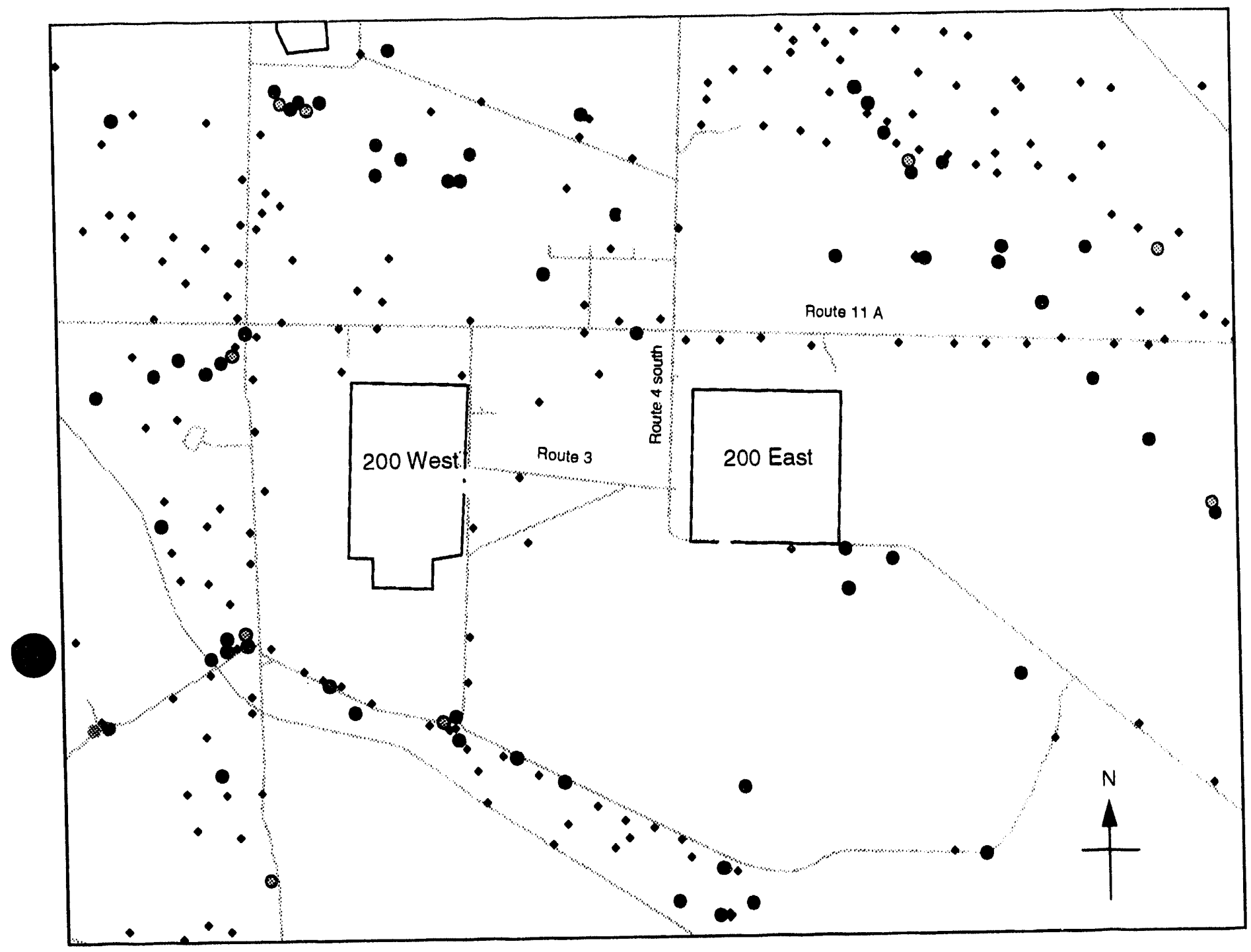

- Swainson's hawks (1992)

- Swainson's hawks (1984-1991)

- Red-tailed hawks (1992)

- Red-tailed hawks (1984-1991)

- Ferruginous hawks (1992)

- Ferruginous hawks (1984-1991)

- Prairie falcons (1984-1990) (incidental observations made during annual raptor surveys)

- Great horned owls (1984-1990) (incidental observations made during annual raptor surveys)

- Long-eared owls (1984-1990) (incidental observations made during annual raptor surveys)

- Northern harriers (1984-1990) (incidental observations made during annual raptor surveys)

- Loggerhead shrikes (1988-1989)

Figure 4. Historic Raptor Nest Sites from 1984-1992 (unpublished data from annual raptor surveys conducted by Pacific Northwest Laboratory [PNL]). Historic Loggerhead Shrike Nest Sites from 1988-1989 (unpublished data from loggerhead shrike surveys conducted by PNL). 
Mr. Dennis Janikowski

January 20, 1994

Page 6

Table 3. Federal and state listed plant and animal species observed along the rail line proposed for the ERDF. Included are species potentially using the ERDF site, based on known habitat associations, that were otherwise undetected during the survey.

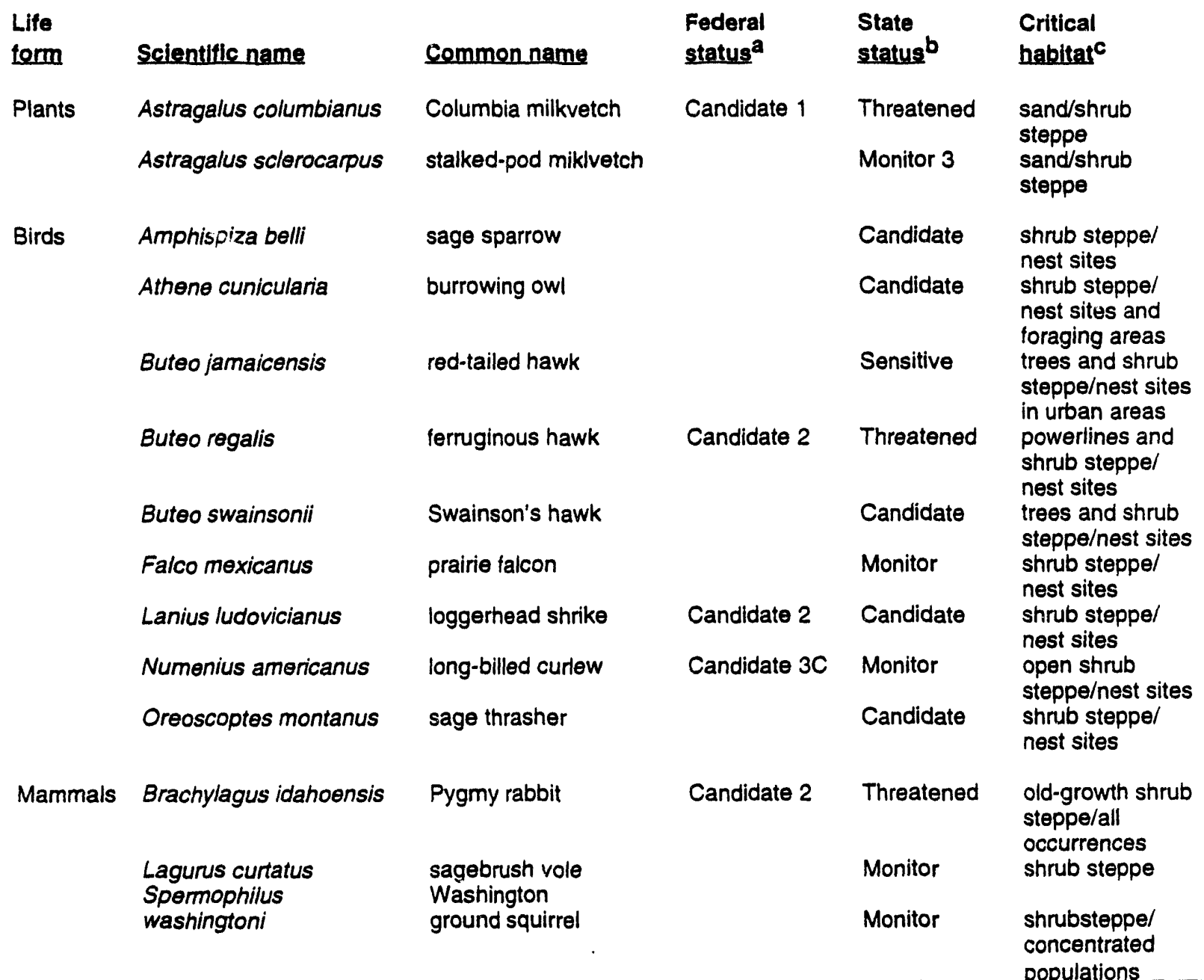

a Federal status for plant species taken from U. S. Department of Interior, U. S. Fish and Wildife Service: 50 CFR Part 17, Endangered and Threatened Wildife and Plants, Review of Plant Taxa for Listing as Endangered or Threatened Species, Proposed Rules, September 30, 1993. Federal status for animal species taken from U. S. Department of Interior, U.S. Fish and Wildife Service: 50 CFR 17 Endangered and Threatened Wildife and Plants, Animal Candidate Review for Listing as Endangered or Threatened Species, Proposed Rule, November 21, 1991. 
Mr. Dennis Janikowski

January 20, 1994

Page 7

Topography along the proposed rail line is level. Substrate on the subject area is primarily Burbank loamy sand intergraded with Rupert sand. The latter consists of relatively broad, stabilized sand dunes, except for a narrow strip along Route 3 which is highly disturbed (designated in Figure 2 as Russian thistle/cheatgrass habitat). The subject area, outside of the highly disturbed area along Route 3, is dominated by mature big sagebrush, cheatgrass, an alien weed species, and Sandberg's bluegrass (Figure 2). Small isolated sandy sites along the rail line loop are dominated by cheatgrass and Indian ricegrass.

The sagebrush habitat along the proposed rail line and within the proposed ERDF site, including the potential ERDF site expansion, is considered priority habitat by the State of Washington, due to its relative scarcity in the State, and to its requirement as nesting/breeding/foraging habitat by loggerhead shrikes (Tables 2 and 3, and Figures 3 and 4), burrowing owls (Tables 2 and 3 , and Figures 3 and 4), long-billed curlews (Table 3), sage sparrows (Table 3), sage thrashers (Table 3), pygmy rabbits (Table 3), Washington ground squirrels (Table 3), and sagebrush voles (Table 3). Although the latter six species were not observed during this survey, the habitat should be considered suitable for their use. Loggerhead shrike nests were sited in the vicinity of the subject area prior to and during this study (Figures 4 and 3, respectively). This species begins to migrate out of the Hanford Site at the beginning of August (Poole 1992), thus no individuals were observed during this survey. Ground squirrel burrows used by burrowing owls and owl pellets were also observed prior to and during this survey (Figures 4 and 3, respectively). An isolated open area with low-growing herbaceous vegetation was observed within the otherwise contiguous stand of sagebrush along the rail line loop (Figure 2). This area is potential nesting habitat for long-billed curlews. Long-billed curlews, burrowing owls, sage sparrows, and sage thrashers also had migrated from the area before this survey was conducted. Pygmy rabbits could not have been observed during this survey because they are primarily crepuscular.

Potential pygmy rabbit habitat where small rabbit feces were observed will be trapped or spotlighted in the spring to evaluate the presence of this species. Ground squirrel burrows were observed during this survey (Table 2). However, ground squirrels had begun hibernation prior to this survey, precluding evaluation of the presence of the Washington ground squirrel. Sagebrush voles also were not observed, as they had likely begun hibernation prior to this survey.

The proposed railroad, ERDF site, and its proposed expansion are virtually devoid of potential nest sites, e.g. trees and utility poles, for raptors that nest above ground such as ferruginous hawks (Table 3), Swainson's hawks (Table 3), red-tailed hawks (Table 3), or prairie falcons (Table 3). However, these species nest outside the subject area in the vicinity of 200 East and 200 West (Figure 4). The subject area contains no known raptor nests, except nests of burrowing owls (Figures 3 and 4). However, the site does provide suitable nesting habitat for short-eared owls (Asio flammeus), a ground-nesting species, and species that may nest on the ground such as northern harriers, great homed owls, and long-eared owls. The site also provides prime foraging habitat for all the above raptor species.

Several milkvetch plants, tentatively identified as Columbia milkvetch (Table 1), were observed near the north end of the proposed rail line (Figure 3). One probable stalkedpod rilkvetch (Table 1) was also observed. No other plant or animal species protected 
Mr. Dennis Janikowski

January 20, 1994

Page 8

under the Endangered Species Act, candidates for such protection, or species listed as threatened, endangered, candidate, sensitive or monitor by the State of Washington were observed on the site.

The results of this preliminary survey do not provide a complete assessment of the biological resources of the site because the survey was conducted outside the growing season for most herbaceous plants and outside the period of residence of most upland birds. To provide a more complete characterization of the habitat, and to resolve uncertainties regarding wildlife use of the subject area, we recommend that a subsequent survey be conducted between April and June, 1994.

\section{POTENTIAL IMPACTS OF RAILROAD CONSTRUCTION AND ERDF SITE DEVELOPMENT}

Loggerhead shrikes, sage sparrows, and sage thrashers are species that depend on mature sagebrush habitat. Shrikes are known to select tall big sagebrush as nest sites (Poole 1992). Sage sparrows and thrashers alsc nest in big sagebrush. Construction of the proposed railroad and development of the ERDF site would remove sagebrush habitat, precluding these species from nesting there. ERDF development would also be expected to reduce the value of the area as foraging habitat for individuals of these species nesting in adjacent areas.

Burrowing owls nest in abandoned burrows of other ground-dwelling animals. Railroad construction and ERDF site development would remove habitat for prey and displace ground-dwelling animals, thereby reducing the suitability of the area for nesting by burrowing owis.

Pygmy rabbits are known to utilize tall clumps of old-growth sagebrush habitat throughout most of their range. However, pygmy rabbits are not known to occur on the Hanford Site. ERDF development would likely reduce the potential for this species' occurrence by removing habitat potentially suitable for its use.

Sagebrush voles are generally found in association with mature sagebrush habitat, although few have been captured outside the Arid Lands Ecology Reserve. They select burrow sites near sagebrush which also comprises a portion of their diet. ERDF development would remove sagebrush habitat, precluding voles from utilizing the area.

Raptor populations may be negatively impacted by disturbance of nesting during railroad construction. Disturbance of nesting raptors can be minimized by confining human activity to the non-nesting period or restricting activity within specified distances from nest sites. Distances have been suggested for the following species: Swainson's hawk - $0.8 \mathrm{~km}$, ferruginous hawk - $1.6 \mathrm{~km}$, prairie falcon $-1.0 \mathrm{~km}$, and red-tailed hawk $0.8 \mathrm{~km}$ (Suter and Jones 1981). Poole et al. (1988) recommended a minimum distance of $2.2 \mathrm{~km}$ for Swainson's hawks on Hanford, where this species is believed to be highly subjected to human disturbance. The ferruginous hawk on Hanford is believed to be extremely sensitive to human disturbance (Fitzner et al. 1992). We therefore recommend $2.2 \mathrm{~km}$ as a minimal distance from ferruginous hawk nests. The proposed rail line and ERDF site are greater than $3.0 \mathrm{~km}$ from any known nest locations of these species (Figure 4). However, the site for the Potential ERDF Expansion (Figure 2) is 
Mr. Dennis Janikowski

January 20, 1994

Page 9

within 2-3 km of Swainson's hawk nests located at the southeast comer of 200 East

(Figure 4). This potential disturbance of Swainson's hawks should be taken into account if the ERDF Expansion is to be developed.

Although the subject area is relatively unimportant as nesting habitat for most raptors, it should be considered an important part of their foraging range. Raptor populations may be negatively impacted by altering foraging habitat. Rail line construction and ERDF site development would displace small mammal populations which are an important component of the prey base of these species. The effects of habitat alteration may be reduced by leaving habitat within the home range of nesting raptors unchanged. Cody (1985) reported average home range sizes for populations of the following species in Oregon, Idaho, Utah, and Califomia; ferruginous hawks ranged from 3.14 to $8.09 \mathrm{~km}^{2}$, red-tailed hawks from 2.18 to $3.08 \mathrm{~km}^{2}$, and Swainson's hawks from 1.09 to $3.81 \mathrm{~km}^{2}$. Poole et al. (1988) reported an average home range size of $6.97 \mathrm{~km}^{2}$ for Swainson's hawks on Hanford. Average home ranges for ferruginous and red-tailed hawks on Hanford have not been documented. A somewhat conservative estimate of home range radius (the distance around a nest site in which habitat should remain unaltered) for these species may be obtained using the largest home range size and assuming home ranges are circular. Home range radii are thus $1.6 \mathrm{~km}$ for ferruginous hawks, $0.99 \mathrm{~km}$ for red-tailed hawks, and $1.49 \mathrm{~km}$ for Swainson's hawks (on Hanford). The proposed rail line and ERDF site, including the Potential ERDF Expansion, are greater than 2.0 $\mathrm{km}$ from any known nest locations of these species (Figure 4). Therefore, habitat losses within home ranges of these species are likely to be minimal. However, impacts to foraging ranges of shrikes, thrashers, sage sparrows, and burrowing owls will be more significant.

There are two known populations of Columbia milkvetch on the Hanford Site (Sackschewsky et al. 1992). Railroad construction would displace the individuals encountered during this survey (Figure 3). ERDF site development would also disturb soils in the area and thus reduce its suitability for colonization by Columbia milkvetch.

Railroad construction will negatively impact individuals of the above species. Yet populations of these species, considered as a whole, would probably not be substantially affected because similar sagebrush habitat is still relatively common on Hanford. However, a number of activities, especially those related to ERDF, will eliminate a large portion of the sagebrush habitat directly, and will contribute to fragmentation of the remaining habitat. Fragmentation not only reduces the overall area of habitat available for use, but also alters the size and shape of habitat patches. The response of these species to fragmentation cannot currently be predicted in any detail and their level of resiliency is unknown. It is reasonable to expect that the cumulative effects of this and further fragmentation would decrease the long-term viability of these species on Hanford. Therefore, it is essential to develop methods for predicting effects and plans for mitigating the cumulative losses and fragmentation of sagebrush habitat on the Hanford Site. 


\section{REFERENCES}

Bonham, C. D. 1989. Measurements for Terrestrial Vegetation. John Wiley \& Sons, New York.

Fitzner, R. E., S. G. Weiss, and J. A. Stegen. 1992. Biological Assessment flor Threatened and Endangered Wildlife Species Related to CERCLA Characterization Activities. WHC-EP-0513, Westinghouse Hanford Company, Richland, Washington.

Poole, L. D., N. V. Marr, and S. M. McCorquodale. 1988. Productivity, Mortality, and Response to Disturbance of Nesting Swainson's Hawks on the Hanford Site. PNL-6496-UC-11, Pacific Northwest Laboratory, Richland, Washington.

Poole, L. D. 1992. Reproductive Success and Nesting Habitat of Loggerhead Shrikes in Shrubsteppe Communities. M.S. Thesis, Oregon State Univ., Corvallis, Oregon. 69 pp.

Sackschewsky, M. R., D. S. Landeen, J. L. Downs, W. H. Rickard, and G. I. Baird. 1992. Vascular Plants of the Hanford Site. WHC-EP-0554, Westinghouse Hanford Company, Richland, Washington.

Stewart, J. W. 1985. "Habitat Selection in Raptorial Birds", In Habitat Selection in Birds, M. L. Cody, ed. pp. 159-188, Academic Press, New York, New York.

Suter, II., G. W. and J. L. Jones. 1981. Criteria for Golden Eagle, Ferruginous Hawk, and Prairie Falcon Nest Site Selection. Raptor Research 15(1): 12-18.

\footnotetext{
Sincerely,

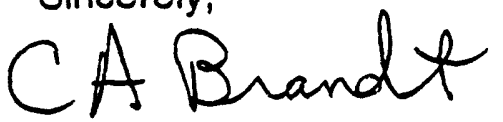

C. A. Brandt, Ph.D.

Senior Research Scientist

Environmental Sciences Department
}

$\mathrm{CAB} / \mathrm{jmb}$

$\begin{array}{ll}\text { bcc: JM Becker } & K 6-63 \\ \text { CA Brandt } & K 6-63 \\ \text { LL Cadwell } & K 6-63 \\ \text { PF Dunigan } & \mathrm{A} 5-15 \\ \text { RH Engeimann } \cdots & \mathrm{H} 6-26 \\ \text { RD Hildebrand } & \mathrm{A} 5-55 \\ \text { CE Hodge } & \mathrm{A} 5-56 \\ \text { LE Rogers } & \mathrm{K} 6-63 \\ \text { RS Weeks } & \mathrm{H6}-26 \\ \text { file } & \end{array}$




\title{
CULTURAL RESOURCES REPORT NARRATIVE
}

\section{HANFORD CULTURAL RESOURCES LABORATORY}

\section{A. NAME AND FULL DESCRIPTION OF THE PROPOSED UNDERTAKING}

\author{
Project Number: $\quad 93-200-001$ \\ Project Name: Environmental Restoration Disposal Facility (ERDF)
}

The Environmental Restoration Disposal Facility (ERDF), located on the Hanford Site (managed by the Department of Energy) will provide the disposal site for the waste exhumed during the Hanford Site CERCLA and RCRA cleanup actions. Excavations at the site will be extensive and may be up to $12 \mathrm{~m}$ deep. The exact site boundaries have not yet been set, however, the proposed site area currently measures about $10.6 \mathrm{~km}^{2}$ (see Figure 1). Since the survey was completed in the summer of 1993, the site boundary has moved about $0.5 \mathrm{~km}$ to the east. We surveyed approximately $11.0 \mathrm{~km}^{2}$.

\section{B. LOCATION AND GENERAL ENVIRONMENTAL SETTING}

The project area is located within the Hanford Site in south central Washington State (see Figure 2) within the Cold Creek Valley in an area locally known as the 200 Area Plateau. The surface topography is low-relief stabilized and semiactive dunes composed of fine sand and silt. The land surface slopes gently to the southwest with elevations ranging from $192 \mathrm{~m}$ (630 ft) above mean sea level (asi) to $229 \mathrm{~m}(750 \mathrm{ft}$ ) asl; the overall gradient is 0.08 . The proposed site is located in T12N, R26E in Sections $7,8,16,17,18,19$, and 21. The closest source of perennial water is Rattlesnake Springs,. which is located approximately $8 \mathrm{~km}$ southwest of the project area.

The area is largely undisturbed. Disturbances include gravel pits, roads, wells and well pads, other pits measuring about $30 \mathrm{~m}$ in diameter by about $5 \mathrm{~m}$ deep, a laydown yard, and a dump site.

The vegetation is a steppe-shrub community (Daubenmire 1970) dominated by big sagebrush (Artemisia tridentata) with an understory of grasses and forbs. Plant species identified during the summer survey within the proposed project area are tallied in Table 1.

Table 1. Plant species within the ERDF project area.

$\begin{array}{ll}\text { shrubs } & \text { Scientific name } \\ \text { Artemisia tridentata } \\ \text { Chrysothamnus nauseosus } \\ \text { Chrysothamnus viscidiflorus } \\ \text { Grayia spinosa } \\ \text { Purshia tridentata } \\ \text { Leptodactylon pungens }\end{array}$

annual grasses Bromus tectorum Festuca octoflora

perennial grasses Koeleria cristata Oryzopsis hymenoides Poa sandbergii Sitanion hystrix Sporobolus cryptandrus Stipa comata

annual forbs

\author{
Ambrosia acanthicarpa \\ Centaurea sp. \\ Cryptantha circumscissa
}

\author{
Common name \\ big sage \\ gray rabbitbrush \\ green rabbitbrush \\ spiny hopsage \\ bitter-brush \\ prickly phlox \\ cheat grass \\ sixweeks fescue \\ prairie junegrass \\ indian ricegrass \\ Sandberg's bluegrass \\ bottlebrush squirreltail \\ sand dropseed \\ needle-and thread grass \\ bur ragweed \\ knapweed \\ matted cryptantha
}




\section{CULTURAL RESOURCES REPORT NARRATIVE}

Project Number: Project Name:

biennial forbs

perennial forbs

93-200-001

Environmental Restoration Disposal Facility (ERDF)

Descurainia pinnata

Descurainia sophia

Epilobium paniculatum

Eriogonum vimineum

Holosteum umbellatum

Lactuca serriola

Microsteris gracilis

Salsola kali

Sisymbrium altissimum

Thelypodium laciniatum

Tragopogon dubius

Achillea millefolium

Arenaria franklinii

Astragalus spp.

Balsamorhiza careyana

Calochortus macrocarpus

Chaenactis douglasii

Comandra umbellata

Crepis atrabarba

- Cymopterus terebinthinus

Erigeron spp.

Lygodesmia juncea

Machaeranthera canescens

Oenothera pallida

Orobanche corymbosa

Phlox longifolia

Penstemon acuminatus

Opuntia polyacantha

Phacelia hastata tansy mustard

flixweed

tall willowherb

broom buckwheat

jagged chickweed

prickly lettuce

pink microsteris

Russian thistle

tumblemustard

cutleaf ladysfoot mustard yellow salsify

yarrow

Franklin's sandwort milkvetch

Carey's balsamioot sagebrush mariposa lily hoary chaenactis

toad flax

slender hawksbeard

turpentine cymopterus

fleabane

skeletonweed

hoary aster

pale evening-primrose

flat-topped broomrape

longleaf phlox

sand beardtongue

starvation pricklypear

whiteleaf scorpionweed

Ground visibility ranged from $100 \%$ in blowouts to $10 \%$ under shrubs and in disturbed areas. The average ground visibility was approximately $65 \%$.

Wildlife or their sign observed in the project area is listed in Table 2. Mice burrows were also noted.

Table 2. Animal species observed/inferred within the ERDF project area.

birds

reptiles
Chordeiles minor Sturnella neglecta Hirundo rustica Amphispiza belli Zenaida macroura

Circus cyaneus Lanius ludovicianus Asio flammeus Athene cunicularia Larus sp.

Uta stansburiana common nighthawk western meadowlark barn swallow sage sparrow mourning dove northern harrier loggerhead shrike short-eared owl burrowing owl gull

side-blotched lizard 


\section{CULTURAL RESOURCES REPORT NARRATIVE}

Project Number: 93-200-001

Project Name: Environmental Restoration Disposal Facility (ERDF)

\section{Pituophis melanoleucus \\ Phrynosoma douglassi}

mammals

\section{Canis latrans Odocoileus hemionus Lepus californicus Taxidea taxus}

\section{gopher snake short-horned lizard}

\author{
coyote \\ mule deer \\ black-tailed jackrabbit \\ badger
}

Nests of loggerhead shrikes and common nighthawks were observed, as well as a possible northern harrier nest.

Aerial photograph(s): EG\&G 5673, exp. 105, 05-07-87, 1:19900

USGS topographic map(s): USGS 7.5 ' Gable Butte Quad, 1986 edition

Legal description: Project to be located in T $12 \mathrm{~N} R 26 \mathrm{E}$ parts of Section(s) \# 7, 8,9,16,17, and 18. Survey occurred in T. 12 N. R. 26 E. parts of Section(s) \# 7, 8, 9, 16, 17, 18, 19, 20, and 21.

UTMs: Corners of area surveyed (see Figure 1).

$\begin{array}{cccc}\text { Map Reference Foint } & \text { Zone } & \frac{\text { m Northing }}{5157610} & \frac{\text { m Easting }}{299950} \\ \text { A } & 11 & 5157520 & 303000 \\ \text { B } & 11 & 5154070 & 302980 \\ \text { C } & 11 & 5154420 & 300360 \\ \text { D } & 11 & 5154430 & 299500 \\ \text { E } & 11 & 5157010 & 299520 \\ \text { F } & 11 & 5157000 & 299810 \\ \text { G } & 11 & 5157200 & 299810 \\ \text { H } & 11 & 5157190 & 299940 \\ \text { I } & 11 & & \end{array}$

\section{PRE-FIELD RESEARCH}

1. Sources of information checked: $[x]$ Survey and Site Location Maps [x] Previous Reports [x] Aerial Photographs [x] GLO Plats [] Other

2. Summary of previous studies in this general area, similar terrain: A literature and records review showed that four surveys had been previously conducted by the HCRL within the proposed project area; HCRC \#89-200-023, HCRC\# 93-600-004, HCRC-93-600-016, and BERC 010. One isolated artifact, a cobble tool (H1-89-016), was located within the project area. The tool was not collected. Six surveys have been previously conducted by the HCRL within $0.8 \mathrm{~km}$ (.0.5 miles) of the proposed project area; HCRC \#89-600-010, HCRC \#92-600-001, HCRC \#93-600-005, HCRC \#93-600-014, HCRC \#93-600-023, and Plot ' 797 SD

Report No./Title HCRC \#89-200-023 HCRC $\# 89-600-010$

HCRC \#93-600-001
Distance/Direction Within proposed ERDF boundary $0.6+\mathrm{km}$ to the northeast of the northeast corner Adjacent to $0.5 \mathrm{~km}$ north of the northern boundary
Results

HI-89-016, an isolated cobble tool No cultural resources identified No cultural resources identified 


\section{CULTURAL RESOURCES REPORT NARRATIVE}

Project Number: 93-200-001

Project Name: Environmental Restoration Disposal Facility (ERDF)

HCRC \#93-600-004

HCRC \#93-600-005

HCRC \#93-600-014

HCRC \#93-600-016

HCRC $\# 93-600-023$

BERC 010

Plot 797 SD
Adjacent to the northwest corner Adjacent to the northern boundary Immediately adjacent to the western boundary

Partially within the proposed ERDF boundary

$0.5 \mathrm{~km}$ north of the northern boundary Within proposed ERDF boundary $0.4 \mathrm{~km}$ south of southwest corner of proposed ERDF boundary (as of July 1993)
No cultural resources identified No cultural resources identified

No cultural resources identified

No cultural resources identified

No cultural resources identified

No cultural resources identified No cultural resources identified

\section{EXPECTED HISTORIC AND PREHISTORIC LAND USE AND SITE SENSITIVITY}

1. Are there known sites in the general area? $\square$ Yes $[X]$ No

\section{Are sites expected? [x] Yes [] No}

A trail was mapped on the 1880 General Land Office Survey map (GLO) in the southern part of the proposed ERDF area, and it is presumed that this area was used by both Native Americans and EuroAmericans. Very few prehistoric sites are found this far from permanent water, however, isolated prehistoric artifacts and historic trash scatters are expected. Isolated prehistoric artifacts have previously been found in the vicinity of historic trails on the Hanford Site, and historic trash scatters are common on site.

\section{E. FIELD METHODS}

1.Areas examined ano' type of coverage: An intensive pedestrian survey was conducted for the project covering $11.0 \mathrm{~km}^{2}$, following procedures in Chatters 1989 . Intensive survey entailed pedestrian search in transects spaced $20 \mathrm{~m}$ apart. Participants scanned an area $5 \mathrm{~m}$ to either side of the transect center line, thus having potential for $100 \%$ discovery of concentrations of surface artifacts larger than $10 \mathrm{~m}$ in diameter, as well as most smaller concentrations. The lowest estimated discovery rate, at $50 \%$, was expected for single, isolated artifacts. All survey transects

I were oriented north/south, except for a few transects in the northwest corner of the survey area which were oriented east/west.

2. Areas not examined and reasons why: A dump area measuring approximately $0.13 \mathrm{~km}^{2}$ in the northwest corner of the proposed ERDF site was not surveyed because of safety concerns. Buckets, wire, wood, and metal barrels were observed from the perimeter of the dump. The age and contents of the dump site is unknown but it may date to the construction or early operations at the 200 West area of the Hanford Site. Most of tris area appears disturbed from exarnination of aerial photographs.

3. Personnel conducting and assisting in this survey: N. A. Cadoret, M. K. Wright, M. V. Dawson, J. G. Longenecker, R. Bayman, J. Woodrutf, J. Pierce, G. Civay, J. Myer, W. Mclntire

4. Date(s) of survey: $7 / 21-9 / 10 / 93$

5. Visibility on surface: Estimate:> $65 \%$ 


\section{CULTURAL RESOURCES REPORT NARRATIVE}

Project Number: 93-200-001

Project Name: Environmental Restoration Disposal Facility (ERDF)

Visibility of subsurface: Estimate:< $5 \%$

6. Problems encountered: None

\section{F. RESULTS}

1. All cultural resources recorded for this area: [None

During the survey, four archaeological sites, one paleontologic site, and nine isolated artifacts were recorded and are listed below. One of the recorded sites was of Native American origin with a historic/modern component, one was a paleontologic site of indeterminate age, and three were historic sites, dating to the beginning of this century. Some artifacts were collected. Also listed below is the isolated cobble tool found within the project area in 1989.

$\begin{array}{lll}\text { HCRL Isolate No. } & \text { Descriotion } & \text { Collected? } \\ \text { HI-89-016 } & \text { cobble tool } & \text { no } \\ \text { HI-93-001 } & \text { rod } & \text { yes } \\ \text { HI-93-002 } & \text { two flakes } & \text { yes } \\ H 1-93-004 & \text { bottle } & \text { yes } \\ H 1-93-005 & \text { can } & \text { yes } \\ H 1-93-006 & \text { flake } & \text { yes } \\ H 1-93-007 & \text { can } & \text { yes } \\ \text { HI-93-009 } & \text { carl } & \text { yes } \\ H 1-93-010 & \text { flake } & \text { yes } \\ H 1-93-012 & \text { rod } & \text { yes }\end{array}$

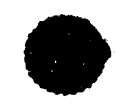

HCRL Site No.

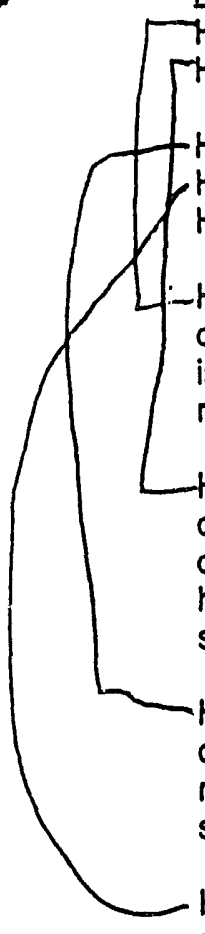

\section{State No.}

Not assigned

Not assigned

Not assigned

Not assigned

Not assigned
Site Iype/descriotion

tooth enamel

two flakes and tooth enamel, histcric/modern debris

jar fragments

collapsed structure

stove/cans

\section{Collected?}

yes

yes

no

no

no

-HP-93-001: This information sensitive and has been deleted. The site fails to meet any of the criteria necessary for listing on the National Register of Historic Places (National Register). There is no indication that the site is of human origin. Additionally, the site is not unique and the research potential of the site has been exhausted through collection.

-HT-93-080: This information sensitive and has been deleted. The site fails to meet any of the criteria necessary for listing on the National Register. The research potential of the prehistoric component of the site has been exhausted through recordation and collection. The historic/modern component holds no unique characteristics and does not retain nationally significant information.

HT-93-081: This information sensitive and has been deleted. The site fails to meet any of the criteria necessary for listing on the National Register. The site holds no unique characteristics, many such historic trash scatters are located on the Hanford Site, and does not retain nationally significant information.

HT-93-083: This information sensitive and has been deleted. By itself, the site does not retain nationally significant information. However, viewed in a broader historic context, Euro- 


\title{
CULTURAL RESOURCES REPORT NARRATIVE
}

\author{
Project Number: $\quad 93-200-001$ \\ Project Name: Environmental Restoration Disposal Facility (ERDF)
}

American ranching in southeastern Washington, the site represents a single part of the greater archaeological record, and may be considered regionally or locally significant viewed in this context.

HT-93-084: This information sensitive and has been deleted. By itself, the site does not retain nationally significant information. However, viewed in a broader historic context, EuroAmerican ranching in southeastern Washington, the site represents a single part of the greater archaeological record, and may be considered regionally or locally significant viewed in this context.

2. Cultural resources noted but not formally recorded: Isolated milk'sanitary cans, modern artifacts, dump sites, and probable military sites from the late 1950 s and 1960 s were noted but not recorded.

\section{Mardesionation Description}

Large cylindrical metal tank on platform consti scted of railroad ties. The tank measures $1.5 \mathrm{~m}$ diameter by $2.1 \mathrm{~m}$ long. The platform measures $2.5 \mathrm{~m}$ long by $2.3 \mathrm{~m}$ wide by $1.1 \mathrm{~m}$ tall. A well with a metal casing with a diameter of $15 \mathrm{~cm}$ is located adjacent to the tank. Probable water tank, perhaps related to military operations in the 1950 s and 1960s.

b Large cylindrical metal tank on platform constructed of railroad ties. The tank measures $4.5 \mathrm{~m}$ long and is covered with tar. The ends are metal and painted green. A green glass, $10 \mathrm{oz}$., crown cap beverage bottle was found nearby. Probable water tank, perhaps related to military operations in the 1950 s and 1960s.

c Large cylindrical metal tank on platform constructed of railroad ties. The metal tank is adjacent of a semisubterranean, $2.2 \mathrm{~m}$ diameter concrete tank which is about 4.5 to $6.0 \mathrm{~m}$ deep. This tank is covered with three circular openings in the top. Diameters of these openings measure $0.25 \mathrm{~m}, 0.4 \mathrm{~m}$, and $0.43 \mathrm{~m}$. A collapsed, three-hole outhouse is located $24 \mathrm{~m}$ north of the metal tank. An aluminum flag pole is located on a dune crest close by. Probable military site.

d Large cylindrical metal tank on platform constructed of railroad ties. Well and bucket adjacent. Probable water tank, perhaps related to military operations in the 1950s and 1960s.

- Military dump containing cans, including food, poison, milk, oil, and solvent cans, "HEEP GOOD" and "Coca Cola" soft drink bottles, metal binding straps, wire nails, 5 gallon metal drum, partly buried, batteries.

$f \quad$ Based on the proximity of the site to the 200 West area, the debris is probably associated with the construction or operations of the Hanford Site. Debris includes wooden benches, a wooden tool box, wire nails, buckets, wire including electrical wire, metal flashing, $1 / 8^{\prime \prime}$ mesh screening in a wooden frame., asbestos (?) siding, concrete fragments, ceiling tiles, canvas fragments, black rubber hose, shovel head, and a 5 gallon paint can.

g Probable laydown yard associated with the construction of Hanford facilities. Debris includes many pieces of lumber, possible structural remains, sidewalks, wire cable, buckles, air filter, metal fasteners, concrete rubble, disused asphalt road, and aluminum flashing. The ground has been disturbed, furrows are visible.

h $\quad 3200 \mathrm{~m}$ arc road and remains of air samplers along the road which were used from 1960-1974 for atmospheric dispersion tests (Nickola et al 1983) 


\section{CULTURAL RESOURCES REPORT NARRATIVE}

Project Number:

Project Name:

93-200-001

Environmental Restoration Disposal Facility (ERDF)

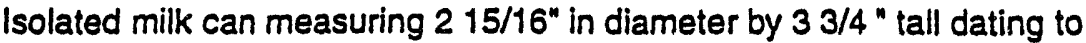
1917-1929 (Simonis n.d.)

Isolated sanitary can measuring $65 / 8^{n}$ in diameter by $73 / 4^{\prime \prime}$ tall, knife -puncture opening, therefore held some kind of liquid.

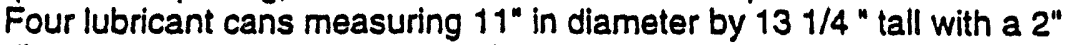
diameter screw top opening, and a sanitary can measuring $61 / 2$ " in

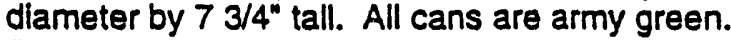

Sanitary can measuring $25 / 8$ " diameter by $31 / 4^{\prime \prime}$ tall.

Wooden construction, perhaps for holding a sign.

6 0z. Coca Cola bottle embossed with "TACOMA WASH L-C"-collected.

Crushed sanitary can measuring $23 / 4^{4}$ : diameter by $33 / 8$ " tall.

Galvanized tub measuring $53 / 4^{\prime \prime}$ tall, diameter of base $14^{\prime \prime}$, upper diameter

17 ". Tub has handles and a 1 " rim.

Clear glass, continuous thread bottle with "PEPSODENT ANTISEPTIC Duraglas" on the base.

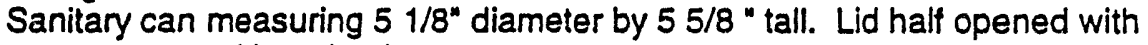
can opener and bent back.

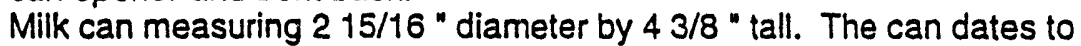
1917-1929 (Simonis n.d.)

Debris from burnt structure including a green lamp fixture, metal door and lock and knob, stove pipe, metal heater, window glass. Large chunks of charcoal and melted glass suggests a hot fire. Undoubtedly dates to Hanford Operations.

u Sanitary can measuring $215 / 16$ " diameter by $43 / 8$ " tall, opened with blade and bent back, hole cut in center of the bottom with a blade.

$\checkmark \quad$ Brown, crown cap, beer? bottle measuring $21 / 2$ " diameter by $61 / 4$ " tall. Embossing on the base reads" 4606 G 200 13"

not mapped not mapped car jack

Sanitary can measuring 4 " in diameter and $45 / 8$ ' tall, top opened with a blade and bent back.

not mapped Milk can measuring $215 / 16$ " in diameter by $37 / 8$ " tall, two round punch hole openings. The can dates to 1917-1929 (Simonis n.d.)

not mapped Milk can measuring $215 / 16$ " diameter by $315 / 16$ " tall. Two small round punctures on can end. Can dates to 1917-1929 (Simonis n.d.)

not mapped Sanitary can measuring $37 / 16$ " diameter by $31 / 2$ " tall, opened with a blade and lid bent back, however., solder at one end appears to be the attachment point for a key.

not mapped Steel beverage can measuring $413 / 16$ " by $211 / 16$ ", opened with a church key.

not mapped Sanitary can measuring 5 " diameter by $61 / 2$ " tall.

not mapped Jack for car/truck

Repository (for all original survey records, photos, maps, and artifacts):

All original records, maps, etc. are stored at the Hanford Cultural Resources Laboratory in Richland, Washington.

\section{G. CONCLUSIONS AND RECOMMENDATIONS:}

Sites HP-93-001, HT-93-080, and HT-93-081 do not meet any of the criteria for listing on the National Register of Historic Places. The research potential of these sites and of all but one of 


\section{CULTURAL RESOURCES REPORT NARRATIVE}

Project Number: $\quad 93-200-001$

Project Name: Environmental Restoration Disposal Facility (ERDF)

the isolates has been exhausted through recordation and collection. Sites HT-93-083 and HT-93-084 by themselves, do not retain nationally significant information. However, viewed in a broader historic context, Euro-American ranching in southeastem Washington, the sites represent part of the greater archaeological record, and may be considered regionally or locally significant viewed in this context.

The project will have no effect on any properties eligible for the National Register. The proposed project should have no effect on sites HT-93-083 and HT-93-084 given the most recent site boundaries. If, however, the project intends to use the area including these sites, mitigation may be necessary.

\section{H. REFERENCES}

Chatters, J. C. 1989 Hanford Cultural Resources Management Plan, PNL-6942, Pacifíc Northwest Laboratory, Richland, Washington.

Daubenmire, R. 1970 Steppe vegetation of Washington. Wasi:. Agric. Expt. Sta. Tech. Bull., 62, $131 \mathrm{pp}$.

Nicola, P. W., J. V. Ramsdell, C. S. Glantz, R. E. Kerns, 1983 Hanford Atmospheric Dispersion Data: 1960 through June 1967, PNL-4814, Pacific Northwest Laboratory, Richland, Washington. .

Simonis, D. Date unknown. Condensed/Evaporated Milk Cans-Chronology for Dating Historical Sites. U.S. Department of the Interior, Bureau of Land Management.

\section{ATTACHMENTS}

1. Site forms for each site recorded?

2. Isolate forms for each isolate recorded?

3. Overview location map

4. Quad map of surveyed area?

5. Other attachments?
$[X]$

$[\mathrm{X}]$

$[\mathrm{X}]$

$[x]$
Four archaeological site forms, one paleontological site form

Ten isolated artifact forms

Project area sketch map based on USGS 7.5 " Gable Mountain Quad Map.

Site and Isolate forms are not included in this version of the report narrative.

\section{J. CERTIFICATION OF RESULTS}

I certify that I conducted the investigation reported here, that my observations and methods are fully documented, and that this report is complete and accurate to the best of my knowledge.
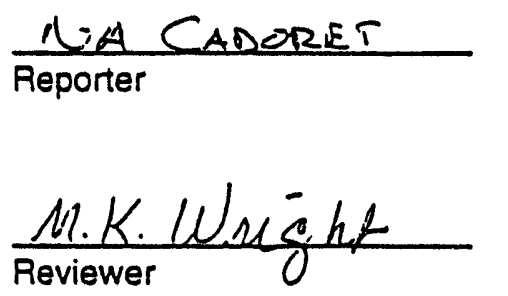

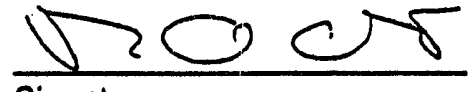

Signature
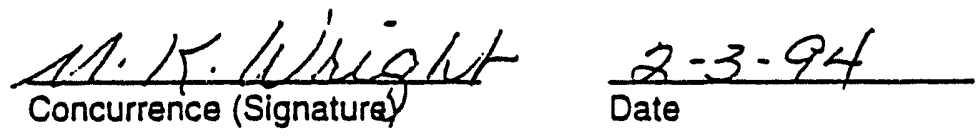


\section{CULTURAL RESOURCES REPORT NARRATIVE}

Project Number: $\quad 93-200-001$

Project Name: Environmental Restoration Disposal Facility (ERDF)

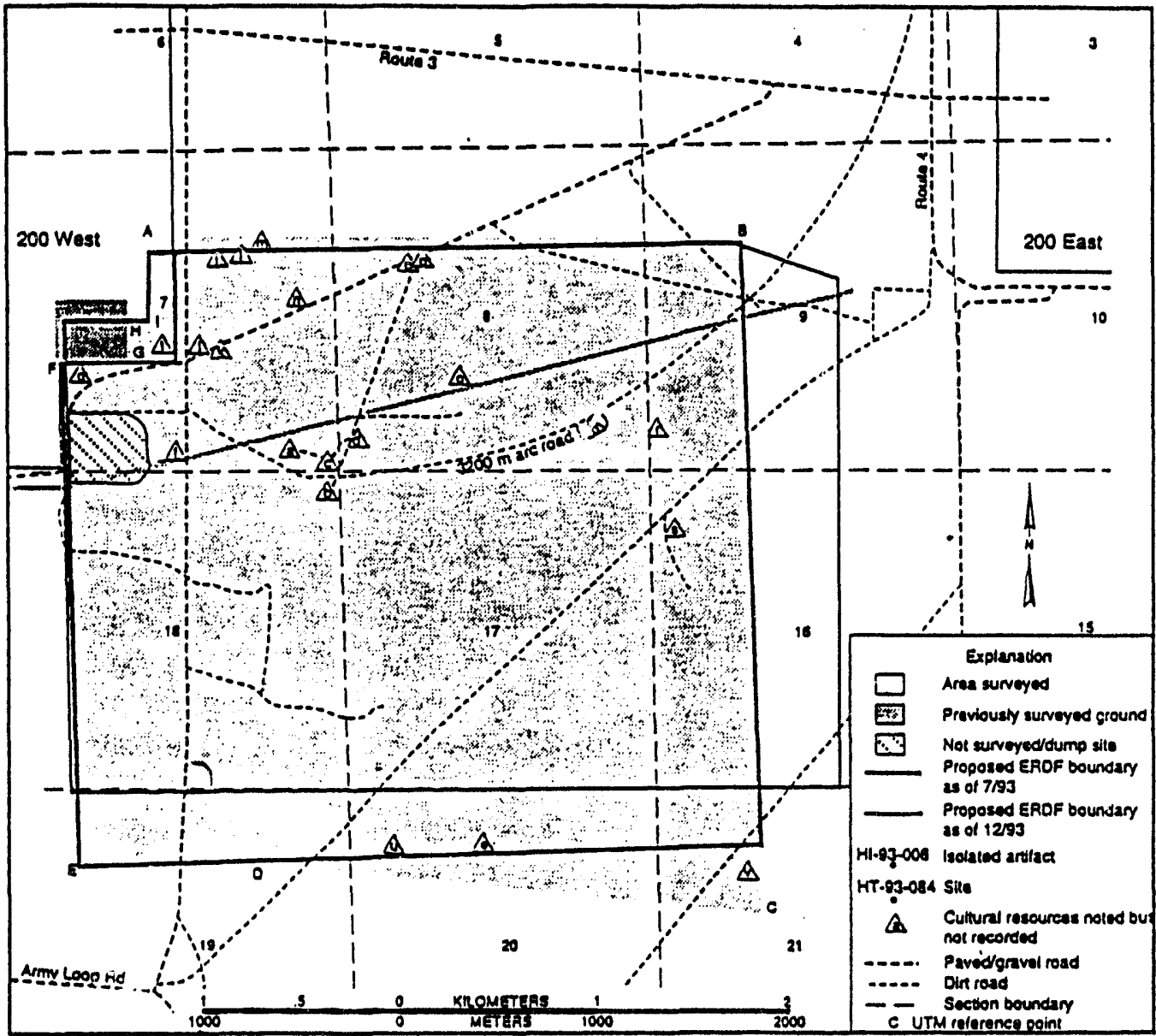

Figure 1. Project area map (base map USGS Gable Butte Quadrangle, Washington, 7.5 Minute Series ( $T 12 \mathrm{~N}, \mathrm{R} 26 \mathrm{E})$ ). Site and isolate locations have been deleted from the map. 
CULTURAL RESOURCES REPORT NARRATIVE

Project Number: $\quad$ 93-200-001

Project Name: Environmental Restoration Disposal Facility (ERDF)

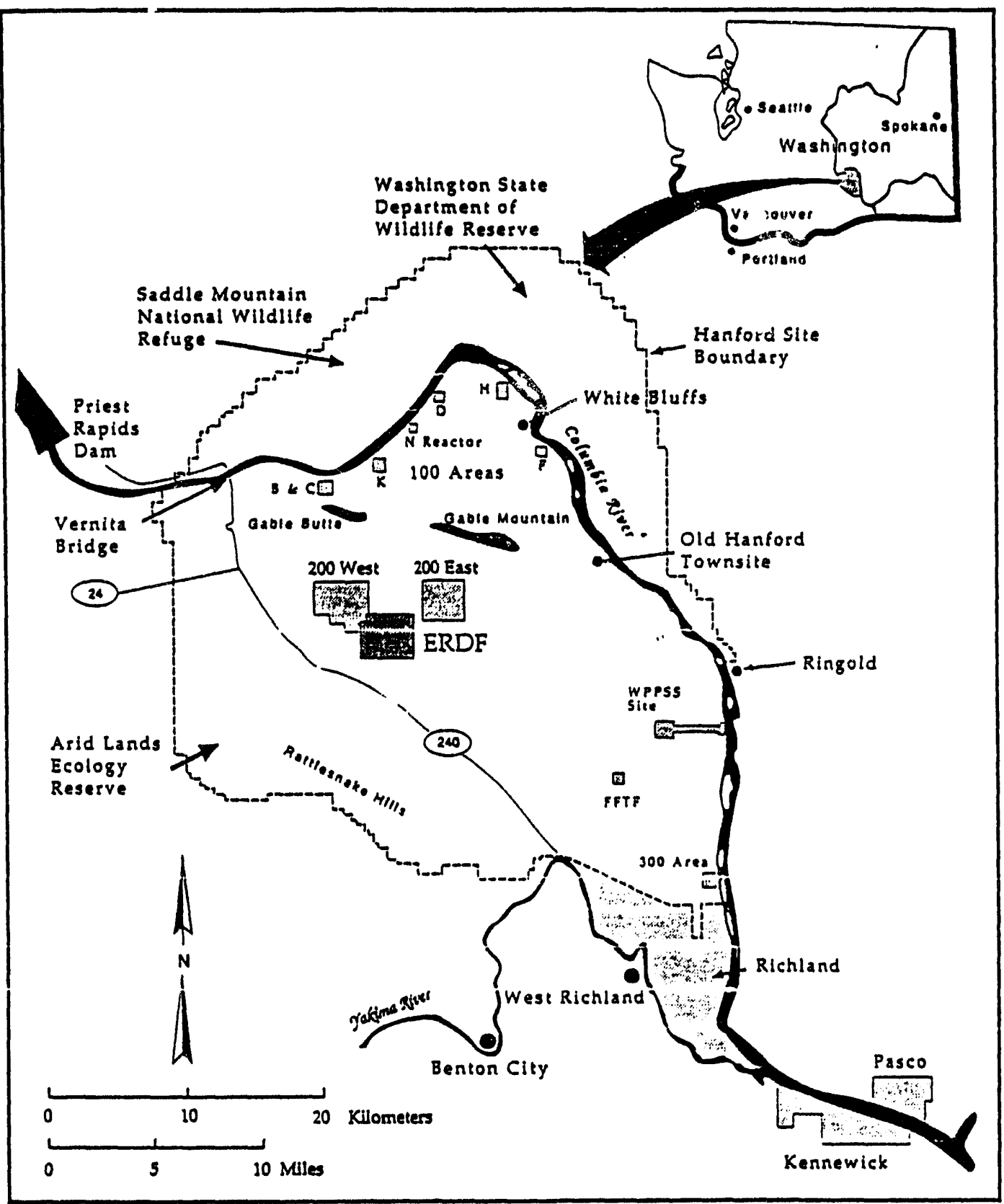

Figure 2. Location of Project on the Hanford Site. 
DOE/RL-94-40, Rev. 0

$06 / 94$

\section{APPENDIX 5A}

MONITORING WELL LOG AND CONSTRUCTION INFORMATION 


$$
\text { DOE/RL-94-40, Rev. } 0
$$

06/94

$$
\begin{aligned}
& 1 \\
& 2 \\
& 3 \\
& 4 \\
& 5
\end{aligned}
$$

This page intentionally left blank. 


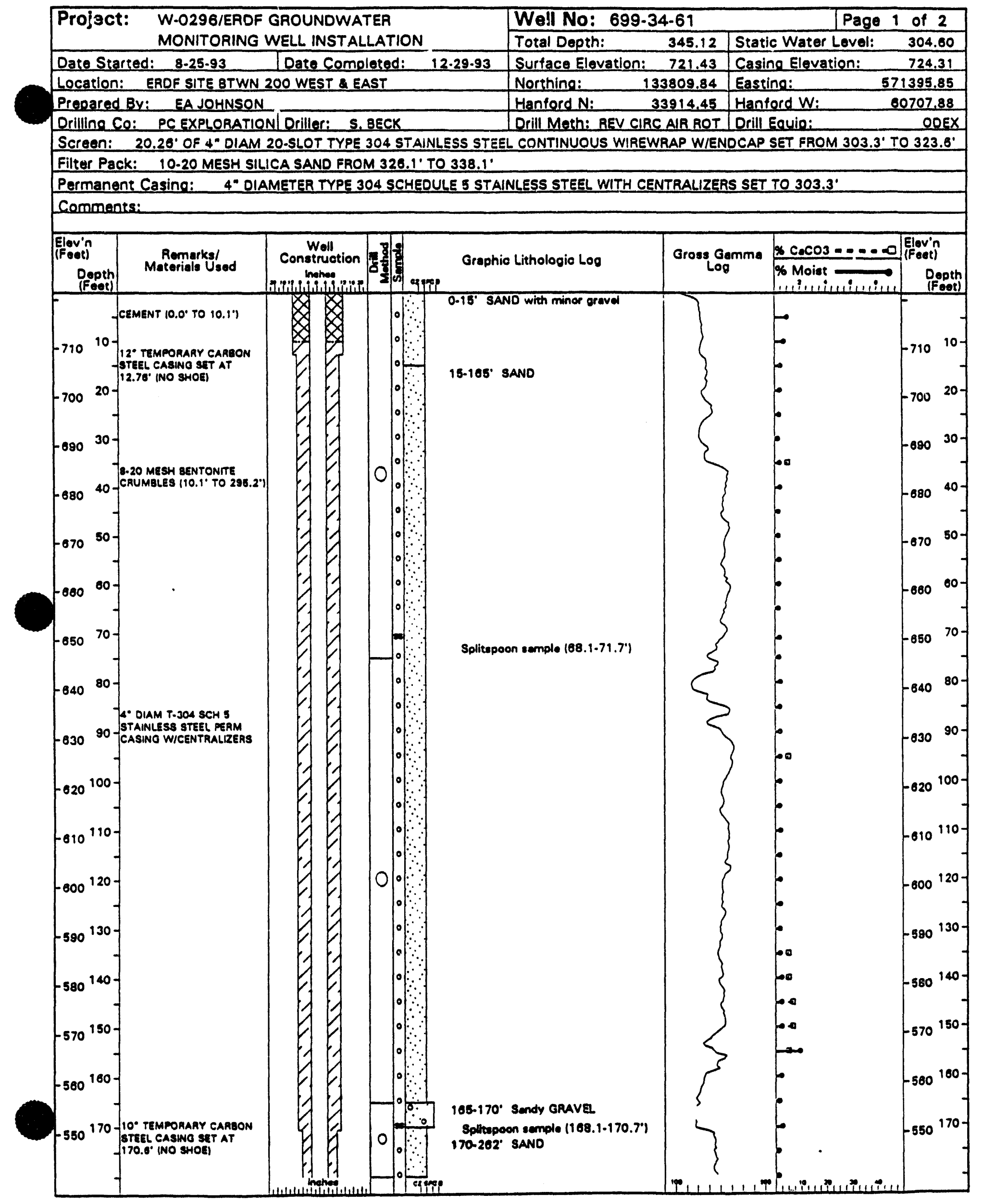




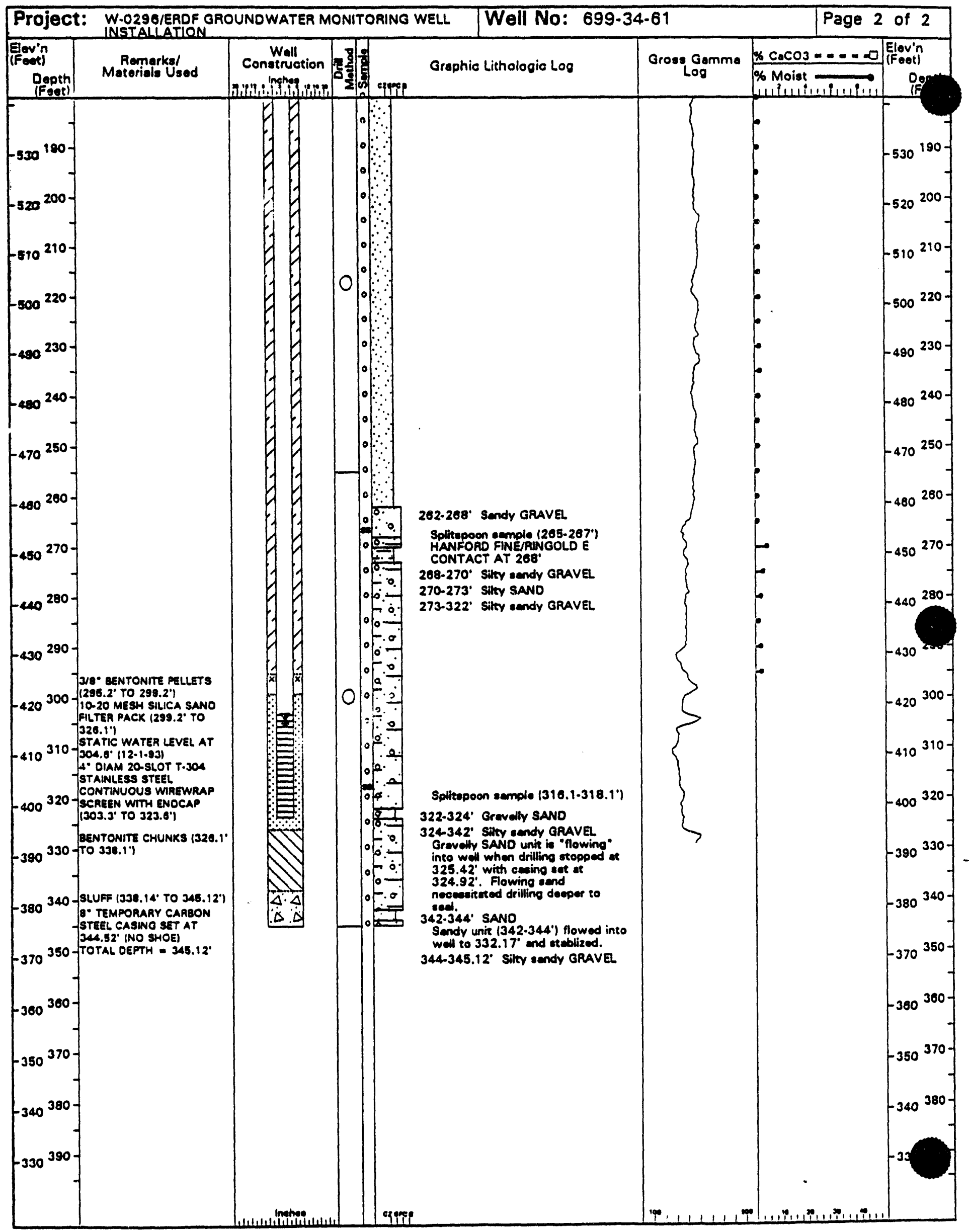




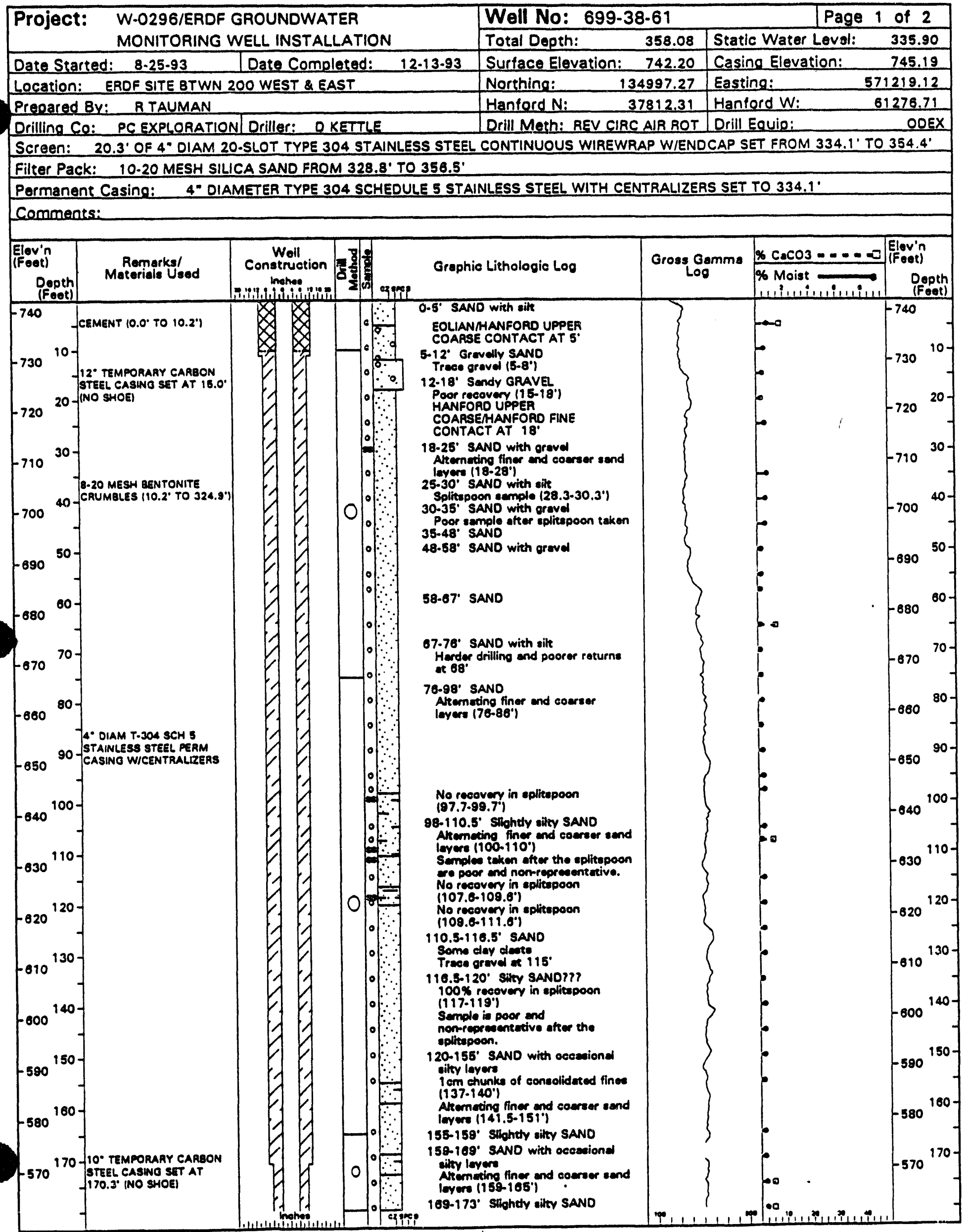




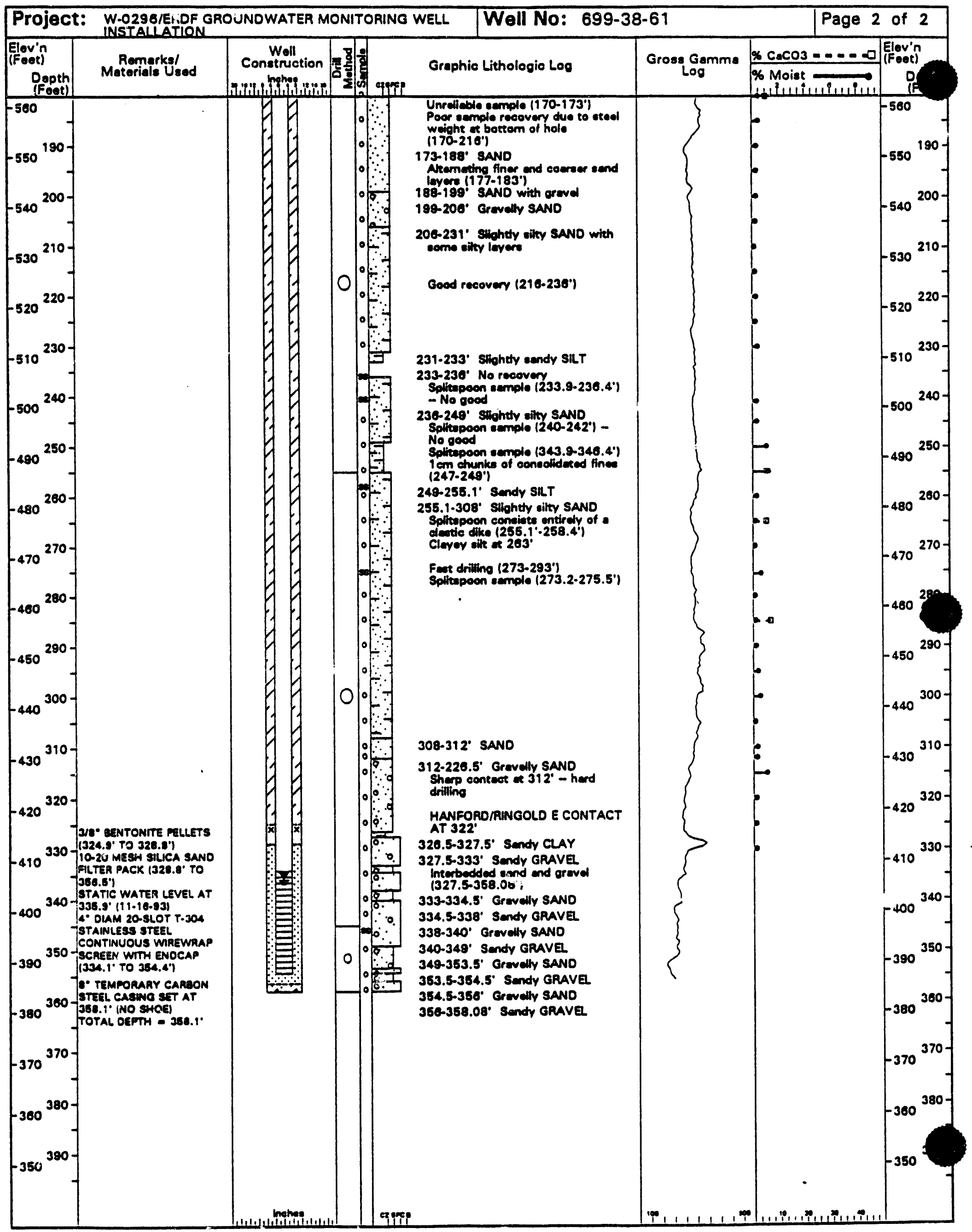




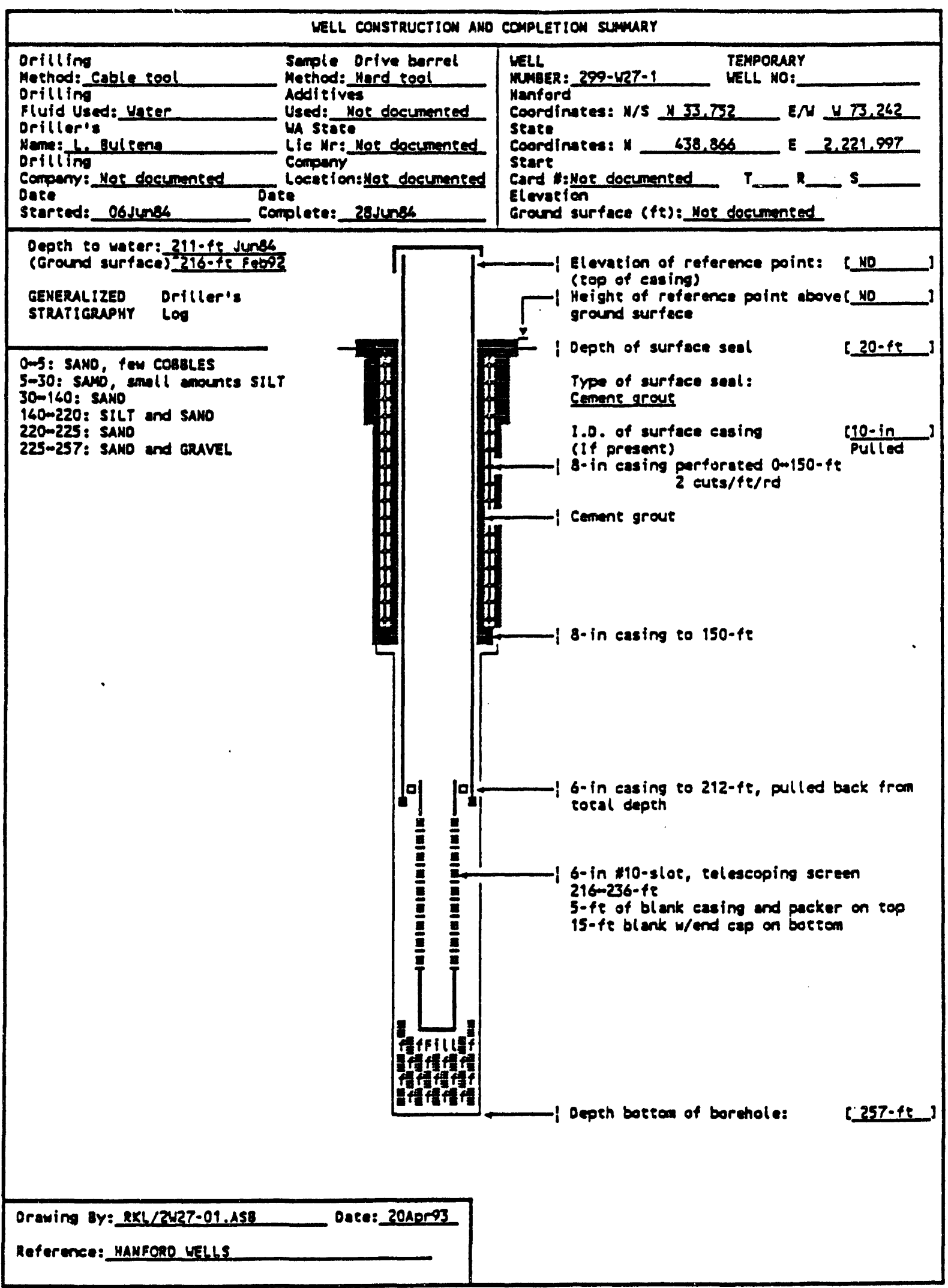


SUMMARY OF CONSTRUCTION DATA AND FIELD OBSERYATIONS RESOURCE PROTECTION WELL - 299-W27-1

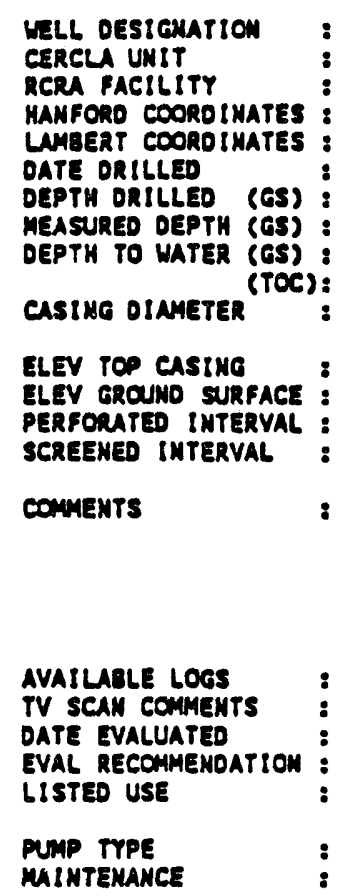

$299-1 / 27-1$

200 Aggregate Area Menogement seudy

Nor epplicable

i. 33,752 473,242

438,366 e 2,221,997 thuncown

Junes

$257 \cdot$ fe

Mot documanted

211-ft dunke;

217.6- ft, 03F ebo2

a-in carbon steal -0m150-ft;

6 - in carbon steel, $+\mathrm{ND}-212-1 \mathrm{t}$

Not doecumented

Not documented

8-in casing 0o150-ft;

6-in tel escoping $2160236-f t, * 10-s$ lor

5-ft blenk on top w/packer. 15-ft blank on botten.

PIELD IMSPECTION, 25 JuLI8,

6-in carben steel casing.

2-ft exement ped. No posts, espond and loeked.

Mo parmanent identifiestion.

Mor in rediation zome.

OTHER:

Driller

Not apol fesble

Not appl iesble

Not appl iesble

Semiamual water level masurement, 120 ecs8mo3feb92;

PML Seninamual, WHC Quarterly water semple sehedule

Electric submarsible 


\section{SUMMARY OF CONSTRUCTION DATA AND FIELD OBSERVATIONS \\ RESOURCE PROTECTION WELL - 299-W22-42}

WELL DESIGNATION :
CERCLA UNIT
RCRA FACILITY
HANFORO COOROINATES :
LNAERT COOROINATES :
DATE DRILLED
OEPTH ORILLED (GS)
MEASURED DEPTH (GS) :
DEPTH TO WATER (GS) :
CASING OLAMETER
ELEV TOP CASING
ELEV GROUNO SURFACE :
PERFORATED INTERVAL:
SCREENED INTERVAL :
COMMENTS

$299-122-42$

200 Aggregete Ares Management seudy

$216 \cdot U \cdot 12$

M 36,052.7 V 73.079 .6 [200W-18Jun90]

$N 41,167 \quad 2,222,153$ [MANCONV]

N 136,652.20m E 567,623.16m [NAO83-18Jumol

Mario

263.6-ft

244.3-ft, 13Margi

227.0-1e, Apr90;

232.2 -fe. 09Margs

4-in, seoinless stent, $+1.0-223.1-f t ;$

6 - In stainless steel. $+2.96-0.5-1 t$ (not documed)

$699.16 \cdot f 8$ (2004-18Jungo]

688.20, Dress eap (200W-18Jungo)

Not apol ieable

223. In-243.4-ft, 10-stot, staintess steel

FIELO IMSPECTION, 13MaYi:

stainless steal easing. 4 -ft by 4 -fe conerete pad, 4 posts, 1 removable cappod and loeked, brass eap in pad with wall to.

Not in radiation zone.

OTHER:

AVATLABLE LOGS

TV SCAN COMHENTS

DATE EVALUATED

Oriller

Not appl ieable

Not appl leable

Hot appl leable

Woter levels masured, 20Nov90m09Mar93

LISTED USE

Not on woter sample schedule

Hydrosear

MAINTENAMCE 


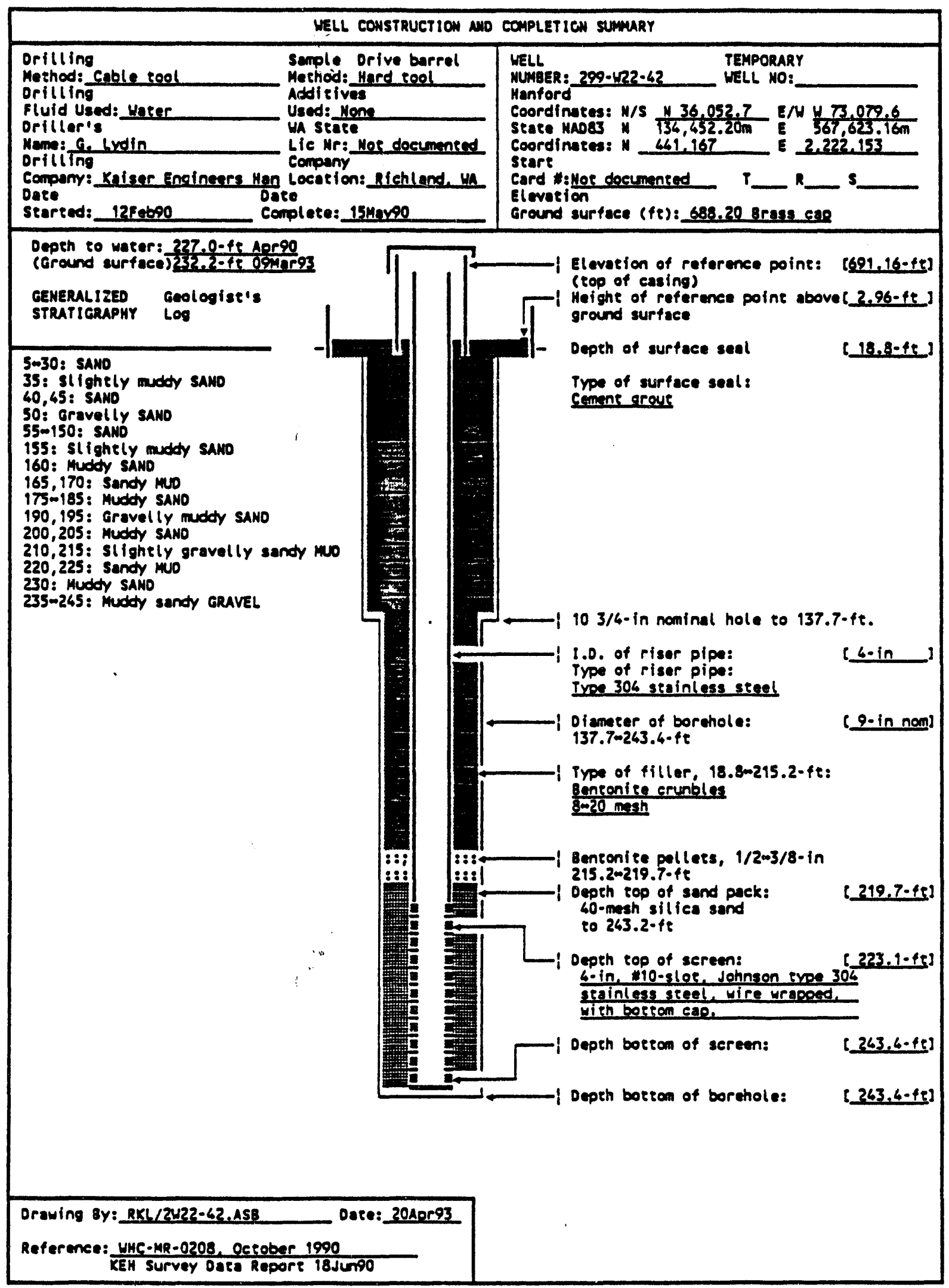


DOE/RL-94-40, Rev. 0 $06 / 94$

\section{APPENDIX 5B}

MONITORING EFFICIENCY MODEL INFORMATION: USER'S MANUAL 
咅

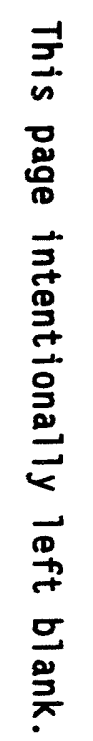

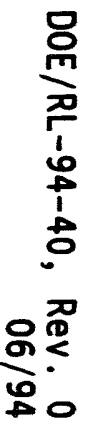

윰

ज्ञ 
User's Manual

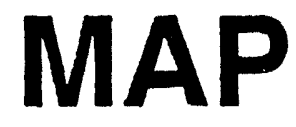

\section{Monitoring Analysis Package Including MEMO, PLUME, and COPRO}

Version 1.1

September 1992
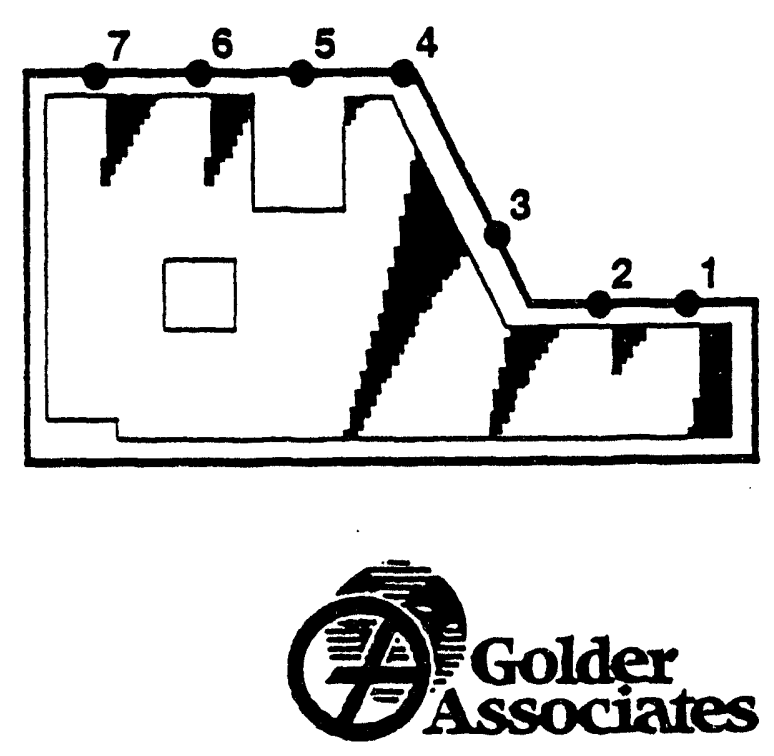
Golder Aesociates Ine.

\$104-148ih Avenue. NE

Redmond. WA USA 98052

Teleohone (200) 883.0777

fox (206) $882 \cdot 5498$

MONITORING ANALYSIS PACKAGE (MAP)

USER'S MANUAL - VERSION 1.1

Prepared by:

Colder Associates Inc.

September, 1992

IP3-1259 


\section{APPLICATION}

Athough this software has been verified, it has not been used extensively in routine applications. If any problems are noted with the information contained herein, or with the operation of MAP, please contact Carl Einberger of Golder Associates Inc., Redmond, Washington 98052, (206) 883-0777, Fax (206) 882-5498. Necessary corrections will be included in future versions of the model software and documentation.

Any use of this software is for information purposes only. The authors and sponsoring organization make no warranty of the accuracy, functionality, or application of this software. Any rights granted to use this software include the express condition that all liability and responsibility for the results of any use of this software are exclusively that of the individual or organization making use of the software. No responsibility is assumed for user support.

\section{ACKNOWLEDGEMENTS}

The concepts incorporated into MAP were originally developed for monitoring well retwork design for facilities at the Hanford Site. Initial software development was supported by Westinghouse Hanford Company. Support for the improvements and refinements incorporated into Version 1.1 of MAP was provided by Golder Associates Inc. and the Idaho National Engineering Laboratory. 
1. INTRODUCTION

1.1 PLUME

1.2 MEMO

1.3 COPRO

2. THEORY

2.1 Plume Generation Model

22 MEMO

221 Theory

222 Solution Method

\section{1}

2.3 COPRO

2

3

3

5

5

5

7

3. PROGRAM INSTALLATION

4. PROGRAM EXECUTION

4.1 Description

4.2 Operation

4.21 Memory Management

4.22 Data Files and Backup Files

42.3 Plot Files

4.2.4 DOS Commands

4.2.5 Default Values and Units

5. PLUMIE OPERATION

5.1 Modify advection time - PLUME Menu Option 1

5.2 Modify source history - PLUME Menu Option 2

5.3 Modify width of line source - PLUME Menu Option 3

5.4 Modify longitudinal dispersivity - PLUME Menu Option 4

5.5 Modify transverse dispersivity - PLUME Menu Option

5.7 Modify first-order decay constant - PLUME Menu Option 7

5.8 Modify average contaminant velocity - PLUME Menu Option 8 13

5.9 Change dilution contour levels - PLUME ME Menu Option 10

5.10 GENERATE and PLOT contours - PLUME Men OP

5.11 Load existing input file - PLUME Menu Option 11

5.12 Save file on disk

5.13 Enter DOS commands - PLUME Menu Option 13 


\section{IABLE OF CONTENTS (Continued)}

6. MEMO OPERATION

6.1 Load existing input file - MEMO Main Menu Option 1

6.2 Input or modify coordinate data - MEMO Main Menu Option 2

6.21 Source area coordinates - Coordinate Menu Option 1. 16

6.22 Line of compliance coordinates - Coordinate Menu Option 2

6.2.3 Buffer zone coordinates - Coordinate Menu Option 3 16

6.24 Gradient zone coordinates - Coordinate Menu Option $4 \quad 17$

6.25 Monitoring well coordinates - Coordinate Menu Option $5 \quad 17$

6.2.6 Modification of scale factor - Coordinate Menu Option $6 \quad 17$

6.3 Define source grid - Main Menu Option 3 17

6.4 Define and generate buffer zone array - Main Menu Option 4

6.5 Modify hydrogeologic parameters - Main Menu Option 5.18

6.6 Adjust monitoring well locations - Main Menu Option $6 \quad 19$

6.6.1 Move well along line of compliance -

Well Movement Option 1

6.6.2 Move well a specified $x$ and y distance - Well Movement Option $2 \quad 19$

6.6.3 Move well a specified distance and angle -

Well Movement Option 3

6.7 Determine monitoring efficiency - Main Menu Option $7 \quad 19$

6.7.1 Determine monitoring efficiency - Solution Menu Option $1 \quad 20$

6.7.2 Modify solution basis - Solution Menu Option $2 \quad 20$

6.7.3 Modify max advection time - Solution Menu Option $3 \quad 20$

6.7.4 Modify accuracy - Solution Menu Option 4 20

6.7.5 Modify TCRIT offset - Solution Menu Option 5

6.7.6 Generate a solution check file - Solution Menu Option $6 \quad 21$

6.8 Display or plot current problem - Main Menu Option 8

6.9 Save file on disk - Main Menu Option $9 \quad 22$

6.10 Print data currently in memory-Main Menu Option 10

6.11 Review data currently in memory - Main Menu Option 11

6.12 Enter DOS commands - Main Menu Option $12 \quad 22$

$\begin{array}{ll}\text { 7. COPRO OPERATION } & 23\end{array}$

7.1 Load existing input file - Main Menu Option 1

7.2 Input or modify coordinate data - Main Menu Option 2

72.1 Source area coordinates - Coordinate Menu Option $1 \quad 2 A$

7.2 .2 Contour zone coordinates - Coordinate Menu Option $2 \quad 24$

7.23 Gradient zone coordinates - Coordinate Menu Option $3 \quad 24$

724 Modification of scale factor 24

7.3 Define source grid - Main Menu Option $3 \quad 25$

7.4 Define contour grid - Main Menu Option 4 25

7.5 Modify hydrogeologic parameters - Main Menu Option 5

7.6 Modify history of source(s) - Main Menu Option $6 \quad 26$

7.7 Determine contamination probability - Main Menu Option 7 


\section{IABLE OF CONTENTS (Continued)}

7.7.1 Determine contamination probabilities - Solution Menu Option 1

7.72 Define contour levels - Solution Menu Option 2

7.73. Generate a solution check file - Solution Menu Option 3

7.8 Display or plot current problem - Main Menu Option 8

7.9 Save file on disk - Main Menu Option 9

7.10 Print data currently in memory - Main Menu Option 10

7.11 Review data currently in memory - Main Menu Option 11

7.12 Enter DOS commands

8. SAMPLE PROBLEMS AND EXAMPLES 29

9. REFERENCES

\section{LIST OF EIGURES}

1. Illustration of Plume Detection in MEMO

2 Test Problem 1

3. Test Problem 2

4. Test Problem 3

5. PLUME Example Output

\section{LIST OF APPENDICES}

$\begin{array}{ll}\text { APPENDIX A } & \text { Test Problem Data Files } \\ \text { APPENDIX B } & \text { Source Code } \\ \text { APPENDIX C } & \text { Verification Plan-MAP Version } 1.1 \\ \text { APPENDIX D } & \text { Verification Report-MAP Version } 1.1\end{array}$




\section{INTRODUCTION}

The Monitoring Analysis Package (MAP) includes the Plume Generation Model (PLUME), the Monitoring Efficiency Model (MEMO) and the Contamination Probability Model (COPRO). MAP has been developed as a tool for investigating sites requiring groundwater monitoring.

MAP contains utilities that facilitate data input and adjustment of well locations for efficiency determinations. MAP provides a direct graphical interface with the screen and with an HP LaserJet III printer. MAP also can create HPGL files which may be printed on other types of plotters through the use of an HPCL compatible program, such as AUTOCAD.

MAP Version 1.1 supersedes MAP Version 1.0. MAP Version 1.0 was developed from MEMO Version 1.1. MEMO is now included as part of the MAP package, and Version 1.1 of MAP supersedes MEMO Versions 1.0 and 1.1. Data files generated using Version 1.0 or 1.1 of MEMO or Version 1.0 of MAAP are compatible with Version 1.1 of MAAP. Version 1.1 of MAP has been verified. Results of the verification are presented in the MAP Version 1.1 Verification Report.

\subsection{PLUME}

PLUME uses an analytical contaminant transport function to generate dilution contour plots of a contaminant plume emanating from a line source of specified length. PLUME also provides a means to display the sizes and shapes of plumes used in MEMO and COPRO. Plots of these plumes may be used to manually determine monitoring efficiencies, and to investigate contaminant distribution from a known source location.

\subsection{MEMO}

MEMO provides a computerized method for optimizing monitoring well locations at waste management areas. The user inputs site geometry, hydrogeologic chafacteristic and initial monitoring well locations, and MEMO determines the efficiency of the monitoring network The efficiency determination is based on one of two solution methods: (1) whether a plume is detected by the monitoring well network before it crosses a specified buffer zone boundary or (2) whether a plume is detected before it migrates for a specified advection time. The user can change the location of wells and add or delete wells to optimize the well efficiency. Source areas where the monitoring system may not detect a potential release are shown, and well locations can be adjusted based on this information. The sensitivity of the monitoring efficiency to changes in other input parameters can also be readily investigated. 


\subsection{COPRO}

COPRO maps the probabilities of downgradient contamination from a single random leak within a defined potential source area(s). The analysis of contamination probabilities is performed over an area selected by the user. COPRO provides the user with a graphical depiction of the susceptibility of an area to contamination, given a single random source location. The user inputs the site geometry, hydrogeologic characteristics, the area to be contoured, and contour levels. 


\section{THEORY}

\subsection{Plume Generation Model}

The plume generation model is the core of MAs. It computes the sizes and shapes of the plumes used in PLUME, MEMO, and COPRO.

The plume generation model used in MAP is based on the two-dimensional analytical transport model presented in Domenico and Robbins (1985) and modified in Domenico (1987). This model assumes that solute is released along a continuous line source in a uniform aquifer, and predicts the concentrations that would be observed at points downstream of the source. The governing equation is:

$$
\begin{aligned}
C(x, y, t)=\quad & \left(C_{d} / 4\right) \exp \left\{\left(x v / 2 D_{x}\right)\left[1-\left(1+4 k D_{x} / v^{2}\right)^{1 / 2}\right)\right\} \\
& \operatorname{erfc}\left\{\left[x-v t\left(1+4 k D_{x} / v^{2}\right)^{1 / 2} y / 2\left(D_{x} t\right)^{1 / 2}\right\}\right. \\
& \left.\left\{\operatorname{erf}(y+Y / 2) / 2\left(D_{y} x / v\right)^{1 / 2}\right]-\operatorname{erf}\left[(y-Y / 2) / 2\left(D_{y} x / v\right)^{1 / 2}\right]\right\}
\end{aligned}
$$

Where:

$\begin{array}{ll}C(x, y, t) & \text { is the concentration at } x, y, t \\ C_{0} & \text { is the source concentration } \\ x & \text { is the distance downstream from the source } \\ y & \text { is the transverse distance from the source } \\ \mathbf{k} & \text { is the first-order radioactive decay constant } \\ Y & \text { is the width of the source } \\ v & \text { is the average contaminant velocity } \\ D_{x} & \text { is the longitudinal dispersion coefficient } \\ D_{y} & \text { is the transverse dispersion coefficient } \\ t & \text { is time }\end{array}$

The average contaminant velocity is computed as:

$$
v=K i / R n
$$

Where:
$K \quad$ is the hydraulic conductivity
$i$ is the groundwater gradient
$R$ is the retardation factor
$\Omega$ is the effective porosity 
The dispersion coefficients are functions of the average contaminant velocity, the dispersivities, and the molecular diffusion coefficient for the chemical of interest in water:

$$
\begin{aligned}
& D_{x}=a_{x} v+D_{m} \\
& D_{y}=a_{y} v+D_{m}
\end{aligned}
$$

Where:

$\alpha_{x}$ and $\alpha_{y}$ are the longitudinal and transverse dispersivities, respectively; and

$D_{m}$ is the effective molecular diffusion coefficient for the chemical of interest through the porous medium

For most field situations, the molecular diffusion coefficient is quite small compared to the advective velocity term and can be neglected. The line source width assumed in the model can be adjusted to account for dispersion in the vadose zone as the leachate migrates toward the water table.

The Domenico and Robbins model also assumes that the volume of leachate is negligible compared with groundwater flow in the aquifer, that a uniform aquifer is present at the site, and that complete mixing of the compound occurs over the thickness of the aquifer zone at the plume source. This implies uniform hydrologic and transport properties and a uniform hydraulic gradient over the length of the plume. Although MAP allows the direction of the gradient to vary beneath the source unit, plumes originating at a point within a given gradient zone will maintain the constant direction defined by the gradient in that zone, regardless of whether they enter another gradient zone.

The default source history in MAP assumes a continuous source. However, COPRO and PLUME allow the user to model a non-continuous source. The user can specify a source removal time and simulate plume migration after source removal. Source removal is based upon the principle of superposition. Plume concentrations are generated from a continuous source for the total simulation time. Plume concentrations are also generated from a continuous source for the time since source removal. The actual plume concentrations are calculated by subtracting the concentrations obtained for the time since source removal from the concentrations obtained for the total simulation time.

MAP is primarily suited to non-complex hydrogeologic environments, because of the simplifying assumptions discussed above. To investigate contaminant migration or monitoring in more complex hydrogeologic environments, the authors recommend using finite difference or finite element contaminant transport modeling, provided the data base is adequate to support such approaches. 


\subsection{MEMO}

\subsubsection{Theory}

MEMO is based on the concept of generation and growth of a plume as it migrates down gradient from a continuous line source. The assumption of a continuous rather than a finite source of leachate assures that releases from leaks near the upgradient end of the waste management area do not disperse to below detection limits. The model provides a map of the waste management site showing where releases would not be detected under the given inputs. The principal output of MEMO is the "monitoring efficiency", defined as the ratio of the area from which a release would be likely to be detected to the total potential source area. This definition of efficiency assumes that development of a release is equally likely at any location within the source, unit.

Figure 1 illustrates the solution method in MEMO. A plume developing from a continuous release at location $A$ on the figure would be detected, because by the time it migrated to the line of compliance, it would have grown large enough to pass through the location of a monitoring well. However, a plume developing from a similar release at location B would not yet have been detected.

This illustrates that within given constraints of plume size, releases occurring at most locations within the source unit would be expected to be detected, but releases occurring at certain locations, such as between the monitoring wells and near the down gradient boundary, would be less likely to be detected. Because monitoring wells are always spaced some finite distance apart, and because uncertainties will always be present in predicting the behavior of a natural geologic system, a level of uncertainty will always be present in the function of any groundwater monitoring network design. MEMO provides a simple way to quantify some of the uncertainty associated with a given network design.

In applying the Domenico and Robbins model, it is interesting to note that the shape of a plume of a given length is the same regardless of the time required to attain that length, if diffusion and molecular radioactive decay are negligible. This means that a plume that traveled 500 feet in five years would be predicted to be the same shape as one that traveled $\mathbf{5 0 0}$ feet in $\mathbf{5 0}$ years. The shape of the plume is, therefore, assumed to be independent of the hydraulic parameters governing rate of movement, including the hydraulic conductivity, hydraulic gradient, and effective porosity, so long as those parameters are constant over the area of the plume.

\subsubsection{Solution Method}

In applying MEMO to a problem, it is necessary to identify an appropriate dilution contour for the plume generation model. Dilution is defined as the ratio of concentration at a down-gradient point to the original concentration of the line source. For the purposes of the model, a plume is defined by the dilution contour. Selection of an appropriate dilution contour value is subject to user judgement, and is discussed in more detail in Section 6.5. 
MEMO allows the user to choose one of two possible solution methods: (1) buffer zone with advection time limit, and (2) advection tine only. In the first solution method, detections are based upon the migration of each plume to a specified limiting distance (buffer zone boundary). This is the default solution method. The time when a plume from a specific source point reaches the limiting distance (the critical time) is found iteratively. In the second solution method detection is based upon the migration of each plume for a given time, and it is not necessary to define a buffer zone.

The model solution is based on integration of the plume generation model with user specified geometry inputs. The basic geometry inputs are:

- Potential source units - Defined as the areas within which sources could exist

- Line of compliance - Defined as the waste management area boundary. This is an optional input providing a line along which wells can be easily moved.

- Buffer zone boundary - Defined as the limit to which a plume may extend before it should be detected by a monitoring well. This is an optional input if the "advection time only" solution method is chosen.

- Hydraulic gradient zones - Plumes originating within a defined gradient zone migrate only in the gradient direction chosen for the zone.

- Monitoring well locations.

For the default solution method ("buffer zone with advection time limit"), a solution is reached in the following manner. A source grid, with spacing defined by the user, is generated within the potential sousce areas. The buffer zone boundary is broken into an array of buffer zone points, with a spacing defined by the user, which are checked for contact by the migrating plume. The spacing of the source grid and buffer zone array influence the accuracy of the solution, as well as the computation time involved in the solution. For each point on the source grid within the potential source area(s), a critical time exists when the dilution contour originating from a source first crosses the buffer zone boundary. The solution algorithm defines this critical time as the time when the concentration at a buffer zone point exceeds the specified dilution contour concentration. Each buffer zone point is checked, to ensure that the minimum time is calculated. At this critical time, the concentration at each monitoring well is determined.

In the "advection time only" solution, the source grid is generated as described above, and the concentration is calculated at each monitoring well for the user specified advection time. No calculation of the critical time is performed or required.

For both solution methods, if the concentration in any well exceeds the dilution contour value, then the leak has been successfully detected. If not, the grid point is flagged as a non-detect poir.t. For grid points withiin a defined source area, plumes are generated and checked to determine the monitoring efficiency. Monitoring efficiency is equal to the ratio 
of grid points where a leak has been detected to the total number of grid points within the potential source area(s).

When the "buffer zone with advection tims limit" solution method is chosen, the specified dilution contour for plumes originating at more distant upgradient release points within the source unit(s) may not reach the buffer zone boundary under conditions where the plume migrates very slowly or where decay is significant. Plumes that do not reach the buffer zone boundary within a user-defined maximum advection time (default: 100 years) and are not detected at a monitoring well are considered by MEMO to be not detected. The presence of such slowly migrating plumes is indicated in the MEMO output by nondetected zones on the upgradient side of the source unit. Such zones are combined with other non-detect areas in computing monitoring efficiency.

\subsection{COPRO}

COPRO generates contamination probabilities over an area, given a random single active source within the potential source area(s). The probability of contamination at a point is equivalent to the monitoring efficiency determined by MEMO for a single well at that point using the "advection time only" solution option. If a single well is placed at a specific location, the monitoring efficiency predicted by MEMO for that well is the same as the contamination probability generated by COPRO at that point.

The contamination probabilities are calculated by determining monitoring efficiencies using the logic incorporated into MEMO. A single well is moved through the defined contour grid, and for each well location the monitoring efficiency is calculated. The well movements and monitoring efficiency determinations are transparent to the user. The values determined at each grid point are then contoured as the contamination probabilities.

COPRO allows the user to enter a different source history for each source unit if source removal is desired. Source history includes the time the source became active, and the source removal time.

It is important to note that COPRO assumes that only a single source is active within the defined potential source area(s) and that a single release is equally likely at any location within the source area(s). COPRO results are intended only to give an indication of susceptibility of an area to contamination. 


\section{PROGRAM INSTALLATION}

The MAP executable program is provided on a 3.5 inch disk, along with four test problems. While the program can be run directly from the disk, it is suggested that you copy the disk to a directory on a hard drive. Execution time will be considerably faster. Approximately $100 \mathrm{~Kb}$ of free disk space should be available for temporary files generated by the program and additional disk space will be required to save data and plot files.

The program has been written and compiled using Microsoft FORTRAN Version 5.0. The code contains FORTRAN statements specific to this version of Microsoft FORTRAN, and will not work successfully with previous versions. Execution of the program requires a math coprocessor ( 80287 or 80387 ) chip. Approximately $400 \mathrm{~Kb}$ of memory are required to run MAP.

In order to run the model correctly, it is important that ANSI.SYS is specified as a device in the CONFIG.SYS file in the root directory. ANSI.SYS is a standard DOS operating system file, used by the model for screen control. If during program execution menus scroll onto the screen, ANSI.SYS is incorrectly installed.

Make sure CONFIC.SYS has the following line with an appropriate directory designation:

device $=$ c:lansi.sys

Also make sure that ANSI.SYS is in the specified directory. In addition, for screen graphics the MODERN.FON file provided on the program disk is required in the working directory.

It is recommended that MAP be run on a color monitor. It can also be run on a monochrome monitor, but screen graphics may be poor quality or may not function, depending upon the graphics interface. Program execution with hard copy output can be readily performed with a monochrome monitor. 


\section{PROGRAM EXECUTION}

\subsection{Description}

The following sections of the User's Manual contains detailed instructions for using the MAP program. MAP has been designed to be "user friendly" and incorporates several error checking routines. Although MAP has been verified, it has not been extensively tested in routine operations. If any problems are noted with the information contained herein or with the operation of the MAP, please contact Golder Associates Inc.

Subprograms PLUME, MEMO, and COPRO have been combined into one package because all are based on the same plume generation routine. MEMO uses the PLUME model and subroutines in its solution, and COPRO uses MEMO subroutines to obtain its solution.

\subsection{Operation}

To begin program execution, type MAP. The following menu appears:

Main MAP Menu

I - RUN MEMO

2 - Run COPRO

3 - RUN PLUME

0 or <enter> - Exit MAP Program

Select the subprogram you wish to run. Exiting the subprogram returns you to the Main MAP Menu.

\subsubsection{Memory Management}

All data stored in MAP's memory is retained until modified or until MAP is exited. Default values are not reset when switehing between subprograms, and data is retained in memory. To clear the program memory and reset default parameters, you must exit MAP and restart the program.

\subsubsection{Data Files and Backup Files}

Data files are generated by MEMO and COPRO when requested by the user, and will contain key subprogram data in memory at the time of file generation. Data files can be reloaded into the subprograms from which they were generated. MEMO and COPRO files are not compatible. 
When a MEMO or COPRO solution is requested by the uses, a backup data file is automatically created called MAP. BCK. This file can be loaded back into the subprograms, if for any reason program execution is halted during the solution process.

\subsubsection{Plot Files}

The three subprograms in MAP have the option of screen or printer graphical output. To produce graphical output at a printer, a plot file must be generated. Either and HPGL or and HPGL2 plot file can be save. HPGL files can be loaded into a plotting program, such as AUTOCAD, to plot on various printers. HPGL2 files can be printed directly on an HP Laser Jet III printer, by using the DOS print command. This can be done without exiting MAP, as described in the following section.

\subsubsection{DOS Commands}

This option is available in all three MAP subprograms. It allows you to temporarily exit MAP to enter a DOS command. To enter one command, type the command and the subprogram will automatically return to MAP. To enter more than one command, type "COMMAND" and the DOS prompt will appear. To return to MAP, type "EXIT". All data in memory is retained during this procedure. This option may be used to print a file at a printer without exiting MAP.

\subsubsection{Default Values and Units}

Several input parameters have default values set when MAP is loaded. No units have been specified in MAP. Any system of units may be used in MAP, but units must be consistent. The following table lists the type of units and the default value for some key input parameters: 


\begin{tabular}{||l|l|l|}
\hline \multicolumn{1}{|c|}{ Parameter } & \multicolumn{1}{|c|}{ Type of Units } & \multicolumn{1}{c|}{ Default Value } \\
\hline Advection time & time & 36500 \\
\hline $\begin{array}{l}\text { Hydraulic gradient } \\
\text { direction }\end{array}$ & $\begin{array}{l}\text { degrees } \\
\text { counterclockwise } \\
\text { from x-axis }\end{array}$ & 0 \\
\hline Dilution contour levels & unitless & $\begin{array}{l}0.001,0.01,0.1 \text { in PLUME } \\
0.001 \text { in MEMO and COPRO }\end{array}$ \\
\hline Longitudinal Dispersivity & length & 70 \\
\hline Transverse Dispersivity & length & 10 \\
\hline $\begin{array}{l}\text { Molecular diffusion } \\
\text { coefficient }\end{array}$ & length ${ }^{2} /$ time & 0 \\
\hline Width of line source & length & 20 \\
\hline First-order decay constant & length ${ }^{-1}$ & 0 \\
\hline $\begin{array}{l}\text { Average contaminant } \\
\text { velocity }\end{array}$ & length/time & 0.1 \\
\hline
\end{tabular}




\section{PLUME OPERATION}

The PLUME code generates and plots dilution contours resulting from specified hydrogeologic parameters. To load PLUME, enter MAP and select option 3 . The following menu appears after the subprogram is selected:

\section{PLUME MenU}

1. Modify advection time [36500.]

2. Modify source history [continuous]

3. Mlodify width of line source [20.]

4. Modify longitudinal dispersivity [70.]

5. Modify transverse dispersivity [10.]

6. Modify diffusion coefficient $[.000 \mathrm{E}+00]$

7. Modify first-order decay constant $[.000 E+\infty 0]$

8. Modify average contaminant velocity $[.1000]$

9. Change dilution contour levels $[0.00100,0.01000,0.10000]$

10. GENERATE and PLOT contours

11. Load existing input file

12. Save file on disk

13. Enter DOS commands

0 or <enter>- Exit program

(current values shown in [ ])

If you do not enter a parameter, it will default to the specified value. Menu options are explained below.

\subsection{Modify advection time - PLUME Menu Option 1}

The advection time is the total simulation time for plume generation. The default advection time is 36500 .

\subsection{Modify source history - PLUME Menu Option 2}

Selecting this option in PLUME allows you to change the source from a continuous source to a finite source, as described in Section 21. Enter the time the source should be removed, relative to the total advection time. The default status is a continuous source. 


\subsection{Modify width of line source - PLUME Menu Option 3}

The width of the line source depends on the type of leak and on the amount of lateral spreading in the vadose zone prior to introduction of the compound to the water table. The line source width defaults to 20.

\subsection{Modify longitudinal dispersivity - PLUME Menu Option 4}

You must estimate the longitudinal dispersivity for a problem domain. Data presented by Gelhar et al. (1985) show a scale-dependent range in longitudinal dispersivities from about 30 to 320 feet. The default longitudinal dispersivity is 70 .

\subsection{Modify transverse dispersivity - PLUME Menu Option 5}

You must estimate the transverse dispersivity for a problem domain. Data presented by Gelhar et al. (1985) and Isherwood (1981) suggest a ratio of longitudinal to transverse dispersivity of between 1 and 10. The default transverse dispersivity is 10 .

\subsection{Modify diffusion coefficient - PLUME Menu Option 6}

In most field situations, the molecular diffusion coefficient is quite small compared to the advective velocity term and can be neglected. For this reason, the default value is 0 .

\subsection{Modify first-order decay constant - PLUME Menu Option 7}

The value of the decay constant is compound specific and is assumed to be zero for nondecaying materials. The default value is 0 .

\subsection{Modify average contaminant velocity - PLUME Menu Option 8}

The average contaminant velocity controls the rate at which the plume migrates. The default value is 0.1 .

\subsection{Change dilution contour levels - PLUME Menu Option 9}

The value of a dilution contour $(C D / C O)$ is defined as the ratio of the concentration at a point in the plume to the concentration at the source. Dilution contours always have a value less than 1. PLUME plots three dilution contours, with default values of $0.1,0.01$, and 0.001 . If fewer contours are desired, set the contours to be discarded to I (equivalent to source concentration). 


\subsection{GENERATE and PLOT contours - PLUME Meriu Option 10}

Selecting this option generates plume concentrations over a grid. The grid is automatically created by the model. After concentrations are generated, the following menu appears:

\section{Plot Menu}

1. Generate Plot

2 - Change scale (currently $=500$ )

[Recommended scale $=500$ ]

3 - Change output device (currently: screen)

0 or <enter> - retum to MAIN MENU

To generate the plot, select menu option 1. If you are sending output to a file, you will be prompted for a file name.

Option 2 controls the plot scale. The recommended scale is calculated by the subprogram to determine an appropriate scale for fitting the plot on the screen. The scale is initially set at the recommended scale. Following the initial setting, the recommended scale appears on the menu, but the user must select option 2 to actually modify the current scale. This allows the user to use a consistent scale for multiple plots.

Option 3 controls the output device. If hard copy is required, either an HPGL or and HPGL2 file can be created. An HPGL file can be loaded into a program such as AUTOCAD for plotting. An HPGL2 file can be printed directly on a HP Laserjet III, by using the DOS print command.

\subsection{Load existing input file - PLUME Menu Option 11}

This option allows a PLUME data file to be loaded into memory.

\subsection{Save file on disk}

This option allows you to save key PLUive data currently in memory to a data file. The data file may be reloaded at any time for further work

\subsection{Enter DOS commands - PLUME Menu Option 13}

Use this option to enter DOS commands, as deseribed in Section 4.2.4. 


\section{MEMO OPERATION}

This section contains detailed instructions for using the MEMO subprogram. To run MEMO, choose Main MAP Menu Option 1. The MEMO Main Menu appears after the subprogram is loaded, and has the following setup:

MEMO Main Menu

1 - Load existing input file

2 - Input or modify coordinate data

3 - Define source grid

4- Define and generate buffer zone array

5 - Modify hydrogeologic parameters

6 - Adjust monitoring well locations

7 - Determine monitoring efficiency

8 - Display or plot current problem

9 - Save file on disk

10. Print data currently in memory

11 - Review data currently in memory

12 - Enter DOS commands

0 or <enter> - Exit MEMO

A summary of each selection follows.

\subsection{Load existing input file - MEMO Main Menu Option 1}

This option allows a MEMO data file to be loaded into memory. Prior to loading of the data file, previous data is removed from memory. A file can contain a complete or partial data set, and can be loaded at any stage of completion. If a file has not previously been prepared for the problem, use Main Menu Option 2 to begin entering data.

\subsection{Input or modify coordinate data - MEMO Main Menu Option 2}

To begin analysis of a waste management area, a coordinate system must be constructed for the site. The coordinate grid can be constructed on any grid scale and converted to the actual field scale using a scale factor.

This option provides a utility for input or modification of coordinate data. Enter I to input coordinates; enter $M$ to modify coordinates. The following menu appears, with the first line reading "Input" or "Modification" depending upon your selection:

Coordinate Input [Modification] Menu

\section{1 - Source area coordinates}


2 - Line of compliance coordinates

3 - Buffer zone coordinates

4. Gradient zone coordinates

5 - Monitoring well coordinates

6 - Modification of scale factor [1.00]

0 or <enter> . Retum to Main menu

For coordinate input, the subprogram prompts for coordinate entry when menu options are chosen. Coordinates should be entered in CLOCKWISE order, and separated by a space or comma. For coordinate modification, the subprogram allows you to review the data in memory and select the coordinate point to modify. A point may be deleted, inserted, or changed. Deleting a point decreases the point number for all point numbers following. Adding a point increases the point number for all points following. Both the input and modification options allow editing entered coordinates.

\subsubsection{Source area coordinates - Coordinate Menu Option 1.}

The potential source areas are defined as the areas within which contamination sources may exist. A rectangular grid with spacing defined by the user is identified for all source units within the area being evaluated. This is referred to as the source grid. A plume is generated from each grid point and tested for detection by a monitoring well. If the plume. is not detected, the grid point is flagged as a non-detect point. Up to 30 separate source areas may be identified by the user. Each source area is identified by an assigned unit number. You may add additional source areas or delete existing ones.

A minimum of three coordinate points are necessary to define a source area. If coordinate points are deleted such that there are fewer than three coordinate points left at one source area, the source area is deleted. Label each coordinate point with the number of the source area to which it corresponds.

\subsubsection{Line of compliance coordinates - Coordinate Menu Option 2}

The line of compliance is defined as the waste management area boundary. This is an optional input providing a line along which wells can be easily moved. To use MEMO's well movement utility, the well must be located on the line of compliance. If the well is not on the line of compliance, it can be moved by modifying well coordinates.

\subsubsection{Buffer zone coordinates - Coordinate Menu Option 3}

The buffer zone boundary is defined as the lisit to which a plume may extend before it should be detected by a monitoring well. The buffer zone boundary is a line that encloses all of the potential source areas. When the "buffer zone with advection time limit" option is chosen, the buffer zone boundary is a required input. For this solution option, plumes that 
are detected before passing the buffer zone boundary are considered to have been detected.

\subsubsection{Gradient zone coordinates - Coordinate Menu Option 4}

All grid points within a gradient zone generate plumes in the gradient direction specified for that zone. In addition to entering coordinates, you must assign a gradient direction, measured as an angle counterclockwise from the $x$-axis.

\subsubsection{Monitoring well coordinates - Coordinate Menu Option 5}

For each monitoring well added to the well system, you must input coordinates. You can easily move wells located on the line of compliance without modifying well coordinate data. Wells not located on the line of compliance can be modified using this menu option.

\subsubsection{Modification of scale factor - Coordinate Menu Option 6}

The scale factor allows you to multiple all entered coordinate values by a specified scale factor. This option can be used to modify grid coordinates to actual field coordinates.

\subsection{Define source grid - Main Menu Option 3}

This option is used after the potential source area coordinates have been input to define the source grid spacing. Enter the desired grid spacing accuracy (defined as: area of source grid element/total potential source area), and a grid spacing is determined for the problem. Alternatively, you may specify the grid spacing directly.

The source grid affects the accuracy of the solution. A more detailed source grid will yield more accurate model results. However, increasing the density of the source grid will increase the computation time required for solution. It is recommended that you perform initial solutions with a larger grid spacing, followed by final solutions with a finer grid spacing.

\subsection{Define and generate buffer zone array - Main Menu Option 4}

This option should be used after the buffer array coordinates have been entered. An array of points with spacing defined by the user is created along the buffer zone boundary. This is called the buffer array, and is used in determining whether a plume is detected by a monitoring well. Enter the desired array spacing accuracy (defined as: distance between buffer array points/total perimeter distance), and an array spacing is determined for the 
problem. You may specify the array spacing directly, if desired. It is recommended that the spacing of the source grid and the buffer array be of the same order of magnitude.

\subsection{Modify hydrogeologic parameters - Main Menu Option 5}

This option presents the following menu:

\section{Hydrogeologic Parameter Menu}

1- Modify groundwater flow directions

2 - Modify dilution contour value $[.00100]$

3 - Modify longitudinal dispersivity $[70.00]$

4 - Modify transverse dispersivity [10.00]

5 - Modify diffusion coefficient $[.000 E+00]$

6 - Modify width of line source [20.00]

7 - Modify first-order decay constant [0]

8 - Modify average contäminant velocity [0.1000]

0 - Retum to main menu

Entry of these values is easily performed by selecting the desired parameter choice. If you do not enter a parameter, it will default to the specified value.

The dilution contour $(C D / C O)$ is used in the solution of the model as the plume contour that determines the critical point, beyond which a plume is considered to be undetected. In the solution, if the concentration in any well exceeds the dilution contour value at this critical point, then the leak has been successfully detected. The choice of an appropriate dilution contour value is subject to user judgement. $C D$ should approximate the detection limit of the indicator compound or group of compounds. $\mathrm{CO}$ is the concentration at the source. It may be determined from direct field measurements or estimated from analysis of leachate migration in the vadose zone. Knowing $C D$ and $C O$, the dilution contour value may be caleulated. The dilution contour value defaults to 0.001 .

The concentration at the source may be difficult to determine. Altematively, $\mathrm{CO}$ may be based upon regulatory criteria, such as the Maximum Contaminant Level (MCL). This is a very conservative approach for the following reason. Since the $M C L$ is usually a low concentration, the ratio of CD/MCL is usually a larger number. The larger ratio is assocjated with smaller, thinner plume contours, since the concentration of a plume decreases as the plume spreads. Smalles, thinner plumes are more difficult to detect. If there is more than one contaminant present at a site, the CDMCL ratio may be calculated for each contaminant. A conservative approach is to select the largest CDMCL ratio. If the MCL is close in value to the detection limit, the ratio approaches " 1 " and may not be representative. In this case, a lower ratio may be selected. There is considerable user judgement involved in selecting $\mathrm{CD} / \mathrm{CO}$, and the user should evaluate the sensitivity of the problem to changes in this parameter as part of the modeling exercise. 
Note that when the "buffer zone with advection time only" solution option is used, the value of the average contaminant velocity set with menu option 8 does not affect the model solution if radioactive decay and molecular diffusion are negligible. This is discussed in more detail in Section 2.2.1. If either the decay constant or diffusion coefficient is not equal to 0 , or the solution basis is changed to advection time only, then the average contaminant velocity must be considered.

Refer to Section 5 for an explanation of the other hydrogeologic parameters.

\subsection{Adjust monitoring well locations - Main Menu Option 6}

Monitoring wells are initially input to the data set using Main Menu Option 2. Wells may be moved using this option. The following menu appears when this option is selected:

\section{Well Movement Menu}

1 - Move well along line of compliance

2 - Move well a specified $x$ and $y$ distance

3 - Move well a specified distance and angle

0 or <enter> - Retum to main menu

\subsubsection{Move well along line of compliance - Well Movement Option 1}

This option allows movement of wells that are located on the line of compliance along this line. Specify the wlel number (designated during coordinate entry and shown on graphical output and in the output file), the direction, and the distance of movement ( + for clockwise, - for counterclockwise).

\subsubsection{Move well a specified $x$ and $y$ distance - Well Movement Option 2}

This option allows movement of wells to any location. Specify the well number and the $x$ and $y$ distance and direction ( $t x$ moves to the right, $+y$ moves upward).

\subsubsection{Move well a specified distance.and angle - Well Movement Option 3}

This option allows the movement of wells to any location, using an angle and a specified distance. The angle is measured counterclockwise from the $x$ axis.

\subsection{Determine monitoring efficiency - Main Menu Option 7}

The following menu appears when this option is selected: 
Monitoring Efịciency Solution Menu

1 - Detemine monitoring efficiency

2 - Modify solution basis (currently: buffer zone/advection time)

3. Modify max. advection time (TMAX $=36500.000$ )

4. Modify accuracy (ACCMIN $=.000100$ )

5 - Modify TCRIT offset (TOFF =

6 - Generate a solution check file? (off)

0 or <enter. - Return to Main menu

\subsubsection{Determine monitoring efficiency - Solution Menu Option I}

This option is used to determine the monitoring efficiency when all parameters have been input into memory and the user has completed any desired modification of parameters in this menu.

\subsubsection{Modify solution basis - Solution Menu Option 2}

This option switches the solution basis between the "buffer zone with advection time limit" and "advection time only" solution methods. For a more detailed discussion, see Section 2.22

\subsubsection{Modify max, advection time - Solution Menu Option 3}

When using the "buffer zone with advection time only" solution option, the maximum advection time limits the maximum simulation time. If a plume does not reach the buffer zone boundary by the maximum advection time, well concentrations are checked at the maximum advection time. For the "advection time only" solution option, the maximum advection time is used to calculate and check well concentrations. The maximum value of the maximum advection time is $1,000,000$ days.

\subsubsection{Modify accuracy - Solution Menu Option 4}

For the "buffer zone with advection time limit" solution method, the model requires a minimum accuracy (ACCMIN) for determination of the critical time. The critical time when the plume reaches the buffer zone boundary has been determined for a grid point when (CD/CO-ACCMIN) < concentration at buffer zone < (CD/CO+ACCMIN). ACCMIN defaults to 0.001 . Development of MEMO has shown this to be a reasonable value, but it is recommended that you experiment with different values for specific applications of MEMO. Note that lower values of ACCMIN increase the computation time of the solution. 
ACCMIN is ignored when the "advection time only" solution method is chosen.

\subsubsection{Modify TCRIT offset - Solution Menu Option 5}

The critical time (TCRIT) when the plume contacts the buffer zone may be offset to investigate the sensitivity of well networks to sampling frequencies. This option is valid only with the "buffer zone with advection time limit" solution methop. : .

\subsubsection{Generate a solution check file - Solution Menu Option 6}

Selecting option 6 creates a solution check file when the monitoring efficiency is determined. This file will designate each source grid point by its row and column integers, and write " $\mathrm{T}$ " if a leak has been detected and "F" if a leak has not been detected. The file provides a check for the graphical output and efficiency solution. However, since the file will contain every grid point in the source area(s), it will be very large for finer grid spacings. Writing the file will also increase the time required for an efficiency solution. For these reasons, op.ion is not recommended for most applications.

\subsection{Display or plot current problem - Main Menu Option 8}

The following menu appears when this option is selected:

Plot Menu

1. Generate Plot

2 - Change scale (currently $=500$ )

[Recommended scale $=500$ ]

3 - Change output device (currently screen)

4-Modify plume plot status and/or origin

(Currently: inactive)

0 or <enter> - retum to MAIN MENU

To generate the plot, select menu option 1. If you are sending output to a file, you will be prompted for a file name.

Option 2 controls the plot scale. The recommended scale is calculated by the subprogram to determine an appropriate scale for fitting the plot on the screen. The scale is initially set at the recommended scale. Following the initial scale setting, the recommended scale appears on the menu, but the user must select option 2 to actually modify the current scale. This allows the user to use a consistent scale for multiple plots.

Option 3 controls the output device. If hard copy is required, either an HPGL or and HPGL2 file can be created. An HPGL file can be loaded into a program such as AUTOCAD 
for plotting. An HPGL2 file can be printed directly on an HP Laserjet III, by using the DOS print command.

You may draw a plume on the plot using option 4. You must enter coordinate points within a designated source area. The entered coordinates will be adjusted to the nearest grid point. If the "buffer zone with advection time limit" solution basis is used, a plume is generated for the critical time. If the "advection time only" solution basis is used, the plume is plotted for the maximum advection time. If no solution is available, the user will be prompted to enter an advection time.

\subsection{Save file on disk - Main Menu Option 9}

This option allows you to save key MEMO data currently in memory to a data file. The data file may be reloaded at any time for further work $A$ file can contain a complete or partial data set, and can be written or loaded at any stage of completion. During well network modifications, intermediate stage solutions should be stored by the user in different files, in order to have a record of various stages of the solution process.

\subsection{Print data currently in memory - Main Menu Option 10}

This option allows you to print data in memory directly to a printer. The printer must be attached to the LPTI port on the computer.

\subsection{Review data currently in memory - Main Menu Option 11}

This option allows you to revirw the data in memory. Use CTRL $S$ to toggle the screen scroll.

\subsection{Enter DOS commands - Main Menu Option 12}

This option allows you to exit MEMO temporarily and enter DOS commands. See Section 4.2.4 for more information. 
DOE/RL-94-40, Rev. 0

06/94

\section{APPENDIX 5C}

GROUNDNATER SAMPLING AND ANALYSIS PLAN FOR THE ENVIRONMENTAL RESTORATION DISPOSAL FACILITY 


\section{DOE/RL-94-40, Rev. 0}

06/94

1
2
3
4
5

This page intentionally left blank. 


\section{APPENDIX 5C}

\section{GROUNDWATER SANPLING AND ANALYSIS PLAN FOR THE ENVIRONEENTAL RESTORATION DISPOSAL FACILITY}

This appendix introduces procedures for sample collection, chain-of-custody, sample preservation, shipment, chemical analysis, quality assurance, and quality control.

All sampling activities are performed under contract by Pacific Northwest Laboratory (PNL) or by an onsite sampling crew. Testing will be carried out by other contract laboratories, to be determined, under contract to PNL.

\section{SAMPLE COLLECTION PROCEDURES}

The procedures for PNL groundwater sample collection, water-level measurements, and field measurements are contained in Procedures for Ground Water Investigations, PNL-6894, and include the following:

- GC-1 - Groundwater Sample Collection Procedure

- GC-2 - In-Line Sample Filtration Procedure

- GC-3 - Disposal of Purge Water from Monitoring Wells

- FA-1 - Temperature Measurement Procedure

- FA-2 - Calibration of Conductivity Meter and Measurement of Field Conductivity

- FA-3 - Calibration of pH Meter and Measurement of Field $\mathrm{pH}$

- WL-1 - Water-Leve1 Measurement Procedure

- WL-2 - Procedure of Standardizing Steel Tapes

- AD-1 - Change Control Procedure

- $A D-2$ - Groundwater Sample Chain-of-Custody.

Other procedures for groundwater sample collection and associated measurement are contained in Environmental Investigations and Site Characterization Manual (WHC 1989a). 
DOE/RL-94-40, Rev. 0

06/94

This page intentionally left blank. 


$$
\text { DOE/RL-94-40, Rev. } 0
$$

2

3

4

5

APPENDIX 7A

BUILOING EMERGENCY PLAN FOR THE

ENIROMMENTAL RESTORATION DISPOSAL FACILITY 


$$
\text { DOE/RL-94-40, Rev. } 0
$$


This plan covers the following buildings and structures: The Environmental Restoration Disposal Facility (ERDF), including the CAMU trench and associated loading and unloading areas, the decontamination facility, grout batch plant, package wastewater treatment facllity, evaporation tanks, fuel storage area, guard shacks, and the ERDF Operations Building.

[WHC will need to determine whether there are any other building/structures]

Approved:

Butding Emergency Director

Emergency Preparedness

Hanford FTre Department
Date

Date

Date

This document will be reviewed annually and updated as required by the Building Emergency Director and approved by the Manager of Emergency Preparedness (or delegate) and the Hanford Fire Department. 
1.0 GENERAL INFORMATION ...................... 4

1.1 FACILITY NAME ................... 4

1.2 FACILITY LOCATION . . . . . . . . . . . . . . . . 4

1.3 OWNER . . . . . . . . . . . . . . . . . . . 4

1.4 DESCRIPTION OF THE FACILITY AND OPERATIONS . . . . . . . . . 4

1.5 BUILDING EVACUATION ROUTING (BUILDING LAYOUT) . . . . . . . . 5

2.0 PURPOSE .......................... 6

3.0 BUILDING EMERGENCY ORGANIZATION . . . . . . . . . . . . . . . . 6

3.1 BUILDING EMERGENCY DIRECTOR . . . . . . . . . . . . . . . 6

3.2 OTHER MEMBERS ....................... . 6

4.0 IMPLEMENTATION OF THE PLAN . . . . . . . . . . . . . . . . 7

5.0 FACILITY HAZARDS . . . . . . . . . . . . . . . . . . 7

5.1 HAZARDOUS MATERIALS .................. . . . 7

5.2 INDUSTRIAL HAZARDS ..................... . 7

5.3 HAZARDOUS/MIXED WASTE .................... 8

5.4 RADIOACTIVE MATERIALS . . . . . . . . . . . . . . . . . 8

5.5 CRITICALITY ...................... 8

6.0 POTENTIAL EMERGENCY CONDITIONS . . . . . . . . . . . . . . 8

6.1 OPERATIONAL . . . . . . . . . . . . . . . . . . . 8

6.1 .1 Loss of Utilities ................. 8

6.1.2 Major Process Disruption/Loss of Plant Control . . . . 8

6.1.3 Pressure Release ................ 9

6.1.4 Fire and/or Explosion .............. 9

6.1.5 Hazardous Material Spil1 .............. 9

6.1.6 Hazardous/Mixed Waste Spi11 ............. 9

6.1.7 Transportation and/or Packaging Incidents ...... 9

6.1.8 Unusual, Irritating or Strong Odors . . . . . . . . . . 9

6.1.9 Radiological Material Release ............. 9

6.1.10 Criticality................. . 9

6.2 NATURAL PHENOMENA .................. 10

6.2.1 Seismic Event . . . . . . . . . . . . . . 10

6.2.2 Volcanic Eruption/Ashfail ............. . 10

6.2.3 High Winds/Tornados ................ . 10

6.2 .4 Flood .................... 10

6.2 .5 Range fire .................... 10

6.2.5 Aircraft Crash .. . . . . . . . . . . . 10

6.3 SECURITY CONTINGENCIES ................ 10

6.3.1 Bomb Threat . . . . . . . . . . . . . . . 10

6.3 .2 Hostage Situation ................ 11

6.3.3 Suspicious object ............... 11

7.0 INCIDENT RESPONSE .......................... . . . 11

7.1 PROTECTIVE ACTIONS RESPONSES . . . . . . . . . . . . 11

7.1.1 Evacuation................. 11 
7.1.2 Take Cover . . . . . . . . . . . . . . . . 12

7.2 RESPONSE TO OPERATIONAL EMERGENCIES . . . . . . . . . . . . . 12

7.2.1 Loss of Utilities . . . . . . . . . . . . . 12

7.2.2 Major Process Disruption/Loss of Plant Control . . . . . 12

7.2.3 Pressure Release ................. 13

7.2.4 Fire and/or Explosion ............... 13

7.2.5 Hazardous Material, Dangerous and/or Mixed Waste Spi11 . 14

7.2.6 Unusual, Irritating or Strong Odors . . . . . . . . 17

7.2.7 Radiological Material Release . . . . . . . . . . 18

7.2 .8 Criticality . . . . . . . . . . . • . . . . . 18

7.3 PREVENTION OF RECURRENCE OR SPREAD OF FIRES, EXPLOSIONS, OR

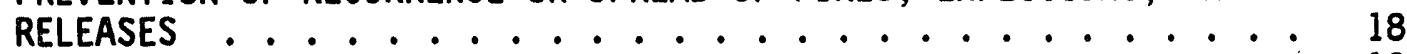

7.4 RESPONSE TO NATURAL PHENOMENA . . . . . . . . . . . . . 19

7.4.1 Seismic Event . . . . . . . . . . . . . . . . 19

7.4.2 Volcanic Eruption/Ashfall ............ 19

7.4.3 High Winds/Tornados . . . . . . . . . . . . . . . . 20

7.4 .4 Flood ................... . 20

7.4 .5 Range Fire.................. 20

7.4.6 Aircraft Crash .. . . . . . . . . . . . . . 20

7.5 SECURITY CONTINGENCIES . . . . . . . . . . . . . . 20

7.5.1 Bomb Threat ................... 20

7.5.2 Hostage Situation ............... 21

7.5.3 Suspicious object ................ 21

8.0 TERMINATION OF EVENT, INCIDENT RECOVERY, AND RESTART OF OPERATIONS • 21

8.1 TERMINATION OF EVENT . . . . . . . . . . . . . . . . 21

8.2 INCIDENT RECOVERY AND RESTART OF OPERATIONS . . . . . . . . . . 22

8.3 INCOMPATIBLE WASTE .. . . . . . . . . . . . . . . . . 22

8.4 POST-EMERGENCY EQUIPMENT MAINTENANCE AND DECONTAMINATION . . . 23

9.0 EMERGENCY EQUIPMENT . . . . . . . . . . . . . . . . . . . . 24

9.1 FIXED EMERGENCY EQUIPMENT . . . . . . . . . . . . . . . . . . . 24

9.2 PORTABLE EMERGENCY EQUIPMENT . . . . . . . . . . . . . . . . 24

9.3 COMMUNICATIONS EQUIPMENT/WARNING SYSTEMS . . . . . . . . . . . 25

9.4 PERSONAL PROTECTIVE EQUIPMENT . . . . . . . . . . . . . . 25

9.5 SPILL CONTROL AND CONTAINMENT SUPPLIES . . . . . . . . . . . 25

9.6 EMERGENCY RESPONSE CENTER . . . . . . . . . . . . . . 25

10.0 COORDINATION AGREEMENTS . . . . . . . . . . . . . . 26

11.0 REQUIRED REPORTS . . . . . . . . . . . . . . . . 26

12.0 PLAN LOCATION . . . . . . . . . . . . . . . . . . 26

13.0 BUILDING EMERGENCY ORGANIZATION . . . . . . . . . . . . . . . 27

14.0 REFERENCES ....................... . . . 29 


\subsection{GENERAL INFORMATION}

The ERDF is located on the Hanford Site, a 560 square mile U. S. Department of Energy (DOE) reservation in southeastern Washington State. The ERDF is located in the center portion of the 600 Area between the 200 East and West Areas near the center of the Hanford Site.

\subsection{FACILITY MAME: $\quad$ U. S. Department of Energy Hanford Site Environmental Restoration Disposal Facility (ERDF)}

\subsection{FACILITY LOCATION: Benton County, Washington; within the 600 Area.}

Buildings/Facilities covered by this plan are: ERDF trench and associated loading and unloading areas; ERDF Decontamination Facility; ERDF Operations Building; ERDF Effluent Treatment Facility

[WHC wili need to determine whether there are any other building/structures]

\subsection{OWNER:}

U. S. Department of Energy

Field Office, Richland

825 Jadwin Avenue

Richland, Washington

FACILITY MANAGER: Westinghouse Hanford Company

P. O. Box 1970

Richland, Washington

\subsection{DESCRIPTION OF THE FACILITY AND OPERATIONS}

The current concept for the ERDF calls fur burial of remediation-derived waste in a single CAMU trench up to 21 meters (70 feet) deep with eventual cover by a RCRA compliant barrier. It has been assumed that a RCRA compliant barrier will be used, which may be the Hanford Barrier. The barrier will be specifically designed for this site to prevent infiltration and limit access to the waste for as long as reasonably possible. Current trench design is a RCRA double-lined area fill type trench. Trench design may change depending on outcome of RI/FS unit design studies. Along with the trench units, the ERDF will include ancillary waste handling and transportation facilities such as an operations building and facilities to decontaminate equipment and containers. Operations information is described in greater detail in DOE/RL/12074--28, Draft Operations Plan for the Hanford Environmental Restoration Disposal Facility. Emergency/Contingency Plans for these support units, which are not part of the CAMU, will be included in forthcoming compliance documentation. 
WESTIMEHOUSE HANFORD COMPANY

\section{BUILDING EMERGENCY PLAN}

FOR ERDF FACILITY
Document:

Page:

Issue Date:
WHC-IP-0263-X)

5 of 30 Hosure. 0.6 te

\subsection{BUILDING EVACUATION ROUTING (BUILDING LAYOUT)}

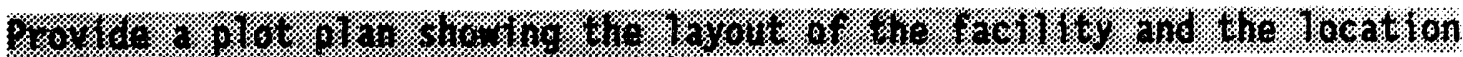

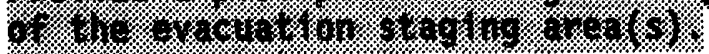




\subsection{PURPOSE}

The purpose of this plan is to describe both the facility hazards and the basic responses to upset and/or emergency conditions. "Emergency" as used in this document includes events meeting the Washington Administrative Code 173-303 definition of Emergency as well as Department of Energy Order 5000.3b categories of Unusual Occurrence and Emergency. These events include spills or releases as a result of processing, fires and explosions, transportation activities, movement of materials, packaging, and storage of hazardous materials and natural and security contingencies. When used in conjunction with the "Hanford Facility Contingency Plan", DOE/RL-93-75, this plan meets the requirements for contingency planning as required by the Washington Administrative Code, WAC-173-303.

\subsection{BUILDING EMERGENCY ORGANIZATION}

\subsection{BUILDING EMERGENCY DIRECTOR}

The overall responsibility for implementation of this $\mathrm{Plan}$ lies with the building emergency director (BED) or their designated alternates. The BED has the responsibilities of the Emergency Coordinator as discussed in WAC 173-303-360 and is also the Event Commander for facility related events. $A$ list of all BEDs and alternates and their work and home telephone numbers is maintained by Emergency Preparedness. The list is distributed to various people and locations throughout the Hanford site. The BEDs have the authority to commit all necessary resources (both equipment and personnel) to respond to any emergency. Additional responsibilities have been delegated to Hanford Fire Department personnel who are authorized to act for the BED when the BED is absent. These Hanford Fire Department personnel have the authority to commit all necessary resources (both equipment and personnel) to respond to any emergency.

\subsection{OTHER MEMBERS}

As a minimum, the BED appoints and trains individuals to perform as Personnel Accountability Aides and Staging Area Managers. The accountability aides are responsible for facilitating the implementation of protective actions (evacuation or take cover) and for facilitating the accountability of personnel after the protective actions have been implemented. Staging area managers are responsible for coordinating/conducting activities at the staging area. In addition, the BED may identify additional support personnel (heaith physics, maintenance, engineering, hazardous material coordinators, etc.) to be part of the building emergency organization.

The Building Emergency Organization for the ERDF facility is listed in Section $13.01 \% 1 \% . \%+\%$ 


\subsection{IMPLEMENTATION OF THE PLAN}

In order to meet the requirements of the WAC, this $P 1$ an will be considered to be implemented when the BED has determined that a release, fire, or explosion has occurred at the facility which could threaten human health or the environment (WAC Emergency). An incident requiring evacuation of personnel or the summoning of emergency response units will not necessarily indicate that the plan has been implemented.

Under the DOE guidance, this plan will be considered implemented whenever the BED determines that one of the incidents 7 isted in Section 6.0 has or will occur and that the severity is or will be such that there is a potential to endanger human health or the environment (DOE Unusual Occurrence or

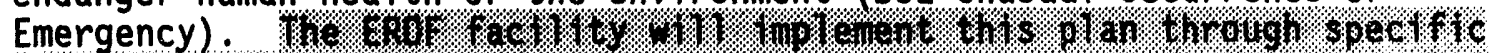

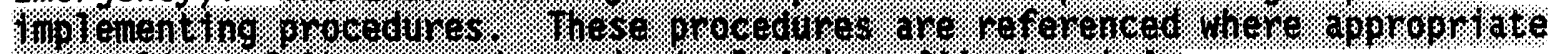

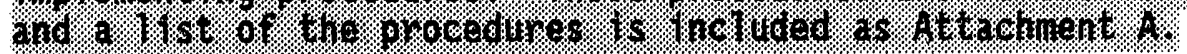

The building emergency director must assess each incident to determine the response necessary to protect the personnel, facility, and the environment. If assistance from Patrol, Fire, or ambulance units is required, the Hanford Emergency Response Number (911) must be used to contact the Patrol Operations Center and request the desired assistance. To request other resources or assistance from outside the facility, the Patrol Operations Center business number is used $(373-3800)$ to request contact of the Emergency Duty officer.

\subsection{FACILITY HAZARDS}

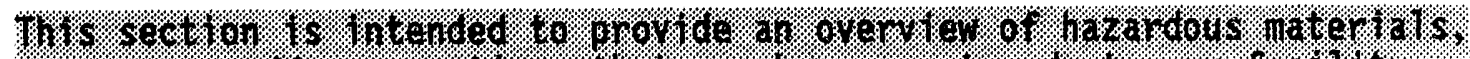

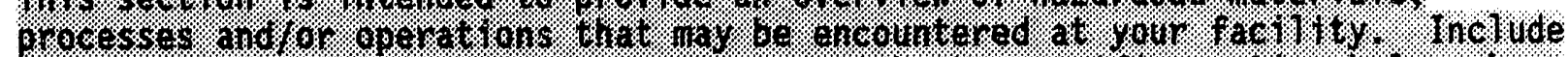

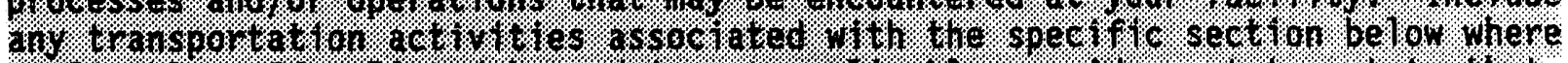

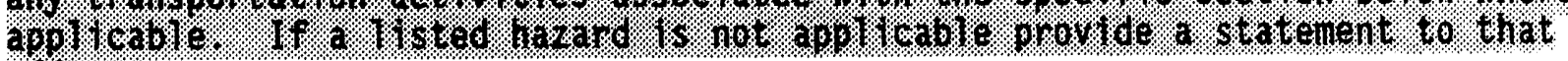
eff tort.

\subsection{HAZARDOUS MATERIALS}

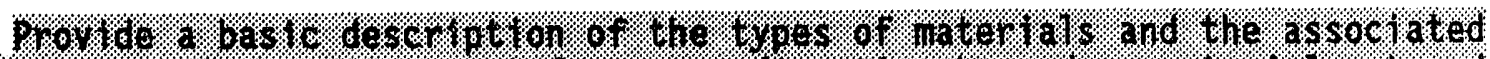

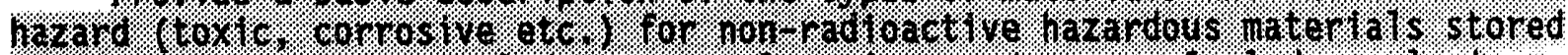

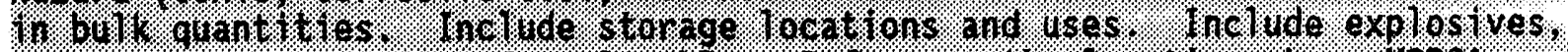

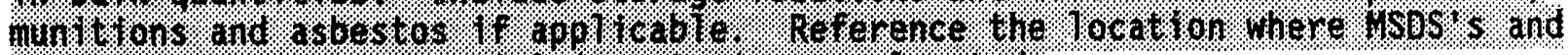

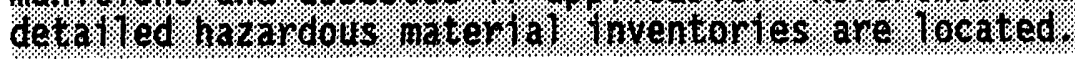

\subsection{INDUSTRIAL HAZARDS}

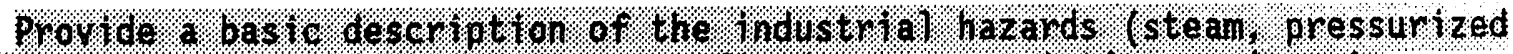

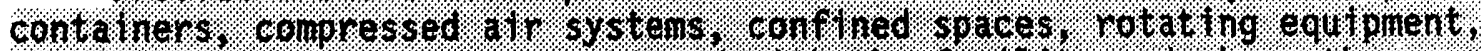

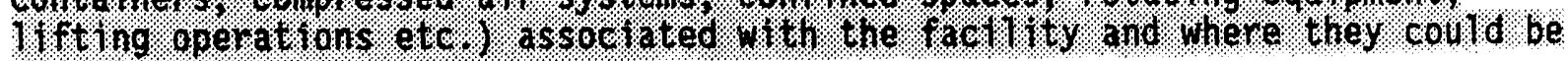
encountered etc. 


\subsection{HAZARDOUS/MIXED WASTE}

9.

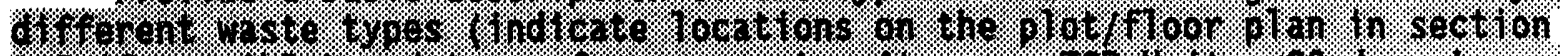

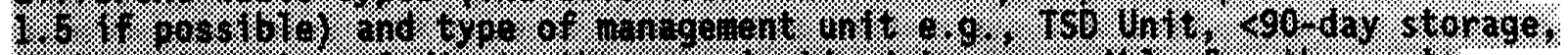

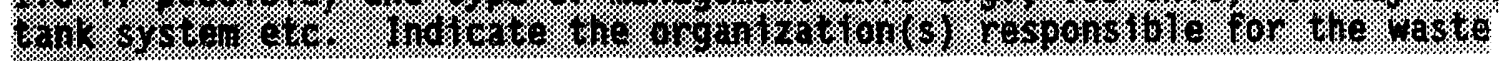
a.t.

\subsection{RADIOACTIVE MATERIALS}

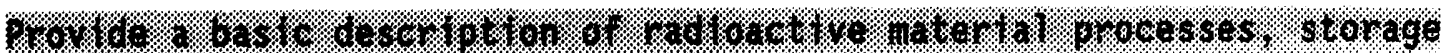
10.7.

\subsection{CRITICALITY}

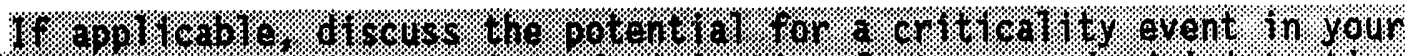

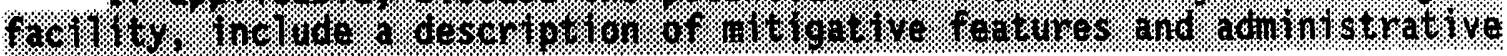

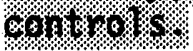

\subsection{POTENTIAL EMERGENCY CONDITIONS}

Potential emergency conditions may fall into one of three basic categories; operational (process upsets, fires and explosions, loss of utilities, spills and releases), natural phenomena (e.g., earthquakes), and security contingencies (bomb threat, hostage situation, etc.). Following are conditions that may lead to an emergency situation (WAC or DOE defined) at the ERDF facility and require the implementation of this plan.

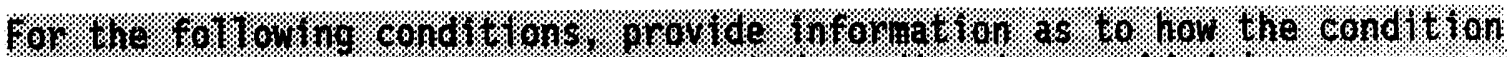

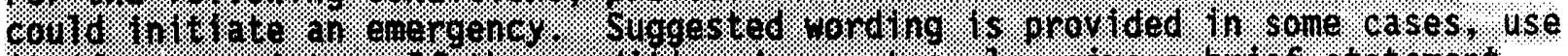
17. I.

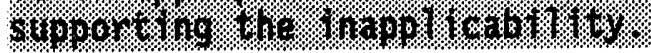

\subsection{OPERATIONAL}

\subsubsection{Loss of Utilities}

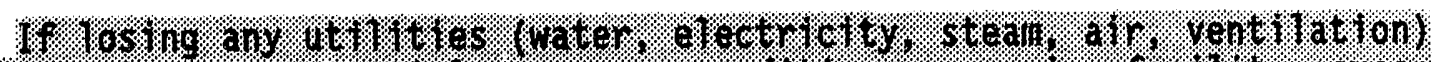

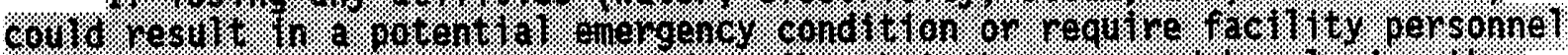

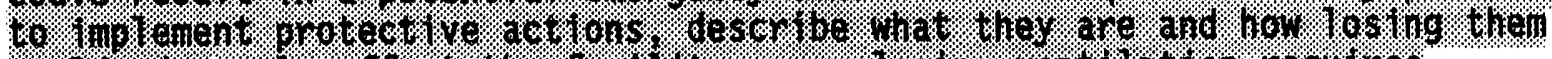

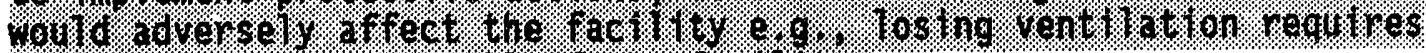

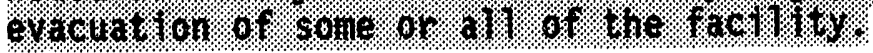

\subsubsection{Major Process Disruption/Loss of P1ant Control}

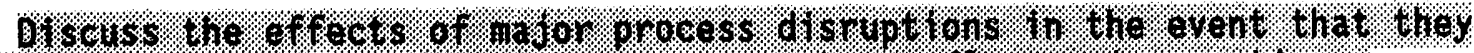

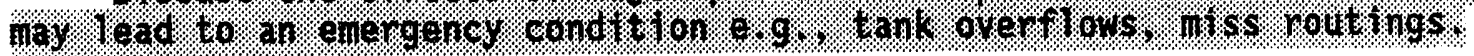




\subsubsection{Pressure Release}

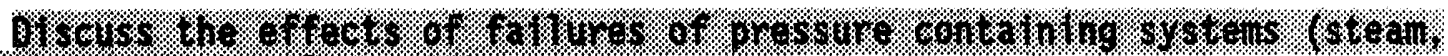

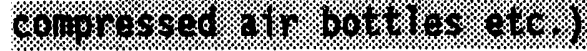

\subsubsection{Fire and/or Explosion}

O.

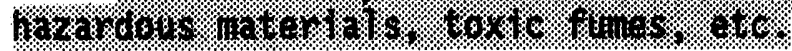

\subsubsection{Hazardous Material Spill}

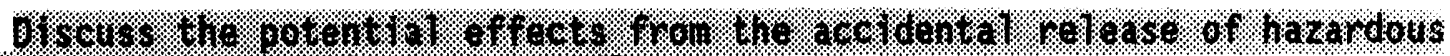

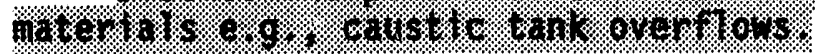

\subsubsection{Hazardous/Mixed Waste Spi11}

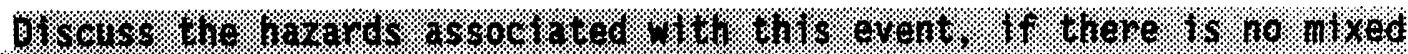
W.5.6. .

\subsubsection{Transportation and/or Packaging Incidents}

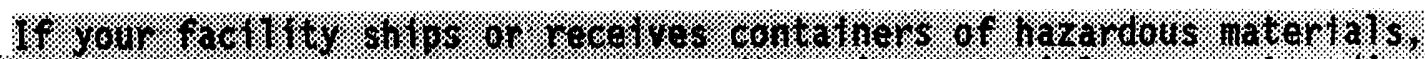

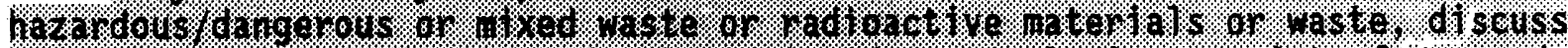

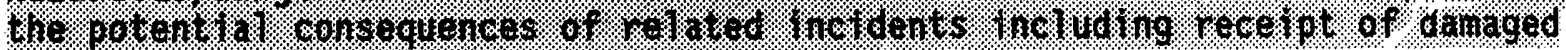

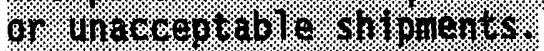

\subsubsection{Unusua1, Irritating or Strong Odors}

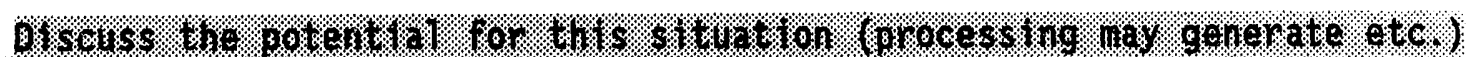
ard a

\subsubsection{Radiological Material Release}

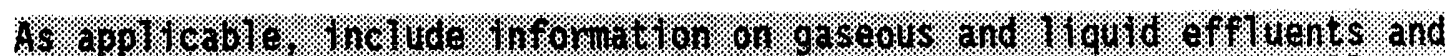

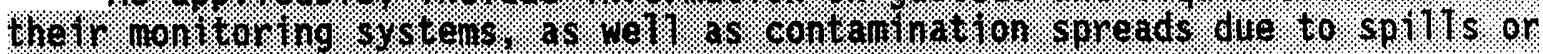
$100 \%$

\subsubsection{Criticality}

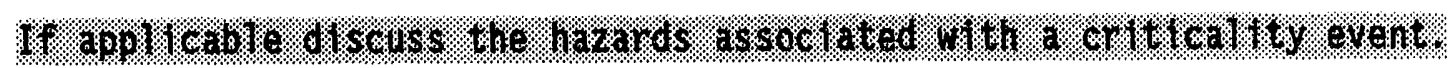




\subsection{NATURAL PHENONENA}

\subsubsection{Seismic Event}

Depending on the magnitude of the event, severe structural damage can occur resulting in serious injuries or fatalities and the release of hazardous materials. Damaged electrical circuits and wiring could result in the initiation of multiple fires.

\subsubsection{Volcanic Eruption/Ashfall}

Though not expected to cause structural damage, the ash could cause shorts in electrical equipment and plug ventilation system filters.

\subsubsection{High Winds/Tornados}

High winds $0:$ tornados may cause structural damage to systems containing hazardous materials resulting in a release to the environment.

\subsubsection{Flood}

Flooding can cause the release of hazardous materials depending on the type of storage containers. Floods can also cause short circuits in electrical wiring located at or below ground level. This may then result in an increased likelihood of fires.

\subsubsection{Range Fire}

The hazards associated with the range fire include those associated with a building fire plus potential site access restrictions and travel hazards such as poor visibility.

\subsubsection{Aircraft Crash}

In addition to the potential serious injuries or fatalities, an aircraft crash could result in the direct release of hazardous materials, or cause a fire that could lead to the release.

\subsection{SECURITY CONTINGENCIES}

\subsubsection{Bomb Threat}

A bomb threat may be received by anyone who answers the telephone or receives mail. The major effect on the facility is that it will need to perform an emergency shutdown in order to be evacuated. In the event that a bomb explodes, the effects are the same as those discussed under fire and explosion. 


\subsubsection{Hostage Situation}

A hostage situation can pose an emergency situation if there is the potential to adversely impact the facility. This can be as a result of losing facility control (operators removed from their stations) or when the situation results in the coercion of an employee to take some malevolent action.

\subsubsection{Suspicious Object}

The major effect on the facility is that it will need to perform an emergency shutdown in order io be evacuated.

\subsection{INCIDENT RESPONSE}

The initial response to any emergency will be to immediately protect the health and safety of persons in the immediate area. Identification of released material is essential to determine appropriate protective actions. Containment, treatment, and disposal assessment will be the secondary responses.

The following sections describe the process for implementing basic protective actions as we 11 as descriptions of response actions for the events 1isted in Section 6.0. The Hanford Facility Contingency Plan (DOE/RL-93-75) provides a description of generic incident responses, describes the process for assessing and identifying the hazardous materials and/or dangerous waste and describes the process for incident categorization and classification.

\subsection{PROTECTIVE ACTIONS RESPONSES}

\subsubsection{Evacuation}

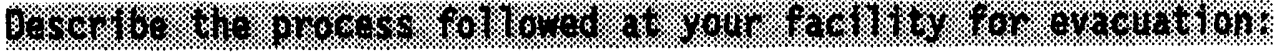

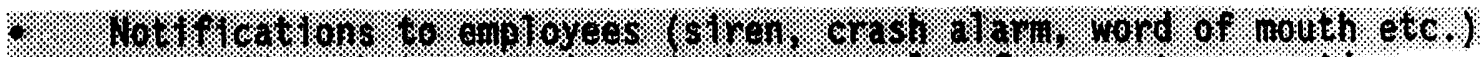

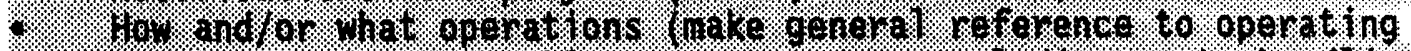

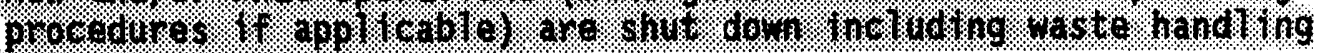

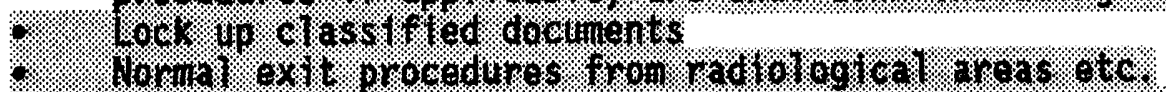

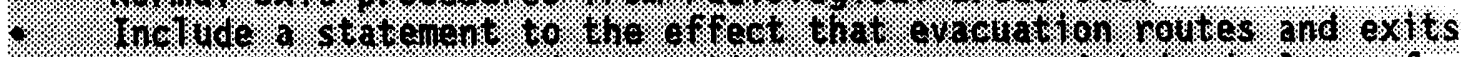

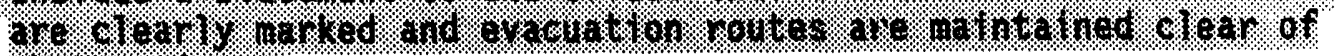

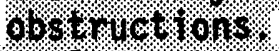

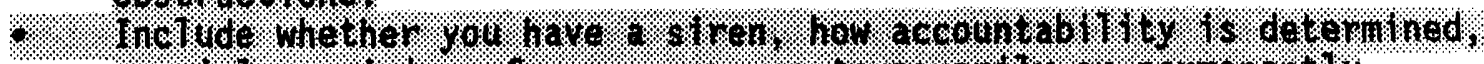

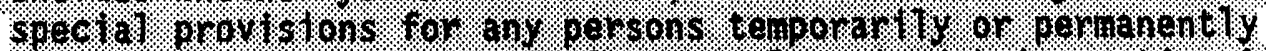

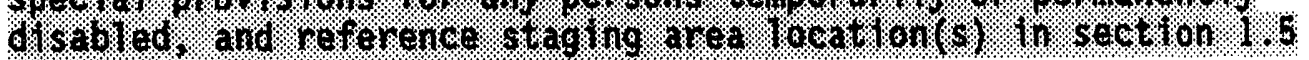

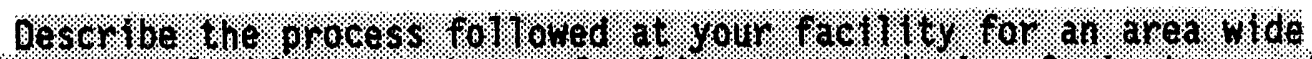

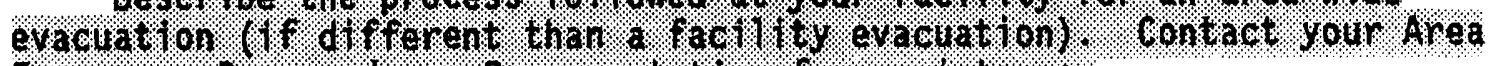

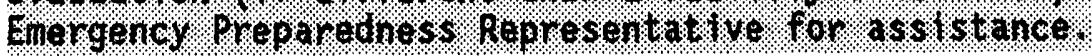




\subsubsection{Take Cover}

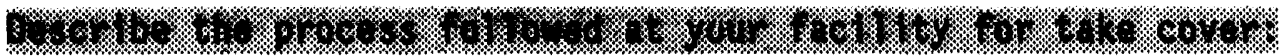

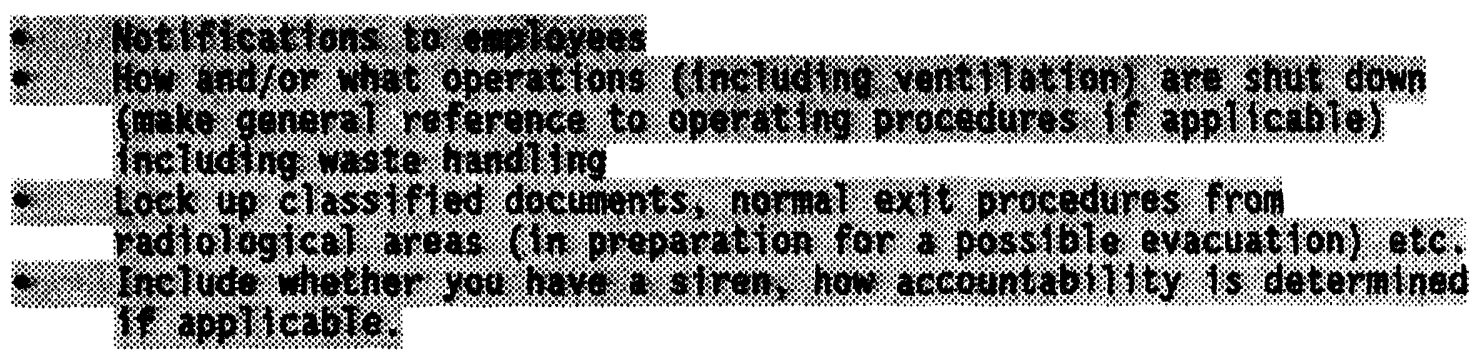

\subsection{RESPONSE TO OPERATIONAL EMERGENCIES}

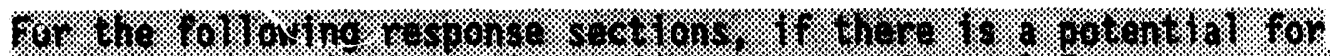

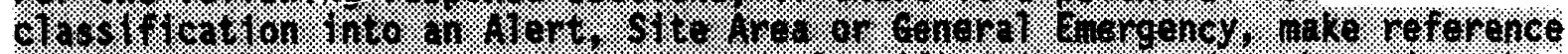

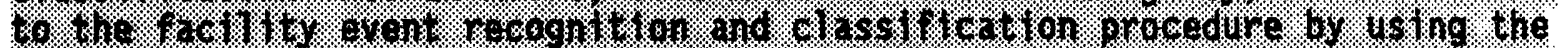

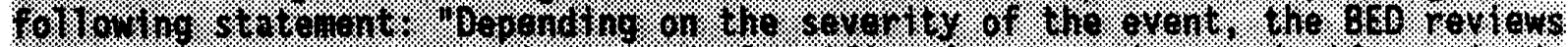

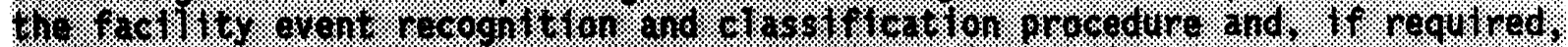

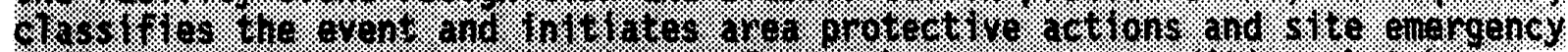

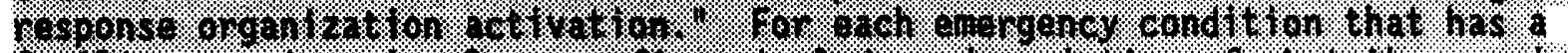

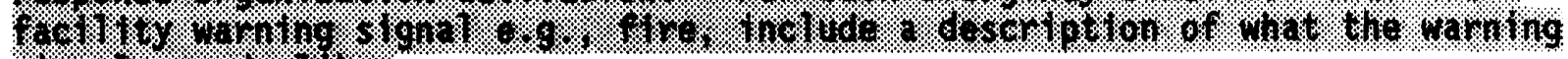

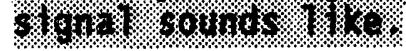

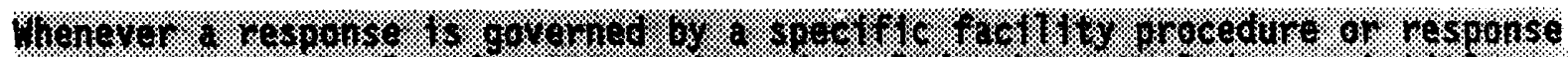

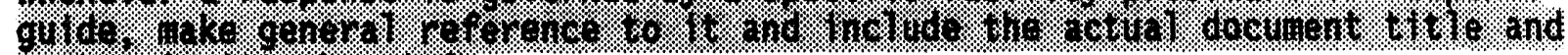

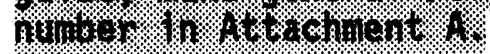

\subsubsection{Loss of Utilities}

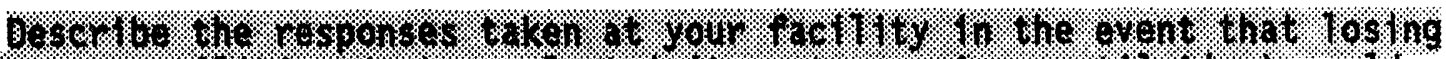

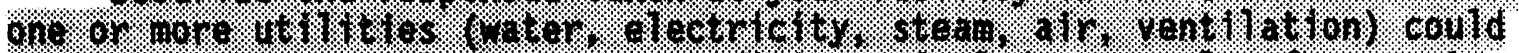

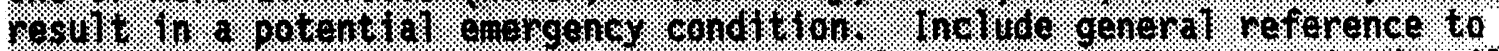

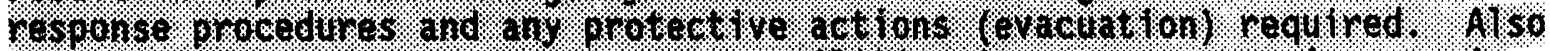

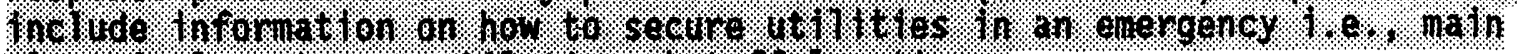

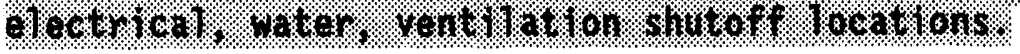

\subsubsection{Major Process Disruption/Loss of P1ant Contro1}

Desco.

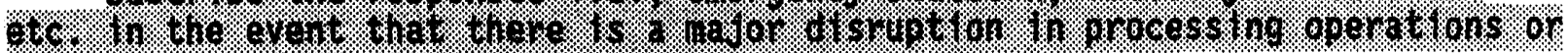
$1000.06 .0014000 \%$ 


\subsubsection{Pressure Release}

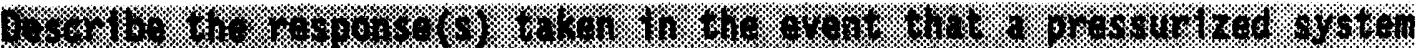

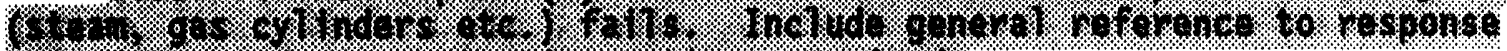

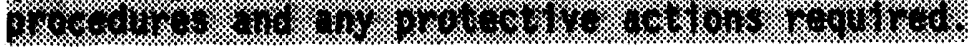

\subsubsection{Fire and/or Explosion}

In the event of a fire, the discoverer activates a fire alarm and calls 911 . Automatic initiation of a fire alarm (through the smoke detectors and sprinkler systems) also is possible. Trained personnel may use portable fire extinguishers for incipient fires. Personnel use their best judgment whether to fight a fire or to evacuate. Under no circumstances do perionnel remain to fight a fire if unusual hazards exist.

1.6.

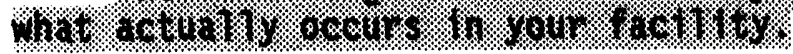

1. On actuation of the fire alarm, personnel shut down equipment, secure waste, and lock up classified documents (or carry the documents with them), ONLY if time permits. The alarm automatically signals the Hanford Fire Department and the Hanford Patrol Operations Center.

2. Personnel leave the area/building by the nearest safe exit and proceed to the designated staging area for accountability unless they are told otherwise.

3. The BED proceeds directly to the scene and obtains all necessary information pertaining to the incident and meets the Hanford Fire Department or sends a representative to meet them and establish an Event Command Post.

4. Depending on the severity of the event, the BED reviews the facility event recognition and classification procedure (see Attachment A) and, if required, classifies the event and initiates area protective actions and site emergency response organization activation.

5. The BED informs the site organization as to the extent of the emergency (including estimates of dangerous waste, mixed waste or radioactive material quantities released to the environment).

6. If operations are stopped in response to the fire, the BED assures that systems are monitored for leaks, pressure buildup, gas generation and ruptures.

7. Hanford Fire Department fire fighters extinguish the fire.

8. The BED assures that all emergency equipment is cleaned and fit for its intended use following completion of cleanup procedures. 


\subsubsection{Hazardous Materiz1, Dangerous and/or Mixed Waste Sp111}

Spills can result from many sources including process leaks, container spills or leaks, damaged packages or shipments or personnel error. Spllls of mixed waste are complicated by the need to deal with the extra hazard presented by the presence of radioactive materlals. These spills normally fall into one of two categories, minor spills or major spills. The response to the two types are discussed below.

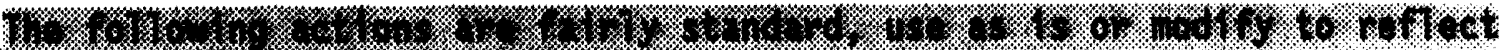

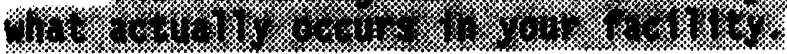

\subsubsection{Response To Minor Spills}

Facility personnel generally perform immediate cleanup of minor spills or releases using sorbents and emergency equipment. Personnel detecting such spills or releases contact the BED who ensures that the Hanford Fire Department, appropriate regulatory support personnel and Health Physics personnel (for mixed waste) are notified. Response to minor spills generally does not require the implementation of this plan.

A spill or release of hazardous material, dangerous or mixed waste is considered 'minor' if all of the following are true:

- The spill does not threaten the health and safety of occupants of the building, i.e., an evacuation is not necessary

- The spill is small in size (generally less than half of the immediately dangerous to 1 ife and health quantities identified in material safety data sheets)

- The composition of the material or waste is known or can be quickly determined from label, manifest, material safety data sheets, or disposal request information.

If one or more of the foregoing conditions are not met, responses are performed as outlined below.

\subsubsection{Response To Major Spills}

The following actions are taken in the event of a major release.

The discover performs the following:

1. Notifies facility personnel (including BED) of discovery of spill or release by sounding the appropriate alarm, using the public address (PA) system, etc.

2. Initiates notifications to the Hanford Fire Department by calling 911 and provides all known information. 
3. Takes action to contain and/or to stop the spill or container leak if all of the following are true:

- The Identity of the substance(s) involved is known

- Appropriate protective equipment and control/cleanup supplies e.g., absorbents are readily avallable

- Discoverer can safely perform the action(s) without assistance, or assistance is readily avallable from other trained personne1.

If any of the above conditions are not met, or there is any doubt, the discoverer evacuates the area and remains outside, upwind of the spill, pending the arrival of the BED. The discoverer rem, available for consultation with the BED, Hanford Fire Department, $c$ other emergency response personnel and restricts access to the area until the arrival of the BED.

The BED performs or arranges for the following:

1. Establishes a command post at a safe location and coordinates further spill mitigation activities.

2. Obtains all avallable information pertaining to the incident and determines if the incident requires implementation of the contingency plan

3. Depending on the severity of the event, the BED reviews the facility event recognition and classification procedure (see Attachment A) and, if raquired, classifies the event and inttiates area protective actions anc site emergency response organization activation.

4. Arranges for care of any injured persons

5. Maintains access control at the incident site by keeping unauthorized personnel and vehicles away from the area. Security personnel can be used to assist in site control if control of the boundary is difficult (e.g., repeated incursions). In determining controlled access areas, considers environmental factors such as wind velocity and direction

6. Arranges for proper remediation of the incident after evaluation.

7. Remains avatlable for fire, patrol, and other authorities on the scene and provides a 11 required information

8. Enlists the assistance of alternate $\operatorname{BED}(s)$, if response activities are projected to be long term. 
9. Ensures the use of proper protective equipment, remedial techniques, transfer procedures, (including ignition source control e.g., nonsparking tools, grounding containers, isolation of ignition sources, use of explosion-proof electrical equipment etc. for flammable or reactive spills), and decontamination procedures by all involved personnel, if remediation is performed by facility personnel.

10. Remains at the scene to oversee activities and to provide information, if remediation is performed by the Hanford Fire Department Hazardous Materials Response Team or cther response teams

11. Ensures proper containerization, packaging, and labeling of recovered spill materials and overpacked containers

- Overpacked containers are marked and labeled in the same manner as the contents. All containers of spill debris, recovered product, etc., are managed in the same manner as waste containers.

Overpacks in use are marked with information pertaining to their contents and noted as to whether the container inside the overpack is leaking or is in good condition.

12. If operations are stopped in response to the release, the BED assures that systems are monitored for leaks, pressure buildup, gas generation and ruptures.

13. Ensures decontamination (or restocking) and restoration of emergency equipment used in the spill remediation before resuming operations

14. Provides required reports after the incident in accordance with DOE/RL-93-75.

\subsubsection{Transportation Incidents}

In addition to the foregoing provisions, the following specific actions could be taken by the discoverer for leaks or spills resulting from a hazardous materials transportation incident if the actions can be performed without jeopardizing personnel safety, as appropriate.

- Determines the nature of incident

- Personnel injuries

- Hazardous material spill with fire

- Hazardous material spill without fire.

- Assists injured personnel.

- Initiates notifications to the single point-of-contact by any means available (telephone, radio, passing motorist, etc.) to request assistance from the Hanford Fire Department (Emergency Coordinator/Event Commander for these type of events), Hanford Patrol and medical personnel. 
- Remains in a safe location and attempts to isolate the area to prevent inadvertent personnel access.

\subsubsection{Receipt of Damaged or Unacceptable Shipments}

When a damaged shipment of hazardous material or dangerous waste arrives at the ERDF facility and the shipment is unacceptable for receipt, the damaged shipment should not be moved. Personnel instead perform the following steps.

- If the release from damaged package is a 'minor' spill under the criteria of Section 7.2.4.1, the following actions are performed.

- Notify the BED, the Hanford Fire Department, and the single point-of-contact to advise of the situation. The BED responds and assists in the evaluation of, and response to, the incident.

- Notify the generating unit of the damaged shipment and request any information necessary to assist in responding to the 'minor' spill.

- Proceed with remedial action, including overpacking damaged containers, cleanup of spilled material, or other necessary actions to contain the spill.

- Implement the section 7.2.4.1, if the release does not meet the criteria of a 'minor' spill as noted previously, or the extent of the spill cannot be determined.

\subsubsection{Unusual, Irritating or Strong Odors}

If an unusual, irritating, or strong odor is detected, and the discoverer has reason to believe that the odor might be the result of an uncontrolled release of a toxic or dangerous material, the discoverer performs the following:

- Activates the building evacuation alarm or fire alarm system to evacuate the building

- Notifies the BED.

If the discoverer knows of the source and scope of the release, this information is reported quickly to the BED. Measures are taken to contain the release as described in section 7.2.4 and ventilate the area, if safe and advisable to do so.

If an unusual odor is detected within the building or structure, and the source of the odor is unknown, the BED considers additional protective actions. 


\subsubsection{Radiological Material Release}

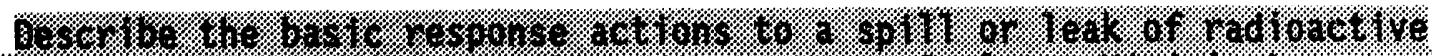

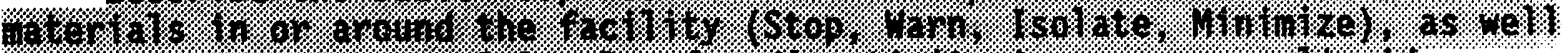

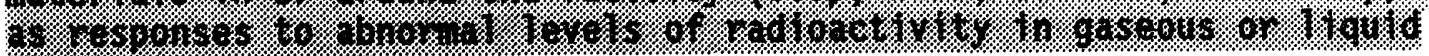

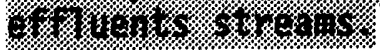

\subsubsection{Criticality}

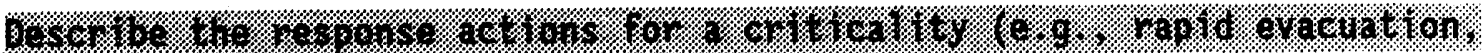
6 (1) \%

\subsection{PREVENTIO.I OF RECURRENCE OR SPREAD OF FIRES, EXPLOSIONS, OR RELEASES}

The BED, in coordination with emergency response organizations, takes the steps necessary to ensure that a secondary release, fire, or explosion does not occur. The following actions are taken:

- Isolates the area of the initial incident by shutting off power, closing off ventilation systems, etc., to minimize the spread of a release and/or the potential for a fire or explosion

- Inspects containment for leaks, cracks, or other damage

- Inspects for toxic vapor generation

- Removes released material and waste remaining inside of containment structures as soon as possible

- Contains and isolates residual waste material using dikes and adsorbents

- Covers or otherwise stabilizes areas where residual released materials remain to prevent migration or spread from wind or precipitation run-off

- Installs new structures, systems, or equipment to enable better management of hazardous materials or dangerous waste

- Reactivates adjacent operations in affected areas only after cleanup of residual waste materials is achieved. 


\subsection{RESPONSE TO NATURAL PHENOMENA}

\subsubsection{Seismic Event}

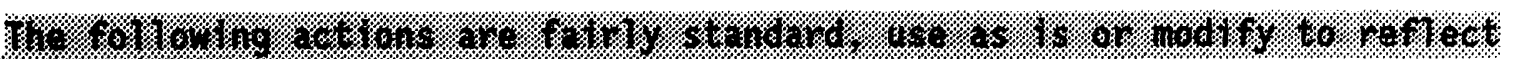

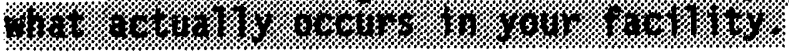

The WHC emergency response organization's primary role in a seismic event is coordinating the initial response to injuries, fires and fire hazards, and acting to contain or control radioactive and/or hazardous material releases.

Individuals should remain calm, stay away from windows, steam lines and hazardous material storage locations. Once the shaking has subsided, they should evacuate carefully and assist those needing help. The location of any trapped individuals is reported to the BED or is reported to 911 .

The BED takes whatever actions are necessary to minimize damage and personnel injuries. Actions include:

- Coordinating searches for personnel and potential hazardous conditions (fires, spills etc.)

- Conducting accountability

- Securing utilities and facility operations

- Arranging rescue efforts and notifying 911 for assistance

- Assembling damage assessment teams

- Determining if hazardous materials were released

- Determine current local meteorological conditions

- Warn other facilities and implement protective actions if release of hazardous materials poses a danger

- Provide personnel and resource assistance to other facilities if required and possible.

\subsubsection{Volcanic Eruption/Ashfall}

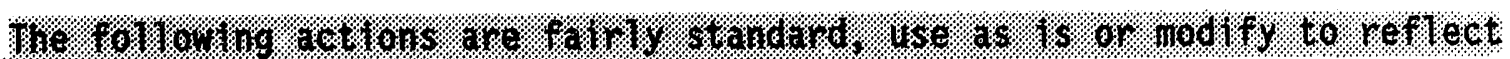

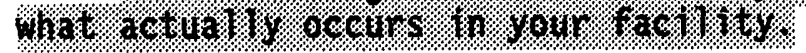

Upon notification of an impending ashfall the BED will implement measures to minimize the impact of the ashfall such as:

- Installing filter media over building ventilation intakes

- Installing filter media or protective coverings on outdoor equipment that may be adversely affected by the ash (diesel generators, equipment rooms etc.)

- $\quad$ Shutting down some or all operations and processes

- Seal secondary use exterior doors

- All but essential personnel may be released to go home

If, as a result of the ashfall, other emergency conditions arise (e.g. fires due to electrical shorts or lightning) response is as described in other paragraphs of this section. 


\subsubsection{High Winds/Tornados}

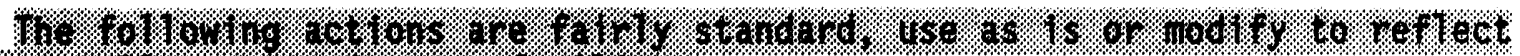
610.

Upon notification of impending high winds, the BED takes steps necessary to secure all outdoor waste and hazardous material containers and storage locations. All doös and windows are shut and personnel are warned to use extreme caution when entering or exiting the building.

\subsubsection{Flood}

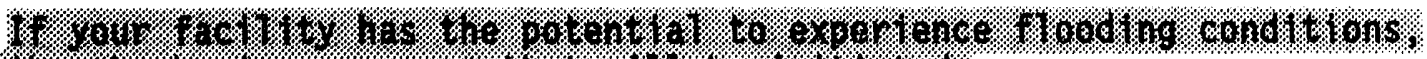

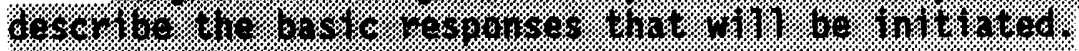

\subsubsection{Range Fire}

Responses to range fires are really handled by preventive measures such as keeping hazardous material and waste accumulation areas free of combustible materials such as weeds and brush. Should a range fire breach the facility boundary, the response is as described in Section 7.2.3.

\subsubsection{Aircraft Crash}

The response to an aircraft crash is the same as that listed in section 7.2.4.3 for responding to transportation incidents.

\subsection{SECURITY CONTINGENCIES}

\subsubsection{Bomb Threat}

\subsubsection{Telephone Threat}

Individuals receiving telephoned threats try to gain as much information as possible from the caller (using the Bomb Threat Checklist if available). Upon conclusion of the call the BED is notified and Security is notified via a 911 call.

The BED evacuates the facility and queries personnel at the staging area regarding any possible suspicious objects in the facility.

Upon arrival of Security personnel, their instructions are followed. 


\subsubsection{Written Threat}

Receivers of written threats handle the letter as little as possible. Notifications are made to the BED and Security. Depending on the content of the letter the facility may or may not be evacuated. The letter is turned over to Security personnel and their instructions are then followed.

\subsubsection{Histage Situation/Armed Intruder}

The discoverer of a hostage situation or armed intruder reports it to 911 and to the BED if possible. The BED, after conferring with security personnel, may covertly evacuate areas of the facility not observable by the hostage taker(s)/intruder. No alarms will be sounded.

Security will determine the remaining response actions and will activate the Hostage Negotiating Team if necessary.

\subsubsection{Suspicious object}

The discoverer of a suspicious object reports it to the BED and to 911 if possible. They will assure that the object is not disturbed.

The BED will evacuate the facility and based on the description provided by the discoverer attempt to determine the identity or owner of the object. This may be done by questioning facility personnel at the staging area.

If the identity/ownership of the object cannot be determined then Security will assume command of the incident. An Emergency Ordinance Team wi11 be dispatched to the facility to properly dispose of the device.

\subsection{TERMINATION OF EVENT, INCIDENT RECOVERY, AND RESTART OF OPERATIONS}

\subsection{TERMINATION OF EVENT}

It is a function of the BED to declare the termination of an event. However, in an event where additional emergency centers are activated only the highest activated level of the emergency organization, in conjunction with the BED, will declare that an event has ended. If the RL-EACT is activated, only the RL director officially terminates the event. In all cases, however, the BED must be consulted before reentry is initiated. 


\subsection{INCIDENT RECOVERY AND RESTART OF OPERATIONS}

A recovery $p l a n$ is developed when necessary. A recovery $p l a n$ is needed following an event when further risk could be introduced to personnel, the facility, or the environment through recovery action and/or to maximize the preservation of evidence. Depending on the magnitude of the event and the effort required to recover from it, recovery planning may involve personnel from RL and other contractors. If a recovery $\mathrm{plan}$ is required, it is reviewed by appropriate personnel and approved by a Recovery Manager before restart. Restart of operations is performed in accordance with the approved plan.

If this plan was implemented for a WAC emergency (see section 4.0), notification must be made to Ecology before operations can resume. Section 9.0 of DOE/RL-93-75 discusses different reports to outside agencies. This notification is in addition to those required reports. This notification must include that there are no incompatibility issues with the waste and released materials from the incident, and that all the equipment has been clean, fit for its intended use and placed back into service. The notification may be made via telephone conference. Any additional information that Ecology requests regarding these restart conditions may be included in the required 15-day report identified in DOE/RL-93-75.

For emergencies not involving activation of the ECC, the BED ensures that conditions are restored to normal before operations are resumed. If the Hanford Site Emergency Organization was activated and the emergency phase is complete, a special recovery organization could be appointed at the discretion of $\mathrm{RL}$ to restore conditions to normal. This process is detailed in RL and WHC emergency procedures. The makeup of this organization depends on the extent of the damage and its effects. The onsite recovery organization will be appointed by the appropriate contractors' emergency director.

\subsection{INCOMPATIBLE WASTE}

After an event, the BED or the onsite recovery organization ensures that no waste that might be incompatible with the released material is treated, stored, and/or disposed of until cleanup is completed. Cleanup actions are taken by facility personnel or other assigned personnel. Actions to be taken might include, but are not limited to, any of the following:

- Neutralization of corrosive spills

- Chemical treatment of reactive materials to reduce hazards

- Overpacking or transfer of contents from leaking containers

- Use of sorbents to contain and/or absorb leaking liquids for containerization and disposal 
- Decontamination of solid surfaces impacted by released material, e.g., intact containers, equipment, floors, containment systems, etc.

- Disposal of contaminated porous materials that cannot be decontaminated and any contaminated soil

- Containerization and sampling of recovered materials for classification and determination of proper disposal technique

- Follow up sampling of decontaminated surfaces to determine adequacy of cleanup techniques as appropriate.

Waste from cleanup activities is designated and managed as newly generated waste. A field check for compatibility before storage is performed as necessary. Incompatible wastes are not placed in the same container. Containers of waste are placed in storage areas appropriate for their compatibility class.

If it is determined that incompatibility of waste was a factor in the incident, the BED or the onsite recovery organization ensures that the cause is corrected. Examples would be modification of an incompatibility chart or increased scrutiny of waste from a generating unit when incorrectly designated waste caused or contributed to an incident.

\subsection{POST-EMERGENCY EQUIPMENT MAINTENANCE AND DECONTAMINATION}

All equipment used during an incident is decontaminated (if practicable) or disposed of as spill debris. Decontaminated equipment is checked for proper operation before storage for subsequent use. Consumables and disposed materials are restocked. Fire extinguishers are recharged or replaced.

The BED ensures that all equipment is cleaned and fit for its intended use before operations are resumed. Depleted stocks of neutralizing and absorbing materials are replenished, self-contained breathing apparatus are cleaned and refilled, protective clothing are cleaned or disposed of and restocked, etc.

Equipment and personnel decontamination stations are established considering the following information and techniques. 


\begin{tabular}{|c|c|c|}
\hline WESTINGHOUSE HANFORD COMPANY & Document: & WHC-IP-0263-XXX \\
\hline $\begin{array}{l}\text { BUILDING EMERGENCY PLAN } \\
\text { FOR ERDF FACILITY }\end{array}$ & $\begin{array}{l}\text { Page: } \\
\text { Issue Date: }\end{array}$ & Mesure of 30 \\
\hline
\end{tabular}

Items to consider when establishing a decontamination station are as follows:

- Water supplies

- Containment/catch basins and/or systems

- Staff necessary to accomplish proper decontamination

- Protective clothing

- Decontamination supplies (buckets, brushes, soap, chemicals as needed)

- Risk to personnel

- Weather conditions; i.e., severe heat, cold (current and forecasted)

- Toxicity of material

- Porosity of equipment to be decontaminated

- Disposal requirements of decontamination rinse

- Use of controlled zones to maintain contamination control.

\subsection{EMERGENCY EQUIPMENT}

Hanford site emergency resources and equipment are described and 1 isted in DOE/RL-93-75 section 7 .

\subsection{FIXED EMERGENCY EQUIPMENT}

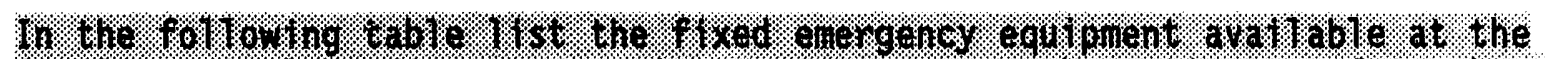

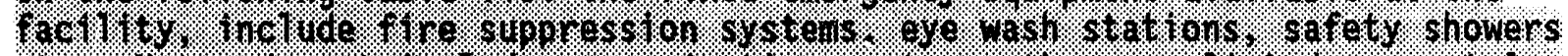

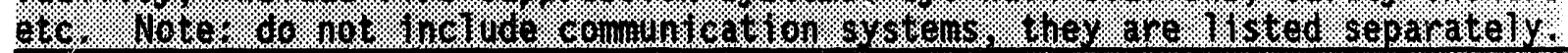

\begin{tabular}{|c|c|c|}
\hline \multicolumn{3}{|c|}{ Fixed Emergency Equipment } \\
\hline Type & Location & Capability \\
\hline & & \\
\hline
\end{tabular}

\subsection{PORTABLE EMERGENCY EQUIPMENT}

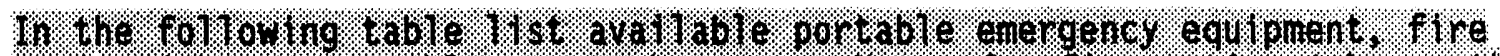

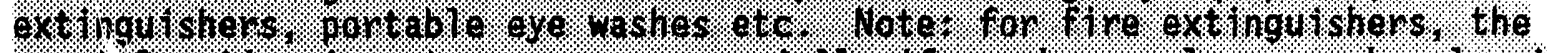

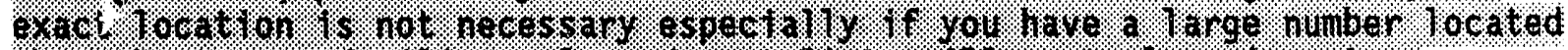

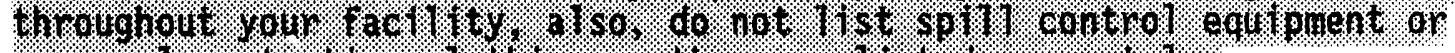

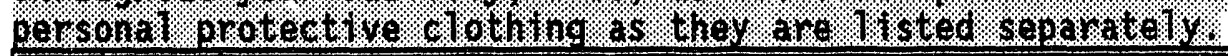

\begin{tabular}{|c|c|c|}
\hline \multicolumn{3}{|c|}{ Portable Emergency Equipment } \\
\hline \hline Type & Location & Capability \\
\hline & & \\
\hline
\end{tabular}




\subsection{COMMUNICATIONS EQUIPMENT/WARNING SYSTEMS}

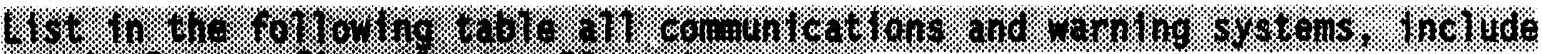

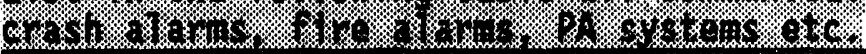

\begin{tabular}{|c|r|r|}
\hline \multicolumn{3}{|c|}{ Communications Equipment } \\
\hline Type & Location & Capability \\
\hline & & \\
\hline
\end{tabular}

\subsection{PERSONAL PROTECTIVE EQUIPMENT}

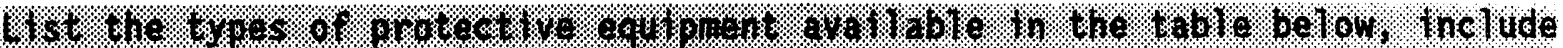

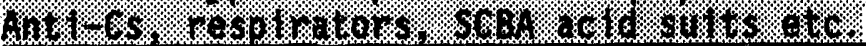

\begin{tabular}{|c|c|c|}
\hline \multicolumn{2}{|c|}{ Personal Protective Equipment } \\
\hline Type & Location & Capability \\
\hline & & \\
\hline
\end{tabular}

\subsection{SPILL CONTROL AND CONTAINMENT SUPPLIES}

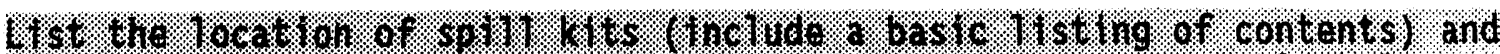

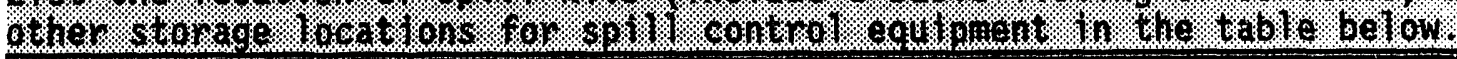

\begin{tabular}{|c|c|c|}
\hline \multicolumn{2}{|c|}{ Spil1 Kits and Spill Control Equipment } \\
\hline Type & Location & Capability \\
\hline & & \\
\hline
\end{tabular}

\subsection{EMERGENCY RESPONSE CENTER}

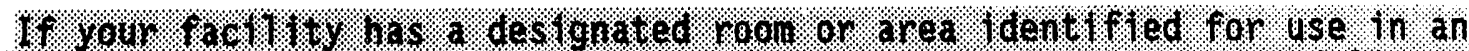

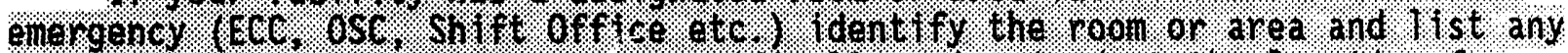

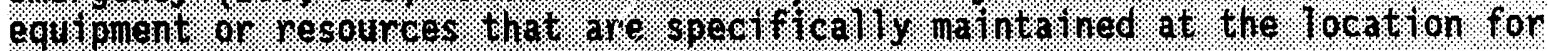

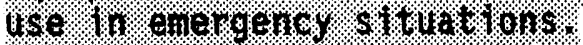




\begin{tabular}{|c|c|c|}
\hline WESTINGHOUSE HANFORD CONPANY & Document: & WHC-IP-0263-XXX \\
\hline $\begin{array}{l}\text { BUILDING EMERGENCY PLAN } \\
\text { FOR ERDF FACILITY }\end{array}$ & $\begin{array}{l}\text { Page: } \\
\text { Issue Date: }\end{array}$ & 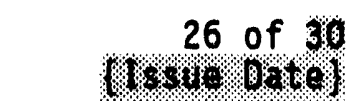 \\
\hline
\end{tabular}

\subsection{COORDINATION AGREEMENTS}

RL has established a number of coordination agreements, or memoranda of understanding (MOUs) with various agencies to ensure proper response resource avallability for incidents involving the Hanford site. A description of the agreements is contained in section 8.0 of DOE/RL-93-75.

\subsection{REQUIRED REPORTS}

Three types of written post-incident reports are required for incidents on the Hanford site. The reports are summarized in DOE/RL-93-75.

\subsection{PLAN LOCATION}

Copies of this Plan are maintained at the following locations:

- 9.9\%).

- Hanford Fire Department (via the Hanford Local Area Network)

- Appropriate Area ECC

- Appropriate Off Site Agencies (e.g. Richland Fire Department)*

* Note: Per coordination agreements, the Hanford Fire Department provides direction during on site event response and provides all needed information to support agencies that may be assisting the on site responses. Therefore only copies of plans for facilities where off site agencies are the initial responders (e.g., 1163 Stores Building) will be provided to off site support agencies. 


\begin{tabular}{|c|c|c|}
\hline WESTINGHOUSE HANFORD COMPANY & Document: & WHC-IP-0263-XXX \\
\hline $\begin{array}{l}\text { BUILDING ENERGENCY PLAN } \\
\text { FOR ERDF FACILITY }\end{array}$ & $\begin{array}{l}\text { Page: } \\
\text { Issue Date: }\end{array}$ & (18.3\% of 30 \\
\hline
\end{tabular}

\subsection{BUILDING EMERGENCY ORGANIZATION}

Q

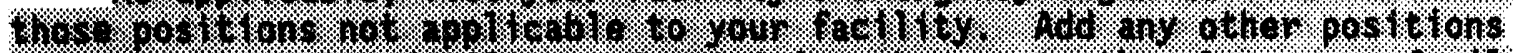
7.

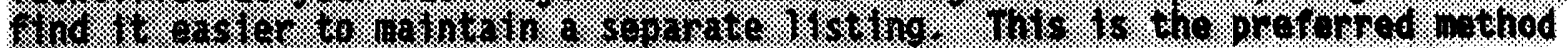

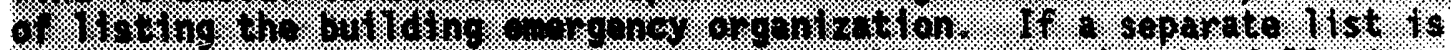

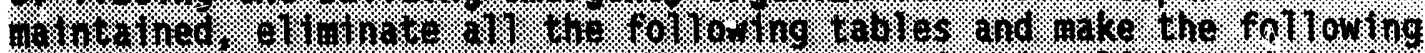
\$8.

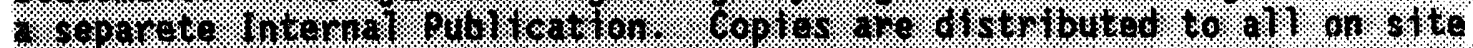

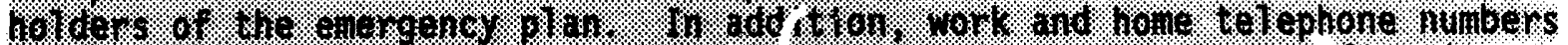

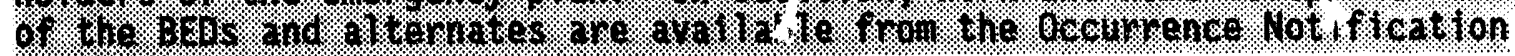

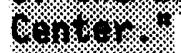

\section{BUILDING EMERGENCY DIRECTOR}

\begin{tabular}{|c|c|c|c|}
\hline & NAME & LOCATION & PHONE \\
\hline PRIMARY & & & \\
\hline ALTERNATE & & & \\
\hline
\end{tabular}

STAGING AREA MANAGERS

\begin{tabular}{|c||c|c|c|}
\hline & NAME & LOCATION & PHONE \\
\hline PRIMARY & & & \\
\hline ALTERNATE & & & \\
\hline
\end{tabular}

PERSONNEL ACCOUNTABILITY AIDES

\begin{tabular}{|c||c|c|c|}
\hline & NAME & LOCATION & PHONE \\
\hline PRIMARY & & & \\
\hline ALTERNATE & & & \\
\hline
\end{tabular}

VOLUNTEER BOMB SEARCH TEAM MEMBERS

\begin{tabular}{|c|c|c|c|}
\hline & NAME & LOCATION & PHONE \\
\hline PRIMARY & & & \\
\hline PRIMARY & & & \\
\hline
\end{tabular}


WEST INGHOUSE HANFORD COMPANY

BUILDING EMERGENCY PLAN

FOR ERDF FACILITY
Document:

Page:

Issue Date:
WHC-IP-0263-X7X

28 of 33

(17.rs. 9*2)

\section{EVACUATION BUS DRIVERS}

\begin{tabular}{||c|c|c|c|}
\hline & NAME & LOCATION & PHONE \\
\hline PRIMARY & & & \\
\hline ALTERNATE & & & \\
\hline
\end{tabular}

SAFETY REPRESENTATIVE (RADIOLOGICAL AND/OR INDUSTRIAL SAFETY)

\begin{tabular}{||c|c|c|c|}
\hline & NAME & LOCATION & PHONE \\
\hline PRIMARY & & & \\
\hline ALTERNATE & & & \\
\hline
\end{tabular}

SECURITY REPRESENTATIVE (AS APPLICABLE)

\begin{tabular}{|c|c|c|c|}
\hline & NAME & LOCATION & PHONE \\
\hline PRIMARY & & & \\
\hline ALTERNATE & & & \\
\hline
\end{tabular}

NUCLEAR MATERIALS REPRESENTATIVE (AS APPLICABLE)

\begin{tabular}{|c|c|c|c|}
\hline & NAME & LOCATION & PHONE \\
\hline PRIMARY & & & \\
\hline ALTERNATE & & & \\
\hline
\end{tabular}

ENGINEERING SUPPORT

\begin{tabular}{|c|c|c|c|}
\hline & NAME & LOCATION & PHONE \\
\hline PRIMARY & & & \\
\hline ALTERNATE & & & \\
\hline
\end{tabular}

MAINTENANCE SUPPORT

\begin{tabular}{|c|c|c|c|}
\hline & NAME & LOCATION & PHONE \\
\hline PRIMARY & & & \\
\hline ALTERNATE & & & \\
\hline
\end{tabular}




\subsection{REFERENCES}

DOE Order 5000.3B, Occurrence Reporting and Processing of Operations Information

DOE Order 5500.1B, Emergency Management Systems

DOE/RL-93-75, Hanford Facility Contingency Plan

NIOSH, 1985, Pocket Guide to Chemical Hazards, National Institute of Occupational Safety and Health, U.S. Department of Health and Human Resources, Public Health Service, Centers for Disease Control, Washington, D.C.

WAC 173-303, Dangerous Waste Regulations, Washington State Department of Ecology, Olympia, Washington.

WHC-CM-4-43, Emergency Management Procedures 

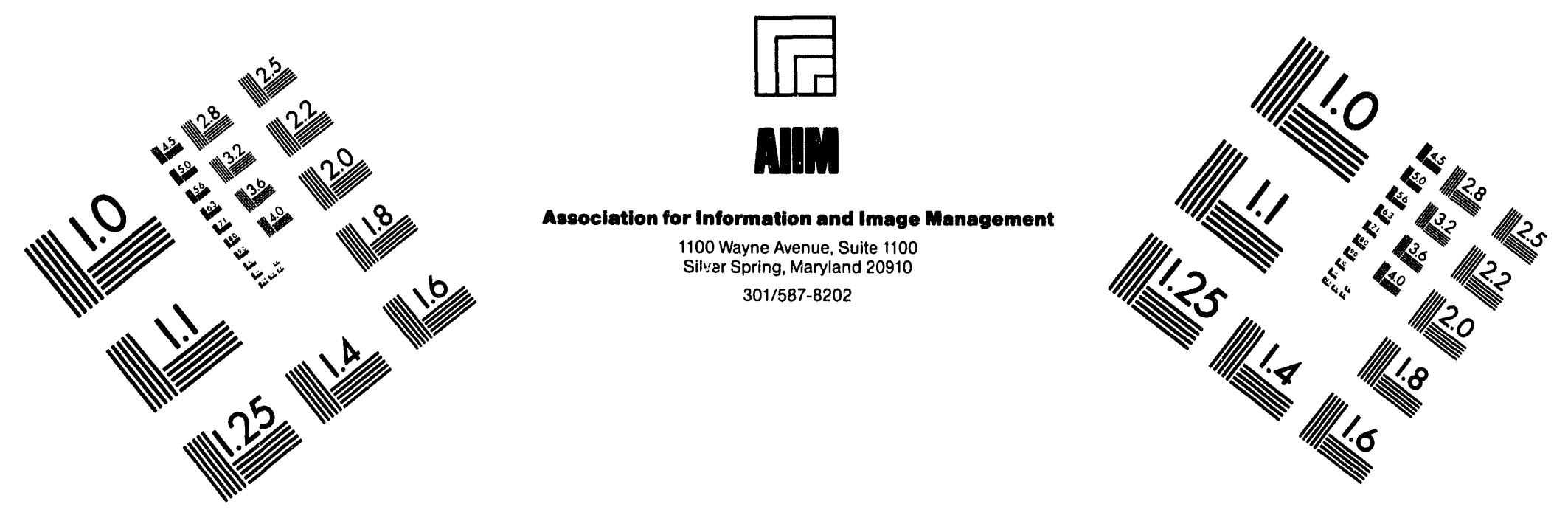

\section{Centimeter}

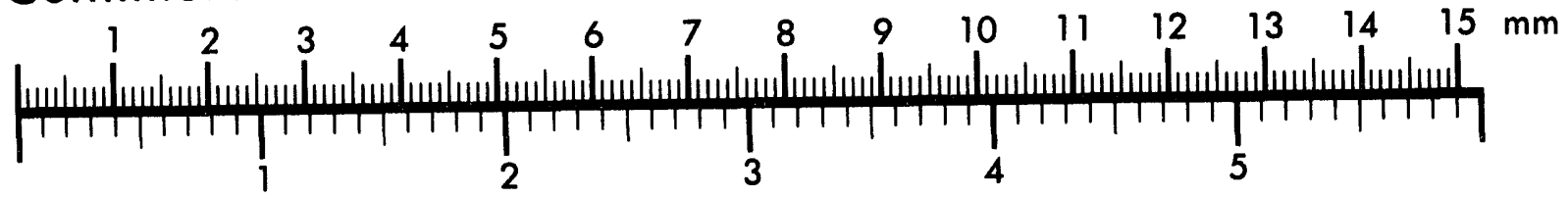
Inches
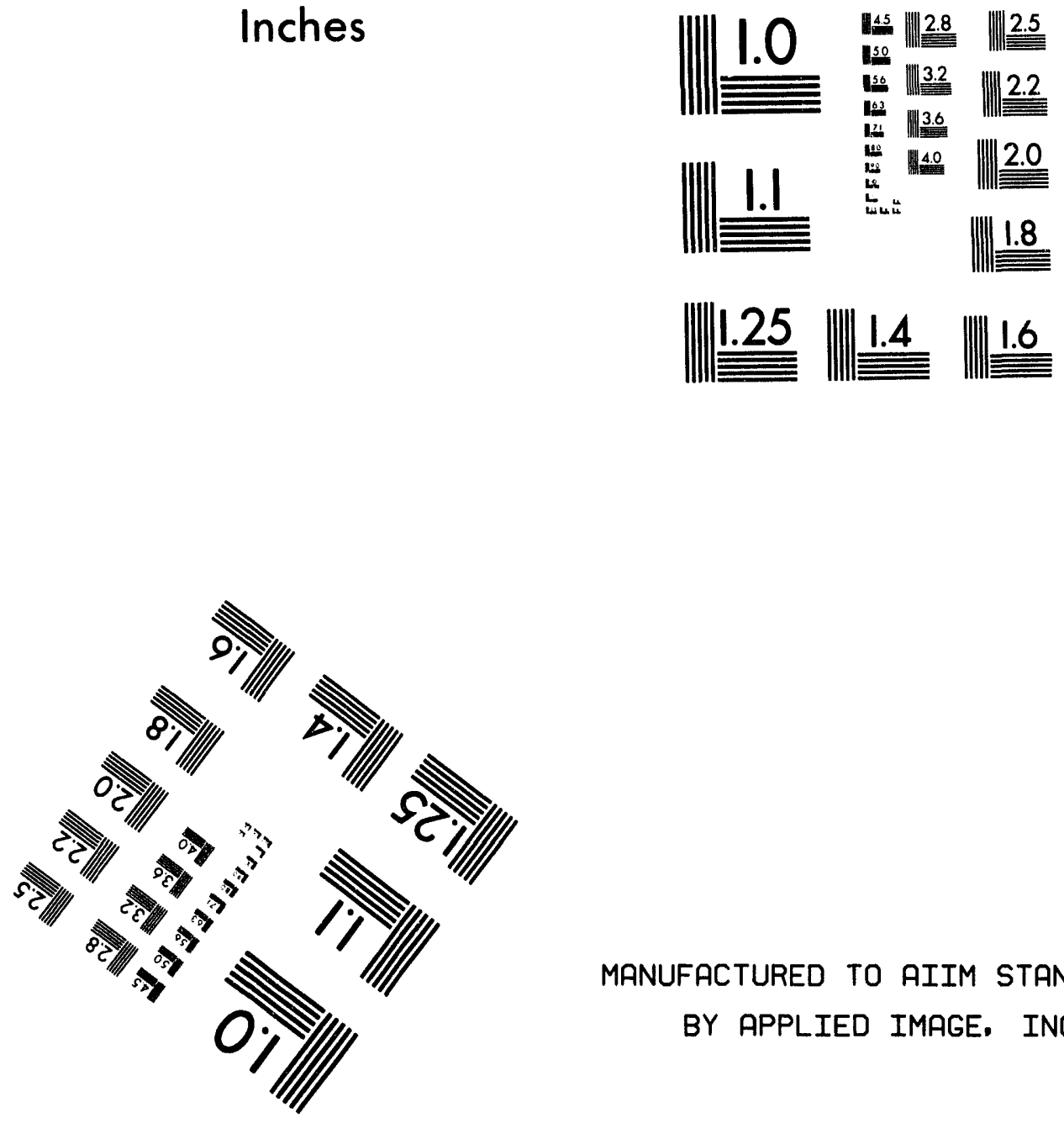

MANUFACTURED TO AIIM STANDARDS

BY APPLIED IMAGE. INC.

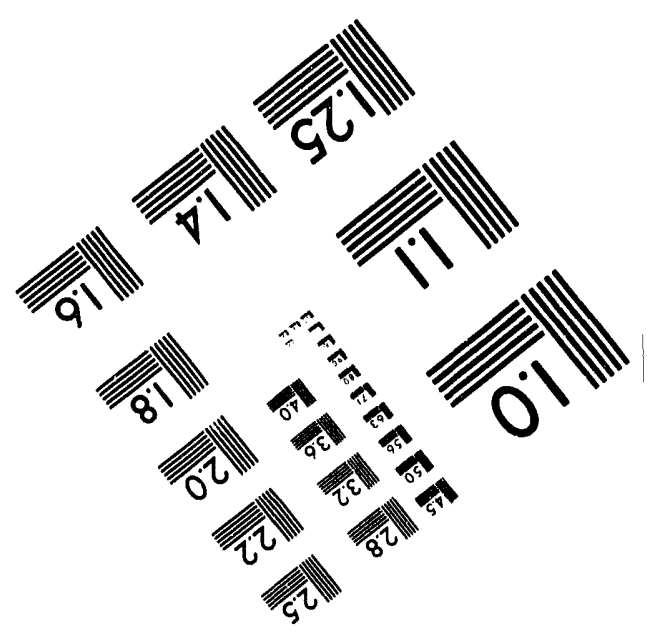



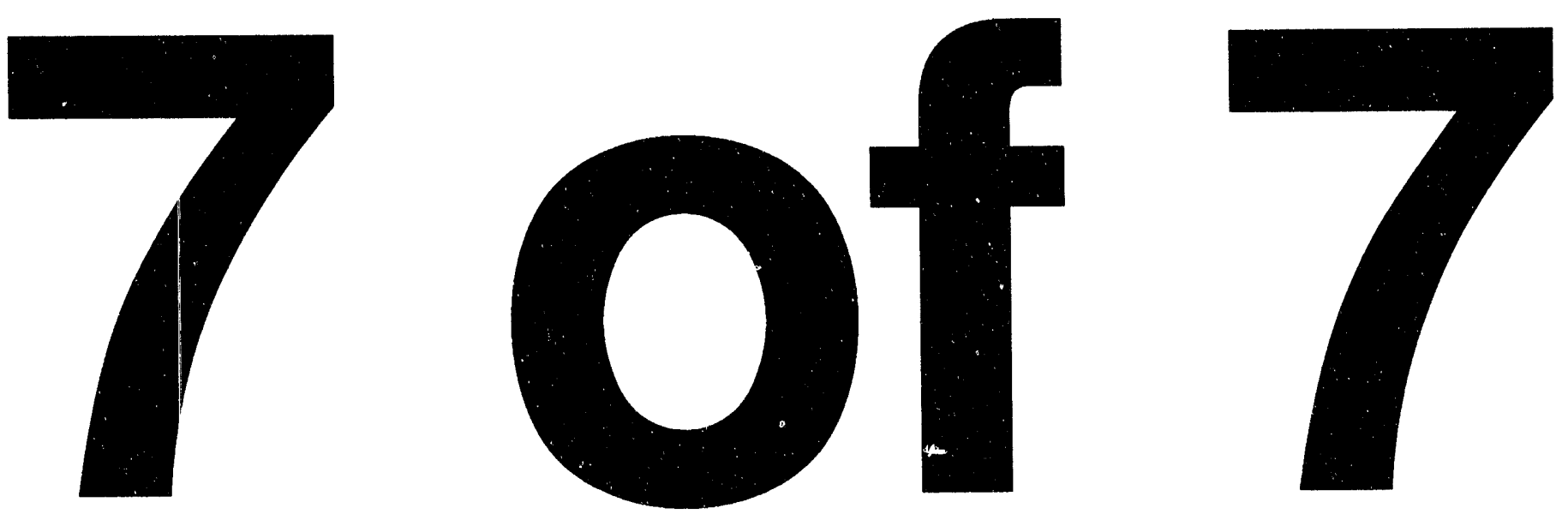


\begin{tabular}{|c|c|c|}
\hline WESTINGHOUSE HANFORD COMPANY & Document: & WHC-IP-0263-XWX \\
\hline $\begin{array}{l}\text { BUILDING EMERGENCY PLAN } \\
\text { FOR ERDF FACILITY }\end{array}$ & $\begin{array}{l}\text { Page: } \\
\text { Issue Date: }\end{array}$ & (6. 30 of 30 \\
\hline
\end{tabular}

\section{ATTACHMENT A}

Listing of Procedures and Guides

This page is intentionally left blank.

The list is maintained at the facility and will be provided upon request.

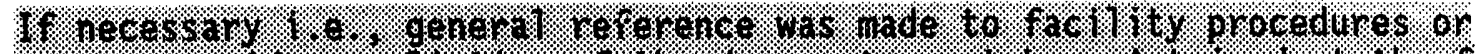

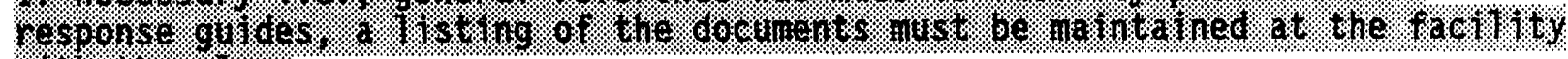
6.7. U.

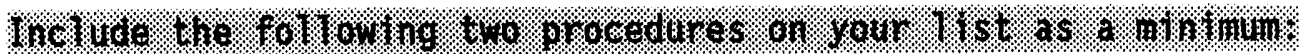

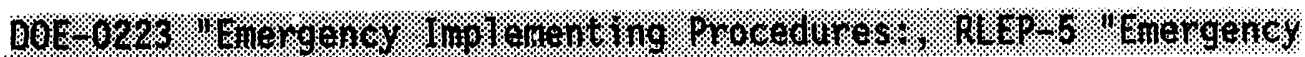

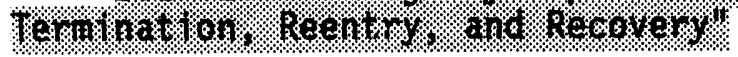

Mro o.

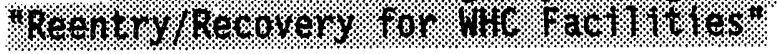


DOE/RL-94-40, Rev. 0 06/94

\section{APPENDIX 8A}

TRAINING PLAN FOR THE ENVIRONAENTAL RESTORATION DISPOSAL FACILITY 


\section{DISTRIBUTION SHEET}

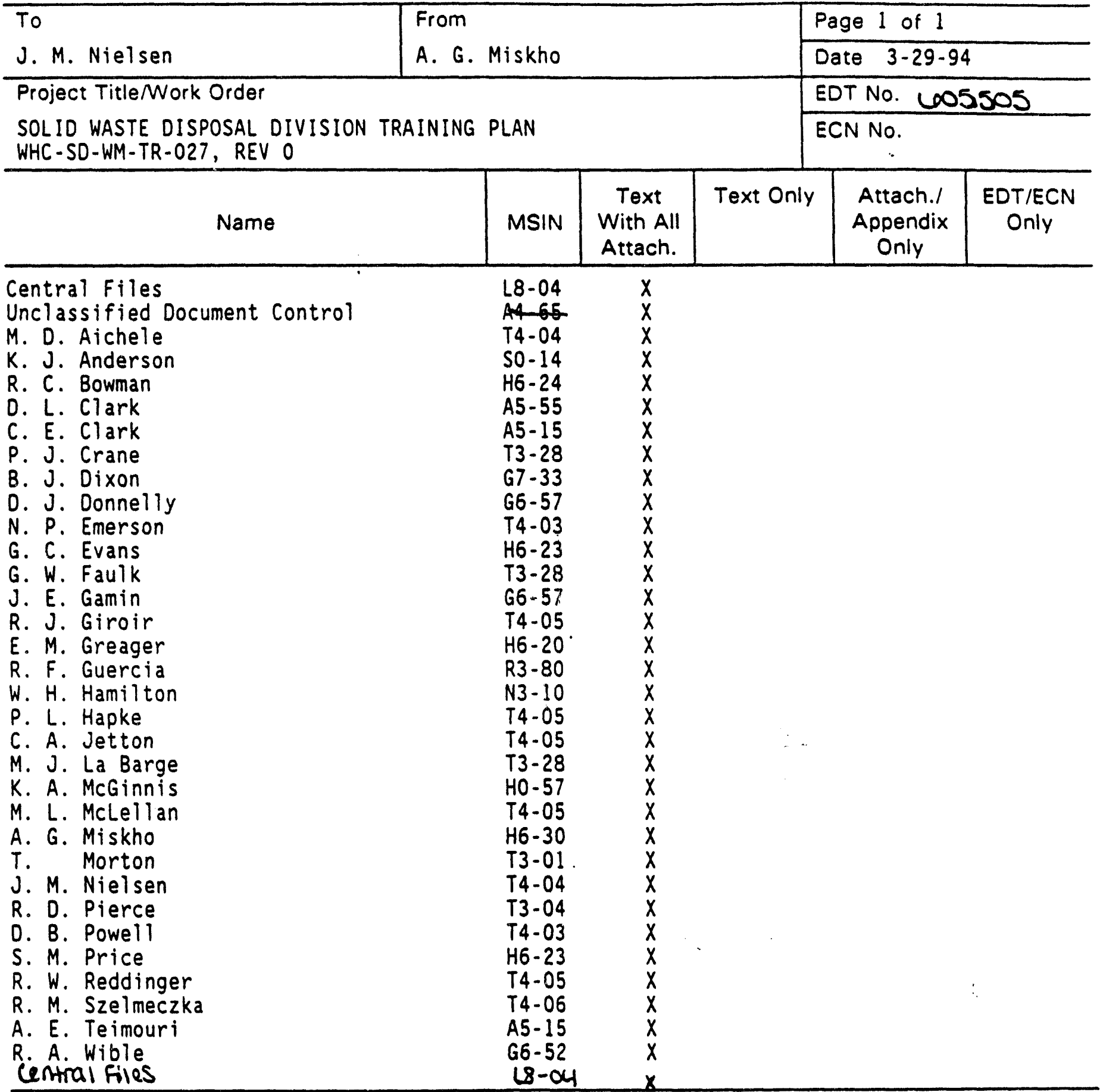




\begin{tabular}{|c|c|c|c|}
\hline $\begin{array}{l}\text { APR O6 } 1994 \\
\text { S5 - it. un al }\end{array}$ & ENGINEERING DATA TRANSMITTAL & $\frac{120}{28}$ & $\begin{array}{l}4-6-94 \text { Pago } 1 \text { of } \frac{1}{1} \\
\text { 1. EOT } 605505\end{array}$ \\
\hline
\end{tabular}

\begin{tabular}{|c|c|}
\hline $\begin{array}{l}\text { 2. To: (Receiving Organization) } \\
\text { J. M. Nielsen, Solid Waste } \\
\text { Training }\end{array}$ & $\begin{array}{l}\text { 3. From: (originating Organization) } \\
\text { A. G. Miskho, RCRA Compliance }\end{array}$ \\
\hline $\begin{array}{l}\text { 5. Proj./Prog./Oept.10iv.: } \\
\text { Sol id Waste Disposal }\end{array}$ & $\begin{array}{l}\text { 6. Cog. Engr.: } \\
\text { A. G. Miskho }\end{array}$ \\
\hline
\end{tabular}

8. Originator Remarks:

"Key" words: Training Plan, 616 NRDWSF, CWC, 224-T TRUSAF, LLBG, ERDF, WRAP, Solid Waste Disposal Division, RCRA

Training, WAC 173-303-330.

4. Related EOT NO.:

R'/A

7. Purchase Order No.:

NIA

9. Equip./Component No.:

Nia

10. System/Bldg./Facility:

616 NRDWSF, CWC, WRAP, 224-T TRUSAF, LLBG, ERDF

11. Receiver Remarks: 12. Mojor Assm. Owg. No.:

Upon receipt, Solid Waste Training is responsibile to ensure this document is implemented and training tables are maintained.

$$
\text { N/A }
$$

13. Permit/Permit Application No.: NiA

14. Required Response Date:

$N \backslash A$

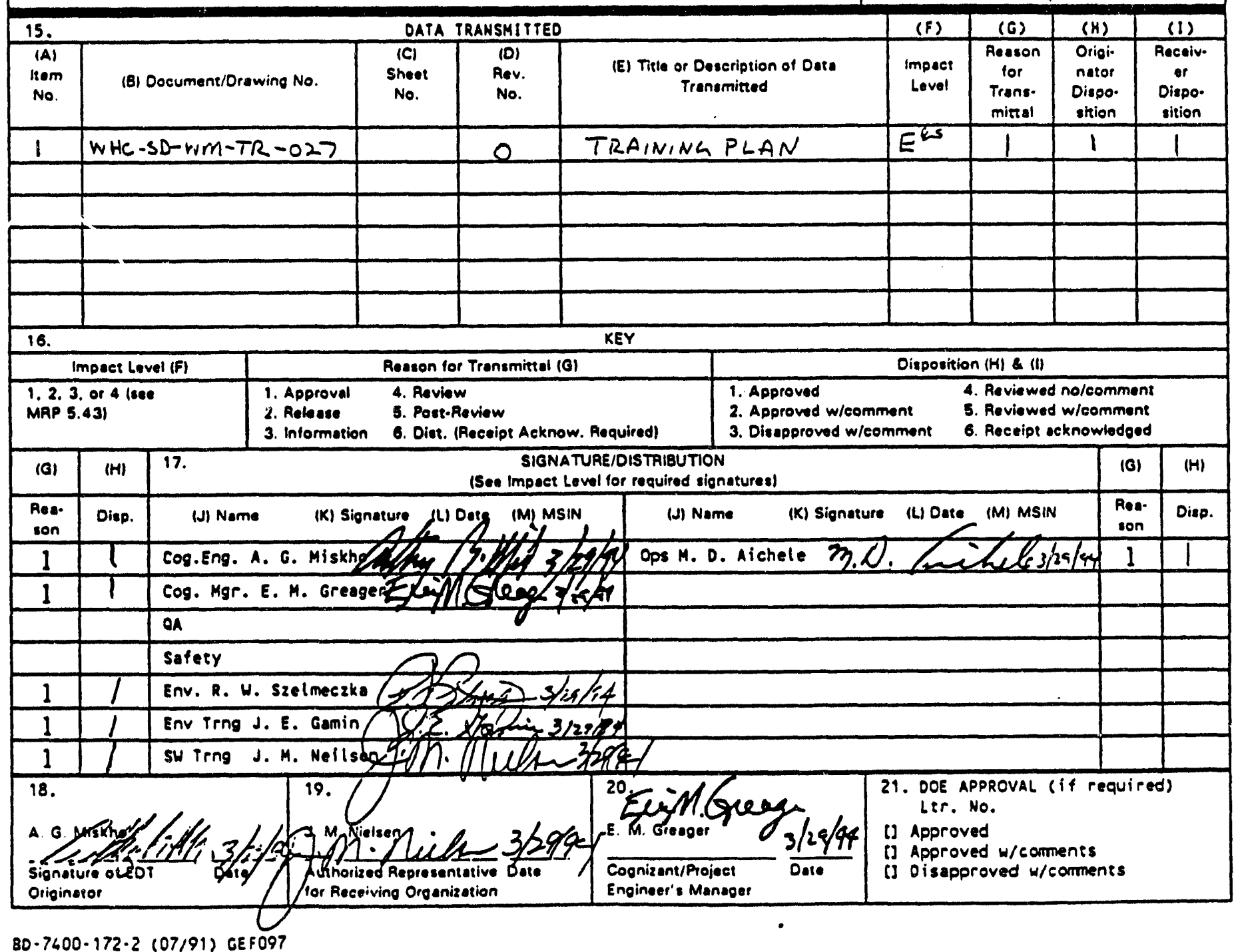




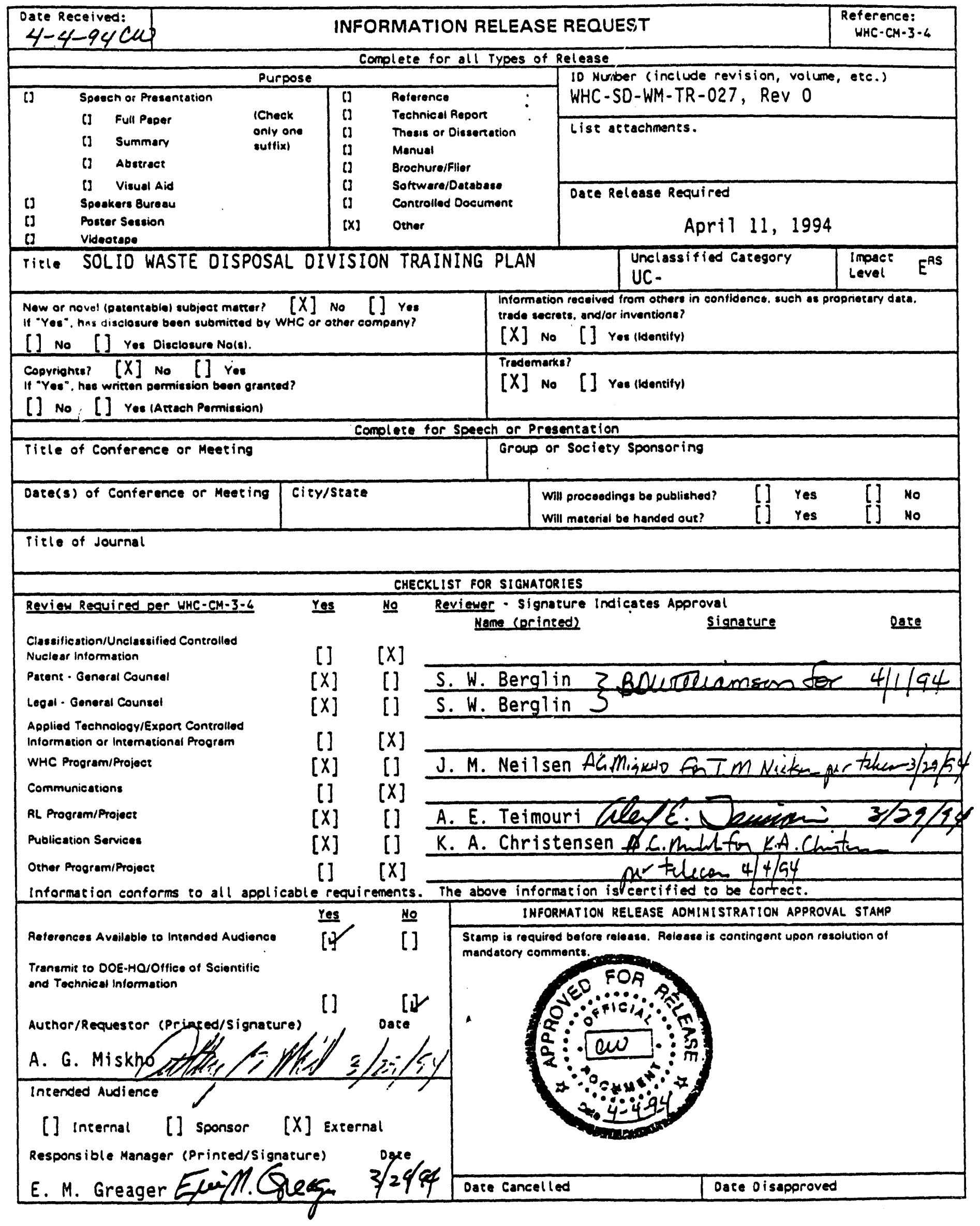




\begin{tabular}{|c|c|c|}
\hline $\begin{array}{l}\text { 2. Tirle } \\
\text { SOLIO WASTE DISPOSAL DIVISION TRAINING PLAN }\end{array}$ & $\begin{array}{l}\text { 3. Number } \\
\text { WHC-SD-WM-TR-027 }\end{array}$ & $\begin{array}{c}\text { 4. Rev No. } \\
0 \\
\end{array}$ \\
\hline $\begin{array}{l}\text { 5. key Words } \\
\text { Training Plan, } 616 \text { NRDWSF, CWC, 224-T TRUSAF, } \\
\text { LLBG, ERDF, WRAO, SOl id Waste Disposal Division, } \\
\text { RCRA Training, WAC } 173-303-330\end{array}$ & $\begin{array}{l}\text { 6. Author } \\
\text { Name: A. G, Miskh } \\
\text { organization/Charge cod }\end{array}$ & $8410 / R+1313$ \\
\hline
\end{tabular}

at)

7. Abstract

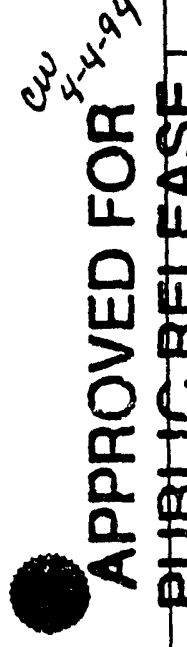

MUPPOSE AND USE OF DOCUMENT - This document was prepared for usa witm the U.S. Depertment of Energy and its contractors. It it to be used iy to perform, direct, or integrate jork under U.S. Departmen Energy contracts. in is document is not approved for public release unist reviewed.

PATENT STATUS - This document gyon since it is transmitsed in advance of patent clearance, is niade avatuble in confidence solely for use in performance of work under maeracts with the U.S. Department of Epargy. This document is not to be published nor its contents othorisise disseminated or used for purposes yether than specified abu before patent approval for such release or tak has been seared, upon request, from the Patent Counsel, U.S. Departintie of intrgy field Office, Richland, WA.

OISCLAIMER - This report was prepared as an account of work sponsored by an agency of the United States Government. Neither the United States Government nor any agency thereof, nor any of their employees, nor any of their contractors, subcontractors or their employees, makes any warranty, express or implied, or assumes any legal liability or responsibility for the accuracy, completeness, or any third party's use or the results of such use of any information, apparatus, product, or process disclosed, or represents that its use would not infringe privately owned rights. Reference herein to any specific commercial product, process, or service by trade name, trademark, manufacturer, or otherwise, does not necessarily constitute or imply its endorsement, recommendation, or favoring by the United states Government or any agency thereof or its contractors or subcontractors. The views and opinions of authors expressed herein do not necessarily state or reflect those of the United States Govermment or any agency thereof.

10.

RELEASE STAMP

OFFICIAL FELEASE BY WHC

DATE APR O6 1994 


\section{WHC-SD-WM-TR-027 REV 0}

\section{CONTENTS}

1.0 SUMMARY OF APPLICATION INTRODUCTIONS FOR CHAPTER 8.0, PERSONNEL TRAINING ..................... . . 1-1

2.0 CHAPTER 8.0, PERSONNEL TRAINING--616 NRDWSF .......... 2-1

3.0 CHAPTER 8.0, PERSONNEL TRAINING--ERDF . . . . . . . . . . . 3-1

4.0 CHAPTER 8.0, PERSONNEL TRAINING--CWC ............. . . 4-1

5.0 CHAPTER 8.0, PERSONNEL TRAINING--LLBG . . . . . . . . . . 5-1

6.0 CHAPTER 8.0, PERSONNEL TRAINING--224-T TRUSAF ......... . 6-1

7.0 CHAPTER 8.0, PERSONNEL TRAINING--WRAP ............. . . 7-1

8.0 REFERENCES ....................... . . 8-1 APPENDICES

8 A RCRA TRAINING .................... . . . $8 A-i$

$8 B$ NON-RCRA TRAINING ................... . . 8B-i

8C TRAINING COURSE DESCRIPTIONS ................. 8C-i

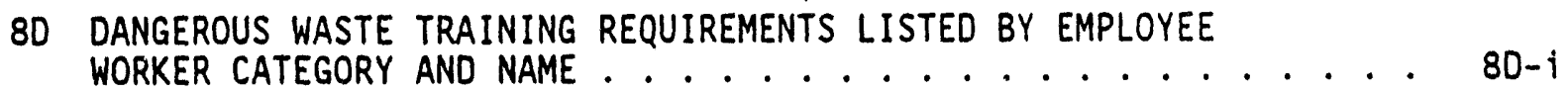


WHC-SD-WM-TR-027 REV 0

This page intentionally left blank. 


\section{SOLID WASTE DISPOSAL DIVISION TRAINING PLAN}

\subsection{SUMMARY OF APPLICATION INTRODUCTIONS FOR CHAPTER 8.0, PERSONNEL TRAINING}

Sections 2.0 through 7.0 of this training plan contain the introductory language for each of the Solid Waste Disposal Division (SWDD) waste management units covered by this training plan: the 616 Nonradioactive Dangerous Waste Storage Facility (616 NRDWSF); the Central Waste Complex (CWC); the Low-Level Burial Grounds (LLBG); the 224-T Transuranic Waste Storage and Assay Facility (224-T TRUSAF); and the Waste Receiving and Processing Facility (WRAP). The introductory language in these sections will be located in Chapter 8.0 of the respective applications. The applications will include both Resource Conservation and Recovery Act of 1976 (RCRA) Part B Permit Applications and Corrective Action Management Unit Applications. As revisions to the applications are developed and submitted to the Washington State Department of Ecology (Ecology), additional introductory sections will be added to this training plan to include the other SWDD waste management units.

The appendices in this training plan, $8 \mathrm{~A}$ through 80 , have been written and formatted so that they can be copied directly into Chapter 8.0 of the respective applications for each of the SWDD waste management units. 


\subsection{CHAPTER 8.0, PERSONNEL TRAINING--616 NRDWSF}

This chapter outlines the training program developed and implemented for Solid Waste Disposal Division (SWDD) waste management units (units). The SWDD units include treatment, storage, and disposal (TSD) units and a Corrective Action Management Unit (CAMU). Specific SWDD units include the 616 Nonradioactive Dangerous Waste Storage Facility (616 NRDWSF); the Central Waste Complex (CWC); the Low-Level Burial Grounds (LLBG); the Environmental Restoration Disposal Facility (ERDF); the 224-T Transuranic Waste Storage and Assay Facility (224-T TRUSAF); and the Waste Receiving and Processing Facility (WRAP). The training plan provided in Appendices $8 \mathrm{~A}$ through 80 discusses training requirements pertaining to the 616 NRDWSF.

The training program is designed to be compliant with all applicable federal, state, and U.S. Department of Energy Richland Operations Office training requirements. The training program complies with requirements contained within WAC-173-303-330 for the development of a written dangerous waste training program. The training program is designed to prepare personnel to manage and maintain SWDO units in a safe, effective, efficient, and environmentally sound manner. In addition to preparing employees to manage and maintain SWDD units under normal conditions, the training program erisures that employees are prepared to respond in a prompt and effective manner should offnormal or emergency conditions occur.

This training plan is divided into four appendices. Appendix $8 \mathrm{~A}$ describes the Resource Conservation and Recovery Act of 1976 (RCRA) training program. Appendix $8 B$ describes the non-RCRA programs that are closely related to the RCRA programs. Appendices $8 C$ and 80 provide additional information supplementing the RCRA requirements. This format provides the ability to select appropriate sections of this training plan when a SWDD TSD unit becomes part of the Hanford Facility RCRA Permit (Permit). It is expected that selected RCRA sections from this training plan will become enforceable conditions included in Part III of the Permit when issued. 
WHC-SD-WM-TR-027 REV 0

This page intentionally left blank. 


\subsection{CHAPTER 8.0, PERSONNEL TRAINING--ERDF}

This chapter outlines the training program developed for the Solid Waste Disposal Division (SWDD) waste management units. The program will be implemented for the Environmental Restoration Disposal Facility (ERDF). The ERDF is not a Resource Conservation and Recovery Act of 1976 (RCRA) treatment, storage, or disposal (TSD) unit. The ERDF is defined as a RCRA Corrective Action Management Unit (CAMU). Though not explicitly required for a CAMU, the SWDD training program developed for SWDD TSD units will be implemented for ERDF.

The training program is designed to be compliant with all applicable federal, state, and U.S. Department of Energy, Richland Field Office training requirements. The training program complies with requirements contained within WAC-173-303-330 for the development of a written dangerous waste training program. The training program is designed to prepare personnel to manage and maintain SWDD units in a safe, effective, efficient, and environmentally sound manner. In addition to preparing employees to manage and maintain SWDD units under normal conditions, the training program ensures that employees are prepared to respond in a prompt and effective manner should offnormal or emergency conditions occur.

This training $p l a n$ is divided into four appendices. Appendix $8 A$ describes the RCRA training program. Appendix $8 B$ describes the non-RCRA programs that are closely related to the RCRA programs. Appendices $8 C$ and $8 D$ provide adoitional information supplementing the RCRA requirements. 
WHC-SD-WM-TR-027 REV 0

This page intentionally left blank. 
WHC-SD-WM-TR-027 REV 0

\subsection{CHAPTER 8.0, PERSONNEL TRAINING--CWC}

To be developed and inserted into respective Part $B$ Permit Applications as revised Part $B$ Permit Applications are submitted to the Washington State Department of Ecology. 
WHC-SD-WM-TR-027 REV 0

This page intentionally left blank. 


\section{WHC-SD-WM-TR-027 REV 0}

\subsection{CHAPTER 8.0, PERSONNEL TRAINING--LLBG}

To be developed and inserted into respective Part $B$ Permit Applications as revised Part $B$ Permit Applications are submitted to the Washington State Department of Ecology. 


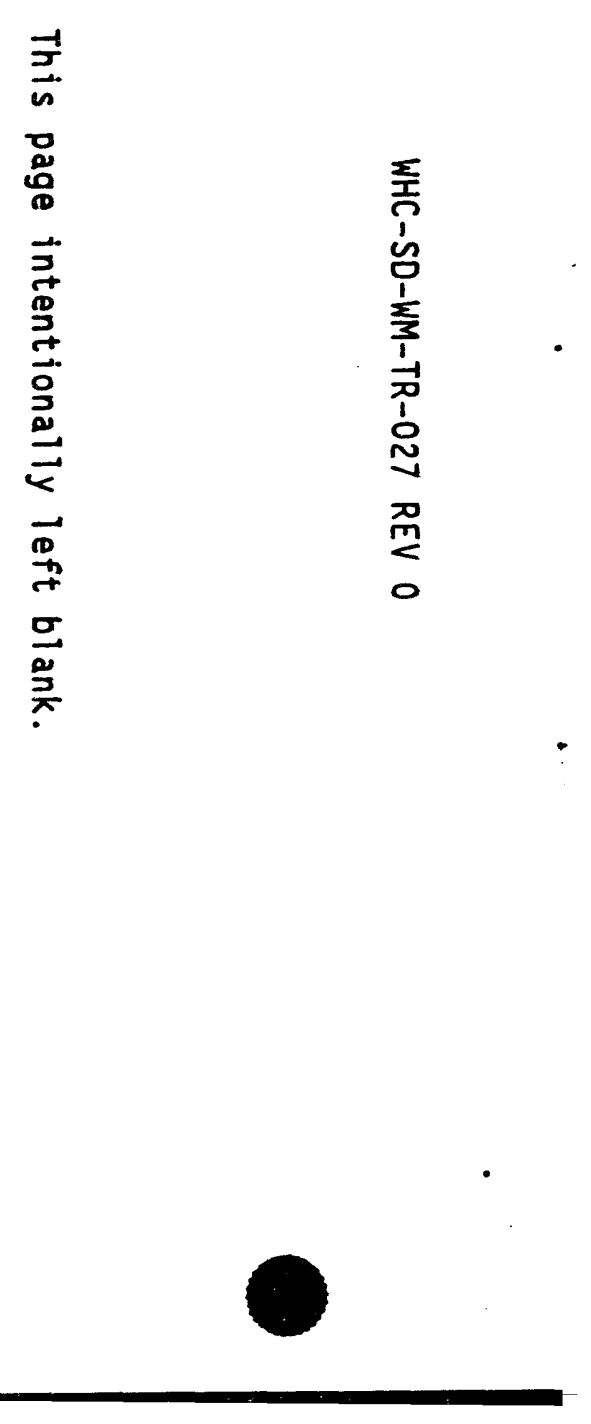


WHC-SD-WM-TR-027 REV 0

\subsection{CHAPTER 8.0, PERSONNEL TRAINING--224-T TRUSAF}

To be developed and inserted into respective Part $B$ Permit Applications as revised Part $B$ Permit Applications are submitted to the Washington State Department of Ecology. 
WHC-SD-WM-TR-027 REV 0

This page intentionally left blank. 
WHC-SD-WM-TR-027 REV 0

\subsection{CHAPTER 8.0, PERSONNEL TRAINING--WRAP}

To be developed and inserted into respective Part $\mathrm{B}$ Permit Applications as revised Part $B$ Permit Applications are submitted to the Washington State Department of Ecology. 
WHC-SD-WM-TR-027 REV 0

This page intentionally left blank. 
WHC-SD-WM-TR-027 REV 0

\subsection{REFERENCES}

Resource Conservation and Recovery Act of 1976, 42 USC 6901, et seq.

WAC 173-303, 1990, "Dangerous Waste Regulations," Washington Administrative Code, as ainended.

40 CFR 265, "Interim Status Standards for Owners and Operators of Hazardous Waste Treatment, Storage, and Disposal Facilities," Code of Federal Regulations, as amended. 
WHC-SD-WM-TR-027 REV 0

This page intentionally left blank. 
WHC-SD-WM-TR-027 REV 0

APPENDIX 8A

RCRA TRAINING

$8 A-i$ 
WHC-SD-WM-TR-027 REV 0

This page intentionally left blank. 


\section{CONTENTS}

8A-1.0 TRAINING PROGRAM DESCRIPTION .............. 8 . .

8A-1.1 TRAINING PROGRAM DIRECTOR ............. 8A-1

8A-1.1.1 SWDD Responsibilities . . . . . . . 8A-1

8A-1.1.2 Training Organization Responsibilities . . $8 A-1$

8A-1.1.3 RCRA Support Organization Responsibilities . $8 A-2$

8A-1.1.4 ICF Kaiser Hanford Company (ICF KH)

$8 A-1.2$

Responsibilities.... $8 A-2$

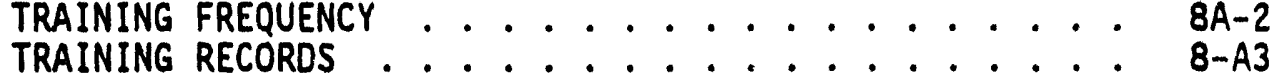

8A-1.3.1 Location of Training Record:.... $8 A-3$

8A-1.3.2 Access of Training Records . . . . . 8A-3

8A-1.3.3 Determining Current Training Status . . . . 8A-3

8A-2.0 ASSIGNING THE CORRECT TRAINING . . . . . . . . . . 8A-4 8A-2.1 EMPLOYEE CATEGORIES, JOB POSITIONS, AND DESCRIPTIONS - 8A-4

8A-2.1.1 All Employees.............. 8A-5

8A-2.1.2 General Worker . . . . . . . . . . . . 8A-6

8A-2.1.3 Advanced General Worker . . . . . . . . . 8A-6

8A-2.1.3.1 SWDD Operators . . . . . . . 8A-6

8A-2.1.4 General Manager . . . . . . . . . . 8A-7

8A-2.1.4.1 SWDD Building Emergency

Director/Aiternate(s) $8 A-7$

8A-2.1.4.2 SWDD Environmental Compliance
Officer

8A-2.1.4.3 SWDD Operations Management : $8 A-8$

8A-2.1.4.4 SWDD Engineers ........ . 8A-8

8A-2.1.5 General Shipper .......... . . 8A-9

8A-2.2 TRAINING PROGRAM AND STRUCTURE .......... . 8A-10

8A-2.2.1 Relevance of Training to Job Positions . . 8A-10

8A-2.2.2 Training Program Descriptions and Courses. . 8A-10

8A-2.2.2.1 Waste Management Orientation . 8A-10

8A-2.2.2.2 Waste Management Awareness . . 8A-12

8A-2.2.2.3 Waste Management Advanced . . . 8A-13

8A-2.2.2.4 Waste Management Administration . 8A-14

8A-2.2.2.5 Unit/Job Specific Training .. 8A-14

8A-2.2.3 Emergency Response Tra ining ....... 8A-15

8A-2.3 TRAINING TABLES AND ATTACHMENTS .......... 8A-16

$8 A-2.4$ LIST OF COURSES AND COURSE NAMES ........... . 8A-19

$8 A-3.0$ REFERENCES .................... . 8A-20 
WHC-SD-WM-TR-027 REV 0

LIST OF TABLES

8A-1 Worker Categories .................. 8A-5

8A-2 DOE-RL Program Area Descriptions . . . . . . . . . . 8A-11

8A-3 Applicability of WAC 173-303-330(1)(d) to SWDD Units . . . 8A-15

8A-4 SWDD Dangerous Waste Training Matrix . . . . . . . . . 8A-17

8A-5 SWDD Units Dangerous Waste Unit/Job Specific Training

Requirements for Advanced General Workers (SWDD Operators)

and General Managers ............... 8A-18

8A-6 Course Listing ................. . . 8A-19 


\section{A-1.0 TRAINING PROGRAM DESCRIPTION}

This appendix describes the Resource Conservation and Recovery Act of 1976 (RCRA) training program that is implemented at Solid Waste Disposal Division (SWDD) waste management units. Terms used in this appendix include Hanford Facility personnel, visitors, and subcontractors. Hanford Facility personnel include employees of the U.S. Department of Energy, Richland Operations Office (DOE-RL), and employees of the Hanford Facility major contractors (i.e., Westinghouse Hanford Company, Pacific Northwest

Laboratories, Bechtel Hanford Company). Visitors include personnel who do not have a contract in place with DOE-RL or the Hanford Facility major

contractors, and regulatory agency personnel who conduct regulatory compliance inspections. Subcontractors refer to any contractor working for DOE-RL or the major Hanford Facility contractors. These definitions could differ from other definitions used on the Hanford Facility to describe training requirements.

\section{A-1.1 TRAINING PROGRAM DIRECTOR}

The manager of each SWDD waste management unit has overall responsibility for all training at the SWDO units under their control. However, no one individual is designated as training director. The position is shared among SWDD, training, and support organizations. The SWDD can access training resources and experts from many different areas on hazardous material, dangerous waste management, and safety rather than rely on the knowledge of one or more persons. This shared responsibility ensures the identification of appropriate training requirements and that the training program meets all applicable dangerous waste management requirements. General responsibilities for training are discussed in the following sections.

\section{A-1.1.1 SWDD Responsibilities}

The SWDD has the following responsibilities related to training:

- Determine training requirements and training compliance for all Hanford Facility personnel, subcontractors, and visitors who obtain access or work within SWDO units

- Request and/or conduct training

- Submit training completion records to the Training Records Information (TRI) system

- Identify training requirements to contractors working in or around SWDD units.

\section{A-1.1.2 Training Organization Responsibilities}

Training organizations have the following responsibilities: 
- Conduct informal job analysis and identify training commensurate with personnel duties and responsibilities

- Design and develop training programs

- Develop and instruct training courses

- Develop and maintain on-the-job training requirements

- Operate and maintain centralized computerized training record files

- Track refresher requirements and maintain current training status for SWDD personnel

- Maintain the TRI system

- Process training completion records received into the TRI system.

\section{A-1.1.3 RCRA Support Organization Responsibilities}

The RCRA support organizations have the following responsibilities:

- Consult with training organizations and SWDD in the development and reevaluation of current training programs

- Assist SWDD managers in determining training requirements and RCRA compliance for personnel

- Maintain current knowledge of RCRA training requirements pertaining to Hanford Facility personnel.

\section{A-1.1.4 ICF Kaiser Hanford Company (ICF KH) Responsibilities}

ICF KH, whose personnel are classified as Hanford Facility personnel, has the following responsibilities:

- Ensure ICF KH employees are trained to meet SWDD unit training requirements

- Maintain ICF KH employee training records and provide them if requested by SWDD.

\section{A-1.2 TRAINING FREQUENCY}

New employee training is completed within the first 6 months of assignment to SWDD or to a new position within the SWDD units, whichever is later. After completing introductory training, employees are required to receive annual refresher training for RCRA-related courses to meet continuing training requirements, unless otherwise justified. When annual refresher training is not warranted, the justification will be provided in the 
WHC-SD-WM-TR-027 REV 0

corresponding course description in Appendix 8C. Refresher training for nonRCRA courses can occur either annually or biennially. Untrained amployees are not allowed to work at SWDD units without supervision by a trained employee. The SWDD operations management is responsible for ensuring that all SWDD employees are trained and that certifications are maintained. To help inform SWDD operations when training will expire, a tickler file is available to indicate when training is within 90 days of expiration.

\section{A-1.3 TRAINING RECORDS}

\section{A-1.3.1 Location of Training Records}

Training records, as described in WAC 173-303-330, consist of documentation that shows training has been completed. Hanford Facility training records include both electronic data storage and hard copies. The electronic data storage information is the training record initially presented to demonstrate that personnel at SWDD units have been trained. After a course is completed, the electronic data storage record is created on the TRI system. The electronic data storage record will contain the course number, course title, date of attendance, and any refresher dates.

Hard coples of training records that are sent to the training record organization for entry onto the TRI system are initially maintained in Richland, Washington. Original hard copy training records are transferred quarterly to the Records Holding Facility in Richland, Washington. After approximately 1 year, the original hard copy training records are archived at the Federal Records Center in Kent, Washington. Electronic data storage and hard copy training records on former employees are kept for at least 3 years from the date the employee last worked at a SWDD unit.

\section{A-1.3.2 Access of Training Records}

When a training record is requested during an inspection, an electronic data storage record will initially be provided. When the electronic data record does not satisfy the inspection concern, a hard copy training record will be provided. Training records on former employees may not be available for normal users and may require a representative from the training records organization to access the TRI system for this information.

\section{A-1.3.3 Determining Current Training Status}

After an electronic data storage training record is obtained, it will be compared to information in Appendices $8 A$ and 80 of this plan. This plan can be used to determine the RCRA training status of all Hanford Facility personnel, visitors, and subcontractors. The electronic data storage training record coupled with this training plan will allow any inspector the ability to quickly determine the training status of personnel in the field. To accomplish this, the correct training must be assigned after properly categorizing personnel into a variety of program areas. 
WHC-SD-WM-TR-027 REV 0

\section{A-2.0 ASSIGNING THE CORRECT TRAINING}

\section{A-2.1 EMPLOYEE CATEGORIES, JOB POSITIONS, AND DESCRIPTIONS}

Five general worker categories are defined for compliance with the Hanford Facility dangerous waste training requirements. Personnel duties and responsibilities may overlap between categories. When overlaps occur, personnel will complete appropriate training pertaining to each category. The determining factor for placing specific personnel within any of the worker categories is the corresponding job duties. The five worker categories are as follows :

1. All Employees

2. General Worker

3. Advanced General Worker

4. General Manager

5. General Shipper.

The duties corresponding to these categories can be divided between "generator" and "SWDO unit" operations. The level of training is determined by the duties associated with each worker category. The descriptions of job duties for each category are general in nature; however, they do provide adequate specifics that can be matched to individual job titles or job positions commoniy employed at the Hanford Facility. A general description of the duties associated with each worker category is contained in Table $8 A-1$.

The SWDD unit personnel are assigned a job title (from the salaried nonexempt or bargaining unit classifications) or position (from the exempt classifications). The job or position descriptions include applicable requisite skills, work experience, education, other qualifications, and a brief 1 ist of duties and/or responsibilities for each job title or position. Information regarding work experience, education, and other qualifications required for each position is maintained on the Hanford Facility. In general, all personnel require a high school diploma or General Educational Development (GED) certificate. Personnel filling exempt management or engineering positions may require a college degree with 2 or more years of industry experience. Many prerequisites exist for these positions. In some cases, a college degree may be waived as a prerequisite requirement. An equivalent combination of education and experience also may be accepted. Additional information on specific prerequisites can be provided upon request to SWDD management.

The following sections describe, within the appropriate worker category, job titles and brief position descriptions of Hanford Facility personnel, visitors, and subcontractors associated with dangerous waste management at SWDD units. Subcontractors and visitors requiring access to work or tour SWDO units must complete the appropriate level of training determined by SWDD management according to their job duties. Most visitors and subcontractors will be trained as if they were in the All Employee or General Worker categories, respectively. 
Table 8A-1. Worker Categories.

\begin{tabular}{|c|c|c|}
\hline Horker cotenoein & ennereter Job putlen. & 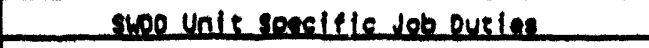 \\
\hline All Employees & $\begin{array}{l}\text { le not categorized as a Genoral Worker, } \\
\text { Advaneed General Worker, Oenoral Manager, } \\
\text { or eenerel shipear. }\end{array}$ & $\begin{array}{l}\text { Outies are the same as for generator job } \\
\text { duties. }\end{array}$ \\
\hline General Worker & 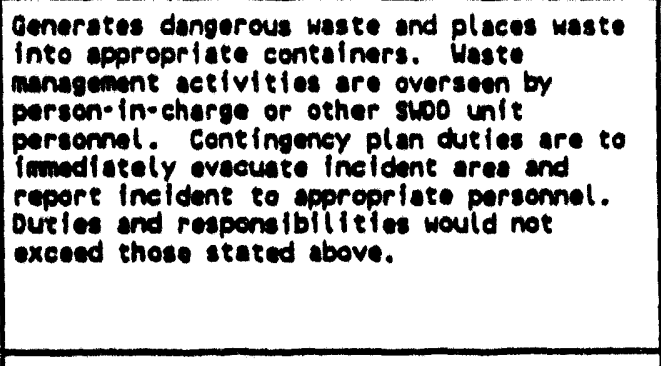 & 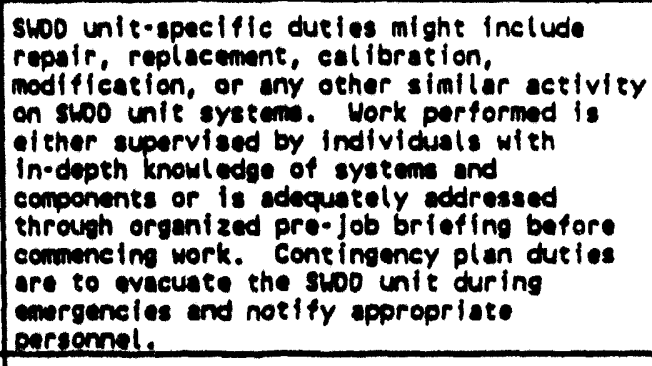 \\
\hline $\begin{array}{l}\text { Advanced General } \\
\text { Worker }\end{array}$ & 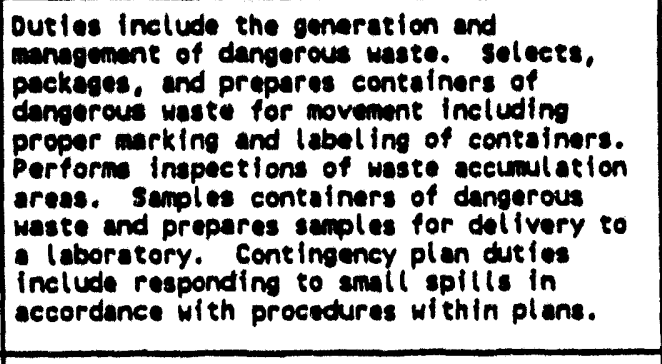 & 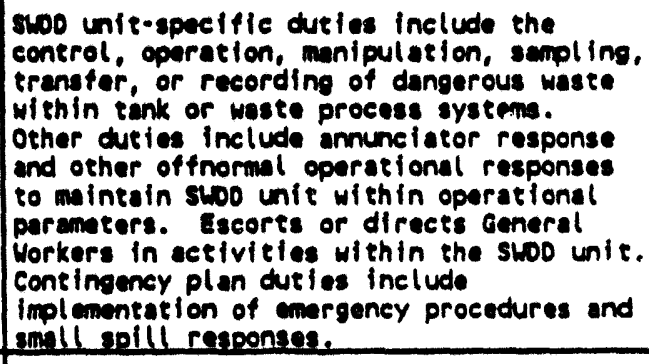 \\
\hline General Manager & 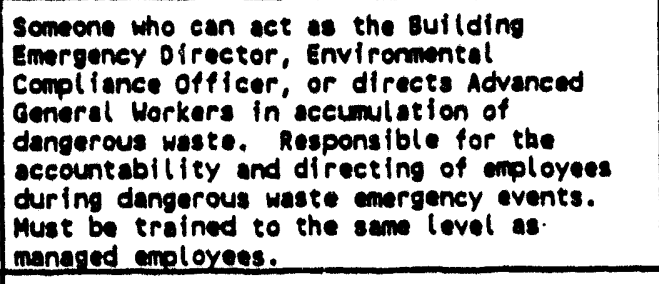 & $\begin{array}{l}\text { Outies are the same as for generator job } \\
\text { duties }\end{array}$ \\
\hline General Shipper & $\begin{array}{l}\text { Dut les include the preparation and shipment } \\
\text { of dangerous waste containars in compli ance } \\
\text { with appl leable requirements. Directs } \\
\text { General and Advanced General workers in } \\
\text { dangerous waste management and/or } \\
\text { transportation ectivitiles. Authorized } \\
\text { individual for signing offsite waste } \\
\text { manifests. }\end{array}$ & $\begin{array}{l}\text { Dutles are the same as for generator job } \\
\text { duties. }\end{array}$ \\
\hline
\end{tabular}

Personnel who have completed training offsite are required to provide a certificate or other suitable training course(s) evidence that meets the requirements of WAC 173-303 and this section. SWDD management, or a delegated representative, must verify the acceptability of offsite training as commensurate with the employee's anticipated job assignment and the minimum training requirements referenced in this section.

\section{A-2.1.1 Al1 Employees}

Hanford Facility personnel included in this category are not categorized into one of the other four worker categories. Personnel in the All Employees category will have no duties or responsibilities associated with the management of dangerous waste in accumulation containers, or with the critical system of the SWDD unit. Most of the personnel categorized as All Employees 
will be administrative personnel and visitors, subcontractors, or support organizations who tour or provide oversight at the SWDO unit. Although visitors and subcontractors are not defined as Hanford Facility personnel, they are still trained to a level equivalent to the All Employees category.

\section{A-2.1.2 General Worker}

Hanford Facility personnel or subcontractors with waste management duties limited to the generation of waste and placing that waste into a pre-approved container are classified as General Workers. In addition, these personnel could be working on the critical system(s) of a SWDD unit conducting maintenance or modification. Employees classifted as General Workers will not assume responsibilities that involve the inspection, advanced marking, or movement of accumulation containers. Personnel who function as General Workers may include, but are not limited to, the following:

- Maintenance personnel

- Health physics techniclans

- Supervisors of ICF KH general workers

- Contractor crafts

- Truck drivers.

\section{A-2.1.3 Advanced General Worker}

Hanford Facility personnel are categorized as Advanced General Workers if their job duties exceed that of General Workers. These personnel manage dangerous waste that can include the inspection, advance marking, or movement of containers. These personnel can also be involved in the operation of the SWDD unit's critical system(s). These personnel typically have responsibility to act and/or notify SWDD operations management when an incident occurs which requires immediate response, such as a spilled container or process upset.

8A-2.1.3.1 SWDD Operators. The SWDD operators can rotate through SWDD units and be assigned to different units during the year. Responsibilities and duties are similar regardiess of the SWDD unit where the operators are currently working. Responsibllities for all SWDD operators at SWDD units include the following:

- Perform SWDD unit work activities in accordance with current operating procedures

- Escort supporting crafts and visitors working in or entering the SWDD unit

- Receive, segregate, sort, inventory, store, and stage dangerous waste

- Perform sampling as required by procedure

- Conduct routine inspections

- Provide surveillance of SWDD unit area for offnormal conditions 
- Assist truck drivers in loading and unloading at the SWDD units

- Ensure that trucks transporting dangerous waste are properly placarded

- Respond to alarms at the SWDD units

- Respond to offnormal and/or emergency conditions according to established procedures

- Respond to dangerous waste leaks or spills

- Ensure that the waste has been properly secured in the transportation vehicle.

\section{A-2.1.4 General Manager}

Vartous types of management are included in this category. In addition, engineers assigned to SWDO units can be classified as General Managers if their involvement in waste management warrants such a classification. Other than the difference in titles, managers and engineers at SWDD units have many similar responsibilities and are required to take the same courses. The following managers are included within this category: (1) personnel who act as the Emergency Coordinator and/or alternate(s), (2) the Environmental Compliance Officer for the SWDD unit, and (3) managers of Advanced General Workers (1.e., operations managers). Engineers can be classified as General Managers if their responsibllities affect the critical system(s) of a SWDD unit.

8A-2.1.4.1 SWDD Buflding Emergency Director/Alternate(s). Responsibilities of the SWDO Emergency Coordinator/alternate(s) include the following:

- Function as the Emergency Coordinator as defined in WAC 173-303-360

- Determine if a RCRA contingency plan has been implemented during the course of an incident or process upset

- Ensure all reports to the Washington State Department of Ecology have been made after an incident or process upset has occurred

- Become thoroughly familiar with SWDD unit contingency plans, operations, activities, location and properties of all wastes handled, location of ail records for the SWDD unit, and the SWDO unit layout.

8A-2.1.4.2 SWDD Environmental Compliance Officer. Responsibilities of the SWDD Environmental Compliance Officer include the following:

- Provide support to the SWDD unit management to ensure compliance with the applicable environmental compliance requirements as identified in this manual, environmental permits, the Hanford Federal Facility Agreement and Consent Order (Ecology et al. 1994), and other compliance orders 
- Ensure that the SWDD unit management is aware of the unit's environmental compliance status and the unit's environmental compliance activities

- Understand and by able to explain the SWDO unit's environmental compliance status with all applicable environmental requirements

- Advise the SWDO unit imenagement of new environmental requirements and policies, the assocted impacts, and recommended implementation mechanisms to ensure compliance.

8A-2.1.4.3 SWDD Operations Management. Responsibilities of the SWDD operations management include the following and are similar for each SWDD unit:

- Maintain control over SWDD unit operations in accordance with established operating procedures and policies, DOE orders, and federal and state regulations

- Direct, control, and coordinate the receipt, storage, transfer, and reprocessing of dangerous waste

- Ensure compliance with SWDO unit operating limits and specifications

- Ensure that pre-job safety and planning meetings are conducted, as applicable, with Hanford Facllity personnel, visitors, and subcontractors involved with the SWDD unit operations

- Ensure that regulatory records are maintained

- Understand SWDO unit operating procedures as applicable

- Respond to and provide remedial guidance and decisions for operational anomalies, offnormal conditions, and equipment malfunctions

- Respond to offnormal and/or emergency conditions according to established procedures

- Coordinate the recovery from, measure, and reestablish control of unplanned releases to the environment and other emergency conditions

- Notify the Emergency Coordinator of any unplanned releases to the environment.

8A-2.1.4.4 SWDO Engineers. Responsibilities of SWDD engineers (may include cognizant, systems, test, and/or maintenance engineers) include the following:

- Ensure that emergency and monitoring equipment, process equipment, procedures, designs, etc., comply with DOE orders, federal and state regulations, national standards, and applicable engineering procedures and management standards 
- Issue and maintain, or provide oversight and review of, operating documentation, operating procedures, flowsheets, sample schedules, specifications, process test plans and procedures, operational safety requirements, and other documents necessary to operate the SWDD units

- Perform routine and comprehensive evaluations of SWDD unit processes to ensure compliance with process control requirements, procedure compliance, and equipment performance, assessing problem areas and implementing timely corrective actions

- Prepare, issue, and review operating procedures and departure authorizations

- Maintain instrument and equipment flow diagrams

- Prepare design criteria and perform and approve design analysis

- Prepare and approve equipment and material specifications for new design

- Prepare and approve engineering design documents and drawings that are in compliance with applicable policies, procedures, and instructions in accordance with recognized national standards and codes

- Provide input to environmental permit applications

- Develop procedures for inspecting and replacing emergency and monitoring equipment

- Ensure compliance with requirements, applicable policies, programs, regulations, and DOE orders to ensure personnel safety, environmental compliance, and public safety

- Review and revise maintenance procedures and work plans, and ensure that procedures are current and accurate

- Provide technical direction for hazardous material and dangerous waste spill responses

- Respond to offnormal and/or emergency conditions according to established procedures.

\section{A-2.1.5 General Shipper}

General Shippers prepare and sign documentation for the shipment of dangerous waste. The SWDD units involve both onsite shipments and offsite shipments as defined by WAC 173-303-040. General Shippers who sign Uniform Hazardous Waste Manifests for offsite shipments are included within this appendix. Requirements for General Shippers who sign paperwork associated with onsite waste movements are discussed in Appendix 88. 
Offsite shipments are made from the 616 Nonradioactive Dangerous Waste Storage Facility (NRDWSF). In the future, offsite shipments may be made from other SWDD units; however, they are not occurring at this time. Offsite shipments may be received at some or all of the SWDD units. These shipments are received at the SWDD unit by SWDD operators who are categorized as Advanced General Workers. The SWDD operators will not be categorized as General Shippers because they are involived in the receipt of an offsite waste shipment.

\section{A-2.2 TRAINING PROGRAM AND STRUCTURE}

The Hanford Factlity training program was developed using a graded approach to training after reviewing DOE orders and federal and state regulations. Tasks performed by personnel in selected job positions were identified and evaluated to determine training requirements. In addition, training needs are evaluated continually in relation to current DOE orders and federal and state regulations. The current training program will be revised as necessary.

\section{A-2.2.1 Relevance of Training to Job Positions}

After assigning Hanford Facility personnel, visitors, and subcontractors into a worker category, the training program must ensure that those individuals receive training commensurate with their duties and responsibilities. Some of these duties are general in nature and can be taught in a course for all personnel within a worker category on the Hanford Facility. Other considerations are specific to either all or one SWDD unit and do not apply to other treatment, storage, and disposal (TSD) units managed on the Hanford Facility. The training program is therefore designed to address concerns on a general perspective and a unit/building perspective.

\section{A-2.2.2 Training Program Descriptions and Courses}

The Hanford Facility training program is divided into five program areas. These program areas are described in Table $8 A-2$ as orientation, awareness, advanced, administration, and unit/job specifics. Three of these program areas are further divided into general training and unit/building specific training categories. These three areas are orientation, awareness, and advanced.

8A-2.2.2.1 Waste Management Orientation. All Hanford Facility personnel are required to complete Waste Management Orientation training. In general, the waste management orientation program includes training to emergency responses, identifying contacts for personnel to obtain dangerous waste management information, and waste minimization concepts. Visitors and subcontractors a) so will receive appropriate training in the Waste Management 
Table 8A-2. DOE-RL Program Area Descriptions.

\begin{tabular}{|c|c|}
\hline Progrem & Deseriptions \\
\hline $\begin{array}{l}\text { Waste Management } \\
\text { Orieritation }\end{array}$ & $\begin{array}{l}\text { Training at this level involves a basic introduction to dangerous waste management and } \\
\text { contacts involving dangerous waste. Correct response to emergencies involving releases } \\
\text { of materials to the environment is addressed. Training also includes discussion of } \\
\text { the Henford facillity contingency Plen (DOE-RL 1993) and other agol ieable conditions. }\end{array}$ \\
\hline $\begin{array}{l}\text { Unie/Bldg } \\
\text { Orientation }\end{array}$ & 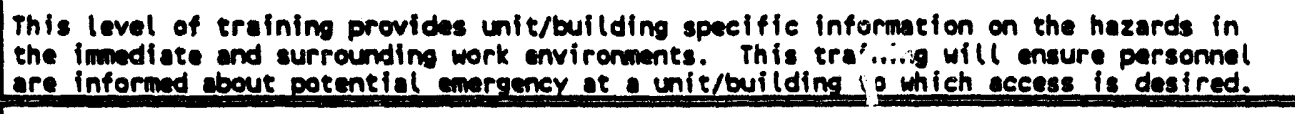 \\
\hline $\begin{array}{l}\text { Waste Managefient } \\
\text { Awareness }\end{array}$ & 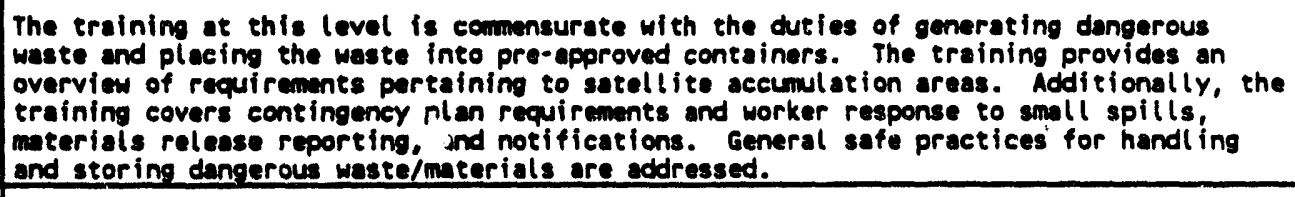 \\
\hline $\begin{array}{l}\text { Unit/Bldg } \\
\text { Awareness }\end{array}$ & $\begin{array}{l}\text { This level of the training encompesses the job-spectfic or building-specific } \\
\text { requirements that supplement the information provided in waste management awareness. } \\
\text { The training provides persomnel with proper waste hendl ing and emergeney procedures } \\
\text { relevent to their responsibilities during normal operations and emergencies. }\end{array}$ \\
\hline $\begin{array}{l}\text { Waste } \\
\text { Management } \\
\text { Advanced }\end{array}$ & $\begin{array}{l}\text { The training at this leval is for personnel required to properly select, package, and } \\
\text { prepare for the movement of dangerous waste containers. General advanced training is } \\
\text { provided only for container management. Training for other RCRA units such as tank } \\
\text { systems, surface impoundments, landfllis, etc., must be covered through the } \\
\text { unit/bui lding specific portion of the advaneed program. This is the most comprehens ive } \\
\text { container waste management training provided to personnel and covers the necessary } \\
\text { information regarding documentation, reporting, reeordkeeping, and other information } \\
\text { pertaining to the generation of dangerous waste and movement of the waste to a TSO } \\
\text { unit. }\end{array}$ \\
\hline Unit/Bldg Advanced & $\begin{array}{l}\text { This level of training provides specific information required to operate, control, and } \\
\text { manage processes and dangerous waste management operations. Cons iderations for this } \\
\text { progran involve container management as well as all other RCRA units sueh as tank } \\
\text { systems, surface impoundments, landfills, etc. This program can be deferred to the } \\
\text { unit/job specific program area if operator/supervisor certification programs must be } \\
\text { administered at the iso unit. Persornel who monitor and inspect tank systems receive } \\
\text { training in this program area for operations, maintenance, and response to nonroutine } \\
\text { conditions. }\end{array}$ \\
\hline $\begin{array}{l}\text { Maste } \\
\text { Management } \\
\text { Achin. }\end{array}$ & $\begin{array}{l}\text { Training at this level is for general shippers and those who must resolve problems and } \\
\text { issues related to dangerous waste management. This training covers aspects of waste } \\
\text { minimization, waste management, and recordkepping for the Hanford Facility. }\end{array}$ \\
\hline $\begin{array}{l}\text { Unit/Job } \\
\text { Specific }\end{array}$ & $\begin{array}{l}\text { The training at this level is des igned to provide additional generator/SwDo } \\
\text { unit/building speeific information for personnel to ensure the safe and efficient } \\
\text { speration and maintenance of SWDO unit processes and operations. Not all training } \\
\text { within this progra will be RCRA related. Some operator/supervisor certification } \\
\text { programs are not based on dangerous waste manugement. in these cases, the training } \\
\text { plan will identify which portions of this program will be included within the RCRA } \\
\text { training progrem. }\end{array}$ \\
\hline
\end{tabular}


Orientation program area for the locations such personnel will be at and the activities that will be undertaken. The concepts must be covered generally as they pertain to the Hanford $F_{a}$. llity and on a unit/building basis to inform personnel of the hazards in their immediate and surrounding environments. When unit/building specific training requirements are waived, personnel must be escorted by qualified SWDD unit personnel. In these cases, it is the escorts responsibility to explain and announce the hazards in their immediate and surrounding environments. The following courses address training concerns within Waste Management Orientation:

\section{Hanford Facility personnel}

- New Hire Orientation (NHO)

Retraining: Hanford General Employee Training (HGET)

- SWDD unit/building specific orientation (this requirement is waived when non-SWDD unit personnel are escorted by qualified SWDD unit personnel)

Retraining: HGET

\section{Visitors}

- Visitor/Vendor Training Retraining: none

- Escorted by qualified SWDD unit personnel (see Appendix 88 for cases when SWDD unit/building specific orientation may be required) Retraining: none

\section{Subcontractors}

- NHO or Visitor/Vendor Training

Retraining: HGET or none: time dependent

- SWDD unit/building specific orientation or escorted by qualified SWDD unit personnel

Retraining: HGET or none: time dependent.

8A-2.2.2.2 Waste Management Awareness. In addition to Waste Management Orientation, General Workers, Advanced General Workers, General Managers, and General Shippers must complete Waste Management Awareness training.

Subcontractors could also fall within this program description because many subcontractors are categorized as General Workers. Training at this level is commensurate with the duties of performing maintenance or construction activities where a dangerous or mixed waste is generated. Unit/building specific training also is provided in the awareness program area. The training courses that are provided for this program include the following:

\section{Hanford Facility personnel}

- Generator Hazards Safety Training Retraining: Provided through the non-RCRA Occupational Safety and Health Administration (OSHA) training in Appendix 8B 
WHC-SD-WM-TR-027 REV 0

- SWDD unit/building specific Building Emergency Plan training (training may be provided through SWDD unit/building specific orientation)

Retraining: same

\section{Visitors}

- SWDO unit/building specific emergency response training (see Appendix 88 for cases when SWDO unit/building specific orientation may be required)

Retraining: none

\section{Subcontractors}

- Generator Hazards Safety Training

Retraining: Provided through the non-RCRA OSHA training in Appendix 88

- SWDD unit/building specific Building Emergency Plan training if not escorted by qualified SWDO personnel (training may be provided through SWDD unit/building specific orientation)

Retraining: same.

8A-2.2.2.3 Waste Management Advanced. Waste Management Advanced training must be completed by Advanced General Workers, General Managers, and General Shippers. General Managers complete training in the environmental regulations and/or environmental compliance course. Advanced General Workers and General Shippers complete training associated with containerized waste management. SWDD units subject to this training plan concern activities associated with container management (i.e., 616 NRDWSF, 224-T Transuranic Waste Storage and Assay Facility [TRUSAF], Central Waste Complex [CWC]), treatment (i.e., Waste Receiving and Processing Facility [WRAP]), and disposal (i.e., Low-Level Burial Grounds [LLBG], and Environmental Restoration Disposal Facility [ERDF]) of dangerous or mixed waste. Courses intended for this program area include the following:

- Core Waste Management training Retraining: Core Waste Management Refresher

- Building Emergency Director Training Retraining: Building Emergency Director refresher

- Environmental Regulations at Hanford Retraining: Environmental Regulations and Compliance Refresher

- Environmental Compliance at Hanford Retraining: Environmental Regulations and Compliance Refresher

- Unit/building specific training (see Section 8A2.2.2.5).

Visitors and subcontractors will not require training under the Waste Management Advanced program as their duties and responsibilities will not involve this program area. 
8A-2.2.2.4 Waste Management Administration. Waste Management Administration training is targeted for General Shippers and personnel who must resolve problems and issues related to waste management. This program ai'ea covers administrative aspects of waste minimization, waste management, and recordkeeping. Courses in this program area include the following:

- Hazardous Waste Shipment Certification Refresher: same

- Waste Management Administrative Retaining: Waste Management Refresher

- Waste Designation Support Retraining: same

- Facility Waste Sampling and Analysis Retraining: $N / A$, one-time course.

8A-2.2.2.5 Unit/Job Specific Training. To ensure that Hanford Facility personnel receive appropriate training in SWDD unit operations, SWDD operators and operations managers/supervisors complete specific courses in preparation for work assignments. Certifications for job-specific work assignments have been developed in accordance with DOE Order 5480.20. The training at this level is designed to provide additional information to ensure the safe and efficient operation and maintenance of SWDD unit processes and operations. Additionally, the training provides more detalled information for the response to emergencies and offnormal events that could occur within the SWDD unit.

A certification program is available for each of the SWDD units. Each certification is developed around dangerous and mixed waste operations and, therefore, all SWDD unit certification packages are included within the RCRA portion of this training plan. Whenever an SWDD operator rotates from one unit to another within SWDD, a different certification package will be completed before personnel are allowed to work unescorted within the SWDD unit.

Certification is required for personnel working in selected job positions (operations managers/supervisors and nuclear operators). To become certified, personnel must successfully complete classroom training, self-study, and on-the-job training as applicable. Classroom instruction and/or self-study is designed to provide personnel with the knowledge required to work safely at SWDD units.

The on-the-job training requires affected SWDD employees to gain experience with the operating procedures. All work involving hazardous materials and dangerous waste management is performed according to approved operating procedures; therefore, an understanding of procedures is crucial to ensure the proper and safe operation of the SWOD units' critical system(s). Personnel learn the procedures by performing, simulating, and/or describing a particular task as specified by the appropriate operating procedure.

Personnel demonstrating the required knowledge and skills are observed by certified personnel. An operational examination administered by an independent evaluator is required following satisfactory completion of the written examination and observation by certified personnel. Certification 
follows satisfactory completion of the operational examination. Courses identified under this program area include the following:

- 616 Nonradioactive Dangerous Waste Storage Facility Operator Certification program

Retraining: same

- 224-T Transuranic Storage and Assay Facility Operator Certification program

Retraining: same

- Central Waste Complex Operator Certification program

Retraining: same

- Low-Level Burial Grounds Operator Certification program

1. Low-Level Burial Grounds

2. TRU Retrieval

3. Environmental Restoration Disposal Facility: TBD

Retraining: same (for all three)

- Waste Receiving and Processing Facility Operator Certification program: TBD

Retraining: same

- Manager/Supervisor Certification program

Retraining: same.

\section{A-2.2.3 Emergency Response Training}

Federal and state regulations require that personnel be able to respond effectively to emergencies. In accordance with WAC 173-303-330(1)(d), personnel are trained on emergency equipment, systems, and procedures. SWDD units involve the management of waste within containers in storage units and waste in disposal units. Treatment of mixed waste is planned for WRAP. Table 8A-3 indicates those items within WAC 173-303-330(1)(d) that are applicable to SWDD unit operations.

Table 8A-3. Applicability of WAC 173-303-330(1)(d) to SWDD Units.

\begin{tabular}{|c|c|}
\hline Wac $173-303-330(1)(d)$ Criterie & Apol icability to swop Units \\
\hline $\begin{array}{l}\text { Procedures for using, inspecting, repairing, and replacing swoo unit } \\
\text { emergency and monitoring equigment }\end{array}$ & Y \\
\hline Key paremeters for automatic waste feed eut-off systems & $y^{1}$ \\
\hline Commichefons or alarm systems & $y$ \\
\hline Response to fires or explosions & $y$ \\
\hline Response to groundwater contamination incidents & $y^{2}$ \\
\hline Shuedown of operations & $\gamma^{1}$ \\
\hline
\end{tabular}

IAppl icable only to WRAP.

2Appl ieable only to LLBG and ERDF. 
Specific topics required by federal and state dangerous waste regulations are included in many courses taught at the Hanford Facility. The courses cover many different program areas. For example, some courses address the orientation program area required of all Hanford Facility personnel. At the other end of the spectrum, some of these courses concern responsibilities of the Emergency Coordinator as defined in WAC 173-303-360. All of the following courses are described in Appendix 8C:

- NHO

- HGET

- Bullding Emergency Plan

- SWDD operator certification training for each SWDD unit

- Solid waste manager/supervisor certification training

- Building Emergency Director training.

\section{A-2.3 TRAINING TABLES AND ATTACHMENTS}

After categorizing Hanford Facility personnel, visitors, and subcontractors into the worker categories, duties and responsibilities are evaluated. The duttes and responsibilities will determine appropriate courses from the five training program areas. Table 8A-4 shows the interaction between worker categories and program areas. Table 8A-5 includes the additional unit/job specific training required for the operator/supervisor certification packages.

Appendix $8 C$ contains a brief description of the training courses for the SWDO RCRA training program, including course title and number, brief course description, mandating document(s) (as applicable), target audience, instructional delivery, evaluation method, length of course, and frequency of retraining.

Appendix 80 provides tables for Hanford Facility personnel who are categorized as Advanced General Workers, General Managers, and General Shippers. These tables identify the required RCRA courses for these Hanford Facility personnel by personnel name. Example tables are provided to eliminate the need to modify Appendix 80 every time a name is changed at the SWDD units. Appendix 80 is used to fllustrate the type of training table that will be avallable upon request to an inspector on a regulatory compliance inspection. The inspector should expect to see a table similar to those in Appendix 80 when making inquiries regarding the proper training of these types of personnel.

Text discussing Waste Management Orientation and Waste Management Awareness in Section $8 A 2.2 .2$ will be used to determine if visitors and subcontractors have received the correct training. Table $8 A-4$ will be used to determine the training status of Hanford Facility personnel who are categorized as All Employees or General Workers. 
Table 8A-4. SWDD Dangerous Waste Training Matrix.

\begin{tabular}{|c|c|c|c|c|c|c|c|}
\hline \multirow[b]{2}{*}{ Program Areo } & \multirow[b]{2}{*}{ Course Title } & \multirow[b]{2}{*}{ Freq } & \multicolumn{5}{|c|}{ Morker Category } \\
\hline & & & $\begin{array}{c}\text { All } \\
\text { Enployees }\end{array}$ & $\begin{array}{l}\text { General } \\
\text { Horker }\end{array}$ & $\begin{array}{l}\text { Mdvenced Ceneral } \\
\text { Yorker }\end{array}$ & $\begin{array}{l}\text { Ceneral } \\
\text { Mangeger }\end{array}$ & $\begin{array}{l}\text { General } \\
\text { Shipper }\end{array}$ \\
\hline $\begin{array}{l}\text { Waste Managewant } \\
\text { Orientation }\end{array}$ & W10 02006A: Refresher 000001 & (1) & $x^{1}$ & $x^{1}$ & $x$ & $x$ & $x$ \\
\hline Unit/Blde orientation & soo Unit orientation: Refresher 000001 & (1) & $x^{1,2}$ & $x^{1,2}$ & $x$ & $x$ & $x$ \\
\hline $\begin{array}{l}\text { Haste Management } \\
\text { Awareness }\end{array}$ & $\begin{array}{l}\text { Generator Mazards Safety Training } 020066 \\
\text { (refer to course description) }\end{array}$ & (1) & & $x^{1}$ & $\mathbf{x}$ & $\mathbf{x}$ & $x$ \\
\hline Unit/Bldg Awareness & $\begin{array}{l}\text { swo Unit Specific Bullding Exergency Plan } \\
\text { (refer to course description) }\end{array}$ & (1) & & $x^{1,2}$ & $\boldsymbol{x}$ & $x$ & $x$ \\
\hline \multirow[t]{3}{*}{$\begin{array}{l}\text { Uaste Management } \\
\text { Advanced }\end{array}$} & $\begin{array}{l}\text { Core Uaste Managewent Training 035100: } \\
\text { Refresher 035110 }\end{array}$ & (1) & & & $x^{3}$ & $x^{4}$ & \\
\hline & $\begin{array}{l}\text { Qullding Emergency Director Training 020280: } \\
\text { Refresher } 037510\end{array}$ & (1) & & & & $x^{5}$ & . \\
\hline & $\begin{array}{l}\text { Environental Compliance at Manford - } 035050 \text { or } \\
\text { Emiromental Regulations at Hanford - 035040: } \\
\text { Refresher } 035055\end{array}$ & (1) & & & & $x^{6}$ & \\
\hline \multirow{4}{*}{$\begin{array}{l}\text { Waste Management } \\
\text { Adtainistration }\end{array}$} & Mazardous Uaste Shipment Certification 020159 & (2) & & & & & $x$ \\
\hline & $\begin{array}{l}\text { Uaste Manageaent Administration 035120: } \\
\text { Refresher 035130 }\end{array}$ & (1) & & & & & $x$ \\
\hline & Waste Designation Support 035010 & (1) & & & & & $x$ \\
\hline & Facillity Waste Sampling and Anatysis 035020 & One time & & & & & $x$ \\
\hline Unit/Job Specific & Certifications or Other Iraining & (1) or (2) & & & $x^{7}$ & $x^{7}$ & \\
\hline
\end{tabular}

(1) Annually

(2) Repeated every 2 years

Equivalent training exists for visitors and subcontractors.

Iraining requirement waived when escorted by qual ified SLDO personnel.

3 Required only for Advanced General Workers managing waste in containers.

5 Required only for Advanced General Worker Managers.

6 Required only for Emergency Coordinator and Al ternates.

6 ECO Engineers, and Level 4, 5, and 6 Managers take 035050.

Refer to Table 8 - 5 . 
Table 8A-5. SWDD Units Dangerous Waste Unit/Job Specific Training Requirements for Advanced General Workers (SWDD Operators) and General Managers.

\begin{tabular}{|c|c|c|c|c|c|c|c|c|}
\hline \multirow{3}{*}{ sido Units } & 616 mousf & cuc & 224-T TRUSAF & maP & \multicolumn{3}{|c|}{ LLEG } & \multirow{3}{*}{$\begin{array}{l}\text { General Hensers } \\
\text { All spo Units } \\
3005 \% \text { (B) }\end{array}$} \\
\hline & \multirow[b]{2}{*}{$300050(8)$} & \multirow[b]{2}{*}{$300020(8)$} & \multirow{2}{*}{$300030(8)$} & \multirow{2}{*}{$(T E D)$} & $\angle L B G$ & EQDF & IwU Retrieval & \\
\hline & & & & & $300040(8)$ & (thd) & $300010(B)$ & \\
\hline 616 meousf & $x / c$ & $x / c$ & $x / c$ & & & & & $x / c$ \\
\hline curc & & $x / c$ & $x / c$ & & $x / c$ & & & $x / c$ \\
\hline 224-T TRUSAF & $x / c$ & & $x / c$ & & & & $x / c$ & $x / c$ \\
\hline LLBG & & $x / c$ & & & $x / c$ & & $x / c$ & $x / c$ \\
\hline map & & & & & & & & \\
\hline
\end{tabular}

(B) = Retraining every other year

$c=$ continuing

$C=$ Continuing
$x=$ Initial

TED $=$ To be developed 


\section{A-2.4 LIST OF COURSES AND COURSE NAMES}

Table 8A-6 contains a listing of courses by number and title.

Table 8A-6. Course Listing.

\begin{tabular}{|c|c|}
\hline couren Hutare & Goures ritlen \\
\hline 000001 & Menford cemeral booloyee ireining \\
\hline 000090 & violtor/Vendor ortenterion \\
\hline 020064 & Wew Hire ortenterion \\
\hline 020060 & oeneretor Mazerde Snfety Iraining \\
\hline 020159 & Mazardous Maste shipaent Certifiention \\
\hline 020289 & Eullding Emeresency olrector Truining \\
\hline 038044 & Wullding Emergeney plen Treining - Lllia \\
\hline 031045 & 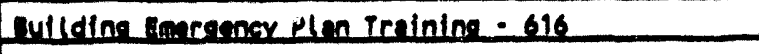 \\
\hline 0313046 & Guildine banrgengy plen Training - Trusap \\
\hline $03: 047$ & Building Emergengy plen Training. CuC \\
\hline TeP & Quildine fmerengy Plen ireinine - URAP \\
\hline rep & Bullding Emereency plen Troining - ERof \\
\hline 035010 & Waste Dest gnation susport \\
\hline 035020 & fecill ty unste sampl ing and Amalyeis \\
\hline 035040 & Environmentel Regulations at Hentord \\
\hline 035030 & Envirommental Comolience at Hanford \\
\hline 035055 & Envirommentel Ruguletions and Coupl lience Refresher \\
\hline 035100 & Core Weste Menerement Training - Initial \\
\hline 035110 & Core Waste Manasement iraining - Requalification \\
\hline 035120 & Weste Menegement Adninistrative - Initial \\
\hline 035130 & Haste Menarement Adninistrative - Requalitication \\
\hline 037510 & Bullding Emergency Director/Worden Requalification \\
\hline 300010 & IRU Retrieval - operator Certification \\
\hline 300020 & Quc - oparator cerelitication \\
\hline 300030 & 226-I TRUSAF - Oparator Certification \\
\hline 300040 & LLBa - Operator Certification \\
\hline 300050 & 616 MROUSF- operetor Certification \\
\hline TBO & WRap - oparator Certiflaction \\
\hline TEO & ERop - Operator Certification \\
\hline 300590 & Swoo Sugerviser/Menerer Certification \\
\hline 300700 & SWOO Unit Orientation Refresher (refer to HGET) \\
\hline 300703 & 616 mRouse Buildine orientation \\
\hline 300710 & LLBG Orientation \\
\hline 300715 & 224-T TRUSAF Orientation \\
\hline 300720 & cuc orientution \\
\hline 300725 & TRU Retrieval orientation \\
\hline TED & EROP Orfentation \\
\hline TBO & WRAP Orientacion \\
\hline
\end{tabular}




\section{A-3.0 REFERENCES}

DOE Order 5480.20, Personnel Selection, Qualification, Training and Staffing Requirements at DOE Reactor and Non-Reactor Nuclear Facllities, U.S. Department of Energy, Washington, D.C.

DOE-RL, 1993, Hanford Facility Contingency Plan, DOE/RL-93-75, U.S. Department of Energy, Richland Operations Office, Richland, Washington.

Ecology, EPA, and DOE, 1994, Hanford Federal Facllity Agreement and Consent Order, Fourth Amendment, Washington State Department of Ecology, U.S. Environmental Protection Agency, and U.S. Department of Energy, olympla, Washington.

Resource Conservation and Recovery Act of 1976, 42 USC 6901, et seq.

WAC 173-303, 1990, "Dangerous Waste Regulations," Washington Administrative Code, as amended. 
$8 B-1$

\title{
WHC-SD-WM-TR-027 REV 0
}

\author{
APPENDIX $8 B$ \\ MON-RCRA TRAINING
}

• 
WHC-SO-WM-TR-027 REV 0

This page intentionally left blank. 


\section{CONTENTS}

88-1.0 ACCESS TO SWDD UNITS .................. 8B-1

8B-1.1 HANFORD FACILITY ACCESS . . . . . . . . . . . . 8B-1

88-1.2 SWDD UNIT/BUILOING ACCESS .............. BB-1

88-1.3 RADIOLOGICAL AREA ACCESS ............ 8B-2

88-2.0 OCCUPATIONAL SAFETY AND HEALTH TRAINING . . . . . . . . . . 88-3

8B-2.1 HAZARO COMMUNICATION ............... 88-3

8B-2.2 HAZARDOUS WASTE OPERATIONS TRAINING........ 8B-4

88-3.0 U.S. DEPARTMENT OF TRANSPORTATION TRAINING . . . . . . . . . 88-4

88-4.0 OTHER ENVIRONMENTAL TRAINING . . . . . . . . . . . . . . 8B-5

8B-5.0 REFERENCES ....................... 8B-5 
WHC-SD-WM-TR-027 REV 0

Thts page intentionally left blank. 


\section{B-1.0 ACCESS TO SWDD UNITS}

This appendix describes the non-RCRA training programs that are closely related to the RCRA programs that are implemented at SWDD waste management units. Terms used in this appendix include Hanford Facility personnel, visitors, and subcontractors. Hanford Facility personnel include employees of DOE-RL, and employees of the Hanford Facility major contractors (i.e., Westinghouse Hanford Company, Pacific Northwest Laboratories, Bechtel Hanford Company). Visitors include personnel who do not have a contract in place with DOE-RL or the Hanford Facility major contractors, and regulatory agency personnel who conduct regulatory compliance inspections. Subcontractors refer to any contractor working for DOE-RL or the major Hanford Facility contractors. These definitions could differ from other definitions used on the Hanford Facility to describe training requirements.

\section{B-1.1 HANFORD FACILITY ACCESS}

Access to the Hanford Facility is controlled through the issuance of badges. The type of badge that is issued will depend on the access frequency of the visitor or subcontractor. In most cases, visitors such as regulatory agency inspectors are issued permanent badges. There are instances where the regulatory agency inspector visit frequency is low and a temporary badge is issued instead of a permanent badge. In either case, to have a badge issued, the visitor or subcontractor must prove U.S. citizenship, provide identification, and view the visitor/vendor video (course number 000090) described in Appendix $8 \mathrm{~A}$. Subcontractors may require escorting (vendor) unti] security background checks have been completed. When the subcontractor vendor status is removed, the subcontractor will complete New Hire Orientation (NHO) (course number 02006A) and has the potential to work unescorted without Solid Waste Disposal Division (SWDD) unit personnel present.

In cases where the visitor is a foreign national, the individual must be processed through the Foreign Visitor and Assignment Program before they are al lowed access to the Hanford Facility. When a foreign national requests access to the Hanford Facility, the extent of documentation will depend on the duration of the stay and whether either the visitor or the facility being visited is classified as "sensitive." Approvals typically take anywhere from 3 to 8 weeks from start to finish. The name of the guest, country of origin, date(s) of visit, and facility(ies) to be visited must be supplied. All personnel escorting the foreign national must be trained in escort training for foreign nationals (course number 000094).

\section{8-1.2 SWDD UNIT/BUILDING ACCESS}

Unit/building access is evaluated on whether the visitor or subcontractor must be escorted (this does not include foreign national considerations). If the visitor or subcontractor is escorted by qualified Hanford Facility personnel assigned to the building or SWDO unit, unit/building orientation is not required unless the visitor. or subcontractor will be working and not touring under a Radiation Work Permit (RWP). For example, when a regulatory 
inspector wants to sample a container during part of an inspection, the inspector must complete the appropriate SWDD unit/building orientation training if the sampling will be conducted under an RWP. This orientation fulfills radiological safety training considerations specific to the hazards present at the SWDD unit. Hanford Facility personnel being escorted by qualified SWDD unit personnel also fall under the same orientation considerations as do the visitors and subcontractors. Although included in Appendix 8A as part of the RCRA training program, the SWDD unit orientation courses are reiterated and include the following:

$\begin{array}{ll}- & 300700 \\ - & 300705 \\ - & 300710 \\ - & 300715 \\ - & 300720 \\ : & 300725 \\ - & \text { TBD } \\ - & \text { TBD }\end{array}$
SWDD unit Orientation refresher (refer to HGET) 516 NRDWSF Building Orientation

LLBG Orientation 224-T TRUSAF Orientation

CWC Orientation

TRU Retrieval Orientation

ERDF Orientation WRAP Orientation.

\section{B-1.3 RADIOLOGICAL AREA ACCESS}

In addition to the requirements for building access, there are also specific requirements pertaining to Radiological Area access. For entry into Radiological Areas, visitors (e.g., regulatory agency inspectors) are allowed access when accompanied by a qualified escort (Hanford Facility personnel assigned to the unit/building). There are limitations, however, on the amount of exposure that visitors may receive, which may impact access over time. Health physics organizations can help ascertain these types of limits.

To enter a radiological area, dosimeters must be acquired. Appropriate dosimeters will be issued to visitors and subcontractors either on a temporary or permanent basis. Regulatory agency inspectors assigned permanent dosimetry are not required to complete a Radiological Area Visitor Form (BC-3000-002) for each visit if a Personnel Radiation Exposure History Form has been completed. Those regulatory agency personnel with permanent dosimetry should possess a valid Qualification Card and should present it at the time of entry to el iminate the need to complete the Radiation Area Visitor Form. Temporary dosimetry is also issued (depending on visit frequency) to visitors and subcontractors and is returned with the temporary badge after the visit. $V$ isitors and subcontractors that are issued temporary dosimetry need to complete the Radiological Area Visitor Form upon each visit to a Radiological Area. The form may be completed at the unit/building which will be accessed, but should be completed at the time the visitor or subcontractor is badged. Visitors and subcontractors who anticipate wearing a respirator, handling radioactive materials, contaminated or potentially contaminated materials, or contaminated equipment shall comply with access qualifications met by Hanford Facility personnel as stipulated by an RWP. In addition, some unit/buildings may require an exit contamination survey.

Whole body counts are only required by the specific RWPs that are written for a specific Radiological Area or for specific radiological work.

Radiological Areas and the respective RWPs for those areas must be identified before the visitors or subcontractors visit the site so whole body counts can 
be completed. Whole body counts can be required for both entry and exit considerations to establish a baseline and to determine any intake of radioactive materials.

There are three types of Radiological Areas that require additional training for visitors and subcontractors: Very High Radiation Areas, High Contamination Areas, and Airborne Areas. For these areas, additional qualifications include those of Hanford Facility radiological workers. These courses/items include the following:

- SWDD unit/buflding orientation (see Section $8 B 1.2$ )

- Radiological Worker II Training - Initial (course number 020001)

- Bioassay testing (if applicable)

- Criticality training (if applicable)

- Mask fit user test (pulmonary capacity).

Finally, all Hanford Facllity personnel, visitors, and subcontractors are required to read the applicable RWP upon initial entry. Personnel must sign that they have read and understood the RWP and agree to comply. with the requirements.

\section{B-2.0 OCCUPATIONAL SAFETY AND HEALTH TRAINING}

Occupational Safety and Health Administration (OSHA) training on the Hanford Facility is described in three terms: Hazard Communication (HAZCOM), Hazardous Waste Operations Training (24/40 hour training), other health and safety training. HAZCOM training and Hazardous Waste Operations training are discussed in sections $8 B 2.1$ and 8B2.2. Other health and safety training can include, but is not limited to, confined space entry, noise conservation, fork lift training, and lock and tag. Hanford Facility health and safety organizations can provide additional clarity on all of these training areas. Regulatory agency inspectors will not be held to any requirements discussed in this section. It is the responsibility of each regulatory agency to provide the necessary training to their personnel in these areas before the inspectors visit the Hanford Facility.

\section{B-2.1 HAZARD COMMUNICATION}

HAZCOM training consists of general training and unit/building specific training as required by 29 CFR 1910.1200. All Hanford Facility personnel resaive general HAZCOM training through NHO (course number 02006A). Only Hanford facility personn i who handle or manage hazardous materials or dangerous wastes (except consumer commodities) must receive unit/building specific HAZCOM training. To administer unit/building specific HAZCOM programs, the Hazard Evaluation Workshop (course number 035030) is provided to managers and personnel who are responsible for developing the unit/building specific program. 


\section{B-2.2 HAZARDOUS WASTE OPERATIONS TRAINING}

Hazardous Waste Operations training, among other things, is required for personnel entering a hazardous waste site or a treatment, storage, and disposal (TSD) unit in accordance with 29 CFR 1910.120. Training requirements for hazardous waste sites involve 40 hours of training (classroom and field experience) whereas training requirements for TSD units involve 24 hours of training (classroom only). Entry requirements for all sWDO units require that Hanford facility personnel receive 24-hour training under this standard. The 24-hour training is applicable to personnel who have a "reasonable possibility of employee exposure to health or safety hazards" at the TSO unit. Some areas of a TSO unit do not have this possibility (e.g., the administrative offices at the 616 Nonradioactive Dangerous Waste Storage Facility [NRDWSF]).

The only RCRA training consideration applied to 24 hour OSHA training involves the 8-hour refresher course (course number 032020 or 032030 ). The 8-hour refresher course is taken by personnel who maintain either a 24- or 40-hour qualification. When Hanford Facility personnel attend the 8-hour refresher, credit is given for refresher training in the Waste Management Awareness program area, Generator Hazards Safety Training (course number 02006G). The Waste Management Awareness program area is discussed in Appendix $8 \mathrm{~A}$.

\section{B-3.0 U.S. DEPARTMENT OF TRANSPORTATION TRAINING}

U.S. Department of Transportation (DOT) training is conducted onsite for Hanford Facility personnel who are involved with transportation, or who offer materials and wastes for transportation. At this time, there are four courses being offered through the transportation organizations on the Hanford Facility:

- 020064 Basic DOT Hazardous Materials Regulation

- 020159 DOT Hazardous Waste Shipment Certification

- 020059 Basic Radioactive Materials Shipment Awareness

- 020069 Radioactive Materials Shipment Certification.

Basic DOT Hazardous Materials Regulation is designed to meet the training needs of "HAZMAT Employees." The Hazardous Waste Shipment Certification course is only included in the RCRA portion of this training plan (Appendix $8 A$ ) when the General Shipper will be shipping an offsite shipment as defined in WAC 173-303. Otherwise, this course will not be enforceable under the Hanford Facility RCRA Permit when issued. The transportation organizations on the Hanford Facility can provide additional information concerning these courses. 


\section{B-4.0 OTHER ENVIRONMENTAL TRAINING}

In addition to RCRA training, other environmental training requirements exist. For example, Toxic Substances Control ACt (TSCA) training exists on the Hanford Facility for polychlorinated biphenyl (PCB) spill response. Training also exists for compliance with reporting under the Emergency Planning and Community Right-to-know Act. There also are asbestos training requirements for workers and supervisors involved in asbestos abatement. In all of these cases, this is non-RCRA training. The environmental training and regulatory support organizations can assist Hanford Facility personnel in determining training needs in these areas.

\section{B-5.0 REFERENCES}

Emergency Planning and Community Right-to-Know Act of 1986, 42 USC 11001, et seq.

Resource Conservation and Recovery Act of 1976, 42 USC 6901, et seq.

Toxic Substances Control Act, 1976, 15 USC 2601 et seq.

WAC 173-303, 1990, "Oangerous Waste Regulations," Washington Administrative Code, as amended.

29 CFR 1910.120, "Hazardous Waste Operations and Emergency Response, Code of Federal Regulations, as amended.

29 CFR 1910.1200, "Hazard Communication," Code of Federal Regulations, as amended. 


\section{WHC-SD-WM-TR-027 REV 0}

This page intentionally left blank 
WHC-SD-WM-TR-027 REV 0

APPENDIX 8C

TRAINING COURSE DESCRIPTIONS

$8 C-1$ 
WHC-SD-WM-TR-027 REV 0

This page intentionally left blank.

$8 C-11$ 
WHC-SD-WM-TR-027 REV 0

\section{CONTENTS}

8C-1.0 HANFORD FACILITY DANGEROUS WASTE TRAINING COURSES . . . . . 8C-1

8C-2.0 HANFORD FACILITY DANGEROUS WASTE TRAINING COURSES . . . . . 8C-10

8C-3.0 REFERENCES ................... 8C-14 
$\wedge !-38$

'xuela zfOL Rlleuolquequl obed s/41

0 А 138 L20-81-WM-OS-JHM 


\section{C-1.0 HANFORD FACILITY DANGEROUS WASTE TRAINING COURSES}

\begin{tabular}{|l|l|}
\hline Title & 000001 Hanford General Employee Training \\
\hline Description & $\begin{array}{l}\text { Course covers U.S. Department of Energy (DOE) orders and } \\
\text { applicable poltcies pertaining to employer and employee } \\
\text { rights and respons fbilities, general radiat fon training, } \\
\text { hazard communicattons, dangerous waste, fire prevention, } \\
\text { personal protective equipment, safety requirements, } \\
\text { certain unit/bullding ortentation refresher training, } \\
\text { emergency preparedness, accident reporting, and avenues } \\
\text { for addressing safety concerns. }\end{array}$ \\
\hline $\begin{array}{l}\text { Mandating } \\
\text { Document(s) }\end{array}$ & $\begin{array}{l}\text { Hanford Facility RCRA Permit (when issued), General } \\
\text { Conditions }\end{array}$ \\
\hline Target Audience & All Hanford Facility personnel \\
\hline Delivery & Computer-based training with interactive video \\
\hline Evaluation & Computer-generated questions \\
\hline Length & Average $=2$ to 6 hours \\
\hline Frequency & Annual \\
\hline
\end{tabular}

\begin{tabular}{|l|l|}
\hline Title & 0000 Visitor/Vendor Orfentation \\
\hline Description & $\begin{array}{l}\text { Course is designed to acquaint and familiarize visitors } \\
\text { and subcontractors with safety, security, and emergency } \\
\text { preparedness requirements and the ir responsibilities to } \\
\text { notify Hanford Facllity personnel when situations arise. } \\
\text { In addition, this orientation identifies the need to obey } \\
\text { signs and labels that may be encountered regarding } \\
\text { radiological areas, hazardous materials, and dangerous } \\
\text { wastes. }\end{array}$ \\
\hline $\begin{array}{l}\text { Mandating } \\
\text { Document(s) }\end{array}$ & $\begin{array}{l}\text { Hanford Factlity RCRA Permit (when issued), General } \\
\text { Conditions }\end{array}$ \\
\hline Target Audience & Visitors/vendors/subcontractors \\
\hline Delivery & Video tape \\
\hline Evaluation & Not applicable \\
\hline Length & 15 minutes \\
\hline Frequency & Annual \\
\hline
\end{tabular}




\begin{tabular}{|l|l|}
\hline Title & O2006A New Hire Orientation \\
\hline Description & $\begin{array}{l}\text { Course covers DOE orders and appl lcable policies } \\
\text { pertaining to employer and employee rights and } \\
\text { respons ibil ities, general radiation training, hazardous } \\
\text { waste, fire prevention, personal protective equipment, } \\
\text { safoty requitrements, accident reporting, and avenues for } \\
\text { addressing safety concerns. }\end{array}$ \\
\hline $\begin{array}{l}\text { Mandating } \\
\text { Document(s) }\end{array}$ & $\begin{array}{l}\text { Hanford Facility RCRA Permit (when issued), General } \\
\text { Conditions }\end{array}$ \\
\hline Target Aud ence & All Hanford Factlity personnel \\
\hline Deliverv & Classroom \\
\hline Evaluation & Not applicable \\
\hline Length & 3 hours \\
\hline Frequency & Initial (Retrained annually by 000001 HGET) \\
\hline
\end{tabular}

\begin{tabular}{|l|l|}
\hline Title & O2006G Generator Hazards Safety Training \\
\hline Description & $\begin{array}{l}\text { Course introduces workers to federal laws governing } \\
\text { chemical safety in the work place. The course provides } \\
\text { the hazardous material/waste worker with the basic } \\
\text { fundamentals for safe use and disposal of hazardous } \\
\text { material. Course defines hazard communication and } \\
\text { hazardous material, reviews label ing requirements, and } \\
\text { introduces material safety data sheets and key terms used } \\
\text { in chemical safety. The course al so introduces methods } \\
\text { for waste minimization. }\end{array}$ \\
\hline $\begin{array}{l}\text { Mandating } \\
\text { Document(s) }\end{array}$ & WAC 173-303-200(2) \\
\hline Target Audience & $\begin{array}{l}\text { Hanford Facility personnel categorized as a General } \\
\text { Worker, Advanced General Worker, General Manager, and } \\
\text { General Shipper }\end{array}$ \\
\hline Delivery & Classroom \\
\hline Evaluation & Written examination - 80\% passing grade \\
\hline Length & 4 hours \\
\hline Frequency & $\begin{array}{l}\text { Annual: Sol id Waste Disposal Division (SWDO) personnel } \\
\text { receive refresher training through 24-hour Occupational } \\
\text { Safety and Health Administration (OSHA) 8-hour refresher. }\end{array}$ \\
\hline
\end{tabular}




\begin{tabular}{|c|c|}
\hline Title & 020159 DOT Hazardous Waste Shipment Certification \\
\hline Description & $\begin{array}{l}\text { Course introduces General Shlppers to Identify shippers' } \\
\text { responsibilities and Ilabilities with regard to compliance } \\
\text { to WAC } 173-303 \text { and U.S. Department of Transportation (DOT) } \\
\text { regulations, including storage, inspection, and loading } \\
\text { requirements. }\end{array}$ \\
\hline $\begin{array}{l}\text { Mandating } \\
\text { Document (s) }\end{array}$ & WAC $173-303-180,-190$, and -370 \\
\hline Target audience & General Shippers \\
\hline Delivery & Classroom \\
\hline Evaluation & Written examination - $80 \%$ passing grade \\
\hline Length & 4 hours \\
\hline Frequency & Every other year \\
\hline
\end{tabular}

\begin{tabular}{|l|l|}
\hline Title & O2028B Building Emergency Director Training \\
\hline Description & $\begin{array}{l}\text { Course provides an overview of the responsibilities of the } \\
\text { building emergency director, identifies the building } \\
\text { emergency organizations, act ions required during an event, } \\
\text { implementing the contingency plan, and discusses drill and } \\
\text { exercise requirements. }\end{array}$ \\
\hline $\begin{array}{l}\text { Mandating } \\
\text { Document(s) }\end{array}$ & WAC 173-303-340, -350, and -360 \\
\hline Target audience & $\begin{array}{l}\text { Building Emergency Directors and their alternates who can } \\
\text { function as the Emergency Coordinator }\end{array}$ \\
\hline Delivery & Classroom \\
\hline Evaluation & Not applicable \\
\hline Length & 2 hours \\
\hline Frequency & $\begin{array}{l}\text { Initial (Retrained annually by 037510 Building Emergency } \\
\text { Director/Warden Requalification) }\end{array}$ \\
\hline
\end{tabular}




\begin{tabular}{|c|c|}
\hline Title & $\begin{array}{ll}\text { 03E044 } & \text { Butlding Emergency Plan Training- LLBG } \\
\text { 03E045 } & \text { Bullding Emergency Plan Training- 616 NRDWSF } \\
\text { 03E046 } & \text { Bullding Emergency Plan Training- 224-T TRUSAF } \\
\text { 03E047 } & \text { Bullding Emergency Plan Training- CWC } \\
\text { TBD } & \text { Bullding Emergency Plan Training- ERDF } \\
\text { TBD } & \text { Bullding Emergency Plan Training- WRAP } \\
\end{array}$ \\
\hline Description & $\begin{array}{l}\text { Course consists of a review of specific hazards associated } \\
\text { with the SWDD unit and job assignment, as covered by each } \\
\text { SWDD unit's Bullding Emergency Plan (WHC-IP-O263-XXX). } \\
\text { The training is completed by the supervisor, manager, or a } \\
\text { designated individual using a checklist. } \\
\text { The unit/building specific information is reviewed } \\
\text { concerning hazards in the work area and emergency response } \\
\text { requirements including, where applicable, waste feed } \\
\text { cut-off, communication and alarm systems, and response to } \\
\text { fires. The checklist acts as a guide to ensure consistent } \\
\text { coverage of necessary topics. }\end{array}$ \\
\hline $\begin{array}{l}\text { Mandating } \\
\text { Document }(s)\end{array}$ & WAC $173-303-330(1)(d),-340$, and -350 \\
\hline Target Audience & $\begin{array}{l}\text { All Hanford Facility personnel categorized as Advanced } \\
\text { General Workers, General Managers, and General Shippers } \\
\text { assigned to SWD units. All General Workers may take this } \\
\text { course, or equivalent training may be given during the } \\
\text { pre-job safety meeting or the SWDD unit/building specific } \\
\text { orientation course. }\end{array}$ \\
\hline Delivery & $\begin{array}{l}\text { One-on-one or as a group with supervisor, manager or } \\
\text { designated individual }\end{array}$ \\
\hline Evaluation & Training checklist documentation \\
\hline Length & 1 hour \\
\hline Frequency & Annual \\
\hline
\end{tabular}




\begin{tabular}{|l|l|}
\hline Title & 035010 Waste Designation Support \\
\hline Description & $\begin{array}{l}\text { Course teaches dangerous waste designation according to } \\
\text { WAC 173-303 Class content includes section-by-section } \\
\text { lecture on the regulations, with examples following each } \\
\text { section, students complete examples using a waste } \\
\text { designation flow chart. Examples addressed include } \\
\text { federally listed waste, discarded chemical products, } \\
\text { dangerous waste source, Washington State criteria } \\
\text { (e.g., toxicity, persistence, carcinogenic), and federal } \\
\text { characteristics (e.g., ignitability, corrosivity, } \\
\text { reactivity, and toxicity). }\end{array}$ \\
\hline $\begin{array}{l}\text { Mandating } \\
\text { Document(s) }\end{array}$ & WAC 173-303-070, and -080 through -100 \\
\hline Target Audience & General Shippers \\
\hline Delivery & Classroom \\
\hline Evaluation & Written examination - $80 \%$ passing grade \\
\hline Length & 12 hours \\
\hline Frequency & Annual \\
\hline
\end{tabular}

\begin{tabular}{|c|c|}
\hline Title & 035020 Facility Waste Sampling and Analys is \\
\hline Description & $\begin{array}{l}\text { Course presents waste sampling methodologies according to } \\
\text { EPA Protocols SW-846, Test Methods for Evaluating Solid } \\
\text { Waste Physical/Chemical Methods. This course also covers } \\
\text { documentation requirements in a sampling plan, field and } \\
\text { laboratory quality control/assurance, and use of actual } \\
\text { sampling equipment. } \\
\text { One-time training is required because the General Shipper, } \\
\text { in most cases, will utilize resources on the Hanford } \\
\text { Facility to acquire samples. This training provides an } \\
\text { overview of information to ensure that sampling efforts } \\
\text { are properly set up. }\end{array}$ \\
\hline $\begin{array}{l}\text { Mandating } \\
\text { Document (s) }\end{array}$ & WAC $173-303-110$ and -070 \\
\hline Target audience & General Shippers \\
\hline Delivery & $\begin{array}{l}\text { Classroom presentation, exercises, demonstration and } \\
\text { discussion }\end{array}$ \\
\hline Evaluation & Written Examination \\
\hline Length & 12 hours \\
\hline Frequency & One time \\
\hline
\end{tabular}




\begin{tabular}{|l|l|}
\hline Title & O35040 Environmental Regulations at Hanford \\
\hline Description & $\begin{array}{l}\text { This course provides an overview of environmental } \\
\text { regulations as they apply to the Hanford Facility. This } \\
\text { course helps enable participants to make informed } \\
\text { decisions relating to environmental compl iance issues. } \\
\text { It includes information on potential legal liabilities, } \\
\text { applicable federal and state regulations, various } \\
\text { reporting requirements, inspections/audits and record } \\
\text { keeping. Information is presented using Hanford Facility } \\
\text { examples. }\end{array}$ \\
\hline $\begin{array}{l}\text { Mandating } \\
\text { Document(s) }\end{array}$ & $\begin{array}{l}\text { WAC } 173-303-145 \text { and general overview of certain } \\
\text { Training covers disciplines from Resource Conservation and } \\
\text { Recovery Act of 1976 (RCRA), National Environmental Policy } \\
\text { Act of 1969 (NEPA), air regulations, Emergency Planning } \\
\text { and Community Right-to-Know Act (EPCRA), Toxic Substances } \\
\text { Control Act (TSCA), spill reporting, and inspection } \\
\text { considerations. }\end{array}$ \\
\hline Target Audience & Level I, II, and III Managers \\
\hline Delivery & Classroom \\
\hline Evaluation & Written examination - 80\% passing grade \\
\hline Length & 8 hours \\
\hline Frequency & Initial (Retraining 035055) \\
\hline
\end{tabular}

\begin{tabular}{|l|l|}
\hline Title & O35050 Environmental Compliance at Hanford \\
\hline Description & $\begin{array}{l}\text { Provides an overview of environmental regulations and } \\
\text { focuses on the use of environmental compl iance manuals to } \\
\text { address compliance issues, Informat ton is presented } \\
\text { through Hanford Facility examples. }\end{array}$ \\
\hline $\begin{array}{l}\text { Mandating } \\
\text { Document(s) }\end{array}$ & $\begin{array}{l}\text { WAC } 173-303-145 \text { and general overview of certain } \\
\text { WAC } 173-303 \text { sections } \\
\text { Training covers disciplines from RCRA, NEPA, air } \\
\text { regulations, EPCRA, TSCA, spill reporting, and inspection } \\
\text { considerations. }\end{array}$ \\
\hline Target Audience & $\begin{array}{l}\text { Environmental Compliance Officers, engineers categorized } \\
\text { as General Managers, and level 4, 5, and 6 managers }\end{array}$ \\
\hline Delivery & Classroom \\
\hline Evaluation & Workbook \\
\hline Length & 8 Hours \\
\hline Frequency & Initial (Retraining 035055) \\
\hline
\end{tabular}




\begin{tabular}{|l|l|}
\hline Title & 035055 Environmental Regulations and Compliance Refresher \\
\hline Description & $\begin{array}{l}\text { This course provides participants with an update of } \\
\text { environmental regulation and compliance issues related to } \\
\text { Work at the Hanford Facility. Emphas is of instruction and } \\
\text { information will be based on current Hanford issues. } \\
\text { Information reviewed may include potential legal } \\
\text { liabilities, applicable federal and state regulations, } \\
\text { various reporting requirements, inspections/audits, and } \\
\text { recordkeeping. Information is presented using Hanford } \\
\text { Facility examples. }\end{array}$ \\
\hline $\begin{array}{l}\text { Mandating } \\
\text { Document(s) }\end{array}$ & $\begin{array}{l}\text { WAC 173-303-145 and general overview of certain } \\
\text { WAC 173-303 sections } \\
\text { Training covers disciplines from RCRA, NEPA, air and water } \\
\text { regulations, EPCRA, TSCA, spill reporting, and inspection } \\
\text { considerations related to current Hanford issues. }\end{array}$ \\
\hline Target Audience & $\begin{array}{l}\text { Managers, Environmental Compliance Officers, engineers } \\
\text { categorized as General Managers who have attended either } \\
\text { Environmental Regulations at Hanford or Environmental } \\
\text { Compliance at Hanford. }\end{array}$ \\
\hline Classroom or self-study \\
\hline Delivery & Workbook \\
\hline Evaluation & About 4 hours \\
\hline Length & Retrained annually \\
\hline
\end{tabular}




\begin{tabular}{|l|l|}
\hline Title & 035100 Core Waste Management - Initial \\
\hline Description & $\begin{array}{l}\text { Course covers basic requirements of waste management, } \\
\text { incorporating 40 CFR 260 through 265, WAC 173-303, DOE } \\
\text { orders, and company pol icy. Includes three practical } \\
\text { exercises for hands-on experience with satel1ite and } \\
90-\text { day accumulation area requirements, labpacks for } \\
\text { dangerous waste and mixed waste, and preparation of } \\
\text { packages for final destination. }\end{array}$ \\
\hline $\begin{array}{l}\text { Mandating } \\
\text { Document(s) }\end{array}$ & WAC 173-303-630, -200 and Waste Minimization \\
\hline Target Audience & $\begin{array}{l}\text { Advanced General Workers and General Managers of Advanced } \\
\text { General Workers }\end{array}$ \\
\hline Delivery & Classroom \\
\hline Evaluation & Written Examination - 80\% passing grade \\
\hline Length & 16 hours \\
\hline Frequency & $\begin{array}{l}\text { Initial (retrained annually by 035110 Core Waste } \\
\text { Management Training - Refresher) }\end{array}$ \\
\hline
\end{tabular}

\begin{tabular}{|l|l|}
\hline Title & 035110 Core Waste Management - Refresher \\
\hline Description & Refreshes Course 035100 \\
\hline Target Audience & $\begin{array}{l}\text { Advanced General Workers and General Managers of Advanced } \\
\text { General Workers }\end{array}$ \\
\hline Delivery & Classroom \\
\hline Evaluation & Written Examination - 80\% passing grade \\
\hline Length & 4 Hours \\
\hline Frequency & Annual \\
\hline
\end{tabular}




\begin{tabular}{|l|l|}
\hline Title & 035120 Waste Management Administration - Initial \\
\hline Description & $\begin{array}{l}\text { Course is designed for personnel preparing to become } \\
\text { authorized shippers of dangerous and/or mixed waste. This } \\
\text { course covers regulatory and company pol icies, forms, } \\
\text { reports, forecasts, and plans. Topics al so covered } \\
\text { include: waste characterization, waste storage disposal } \\
\text { request, low-level waste storage/disposal record, } \\
\text { transuranic waste storage/disposal record, and radioactive } \\
\text { mixed waste attachment sheet. In addition, students wil1 } \\
\text { learn how these forms are used to complete shipping } \\
\text { papers. }\end{array}$ \\
\hline $\begin{array}{l}\text { Mandating } \\
\text { Document(s) }\end{array}$ & $\begin{array}{l}\text { Hanford Facility RCRA Permit (when issued), Part II, } \\
\text { condition II.0 }\end{array}$ \\
\hline Target Audience & General Shippers \\
\hline Delivery & Classroom \\
\hline Evaluation & Written examination - 80\% passing grade \\
\hline Length & 8 hours \\
\hline Frequency & $\begin{array}{l}\text { Initial (Retrained annually by 035130 Waste Manageme: } \\
\text { Administration - Refresher) }\end{array}$ \\
\hline
\end{tabular}

\begin{tabular}{|l|l|}
\hline Title & 035130 Waste Management Administration - Refresher \\
\hline Description & Refreshes course 035120 \\
\hline Target Audience & General Shippers \\
\hline Delivery & Classroom \\
\hline Evaluation & Written examination - 80\% passing grade \\
\hline Length & 4 hours \\
\hline Frequency & Annual \\
\hline
\end{tabular}

\begin{tabular}{|l|l|}
\hline Title & 037510 Building Emergency Director/Warden Requalification \\
\hline Description & Refresher for Building Emergency Director Training \\
\hline Target audience & Building Emergency Directors and alternates \\
\hline Delivery & Classroom \\
\hline Evaluation & Not applicable \\
\hline Length & 2 hours \\
\hline Frequency & Annual \\
\hline
\end{tabular}




\section{C-2.0 HANFORD FACILITY DANGEROUS WASTE TRAINING COURSES}

\begin{tabular}{|l|l|}
\hline Title & 300010 TRU Waste Retrieval Operator Certification \\
\hline Description & $\begin{array}{l}\text { Operator qual ification course that defines the processes } \\
\text { and equipment associated with transuranic (TRU) retrieval } \\
\text { activities in and around the Low-Level Burial Grounds } \\
\text { (LLBG) based on operations as defined in current plant } \\
\text { operating procedures and controlled documents. Covers } \\
\text { evaluation, inspection, acceptance, movement, and } \\
\text { storage/disposal of transuranic solid waste packages. }\end{array}$ \\
\hline $\begin{array}{l}\text { Mandating } \\
\text { Document (s) }\end{array}$ & DOE Order 5480.20, WAC 173-303-400, and -170 \\
\hline Target Audience & Nuclear Operators \\
\hline Delivery & Classroom, self-study, on-the-job training (OJT) \\
\hline Evaluation & $\begin{array}{l}\text { Operational examination - 70\% of job performance measures } \\
\text { (JPM) must receive satisfactory grade. }\end{array}$ \\
\hline Length & Approximately 24 hours \\
\hline Frequency & Every 2 years (0JT excluded in refresher) \\
\hline
\end{tabular}

\begin{tabular}{|l|l|}
\hline Title & 300020 Central Waste Complex Operator Certification \\
\hline Description & $\begin{array}{l}\text { Operator qualification course that defines the processes } \\
\text { and equipment as sociated with the Central Waste Complex } \\
\text { (CWC) based on operations as defined in current plant } \\
\text { operating procedures and controlled documents, Covers } \\
\text { receipt, inspection, acceptance, movement, and storage of } \\
\text { radioactive mixed waste packages. }\end{array}$ \\
\hline $\begin{array}{l}\text { Mandating } \\
\text { Document(s) }\end{array}$ & DOE Order 5480.20, WAC 173-303-400, 40 CFR 265, Subpar't I \\
\hline Target Audience & Nuclear Operators \\
\hline Delivery & Classroom, self-study, OJT \\
\hline Evaluation & $\begin{array}{l}\text { Operational examination - 70\% of JPM must receive } \\
\text { satisfactory grade. }\end{array}$ \\
\hline Length & Approximately 24 hours \\
\hline Frequency & Every 2 years (0JT excluded in refresher) \\
\hline
\end{tabular}




\begin{tabular}{|l|l|}
\hline Title & 300050 616 NRDWSF Operator Certification \\
\hline Description & $\begin{array}{l}\text { Operator. qualification course that defines the processes } \\
\text { and equipment associated With the } 616 \text { Nonradioactive } \\
\text { Dangerous Waste Storage Facil ity (616 NRDWSF) based on } \\
\text { operations as defined in current plant operating } \\
\text { procedures and controlled documents. Covers receipt, } \\
\text { inspection, acceptance, movement, and storage of } \\
\text { nonradioactive dangerous waste packages. }\end{array}$ \\
\hline $\begin{array}{l}\text { Mandating } \\
\text { Document(s) }\end{array}$ & $\begin{array}{l}\text { DOE Order 5480.20, WAC 173-303-600, Hanford Facility RCRA } \\
\text { Permit (when issued), Part III }\end{array}$ \\
\hline Target Audience & Nuclear Operators \\
\hline Delivery & Classroom, self-study, 0JT \\
\hline Evaluation & $\begin{array}{l}\text { Operational examination - 70\% of JPM must receive } \\
\text { satisfactory grade. }\end{array}$ \\
\hline Length & Approximately 24 hours \\
\hline Frequency & Every 2 years (OJT excluded in refresher) \\
\hline
\end{tabular}

\begin{tabular}{|l|l|}
\hline Title & $\begin{array}{l}\text { ERDF Operator Certification (TBD) } \\
\text { WRAP Operator Certification (TBD) }\end{array}$ \\
\hline Description & TBD \\
\hline $\begin{array}{l}\text { Mandating } \\
\text { Document (s) }\end{array}$ & $\begin{array}{l}\text { DOE Order 5480.20, WAC 173-303-400 and Corrective Action } \\
\text { Management Unit (CAMU) RCRA Correct ive ACtion } \\
\text { requirements: WAC 173-303-646 and 40 CFR 264.552 }\end{array}$ \\
\hline Target Audience & Nuclear Operators \\
\hline Delivery & Classroom, self-study, 0JT \\
\hline Evaluation & $\begin{array}{l}\text { Operational examination - 70\% of JPM must receive } \\
\text { satisfactory grade. }\end{array}$ \\
\hline Length & Approximately 24 hours \\
\hline Frequency & Every 2 years (OJT excluded in refresher) \\
\hline
\end{tabular}


WHC-SD-WM-TR-027 REV 0

\begin{tabular}{|l|l|}
\hline Title & 300030 224-T TRUSAF Operator Certification \\
\hline Description & $\begin{array}{l}\text { Operator qual ification course that defines the processes } \\
\text { and equipment associated with the 224-T Transuranic Waste } \\
\text { Storage and Assay Facil Ity (224-T TRUSAF) based on } \\
\text { operations as defined in current plant operating } \\
\text { procedures and controlied documents. Covers evaluation, } \\
\text { inspection, acceptance, assay, movement, and storage of } \\
\text { transuranic waste packages. }\end{array}$ \\
\hline $\begin{array}{l}\text { Mandating } \\
\text { Document(s) }\end{array}$ & DOE Order 5480.20, WAC 173-303-400, 40 CFR 265, Subpart I \\
\hline Target Audience & Nuclear Operators \\
\hline Delivery & Classroom, self-study, 0JT \\
\hline Evaluation & $\begin{array}{l}\text { Operational examination - 70\% of JPM must receive } \\
\text { satisfactory grade. }\end{array}$ \\
\hline Length & Approximately 24 hours \\
\hline Frequency & Every 2 years (0JT excluded in refresher) \\
\hline
\end{tabular}

\begin{tabular}{|l|l|}
\hline Title & 300040 LLBG Operator Certification \\
\hline Description & $\begin{array}{l}\text { Operator qual ification course that defines the processes } \\
\text { and equipment associated with the LLBG based on operations } \\
\text { as defined in current plant operating procedures and } \\
\text { controlled documents. Covers evaluation, inspection, } \\
\text { acceptance, movement, and storage/disposa? of solid waste } \\
\text { packages. }\end{array}$ \\
\hline $\begin{array}{l}\text { Mandating } \\
\text { Document(s) }\end{array}$ & DOE Order 5480.20, WAC 173-303-400, 40 CFR 265, Subpart N \\
\hline Target Audience & Nuclear Operators \\
\hline Delivery & Classroom, self-study, OJT \\
\hline Evaluation & $\begin{array}{l}\text { Operational examination - 70\% of JPM must receive } \\
\text { satisfactory grade. }\end{array}$ \\
\hline Length & Approximately 24 hours \\
\hline Frequency & Every 2 years (0JT excluded in refresher) \\
\hline
\end{tabular}


WHC-SD-WM-TR-027 REV 0

\begin{tabular}{|c|c|}
\hline Title & 300590 SWDD Supervisor/Manager Certification \\
\hline Description & $\begin{array}{l}\text { Course includes the following toples to prepare the } \\
\text { Manager in SWDD operations: } \\
\text { - Administrative information } \\
\text { - Technical information } \\
\text { - Hazardous material/dangerous waste requirements } \\
\text { - Handling dangerous waste } \\
\text { - Opery analys is reports } \\
\text { - Radiational safety requirements } \\
\text { - Occurrence reporting } \\
\text { - Jobs conducted in the area of assigned responsibility } \\
\text { - Processes and services } \\
\text { - Equipment. }\end{array}$ \\
\hline $\begin{array}{l}\text { Mandating } \\
\text { Document (s) }\end{array}$ & $\begin{array}{l}\text { DOE Order } 5480.20 \text {, WAC } 173-303-400 \text { or }-600 \text { depending on } \\
\text { the SWDD unit }\end{array}$ \\
\hline Target Audience & Operations supervisors and managers \\
\hline Delivery & Classroom, self-study, OJT \\
\hline Evaluation & Written examination - $80 \%$ passing grade, oral board \\
\hline Length & Self-paced \\
\hline Frequency & Every 2 years \\
\hline
\end{tabular}

\begin{tabular}{|c|c|}
\hline Title & \begin{tabular}{|ll}
300705 & 616 NRDWSF Building Orientation \\
300710 & LLBG Orientation \\
300715 & $224-T$ TRUSAF Orientation \\
300720 & CWC Orientation \\
300725 & TRU Retrieval Orientation \\
TBD & ERDF Orientation \\
TBD & WRAP Orientation \\
\end{tabular} \\
\hline Description & $\begin{array}{l}\text { This course covers SWDO orientation considerations } \\
\text { pertaining to the health and safety hazards concerning the } \\
\text { hazardous materials and dangerous wastes within the } \\
\text { immediate and surrounding work environments. The course } \\
\text { can also describe appropriate radiological procedures for } \\
\text { access and exit of the SWDD unit. }\end{array}$ \\
\hline $\begin{array}{l}\text { Mandating } \\
\text { Document }(s) \\
\end{array}$ & $\begin{array}{l}\text { Hanford Facility RCRA Permit (when issued), Part II.C, and } \\
\text { Hazard Communication }\end{array}$ \\
\hline Target Audience & $\begin{array}{l}\text { Al1 SWDD unit personnel requiring access to SWDD units. } \\
\text { All Hanford Facility personnel, visitors, and } \\
\text { subcontractors who will not be escorted by qualified SWDD } \\
\text { unit personnel. }\end{array}$ \\
\hline Delivery & Classroom presentation \\
\hline Evaluation & None \\
\hline Length & 30 minutes \\
\hline Frequency & $\begin{array}{l}\text { Annual - Refresher training provided through HGET for al1 } \\
\text { SWDD units (course number } 300700 \text { ) }\end{array}$ \\
\hline
\end{tabular}




\section{C-3.0 REFERENCES}

DOE Order 5480.20, Personnel Selection, Qualification, Training and Staffing Requirements at DOE Reactor and Non-Reactor Nuclear Factitities,

U.S. Department of Energy, Washington, D.C.

Emergency Planning and Comnunity Right-to-Know Act of 1986, 42 USC 11001, et seq.

National Environmental Policy Act of 1969, 42 USC 4321 et seq.

Resource Conservation and Recovery Act of 1976, 42 USC 6901, et seq.

Toxic Substances Control Act, 1976, 15 USC 2601 et seq.

WAC 173-303, 1990, "Dangerous Waste Regulations," Washington Administrative Code, as amended.

40 CFR 260, "Hazardous Waste Management System-General," Code of Federal Regulations, as amended.

40 CFR 261, "Identification and Listing of Hazardous Waste," Code of Federal Regulations, as amended.

40 CFR 262, "Standards Applicable to Generators of Hazardous Waste, Code of Federal Regulations, as amended.

40 CFR 263, "Standards Applicable to Transporters of Hazardous Waste," Code of Federal Regulations, as amended.

40 CFR 264, "Standards for Owners and Operators of Hazardous Waste Treatment, Storage, and Disposal Facilities, "Code of Federal Regulations, as amended.

40 CFR 265, "Interim Status Standards for Owners and Operators of Hazardous Waste Treatment, Storage, and Disposal Facilities," Code of Federal Regulations, as amended. 


\section{WHC-SD-WM-TR-027 REV 0}

\section{CONTENTS}

8D-1.0 SWDD DANGEROUS WASTE TRAINING REQUIREMENTS FOR ADVANCED GENERAL WORKERS .................... 8D-1

80-2.0 SWDD DANGEROUS WASTE TRAINING REQUIREMENTS FOR GENERAL MANAGERS ....................... 8D-2

8D-3.0 SWDO DANGEROUS WASTE TRAINING REQUIREMENTS FOR COGNIZANT, TEST, AND SYSTEMS ENGINEERS ................ 8D-3

8D-4.0 SWDD DANGEROUS WASTE TRAINING REQUIREMENTS FOR GENERAL SHIPPERS .................. 80-4 
WHC-SD-WM-TR-027 REV 0

This page intentionally left blank. 
8D-1.0 SWDD DAMGEROUS WASTE TRAIMIMG REQUIREEETTS FOR MVAMCED GEMERAL WORKERS (SWDD OPERATORS) (EXMPLE)

\begin{tabular}{|c|c|c|c|c|c|c|c|c|c|c|c|c|}
\hline \multirow{5}{*}{ SLOD Operators } & \multicolumn{12}{|c|}{ Iraining Courses } \\
\hline & \multicolumn{7}{|c|}{ Meste Manegement Orientation, Ausreness, and advenced } & \multicolumn{5}{|c|}{ Unit/sob specific } \\
\hline & \multirow{3}{*}{$\begin{array}{c}020064 \\
\text { or } \\
000001 \text { (A) }\end{array}$} & \multirow{3}{*}{ (A) } & LLEG & 616 & $\begin{array}{l}224-1 \\
\text { Teusaf }\end{array}$ & axc & & 616 medusf & ax & 226-1 & \multicolumn{2}{|c|}{$4 \times 6$} \\
\hline & & & \multirow{2}{*}{$\begin{array}{l}\text { O3E0044 } \\
\text { and } \\
300710^{2} \\
\text { (a) }\end{array}$} & \multirow{2}{*}{$\begin{array}{l}03 E 045 \\
\text { and } \\
300705^{2} \\
\text { (A) }\end{array}$} & \multirow{2}{*}{$\begin{array}{c}\text { 03E046 } \\
\text { md } \\
30071^{2} \\
(A)\end{array}$} & \multirow{2}{*}{$\begin{array}{c}03 E 047 \\
\text { snd } \\
30070^{2} \\
(A)\end{array}$} & \multirow{2}{*}{$\underset{\text { (A) }}{035110}$} & \multirow[t]{2}{*}{$300050(8)$} & \multirow{2}{*}{$300020(8)$} & \multirow{2}{*}{$300030(8)$} & 406 & $\begin{array}{c}\text { Twe } \\
\text { extrievel }\end{array}$ \\
\hline & & & & & & & & & & & 308040 (A) & $300010(B)$ \\
\hline \multicolumn{13}{|c|}{ (a) 1 (n) } \\
\hline Andersan, d. 0. & $x / c$ & $x$ & $x / c$ & & & . & $x / c$ & & & & $x y c$ & $x / c$ \\
\hline Brown, B. L. & $x / c$ & $x$ & & $x \in c$ & & & $\mathbf{x / c}$ & $x / c$ & & & & \\
\hline Jones, H. A. & $x / c$ & $x$ & $x / c$ & & $x / c$ & & $x / c$ & & & $x y c$ & $x / c$ & $x \in c$ \\
\hline SHITH, T. R. & $x / c$ & $x$ & & & & $x / c$ & $x / c$ & & $x / c$ & & & \\
\hline LUITE, M. L. & $x / c$ & $x$ & $x / c$ & & & & $x / c$ & & & & $x / c$ & $x \in c$ \\
\hline
\end{tabular}


8D-2.0 SMDD DAMGEROUS MASTE TRAIMING REQUIREMENTS FOR GEMERAL MMMGERS (EXMPLE)

\begin{tabular}{|c|c|c|c|c|c|c|c|c|c|c|c|}
\hline \multirow[b]{4}{*}{$\begin{array}{c}\text { Managers by Job } \\
\text { Positions }\end{array}$} & \multicolumn{11}{|c|}{ Iraining courses } \\
\hline & \multicolumn{10}{|c|}{ Unste Manegement Orientation, Muereness, and Advanced } & \multirow{3}{*}{$\begin{array}{l}\begin{array}{l}\text { Unit/job } \\
\text { Specific }\end{array} \\
\text { All soD } \\
300590 \text { (B) }\end{array}$} \\
\hline & \multirow{2}{*}{$\begin{array}{c}020064 \\
\text { or } \\
000001 \\
\text { (a) }\end{array}$} & \multirow{2}{*}{${ }_{(A)}^{020090}$} & \multirow{2}{*}{$\begin{array}{c}\text { 03E046 } \\
\text { and } \\
30070^{2} \\
(A) \\
\end{array}$} & \multirow{2}{*}{$\begin{array}{c}\text { 03E0.45 } \\
\text { and } \\
300705^{2} \\
\text { (A) }\end{array}$} & \multirow{2}{*}{$\begin{array}{c}\text { O3E046 } \\
\text { nnd } \\
300715^{2} \\
(A)\end{array}$} & \multirow{2}{*}{$\begin{array}{l}\text { O3Eent } \\
\text { and } \\
300720^{2} \\
\text { (A) } \\
\end{array}$} & \multirow{2}{*}{$\begin{array}{c}020200 \\
\text { or } \\
\text { osf510 } \\
\text { (A) }\end{array}$} & \multirow{2}{*}{$\begin{array}{c}05860 \\
\text { of } \\
\text { ossess } \\
\text { (a) }\end{array}$} & \multirow{2}{*}{$\begin{array}{c}035050 \\
00 \\
055055 \\
\text { (A) }\end{array}$} & \multirow{2}{*}{$\begin{array}{c}035100 \\
0 \% \\
065110 \\
(A)\end{array}$} & \\
\hline & & & & & & & & & & & \\
\hline Exmples & & & & & & & & & & & \\
\hline \multicolumn{12}{|c|}{ Dullding Emerency Directors } \\
\hline Worker, J. Q. & $x / c$ & $x$ & $x / c$ & & - & & $x / c$ & $\mathbf{x}$ & & & \\
\hline \\
\hline \multicolumn{12}{|c|}{ Operations nemer } \\
\hline Otson, J. I. & $x / c$ & $x$ & & $x / c$ & & & & & $x$ & $x / c$ & $x / c$ \\
\hline \multicolumn{12}{|c|}{ Environental complimes officer } \\
\hline Broun, B. L. & $\overline{x / c}$ & $x$ & $x / c$ & $x / c$ & $x / c$ & $x / c$ & $x / c$ & & $\mathbf{x}$ & & \\
\hline & & & & & & & & & & & \\
\hline
\end{tabular}

1Contimuing training provided through 24-hour osw iso mazardous Uaste Horker Iraining Refresther. $2_{\text {continuing training provided through MeET (Course } 300700 \text { ). }}$

(A) $=$ Anseatily

$(B)=$ Every 2 years

$c=$ continuing

$x=$ Initial 


\section{D-3.0 SWDD DANGEROUS WASTE TRAINING REQUIREMENTS FOR COGNIZANT, TEST, AND SYSTEMS ENGINEERS (EXAMPLE)}

\begin{tabular}{|c|c|c|c|c|c|c|c|c|}
\hline \multirow[b]{3}{*}{$\begin{array}{l}\text { Cognizant, Test, and } \\
\text { Systems Eng ineers }\end{array}$} & \multicolumn{8}{|c|}{ Training Courses } \\
\hline & \multicolumn{8}{|c|}{ Waste Management Orientation, Awareness, and Advanced } \\
\hline & $\begin{array}{l}02006 n \text { or } \\
000001(A)\end{array}$ & 020066 & $\begin{array}{c}\begin{array}{c}\text { 03E044 and } \\
300710^{2} \\
(A)\end{array} \\
\end{array}$ & $\begin{array}{c}\begin{array}{c}03 E 045 \text { and } \\
300705^{2} \\
(A)\end{array} \\
\end{array}$ & $\begin{array}{c}03 E 046 \text { and } \\
300715^{2} \\
(A)\end{array}$ & $\begin{array}{c}03 E 047 \text { and } \\
300720^{2} \\
(A)\end{array}$ & $\begin{array}{c}035050 \text { or } \\
035055 \\
(A)\end{array}$ & \begin{tabular}{|c|}
035100 \\
or \\
$035110(A)$ \\
\end{tabular} \\
\hline \multicolumn{9}{|l|}{ Examples } \\
\hline Anderson, J. 0. & $x / c$ & $x$ & $x / c$ & $x \mid c$ & & & $x$ & $x / c$ \\
\hline Broun, B. L. & $x / c$ & $x$ & & & $x / c$ & & $x$ & $x / c$ \\
\hline Jones, H. A. & $x / c$ & $x$ & & & & $x / c$ & $x$ & $x / c$ \\
\hline & & & & & & & & \\
\hline
\end{tabular}

1 conting training provided through 24-hour OSHA ISO Hazardous Waste Norker Iraining Refresher. 2 continuing training provided through HGET (Course 300700).

(A) $=$ Anrually

(B) = Every 2 years

$\mathrm{C}=$ Continuing

$x=$ Initial 
8D-4.0 SWDD DANGEROUS WASTE TRAINING REQUIRENENTS FOR GENERAL SHIPPERS (EXAMPLE)

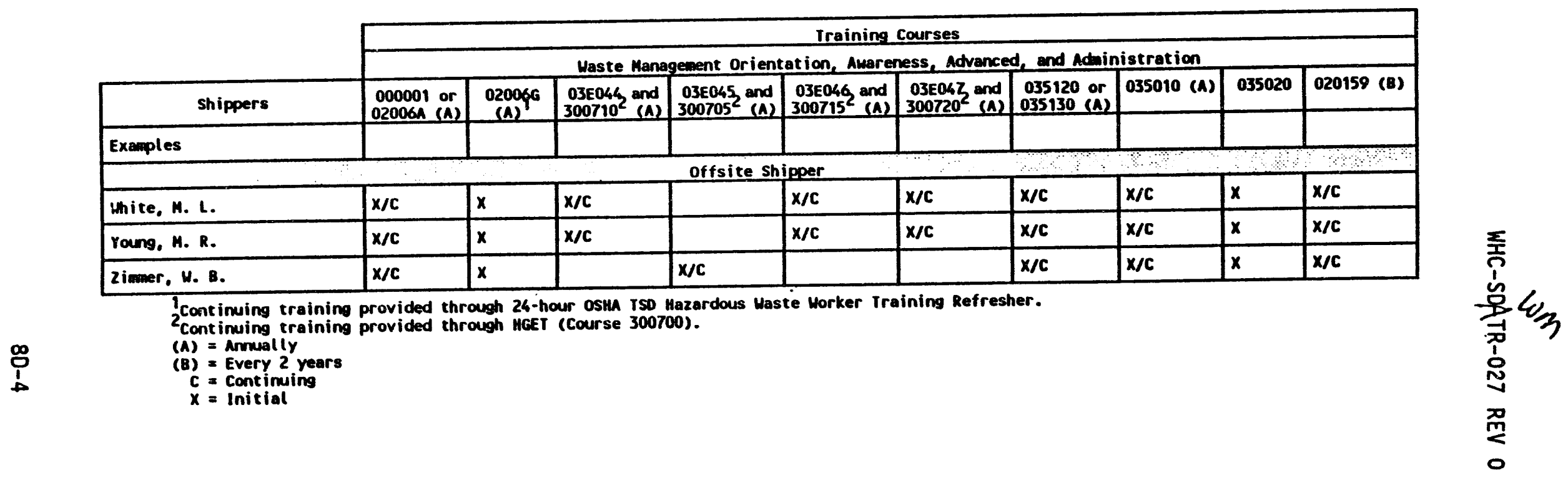


DOE/RL-94-40, Rev. 0

06/94

\section{DISTRIBUTION}

Number of copies

OFFSITE

MSIN

5

Washington State Department of Ecology

N. T. Hepner (5)

B5-18

5

U,S. Army Corps of Engineers

W. L. Greenwald (4)

A5-20

G. K. Rhoades

A5-20

8

U.S. Environmental Protection Agency

P. S. Innis (8)

B5-01

1

Yakima Indian Nation

J. Broder

G1-02

ONSITE

21

U.S. Department of Energy, Richland Operations office

C. E. Clark

A5-15

M. S. Collins

A5-18

A. K. Crowell (3)

B. L. Foley (14)

Public Reading Room (2)

R3-80

A5-19

Pacific Northwest Laboratory

Hanford Technical Library

P8-55

SEG

W. W. Fillingame (4)

N3-13

71

West inghouse Hanford Company

R. C. Bowman

H6-24

B. J. Broomfield

D. J. Carrell

M. A. Casbon

V. R. Dronen

J. H. Dunkirk

T3-04

H6-22

A5-56

A5-56

B3-06 


$$
\begin{array}{r}
\text { DOE/RL-94-40, Rev. } 0 \\
06 / 94
\end{array}
$$

C. B. Evans

G. C. Evans (10)

D. E. Gilkeson (2)

L6-51

M. R. Greutman

H6-23

W. H. Hamilton

A5-56

P. L. Hapke

C. E. Hodge

G. H. Landeen

H4-70

N3-10

T4-05

A5-56

F. A. Marsh

H6-23

D. E. McKenney

T3-03

D. R. Myers

N3-13

F. V. Roeck

H4-14

H6-01

H. Spanheimer

G6-47

K. S. Tollefson

H6-30

D. C. Weekes

H6-06

R. S. Weeks

M. I. Wood

H6-26

N3-13

EDC

EPIC (9)

Information Release Administration (3)

Project File (D. Trinidad)

Public Involvement ( $L$. Thiede) (24)

H6-07

H6-08

H4-17

G6-51

B3-35

Bechtel Hanford Inc.

John Darby

H4-97

H4-97

J. R. James

H4-79

S. R. Weil

R. H. Wyer

$\mathrm{H} 4-79$ 

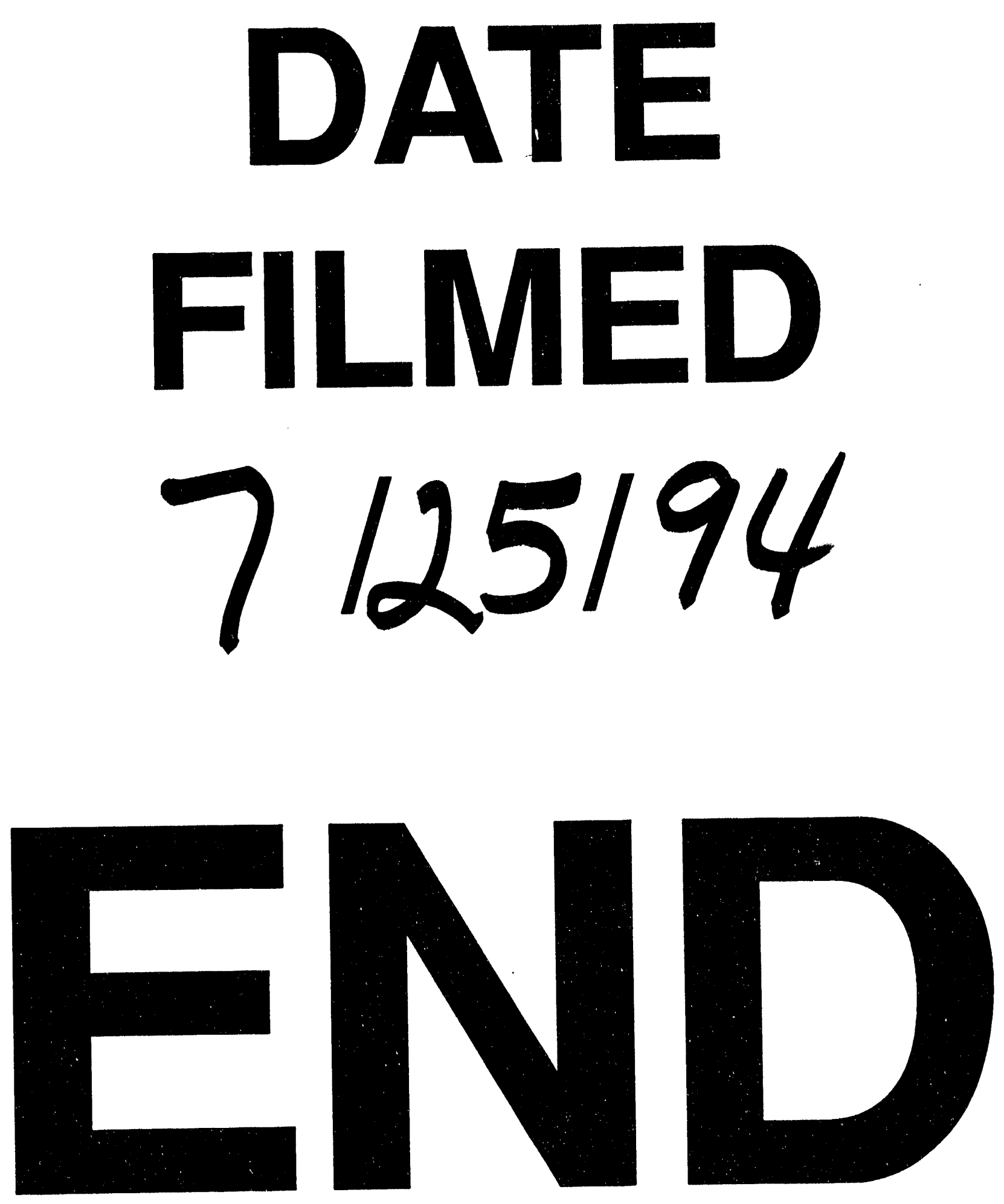
